


\section{UNIVERSITY OF CALIFORNIA AT LOS ANGELES}
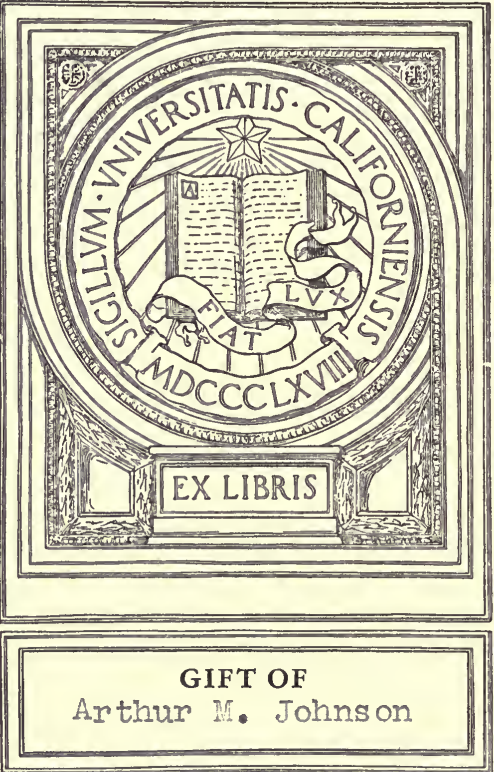


$$
\begin{aligned}
& \text { added } \\
& \text { a de } \\
& 192 \\
& p 66 f
\end{aligned}
$$

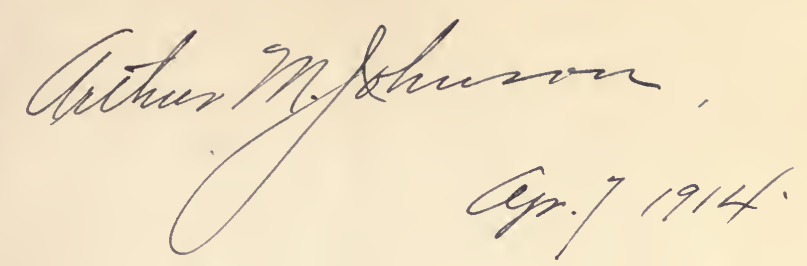

Apotacue. Tharh.

MGlk. 






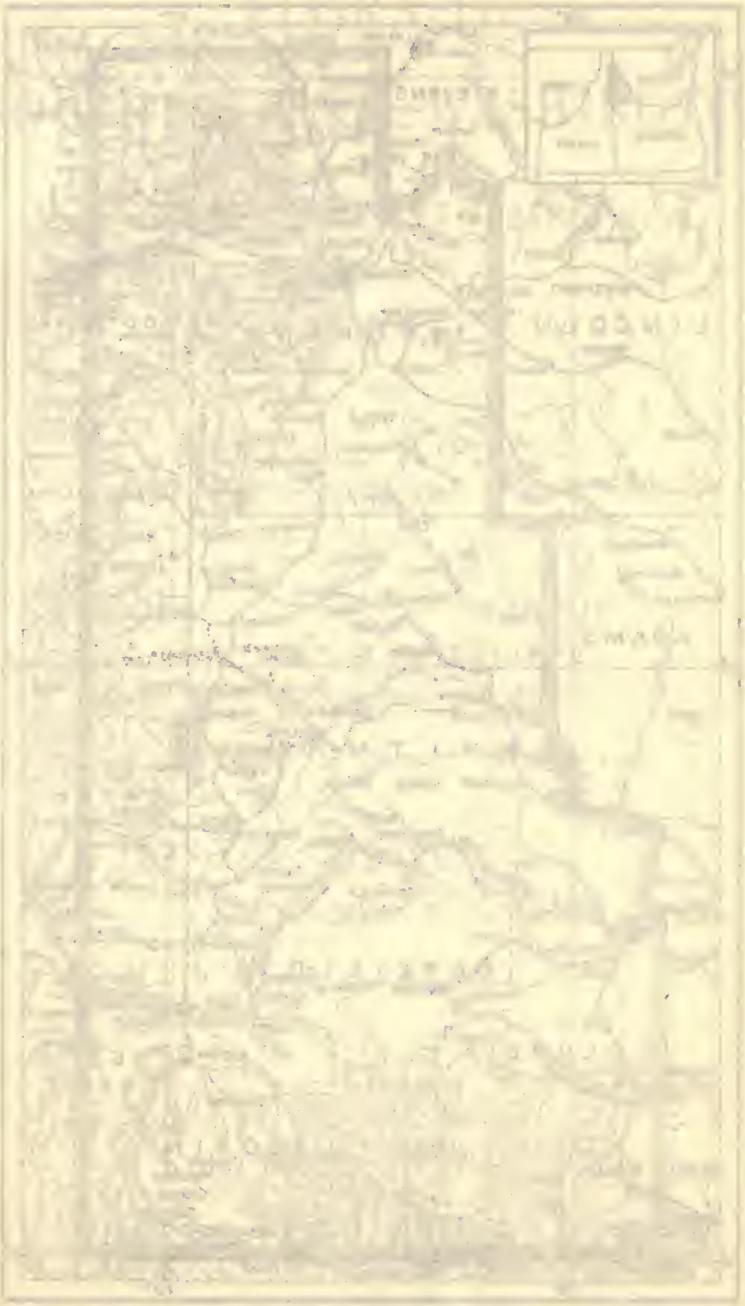

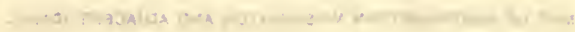




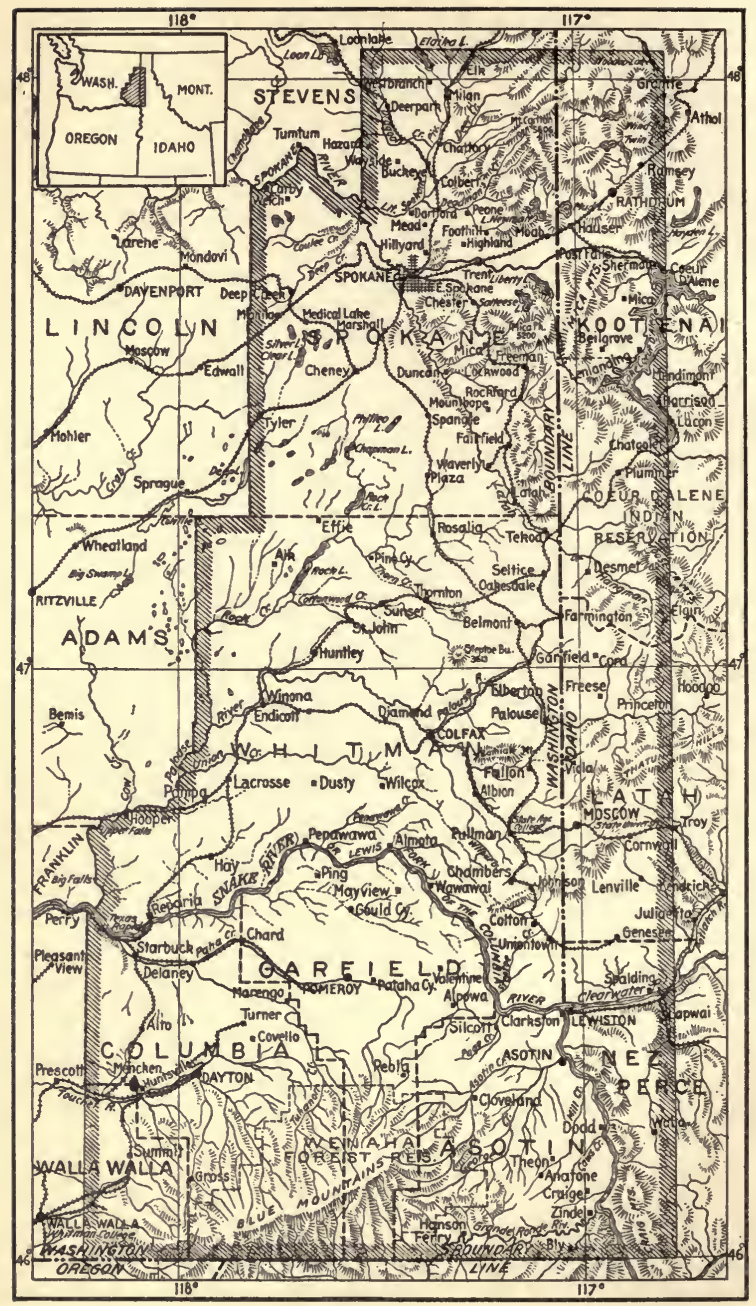

MAP OF SOUTHEASTERN WASHINGTON AND ADJACENT IDAHO. 


\title{
FLORA OF
}

\section{SOUTHEASTERN WASHINGTON}

\author{
AND ADJACENT IDAHO
}

BY

CHARLES V. PIPER

PROFESSOR OF BOTANY, THE STATE COLLEGE OF WASHINGTON, I893-I903

AND

R. KENT BEATTIE

PROFESSOR OF BOTANY, THE STATE COLLEGE OF WASHINGTON, I903-I9I2

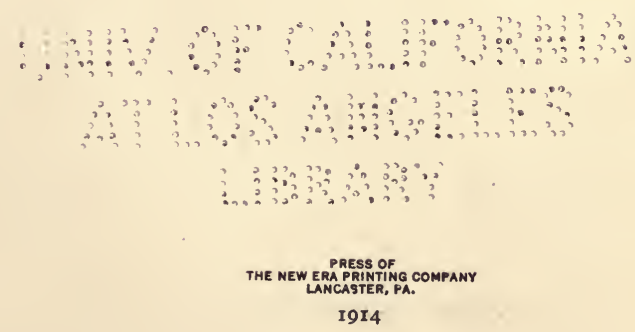


Copyright, 1914, by

C. V. Piper and R. Kent Beattie

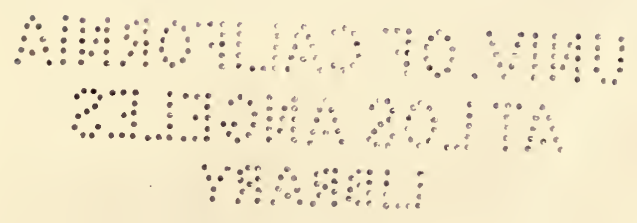

Issued January 22, 1914 


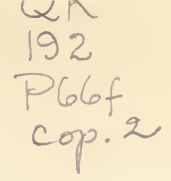

\section{INTRODUCTION.}

This work is an extension of the Flora of the Palouse Region published by the authors in 1901. As enlarged, it covers all of Spokane, Whitman, Asotin, Garfield. Columbia and part of Walla Walla Counties, Washington, and the western portions of Kootenai, Latah, and $\mathrm{Nez}$ Perces Counties, Idaho.

This region embraces the richest wheat lands of the Northwest, the high rolling hills known locally as the Palouse country. The deep black wheat soils are mainly residual, formed by the disintegration of the Columbia basalt which covers the greater part of the region to the depth of 700 meters or more.

The extreme southern part of the area includes the northern portion of the Blue Mountains, here an upraised dome of basalt reaching an altitude of two thousand meters. Separated only by the deep canyon of Snake River are the Craig Mountains, Idaho, geologically a part of the Blue Mountain uplift.

Near the Washington-Idaho line, but mainly in Idaho, a series of low mountains extends from near Moscow northward. These mountains are all formed of metamorphic rocks, mainly granite and quartzite. The highest are Cedar Mountain, about 1,600 meters; Mica Peak, 1,595 meters; and Mount Carlton, 1,720 meters. Outlying lower peaks of the same series are Kamiack Butte and Steptoe Butte.

The drainage of the region is in general westward. The principal rivers are the Snake and the Spokane. The former has hewn an enormous canyon through the basalt, which averages about 500 meters in depth but where it cuts through the Blue Mountains is nearly twice as deep. All of its tributary streams in the area considered, except the Clearwater, are small and flow in shallow canyons.

The Spokane river has filled much of its old valley with glacial gravels, so that only its lower two-thirds now flows in a canyon. On the Spokane gravels occur many species of plants not elsewhere found in the region.

Lakes are numerous in Northwestern Whitman County, Spokane County and adjacent Idaho. Little is known of their geological formation, but most of them lie in the channels of existing or of geologic streams.

The flora of the greater part of the region is Arid Transition, part of it timbered with Yellow pine (Pinus ponderosa), the rest treeless and characterized especially by the abundance of bunchgrass (Agropyron spicatum). The bottom of Snake River canyon is occupied by an extension of Upper Sonoran plants such as sagebrush and other species which commonly grow with it. The highest dome of the Blue Mountains supports various Hudsonian plants such as Subalpine fir, while a broad zone of Canadian Zone plants occupies the slopes down to the Yellow pines. Conspicuous Canadian plants are White fir, Engelmann spruce, and Mountain ash.

The total flora of the region herein described consists of 20 Pteridophytes, 11 Gymnosperms, 270 Monocotyledons and 838 Dicotyledons. Some additions to this list may be expected along the western borders of the area where a number of Upper Sonoran plants are likely to occur, and most of the higher mountain peaks require much more exploration.

The material upon which this flora is based is mainly that contained in the herbarium of the State College of Washington. Thanks are due to the officials of that institution for encouragement and support in the preparation of this volume. 


\section{ANALYTICAL KEYS TO THE FAMILIES.}

Plants with woody bundles, reproducing by spores.

Plants with woody bundles, reproducing by seeds.

Phylum PTERIDOPHYTA, 1.

Phylum SPERMATOPHYTA, 8.

\section{Phylum PTERIDOPHYTA.}

Leaves few, large; stems mostly underground.

Leaves 4 -foliolate, clover-like; spore cases in closed pod-like sporocarps.

Marsileaceae, 5.

Leaves not 4-foliolate; spore cases not in sporocarps.

Spore cases in the tissue of a prominent and distinct fertile lobe of the leaf.

OPHIOGLOSSACEAE, 4.

Spore cases formed of outgrowths from the surface of the leaf.

Leaves numerous, small; stems aerial and underground.

Leaves minute, whorled; stems jointed, hollow. EQUiSETACEAE, 5.

Leaves small, not whorled; stems not jointed, solid.

Spore cases in the enlarged bases of the leaves; stems short, corm-like.

Spore cases in the axils of the leaves; stems elongated.

ISOETACEAE, 7.

Selaginellaceae, 6.

\section{Phylum SPERMATOPHYTA.}

Ovules and seeds not in a closed cavity, usually on the face of an open scale-leaf; stigmas none. Class Gymnospermae, 8.

Ovules and seeds contained in a closed cavity surrounded by one or more closed and modified leaves forming an ovary; stigmas present.

Cotyledon one; stem with no distinction into Class Angrospermae, 12. bark, wood and pith (endogenous); leaves usually parallel-veined; parts of the flowers nearly always in threes. Sub-class

Cotyledons two; stem (with rare exceptions) of bark, wood and pith (exogenous); leaves usually net-veined; parts of the flower in fours, fives or sixes, never in threes. Sub-class Dicotrledones, 72.

Class GYMNOSPERMAE.

Fruit a cone.

Fruit drupe-like.
Pinaceae, 9.

TAXACEAe, 8. 


\section{Class ANGIOSPERMAE.}

\section{Sub-class MONOCOTYLEDONES.}

Plants small, floating, with no distinction of stem and leaves.

Plants with normal foliage.

Inflorence a fleshy spadix.

Lemnaceae, 53.

Inflorescence not a fleshy spadix.

Araceae, 52.

Perianth none, or of bristles, chaffy scales or a hyaline envelope.

Flowers not in the axils of chaffy bracts.

Perianth herbaceous or none.

Flowers solitary, axillary.

Flowers in axillary or terminal

NAJADACEAE, 16. clusters.

Carpels 3 or 6 , united into a compound ovary.

SCHEUChZERIACEAE, 16.

Carpels 2-5 (usually 4), separate. Potamogetonaceae, 14.

Perianth of bristles or chaffy scales.

Flowers in terminal cylindrical spikes.

Typhaceae, 13.

Flowers in axillary globular heads. SPARGANIACEAE, 13.

Flowers in the axils of chaffy bracts.

Stems mostly hollow, jointed; leaves 2-ranked.

Stems solid; leaves 3-ranked.

Perianth present, the parts glume- or petal-

Poaceae, 18.

CyPeraceae, 42. like.

Perianth of glume-like segments.

Perianth at least in part petal-like.

Carpels distinct.

JUNCACEAE, 54.

Carpels united.

Alismaceae, 17.

Ovary superior.

Flowers more or less irregular, surrounded by a spathe.

Flowers regular, without a spathe.

Ovary inferior.

Flowers regular.

Flowers irregular.

Pontederiaceae, 53.

Liliaceae, 58.

IRIDACEAE, 66.

ORCHIDACEAE, 67.

\section{Sub-class DICOTYLEDONES.}

\section{Petals Distinct to the Base or Wanting.}

A. Petals None.

Plant parasitic on other plants and without chlorophyll.

$P$. not parasitic and chlorophyll-bearing.

LORANTHACEAE, 79.

Trees or shrubs.

Leaves opposite.

Leaves alternate.

ACeraceae, 159.

Pistillate flowers not in aments.

Ovary 1-celled.

Ovary 2-4-celled.

ULMACEAE, 78.

Pistillate flowers in aments. 
Calyx present.

Calyx not present.

Herbs (sometimes somewhat woody at base).

Leaves opposite.

Flowers perfect.

Style 1.

Styles 2-5.

Flowers monoecious.

Ovary 1-celled; stamens 2-5.

Ovary more than 1-celled; stamen 1.

Ovary 4-celled.

Ovary 3-celled.

Leaves not opposite.

Flowers monoecious.

Ovary 3-celled, 3-ovuled.

Ovary 1-celled, 1-ovuled.

Flowers with scarious bracts.

Flowers bractless or, if bracted, the bracts not scarious.

Flowers perfect or dioecious.

Pistils more than one.

Stamens perigynous.

Stamens hypogynous.

Pistil one.

Ovary more than 1-celled.

Ovary 2 -celled.

Stamens 6.

Stamens 2.

Ovary more than 2-celled.

Ovary 6-celled.

Ovary 3-5-celled.

Ovary 1-celled.

Ovary superior.

Fruit an akene.

Fruit not an akene.

Ovary partly inferior.

Flowers on a scape.

Flowers on a leafy stem.
Betulaceae, 76.

SALICACEAE, 72.

Isnardia, 169.

Caryophyllaceae, 95.

URTICACEAE, 78.

Callitrichaceae, 157.

EUPHORBIACEAE, 156.

EUPHORBIACEAE, 156.

Amaranthaceae, 90.

Chenopodiaceae, 87.

Rosaceae, 130.

Ranunculaceae, 102.

Cruciferae, 113.

Synthyris, 124.

Aristolochiaceae, 81. Aizoaceae, 91.

Polygonaceae, 81.

Chenopodiaceae, 87.

Heuchera, 130.

SaNTAlaceae, 80.

\section{B. Petals Present.}

1. Stamens numerous, at least more than ten and more than twice the sepals or calyx-lobes.

Calyx free and separate from the ovary.

Pistils more than one.

Ovaries cohering in a ring around a central axis.

Malvaceae, 162.

Ovaries separate or, if united, not cohering in a ring around a central axis.

Stamens perigynous.

Stamens hypogynous.

Rosaceae, 130.

Aquatic plants; leaves not dissected. NymphaEAcEaE, 101.

Terrestrial plants or, if aquatic, the submersed leaves dissected.

Pistil one, with one to several styles and stigmas.

RaNunculaceaE, 102.

Leaves minutely punctate with pellucid dots. HyPERICACEAE, 163.

Leaves not punctate with pellucid dots. 
Ovary simple.

Stamens hypogynous.

Stamens perigynous.

Ranunculaceae, 102.

Ovary compound.

ROSACEAE, 130.

Ovary 1-celled with a central placenta. Portulacaceae, 92.

Ovary several-celled.

Calyx more or less coherent with the surface of the

NYMPHAEACEAE, 101. compound ovary.

Ovary more than 1-celled.

Leaves alternate, with stipules.

Leaves opposite, without stipules.

Rosaceae, 130.

Philadelphus, 127.

Ovary 1-celled.

Placenta basal.

Portulacaceae, 92.

Placenta parietal.

Plants fleshy, leafless or with minute leaves; petals many.

Plants rough-leaved; petals 5-10.

Cactaceae, 167.

LOASACEAE, 166.

2. Stamens not more than twice as many as the petals.

Stamens opposite the petals.

Ovary 2-4-celled.

Ovary 1-celled.

Anthers opening by uplifted valves.

Anthers not opening by uplifted valves.

Stamens not opposite the petals.

Ovary wholly superior.

Ovaries two or more.

Ovaries somewhat united at the base, separate above.

Trees.

Aceraceae, 159.

Herbs.

Rhamnaceae, 160.

BERBERIDACEAE, 111. Portulacaceae, 92.

Ovaries entirely separate.

Stamens united with each other and with the stigma.

Stamens free from each other and from the stigma.

Stamens hypogynous.

Leaves not fleshy.

Leaves thick and fleshy.

SAXIFRAGACEAE, 125.

Stamens perigynous.

Stamens just twice as many as the pistils.

AsClePIAdACEAE, 195.

Stamens not just twice as many as the pistils.

Leaves without stipules. Leaves with stipules.

Ranunculaceae, 102.

Crassulaceae, 124.

Ovary only one.

Crassulaceae, 124.

SAXIFRAGACEAE, 125. ROSACEAE, 130.

Ovary $3-5$-lobed and beaked with a united style.

Ovary not lobed and beaked.

Geraniaceae, 154.

Ovary simple with 1 parietal placenta. Leguminosae, 142.

Ovary compound, as shown by the number of cells, placentae, styles or stigmas.

Ovary 1-celled.

Corolla irregular.

Stamens 6; petals 4.

Stamens and petals 5 . 
Corolla regular or nearly so.

Ovule 1.

Shrubs or trees.

Herbs.

Anacardiaceae, 158.

Ovules more than 1.

CRUCIFERAe, 113.

Placenta central or basal CARYophyllaceae, 95.

Placentae parietal.

Leaves punctate with pellucid dots. Leaves not punctate. Petals 4. Petals 5.

Ovary 2-several-celled.

HYPERICACEAE, 163.

Capparidaceae, 123.

SAXIFRAGACEAE, 125.

Stamens neither just as many nor twice as many as the petals.

Stamens 6, tetradynamous.

Stamens 5, regular.

Stamens either just as many or twice as many as the petals.

Ovules 1 or 2 in each cell of the ovary.

Herbs.

Cells of the fruit 5. Geraniaceae, 154.

Cells of the fruit 10. LinaceaE, 155.

Shrubs or trees.

Low pinnately veined shrubs. Celastraceae, 159.

Palmately-veined trees.

Ovules several to many in

Cruciferae, 113.

BALSAMiNACEAE, 160. each cell of the ovary.

Leaves opposite, with stipules.

Aceraceae, 159.

Leaves, when opposite, without stipules.

Stamens on the calyx. Style 1.

Styles 2-3.

Stamens free from the calyx.

Style 1.

Styles 2-5.

Stamens and calyx free

from the ovary.

Stamens and c a 1 y $x$

united to

Ovary at least half inferior.

the ovary. Araliaceae, 175.

Elatinaceae, 164.

LYTHRACEAE, 167.

SAXIF RAGACEAE, 125.

Pyrolaceae, 185.

Caryophyllaceae, 95.

Ovules and seeds more than one in each cell of the ovary.

Onagraceae, 168.

Ovules and seeds but one in each cell of the ovary. 
Petals 2 or 4.

Stamens 2 or 8 ; fruit indehiscent and nut- or bur-like.

Petals 5 .

Stamens 4; fruit a drupe.

ONAGRACEAE, 168.

CoRnACEAE, 184.

Trees or shrubs; flowers in corymbs. Crataegus, 133.

Herbs; flowers in umbels or heads. UMBELLIFERAE, 176.

\section{Petals More or Less United into One Piece.}

Stamens more numerous than the corolla-lobes.

Ovary 1-celled.

Ovary with 1 parietal placenta.

Ovary with 2 parietal placentae.

Ovary 3-many-celled.

Stamens free from the corolla.

LEguminosae, 142.

Papaveraceae, 112.

Stamens united with the base of the corolla.

Stamens as many as the corolla-lobes or fewer.

Stamens opposite the corolla-lobes.

Stamens alternate with the corolla-lobes or fewer.

Ovary superior.

Corolla more or less irregular.

Fertile stamens 5 .

Fertile stamens 4 or 2 .

ERICACEAE, 188.

Ovules solitary in the cells of the ovary.

Ovary 4-lobed, the style rising from between the lobes.

Ovary not lobed, the style rising from its apex.

Ovules 2 or more, usually numerous, in each cell.

Ovary and pod 1-celled.

Ovary and pod 2-celled.

Corolla regular.

Stamens fewer than the corolla-lobes.

Corolla scarious.

Corolla not scarious.

Style 2-lobed.

Style single.

Primulaceae, 189.

Verbascum, 220.

ens as many as the corolla-lobes.

Stamens as many as th
Ovaries 2 , separate.

Filaments distinct.

Filaments monadelphous.

Labiatae, 211.

VERBENACEAE, 211.

Orobanchaceae, 231.

SCROPHULARIACEAE, 219.

Ovary 1.

Ovary deeply 4-lobed around the style.

Leaves alternate.

Leaves opposite.

Ovary not deeply lobed.

Ovary 1-celled.

Leaves entire, opposite. Gentianaceae, 192.

Leaves, if entire, alternate or basal.

Corolla conspicuously bearded on the upper surface.

Plantaginaceae, 232.

Lycopus, 212.

Veronica, 225.

Apocynaceae, 194.

Asclepiadaceae, 195.

Boraginaceae, 204.

Mentha, 213.

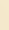

Menyanthaceae, 193. 
Corolla not conspicuously bearded.

HYDROPHYLLACEAE, 202. Ovary 2 or more celled.

Stamens free from the corolla.

Stamens on the corolla. tube.

Stamens 4.

Stamens 5.

Ericaceae, 188.

Fruit a many-
seeded pod or
berry. Sol few-
Fruit a fonaceaE, 217.
seeded pod.

Style 3-lobed. Polemoniaceae, 197.

Style undi vided or 2-cleft.

Whitish or yellow chlorop h y 11 $1 \mathrm{e} s \mathrm{~s}$ plants. Cuscutaceae, 196.

Ovary inferior.

$\mathrm{G} r$ e e $n$ plants. Convolvulaceae, 196.

Anthers united into a ring or tube (syngenesious).

Flowers in an involucrate head on a common receptacle.

Flowers separate, not involucrate. CAMPANULACEAE, 239.

Anthers not united.

Stamens on the ovary.

Stamens on the corolla.

Stamens 1-3.

Stamens 4-5.

Plantaginaceae, 232.

Ovary 1-celled; flowers in a

dense involucrate head. DipsacaceaE, 239.

Ovary 2-5-celled; flowers not in an involucrate head.

Leaves opposite or whorled, when opposite with stipules.

Leaves opposite, without stipules.

Campanulaceae, 239.

Valerianaceae, 237.

Rubiaceae, 233.

Caprifoliaceae, 235. 



\section{FLoRA OF SOUTHEASTERn Washington.}

\section{PHYLUM I. PTERIDOPHYTA. Fern Plants.}

Plant containing woody tissue and vessels in the stem and producing spores asexually which, on germination, develop very small structures called prothallia, on which are borne the sexual reproductive organs from which the asexual plant is developed. The sexual plant is rarely collected, and the classification is based mainly on the characters of the asexual plant.

\section{Class I. FILICINEAE.}

Plant highly organized, vascular, with green usually large leaves; spores borne within the tissue of, or in modified hairs on, modified or unmodified foliage leaves; stem solid, underground (in ours).

\section{Family 1. POLYPODIACEAE.}

Sporangia stalked, surrounded by a more or less complete vertical annulus and bursting transversely; fruit dots on the backs or the margins of the leaves, with or without indusia.

Indusium none; fruit dots roundish.

1. Phegopteris, 2.

Indusium present.

Fruit dots with marginal false indusia formed of the more or less altered edge of the leaf.

Sporangia on a marginal vein which connects the ends of the lateral veins.

Sporangia at or near the ends of unconnected veins.

False indusium continuous.

False indusium not continuous.

Fruit dots on the lower surface or margin of the

2. Pteridium, 2.

3. Pellaea, 2.

4. Cheilanthes, 2. leaves, each with a special indusium.

Fruit dots linear or oblong; indusium more than twice as long as broad.

Fruit dots roundish; indusium less than twice as long as broad.

Indusium conspicuous, peltate.

Indusium inconspicuous, not peltate.

Veins of pinnules pinnately branched.

5. Athyrium, 3. 


\section{PHEGOPTERIS. BEECH FERN.}

Medium sized or small ferns; leaves twice to thrice pinnate or ternate; leaf-stalk continuous with the rootstock; fruit dots small, round, without an indusium, borne on the backs of the veins below or near their ends; veins free.or reticulate.

Phegopteris dryopteris (L.) Fee. Rootstock slender, horizontally creeping; petioles $15-25 \mathrm{~cm}$. tall, pale straw-colored, shiny, bearing a few brownish scales toward the base; blades broadly triangular in outline, $10-20 \mathrm{~cm}$. wide, ternate, the lateral primary divisions bipinnate, the terminal usually tripinnate, all naked at the base; pinnae oblong, 2-5 cm. long, glabrous, pinnately-cleft or divided into 15-25 obtuse lobes; fruit dots near the margin, on the ends of free veins. Common in rich woods.

\section{PTERIDIUM.}

Large, mostly coarse ferns, with variously divided leaves; fruit dots marginal, linear, continuous on a slender thread-like receptacle which connects the tips of free veins; false indusium membranous, formed of the reflexed margin of the leaf.

Pteridium aquilinum pubescens Underw. Bracken or Brake. Rootstock stout, black, subterranean, horizontally-creeping; petioles $30-90 \mathrm{~cm}$. high, erect, pale-green or straw-color; leaf-blades $60-120 \mathrm{~cm}$. long, $30-90 \mathrm{~cm}$. wide, glabrous above, pubescent beneath, ternate, the three branches each bipinnate; pinnules oblong, acutish, mostly entire, the uppermost coalescent, the lower more or less lobed. Common in coniferous woods, otherwise infrequent.

\section{PELLAEA.}

Small and smooth tufted rock ferns; leaves $1-4$ times pinnate, the petioles mostly dark colored; fruit dots terminal on the veins, roundish but often confluent in a continuous band; false indusium continuous, broad, formed by the reflexed margins of the pinnules.

Pellaea densa (Brack.) Hook. Densely tufted, 10-20 cm. high; petioles dark brown, longer than the blades; blades 3-6 cm. long, ovate or ovateoblong, tripinnate; leaflets crowded, linear-lanceolate, 6-12 $\mathrm{mm}$. long, mucronate, entire on the fertile leaves, serrate on the sterile ones. On cliffs and among boulders, Blue Mountains and top of Cedar Mountain, Idaho.

\section{CHEILANTHES.}

Mostly pubescent or tomentose rock-loving and small ferns with much divided leaves; fruit dots on or near the ends of the veins, at first small and distinct, afterwards crowded; sporangia often concealed in the scales or hairs which in many species cover the segments.

The species occurring within our limits have the ultimate segments of the pinnae very small and circular in form and the 
false indusia formed by the incurving of the whole of the leaf margin.
Leaf-blades glabrate above, bipinnate; ultimate segments mostly entire.
Leaf-blades pubescent above, tripinnate or tripinnatifid; ulti- mate segments mostly crenate.
C. gracillima.
C. feei.

Cheilanthes gracillima D. C. Eaton. Lace Fern. Petioles densely tufted, shining brown, 4-8 $\mathrm{cm}$. high, bearing a few scattered lanceolate scales; blades 2-8 cm. long, oblong-lanceolate, bipinnate; pinnae numerous, crowded, pinnately divided into 5-9 oval mostly entire pinnules, glabrate above, pubescent beneath with rusty matted wool. Common in rock crevices in the mountains.

Cheilanthes feei Moore. Petioles densely tufted, 4-6 cm. high, brownish, when young covered with long hair-like scales, at length glabrate; blades 4-8 $\mathrm{cm}$. long, oblong-ovate, the lowest usually remote; ultimate segments orbicular or oblong, entire or crenate, crowded; upper surface with a few long hairs, the lower densely matted with whitish or pale-brown long hairs. Bluffs of Snake River near Almota.

\section{ATHYRIUM.}

Large or small ferns with simple, lobed, 2-3-pinnate or pinnatifid leaves; fruit dots oblong or linear (nearly round when young), oblique, separate; indusium more or less curved, sometimes horseshoe-shaped, often crossing to the outer or lower side of the vein; veins fref.

Athyrium cyclosorum Rupr. Rootstock creeping, short, densely covered by the bases of the petioles; petioles tufted, $20-30 \mathrm{~cm}$. long, straw-colored or brownish; blades delicate, glabrous, broadly oblong-lanceolate or oblongovate, acuminate at the apex, $30-90 \mathrm{~cm}$. long, bipinnate to tripinnatifid; pinnae oblong-lanceolate, $5-20 \mathrm{~cm}$. long; pinnules oblong, obtuse, obscurely 9-13-lobed, the lobes serrate; terminal pinnules confluent; fruit dots short. straight or curved. Common in moist woods.

\section{POLYSTICHUM.}

Large or medium sized ferns, mostly with firm evergreen leaves, pinnate, bipinnate or bipinnatifid, the leaflets serrate and usually auricled at the base on the upper side; veins free; indusium orbicular and peltate, depressed in the center and attached by a stalk to the middle of the fruit dot; fruit dots round.

Polystichum munitum (Kaulf.) Presl. Leaves simply pinnate, 60-120 cm. long, forming a crown; petioles stout, chaffy with numerous brown scales; rachis also chaffy; leaflets linear or lanceolate-linear, acuminate, very sharply and often doubly serrate, sometimes chaffy on the midvein beneath, $3-10 \mathrm{~cm}$. long; fruit dots abundant, arranged in a row on each side of the midrib halfway to the margin. In deep woods of the Blue Mountains.

\section{WOODSIA.}

Small or medium sized ferns, growing in rocky places; leaves once or twice pinnate or pinnatifid; fruit dots round, borne on 
the backs of simply forked free veins; indusium attached under the fruit dot, round or star-shaped, delicate, early withering.

Leaves glabrous or nearly so; lobes of the indusium hair-like. W. oregana. Leaves viscid-puberulent; lobes of the indusium broader at base. W. scopulina.

Woodsia oregana D. C. Eaton. Rootstock short; petioles glabrous, not jointed, brownish below; blades glabrous or slightly roughened, 5-28 cm. long, elliptic-lanceolate, the sterile shorter than the fertile; pinnae triangularoblong, obtuse, pinnatifid; lower pinnae reduced in size and somewhat remote from the others; rachis straw-colored; segments oblong or ovate, dentate or crenate, the teeth often reflexed and covering the fruit dots; indusium deeply cleft into hair-like segments. Common in crevices in rocks usually in shady places.

Woodsia scopulina D. C. Eaton. Similar to W. oregana but the leaves puberulent with minute white jointed hairs and with stalked glands; indusium deeply divided into segments that are broader at the bases. In rock crevices near Spokane and about Lake Coeur d'Alene, Idaho.

\section{FILIX.}

Delicate rock-ferns; leaves 2-3-pinnate or pinnatifid; leafstalks slender; fruit-dots round, borne on the backs of the veins; indusium attached by a broad base on the inner side partly under the fruit dot, early opening and withering away.

Filix fragilis (L.) Underw. Bladder Fern. Rootstock short; petioles 10 $20 \mathrm{~cm}$. long; blades thin, oblong-lanceolate, only slightly tapering below, 10-25 $\mathrm{cm}$. long, 3-7 cm. wide, 2-3-pinnatifid or pinnate; pinnae lanceolate-ovate, irregularly pinnatifid with bluntly or sharply-toothed segments along the margined or winged rachis; texture membranous. In shady woods, mostly on rocks.

\section{Family 2. OPHIOGLOSSACEAE.}

Plant consisting of an underground stem bearing one or more leaves which rise above ground and are divided usually into two parts, a fertile portion and a sterile portion, the latter being the foliage part of the leaf; frequently the fertile portion lacking in some of the leaves; sporangia borne within the tissue of the fertile portion, ringless, opening by a transverse slit.

\section{BotRYChIUM. Grape Fern.}

Rootstock very short, with clustered fleshy roots; sterile part of the leaf ternately or pinnately divided or compound; veins free; fertile segment 1-3-pinnate, each pinnule bearing a double row of sessile sporangia; spores numerous, sulphur-yellow.

Botrychium silaifolium Presl. Stout, rather fleshy, $10-35 \mathrm{~cm}$. high; stem very short and stout, swollen with the contained bud of the succeeding season; leaves one or two, their petioles stout, 2-12 cm. long; sterile blades $8-20 \mathrm{~cm}$. wide, scarcely as long, ternate, the primary divisions tripinnate or quadripinnatifid; ultimate segments obliquely ovate, $1-1.5 \mathrm{~cm}$. long, thick, entire or wavy, the veins few, obscure; sporophyll erect, the petiole stout, the fruiting 
portion quadripinnate below, gradually simpler above; sporangia numerous, crowded, bright yellow. Rare, in wet meadows, near Moscow, Idaho.

\section{Family 3. MARSILEACEAE.}

Plant perennial, herbaceous, rooting in the mud, with slender creeping rootstock and four-foliolate or filiform leaves; sporangia borne within closed receptacles (the sporocarps) which arise from the rootstock near the leafstalks or are consolidated with them; spores of two kinds, large ones (megaspores) and small ones (microspores), both contained in the same sporocarp.

\section{MARSILEA.}

Marsh or aquatic plants; leaves slender petioled, quadrifoliolate, commonly floating on the surface of shallow water; sporocarps ovoid or bean-shaped, peduncled and rising from the petiole or from the rootstock at the base of the petiole, composed of two vertical valves having several transverse compartments (sori) in each valve; also provided inside with a ring which at the opening of the valves swells and tears the sori from their positions; sori composed of both megasporangia and microsporangia.

Marsilea vestita Hook. \& Grev. Rootstock slender, creeping; leaves more or less pubescent with white hairs; petioles slender, 4-12 cm. long; leaflets deltoid-obovate, 4-12 $\mathrm{mm}$. long, mostly entire; sporocarps solitary on the stalks, 4-8 mm. long, 3-5 mm. wide, with a short raphe, a short blunt lower tooth, and an acute upper one, densely pubescent with white appressed hair-like scales; sori 6-11 in each valve. Common on the banks of ponds, frequently aquatic, the leaves floating on the surface in spring and early summer.

\section{Class II. EQUISETINEAE.}

Plants rush-like with hollow jointed stems rising from subterranean rootstocks; sterile leaves reduced to minute scales, whorled, forming sheaths at the joints; fertile.leaves forming a short spike terminating the stem; epidermis rough.

\section{Family 4. EQUISETACEAE.}

Branches, when present, whorled; sporangia one-celled, clustered under the scales of the terminal cone-like spikes; spores of but one kind furnished with narrow ribbon-like appendages (elaters) attached at the middle, coiling around them when moist and spreading in the form of a cross when dry and mature; epidermis impregnated with silica, rough. 


\section{EQUISETUM. HoRsetaIl.}

Perennial plants with extensively creeping rootstocks; stems simple or with whorled branches, furrowed lengthwise, hollow; sporangia adhering on the under side of the shield-shaped scales of the spike, one-celled, opening down the inner side; spores of one kind, with elaters.

Stems annual, of two kinds, the pale brown fertile ones appearing in spring before the herbaceous sterile ones; spikes not apiculate.

Stems perennial, all alike, evergreen; spikes tipped with a rigid point.

Ridges of the stem somewhat roughened with tubercles.

Ridges of the stem nearly smooth.

E. arvense.

Equisetum arvense L. Aërial stems annual, of two kinds; the fertile pale-brown and short-lived, appearing in early spring before the sterile; fertile stems $10-20 \mathrm{~cm}$. tall, simple, terete, bearing about four loose scarious distant sheaths, these whitish with about 12 brownish acuminate teeth; sterile stems pale green, $10-40 \mathrm{~cm}$. tall, marked with 6-19 furrows, with numerous whorls of mostly simple, solid branches, these 4 -angled or rarely 3 -angled; cavity of the main stem small; spike $2-3 \mathrm{~cm}$. long. Common in moist places.

Equisetum hyemale robustum (A. Br.) A. A. Eaton. Scouring rush. Aërial stems evergreen, all alike, $40-120 \mathrm{~cm}$. tall, 5-20 mm. thick, marked with 20-36 furrows; ridges roughened usually with a single series of transverse siliceous tubercles; sheath short, commonly marked with a black girdle at the base and another at the base of the early-falling teeth; spike nearly sessile in the uppermost sheath, 2-3 cm. long, tipped with a rigid point.

Common in moist places. The stems are usually simple but under certain conditions branches may be produced.

Equisetum laevigatum A. Braun. Aërial stems evergreen, pale, mostly simple, $40-90 \mathrm{~cm}$. tall, marked with 14-30 furrows, the ridges nearly smooth; each sheath marked with a black girdle at the base of the deciduous whitemargined teeth, and sometimes with another at its base; wall of the stem thin, the cavity large; spikes $2-3 \mathrm{~cm}$. long, borne on a stalk that usually exceeds the uppermost sheath.

Common in low ground, on railway embankments, etc. When the primary stems are cut off near the base a large number of smaller stems are produced, resulting in a form very similar to $E$. variegatum Schleich.

\section{Class III. LYCOPODINEAE.}

Plant moss-like; stems branched, solid, with numerous small leaves; sporangia solitary in the axils of the leaves or on their upper surface.

\section{Family 5. SELAGINELLACEAE.}

Terrestrial, annual or perennial moss-like plants with branching stems and scale-like leaves, which are many-ranked and uniform, or four-ranked and of two kinds spreading in two planes; spo- 
rangia 1-celled, in the axils of leaves which are so arranged as to form more or less quadrangular spikes; spores of two kinds, some sporangia (megasporangia) containing four megaspores, others (microsporangia) containing numerous microspores.

\section{SELAGINELLA.}

Sporangia in the axils of leaves forming terminal cone-like spikes; sporangia minute, subglobose, opening transversely; megaspores globose, four in each megasporangium; microspores small, numerous.

Selaginella wallacei Hieron. Stems densely tufted, 5-10 cm. long, prostrate or ascending, much branched; leaves closely imbricate, narrowly lanceolate, ciliate margined, channeled on the back, tipped with a slender white awn; spikes quadrangular, $1-1.5 \mathrm{~cm}$. long; bracts like the leaves but the awns shorter and the margin more ciliate. Abundant on the basaltic bluffs of Snake River.

\section{Family 6. ISOETACEAE.}

Plant aquatic, usually submersed or sometimes growing on moist soil, consisting of a short, two or three-lobed fleshy stem with a dense tuft of fibrous roots and a compact cluster of rush or grass-like leaves; sporangia in small lobes enclosed in the bases of the leaves; spores of two kinds, large (megaspores) and small (microspores).

\section{ISOETES. QUILLWORT.}

Stem a fleshy corm rooting just above the base, surrounded above by the swollen bases of the awl-shaped linear leaves; sporangia large, enclosed in the bases of the leaves; those of the outer leaves with megaspores, those of the inner with microspores; the sides of the sporangia more or less covered with a fold of the inner side of the leaf base (the velum).

Leaves without stomata or bast-bundles; plant submersed, with rigid leaves.

Leaves with stomata and bast-bundles; plants of shallow water

I. paupercula. or muddy places, often emersed.

Trunk trilobed; leaves setaceous; megaspores with blunt spines.

Trunk bilobed; leaves not setaceous.

I. minima.

Megaspores with scattered low tubercles or fragmentary walls.

I. howellii.

Megaspores smooth or with low tubercles or wrinkles. I. melanopoda.

Isoetes paupercula (Engelm.) A. A. Eaton. (I. occidentalis Henderson.) Trunk bilobed; leaves $40-60$ or fewer in small plants, spreading, rigid, quadrangular, sharp-pointed, dark-green, 10-20 cm. long; velum narrow, covering about one third of the sporangium; megaspores covered with scattered 
irregular ridges; microspores papillose to spinulose. Submersed in 1-3 feet of water, Lake Coeur d'Alene, Idaho, and doubtless most of the lakes of the region.

Isoetes minima A. A. Eaton. Leaves 6-12, 2-4 cm. long, terete, slender; sporangia not spotted; velum broad, covering most of the sporangium; megaspores with a circle of long spines on the equator; microspores papillose and with few spinules. Wet places near Waverly, Suksdorf.

Isoetes howellii Engelm. Leaves 18-50, rather slender, 10-35 cm. long, erect or nearly so, semi-lunate or helmet-shaped in cross section, striate, with abundant stomata above; megasporangia dark-brown, the megaspores bright white, rough, with low, more or less confluent tubercles; microsporangia olivaceous, elliptic or oblong, much pitted, 6-8 mm. long, partly covered by the narrow wings of the velum, the microspores unsymmetrical, spinulose on the ridges.

Borders of ponds near Moscow, Idaho. The species has been redescribed as Isoetes underwoodii Henderson.

Isoetes melanopoda J. Gay. Leaves 15-60, dark-colored at base, 10-45 $\mathrm{cm}$. long, with four principal and numerous peripheral bast-bundles; velum very narrow; sporangia spotted; microspores spinulose. Shallow ponds in the Craig Mountains, Idaho, Heller.

\section{PHYLUM II. SPERMATOPHYTA. SeEd Piants.}

Highly organized plants, mostly producing flowers and always producing seeds, each of which contains a young plant (the embryo) usually composed of a stem-like structure (the caulicle or hypocotyl), one or more rudimentary leaves (the cotyledons) and a terminal bud (the plumule or epicotyl); megasporangia (ovules) usually borne on the side or face of an open or closed modified leaf (the carpel); microsporangia (anther-sacs) on the end or side of a modified leaf (the filament) and bearing numerous microspores (pollen grains).

\section{Class IV. GYMNOSPERMAE.}

Ovules (megasporangia) naked, not enclosed in an ovary, usually on the face of an open scale but sometimes on the axis, in which case the scale is rudimentary or wanting; stigmas none; cotyledons mostly several in a whorl, occasionally only two; perianth none.

\section{Family 7. TAXACEAE. Yew Family.}

Trees or shrubs with evergreen linear leaves; flowers dioecious, the staminate of a few scaly bracts and a few naked stamens, the ovule-bearing of an erect ovule which in fruit becomes a bony seed surrounded by a fleshy disk. 


\section{TAXUS.}

Evergreen trees or shrubs with spirally arranged, shortpetioled linear flat leaves, spreading so as to appear two-ranked; aments very small, axillary and solitary, sessile or nearly so; staminate aments consisting of a few scaly bracts and 5-8 stamens; ovules solitary, axillary, erect, subtended by a fleshy ring-shaped disk; fruit consisting of the fleshy disk which becomes cup-shaped, red and nearly encloses the bony seed.

Taxus brevifolia Nutt. Western Yew. Small tree, 4-10 m. high, sometimes much larger, the bark loose and reddish; branches slender, horizontal or drooping; leaves horizontal, 1-2 cm. long, linear, acuminate, cuspidate, with revolute margins, shiny green above, glaucous beneath, abruptly narrowed at the base into a short petiole; staminate aments globose, $3 \mathrm{~mm}$. broad; fruit bright red, insipid in taste; stone broadly ovate, acute, somewhat flattened, $3-4 \mathrm{~mm}$. long. Along streams in the mountains.

\section{Family 8. PINACEAE. Pine Family.}

Resinous trees or shrubs, mostly with evergreen narrow entire or scale-like leaves; pollen sacs and ovules borne in separate spikes (aments); usually monoecious, rarely dioecious; ovules solitary or several together on the surface of a scale, which is in the axil of a bract in most genera; fruit a cone with numerous, several or few woody papery or fleshy scales; seed wingless or winged.

Scales of the cones few (3-12); leaf-buds naked.

Fruit fleshy and berry-like.

Fruit a dry cone.

Scales of the cone numerous; leaf-buds scaly.

Leaves clustered on very short lateral branchlets.

Cone-scales woody; leaves needle-shaped, 2-5 in a sheath, persistent.

Cone-scales thin; leaves filiform, clustered, but not in sheaths, deciduous.

Leaves scattered on the branches.

Branchlets rough from the prominent persistent leaf-bases; bracts smaller than the scales.

Branchlets smooth; leaf-scars not prominent; bracts longer than the cone-scales.

Cones erect; scales deciduous; leaves sessile. 20. ABIES, 11.

Cones pendulous; scales persistent; leaves petioled.

15. Juniperus, 9.

16. ThuJA, 10.

17. Pinus, 10.

18. LARIX, 11.

19. Picea, 11.

\section{JUNIPERUS. JUNIPER.}

Evergreen shrubs or small trees; leaves scale-like or needle-like, opposite or in whorls of three; flowers dioecious or monoecious, small and lateral; anther-cells 3-6, attached to the lower edge of the shield-shaped scale; ovule-bearing aments ovoid, of 3-6 fleshy coalescent scales, each 1-ovuled, in fruit forming a bluishblack berry. 
Juniperus scopulorum Sargent. Rocky Mountain Juniper. A shrub or scraggly tree, 1-6 m. high, much branched, the branches often drooping; foliage often glaucous; leaves small, acute, each with a linear indistinct gland on the back; berries blue-black with a thick whitish bloom, maturing the second year; seeds usually 2, grooved longitudinally. Spokane.

\section{ThUja. ARbor Vitae.}

Evergreen trees or shrubs; leaves small or minute, scale-like, appressed, opposite, 4-ranked; flowers monoecious, both kinds terminal, the staminate globose, the ovule-bearing ovoid or oblong, small, their scales opposite, each bearing 2, rarely 2-5 erect ovules; cones ovoid or oblong, mostly spreading or recurved, their scales 6-10, coriaceous, opposite, dry, spreading when mature.

Thuja plicata Donn. Giant Cedar. Handsome pyramidal tree, $30-50$ or even $80 \mathrm{~m}$. high, $1-5 \mathrm{~m}$. in diameter, the trunk rapidly tapering from the large base; branches usually somewhat drooping; bark pale grayish, thin, fibrous, longitudinally fissured; wood soft, the heart-wood reddish, odorous; leaves oblong-ovate, bright green, rapidly tapering to an acuminate cuspidate apex; staminate aments minute, dark purple; pistillate aments usually crowded near the tips of the branchlets; cones oblong, 1-1.5 cm. long, light colored, consisting of about 6 pairs of scales, these elliptical, mucronate on the back near the apex. In moist places, Kamiack Butte, and the foothills of the Coeur d'Alenes but absent from the Blue Mountains.

\section{PINUS. PINE.}

Evergreen trees with two kinds of leaves; the primary ones scale-like with deciduous tips; the secondary ones forming the ordinary foliage, needle-like, arising from the axils of the former in clusters of 2-5; ovule-bearing aments solitary or clustered, each composed of numerous minute bracts, each with an ovulebearing scale in its axil; ament, upon maturing, becoming a cone; the scales elongating and becoming woody; seeds two on the base of each scale.

Cone scales without prominent thickenings; leaves five in a fascicle.

P. monticola.

Cone scales with prominent thickenings.

Leaves two in a fascicle.

Leaves three in a fascicle.

P. murrayana.

$P$. ponderosa.

Pinus monticola Dougl. Western White Pine. Tree 50-100 m. high, 1-2 m. in diameter; bark gray, rather smooth, longitudinally cracked; leaves pale green, in fascicles of five, 4-7 cm. long; cones narrowly cylindrical, $15-30 \mathrm{~cm}$. long, about $4 \mathrm{~cm}$. thick. In the mountains at low altitudes.

Pinus murrayana Balf. Lodgepole Pine. Small tree, 10-20 m. tall, the dark bark usually deeply checked; leaves 4-8 cm. long, dark green; cones small, ovoid, 4-5 cm. long; scales thickened at the apex and armed with a stout point. In the mountains at low altitudes often forming dense pure growths of nearly equal-sized trees. 
Pinus ponderosa Dougl. Yellow or Bull Pine. Large tree, $30-80 \mathrm{~m}$. tall, 1-4 $\mathrm{m}$. in diameter, the reddish bark thick and deeply furrowed; leaves in fascicles of three, $15-25 \mathrm{~cm}$. long, minutely serrulate; staminate aments cylindric, somewhat flexuous, 4-6 cm. long, crowded at the base of young shoots; pistillate aments 1-6, greenish or purplish, borne near the apex of the shoots of the season; cones brown, ovoid, $7-10 \mathrm{~cm}$. long, 5-6 cm. thick, frequently in clusters of $3-5$; scales much thickened near the apex and bearing a stout sharp point. Throughout our limits where the soil is gravelly.

\section{LARIX.}

Tall trees with horizontal or ascending branches and small narrowly linear deciduous leaves, without sheaths, in clusters on short lateral scaly bud-like branchlets; aments short, lateral; staminate from leafless buds; ovule-bearing buds commonly leafy at the base and the aments red; mature cones ovoid or cylindrical, small, erect; scales thin, spirally arranged, obtuse, persistent; ovules two on the base of each scale, ripening into two reflexed somewhat winged seeds.

Larix occidentalis Nutt. Western Larch or Tamarack. A large tree, 30-70 m. high, 1-2 m. in diameter; bark thick, reddish, longitudinally fissured; branches short, horizontal, the branchlets glabrous; buds spherical; leaves narrowly linear, 2-4 cm. long, in alternate fascicles of 12-18, deciduous; cones ovate-cylindric, reddish when young, brown when mature, $2-3 \mathrm{~cm}$. long; scales broadly oblong, truncate, ciliate-fringed when young; bracts scarious, dilated at the base, the narrow terminal part exceeding the scale. A common tree in the timbered foothills.

\section{PICEA.}

Evergreen conical trees, with linear short four-sided leaves, spreading in all directions, falling away from the twig in drying, leaving it covered with small projections; leaf-buds scaly; staminate aments axillary, nearly sessile; ovule-bearing aments terminal, ovoid or oblong; ovules two on the base of each scale, reflexed, ripening into two more or less winged seeds; cones ovoid or oblong, obtuse, pendulous; their scales numerous, spirally arranged, thin, obtuse, persistent.

Picea engelmanni Parry. Engelmann Spruce. Handsome pyramidal tree, $30-40 \mathrm{~m}$. tall, the bark gray and scaly; branchlets pubescent; leaves darkgreen, quadrangular in cross section, very sharply pointed, $1.5-2 \mathrm{~cm}$. long; cones cylindric-ovate, 3-6 $\mathrm{cm}$. long, the scales ovate, truncate, rounded or retuse, crenulate. In moist places in the mountains.

\section{ABIES.}

Evergreen trees with linear flat scattered sessile leaves, spreading so as to appear 2-ranked but in reality spirally arranged, commonly quite persistent in drying; staminate aments axillary; ovule-bearing aments lateral, erect; ovules two on the base of each scale, reflexed; the scale shorter than or exceeding the thin 
papery bract; cones erect, subcylindrical or ovoid, their orbicular or broader scales deciduous from the persistent axis.

Leaves notched at the apex, usually spreading horizontally on the branches; cones green.

Leaves not notched at the apex, not horizontally spreading; cones purple.

A. grandis.

A. lasiocarpa.

Abies grandis Lindl. White Fir. Large tree, sometimes $100 \mathrm{~m}$. tall and $2 \mathrm{~m}$. in diameter, with thin, dark gray, rather smooth bark; branches horizontal or the lower drooping; leaves linear, obtuse or notched, shining green above, marked beneath by two white lines, $18-30 \mathrm{~mm}$. long, usually arranged in two ranks, giving the foliage a flattened appearance; cones cylindric-oblong, 7-10 cm. long, dark green, more or less covered with drops of resin; scales broader than long, entire; bracts small. In the mountains; especially abundant in the Blue Mountains.

Abies lasiocarpa (Hook.) Nutt. Subalpine Fir. Narrowly conical usually densely branched trees, $20-30 \mathrm{~m}$. high and $20-40 \mathrm{~cm}$. in diameter; bark pale, rather smooth but with large resin blisters; leaves $3-5 \mathrm{~cm}$. long, acute, usually sharp-pointed; cones narrowly barrel-shaped, usually dark-purple, puberulent, 5-10 cm. long; bracts usually not exserted. Blue Mountains, at 6000 feet altitude.

\section{PSEUDOTSUGA.}

Very large trees, at first pyramidal and spruce-like, often at last more spreading; leaves linear, flat, somewhat two-ranked by a twist at the base; aments from the axils of the leaves of the preceding year; staminate aments in an oblong or cylindrical column, surrounded or partly enclosed by numerous, conspicuous, round bud-scales; ovule-bearing aments with the scales much shorter than the broadly linear acutely two-lobed bracts; cones maturing the first year; scales persistent.

Pseudotsuga mucronata (Raf.) Sudw. Red Fir, Douglas Spruce. Very large tree, $50-100 \mathrm{~m}$. high, 1-4 m. in diameter; bark thick, reddish within, deeply cracked longitudinally; branches usually short and horizontal; leaves linear, obtusish, $20-30 \mathrm{~mm}$. long, narrowed at the base, dark green above, paler beneath; staminate aments light brown, oblong-cylindric, $1 \mathrm{~cm}$. long, half enclosed in the large bracts; pistillate aments green or purplish; cones pendent, cylindric-ovate, $6-10 \mathrm{~cm}$. long, the tridentate bracts conspicuously exceeding the scale. A very common tree.

\section{Class V. ANGIOSPERMAE.}

Ovules (megasporangia) enclosed in a cavity (the ovary) formed by the infolding and uniting of the margins of a modified rudimentary leaf (carpel), or of several such leaves joined together, in which the seeds are ripened; stigmas present; cotyledons one or two, very rarely wanting; perianth present or wanting. 


\section{SUB-CLASS I. MONOCOTYLEDONES.}

Embryo of the seed with but a single cotyledon, that is with the first leaves of the germinating plantlet alternate; stem composed of a mass of soft tissue in which the woody bundles appear in cross section to be irregularly imbedded, there being no distinction into bark, wood and pith; leaves usually parallel-veined, mostly alternate and entire, commonly sheathing the stem at the base and of ten with no distinction of blade and petiole; parts of the flowers mostly in threes.

\section{Family 9. TYPHACEAE. Cat Tail Family.}

Marsh or aquatic herbs with creeping rootstocks and linear flat sheathing leaves; stems erect, terete; flowers monoecious, densely crowded in terminal spikes which are subtended by spathaceous bracts; ovary one, 1-2-celled, with as many persistent styles; fruit nutlike.

\section{TYPHA.}

Flowers in a dense cylindrical spike; staminate and pistillate portions of the spike contiguous; stamens with very short connate filaments, mixed with numerous long hairs; ovary longstalked, 1-celled, surrounded by numerous bristles and rudimentary ovaries; fruit minute, usually splitting on one side.

Typha latifolia L. Cat-tail. Stout, 1-3 m. tall; leaves flat, sheathing at base, 1-2 cm. wide; pistillate and staminate portions of the spike close together, each 8-30 cm. long, the pistillate dark brown; stigmas rhombicspatulate; pollen grains in fours. In shallow water, not rare.

\section{Family 10. SPARGANIACEAE. BUR-REEd FAMILY.}

Marsh or pond herbs with creeping rootstocks and erect or floating stems; leaves linear, alternate, 2-ranked, sessile, sheathing at the base; flowers monoecious, densely crowded into globose heads which are in a raceme on the upper parts of the stem and branches, the staminate above; spathes linear; perianth of a few chaffy scales; stamens usually 5 ; fruit mostly 1-celled, nut-like.

23. SPARGANIUM. BUR REED.

Characters of the family. 
Fertile flowers sessile; fruit broadly obovoid.

Fertile flowers stalked; fruit fusiform.

Heads all axillary; inflorescence branched.

Heads, or at least some of them, supra-axillary.

Leaves, or at least the larger ones, keeled; usually terrestrial.

Leaves not keeled; floating aquatics.

Beak of fruit short-conical; stigma oblong.

Beak of fruit slender; stigma linear.
S. eurycarpum.

S. androcladum.

S. simplex.

S. minimum.

S. angustifolium.

Sparganium eurycarpum Engelm. Stems stout, erect, 100-150 cm. high; leaves flat, slightly keeled; staminate heads several to many; pistillate heads $2-4$, sessile or peduncled, $15-30 \mathrm{~mm}$. in diameter; fruit obtusely 4 or 5 angled, $7-8 \mathrm{~mm}$. long, abruptly tipped in the center. Common in marshes and on lake margins.

Sparganium androcladum (Engelm.) Morong. Stems stout, 40-100 cm. high; leaves 5-12 mm. wide, dark green; inflorescence branched, the branches strictly axillary, each bearing 3-7 staminate heads and usually 1 or 2 pistillate heads; fruiting heads $2-2.5 \mathrm{~cm}$. in diameter; fruits dull, the fusiform body 5-6 mm. long, the beak about $3 \mathrm{~mm}$. long. Mouth of St. Joe River, Idaho.

Sparganium simplex Huds. Stems rather stout, $30-60 \mathrm{~cm}$. high; leaves thin, $6-15 \mathrm{~mm}$. broad, scarious-margined below; inflorescence simple; fruiting heads $12-25 \mathrm{~mm}$. in diameter, some of them supra-axillary; fruit fusiform, somewhat shiny, the body 3-4 mm. long, tipped with a beak about as long; stalk 1-2 mm. long; stigmas linear. In bogs or pond margins.

Two forms occur in our limits, one having heads about $2 \mathrm{~cm}$. in diameter with very shiny fruits whose conical body is shorter than the beak; the other with smaller heads, $15 \mathrm{~mm}$. in diameter, and the fruits rather dull, with the body abruptly tipped with a shorter beak. Perhaps neither plant is true S. simplex.

Sparganium minimum Fries. Aquatic; stems very slender, $10-40 \mathrm{~cm}$. long; leaves thin and grass-like, $2-4 \mathrm{~mm}$. broad, floating; inflorescence simple; heads sessile or nearly so, the pistillate about $1 \mathrm{~cm}$. in diameter when mature; nutlets smooth, ovoid, conically short-beaked, easily detached. In the lakes of Spokane County and northern Idaho.

Sparganium angustifolium Michx. Aquatic; stems slender, 30-100 cm. long; leaves very long and narrow, rather firm, 2-4 mm. wide; inflorescence simple; heads sessile or the lower peduncled, the pistillate $15-20 \mathrm{~mm}$. in diameter when mature; nutlets abruptly slender-beaked, firmly attached. In the lakes of northern Idaho.

\section{Family 11. POTAMOGETONACEAE.}

Herbs, submersed or floating in fresh or salt water; with mostly 2-ranked leaves; flowers mostly small, solitary or in spikes, unisexual or perfect, regular; perianth none or rarely sheath-like; stamens 1-4; carpels 1-4, each 1-ovuled; fruits drupaceous or membranaceous.

Flowers perfect, in spikes.

Flowers unisexual, in axillary clusters.
24. Potamogeton, 15. 25. ZaNNichellia, 16. 


\section{POTAMOgetoN. Pondweed.}

Leaves alternate or the uppermost opposite, often of two kinds, the submersed mostly linear, the floating lanceolate, ovate or oval; spathes enclosing the young buds usually perishing soon after expanding; flowers small, perfect, spicate, green or red; parts of flower in fours; ovaries 4, sessile, distinct, 1-celled, 1-ovuled.

Leaves all submersed, linear.

Stipules free from the blades; fruit 1.5-2 $\mathrm{mm}$. long.

Stipules united to base of blades; fruit 3-4 mm. long.

Leaves not all submersed; floating ones broad.

Submersed leaves ribbon-like, linear.

Submersed leaves lanceolate.

Floating leaves cordate at base.

Floating leaves rounded or tapering at base.

Floating leaves $30-50$ nerved.

Floating leaves $10-25$ nerved.

P. californicus.

$P$. pectinatus.

P. epihydrus.

$P$. pulcher.

P. amplifolius.

P. americanus.

Potamogeton californicus (Morong) Piper. Stems slender, much branched, flattened or somewhat winged, $30-50 \mathrm{~cm}$. long, wholly submersed; leaves linear, sessile, $2-5 \mathrm{~cm}$. long, $0.2-1 \mathrm{~mm}$. wide, 3-5-nerved, the midvein thick; peduncles erect, club-shaped; spike containing 6-12 globose fruits, these crested on the back, angled in front, short-beaked, about $2 \mathrm{~mm}$. long. Ponds, common.

Potamogeton pectinatus L. Stems filiform, branched, $30-90 \mathrm{~cm}$. long; leaves narrowly linear, attenuate to the apex, 1-nerved, $2-10 \mathrm{~cm}$. long; peduncles slender; flowers in whorls; fruit obliquely obovoid, compressed, turgid, $3.5-4.5 \mathrm{~mm}$. long; style straight or nearly so. In ponds, not rare.

Potamogeton epihydrus Raf. ( $P$. nutlallii C. \& S.) Stems simple or branched, compressed, $60-120 \mathrm{~cm}$. long; floating leaves oblong, obtuse or acutish, attenuate into a short petiole; submersed leaves numerous, linear, thin, 5-7-nerved, with a coarse cellular reticulation between the inner nerves; stipules short, obtuse; spikes 1-4 cm. long, on stout peduncles; fruit obovoid, apiculate, 2-3 mm. long, 3-keeled when dry. Waitsburg, Horner.

Potamogeton pulcher Tuckerm. Stems mostly simple, slender, terete, black-spotted, $30-70 \mathrm{~cm}$. long; floating leaves large, ovate, somewhat cordate at base, 25-37-nerved, large, 5-10 cm. long; submersed of two kinds, the upper ones very thin, 10-15-nerved, lanceolate, long-acuminate, the lowermost oval or oblong and thicker; peduncles as thick as the stem, 5-10 cm. long; spikes $2-4 \mathrm{~cm}$. long; fruit 4-4.5 mm. long, turgid, beaked, 3-keeled. Reported from Lake Tesemini (Spirit Lake), Idaho.

Potamogeton amplifolius Tuckerm. Stem stout, simple or branched; floating leaf-blades oblong-oval, acute, rounded at the base, 5-10 cm. long, on petioles one to two times as long; submersed leaves mostly linear-lanceolate to lanceolate, the uppermost frequently oval or oblong; stipules large, 5-10 cm. long, spike stout, dense, 2-4 cm. long, on stout peduncles; fruit large, 4-5 mm. long, with a broad beak. Pullman, rare.

Potamogeton americanus C. \& S. (P. lonchitis Tuckerm.) Stems slender, flaccid, branched, 50-100 cm. or more long; floating leaves narrowly elliptic, pointed at each end, 5-10 cm. long, many-nerved, narrowed at the base into a petiole about as long; submersed leaves linear; stipules narrow, $3-8 \mathrm{~cm}$. long; spike dense, $2-4 \mathrm{~cm}$. long, on rather stout peduncles; fruit about $3-4 \mathrm{~mm}$. long. In ponds and pools, not common. 


\section{ZAN NICHELLIA.}

Submersed herbs; leaves small, linear; stems, flowers and leaf buds at first enclosed in a hyaline envelope; flowers unisexual, in axillary clusters, each composed of one staminate and 2-5 pistillate flowers; staminate flower with no perianth; pistillate with a funnel-shaped undivided perianth; ovary flask-shaped with a short style.

Zannichellia palustris L. Stems slender, branching, leafy, 10-60 cm. long; leaves thin, filiform, 1-nerved, 5-8 cm. long; fruit nearly sessile, flattened, somewhat incurved, often more or less toothed on the back, 2-3 mm. long, about twice as long as the style. In clear ponds and slow streams.

\section{Family 12. NAJADACEAE.}

Submersed aquatic herbs with slender branching stems; leaves flat or filiform, opposite, alternate or whorled; flowers monoecious or dioecious, axillary, solitary; staminate enclosed in a membranous sheath; stamen 1 , sessile or stalked with a 1-4 celled anther; ovary 1 with a short style, 1-celled, 1-ovuled; endosperm none.

\section{NAJAS.}

Characters of the family.

Najas flexilis (Willd.) Rostk. \& Schmidt. Stems slender; leaves numerous, linear, acute or acuminate, $1-2 \mathrm{~cm}$. long, minutely serrulate, the sheath broadlyoblong; fruit $3 \mathrm{~mm}$. long, oblong-linear, tipped with the persistent style; seed pale-brown, shining. Near Viola, Idaho, Henderson.

\section{Family 13. SCHEUCHZERIACEAE. ARrow Grass} FAMILY.

Swamp plants with narrow leaves and terminal racemose or spike-like inflorescences; flowers perfect or unisexual, naked or with a usually evanescent bract-like perianth; stamens 2 or 3 ; carpels 3-6, each 1-2-ovuled, more or less united till maturity, dehiscent or indehiscent.

27. TRIGLOCHIN. ARrow Grass.

Flowers small, perfect, in terminal scapose, spike-like racemes; perianth segments 3-6, greenish, evanescent; stamens 3-6; anthers 2-celled, on very short filaments; carpels 3-6, united into a compound pistil; ovules solitary; capsule, when ripe, splitting into 3-6 carpels with a persistent central axis.

Triglochin maritima L. Scapes subterete, $20-40 \mathrm{~cm}$. high, exceeding the leaves; leaves thickish, narrow; raceme elongate, $15-40 \mathrm{~cm}$. long; fruit ovoid, angled, 5-6 mm. long; carpels usually 6 , sometimes 3 . In salt marshes. 


\section{Family 14. ALISMACEAE.}

Aquatic or marsh herbs with fibrous roots, scape-like stems and basal long-petioled leaves; inflorescence a raceme or panicle; flowers regular, perfect, monoecious or dioecious, pedicelled; the pedicels whorled and subtended by bracts; sepals 3, persistent; petals 3 , deciduous; stamens 6 or more; ovaries numerous or rarely few, 1-celled, usually 1-ovuled; carpels becoming akenes in fruit; endosperm none.

Carpels in a ring upon a small flat receptacle; leaves ovate (in ours).

Carpels crowded in many series upon a large convex receptacle; leaves sagittate (in ours).

28. Alisma, 17

29. SagitTaria, 17.

\section{ALISMA.}

Perennial or rarely annual herbs with erect or floating leaves; inflorescence a panicle or umbel-like panicle; flowers perfect, small, numerous, on unequal 3-bracted pedicels; petals small; stamens 6 or 9 ; ovaries few or many, more or less in one whorl on a small flat receptacle.

Alisma plantago-aquatica L. Water Plantain. Scapes stout, 30-100 cm. tall; leaves all radical, erect or floating, the petioles usually long; the blades ovate or oblong, acute, rounded or subcordate at the base, 5-15 cm. long, 5-7nerved; flowers in a large panicle composed of 3-6 whorls of branches, these again branched once or twice; flowers on pedicels $1-5 \mathrm{~cm}$. long; petals white, hardly exceeding the sepals; akenes obliquely obovate, compressed, arranged in a circle on the receptacle. Common in ponds and wet places.

\section{SAGITTARIA. ARROWHEAD.}

Perennial aquatic or marsh herbs with basal long-petioled leaves; flowers monoecious or dioecious, borne near the summits of the scapes in whorls of 3 , the staminate usually uppermost; petals usually conspicuous; stamens usually numerous; ovaries numerous, crowded in globose heads.

Petioles short, usually curved; bracts $8-20 \mathrm{~mm}$. long; usually terrestrial.

Petioles long and slender; bracts 4-6 mm. long; aquatic.

S. arifolia.

S. cuneata.

Sagittaria arifolia Nutt. Terrestrial or rarely aquatic, $10-50 \mathrm{~cm}$. tall; petioles stout, ascending, 10-30 cm. long; blades $6-18 \mathrm{~cm}$. long, sagittate, acute, the basal lobes diverging and usually much smaller than the terminal one; sepals becoming reflexed; petals white; fruiting head globose, 8-15 $\mathrm{mm}$. in diameter; akenes $2 \mathrm{~mm}$. long, obovate-cuneate, much flattened, with a minute erect beak. Common on the margins of ponds and streams.

Sagittaria cuneata Sheldon. Submerged aquatic; petioles long and slender; blade floating, the lobes narrow; inflorescence scarcely raised above the water; fruiting head $10 \mathrm{~mm}$. in diameter; akenes $1 \mathrm{~mm}$. long. Phileo Lake, Suksdorf. This is probably only an aquatic form of $S$. arifolia. 


\section{Family 15. POACEAE. Grass Family.}

Annual or perennial herbs, rarely shrubs or trees; stems (culms) generally hollow; nodes closed; leaves 2-ranked, sheathing, the sheaths usually split to the base on the side opposite the blade; a scarious or membranous appendage (the ligule) borne at the opening of the sheath, rarely obsolete; inflorescence a spike, a raceme or a panicle, consisting of spikelets composed of two to many 2-ranked imbricated bracts; the lowest two (glumes) without flowers or rarely wanting; one or more of the upper (lemma) containing in its axil a flower, which is usually enclosed by a bract-like, generally 2-keeled, awnless organ (palea) opposite the glume and with its back toward the axis (rachilla) of the spikelet; lemma sometimes bearing an indurated thickening (callus) at the base; flowers perfect or sometimes monoecious or dioecious, subtended by 1-3 minute hyaline scales (lodicules); stamens 1-6, usually 3; ovary 1-celled, 1-ovuled; styles 1-3, commonly 2 and lateral; stigmas hairy or plumose; fruit a seedlike grain (caryopsis) or rarely a utricle; endosperm starchy.

Spikelets with one perfect flower.

Spikelets with only one flower.

Rachilla jointed below the glumes which fall with the seed.

Rachilla jointed above the glumes which do not fall with the seed.

First two lemmas empty, variously modified, the third with a flower.

First lemma flower-bearing.

Spikelets crowded in two rows in onesided spikes.

Spikelets not in one-sided spikes.

Spikelets in two opposite rows.

Hordeum in Tribe 7. HORDEAE.

Spikelets not in two opposite rows. Tribe 3. AgrostideaE.

Spikelets with a staminate or neutral flower in

Tribe 1. Paniceae.

Tribe 2. Phalarideae.

Tribe 6. ChlorideaE. addition to the perfect one.

Rachilla jointed below the glumes which fall with the seed.

Rachilla jointed above the glumes which do

Tribe 1. Paniceae. not fall with the seed.

Imperfect flower below the perfect.

Imperfect flower above the perfect.

Arrhenatherum in Tribe 4. Aveneae.

Holcus in Tribe 4. Aveneae.

Spikelets with two or more perfect flowers.

Spikelets sessile on the rachis; inflorescence a spike.

Spikelets pedicelled; inflorescence a panicle,

Tribe 7. HORDEAE. 
spike-like panicle or raceme.

Lemmas shorter than the glumes, usually with a bent awn rising from the back.

Lemmas longer than the glumes, awnless or with a straight apical awn.

Tribe 4. Aveneae.

Tribe 5. Festuceae.

\section{TRIBE 1. PANICEAE.}

Spikelets in clustered racemes or spikes.

30. EсHiNOCHLOA, 20.

Spikelets not in clusters.

Inflorescence a dense spike-like panicle; pedicels bristly.

Inflorescence a loose panicle; pedicels not bristly. 32. Panicum, 21.

TRIBE 2. PHALARIDEAE.

First and second lemmas small, empty and not awned. 33. Phalaris, 21.

\section{Tribe 3. AGROSTIDEAE.}

Lemma with a long terminal awn and closely enveloping the grain.

Fruiting lemma thin and membranaceous.

Fruiting lemma firm and indurated.

Awns 3-branched.

Awns simple, twisted.

Lemma awnless or short-awned and loosely enveloping the grain.

Inflorescence a dense spike-like raceme or panicle.

Lemma awnless.

Lemma awned.

Glumes awnless.

Glumes awned.

Inflorescence a loose panicle.

Palea 1-nerved, stamen 1.

Palea 2-nerved; stamens 3.

34. Muhlenbergia, 22.

35. Aristida, 22.

36. STIPA, 22.

Lemma 1-nerved, rarely 3-nerved; fruit a utricle.

Lemma 3-5-nerved; fruit a grain.

31. Chaetochloa, 20.

Callus with a tuft of long hairs at the base.

Callus naked.

37. Phleum, 23.

38. Alopecurus, 24.

39. POLYPOGON, 24.

40. Cinna, 24.

41. Sporobolus, 25.

42. Calamagrostis, 25.

43. Agrostis, 26.

Tribe 4. AVENEAE.

Perfect flower only one, the other staminate.

Lower flower perfect, awnless; upper staminate, awned.

Lower flower staminate, long awned; upper perfect, awnless.

44. Holcus, 27. ect flowers two or more.

Awn of lemma from between the 2 terminal teeth.

Awn of lemma dorsal or none.

Spikelets large, more than $15 \mathrm{~mm}$. long.

Spikelets small, less than $15 \mathrm{~mm}$. long.

Lemma erose-truncate.

Lemma 2-toothed.

45. ArrhenatherUM, 27.

46. Merathrepta, 28.

47. Avena, 28.

48. Deschampsia, 28.

49. Trisetum, 29. 
Tribe 5. FESTUCEAE.

Lemma 3-nerved, rarely 1-nerved.

Glumes obtuse, very unlike.

50. Sphenopholis, 30 .

Glumes acute, subequal.

Panicle close; spikelets 2-4-flowered. 51. KoEleria, 30.

Panicle looser; spikelets usually manyflowered.

Lemma 5-nerved or more.

52. ERAGROSTIS, 30.

Spikelets with the upper florets sterile and folded about each other.

Spikelets with the upper florets perfect, or narrow and abortive.

Stigmas arising below the apex of the ovary. 54. Bromus, 32.

Stigmas arising at the apex of the ovary.

Lemmas compressed and keeled.

Lemma awn-pointed.

Lemmas pointless.

55. DACTYLIS, 33.

Lemmas convex or rounded on the back.

Lemmas acute or awned.

56. POA, 33.

Lemmas obtuse and scarious at apex.

57. Festuca, 36.

58. Panicularia, 37.

\section{Tribe 6. CHLORIDEAE.}

Spikelets much flattened; glumes unequal, keeled.

Spikelets subterete; glumes equal, convex.

59. SPARTINA, 38.

60. BeckMaNnia, 38.

TRIBE 7. HORDEAE.

Spikelets solitary at the notches of the rachis; glumes usually acute, or awned.

Spikelets 2-6 at each notch of the rachis; glumes mostly long-awned.

Rachis not readily breaking into joints; spikelets 1-7-flowered, 2-4 at each joint.

Rachis readily bieaking into joints.

Spikelets 1-flowered, 3 at each joint, only the central one perfect.

Spikelets 1-5-flowered, 2-4 at each joint, all perfect.

61. Agropyron, 39.

62. Elymus, 40.

63. HORDEUM, 41.

64. Sitanion, 42.

\section{ECHINOCHLOA.}

Coarse annuals with long leaves; spikelets 1-flowered, with sometimes a staminate flower below, nearly sessile in 1-sided spikes or racemes; glumes unequal, hispid, mucronate; sterile lemma similar and usually awned from the apex.

Echinochloa crus-galli (L.) Beauv. Barnyard Grass. Glabrous; stems stout, branching at the base, $30-120 \mathrm{~cm}$. tall; panicle dense, $10-20 \mathrm{~cm}$. long, composed of many ascending or spreading racemes; spikelets green or purple, $3 \mathrm{~mm}$. long, densely crowded in 3 or 4 rows; sterile lemma awned or in some forms awnless. Introduced from Europe, a weed in moist ground.

\section{CHAETOCHLOA.}

Annual grasses with erect stems and flat leaves; spikelets with one perfect flower and rarely also a staminate one, in spike-like 
panicles; pedicels bearing bristles; glumes and lower lemma membranous, the latter often containing a palea and rarely a staminate flower; upper lemma papery with a similar palea and a perfect flower.

Chaetochloa viridis (L.) Scribn. Green Foxtail. Annual, usually tufted, green; stems 30-90 cm. high; leaf-blades flat, 4-10 mm. wide, scabrous on the margins; spikes green, $3-5 \mathrm{~cm}$. long, the rachis villous; bristles $1-3$, upwardly barbed, 6-12 mm. long; spikelets $2 \mathrm{~mm}$. long; fertile lemma faintly wrinkled. Introduced in fields and waste places.

\section{PANICUM.}

Spikelets with one perfect flower, often with a staminate one below it; glumes 2 , membranous; lemmas 2 , the lower empty or including the staminate flower, the upper papery, shining, enclosing a similar palea and the perfect flower; awns none (in ours); grain free, enclosed in the hardened glume and palea.

Spikelets acuminate.

$P$. barbipulvinatum.

Spikelets obtuse.

Stems stout; spikelets $3 \mathrm{~mm}$. long

Stems slender; spikelets 1.8-2 mm. long.

$P$. scribnerianum.

$P$. pacificum.

Panicum barbipulvinatum Nash. Annual; stems erect or decumbent at the base, $15-50 \mathrm{~cm}$. tall, mostly simple; leaf blades $5-30 \mathrm{~cm}$. long, pubescent; sheaths villous; panicle $10-20 \mathrm{~cm}$. long, the capillary branches solitary or in twos, ascending, branched and spikelet-bearing above the middle; spikelets $3 \mathrm{~mm}$. long, ovoid, usually on peduncles as long or longer. In sandy soil, common.

Panicum scribnerianum Nash. Annual, the stems $10-50 \mathrm{~cm}$. tall, erect or ascending, simple or branched above; stem leaves about 6 , the blades lanceolate, 4-10 cm. long, 6-15 mm. wide, stiff, ascending, glabrous or sometimes: pilose below; sheaths usually pilose, loose; panicles oblong or pyramidal, 3-8 cm. long, loose, exserted or the smaller ones included; spikelets turgid, ovoid, $3 \mathrm{~mm}$. long. Sandy banks of Snake River.

Panicum pacificum Hitchc. \& Chase. Perennial, the stems tufted, $25-50 \mathrm{~cm}$. tall, ascending in the spring and prostrate and spreading in the autumn, branching from the upper nodes, leafy, papillose-pilose with spreading hairs; stem-leaves 5 or 6 , the blades erect or ascending, 5-10 cm. long, 5-8 mm. wide, acuminate, narrowed toward the rounded base, papillose-pilose above, appressed papillose-pubescent beneath; sheaths papillose-pilose; panicles usually rather short-exserted, 5-10 cm. long, about three fourths as wide; spikelets 1.8-2 mm. long, obovate, obtuse, turgid. Spokane, Kreager.

\section{PHALARIS.}

Annuals or perennials with spike-like or narrow panicles; spikelets crowded, 1 -flowered; glumes 2, about equal, compressed; lemmas 3 , the first two much reduced and sterile, the third enclosing a palea and a perfect flower; stamens 3 .

Panicle very dense, ovoid; glumes wing-keeled.

Panicle branched; glumes wingless.

$P$. canariensis.

$P$. arundinacea. 
Phalaris canariensis L. Canary grass. Annual, pale green, erect, $30-70$ $\mathrm{cm}$. high; inflorescence $2-3 \mathrm{~cm}$. long; spikelets obovate, $5-6 \mathrm{~mm}$. long; glumes white with green veins. Introduced in waste places.

Phalaris arundinacea L. Reed canary grass. Stout tufted perennial, $50-200 \mathrm{~cm}$. tall; leaves flat, green, 6-10 mm. wide; panicle erect, $6-15 \mathrm{~cm}$. long; spikelets lanceolate, $5 \mathrm{~mm}$. long. Common in wet places, often in shallow water.

\section{MUHLENBERGIA.}

Perennial grasses with small 1-flowered spikelets; glumes usually unequal and shorter than the lemma, acute or sometimes awned; lemma narrow, 3-5-nerved, with a straight awn from the apex or from between the teeth.

Muhlenbergia sylvatica setiglumis Wats. Stems erect or nearly so, 60-90 cm. high, branched; leaves flat, 3-4 mm. wide, 6-12 cm. long; panicles purple, narrow, 6-12 cm. long, exserted; spikelets crowded on short appressed branches; glumes very narrow, scabrous, awn-pointed; lemmas scabrous and tipped with an awn 6-12 mm. long. In moist rocky places, rare.

\section{ARISTIDA.}

Spikelets narrow, 1-flowered; glumes 2, narrow, slightly keeled; lemma 1, convolute, bearing a 3-branched awn; palea short; grain free, tightly enclosed in the lemma.

Aristida purpurea robusta (Merrill) Piper. Perennial, tufted, $15-40 \mathrm{~cm}$. high; radical leaves numerous; stem leaves about 3 , all strongly involute and filiform, scabrous; panicle loose, purplish, 10-20 cm. long; awns of the flowering glume capillary, 5-10 cm. long, the central slightly longer than the others. Dry soil, not common.

\section{STIPA.}

Tufted grasses; inflorescence a panicle; spikelets 1-flowered, narrow; lemma 1, bearing a twisted or bent awn which is spiral and articulated at the base; grain narrow, free, tightly closed in the lemma. All in our limits are perennials.

Awns 10-20 times longer than the lemmas.

S. comata.

Awns 4-7 times longer than the lemmas.

Awns plumose.

Ligules 2-4 mm. long; sheaths smooth or scabrous.

Ligules $1 \mathrm{~mm}$. long or less; sheaths pubescent.

Awns not plumose.

Callus very short, obtuse.

Callus acute or acuminate.

Awns 1-3 cm. long.

Awns 3.5-6 cm. long.

S. thurberiana.

$S$. elmeri.

S. lemmoni.

S. minor.

S. nelsoni.

Stipa comata Trin. \& Rupr. Tufted, pale green, 40-80 cm. high; blades involute; ligule 4-5 mm. long, conspicuous; panicle open, 20-30 cm. long, often included at base, the branches spreading and few-flowered; glumes 5nerved, subequal, 15-25 mm. long; lemma 10-12 mm. long; awn 10-15 cm. long. In the neighborhood of Spokane and Walla Walla. Common in the sagebrush region of Central Washington. 
Stipa thurberiana Piper. Tufted, pale green; stem slender, $30-75 \mathrm{~cm}$. high, pubescent at the nodes; blades involute, rather rigid; ligules large and conspicuous; panicle erect, 8-15 cm. long, rather dense, often included at base in the upper sheath; lower glume 5-nerved, longer than the 3-nerved upper glume; lemma 6-7 mm. long, pubescent; awn 3-5 cm. long, plumose to the second bend. Common in the sagebrush region of Central Washington, but rare in our limits.

Stipa elmeri Piper \& Brodie. Tufted, pale green, $60-75 \mathrm{~cm}$. high, the whole plant pubescent; blades mostly involute; ligules very short; panicle erect, rather dense, $5-20 \mathrm{~cm}$. long, its base usually included; glumes subequal, the lower 5-nerved, the upper 3-nerved; lemma $6 \mathrm{~mm}$. long, pubescent; awn 20-25 mm. long, pubescent to the second bend. Near Spokane, but more common westward in the sagebrush region.

Stipa lemmoni Scribn. Stems slender, rigid, glabrous, 40-60 cm. high; leaves rather numerous; sheaths glabrous, shorter than the internodes; ligule $1.5 \mathrm{~mm}$. long; blades 5-10 $\mathrm{cm}$. long, 2-3 $\mathrm{mm}$. wide, glabrous beneath, striate and pubescent above, strongly involute; panicle narrow, erect, 5-12 cm. long; spikelets pale green or purplish, shiny; glumes nearly equal, broadly lanceolate, long-acuminate, scarious, about $12 \mathrm{~mm}$. long; lemmas oblong, 5-7 mm. long, 2-toothed, sparsely pilose; callus obtuse, short-bearded; awns 10-12 mm. long, sparsely pilose to the second bend. In rocky soil in the mountains.

Stipa minor (Vasey) Scribn. Perennial, tufted, 50-100 cm. tall, dark green; leaf-blades involute, long-attenuate, 10-30 cm. long, scabrous; sheath shorter than the internodes, loose, smooth; ligule very short; panicle erect, rather dense, 8-20 cm. long, narrow, its base included in the uppermost sheath, the branches mostly in pairs; spikelets 8-12 $\mathrm{mm}$. long, purple-tinged; lemma sparsely appressed-hairy, the awns 20-30 mm. long, bent near the middle, below which they are pubesceni. Grassy hillsides and pine woods, infrequent.

Stipa nelsoni Scribn. Stout, glabrous, 70-90 cm. high; basal leaves rather few; stem leaves 3 ; sheaths long, nearly equalling the internodes; ligules very short, fringed; blades $10-30 \mathrm{~cm}$. long, involute, strongly nerved; panicle erect, 10-15 cm. long, the branches appressed; glumes subequal, thin and hyaline, acuminate, 9-10 $\mathrm{mm}$. long; lemmas $7 \mathrm{~mm}$. long, pilose, the apex 2-toothed; awn minutely scabrous, $3.5-6 \mathrm{~cm}$. long; callus acute. In dry ground, rather common.

\section{PHLEUM.}

Annuals or perennials; inflorescence a spike-like raceme; spikelets 1-flowered; glumes membranous, compressed, keeled, the apex obliquely truncate, the mid-nerve produced into an awn; lemma much shorter; grain ovoid, free, enclosed in the lemma and palea.

Spike-like racemes cylindric; awns of glumes short.

$P$. pratense. Spike-like racemes ovate-oblong; awn as long as body of glume. P. alpinum.

Phleum pratense L. Timothy. Tall, erect, $60-150 \mathrm{~cm}$. tall; leaf blades 15-20 cm. long, 8-10 mm. wide, smooth or scabrous; spike-like raceme narrowly cylindrical, erect, $5-15 \mathrm{~cm}$. long; spikelets $2-5 \mathrm{~mm}$. long; empty glumes ciliate on the keels which are prolonged into awns $1 \mathrm{~mm}$. long. Abundantly introduced.

Phleum alpinum L. Mountain Timothy. Stems 20-60 cm. high; leaf blades flat, rather short; spike-like raceme usually purple, cylindric, $2-3 \mathrm{~cm}$. long; awns of glumes $2 \mathrm{~mm}$. long. In alpine meadows, Craig Mountains. 


\section{ALOPECURUS.}

Annuals or perennials; inflorescence a spike-like panicle; spikelets 1-flowered, flattened; glumes acute, sometimes short-awned; lemma 3-nerved, awned on the back, usually with a palea.

Awns scarcely exceeding the glumes; spikelets 2 to $2.5 \mathrm{~mm}$.

long.

Awns much exceeding the glumes.

Spikelets $3 \mathrm{~mm}$. long; anthers orange.

Spikelets $4 \mathrm{~mm}$. long; anthers white.

A. geniculatus.

A. californicus.

A. saccatus.

Alopecurus geniculatus fulvus (Smith) Sonder. Pale green and glabrous or nearly so; stems decumbent and branched at base, 15-60 cm. long; leaf blades flat, somewhat scabrous above; sheaths little inflated; panicles slender, erect, 3-7 cm. long; spikelets $2.5 \mathrm{~mm}$. long; glumes ciliate on the keels; lemma shorter than the glumes, bearing a short awn. In wet places, often partly floating.

Alopecurus californicus Vasey (A. pallescens Piper). Perennial, tufted, pale green, the smooth stems $30-50 \mathrm{~cm}$. tall, erect or slightly geniculate at the base; stem leaves 3; sheaths rather loose and inflated, shorter than the internodes, smooth; blades flat, 6-12 cm. long, 2-6 mm. wide, acuminate, strongly scabrous above, less so beneath; ligule scarious, $3-5 \mathrm{~mm}$. long; panicle usually well exserted, pale and silvery, $2-7 \mathrm{~cm}$. long, about $5 \mathrm{~mm}$. thick, erect, straight or somewhat flexuous; glumes $2-5 \mathrm{~mm}$. long, nearly equal, strongly ciliate on the keels, obtuse; lemma hyaline, 2-4-nerved, as long as the glumes, obtuse, bearing from near the base a stout geniculate awn, $5 \mathrm{~mm}$. long, scabrous above the bend. Common in wet places.

Alopecurus saccatus Vasey. Pale green, glabrous, simple or tufted, 10-30 $\mathrm{cm}$. high, erect or geniculate at base; sheaths much inflated, about as long as the internodes; ligule well developed; blades short, 2-8 cm. long, 2-4 mm. broad; panicles usually exserted, $2-5 \mathrm{~cm}$. long, thick, pale green or purplish; glumes strongly ciliate on the keels; lemma shorter than the glumes and bearing a divergent awn 6-7 mm. long. In moist ground, local.

\section{POLYPOGON.}

Annual grasses; inflorescence a spike-like panicle; spikelets 1-flowered; glumes each extended into an awn; lemma smaller, generally hyaline, short-awned, with a palea which is shorter than the lemma; grain free, enclosed in the lemma and palea.

Polypogon monspeliensis Desf. Annual, with erect or ascending stems, 8-30 cm. high; leaf blades flat, more or less scabrous; sheaths loose, shorter than the internodes; spike-like panicle densely flowered, oblong, rarely interrupted, 2-7 cm. long; empty glumes elliptic, notched at the apex, about $2 \mathrm{~mm}$. long, bearing terminal awns 3 or 4 times as long; flowering glume truncate, $1 \mathrm{~mm}$. long, bearing a terminal awn somewhat longer. Moist places, especially where somewhat alkaline.

\section{CINNA.}

Tall perennial grasses with flat leaves, conspicuous hyaline ligules and usually many-flowered nodding panicles; spikelets 1-flowered; rachilla articulated below the glumes and prolonged behind the palea into a minute bristle; glumes narrow; lemma 3-5-nerved; palea 1-nerved; stamen 1. 
Cinna latifolia (Trev.) Griseb. Stems solitary or few, erect, 60-120 cm. high; leaf blades flat, green, 1-1.5 cm. broad, scabrous; panicle pale green, drooping, 10-30 cm. long; glumes subequal, scabrous, $4 \mathrm{~mm}$. long; lemma shorter, scabrous, bearing a short straight awn; palea 2-nerved. In moist places in woods.

\section{SPOROBOLUS.}

Annuals or perennials with small 1-flowered spikelets; inflorescence an open contracted panicle; glumes membranous, the first somewhat shorter; lemma membranous, equalling or longer than the glumes; grain free and often deciduous.

Panicle open, branches mostly spreading.

S. cryptandrus.

Panicle contracted, spike-like.

Glume one-third to one-half the length of the lemma. S. richardsoni.

Glume from two-thirds to almost the whole length of the lemma.

S. depauperalus.

Sporobolus cryptandrus (Torr.) Gray. Stems $50-100 \mathrm{~cm}$. tall, erect, usually simple, smooth; leaf blades flat, becoming involute, 10-15 cm. long, 3-4 mm. wide; ligule minute; sheaths long, bearded at the throat; panicle erect, narrowly pyramidal, $10-20 \mathrm{~cm}$. long, its base enclosed in the uppermost sheath; branches mostly in pairs, ascending; spikelets crowded, leaden-colored, $1.5 \mathrm{~mm}$. long. Sandy bars of Snake River.

Sporobolus richardsoni (Trin.) Merrill. Somewhat tufted; stems very slender, $20-50 \mathrm{~cm}$. high, minutely roughened; ligule acute, $2 \mathrm{~mm}$. long; panicle small; spikelets $3 \mathrm{~mm}$. long, acute; lemma cuspidate. Medical Lake, Henderson.

Sporobolus depauperatus (Torr.) Scribn. Densely matted, 10-15 cm. high; stems strongly decumbent at base; leaf blades 5-8 cm. long, narrow, involute, minutely scabrous; stem leaves 4-5; ligules entire, acute; panicle very narrow, $2-5 \mathrm{~cm}$. long, erect, frequently with its base in the uppermost sheath; spikelets 2-2.5 mm. long; lemma acuminate, scabrous above. In low swales, common.

\section{CALAMAGROSTIS.}

Tall perennial grasses with small spikelets in many-flowered terminal panicles; spikelets 1 -flowered, the pubescent rachilla prolonged behind the palea; glumes subequal, longer than the lemma which is hyaline and obtuse, and bears a dorsál awn; callus copiously hairy; palea shorter; grain free, enclosed in the lemma.

Awn strongly geniculate; callus hairs much shorter than the lemma; panicle dense.

Awn straight; callus hairs not much shorter than the lemma.

C. rubescens.

Panicle loose; leaf-blades soft.

Glumes 2-2.5 mm. long.

Glumes 3-4 mm. long.

C. macouniana.

Panicle narrow, rather close.

Leaf-blades soft, not stiff.

C. canadensis.

Leaf-blades stiff.

C. neglecta.

C. hyperborea. 
Calamagrostis rubescens Buckl. Stems tufted, $60-100 \mathrm{~cm}$. tall; stem leaves 3 or $4,2-4 \mathrm{~mm}$. wide; panicle usually narrow and dense, $8-12 \mathrm{~cm}$. long, erect, pale green, rarely purple, the branches short and flower-bearing to the base; spikelets 3-4 mm. long; lemma shorter than the glumes, obtuse, 4-toothed at apex, bearing a stout, nearly basal, geniculate awn, as long as or longer than itself. The most abundant grass in pine forests. Includes $C$. suksdorfii Scribn.

Calamagrostis macouniana Vasey. Stems $60-120 \mathrm{~cm}$. high, erect, slender; leaf blades narrow, flat, long-attenuate, $15-25 \mathrm{~cm}$. long; panicle $10-12 \mathrm{~cm}$. long, purple, narrow or pyramidal, loose, the branches in fives, slender, naked below; spikelets small, 2-2.5 mm. long; lemma equalling the glumes, 2-lobed at apex, bearing a very short straight awn from above the middle of the back. Wet banks of the Palouse at Pullman, not common.

Calamagrostis canadensis (Michx.) Beauv. Similar to $C$. macouniana, but usually stouter; panicle looser; spikelets larger. In wet meadows and along streams.

Calamagrostis canadensis acuminata Vasey. Spikelets larger, 4-5 mm. long. With the species in wet meadows and along streams.

Calamagrostis neglecta (Ehrh.) G., M. \& S. Rootstock slender; stems slender, 40-65 cm. high; leaves soft, 1-3 cm. long, smooth; panicle narrow, glomerate and lobed, 5-10 cm. long; spikelets about $4 \mathrm{~mm}$. long; glumes acute; callus-hairs a little shorter than the floret and as long as those of the rudiment; awn from the middle of the thin lemma or lower, scarcely exceeding it. Spokane County, Suksdorf.

Calamagrostis hyperborea Lange. Stems tufted, 40-90 cm. high, stiffly erect; leaves stiff, erect, scabrous, somewhat involute; panicle erect, narrow, densely flowered, 8-12 cm. long; glumes scabrous, acute, 4-4.5 mm. long. In wet meadows, Spokane County.

\section{AGROSTIS.}

Annual or usually perennial grasses with small 1-flowered spikelets, usually in diffuse panicles; glumes membranous, keeled, acute; lemma shorter, obtuse, hyaline, sometimes bearing a dorsal awn; palea shorter than the lemma, sometimes minute or wanting; grain free, enclosed in the lemma.

Plants with rootstocks.

Palea present; panicle usually large.

Palea absent; panicle small.

Plants tufted, without rootstocks.

Panicle loose, open.

Inflorescence very diffuse; herbage scabrous.

Inflorescence not diffuse; herbage smooth.

Panicle narrow, close.

Glumes 2.5-3.5 mm. long; panicle 5-30 cm. long; tall lowland plant.

Glumes $2 \mathrm{~mm}$. long; panicle $3-6 \mathrm{~cm}$. long; low alpine plant.

A. alba.

A. pallens.

A. hyemalis.

A. idahoensis.

A. exarata.

A. rossae.

Agrostis alba L. Redtop. Perennial with creeping rootstocks; stems erect, 50-100 cm. tall; leaf blades flat, usually scabrous, the sheaths smooth; panicle 7-25 cm. long, open at first, then contracted, greenish or purple; palea present, one-third to one-half the length of the lemma. Abundantly introduced. 
Agrostis pallens foliosa (Vasey) Hitchc. Perennial with running rootstocks; stems slender, erect, about $60 \mathrm{~cm}$. tall; radical leaves numerous, those of the stem usually $2-3$, the blades flat, $1-2 \mathrm{~mm}$. broad, 7-10 cm. long, strongly scabrous, the sheaths nearly smooth; panicle erect, narrow, purplish, 7-12 cm. long, the branches scabrous, naked below. In moist soil, not common.

Agrostis hyemalis (Walt.) B.S.P. Annual, tufted, 15-90 cm. tall; leaves flat or involute, narrow, very scabrous; panicle very loose, $15-30 \mathrm{~cm}$. long; branches in whorls of $2-12$, capillary, $5-15 \mathrm{~cm}$. long, branched above the middle and spikelet-bearing only near the tips. Common in both dry and moist places.

Agrostis idahoensis Nash. Delicate, loosely-tufted, glabrous, perennial, 10-30 cm. high; blades flat, narrow, 1-6 cm. long; panicle loose, green or purple, 5-10 cm. long; rays capillary; spikelets about $1.5 \mathrm{~mm}$. long; lower glume scabrous on the keel, slightly larger than the upper; lemma truncate, awnless, $1 \mathrm{~mm}$. long; palea minute. In alpine woods, Craig Mountains.

Agrostis exarata Trin. Perennial, tufted, the stems $30-90 \mathrm{~cm}$. tall; leaves erect, the blades flat, 2-6 mm. broad, 5-10 cm. long, scabrous, the upper distant from the panicle; panicle strict, pale green, spike-like or interrupted, the short branches appressed and spikelet-bearing to the very base; glumes 2.5-3.5 mm. long, usually scabrous on the back. Common in moist soil.

Agrostis rossae Vasey. Tufted, $10-20 \mathrm{~cm}$. high; leaves mostly basal, 2-5 cm. long, 1-2 mm. broad, flat or folded; panicle narrow, erect, $3-6 \mathrm{~cm}$. long, green or purple; glumes $2 \mathrm{~mm}$. long, not scabrous. Meadows, on the highest ridges of the Blue Mountains.

\section{HOLCUS.}

Annual or perennial grasses with densely-flowered terminal panicles; spikelets deciduous, 2-flowered, the lower flower perfect, the upper staminate; glumes membranous, keeled, the lower 1nerved, the upper 3-nerved and of ten short-awned; lemmas 2, papery, that of the upper flower bearing a bent awn; palea narrow; grain oblong, free, enclosed in the lemma.

Holcus lanatus L. Velvet Grass or Mesquite. Perennial; the whole plant downy with pale pubescence; stems erect, 30-90 cm. high; leaf blades flat, rather broad and short; sheath loose, shorter than the internodes; panicle pale purplish, 5-10 cm. long, rather densely-flowered, the branches in twos or threes; spikelets 4-6 mm. long; upper glume short-awned near the apex; lemma of the staminate flower with a hook-like awn. Sparingly introduced.

\section{ARRHENATHERUM}

Tall perennials with long narrow panicles; spikelets 2-flowered, lower flower staminate, upper perfect; rachilla extending beyond the flowers; glumes thin-membranous, keeled, very acute or awn-pointed, unequal, persistent; lemmas 2, rigid, 5-7-n̨erved, deciduous, the first bearing a long bent and twisted dorsal awn inserted below the middle, the second unawned; palea hyaline, 2-keeled; grain ovoid, free.

Arrhenatherum elatius (L.) Beauv. Tall Meadow Oatgrass. Glabrous perennial, 100-150 cm. high; stem leaves 3 , the blades flat, minutely scabrous, 
the sheaths shorter than the internodes; panicle shining, 15-25 cm. long, rather narrow, the branches suberect; lemmas $6-7 \mathrm{~mm}$. long, the lower bearing a long dorsal geniculate awn. Sparingly escaped from cultivation.

\section{MERATHREPTA.}

Flowers solitary or few in a small racemè or panicle; spikelets 3 to many-flowered, the flowers all perfect or the upper staminate; rachilla pubescent, extending beyond the flowers; glumes keeled, acute, subequal, persistent, generally extending beyond the uppermost lemma; lemmas rounded on the back, 2-toothed, deciduous, the bent awn flat and twisted at the base, arising from between the acute or awned teeth; palea hyaline, 2-keeled near the margins, obtuse or 2-toothed; grain free, enclosed in the lemma.

Spikelets in small racemes; leaves merely scabrous. Spikelets mostly solitary; leaves hairy.

M. californica. M. unispicata.

Merathrepta californica (Boland.) Piper. Erect, 50-100 cm. tall; leaf blades flat, scabrous; sheaths loose, shortly retrorse-pubescent, with a tuft of hairs at the throat; spikelets $1-2 \mathrm{~cm}$. long, 3-5 in a raceme, rarely more numerous or even solitary, usually long-pedicelled; lemma long-ciliate below the middle, two cleft at apex, bearing an awn of about equal length. Common in low places.

Merathrepta unispicata (Thurb.) Piper. Closely resembling $M$. californica but not so large, $15-30 \mathrm{~cm}$. tall; leaf blades sparsely hairy, the sheaths villose with long white hairs; spikelets small, solitary. In dry soils, rare.

\section{AVENA. OATS.}

Annuals with large spikelets; inflorescence a panicle; spikelets 2-many-flowered; lower flowers perfect, the upper often staminate; glumes somewhat unequal, membranous, persistent; lemmas deciduous, rounded on the back, acute, generally bearing a dorsal awn; apex often 2-toothed; palea narrow, 2-toothed; grain oblong, deeply furrowed, enclosed in the lemma and palea, free or sometimes adheren: to the latter.

Avena fatua glabrata Petermann. Smooth Wild Oat. Stems stout, pale, smooth, 50-100 cm. tall, erect; leaf blades broad and flat, the sheaths about equalling the internodes; panicle loose $15-30 \mathrm{~cm}$. long; spikelets, including awns, 3.5-4 cm. long, erect or drooping, on slender branches; lemma smooth, except the scabrous apex and the ring of stiff white hairs at the base, bearing on the back a geniculate, stout, twisted awn below the 2-cleft apex. A troublesome weed in cultivated land.

\section{DESCHAMPSIA.}

Annuals or perennials; inflorescence a contracted or open panicle; spikelets 2 -flowered, both flowers perfect, the hairy rachilla extending beyond the flowers or rarely terminated by a staminate one; glumes keeled, acute, membranous, shining, 
persistent; lemmas of about the same texture, deciduous, each bearing a dorsal awn, the apex erose-truncate; palea narrow; grain oblong, free, enclosed in the lemma.

Glumes scarcely equalling the lemma.

D. caespilosa.

Glumes exceeding the lemma.

Glume about $4 \mathrm{~mm}$. long.

Glume about $7 \mathrm{~mm}$. long.

D. elongata.

D. calycina.

Deschampsia caespitosa (L.) Beauv. Densely tufted perennial; stems 60$150 \mathrm{~cm}$. high, much exceeding the numerous basal leaves; stem leaves 3 , the blades narrow, involute, 5-12 cm. long, scabrous, the smooth sheaths shorter than the internodes; panicle $10-30 \mathrm{~cm}$. long, usually open, the capillary branches in whorls of $2-5$, flower-bearing above the middle; spikelets shining, greenish or purplish, 2-3 mm. long; lemma hairy at the base, erose-toothed at the apex, bearing a slender awn near the base. Plentiful in wet ground.

Deschampsia elongata (Hook.) Munro. Stems densely tufted, smooth, 30-90 cm. tall; leaves filiform, commonly involute, smooth; panicle narrow, $15-45 \mathrm{~cm}$. long, somewhat nodding; branches very unequal, ascending or appressed, very slender, naked below; spikelets pale green, usually purpletinged near the apex; lemmas hairy at base, shining, irregularly toothed at apex, bearing a slender awn about twice as long. Common in dry soil.

Deschampsia calycina Presl. Annual; the slender stems erect, $15-40 \mathrm{~cm}$. tall; leaves narrow, involute, the blades $2-6 \mathrm{~cm}$. long; panicle very loose, $7-20$ $\mathrm{cm}$. long, with subequal branches mostly in twos, these capillary, branched above and bearing spikelets near the tips; spikelets pale green, sometimes purple-tinged, about $7 \mathrm{~mm}$. long; lemma long-hairy at the base, minutely toothed at the apex, bearing a geniculate awn three or four times as long. Very abundant in dry soil.

\section{TRISETUM.}

Ours all cespitose perennials; inflorescence a spike-like or open panicle; spikelets 2-4-flowered, the flowers all perfect or the uppermost staminate; rachilla glabrous or with long soft hairs, extending beyond the flowers; glumes unequal, acute, persistent; lemmas 2-4, usually shorter than the glumes, deciduous, 2-toothed, bearing a dorsal awn below the apex or sometimes awnless; palea narrow, hyaline, 2-toothed; grain free, enclosed in the lemma.

Lemmas awnless; panicle narrow.

T. muticum.

Lemmas awned.

Panicle dense and spike-like; ovary smooth.

Panicle loose and open; ovary hairy at apex.

T. spicatum.

Sheaths glabrous; lemma 3-4 mm. long.

Sheaths pubescent; lemma $7 \mathrm{~mm}$. long.

T. cernuum.

$T$. canescens.

Trisetum muticum (Boland.) Scribn. Stems erect, 30-75 cm. high; blades flat, scabrous or sometimes pubescent; panicles narrow, erect, rather dense; spikelets 2-flowered; glumes subequal, acute; lemmas smooth, awnless or very short awned. A rare grass only known in our limits from near Spangle.

Trisetum spicatum (L.) Richter. Densely tufted, $10-40 \mathrm{~cm}$. high, pubescent to glabrous with the sheaths pubescent; panicle oblong-ovate, 5-15 cm. 
long, shining and often brownish-purple; glumes ciliate on the keels, the lower short; lemma 5-6 mm. long, its awn divergent and about as long. A common alpine grass occurring in the Blue Mountains at 1700 meters altitude.

Trisetum cernuum Trin. Stems $60-100 \mathrm{~cm}$. tall, erect, the nodes pale; leaf blades flat, merely scabrous, $15-20 \mathrm{~cm}$. long, 6-10 mm. wide; panicle $10-15 \mathrm{~cm}$. long, loose, nodding; branches in distant whorls, capillary, cernuous, flower-bearing above the middle; spikelets 2-4-flowered, 6-7 $\mathrm{mm}$. long without the awn; lemma 3-4 mm. long, bearing an awn about twice its length. Moist woods and copses.

Trisetum canescens Buckl. Much like $T$. cernuum, the leaf blades and sheaths pubescent; nodes usually dark; panicle erect, 7-16 cm. long; lemma $7 \mathrm{~mm}$. long. In coniferous woods.

\section{SPHENOPHOLIS.}

Panicles contracted; spikelets 2-flowered; the rachilla extending beyond the flowers; glumes shorter than the spikelet; the lower linear, acute, 1-nerved; the uppes much broader, 3-nerved, obtuse or rounded at the apex, or sometimes acute, the margins scarious; lemmas narrower, generally obtuse, 1-3-nerved, awnless; palea narrow, 2-nerved; grain free, loosely enclosed in the scale and palea.

Panicle dense, erect; lemma obtuse.

Panicle loose, usually nodding; lemma acutish.

S. obtusata. S. pallens.

Sphenopholis obtusata lobata (Trin.) Scribn. Somewhat tufted, perennial, 60-100 cm. tall, the stems smooth; leaf blades flat, scabrous, 10-15 cm. long, 3-5 mm. wide; panicle erect, narrow, 5-12 cm. long, pale green, the branches short and densely flowered; lemma narrowly obovate, obtuse. Rather rare, on sandy bars of Snake River.

Sphenopholis pallens major (Torr.) Scribn. Stems $30-90 \mathrm{~cm}$. tall, glabrous; leaf blades $6-15 \mathrm{~cm}$. long; panicle slender, 8-15 cm. long, usually loose and nodding, the branches 3-7 cm. long; spikelets about $3 \mathrm{~cm}$. long, usually numerous; lemma narrow, acutish. Infrequent.

\section{KOELERIA.}

Tufted perennial grasses with narrow leaves and densely flowered spike-like panicles; spikelets 2-4-flowered; rachilla articulated between the lemmas; glumes acute, subequal, keeled, scarious on the margins; lemmas 3-nerved, keeled, acute; palea hyaline, acute; grain free, enclosed in the lemma and palea.

Koeleria cristata (L.) Pers. Perennial, the erect stems densely tufted, $30-70 \mathrm{~cm}$. tall, usually glabrous; leaves narrow, commonly involute; panicle dense, greenish or purplish, shining, 5-15 cm. long, often more or less interrupted; spikelets 4-5 mm. long, 2-4-flowered. Common on dry hillsides.

\section{ERAGROSTIS.}

Annual or perennial grasses; inflorescence a contracted or open panicle; spikelets many-flowered, more or less flattened; 
glumes unequal, shorter than the lemmas, keeled, 1-nerved; lemmas membranous, keeled, 3-nerved, awnless; palea shorter than the lemmas, prominently 2-nerved or 2-keeled, usually persisting on the rachilla after the lemma has fallen; grain free, loosely enclosed in the lemma and palea.

Stems erect; leaves $2-12 \mathrm{~cm}$. long.

Stems creeping; leaves 15-30 mm. long.

E. lutescens.

E. hypnoides.

Eragrostis lutescens Scribn. Stems tufted, erect, $10-30 \mathrm{~cm}$. high, branched near the base; leaf blades $2-12 \mathrm{~cm}$. long, 2-4 mm. wide, scabrous above; panicle silvery green, narrow, 5-10 cm. long, the branches ascending, naked below; spikelets oblong, 4-7 mm. long, usually 10-12-flowered. Very rare, on the sandy banks of Snake River near Almota.

Eragrostis hypnoides (Lam.) B.S.P. Stems prostrate, creeping, much branched from the base, forming dense circular mats; leaf blades $2-3 \mathrm{~cm}$. long, somewhat pubescent; sheaths loose, inflated, hairy; panicles very numerous, pale green, dense, $2-4 \mathrm{~cm}$. long, usually with their bases included in the uppermost sheaths; spikelets oblong, 4-7 mm. long. Banks of Snake River, common.

\section{MELICA.}

Perennial grasses with simple stems; inflorescence a contracted or open panicle; spikelets 1-several-flowered, often one-sided; rachilla extending beyond the flowers and usually bearing 2-3 empty club-shaped or hooded lemmas twisted around each other; glumes membranous, the lower 3-5-nerved, the upper 5-9-nerved; lemmas larger, rounded on the back, 5-7-nerved, awnless, the margins more or less scarious; palea broad, shorter than the lemma; grain free, enclosed in the lemma and palea.

Lemma notched at the apex, awned.

M. smithii.

Lemma not notched at the apex, awnless.

Apex of lemma long-acuminate.

Apex of lemma obtuse.

M. subulata.

M. spectabilis.

Melica smithii (Porter) Vasey. Glabrous; stems tufted, usually few, not bulbous at base; blades flat; panicle loose, the solitary branches at length spreading or reflexed; spikelets 3-6-flowered; glumes unequal; lemmas glabrous, $10 \mathrm{~mm}$. long, the straight awns half as long or less. Rich open woodlands, Blue Mountains.

Melica subulata (Griseb.) Scribn. Glabrous; stems tufted, usually few, bulbous at base; blades flat, shining; panicle narrow and rather loose, suberect, 10-20 cm. long; spikelets 3-5-flowered; glumes unequal, usually purplish; lemmas pubescent, $12 \mathrm{~mm}$. long. In open woods and copses.

Melica spectabilis Scribn. Stems $30-90 \mathrm{~cm}$. tall, erect, smooth, mostly solitary, with bulbous bases about $1 \mathrm{~cm}$. in diameter, these appearing on the apices of stout rootstocks; stem leaves 3 , rarely 4 ; sheaths strongly veined, scabrous, nearly as long as the internodes, sometimes overlapping; blades flat, linear, attenuate at apex, $10-15 \mathrm{~cm}$. long, 2-4 mm. wide, glabrous on both sides; panicle erect, narrow, 5-15 cm. long; lower branches mostly in threes, the two outer of which are short and bear a single spikelet, the central longer and bearing 2-5 spikelets; upper branches solitary, bearing a single 
spikelet; spikelets ovate-lanceolate, 10-12 cm. long, 5-7-flowered, usually purple; lower glume $5 \mathrm{~mm}$., the upper 7-8 $\mathrm{mm}$. long, acutish; lemmas about $7 \mathrm{~mm}$. long, all minutely scabrous. In low meadows, infrequent.

\section{BROMUS. BROMEGRASS.}

Annuals, biennials or perennials with flat leaves and terminal panicles of large spikelets; peduncles thickened at the summit; spikelets few-many-flowered; glumes unequal, acute; lemmas rounded on the back, or sometimes compressed-keeled, 5-9. nerved, the apex usually 2-toothed, generally bearing an awn just below the summit; palea shorter than the lemma; grain adherent to the palea.

Spikelets strongly flattened.

Awns less than $7 \mathrm{~mm}$. long.

Awns more than $7 \mathrm{~mm}$. long.

Spikelets subterete, not strongly flattened.

Perennial, native; spikelets narrow, pubescent. B. eximius.

Annuals or biennials, introduced.

Awn much longer than the body of the lemma.

Lemma pubescent; awns 13-15 mm. long. $\quad B$. tectorum.

Lemma not pubescent; awns longer.

Awns 20-30 mm. long.

Awns 35-45 mm. long.

Awn not longer than the body of the lemma, or none.

Awns minute or wanting.

Awns well developed.

Panicle dense, small.

Panicle loose, open.

Sheaths glabrous.

Sheaths pubescent.

B. marginatus.

B. carinatus.

$B$. sterilis.

B. maximus.

B. brizaeformis.

$B$. hordeaceus.

$B$. secalinus.

B. commutatus.

Bromus marginatus Nees. Perennial, tufted; the stout stems about $1 \mathrm{~m}$. high; leaf blades coarse, sparsely pubescent; panicle $15-25 \mathrm{~cm}$. long, rather narrow, the branches in whorls of $2-4$, about $7 \mathrm{~cm}$. long, and bearing two spikelets; spikelets $2.5-4 \mathrm{~cm}$. long, 5-7 mm. wide, compressed and keeled, 7-9flowered; lemma rough-pubescent, 11-14 $\mathrm{mm}$. long, 2-toothed at apex, and bearing a stout awn 4-7 mm. long. Mostly in mountain woods.

Bromus marginatus latior Shear. Larger and stouter, 100-150 cm. tall; panicle $20-30 \mathrm{~cm}$. long; the lower branches $10-20 \mathrm{~cm}$. long. Common at the edges of wheat fields, roadsides, etc.

Bromus carinatus Hook. \& Arn. Short-lived perennial or sometimes annual; sheaths and blades pilose; glumes glabrous or nearly so; awns of the lemmas 7-10 mm. long; otherwise similar to $B$. marginatus. In sandy or gravelly soil, especially along Snake River.

Bromus eximius umbraticus Piper. Perennial; the stem slender, 80-100 $\mathrm{cm}$. tall; leaf blades $15-25 \mathrm{~cm}$. long, glabrous or sparsely pilose; sheaths pilose with spreading or reflexed hairs; ligule truncate, fringed, 3-5 mm. long; panicle sparse, more or less nodding, $8-12 \mathrm{~cm}$. long; spikelets $2-3 \mathrm{~cm}$. long, 2-4 mm. wide; lemma 8-10 mm. long, sparsely pubescent on the back, somewhat ciliate on the margin, the awn $6-9 \mathrm{~mm}$. long. In woods, Thatuna Hills.

Bromus tectorum L. Annual, 20-60 cm. tall, mostly erect; panicle onesided, drooping, the slender branches in threes and fours, and bearing several 
spikelets above the middle; spikelets nodding, 15-20 mm. long, rather dense; lemma lanceolate, pubescent, 11-13 mm. long, the awn 13-15 mm. long. Sparingly introduced in waste places.

Bromus sterilis L. Annual, the stout stems $50-100 \mathrm{~cm}$. high, usually decumbent at base; panicle 10-20 cm. long, loose and drooping, its branches in whorls of $2-6$, long and slender, usually bearing but one spikelet; spikelets drooping, $2.5-3.5 \mathrm{~cm}$. long, 6-10-flowered; lemma narrowly lanceolate, 17-20 $\mathrm{mm}$. long, bearing a stout rough awn, 20-30 $\mathrm{mm}$. long. In waste places, infrequent.

Bromus maximus Desf. Stems $20-40 \mathrm{~cm}$. high; sheaths and blades pilose; panicle erect, 5-10 cm. long, somewhat one-sided, the branches rather short and erect or nearly so after flowering. Sparingly introducẹd from Europe.

Bromus brizaeformis Fisch. \& Mey. Annual, erect, 30-60 cm. tall; leaf blades pubescent; panicle 5-25 $\mathrm{cm}$. long, loose, one-sided, nodding; spikelets 15-25 mm. long, elliptical, compressed; lemmas very broad, smooth, awnless, or the uppermost with short awns, 1-2 cm. long. Introduced and becoming abundant.

Bromus hordeaceus L. Annual, erec ${ }^{\star}, 20-60 \mathrm{~cm}$. tall; leaf blades pilose or smooth, the sheaths pubescent with retrorse hairs; panicle narrow, dense, 5-10 cm. long; spikelets erect, 12-15 mm. long, 5-12-flowered; lemma pubescent, bearing a stout straight or somewhat twisted awn $6-9 \mathrm{~mm}$. long. Very common.

Bromus hordeaceus glabrescens (Coss.) Shear. Spikelets smooth or nearly so. Very common.

Bromus secalinus L. Annual, erect, 30-70 cm. tall; leaf blades 10-20 cm. long, sparsely hairy above, smooth beneath; sheaths glabrous; panicle 8-18 $\mathrm{cm}$. long, pyramidal, erect at first, in fruit somewhat drooping; spikelets oblong-lanceolate, turgid in fruit, $10-18 \mathrm{~mm}$. long; lemma glabrous or nearly so, 6-8 mm. long, its margins involute in fruit, tipped with an awn 2-5 mm. long; palea nearly equal to the lemma. Common in fields.

Bromus commutatus Schrad. Very similar to B. secalinus; panicle more drooping; lemma broader, not inrolled in fruit, tipped with a stout straight awn 7-8 mm. long. Introduced from Europe.

\section{DACTYLIS.}

Perennial grasses with flat leaves; inflorescence a densely clustered or interrupted panicle; spikelets 3-5-flowered, shortpedicelled, in small fascicles, the flowers all perfect or the upper staminate; glumes thin, membranous, keeled, unequal, mucronate; lemmas larger than the glumes, rigid, 5-nerved, keeled, the midnerve extending into a point or short awn; palea shorter than the lemma; grain free, enclosed in the lemma and palea.

Dactylis glomerata L. Orchardgrass. Perennial, tufted, the stout stems 60-150 cm. tall; leaf blades flat, scabrous, $6-8 \mathrm{~mm}$. broad; sheath scabrous, exceeding the internode; panicle $3-10 \mathrm{~cm}$. long, pyramidal-ovate, greenish or purplish; branches solitary, ascending, spikelet-bearing above; lemmas conspicuously ciliate on the keels. Escaped from cultivation.

\section{POA. Bluegrass.}

Annual or perennial grasses with simple stems and narrow usually flat leaves; inflorescence a contracted or open panicle; 
spikelets 2-6-flowered, compressed, the rachilla usually glabrous; flowers perfect or rarely dioecious; glumes membranous, keeled, 1-3-nerved; lemmas membranous, keeled, awnless, longer than the glumes, generally with a tuft of cobwebby hairs at the base, 5-7-nerved, marginal nerves usually pubescent, often also the dorsal one; palea a little shorter than the lemma, 2-nerved or 2-keeled; grain free, or sometimes adherent to the palea.

Annual; lemma without cobwebby hairs at base.

P. annua. Perennials.

Plants with creeping rootstocks.

Stems compressed, 2-edged; panicles small.

Stems cylindric.

P. compressa.

Lemma webbed, that is with a tuft of hairs at base. $P$. pratensis.

Lemma without a tuft of hairs at base. $P$. olneyae.

Plants tufted, without rootstocks.

Web present at base of lemma.

Panicle close; leaf blades flat, thin and lax. $\quad P$. bolanderi.

Panicle open; leaf blades narrow, not thin and lax.

Ligule 3-5 $\mathrm{mm}$. long; panicle loose, somewhat drooping, 10-30 cm. long.

Ligule very short; panicle erect, $4-10 \mathrm{~cm}$. long. $P$. nemoralis.

Web absent from base of lemma.

Stems coarse and tall, $60-100 \mathrm{~cm}$. high.

Leaves narrow, pale, involute; panicle narrow, erect.

Leaves flat, rarely involute, green or rarely glaucescent; panicle ample.

Stems not coarse or tall, usually less than $60 \mathrm{~cm}$. tall.

Leaves flat or folded, not filiform.

Lemmas pubescent at base; leaves $1 \mathrm{~mm}$. broad, usually folded.

Lemmas puberulent at base; leaves $2 \mathrm{~mm}$. broad, usually flat.

Leaves involute and filiform.

Florets close; ligule long.

Florets loose; ligule short.

P. brachyglossa.

P. ampla.

$P$. sandbergii.

P. saxatilis.

$P$. idahoensis.

$P$. capillarifolia.

Poa annua L. Annual Bluegrass. Annual, the compressed stems 5-15 cm. tall; leaves glabrous, the blades short and soft; panicle pyramidal, sometimes 1-sided; spikelets 3-7-flowered, crowded, $4 \mathrm{~mm}$. long; lemma 3-3.5 $\mathrm{mm}$. long, not hairy at base. In moist places becoming common, apparently native in the foothills.

Poa compressa L. Canada Bluegrass. Usually low, spreading by rootstocks and forming dense mats; the much compressed stems $15-40 \mathrm{~cm}$. high, decumbent at base, glabrous; panicle 3-7 $\mathrm{cm}$. long, contracted, the branches spikelet-bearing to the base or nearly so; spikelets 3-9-flowered; lemmas obscurely nerved, the nerves slightly pubescent below. Sparingly introduced.

Poa pratensis L. Kentucky Bluegrass. Perennial, with conspicuous running rootstocks, the terete stems $30-90 \mathrm{~cm}$. tall; panicle pyramidal, open, 6-20 $\mathrm{cm}$. long, the ascending or spreading branches in whorls of 3-5, spikeletbearing above the middle; spikelets 3-5-flowered; lemmas 3-5 $\mathrm{mm}$. long with prominent intermediate nerves, silky-pubescent on the midnerve and margins, cobwebby at the base. Everywhere introduced. 
Poa olneyae Piper. Glabrous tufted perennial, the stems $30-50 \mathrm{~cm}$. high; leaf blades numerous, flat or folded; ligule small, usually $1-1.5 \mathrm{~mm}$. long; panicle green or purple, narrow, more or less drooping; spikelets 4-6-flowered, 7-10 mm. long; lemma smooth, excepting the scabrous nerves. In open pine woods about Spokane.

Poa bolanderi Vasey. A glabrous, loosely tufted, short-lived perennial, $30-50 \mathrm{~cm}$. high, erect; leaf blades few, thin, soft, rather short; panicle erect, narrow, 10-12 cm. long, the branches few at the well separated nodes and usually remaining erect; spikelets $1-3$-flowered, 2-3 mm. long; lemma smooth, the basal web scanty. In open woods in the Blue Mountains.

Poa triflora Gilib. Fowl Meadow Grass. Tufted, the stems $60-90 \mathrm{~cm}$. high; leaves narrow linear, smooth and soft; ligule conspicuous; panicle usually purple, $10-30 \mathrm{~cm}$. long, the branches mostly in fives; spikelets 2-5-flowered; lemma obscurely nerved. In wet meadows.

Poa nemoralis L. Similar to $P$. triflora; stems tufted, slender, $30-70 \mathrm{~cm}$. high; blades $3-10 \mathrm{~cm}$. long, $2 \mathrm{~mm}$. wide, glabrous; panicle open in flower, pyramidal, 4-10 cm. long; spikelets 2-5-flowered; lemmas 2-3 $\mathrm{mm}$. long, the marginal and middle nerves pubescent, the intermediate ones faint; webby hairs at base scanty. Rare in our limits and perhaps only introduced.

Poa brachyglossa Piper. Perennial, densely tufted, glabrous, pale green or glaucescent; stems $60-100 \mathrm{~cm}$. high; leaves very narrow, folded or involute, rather stiff, almost leathery in texture, $5-20 \mathrm{~cm}$. long; panicle narrow, erect; spikelets 3-6-flowered, 7-10 mm. long; lemma oblong-ovate, rather obtuse, smooth or nearly so, faintly nerved, the sides inrolled. In moist usually alkaline soil; in such situations often abundant.

Poa ampla Merrill. Tufted, pale and glaucous throughout; the stout stems $60-90 \mathrm{~cm}$. tall; basal leaves numerous, 30-40 cm. long, flat or involute, smooth or nearly so; stem leaves 2 ; panicle erect, $10-25 \mathrm{~cm}$. long, narrow, dense, the appressed branches in half-whorls of 3-5, the shorter ones spikelet-bearing to the base; spikelets 8-12 mm. long, 4-8-flowered; lemmas minutely scabrous, 4-5 mm. long. A common bunch grass.

Poa sandbergii Vasey. Perennial, glabrous, not glaucous, tufted; the stems $15-50 \mathrm{~cm}$. tall; basal leaves numerous, the blades $5-10 \mathrm{~cm}$. long, linear; stem leaves 2 , low down, the blades $1-2 \mathrm{~cm}$. long, the sheaths often purple; panicle 4-10 cm. long, narrow, the ascending branches in whorls of 2-5, spikelet-bearing near the top; spikelets 2-4-flowered, usually purplish; lemmas oblong, $3.5 \mathrm{~mm}$. long, sparsely pubescent above, villous near the base. The commonest native species, flowering early.

Poa saxatilis Scribn. \& Williams. Densely tufted alpine perennial, 20$30 \mathrm{~cm}$. tall; basal leaves numerous, green, the blades $2-6 \mathrm{~cm}$. long, flat, slightly scabrous, about $2 \mathrm{~mm}$. broad; stem leaves 2; ligules well developed; sheaths loose, becoming scarious; panicles green or purple, erect, rather loose, 4-7 cm. long, the rays mostly in twos; spikelets lanceolate, 6-9 mm. long, loosely 3-5flowered; glumes subacute, smooth, subequal, about $4 \mathrm{~mm}$. long; lemma obscurely 5-nerved, oblong, subacute, scabrous on the back, puberulent at base and on the keel, $4-4.5 \mathrm{~mm}$. long. In rocky places, high ridges of the Blue Mountains.

Poa idahoensis Beal. Perennial, pale green, in dense tufts; stems 30-70 $\mathrm{cm}$. high, scabrous above; leaves filiform, involute, scabrous, $15-30 \mathrm{~cm}$. long; ligule very short; panicle narrow, the rays in threes or fours, scabrous; spikelets 5-9 mm. long, loosely 4-7-flowered; lemma scabrous. Hatwai Creek, Idaho.

Poa capillarifolia Scribn. \& Williams. Very similar to $P$. idahoensis, but bright green and quite smooth; ligules well developed; panicle closely-flowered, the rays mostly in twos or threes; spikelets 5-9 mm. long, 2-5-flowered. Bluffs of Snake River, rare. 


\section{FESTUCA. Fescue.}

Annuals or perennials with terminal panicles, sometimes reduced to racemes; spikelets 2-many-flowered; glumes more or less unequal, acute, keeled, the lower 1-, rarely 3 -nerved, the upper 3-, rarely 5-nerved; lemmas lanceolate, firm in texture at least near the base, narrow, rounded on the back or slightly keeled, always 5-nerved, acute or usually awned; palea usually about equalling the lemma; grain glabrous, elongated, often adherent to the palea.

Annuals; stamen usually solitary.

Spikelets densely 8-13-flowered.

Spikelets loosely $2-5$ rarely 6 -flowered.

$\begin{array}{ll}\text { Lemma ciliate; panicle rays not spreading. } & F \text {. megalurc. } \\ \text { Lemma not ciliate; panicle rays at length spreading. } & F \text {. pacifica. }\end{array}$

Perennials; stamens three.

Leaves flat, rather broad.

Lemma coriaceous, not at all keeled.

Lemma membranaceous, keeled.

Leaves narrow, involute.

Plants with rootstocks.

Plants without rootstocks.

F. octoflora.

F. megalura.

F. pacifica.

Leaves smooth; ovary hairy at apex.

Lemmas awned.

Lemmas awnless.

Leaves rough; ovary not hairy at apex.

Lemmas awned.

Lemmas awnless or nearly so.

F. elatior.

F. subulata.

F. rubra.

F. occidentalis.

F. viridula.

F. ovina ingrata.

F. hallii.

Festuca octoflora Walt. Tufted annual, $8-30 \mathrm{~cm}$. tall; panicle $2-6 \mathrm{~cm}$. long, rather dense, of ten one-sided; spikelets 6-10 mm. long, 7-13-flowered; lemmas 3-4 mm. long, scabrous, attenuate into an awn about as long. Banks of Snake River near Lewiston, rare; also near Steptoe Butte.

Festuca megalura Nutt. Tufted annual, $30-40 \mathrm{~cm}$. tall, smooth; panicle spike-like, elongated, flexuous, $5-25 \mathrm{~cm}$. long, pale-green; spikelets 4-5-flowered, 2-2.5 cm. long, including the awns; lemma lanceolate, scabrous, the body 5 $\mathrm{mm}$., the awn 10-15 mm. long. Recently introduced but now abundant.

Festuca pacifica Piper. Annual; stem single or a few in a loose tuft, 5-30 cm. tall; panicle 4-10 cm. long; branches mostly solitary, longest below, all erect at first but becoming spreading or reflexed by means of a prominent pulvinus at the base; spikelets 2-6-flowered; lemma 6-7 mm. long, the awn two to three times as long. Very common.

Festuca elatior L. Perennial; the stout stem $100-150 \mathrm{~cm}$. tall, smooth and glabrous throughout; leaves flat, dark green, $7-15 \mathrm{~cm}$. long, 3-4 mm. wide; panicle narrow, erect, $10-25 \mathrm{~cm}$. long, the branches solitary or in twos; spikelets rather crowded, lanceolate-oblong, 12-18 mm. long, 5-10-flowered; lemma scarious-margined, acute, awnless. Escaped from cultivation.

Festuca subulata Trin. Loosely tufted, glabrous or nearly so; stems $40-$ $120 \mathrm{~cm}$. high; leaf blades flat, thin, 3-10 mm. broad; panicle very loose and somewhat drooping, 15-40 cm. long; rays in 3-5 sets; spikelets pale green, 3-5-flowered, 7-12 mm. long; lemma membranaceous, narrowly lanceolate, keeled its entire length, 5-7 mm. long, with an awn 5-20 mm. long. In wet places in woods. 
Festuca rubra L. Perennial, with short running rootstocks; the whole plant smooth; stems $60-100 \mathrm{~cm}$. tall, slender; leaves narrow, involute, 10-20 $\mathrm{cm}$. long; panicle narrow, erect, about $10 \mathrm{~cm}$. long, the short erect branches in twos, spikelet-bearing to the base; spikelets frequently purplish, $10-12 \mathrm{~cm}$. long, 5-6-flowered; lemma smooth, 5-6 mm. long, tipped with an awn 3-4 mm. long. In moist soil.

Festuca occidentalis Hook. Densely tufted, the whole plant smooth and bright green; stems $30-60 \mathrm{~cm}$. high; leaf blades smooth, becoming longitudinally grooved when dry; panicle narrow, loose, $8-20 \mathrm{~cm}$. long, of ten drooping at the summit; spikelets green, 3-5-flowered; lemmas scabrous near the apex or smooth, 5-6 mm. long, bearing a slender awn of equal length. In open coniferous woods.

Festuca viridula Vasey. Densely tufted, dark green, smooth; stems 50$100 \mathrm{~cm}$. high; leaves narrow, erect, soft, 7 -nerved, the basal ones involute; panicle loose and open, suberect, $10-15 \mathrm{~cm}$. long; spikelets 3-6-flowered; lemma firm, keeled toward the apex, 5-nerved, acute or sometimes mucronate, smooth or nearly so, 6-7 mm. long. Mt. Carlton, Kreager. Abundant in high mountain meadows.

Festuca ovina ingrata Hack. Blue Bunchgrass. Densely tufted, the whole plant pale or glaucescent; stems $30-40 \mathrm{~cm}$. tall; leaf blades very numerous, setaceous, mostly basal, firm and harshly scabrous; panicle $3-8 \mathrm{~cm}$. long, narrow, one-sided, the branches erect; spikelets 3-5-flowered; lemma 3-5 $\mathrm{mm}$. long, tipped by an awn of equal length. Abundant on the prairies.

Festuca hallii (Vasey) Piper. Densely tufted perennial, 50-100 cm. tall, scabrous throughout; leaf blades very scabrous, strongly involute, breaking away early from the sheaths which remain for several seasons at the base; panicle $7-10 \mathrm{~cm}$. long, narrow, the ascending branches mostly in pairs, spikeletbearing above the middle; spikelet $8-10 \mathrm{~cm}$. long, 3-5-flowered; lemmas 6-7 $\mathrm{mm}$. long, very short awned. Near Steptoe Butte.

\section{PANICULARIA.}

Tall aquatic perennial grasses with terminal panicles; spikelets few-many-flowered, terete, or somewhat flattened; glumes unequal, obtuse or acute, 1-3-nerved; lemmas membranous, obtuse, rounded on the back, 5-9-nerved, the nerves disappearing in the hyaline apex; palea scarcely shorter than the lemma, rarely longer; grain smooth, enclosed in the lemma and palea, free, or when dry slightly adhering to the latter.

Spikelets 10-17 mm. long, linear.

$P$. borealis.

Spikelets 2-8 $\mathrm{mm}$. long, ovate or oblong.

Lemma with 5 prominent nerves.

Lemma with 7 prominent nerves. Spikelets 3-4 mm. long. Spikelets 4-6 mm. long.

$P$. pauciflora.

$P$. nervata.

$P$. americana.

Panicularia borealis Nash. Stems weak, erect, glabrous, 50-100 cm. tall; leaf blades $8-20 \mathrm{~cm}$. long, pale green, nearly smooth; sheaths loose, longer than the internodes; panicle lax, 15-30 cm. long, the branches single or in twos, usually short and erect; spikelets linear, 10-15 mm. long; lemmas thin, 3.5-4 $\mathrm{mm}$. long, 7 -nerved, the nerves minutely hispid. Common in shallow ponds. 
Panicularia pauciflora (Presl.) Kuntze. Stems 50-100 cm. high, smooth; leaf blades 10-20 cm. long, nearly $1 \mathrm{~cm}$. broad, acute, scabrous; sheaths nearly equalling the internodes; panicle loose, $15-20 \mathrm{~cm}$. long, usually purplish, its base included in the upper sheath; branches slender, spreading, 2-5 at a node, flower-bearing above the middle; spikelets 4-5 $\mathrm{mm}$. long, 4-6-flowered; lemmas prominently 5-nerved, rarely 7 -nerved. In moist places or even in water, not rare.

Panicularia nervata (Willd.) Kuntze. Stems 50-100 cm. tall, slender, glabrous; leaf blades $15-30 \mathrm{~cm}$. long, 4-5 $\mathrm{mm}$. wide, scabrous above; panicle 6-20 cm. long, long-peduncled, its branches in twos and threes, slender and spreading; spikelets $2-4 \mathrm{~mm}$. long, 4-7-flowered; lemma prominently 7 -nerved. In wet places, infrequent.

Panicularia nervata elata (Nash) Piper. Leaf blades 5-8 mm. broad; stems taller and panicles larger. In wet places in woods.

Panicularia americana (Torr.) MacM. Reed Meadow Grass. Stems stout, $100-150 \mathrm{~cm}$. high; leaf blades $6-15 \mathrm{~mm}$. wide; panicle large and loose, $20-40$ $\mathrm{cm}$. long, nodding at the top; spikelets 4-7-flowered; second glume 2-2.5 mm. long. In wet places, Steptoe, G. R. Vasey; Waitsburg, Horner.

\section{SPARTINA.}

Coarse perennial grasses with strong creeping rootstocks, rigid simple stems and long tough leaves; inflorescence of one-sided spreading or erect alternate spikes; spikelets 1 -flowered, narrow, deciduous, borne in two rows on the rachis, articulated with the very short pedicels below the glumes; glumes keeled, very unequal; lemma keeled, equalling or shorter than the second glume; palea often longer than its lemma; grain free.

Plant stout; spikelets 12-14 mm. long.

Plant slender; spikelets 6-9 mm. long.

S. michauxiana.

S. gracilis.

Spartina michauxiana Hitchc. Stems 1-2 m. tall, simple, smooth; leaf blades flat, keeled, long-acuminate, involute in age, scabrous on the margins; spikes 5-20, 5-12 cm. long, ascending, sometimes peduncled; spikelets closely imbricated; glumes very scabrous on the keels, awn-pointed; lemma scabrous on the midrib, which terminates below the 2-toothed apex. Rocky banks of Snake River at Almota and Lake Tesemini, Idaho.

Spartina gracilis Trin. Stems $30-60 \mathrm{~cm}$. high, erect, stiff; leaf blades pale green, flat or slightly involute, $15-30 \mathrm{~cm}$. long, $2-4 \mathrm{~mm}$. wide, somewhat scabrous; spikes mostly 5-7, appressed, $1.5-2 \mathrm{~cm}$. long; glumes acute, scabrous on the keels; lemma entire, acute, scabrous on the keels. In alkaline soil, Spokane County.

\section{BECKMANNIA.}

Tall erect perennials; inflorescence a terminal panicle of erect spikes; spikelets 1-2-flowered, globose, compressed; glumes membranous, saccate, obtuse or abruptly acute; lemmas 1 or 2 , narrow, thin-membranous; palea hyaline; grain oblong, free, enclosed in the lemma.

Beckmannia erucaeformis (L.) Host. Perennial, the stems stout, 60$90 \mathrm{~cm}$. tall, glabrous throughout; leaf blades $10-30 \mathrm{~cm}$. long, 6-10 mm. wide, 
scabrous, the loose sheaths exceeding the internodes; panicle narrow, 10-30 $\mathrm{cm}$. long, the densely-flowered branches mostly solitary and erect; spikelets nearly orbicular, flattened, $2 \mathrm{~mm}$. long. In shallow water or very moist places.

\section{AGROPYRON. WHEATGRASS.}

Perennials with simple stems and terminal spikes; spikelets 3-many-flowered, sessile, single and alternate at each notch of the usually continuous rachis, the side of the spikelet, that is the edge of the glumes toward the rachis; lemmas rigid, rounded on the back, 5-7-nerved, usually acute or awned at the apex; palea often with hairy keels; grain pubescent at the apex.

Plants densely tufted, seldom producing stolons.

Spikelets subterete, the florets close; lemma short-awned.

Spikelets flattened, the florets loose; lemma usually awned. Glumes awnless.

Glumes awned.

Plants producing abundant stolons.

Lemma puberulent.

A. tenerum.

A. spicatum.

A. flexuosum.

A. lanceolatum

Lemma glabrous.

Leaves pale, scabrous above; nerves prominent.

Leaves green, pubescent above; nerves rather obscure.
A. occidentale.

A. repens.

Agropyron tenerum Vasey. Perennial, tufted; stems erect, $30-100 \mathrm{~cm}$. high, rather slender, glabrous; stem leaves 3 or 4 , the blades becoming involute, scabrous on both sides; the sheaths glabrous and shorter than the internodes; spike 10-20 cm. long, narrow, the spikelets densely crowded; lemmas linear-oblong, 5-nerved, scabrous, acuminate or short-awned. Common in low ground.

Agropyron spicatum (Pursh) Scribn. \& Smith. Wheat Bunch-grass. Stems 50-100 cm. tall, densely tufted, glabrous and glacuous; stem leaves 3 , the blades becoming strongly involute, minutely pubescent above, scabrous beneath, the sheaths smooth or pubescent; spikes erect, $5-15 \mathrm{~cm}$. long; spikelets regularly scattered, lanceolate-oblong, 10-20 $\mathrm{mm}$. long, without the awns; lemma tipped with a stout divergent awn, 1-2 cm. long. Very abundant on dry hills and exposed edges. Under some conditions, the plants produce long stolons.

Agropyron spicatum inerme (Scribn. \& Smith) Heller. Stems usually more slender; spikelets smaller; awns wanting. Very abundant on dry hills and exposed ledges. The species and the subspecies are frequently found growing together.

Agropyron flexuosum Piper. (Sitanion flexuosum Piper.) Very similar in appearance to $A$. spicatum. Spikelets looser, flexuous; spikelets often two at a node; glumes awned, of ten trifid; lemma usually bifid, its awn $3.5-4 \mathrm{~cm}$. long. Banks of Snake River at Wawawai.

Agropyron lanceolatum Scribn. \& Smith. Stems erect, 60-120 cm. tall, smooth, from elongated creeping rootstocks; stem leaves 4 , the blades becoming involute, rather narrow, ascending, strigose above, smooth beneath, the sheath loose, exceeding the internodes; spikes erect, 15-25 cm. long; spikelets not crowded, 2-2.5 cm. long, 6-10-flowered; lemmas sparsely pubescent, tipped with a very short awn. Common on the dry sandy bars of Snake River.

Agropyron occidentale Scribn. Bluestem. Whole plant pale or glaucous; stems erect, $30-100 \mathrm{~cm}$. high; leaves firm, the nerves thick and prominent; 
spike 8-15 cm. long, compact; spikelets 7-13-flowered, 12-20 mm. long, glabrous; lemma firm, awn-pointed, the nerves faint. Introduced along the railway, probably from Montana.

Agropyron repens L. (Couch or Quack Grass.) Stems erect, 100-150 cm. high; leaf blades green, pilose above, the nerves not prominent; spike $5-15 \mathrm{~cm}$. long; spikelets 5-flowered; lemma glabrous or nearly so, strongly nerved, usually awn-pointed. A dangerous weed sparingly introduced from Europe.

\section{ELYMUS. RYEGRASS.}

Perennial or annual grasses with spike-like inflorescences which do not readily break up into segments; spikelets 1-7-flowered, 2-4 at each joint of the rachis or rarely solitary; glumes entire, equal, rigid, narrow; lemmas acute, acuminate or awned, entire.

Annual; awns 5-10 cm. long.

E. caput-medusae.

Perennials; awns short or none.

Plants spreading by rootstocks; lemma glabrous.

Plants tufted.

Culms very stout, $1-2 \mathrm{~m}$. high.

Clums slender, seldom $1 \mathrm{~m}$. high.

Lemma pubescent; spike nodding.

Lemma not pubescent; spike erect.

Glumes lanceolate.

Glumes subulate.

E. triticoides.

E. condensatus.

E. canadensis.

E. glaucus.

E. leckenbyi.

Elymus caput-medusae L. Glabrous annual; stems $20-50 \mathrm{~cm}$. high, erect or geniculate at base; leaves 1-2 $\mathrm{mm}$. broad, becoming involute; spike stout, erect, green or becoming purplish, $1-4 \mathrm{~cm}$. long without the awns; spikelets 2 at each node, 1 or rarely 2-flowered; glumes subulate, rigid, $2-2.5 \mathrm{~cm}$. long; lemma lanceolate, very scabrous, tipped with a stout awn $5-10 \mathrm{~cm}$. long. Introduced from Europe about Steptoe Butte and spreading rapidly.

Elymus triticoides Buckl. Stems erect, about $1 \mathrm{~m}$. tall, not densely tufted; leaves 4-6 $\mathrm{mm}$. wide, sometimes scabrous; panicle spike-like or with some of the lower branches elongated, usually purplish, rather loose; lemma acuminately short-awned. Moist places.

Elymus condensatus Presl. Stems 1-2 m. tall, stout, densely tufted; leaf blades flat, glaucous, smooth except the scabrous margin, usually $1-2 \mathrm{~cm}$. broad; spikes 3-30 cm. long, erect; spikelets 3-6-flowered, usually several at each node, commonly densely crowded; lemmas mucronate-pointed. Abundant in moist soil.

Elymus canadensis L. Stems stout, about $1 \mathrm{~m}$. tall, pale and somewhat glaucous throughout; leaf blades flat or involute, nearly smooth; spike palegreen, flexuous or nodding, $10-15 \mathrm{~cm}$. long; spikelets 3-5-flowered, mostly in pairs, somewhat divergent; lemma pubescent, the awn $2-3 \mathrm{~cm}$. long, usually spreading. Not common.

Elymus glaucus Buckl. Stems $50-100 \mathrm{~cm}$. tall, erect; leaf blades spreading or drooping, $10-30 \mathrm{~cm}$. long, 6-16 mm. wide; spike-like panicle narrow, erect or rarely nodding above, 5-15 cm. long, greenish or purplish, glaucescent; spikelets usually appressed, mostly in pairs, 3-6-flowered; glumes lanceolate; lemma not pubescent but rough near the apex, tipped with an awn about twice as long. Common and variable; some forms approach E. canadensis. 
Elymus leckenbyi Piper. Stems stout, erect, $60-80 \mathrm{~cm}$. tall; leaf blades stiff, erect or ascending, 4-12 cm. long, involute, glabrous beneath, strigose above, sharply acuminate; sheaths glabrous, or on sterile shoots ciliate; spike 10-15 cm. long, slender, usually erect, long-exserted; glumes 2, equal, entire, or unequally bifid, subulate, $2.5-3 \mathrm{~cm}$. long; lemma lanceolate, 8-9 mm. long, smooth at base, scabrid above, bifid at apex and tipped with a straight awn, 3-4 cm. long. Bars of Snake River at Wawawai.

\section{HORDEUM. WILD BARLEY.}

Cespitose annuals or perennials with terminal cylindrical spikes; spikelets 1-flowered, usually in threes at each joint of the rachis, the lateral generally short-stalked and imperfect; rachilla produced beyond the flower; lower glumes often reduced to awns and forming an apparent involucre around the spikelets; glumes rigid; lemmas rounded on the back, 5-nerved at the apex, awned; palea scarcely shorter than the lemma; grain usually adherent to the lemma, hairy at the summit.

Floret of central spikelet pedicelled, its glumes ciliate.

Floret of central spikelet sessile, its glumes not ciliate.

Glumes not all subulate, the inner ones obliquely lanceolate.

Glumes all alike, subulate.

Lateral florets long-awned.

Lateral florets awnless or short-awned.

Florets of lateral spikelets neutral.

Florets of lateral spikelets perfect.

H. murinum.

H. geniculatum.

H. jubatum.

$H$. nodosum.

H. boreale,

Hordeum murinum L. Wall Barley. Stems 15-30 cm. tall; leaf blades 2-12 cm. long, 2-6 mm. wide; spikes 5-10 cm. long, thick; spikelets mostly in threes, all stalked; both glumes of the central spikelet and the inner glume of the lateral spikelets ciliate and flattened, bearing awns 20-25 mm. long; outer glumes of lateral spikelets neither flattened nor ciliate; lemma scabrous at the apex, long-awned. A troublesome weed, sparsely introduced.

Hordeum geniculatum All. Annual, glabrous, 10-30 cm. high; upper sheath inflated; spike cylindrical, green, 2-5 cm. long; lemma $2-2.5 \mathrm{~cm}$. long including the stiff straight awn. Sparingly introduced from Europe.

Hordeum jubatum L. Squirrel Tail. Annual, tufted, erect, $30-60 \mathrm{~cm}$. high, glabrous or sometimes pubescent; leaf blades flat, becoming involute, the sheaths shorter than the internodes; spike-like panicle pale green or yellowish, 7-10 cm. long, readily breaking apart; central spikelet sessile, fertile, the lateral ones peduncled and sterile; glumes all subulate, 3-6 cm. long. In moist places.

Hordeum nodosum L. Annual or perennial, 30-90 cm. high, erect; leaf blades flat or involute, the sheaths smooth or hairy; spikelike panicle $3-8 \mathrm{~cm}$. long, narrow, usually flexuous, readily separating into joints; central spikelet sessile, fertile, the lateral ones peduncled and sterile; glumes all subulate, 2 $\mathrm{cm}$. or less in length. Common in moist ground.

Hordeum boreale Scribn. \& Smith. Similar in every way to $H$. nodosum except for the perfect lateral florets. It is probably a subspecies at best. In moist ground. 


\section{SITANION.}

Cespitose perennials, with spike-like panicles, which readily break up into segments; spikelets $2-3$ at each joint of the rachis, rarely solitary, 1-5-flowered; glumes subulate and entire, or lanceolate and bifid, or parted into several long-awned lobes; lemmas lanceolate and acute, or those of the lowest floret sterile and subulate, entire with a single awn, or trifid and three-awned. This genus is hardly distinct from Elymus.

Glumes cleft or parted into 3 to many lobes; awns of lemma 8-10

$\mathrm{cm}$. long.

Glumes entire or only 2-cleft or 2-parted.

Sheaths and upper leaf surfaces glabrous.

Blades 2-5 mm. broad.

Blades 5-7 mm. broad.

Sheaths and upper leaf surfaces pubescent.

Culm leaves 7-12 cm. long.

Culm leaves $2-6 \mathrm{~cm}$. long.

S. jubatum.

S. rigidum.

S. latifolium.

S. hystrix.

$S$. velutinum.

Sitanion jubatum J. G. Smith. Stems stout, mostly erect, 20-30 cm. high; leaf blades short, flat, strigose-pubescent and somewhat hirsute, 4-8 cm. wide; sheaths densely hirsute; spike $6-8 \mathrm{~cm}$. long, the base enclosed in the elongated upper leaf sheath; glumes 3-8-parted, each lobe bearing a slender awn 3-8 cm. long; lowest floret sterile, its lemma resembling the glumes; lemma of perfect florets lanceolate, 3-awned, the middle awn stout, 8-10 cm. long, the lateral ones slender and usually shorter. Common in dry ground.

Sitanion rigidum J. G. Smith. Stems $10-20 \mathrm{~cm}$. high; leaf blades green or slightly glaucous, rigid, $2-5 \mathrm{~mm}$. wide, flat or at length involute; spike green, $2-8 \mathrm{~cm}$. long, erect or nearly so, often included at base in the upper sheath; glumes or glume divisions 4 and entire or 6 , that is the lateral ones divided to the base, all awned; lemma 7-9 $\mathrm{mm}$. long, tipped with a stout awn 3-4 mm. long. On high ridges in the Blue Mountains.

Sitanion latifolium Piper. Similar to $S$. rigidum but larger; leaves broader; glumes or their divisions 8 or sometimes 6 , all awned. Perhaps not distinct from $S$. rigidum. High alpine ridges in the Blue Mountains.

Sitanion hystrix (Nutt.) J. G. Smith. Stems 10-30 cm. high; sheaths and blades pilose-canescent, the blades 1-4 $\mathrm{mm}$. wide, flat or at length involute; spike 5-7 cm. long, erect or nearly so; glumes or divisions 8 , all awned; lemma puberulent, 3 -awned, the recurved middle awn about $3 \mathrm{~cm}$. long. In dry soil, Spokane and Walla Walla.

Sitanion velutinum Piper. Stems $30-40 \mathrm{~cm}$. high; whole plant densely puberulent with white soft hairs; blades flat; spikes 4-8 cm. long, erect; glumes puberulent, entire, or rarely cleft or divided, all awned; lemma puberulent, 3-awned, the awns 3-5.5 cm. long. Steptoe, G. R. Vasey.

\section{Family 16. CyPERACEAE. Sedge Family.}

Grass-like or rush-like herbs; stems slender, solid (rarely hollow), triangular, quadrangular, terete or compressed; leaves narrow with closed sheaths; flowers perfect or unisexual in spikelets, one (rarely two) in the axil of each scale (glume or bract); 
spikelets solitary or clustered, 1 to many-flowered; scales tworanked or in a spiral, persistent or deciduous; perianth hypogynous, of bristles, or interior scales wanting; stamens 1-3, rarely more; ovary 1-celled, 1-ovuled; style 2-or 3-cleft; fruit a lenticular or three-sided akene; endosperm mealy; embryo minute.

Flowers monoecious or dioecious, usually borne in separate spikes.

Flowers of the spikelet all, or at least one of them perfect; spikelets all similar.

Spikelets compressed; scales 2-ranked.

Spikelets not compressed; scales in a spiral.

Base of style swollen, persistent as a tubercle on the akene.

Base of style not swollen, deciduous or persistent as a subulate tip.

Bristles present; hyaline scales none.

Bristles none; perianth of a single minute posterior scale.

65. Carex, 43.

66. Cyperus, 49.

67. Eleocharis, 50.

68. SCIRPUS, 51.

69. Hemicarpha, 52.

65. CAREX. SEDGe.

Grass-like sedges, perennial by rootstocks; stems mostly triangular; leaves 3-ranked, the upper (bracts) elongated or very short, and subtending the spikes of flowers, or wanting; flowers solitary in the axils of bracts (scales), monoecious or dioecious; spikes either wholly staminate, or pistillate, or sometimes androgynous; perianth none; staminate flowers of 3 stamens; pistillate flower of a single pistil with a style and 2-3 stigmas borne in the axil of a second bract (the perigynium) which completely encloses the akene; akene 3 -angled, lenticular or planoconvex.

Sectron 1. Spikes sessile, all alike, bearing the inconspicuous staminate flowers either at the base, at the top, or rarely scattered; stigmas 2; akenes lenticular.

Subgenus VigneA.

Spikes not densely aggregated, the individual ones easily distinguished.

Perigynia wing-margined.

Perigynia 6-7 $\mathrm{mm}$. long; spikes acute.

Perigynia 3-4 mm. long; spikes obtuse.

Bract present; perigynia twice as long as broad.

Bract wanting; perigynia as broad as long.

Perigynia not wing-margined.

Spikes 10-30-flowered; perigynia straight. $\quad$ C. bolanderi.

Spikes 4-8-flowered; perigynia curved.

Spikes densely aggregated, the individual ones, at least the

C. liddoni.

C. bebbii.

C. festucacea. uppermost, distinguishable with difficulty.

Perigynia margined.

Dioecious or with the staminate and pistillate flowers irregularly scattered. 
Heads pale, dense, ovoid; perigynia lanceolate, the smooth beak as long as the body.

Heads brown, looser, elongate; perigynia ovate, the short beak serrulate.

Not dioecious, the staminate flowers either at the top

C. douglasii.

C. camporum. or the base of the spikelets; heads very dense.

Bract exceeding the head.

Bract small or wanting.

Spikes staminate at top; perigynia dark, narrowly margined.

Spikes staminate at base; perigynia pale, rather broadly margined.

Heads pyramidal-ovate, very dense.

Heads looser, some of the lower spikes separate.

Perigynia not margined.

Staminate flowers at base of spikelets; head bractless; beak of the perigynium serrulate.

Staminate flowers at the top of spikelets; bract present; beak of perigynium not serrulate.

Inflorescence dense, oblong or pyramidal; perigynia pale, spongy at base, 4-5 mm. long.

Inflorescence branched at base, rather loose; perigynia brown, not spongy at base, $3 \mathrm{~mm}$. long.

C. athrostachya.

C. hoodii.

C. pachystachya.

C. multimoda.

C. arcta.

C. stipata.

C. diandra.

SECTION 2. Spikes of two sorts, except when solitary, the lower wholly pistillate, sessile or stalked, the upper one or two slender and wholly staminate, or sometimes bearing pistillate flowers at base or apex; stigmas 3 and akenes 3 -angled, or if stigmas 2 and akenes lenticular the lower spikes are stalked.

Spike solitary and terminal. Subgenus EUCAREX.

Leaves filiform; bract scale-like.

Leaves flat; bract foliaceous.

Spikes several, distinct.

Stigmas 2; akenes lenticular.

Perigynia subglobose, almost beakless. $\quad C$. aurea.

Perigynia flattened, short-beaked.

Scales acute; perigynia strongly nerved.

Scales obtuse; perigynia faintly nerved.

C. filifolia.

C. geyeri.

C. nebrascensis.

Perigynia stipitate; scales partly green; sheaths green.

Perigynia not stipitate; scales wholly purple; sheaths purple.

Stigmas 3; akenes 3-angled.

Beak of perigynium short, entire or merely emarginate.

Perigynia pubescent.

Scales acuminate.

Scales obtuse.

Perigynia glabrous.

Leaves broad; spikes 6-10 cm. long.

Leaves rather narrow; spikes $1-3 \mathrm{~cm}$. long.

Beak of perigynium rather long, bidentate.

Perigynia hairy, firm.

Perigynia glabrous.

Perigynia not inflated, strongly nerved, the teeth $2 \mathrm{~mm}$. long, recurved.

Sheaths pubescent; spikes ascending.

Sheaths glabrous; spikes nodding.

C. kelloggii.

C. prionophylla.
C. rossii.

C. concinnoides.

C. amplifolia.

C. aperta.

C. lanuginosa.
C. atherodes.

C. comosa. Perigynia inflated, thin. 
Leaves and sheaths conspicuously crossveined; stems spongy at base.

Leaves and sheaths slightly or not at all cross-veined; stems not spongy at base.

Perigynia ascending, straight; leaves firm.

Perigynia curved, spreading; leaves soft.

C. utriculata.

C. monile.
C. retrorsa.

Carex liddoni Boott. Culms erect, $30-60 \mathrm{~cm}$. tall, scabrous above; leaves 2-4 mm. wide, shorter than the stems; spikes 3-6, ovoid or oblong, pointed at each end, $2 \mathrm{~cm}$. long, all androgynous, pale, sessile, distinct but usually close together; perigynium smooth, broadly lanceolate, 6-7 $\mathrm{mm}$. long, the broad beak exceeding the body in length; scales acuminate, about as long as the perigynia. Infrequent.

Carex bebbii Olney. Stems slender, erect, $20-60 \mathrm{~cm}$. high; leaves not stiff, 2-4 mm. wide, shorter than the stems; bracts setaceous; spikes $3-12$, brown, ellipsoid, 5-8 mm. long, closely crowded in an ovoid cluster; scales oblong, acuminate; perigynia ascending, firm, narrowly ovate, $3-3.5 \mathrm{~mm}$. long, exceeding the scales, nerveless or faintly nerved; stigmas 2 . In low meadows, rare.

Carex festucacea brevior (Dewey) Fernald. Stems tufted, slender, erect, 40-60 cm. high; leaves 2-4 mm. wide, stiff, shorter than the stem; sheaths with a pale marginal band; spikes 3-6, straw-colored, approximate, broadly ovoid, obtuse, 8-12 mm. long, staminate at base; scales obtuse; perigynia spreading, firm, broadly ovate, strongly 7-15-nerved on the outer face, 4.5-5 mm. long, the orifice minutely bidentate; stigmas 2 . In rather dry soil, not common.

Carex bolanderi Olney. Tufted, pale green; stems $20-100 \mathrm{~cm}$. long, rather slender, weak and spreading; leaves soft, smooth, 2-4 mm. wide, shorter than the stems; inflorescence of 4-10 scattered spikes; spikes oblong, 10-15 mm. long, sessile or nearly so; perigynia lanceolate, faintly nerved, $4 \mathrm{~mm}$. long, the body gradually tapering into the nearly equal serrulate deeply 2-toothed beak; scales white, scarious, with a broad green midvein, ovate-lanceolate, acuminatecuspidate, as long as the perigynia. In moist mountain woods.

Carex laeviculmis Meinsch. Glabrous throughout, tufted; stems very slender, $30-50 \mathrm{~cm}$. high; leaves numerous, flat, $1-1.5 \mathrm{~mm}$. broad, shorter than the culms; spikes 3-7, sessile, 3-5 $\mathrm{mm}$. long, the lower ones scattered; bract solitary, usually shorter than the inflorescence; perigynia spreading when mature, lanceolate, shortly stipitate, strongly curved, flat above, convex beneath, pale green, short-beaked, faintly 7-nerved on each face; scales ovate, hyaline except the midrib, shorter than the perigynia. In moist shady places in the mountains.

Carex douglasii Hook. Dioecious; rootstocks creeping, brownish; stems erect, $15-30 \mathrm{~cm}$. high, smooth; leaves pale, 2-4 mm. wide, very tapering, shorter than the stems; bracts slender, usually exceeding the head; heads ovateoblong, pale brown, 2-3 cm. long, composed of many crowded spikes; perigynia $4 \mathrm{~mm}$. long, lanceolate, narrowly margined, stipitate, acuminate, obscurely nerved, the smooth beak as long as the body; scales lanceolate, acute or cuspidate, much longer than the perigynia; stigmas 2, very long. Abundant in alkaline soil.

Carex camporum Mackenzie. (C. marcida Boott.) Stems slender, erect, scabrous, $30-40 \mathrm{~cm}$. high, from stout scaly black rootstocks; leaves pale, 1-3, usually $2 \mathrm{~mm}$. broad, shorter than the stems; inflorescence narrow, $2-4 \mathrm{~cm}$. long, of about 6-12 crowded spikes; spike brown, ovate, 4-7 $\mathrm{mm}$. long; perigynia stipitate, broadly ovate, beaked, bidentate, narrowly margined, minutely serrulate, $2 \mathrm{~mm}$. long; scales ovate, acute to cuspidate, hyaline-margined, as 
long as the perigynia. This species tends to be dioecious and is sometimes truly so. Common in alkaline soil.

Carex athrostachya Olney. Stems tufted, 30-60 cm. tall; leaves 2-3 mm. wide, shorter than the stems; inflorescence a dense ovoid straw-colored head composed of 5-20 crowded spikes, these staminate below; lower bracts $2-5$, exceeding the head; perigynia lanceolate, spongy at base, the long beak 2-toothed, its margins serrulate; scales acuminate, about equalling the perigynia. Common in wet places.

Carex hoodii Boott. Slender, erect, tufted, very smooth, 30-60 cm. high; leaves many, pale, 2-3 mm. broad, shorter than the stems; spikes about 6, densely crowded into an ovoid or oblong head, 1-2 cm. long; perigynia spreading, lanceolate, rather thick, $5 \mathrm{~mm}$. long, dark when mature, obscurely nerved, narrowly wing-margined, somewhat stipitate at base, narrowed into a roughmargined beak nearly as long as the body; scales lance-ovate, acuminate, scarious margined, brownish, as long as the perigynia. In moist places, not common.

Carex pachystachya Cham. Stems tufted, 30-90 cm. tall; leaves flat, flaccid, 3-4 mm. broad, shorter than the stems; inflorescence a dense oblong head 10-12 mm. long, composed of 6-12 crowded sessile brownish spikes; perigynia spreading, ovate-lanceolate, flat, about $4 \mathrm{~mm}$. long, the beak bidentate, serrulate on the thin margins; scales acutish, equalling the perigynia. Very common in wet meadows.

Carex multimoda Bailey. Very similar to $C$. pachystachya but the head less dense, one or more of the lower spikes clearly separate or if crowded the head oblong; perigynia indistinguishable. Common in the Blue Mountains.

Carex arcta Boott. Loosely tufted, pale green; stems $20-60 \mathrm{~cm}$. high, smooth or nearly so; leaves pale green, $2.5-4 \mathrm{~mm}$. long, usually larger than the stems; head ovate-oblong, green or brownish, of 5-12 crowded spikes; spikes oblong or ovoid, 6-8 mm. long; perigynia spreading, ovate, somewhat cordate, gradually tapering into the serrulate beak, strongly nerved on the outer face, 2-3 mm. long; scales hyaline, of ten brownish, acute, shorter than the perigynia. In moist meadows and copses.

Carex stipata Muhl. Stems 50-100 cm. tall, sharp-angled; leaves flat, 6-8 $\mathrm{mm}$. wide, shorter than the stem; sheaths somewhat rugulose on the inner side; inflorescence a dense ovate head of many crowded spikes, 3-5 cm. long, straw-colored or olivaceous, commonly exceeded by the slender lowest bract; perigynia spreading, triangular-ovate, many-nerved, tapering into a long stout 2-toothed beak, whose margins are serrulate; scales much shorter than the perigynia. Moist woods and copses.

Carex diandra ampla (Bailey) Piper n. comb. (C. teretiuscula ampla Bailey.) Densely tufted, the slender stems $90-120 \mathrm{~cm}$. high; leaves narrow, 2-4 mm. broad, mostly shorter than the stems; spikes $6-20$, brown, in elongated often nodding usually branched inflorescences, 5-12 cm. long; terminal florets staminate; perigynia spreading, ovoid, stipitate, nerved at the base on both sides, 3 $\mathrm{mm}$. long, the serrulate beak as long as the thick body; scales brown, ovate, acuminate-cuspidate, as long as the perigynia. In boggy places, Latah County, Idaho.

Carex filifolia Nutt. Wool grass. Densely matted in extensive tufts; stems $10-20 \mathrm{~cm}$. tall; leaves numerous, filiform, about equalling the stem; inflorescence a solitary terminal spike, the upper portion of which is staminate; perigynium triangular-ovoid, pale below, darker at apex and very minutely pubescent, the short beak with an entire orifice. In dry soil, sometimes very abundant. Exceedingly difficult to plow up. 
Carex geyeri Boott. Densely tufted, $30-45 \mathrm{~cm}$. high; leaves flat, rigid, very scabrous, $2 \mathrm{~mm}$. wide, about as long as the stems; inflorescence a single terminal straw-colored spike, the upper and larger portion of which is staminate; pistillate flowers several, usually but one maturing; perigynium smooth, oblong, with a very short entire beak, 1-nerved on each side; scales pale or rusty, elongated, acuminate, exceeding the perigynia. Very abundant on dry hillsides.

Carex aurea Nutt. Stems loosely tufted, from long horizontal rootstocks, 10-30 cm. high; leaves flat, pale green, 3-4 $\mathrm{mm}$. wide, usually overtopping the stems; spikes 3-6, all stalked, the uppermost staminate and linear, or rarely androgynous, the rest pistillate, narrowly cylindrical, loosely flowered, 1-3 $\mathrm{cm}$. long; bracts mostly exceeding the stem; perigynia globose, very minutely beaked, reddish when mature, strongly nerved. In low meadows.

Carex nebrascensis Dewey. Stems $50-100 \mathrm{~cm}$. tall, from stout horizontal rootstocks; leaves pale, $5-10 \mathrm{~mm}$. broad, shorter than the stems; inflorescence of from 3-6 spikes, these sessile or nearly so; bracts foliaceous, usually exceeding the stems; staminate spikes 1-3; pistillate spikes $2-3$, cylindric, dense, 2-3 cm. long, about $6 \mathrm{~mm}$. thick; perigynia oval or obovate, brownish, resinousdotted, short-beaked, the beak bidentate; scales purple, with a green midrib, usually shorter than the perigynia. Wet places, frequent.

Carex kelloggii Boott. Stems tufted, !slender, 15-40 cm. tall, erect; leaves numerous, flat, $2-3 \mathrm{~mm}$. wide, commonly as long as the stem, sometimes longer; spikes 4-15, the bracts commonly exceeding the stem; staminate spike usually single, slender, purplish; pistillate spikes 3 to many, mostly sessile or nearly so, greenish, dense, $2-4 \mathrm{~cm}$. long, $3 \mathrm{~mm}$. thick; perigynia promptly deciduous, $2 \mathrm{~mm}$. long, smooth, flattened, 3- or 4-nerved on the outer face, stipitate at the base, short-beaked, the beak emarginate; iscales green with purple margins, obtusish, shorter than the perigynia. On wet stream banks and lake shores.

Carex prionophylla Holm. Stoloniferous, in loose clumps; stems slender, 60-100 $\mathrm{cm}$. high, rough near the top; sheaths purple, the lower bladeless; leaves flat, soft, bright green, 4-5 mm. wide, as long as the stems; bract 5-8 $\mathrm{cm}$. long, not equalling the inflorescence; spikes 4 , sessile, the terminal staminate, 1-2 cm. long; perigynia $2 \mathrm{~mm}$. long, obovate, narrowed at base, abruptly short-beaked, $2 \mathrm{~mm}$. long, the beak emarginate; scales obtuse, dark purple, nearly as long as the perigynia. In moist woods, Mt. Carlton.

Carex rossii Boott. Densely tufted, the stems $20-40 \mathrm{~cm}$. tall; leaves pale, flat, scabrous, 1-3 mm. wide, commonly equalling the stems; inflorescence of 1-4 spikes, the uppermost staminate; staminate spike slender, 2-3 $\mathrm{mm}$. long, pale, long-stalked; pistillate spikes $1-3$, distinct, loosely few-flowered; perigynia oblong, pubescent, with a 2-toothed beak; scales purple with hyaline margins, or greenish, sharply acuminate, shorter than the perigynia. In stony soil, in the mountains.

Carex concinnoides Mackenzie. Stoloniferous; stems 10-20 cm. high, erect; leaves numerous, firm, pale, strongly striate, shorter than the stems, 3-5 mm. broad; stem leaves bladeless or with very small blades; bract short; pistillate spikes 1 or 2, 5-10 mm. long, nearly sessile, few-flowered; staminate 10-20 mm. long, with purple ovate obtuse scales; perigynia oblong-elliptic, shortly stipitate, abruptly short-beaked, loosely pubescent, 2.5-3 mm. long; scales ovate-lanceolate, acute, purple, hyaline-margined, shorter than the perigynia. In coniferous woods, Blue Mountains and Thatuna Hills. Very closely allied to the more eastern $C$. richardsoni $\mathrm{R}$. Br.

Carex amplifolia Boott. Stems about $2 \mathrm{~m}$. tall, smooth; leaves flat, 12-20 $\mathrm{mm}$. broad, longer than the stem; bracts very large, the lower overtopping 
the stem; spikes 5-7, the uppermost staminate, 5-8 cm. long; pistillate spikes narrowly cylindrical, straight or curved, $6-10 \mathrm{~cm}$. long, dark olivaceous, the lower ones long-peduncled; perigynium subglobose, glabrous, the beak with an oblique entire orifice; scales purple with a green midrib. Along streams in woods.

Carex aperta Boott. (C. bovina Howell.) Tufted, smooth throughout; stems $30-60 \mathrm{~cm}$. high; leaves flat but keeled, 4-6 mm. broad, rather shorter than the stems; spikes 3-4, the terminal staminate, mostly short peduncled; pistillate spikes $1-3 \mathrm{~cm}$. long, densely flowered, $5 \mathrm{~mm}$. thick; scales equalling the perigynia, acuminate, purple with a green midrib; perigynia $2 \mathrm{~mm}$. long, turgid, broadest at the middle, tapering to each end, brown when mature, the two or three angles pale; beak short and entire. On overflowed river bottoms, often very abundant and cut for hay.

Carex lanuginosa Michx. Stems erect, slender, 30-60 cm. tall, somewhat tufted; leaves flat, $2-5 \mathrm{~mm}$. wide, as long or nearly as long as the stem; staminate spikes $1-3$, sometimes pistillate at base; pistillate spikes 1-3, mostly long-peduncled, 18-30 mm. long; perigynia oval, densely pubescent, with a short 2-toothed beak; bracts acute or acuminate, about equal to the perigynium. Swamps, not rare.

Carex atherodes Spreng. (C. aristata R. Br.) Rather stout, $60-100 \mathrm{~cm}$. high; stems sharply angled; leaves numerous, 3-5 $\mathrm{mm}$. wide, exceeding the stems, the lower surface and sheaths hairy; spikes $2-8$, scattered, short peduncled, the upper 1-4 staminate; staminate spikes pale, slender, $2-6 \mathrm{~cm}$. long; pistillate spikes $2-5 \mathrm{~cm}$. long, rather loosely flowered; perigynia ovoidlanceolate, strongly nerved, the body $5 \mathrm{~mm}$. long, the stout recurved teeth $2 \mathrm{~mm}$. long; scales paler, awn-pointed, shorter than the perigynia. In wet places, infrequent.

Carex comosa Boott. Tufted, the stem stout, $50-150 \mathrm{~cm}$. high, rough and sharply angled; leaves broad, 6-15 $\mathrm{mm}$. wide, scabrous on the margins; spikes 4-6, drooping, on slender peduncles, the uppermost staminate, linear, brownish, 3-9 cm. long, of ten partly pistillate; pistillate spikes pale green, cylindric, about $1.5 \mathrm{~cm}$. thick, densely flowered; perigynia spreading, firm, lance-ovate, strongly many-nerved, attenuate into a long 2-toothed beak, the teeth 1-2 $\mathrm{mm}$. long and spreading; scales brownish, awned, about as long as the perigynia. Usually in shallow water.

Carex utriculata Boott. Stems stout, spongy at base, 60-100 cm. high; leaves broad, 4-10 $\mathrm{mm}$. wide, much longer than the stems, nodose-reticulate; bracts leaf-like, exceeding the stem; staminate spikes $2-5$, linear, 3-12 cm. long, sometimes pistillate at the top; pistillate spikes 2-6, peduncled, cylindric, green or brownish, 2-12 cm. long, often staminate at the top; perigynia 5-6 $\mathrm{mm}$. long, ovoid-conic, inflated, shining, gradually contracted into the beak, strongly nerved; scales lance-oblong, purple, mostly obtuse, shorter than the perigynia. Common in wet places.

Carex monile pacifica Bailey. Stems $30-100 \mathrm{~cm}$. tall, rather slender; leaves pale, flat, 3-5 mm. wide, shorter than the stem or little exceeding it, more or less nodose, reticulate; lower sheaths fibrose-margined; inflorescence of from 3-6 spikes, overtopped by the long bracts; staminate spikes 1-3, $2-4 \mathrm{~cm}$. long, sometimes pistillate at top; pistillate spikes usually 3 , yellow, 3-5 cm. long, short-stalked or sessile; perigynia 7-8 $\mathrm{mm}$. long, ovate, turgid, strongly nerved, with a stout 2-toothed beak; scales pale, acuminate, much shorter. Wet places, quite common.

Carex retrorsa Schwein. Tufted; stems stout, smooth, $40-80 \mathrm{~cm}$. high; leaves 5-10 $\mathrm{mm}$. broad, longer than the stem; bracts leaf-like; staminate spikes usually $1-4$, slender, $2-5 \mathrm{~cm}$. long, sometimes only part of the terminal 
spike staminate; pistillate spikes 3-8, usually close together, sessile or nearly so, 2-5 cm. long; perigynia thin, much inflated, $8-10 \mathrm{~mm}$. long, ovoid, attenuate into a long beak, strongly nerved, reflexed, much longer than the sharp pointed scales. In wet places.

\section{CYPERUS.}

Annual or perennial; stems simple, triangular, leafy near the base, and with one or more leaves at the summit which form an involucre for the simple or compound umbellate or capitate inflorescence; rays of the umbel sheathed at the base, usually very unequal, one or more of the heads or spikes commonly sessile; spikelets flat or roundish, few to many-flowered; scales concave, 2-ranked, all but the lower one flower-bearing; flowers perfect; perianth none; stamens 1-3; akene lenticular or triangular.

Rachilla of spikelets not winged; annuals.

Scales with recurved tips.

Rachilla of spikelets winged.

Scales acuminate, without recurved tips.

Wing of rachilla separating in scale-like pieces; annual.

Wing of rachilla persistent; perennials.

Scales of spikelets deciduous from the rachilla; plant stoloniferous and tuberiferous.

Scales of spikelets persistent, the whole spikelet

C. aristatus.

C. acuminatus.

C. erythrorhizos.

C. esculentus. breaking away from the axis early; plants with hard corm-like bases.

Spikelets much flattened; akene narrowly oblong. Spikelets not much flattened; akenes broadly obovoid.

\section{C. strigosus.}

C. houghtonii.

Cyperus aristatus Rottb. Annual, stems 1-15 cm. tall, ascending; leaves flat, about $1 \mathrm{~mm}$. wide, of ten curved, about equalling the stems; bracts much exceeding the inflorescence; spikelets ovate-lanceolate, 3-5 $\mathrm{mm}$. long, in dense heads, terminating the branches of an unequally rayed umbel, or rarely all aggregated into a single compound head; scales green, becoming brown, all with strongly recurved awn-like tips. Stream banks, common.

Cyperus acuminatus Torr. \& Hook. Much like C. aristatus, usually taller; spikelets pale green, oblong-lanceolate, the scales merely acuminate, the tips but slightly recurved. Banks of Snake River at Almota, rare.

Cyperus erythrorhizos Muhl. Annual; stems usually $15-60 \mathrm{~cm}$. tall, sometimes much smaller; leaves flat, commonly 2-4 mm. broad, shorter than the stem; involucral leaves 4-8, broad at base, far exceeding the inflorescence; spikelets bright chestnut, linear, 5-6 mm. long, densely crowded into flattened spikes, 1-3 cm. long, the latter umbelled on the unequal branches of the primary umbel; scales oblong, keeled, the green midrib prolonged into a short, mucronate tip; wings of the rachis separating to the base, forming pairs of small scales. Banks of Snake River, frequent.

Cyperus esculentus L. Nut Grass. Perennial, with horizontal tuberbearing rootstocks; stems $30-60 \mathrm{~cm}$. tall; leaves flat, 4-5 mm. long, exceeding the stem; involucral leaves as long as the others, far exceeding the inflorescence; umbel usually simple or nearly so, the rays very unequal, the spikelets arranged in loose spikes; spikelets linear, diverging, mostly two-ranked, 8-12 mm. long; 
scales yellowish or rusty, strongly-nerved, scarious-margined, the green midribs ending in very short points; wing of the rachis narrow, not becoming divided into scale-like parts. Banks of Snake River, rare.

Cyperus strigosus L. Perennial from a globose tuber; stems erect, 10-50 $\mathrm{cm}$. high; leaves flat, 4-6 $\mathrm{mm}$. wide; umbel simple or compound, the longest rays $8-12 \mathrm{~cm}$. long, their sheaths terminating in 2 bristles; spikelets linear, 8-16 mm. long, 7-15-flowered; scales pale, oblong-lanceolate, appressed, subacute; akene linear-oblong, acute. Sandy bars of Clearwater River.

Cyperus houghtonii Torr. Perennial; stems $20-60 \mathrm{~cm}$. high, much exceeding the leaves; leaves narrow, 1-2 mm. wide; involucral leaves about as long as the inflorescence; umbel with 1-5 unequal rays, some nearly sessile, a few elongate; spikelets in loose heads, oblong-linear, 8-14 mm. long, 11-15flowered; scales brownish, mucronate, strongly nerved, exceeding the brown akene. Along the Clearwater River near Lewiston, Idaho.

\section{ELEOCHARIS. SPIKE Rush.}

Annual or perennial; stems simple, triangular, quadrangular, terete, flattened or grooved, the leaves reduced to sheaths or the lowest very rarely blade-bearing; spikelets solitary, terminal, erect, several-many-flowered, not subtended by an involucre; scales concave, in a spiral; perianth of 1-12 bristles usually barbed; stamens 2 or 3; akene 3 -angled or biconvex; base of the style persistent on the summit of the akene forming a terminal tubercle.

Akenes 3-angled; spikelets few-flowered.

E. acicularis.

Akenes biconvex; spikelets many-flowered.

Plants not tufted; perennial with running rootstocks.

Plants tufted, annual.

Heads ovoid; bristles longer than the akenes.

E. palustris.

Heads oblong; bristles not longer than the akenes.

E. obtusa.

E. monticola.

Eleocharis acicularis (L.) Roem. \& Schult. Perennial by creeping rootstocks, usually forming extensive mats; stems very slender, $7-15 \mathrm{~cm}$. tall, erect; spikes 3-10-flowered, 3-5 mm. long; bristles 3 or 4 , shorter than the akene, or wanting; akene oblong or obovoid, somewhat 3-angled, marked with 9-12 longitudinal ribs, with very numerous cross-lines between them; tubercle broad, contracted at its junction with the akene; style 3-cleft. Very abundant in wet places.

Eleocharis acicularis bella Piper. Rootstocks very short, so that the plant forms dense round tufts $5-10 \mathrm{~cm}$. in diameter; stems ascending or spreading, only $2-5 \mathrm{~cm}$. long; otherwise as in the species. Rare on muddy banks of streams. In habit very different from $E$. acicularis, but lacking good morphological characters. In marked contrast to the species, the subspecies produces akenes freely.

Eleocharis palustris (L.) Roem. \& Schult. Rootstocks extensively creeping; stems 30-70 cm. tall; spike lanceolate-oblong, 1-2 cm. long; bristles 4, usually exceeding the obovate smooth biconvex akene; tubercle pobtuse, contracted at its junction with the akene; style 2-cleft. Abundant at the edges of ponds or in shallow water.

Eleocharis obtusa Schult. Stems erect or ascending, densely tufted, 5 to $7 \mathrm{~cm}$. high; spikelets brownish, ovoid, obtuse, 2-13 $\mathrm{mm}$. long; bristles $6-8$, exceeding the brown shining akene; tubercle very short and broad, deltoid, acute. In muddy places, uncommon. 
Eleocharis monticola leviseta Fernald. Stems in dense tufts, 10-25 cm. high; heads lance-ovate to lance-oblong, 6-9 mm. long; scales chestnut-brown with paler margins and midribs, acutish; akenes obovate, the flattish tubercle nearly as broad and about one-fourth as long as the body; scales very short, not barbed. In wet places near the mouth of the St. Joe River, Idaho, Humphrey.

\section{SCIRPUS.}

Annual or perennial; stems leafy or the leaves reduced to basal sheaths; spikelets terete (in ours), solitary, or in a terminal cluster, when it is subtended by a 1-several-leaved involucre; scales in a spiral, usually all fertile, one or two of the lowest sometimes empty; flowers perfect; perianth of 1-6 bristles, or sometimes none; stamens 2-3; style 2-3-cleft, not swollen at the base; akene triangular, lenticular or planoconvex.

Spikelet solitary, terminal; plant very small.

S. nanus.

Spikelets several to many; plants large.

Stems terete.

Akenes 2.5-3 mm. long, the scales one-fourth longer.

Akenes $2 \mathrm{~mm}$. long, the scales little longer.

S. occidentalis.

S. validus.

Stems 3-angled.

Involucral leaf solitary, erect.

Involucral leaves several, spreading.

Akenes plano-convex; bristles 4 .

Akenes 3-angled; bristles 6.

S. americanus.

S. microcarpus.

$S$. atrovirens.

Scirpus nanus Spreng. Densely tufted, the stems flattened and grooved, 1-6 cm. high; roots with minute tubers; spikelet ovoid, greenish, bearing 2-4 or rarely more florets; scales acutish, the lowest usually larger, when present longer than the smooth shining akene. In wet places, near Viola, Idaho.

Scirpus occidentalis (Wats.) Chase. Western Bulrush or Tule. Stems 1-2 m. high, from stout scaly rootstocks; panicle loose, the suberect slender branches 1-9 cm. long, slender; spikelets mostly in clusters of $2-7$, pale brown, subcylindric, 10-20 mm. long; scales oblong-ovate, viscid near the apex, aristate. Common in the shallow water of lake margins.

Scirpus validus Vahl. Very similar to $S$. occidentalis; panicle not so large, its branches 1-6 cm. long; spikelets solitary or in clusters of $2-5$, rusty brown, ovoid, 5-10 cm. long; scales almost orbicular, pubescent on the back, mucronate. Waitsburg, Horner. Rare in our limits.

Scirpus americanus Pers. Stems sharply 3-angled, $20-90 \mathrm{~cm}$. high, from stout elongated rootstocks; leaves $1-4$, shorter than the stem, channeled; bract $2-10 \mathrm{~cm}$. long, pointed; spikelets $1-6$, ovoid, closely crowded; scales brown, ovate, 2-cleft at apex and often awned; bristles 2-6, shorter than the plano-convex smooth akene. In wet places especially where somewhat alkaline.

Scirpus microcarpus Presl. Perennial, the stout stems about $1 \mathrm{~m}$. tall; leaves $8-10 \mathrm{~mm}$. broad, smooth beneath, rough on the margins and upper surface of the midvein, the upper leaf usually exceeding the stem; inflorescence a two to three times compound umbel, the primary rays $3-10 \mathrm{~cm}$. long, unequal; bracts leaf-like, about equalling the inflorescence; spikelets ovoid, numerous, dark green, 3-5 mm. long, in heads of 3-12 or more; scales broadly ovate, acute; stamens 2; styles bifid; bristles 4 ; nutlet white, oblong-lenticular, very short-beaked. Common on the margins of ponds and streams. 
Scirpus atrovirens Muhl. Similar to $S$. microcarpus; stems taller, often $100-150 \mathrm{~cm}$. high; panicle much denser; spikelets dark greenish-brown, ovoid to cylindric, 3-8 mm. long, in heads of 10-30; scales acuminate; akene oblong. obovoid, sharply pointed. Waitsburg, Horner.

\section{HEMICARPHA.}

Mostly annual, low tufted plants; stems and leaves erect or spreading, almost filiform; spikelets terete, terminal, clustered or solitary, subtended by a 1-3-leaved involucre; scales in a spiral, deciduous, all subtending perfect flowers; perianth of a single hyaline bract between the flower and the rachilla; bristles none; stamens 1-3; style 2-cleft, deciduous, not swollen at the base; akene oblong, turgid or lenticular.

Hemicarpha aristulata (Coville) A. Nelson. Tufted, glabrous, the numerous stems 5-8 cm. tall, erect or spreading; leaves narrow, involute, the recurved blades $1-3 \mathrm{~cm}$. long, as long as or longer than the sheaths; spikelets ovoid, obtuse, solitary or two in a cluster, $2-4 \mathrm{~mm}$. long; involucral bracts 3 , the uppermost 1-3 cm. long, the others much shorter; scales 1-1.5 mm. long, broadly obovate, the abruptly-acuminate recurved apex as long as the body; akene oblong, ovate or obovate, $0.5 \mathrm{~mm}$. long, with a short beak, the surface very minutely and regularly hexagonal-reticulate and rugose; styles shorter than the akene, 2-cleft half-way to the base; hyaline bract triangular-ovate. Very rare on the banks of Snake River at Almota. The species has the habit of $H$. subsquarrosa Nees, but the heads of $H$. occidentalis Gray.

\section{Family 17. ARACEAE. ARUM FAMILy.}

Plants with acrid or pungent juice and simple or compound leaves; flowers crowded on a spadix, perfect, monoecious or dioecious; spathe present or none; perianth of 4-6 sepals or none; fruit usually a 1-4-celled 1 -seeded berry.

\section{LYSICHITON.}

Acaulescent swamp herbs with large leaves from a thick horizontal rootstock; spathe sheathing at base, with or without a broad colored lamina, at first enveloping the cylindrical spadix which later becomes long-exserted on a stout peduncle; flowers perfect, crowded, covering the spadix; perianth 4-lobed; stamens 4 , opposite the perianth-segments; ovary 2-celled, 2-ovuled; fruit fleshy, somewhat immersed in the rachis and coalescent.

Lysichiton camtschatcense (L.) Schott. Yellow Skunk Cabbage. Leaves large, 30-90 cm. long, oblong, acute or acutish, narrowed at base into a short margined petiole; spathe golden-yellow, the blade oblong, acute, narrowed into a sheathing petiole; peduncle stout, $20-30 \mathrm{~cm}$. long; spadix cylindric, in fruit 5-12 cm. long. In swamps, the brilliant malodorous flowers appearing before the leaves. 


\section{Family 18. LEMNACEAE. Duckweed Family.}

Very small thallose plants floating free on the water, propagating by the division of the thallus; flowers $1-3$, monoecious, from the edge or upper surface, rare; fruit a 1-7-seeded utricle.

Thallus 1-5-nerved, with a single rootlet.

Thallus 5-12-nerved, with several rootlets.
71. LEMNA, 53.

71a. SPIRODELA, 53.

\section{LEMNA.}

Thallus 1-5-nerved, producing a single rootlet beneath; flowers produced from a cleft in the margin of the thallus, usually 3 together, surrounded by a spathe; two staminate, each of a single stamen, the other pistillate of a simple pistil; ovary 1-celled.

Thalli oblong, separate or soon separating.

Thalli oblong, each narrowed into a sheath-like base, remaining connected.

L. minor.

Lemna minor L. Thalli round to elliptic-ovate, 2-5 $\mathrm{mm}$. long, very obscurely 3 -nerved; seeds oblong-obovate, amphitropous, with prominent operculum. Common in ponds, very rarely fruiting.

Lemna trisulca L. Thalli thin, oblong to oblong-lanceolate, attenuate into a stalk-like base, usually several remaining connected, each faintly 3nerved; seeds ovate, amphitropous, with a small round operculum. In ponds near Potlatch, Idaho.

\section{1a. SPIRODELA.}

Very similar to Lemna but rootlets several, with axile vascular tissue; anther-cells divided by a vertical partition and dehiscing longitudinally.

Spirodela polyrhiza (L.) Schleid. Thallus round-obovate, 3-8 $\mathrm{mm}$. long, thick, purple and rather convex beneath, dark green above, palmately, mostly 7-nerved. Silver Lake, Pullman, Darlington.

Family 19. PONTEDERIACEAE. Pondweed Family.

Aquatic herbs with perfect more or less irregular flowers, surrounded by a spathe; perianth of 6 petal-like segments free from the 3 -celled ovary; stamens 3 or 6 , unequal or dissimilar, on the throat of the perianth; style 1; fruit a 1-3-celled capsule or 1-celled utricle.

\section{HETERANTHERA.}

Low herbs living in mud or shallow water, with a 1-fewflowered spathe bursting from the sheathing side or base of a petiole; perianth-limb somewhat equally 6-parted; stamens in the throat, usually unequal; capsule 1 or incompletely 3 -celled. 
Heteranthera dubia (Jacq.) MacM. Stems slender, branched, leafy, 30-100 cm. long; leaves sessile, linear, acute; spathe terminal, 1-flowered; flowers small, pale yellow, the tube very slender, 3-6 cm. long; capsule 1-celled, 6-8 mm. long. Marshall Junction, Suksdorf.

\section{Family 20. JUNCACEAE. Rush Family.}

Perennial, grass-like, usually tufted herbs; inflorescence a compound panicle, corymb or umbel, with the flowers singly or loosely clustered or aggregated into spikes or heads (rarely reduced to a single flower); flowers small, regular, with or without bractlets; perianth 6-parted, the parts glumaceous; stamens 6 , rarely 3 ; pistil superior, tricarpellary; ovary 3 -celled, or 1-celled with 3 parietal placentae; ovules 3-many; stigmas 3; fruit a loculicidal capsule; seeds 3-many, small.

Leaf-sheaths open; capsule 1 or 3-celled, many-seeded; placentae parietal or axial.

73. Juncus, 54.

Leaf-sheaths closed; capsule 1-celled, 3-seeded; placentae basal.

74. JunCOIDES, 57.

73. JUNCUS. RUSH.

Annual or perennial plants; stems leaf-bearing or scapose; leaves glabrous, round, grass-like or channeled; inflorescence a panicle or corymb, often one-sided, bearing its flowers either singly and with two bractlets or in heads and without bractlets, but each head in the axil of a bract; stamens 6 , rarely 3 ; ovary 1-celled or 3-celled; placentae parietal or axial; seeds several to many.

Lowest leaf of the inflorescence appearing like a continuation of the stem, the inflorescence therefore appearing lateral.

Flowers solitary or in clusters of 2 or 3.

Inner sheaths bristle-tipped; capsule retuse. $J$. subtriflorus.

Inner sheaths bearing a leaf blade; capsule acute. J. parryi.

Flowers numerous, in compound panicles.

Perianth segments brown, a green stripe on each side of the midrib; leaf of the inflorescence usually much shorter than the stem.

Perianth segments green; leaf of the inflorescence as long as the stem.

Lowest leaf of the inflorescence not appearing like a continuation of the stem.

Leaves not provided with cross partitions, either flat and grass-like or terete and channeled.

Annuals; stems branched, leafy.

Capsule oblong.

Capsule globose.

Perennials; stems simple.

Flowers bracteolate, loosely scattered or somewhat congested but not in true heads.

J. balticus.

J. filiformis.
J. bufonius.

J. sphaerocarpus. 
Auricles at summit of sheaths short and cartilaginous.

Auricles at summit of sheaths elongated and scarious.

Capsule ovate or oval, 1-celled; perianthsegments spreading, three-fourths the length of the capsule.

Capsule oblong, 3-celled; perianth-segments erect, about equalling the capsule.

Perianth-segments straw-colored, $4 \mathrm{~mm}$. long, the outer scarious only at base; cyme rather crowded.

Perianth-segments fuscous, $3.5-4 \mathrm{~mm}$. long, scarious margined to the apex; cyme congested.

Flowers not bracteolate, in true heads.

J. dudleyi.

J. tenuis.

J.brachyphyllus.

J. confusus.

Auricles of leaf-sheaths present; perianth parts smooth.

Auricles of leaf-sheaths wanting; perianth parts rough.

Seeds tailed.

Seeds not tailed.

Leaves provided with distinct cross partitions.

Blade of the leaves equitant.

Head black, solitary; stem terete.

Heads black or brown, 2-many; stem 2-edged.

Blade of the leaves cylindric or only slightly compressed.

Capsules subulate; bract exceeding the inflorescence.

Capsules oblong, acute; bract not exceeding the inflorescence.

Panicle loose; heads dark brown.

Panicle dense; heads cinnamon brown.

J. longistylis.

J. regelii.

J. orthophyllus.

$J$. mertensianus.

J. ensifolius.

J. nodosus.

J. suksdorfii.

J. columbianus.

Juncus subtriflorus (Meyer) Coville. Tufted; stems slender, 10-25 cm. high; inner leaf-blades reduced to bristles; bract as long as or longer than the inflorescence; perianth segments acute or acuminate, brownish, the outer longer, exceeding the brown oblong retuse capsule. Alpine on the higher parts of the Blue Mountains.

Juncus parryi Engelm. Densely tufted; stems $20-40 \mathrm{~cm}$. high; inner leaf blades not reduced; bract much exceeding the inflorescence; perianth segments brown, acute, the outer $7 \mathrm{~mm}$. long, slightly exceeding the inner; capsule oblong, acute, exceeding the perianth. Mt. Carlton, Kreager.

Juncus balticus Willd. Stems erect, terete, naked, 30-60 cm. tall, from stout horizontal rootstocks; leaves consisting only of sheaths; panicle apparently lateral, the elongated bract appearing like a continuation of the stem; panicle simple or compound, 1-10 cm. long; perianth segments lanceolate, acute, or obtusish, about $4 \mathrm{~mm}$. long, usually brown; stamens 6 ; capsule acutely angled and short-beaked; seeds oblong, the surface reticulated. Abundant in wet places.

Juncus filiformis L. Stems very slender, 15-60 cm. high, most of them usually sterile; sheaths obtuse, the blades small and bristle-like; inflorescence few-flowered, cymose, nearly simple; segments of the perianth green, lanceolate, acute, the inner a little shorter, about $3 \mathrm{~mm}$. long; capsule green, obovoid, shorter than the perianth; seeds thick, short-pointed at each end. Lake Tesemini, Idaho. 
Juncus bufonius L. Annual, branching from the base, 5-30 cm. tall; leaf blades flat or involute, slender; flowers loosely scattered, usually on but one side of the long branches of the panicle; perianth segments pale, scariousmargined, lanceolate, acuminate; stamens 6 ; capsule narrowly oblong, with a short blunt beak; seeds very finely reticulate. Everywhere common.

Juncus sphaerocarpus Nees. Very similar to J. bufonius in all respects save the capsule which is globose. Probably common but rarely collected.

Juncus dudleyi Wiegand. Densely tufted, stiffly erect, $30-50 \mathrm{~cm}$. high; leaves short, usually less than half as long as the stems; auricles yellowish; panicle rather close, $2-7 \mathrm{~cm}$. long; perianth segments spreading, pale, 4-5 $\mathrm{mm}$. long, slightly exceeding the 1-celled ovoid capsule. Common in low ground; easily distinguished by the cartilaginous auricles.

Juncus tenuis Willd. Densely tufted, $15-30 \mathrm{~cm}$. tall; leaves flat or somewhat involute, narrow, shorter than the stems; auricles whitish, 1-1.5 mm. long; panicle loose, seldom exceeded by the slender bract; perianth segments lanceolate, pale, 3-4.5 mm. long; capsule ovoid, thin-walled, rounded at the apex, 1-celled with 3 parietal placentae; seeds minutely reticulate. Very common.

Juncus brachyphyllus Wiegand. Stems tufted, stiff, erect, $30-50 \mathrm{~cm}$. high; leaves flat, $1.5-2 \mathrm{~mm}$. broad, only one-fourth to one-third the length of the culms; inflorescence many-flowered, short and rather crowded, usually exceeded by the bracts; perianth-segments subulate, acute; capsule oblong, the triangular apex usually obtuse. Blue Mountains and Craig Mountains, Idaho.

Juncus confusus Coville. Pale green, tufted, erect, the culms $40-50 \mathrm{~cm}$. high; leaves very narrow, flat or involute, one-half to two-thirds as long as the culms; inflorescence dense, 5-20 mm. long, exceeded by the bracts; perianth-segments lanceolate, acutish, 3.5-4 $\mathrm{mm}$. long, the margins scarious; capsule oblong, the triangular apex retuse. Spangle, Suksdorf.

Juncus longistylis Torr. Stems $30-60 \mathrm{~cm}$. high; leaves $15-30 \mathrm{~cm}$. long; bract shorter than the inflorescence; panicle consisting of 5-20 heads, these few-flowered; perianth segments lanceolate, acute or acuminate, pale brown, smooth; stamens 6; capsule oblong, 3-angled above, much shorter than the segments.

Juncus regelii Buch. Perennial, stoloniferous, pale green; stems smooth or minutely scabrous, $12-50 \mathrm{~cm}$. high, erect; leaves flat, $1.5-2 \mathrm{~mm}$. broad; heads solitary or sometimes 2 or 3 , globose, many-flowered; outer perianth segments lanceolate, acute, inner ovate, obtuse, all rough, brown with pale margins; stamens 6; capsule longer than the perianth; seeds linear, tailed at each end. In springy places, rare.

Juncus orthophyllus Coville. Perennial, with creeping rootstocks; stems leafy, 30-70 cm. tall; leaves flat, 2-3 mm. broad, pale green, shorter than the sheaths, without ligules; flowers aggregated into few-flowered heads, these panicled; perianth segments straw-colored, lanceolate, acuminate, scariousmargined, rough, $5 \mathrm{~mm}$. long; stamens 6; capsule 3-angled, oblong, acute, short-beaked. Common along streams.

Juncus mertensianus Bong. Stems terete, weak, crowded, $10-30 \mathrm{~cm}$. high, from short creeping rootstocks; leaves $5-15 \mathrm{~cm}$. long, about $2 \mathrm{~mm}$. wide; ligules scarious; heads solitary, globose, dark brown, about $1 \mathrm{~cm}$. broad; perianth segments lanceolate, acuminate, $3 \mathrm{~mm}$. long, exceeding the obtuse capsule. Moist meadows in the Blue Mountains at high altitudes.

Juncus ensifolius Wiks. Rootstocks thick, creeping; stems leafy, 15-30 $\mathrm{cm}$. high; heads few, globose, dark brown or nearly black; perianth segments lanceolate, acuminate, $3 \mathrm{~mm}$. long; stamens 3 (rarely 6); capsule 3 -angled, acute, barely exceeding the perianth. In wet places especially in the mountains. 
Juncus ensifolius major Hook. Differs from the species in its larger size, $30-60 \mathrm{~cm}$. high, and numerous smaller brown heads. Common in wet places.

Juncus nodosus $\mathrm{L}$. Stems $15-60 \mathrm{~cm}$. high, terete, from slender creeping tuberiferous rootstocks; leaves narrow; bract exceeding the inflorescence; heads few to several, globose, 8-20-flowered; perianth segments lanceolate, acuminate, the inner longest; capsule subulate, exceeding the perianth. Wet places, rare in our limits.

Juncus suksdorfii Rydberg. Stems terete, leafy, 30-60 cm. tall, from running rootstocks; leaves slightly flattened, with few partitions, $2-3 \mathrm{~mm}$. wide, $15-30 \mathrm{~cm}$. long; ligules present; panicle loose, composed of numerous small dark brown heads, these few-flowered; perianth segments lanceolate, acuminate, $4 \mathrm{~mm}$. long, smooth; stamens 6 . Common along streams. It very rarely produces good seeds.

Juncus columbianus Coville. Stems terete, leafy, $30-45 \mathrm{~cm}$. tall, slender; leaves narrowly linear, becoming somewhat involute, with few cross partitions, 10-15 cm. long; heads cinnamon color, aggregated into a dense panicle; perianth segments lanceolate, acuminate, equalling the three-angled acute capsule; stamens 6 . In springy places, rare.

\section{JUNCOIDES. WOOD RUSH.}

Perennial, with glabrous or sparingly pubescent herbage; stems leaf-bearing; leaf sheaths with united margins; blades grass-like; inflorescence umbellate, paniculate or congested into head-like clusters; flowers always bracteolate; ovary 1-celled with 3 basal ovules.

Flowers congested into 1-several head-like clusters. Flowers solitary or in clusters of 2 or 3 in an open panicle.

\section{J. campestre.}

Leaves 10-12 mm. broad; perianth brown, 3-3.5 mm. long. J. glabratum.

Leaves $6-8$ or $10 \mathrm{~mm}$. broad; perianth pale green, $1.5-2.5$ $\mathrm{mm}$. long.

J. parviflorum.

Juncoides campestre (L.) Kuntze. Stems tufted, 15-40 cm. tall, the whole plant loosely villous; leaves flat, $2-5 \mathrm{~mm}$. broad, $5-15 \mathrm{~cm}$. long; flowers in short spikes, these in cymes; longest bract usually exceeding the inflorescence; spikes oblong, 5-15 mm. long, on peduncles $1-5 \mathrm{~cm}$. long, erect or nodding; perianth segments straw-color or brownish, lanceolate, acuminate, $3 \mathrm{~mm}$. long; capsules obtuse, short-beaked, equalling the perianth. Dry woods, common.

Juncoides glabratum (Hoppe) Sheldon. Glabrous throughout; stems $30-50 \mathrm{~cm}$. high, from creeping rootstocks; leaves dark green, flat, $10-20 \mathrm{~cm}$. long, 10-12 $\mathrm{mm}$. broad, acute; panicle loose and nodding; bracts small; perianth segments dark brown, lance-ovate, acute, shorter than the apiculate nearly black capsule. Mt. Carlton, Kreager. An alpine species greedily eaten by horses.

Juncoides parviflorum (Ehrh.) Coville. Very similar to J. glabratum but taller and more slender; leaves usually with a few long hairs at base; panicle very loose; perianth segments straw-color, lanceolate, acuminate, hardly equalling the straw-colored capsule. In swamps in woods. 


\section{Family 21. LILIACEAE. Lily Family.}

Terrestrial herbs or sometimes woody plants; stems usually from bulbs, corms, or more or less thickened rootstocks; flowers mostly perfect, regular; perianth not glumaceous, of 6 separate or united segments free from the ovary; stamens 6 , opposite the perianth-segments; ovary 3-celled; fruit a few to manyseeded 3-celled capsule or berry.

Plants with bulbs or corms.

Flowers in umbels.

Perianth-lobes united, funnel-form; stamens on the throat.

Perianth-lobes not at all or but slightly united; stamens on the bases of the lobes.

Flowers solitary or in racemes or cymes.

Outer perianth-segments narrower than the inner.

Perianth-segments all alike or nearly so.

Leaves on the stem.

Leaves only two at the surface of the ground but near the middle of the stem, appearing basal; flowers bractless.

Stem leafy; flowers leafy-bracted.

Leaves linear, basal; flowers bracted.

Flowers small, greenish-white.

Plants with rootstocks.

Flowers large, blue.

75. HOOKERA, 58.

76. Allium, 59.

77. Calochortus, 60.

78. ERYTHRONIUM, 61.

79. Fritillaria, 61.

80. Zigadenus, 62.

81. Quamasia, 62.

82. Clintonia, 63.

Leaves cauline.

Leaves in a whorl of three below the flower.

Leaves alternate.

Flowers axillary.

Flowers terminal.

Leaves linear, rigid.

Leaves broader, not rigid.

Flowers umbelled or solitary, terminal.

Flowers racemed or panicled.

Flowers polygamous or monoecious, rather large.

Flowers perfect, small.

83. TRILLIUM, 63.

84. StReptopus, 63.

85. Xerophyllum, 64.

86. Disporum, 64.

87. Veratrum, 64.

88. VAGNERA, 65.

\section{HOOKERA. ( DFن}

Usually erect scapose herbs from a membranous-coated corm; leaves linear; inflorescence a several-bracted umbel of few to many flowers, on jointed pedicels; perianth funnel-form not contracted at the throat, blue, purple, yellow or white, the segments united; stamens 3 on the throat opposite the inner lobes and alternate with three sterile stamens, or 6 in one or two rows; ovary stalked or sessile, 3-celled, each cavity containing 3-8 seeds. 
Flowers white, the stamens in one row.

Flowers blue, the stamens in two rows.

H. hyacinthina. H. douglasii.

Hookera hyacinthina (Lindl.) Kuntze. Scapes 30-70 cm. tall; leaves linear-lanceolate, shorter than the stem, $5-8 \mathrm{~mm}$. broad; flowers numerous; perianth open-campanulate, white, each lobe with a green midvein, the tube about half as long as the lobes; stamens in one row, the filaments broadly dilated, equal; capsule subglobose. Low meadows, common.

Hookera douglasii (Wats.) Piper. Wild Hyacinth. Scape tall; corm globose, the outer coats coarsely fibrous; leaves two or three, shorter than the stem, 2-4 mm. broad; flowers blue, usually numerous, in a dense umbel; pedicels 2-30 $\mathrm{mm}$. long; perianth tubular-campanulate, $2-3 \mathrm{~cm}$. long, the tube longer than the lobes; stamens in two rows, the upper and longer ones on the petals; filaments naked; capsule oblong-ovate, short-stipitate. Plentiful on hillsides.

76. ALLIUM. ONION.

Pungent herbs with the characteristic odor of the onion, the leaves and usually scapose erect stem from a coated bulb; leaves narrowly linear, or rarely lanceolate or oblong, sheathing; inflorescence a terminal simple umbel, in the axils of 2 or 3 membranous, separate or united bracts; pedicels slender, not jointed; flowers white, or pink; perianth-segments 6 , separate or united by their very bases; stamens 6 , on the bases of the perianthsegments; ovary sessile or nearly so, completely or incompletely 3 -celled; ovules 1-6 in each cavity.

Outer bulb-coat fibrous.

Outer bulb-coats not fibrous, with or without reticulations.

A. geyeri.

Flowers white; umbel flat.

Reticulations narrow, wavy.

A. collinum.

Reticulations none.

A. macrum.

Flowers red; umbel globose or flat.

Leaves narrow; umbel flat; reticulations distinct, polygonal.

Leaves rather broad; umbel globose or flat; reticu-

A. acuminatum. lations wanting or very obscure.

Scapes compressed, $8-15 \mathrm{~cm}$. high; umbel flat or merely convex.

Scapes terete.

Heads dense, globose; stems $20-40 \mathrm{~cm}$. high; perianth segments $8-10 \mathrm{~mm}$. long.

Heads convex; stems $15-30 \mathrm{~cm}$. high; perianth segments 6-8 mm. long.

A. cusickii.

A. douglasii.

A. nevii.

Allium geyeri Wats. Stems slender, $15-30 \mathrm{~cm}$. tall; bulbs elongate, the coats fibrous; leaves 2-4, slender, blunt, $10-20 \mathrm{~cm}$. long; flowers pale rosecolor; bracts broad; perianth segments ovate, acute or acuminate; ovary crested. Low meadows, not common.

Allium collinum Dougl. Usually cespitose; bulbs globose, the outer coats marked with fine narrow curved reticulations; stems $10-15 \mathrm{~cm}$. high; leaves narrowly linear; flowers white, in flat-topped small umbels; perianth segments 5-8 mm. long, acute. High ridges of the Blue Mountains. 
Allium macrum Wats. Similar to $A$. collinum in all respects, but outer bulb coat without reticulate markings. High ridges of the Blue Mountains.

Allium acuminatum Hook. Stems 10-20 cm. tall; bulbs globose, the outer coats finely reticulate; leaves terete, narrow, shorter than the stem; flowers many, pink, on pedicels $2-3 \mathrm{~cm}$. long; perianth segments ovate, acuminate, 10-12 mm. long; ovary only obscurely crested. Rocky soil, abundant.

Allium acuminatum cuspidatum Fernald. Perianth segments smaller, 7-8 mm. long, abruptly cuspidate. Near Wawawai.

Allium cusickii Wats. Scapes flattened, 2-edged, 10-15 cm. high; bulb ovoid, 1-2 cm. long, the outer coats black, not reticulated; leaves two, falcate, 4-8 mm. broad, exceeding the scape; umbel rather densely many-flowered, convex; pedicels slender, 15-20 mm. long; perianth pink, the segments attenuate-acuminate, 8-10 $\mathrm{mm}$. long, much exceeding the stamens and style. Bluffs of the Snake and Clearwater Rivers, in thin rocky soil.

Allium douglasii Hook. Stems stout, $15-25 \mathrm{~cm}$. tall; bulb ovate, $2 \mathrm{~cm}$. long, the coats not reticulated; leaves two, $10-20 \mathrm{~cm}$. long, about $1 \mathrm{~cm}$. wide, flat; flowers very numerous, in a dense globose umbel, dark red; bracts 2 , large; perianth segments broadly lanceolate, acuminate, 7-10 $\mathrm{mm}$. long; pedicels 15-20 mm. long; ovary not crested. In gravelly springy places, rare.

Allium nevii Wats. Stems stout, 10-20 cm. high; bulb ovate, about $2 \mathrm{~cm}$. long, the coats usually purplish and the reticulations very obscure, transversely polygonal; leaves 2 , flat, $3-4 \mathrm{~mm}$. broad, $10-20 \mathrm{~cm}$. long; flowers pink, rather numerous; bracts 2 , large; perianth segments ovate, cuspidate, $6-7 \mathrm{~mm}$. long; pedicels 5-7 mm. long; ovary not crested. Spokane, Henderson; more common in central Washington.

\section{CALOCHORTUS. MARIPOSA LiLy.}

Branched or simple herbs with coated corms; leaves narrowly linear; flowers large, showy, peduncled; perianth-segments separate, spreading, whitish, purplish or variegated; the three outer sepal-like, narrow; the three inner petal-like, gland-bearing, and bearded or spotted within; stamens 6 , hypogynous; ovary 3celled; ovules numerous.

Flowers white or yellowish, nodding.

Petals pale yellow, sparsely hairy.

Petals white, very hairy inside.

Flowers erect, usually pink.

Petals obtuse, with a peacock-eye spot at the base.

Petals acute or acuminate, yellow at base.

C. apiculatus.

C. elegans.

C. nitidus.

C. macrocarpus.

Calochortus apiculatus Baker. Stem erect, 30-60 cm. high, bearing 1-3 flowers; leaf solitary, 15-30 cm. long, 6-18 $\mathrm{mm}$. broad; bracts linear, acuminate; sepals acute, lanceolate, 1-2 cm. long; petals yellowish, broadly obovate, sparingly hairy, except about the deep pit at the base which lacks a scale; anthers acuminate, as long as the filaments; capsule oblong, $2.5-3 \mathrm{~cm}$. long. In moist grassy places, common near Priest Lake, Idaho. Near Spokane, Miss Reed.

Calochortus elegans Pursh. Low, the stems 5-15 cm. tall, bearing a single lanceolate leaf, which much exceeds the stem; flowers solitary, or $2-5$ in a cyme, the pedicels ascending, $2-6 \mathrm{~cm}$. long, each subtended by a lanceolateacuminate bract; sepals broadly lanceolate, acuminate, greenish or purplish, 
shorter than the petals; petals ovate, obtuse, greenish-white with a purpleviolet blotch at base, very hairy on the upper surface; nectary covered by a fringed scale. Common especially in open pine woods.

Calochortus nitidus Dougl. Stems slender, 30-50 cm. tall; cauline leaves 2 , the lower nearly as long as the stem; flowers usually $2-4$ in an umbei-like cyme; sepals lanceolate, acuminate, $2-3 \mathrm{~cm}$. long, scarious-margined, purple tinged; petals cuneate-obovate, truncate or rounded, lilac-purple, sparsely hairy over the upper surface, about $4 \mathrm{~cm}$. long; nectary oblong, covered with a small densely hairy scale, the whole surrounded with several arched bands of yellow and purple; capsule oval, acuminate, prominently winged, $2-3 \mathrm{~cm}$. long. Common in low meadows.

Calochortus macrocarpus Dougl. Stems stout, 30-60 cm. tall; leaves $3-5$, involute, narrow, 7-15 cm. long; flowers 1-4; sepals greenish or purplish, lanceolate, acuminate, scarious-margined, $3-5 \mathrm{~cm}$. long, equalling the petals; petals broadly obovate, abruptly acuminate, pink-purple, paler toward the base; nectary oblong, hairy; capsule lance-oblong, not winged, 3-4 cm. long. Dry hills, quite common. A white flowered form rarely occurs.

\section{ERYTHRONIUM. ADDER'S TONGUE.}

Low herbs, from deep membranous-coated corms; stem simple; leaves but one pair, broad or narrow, usually below the middle of the stem where it rises from the ground and thus appears basal; flowers large, nodding, bractless, solitary or several; perianth-segments separate, lanceolate, oblong or oblanceolate; stamens 6, hypogynous, shorter than the perianth; ovary sessile, 3 -celled; ovules numerous or several in each cavity.

Anthers purple; perianth yellow.

E. grandiflorum.

Anthers white.

Perianth white.

Perianth yellow.

E. grandiflorum candidum.

E. parviflorum.

Erythronium grandiflorum Pursh. Scape 15-30 cm. tall; corm elongate; leaves dark green, oblong-lanceolate, acute, 10-20 cm. long; petioles short, grooved above; flowers solitary or rarely $2-6$ in a cluster; perianth segments yellow, pale at base, becoming recurved; anthers purple; capsule oblanceolate, attenuate at base, $2-3 \mathrm{~cm}$. long. Abundant on north hillsides.

Erythronium grandiflorum candidum Piper n. subsp. Flowers wholly white. Near Cheney, Professor J.W. Hungate.

Erythronium parviflorum (Wats.) Goodding. Very similar to E. grandiflorum, but usually a little smaller; flowers paler, the perianth segments usually shorter; anthers white. In Blue Mountains at 1500 to 2000 meters altitude. This species or perhaps subspecies always replaces $E$. grandiflorum in the mountains and the two seem never to grow together.

\section{FRITILLARIA.}

Bulbous herbs; stems simple, leafy; inflorescence of rather large nodding solitary or racemed leafy-bracted flowers; perianth mostly campanulate, of 6 separate and nearly equal oblong or ovate segments, each with a nectar-pit or spot at the base; stamens 6, hypogynous; ovary nearly or quite sessile, 3-celled; ovules numerous in each cavity. 
Flowers yellow; styles united the whole length.

Flowers brown, spotted; styles not united the whole length.

F. pudica.

F. lanceolata.

Fritillaria pudica (Pursh) Spreng. Stems 10-30 cm. tall; bulb-scales round, numerous; leaves several, linear, obtuse, 4-12 cm. long, 5-12 mm. wide, in a single whorl or scattered; flowers commonly single, sometimes 2-6; perianth-segments oblong, obtuse, 1-2 cm. long, yellow, each with a reddish mark at the base; stamens about equalling the united styles; capsule oblong, not winged. Hillsides, common.

Fritillaria lanceolata Pursh. Stems $30-90 \mathrm{~cm}$. tall, glaucous; leaves in two or three whorls of $4-6$, lanceolate, sessile, 5-12 cm. long; flowers 1-6, brown-purple with greenish-yellow spots; segments oblong-lanceolate; nectaries conspicuous; capsule 2-3 cm. long, with 6 broad wings. Near Palouse City.

\section{ZIGADENUS.}

Glabrous erect perennial herbs from coated bulbs each crowning a very short rhizome, and with leafy stems; leaves linear; inflorescence a terminal panicle or raceme; flowers perfect or polygamous, greenish, yellowish or white; perianth-segments lanceolate or ovate, separate or united below, sometimes adnate to the lower part of the ovary, with one or two glands or a spot just above the narrowed base; stamens free from the perianthsegments, about equalling them in length; ovary 3-celled; ovules several or numerous in each cavity.

Inflorescence racemose; perianth-segments obtuse. Inflorescence paniculate; perianth-segments acute.

Z. venenosus.

Z. paniculatus.

Zigadenus venenosus Wats. Death Camas. Stems $30-50 \mathrm{~cm}$. tall, from ovate, dark-coated bulbs; leaves several, linear, keeled, 3-5 mm. broad, shorter than the stems; raceme many-flowered, 5-10 cm. long, much longer in fruit; flowers yellowish, on pedicels 5-10 mm. long; bracts awl-shaped; perianthsegments clawed, elliptical, the blade obtuse; nectaries with thick margins. Common in meadows and on hillsides. Bulbs poisonous.

Zigadenus paniculatus Wats. Similar to $Z$. venenosus but stouter and of ten taller; bulb larger, of ten elongate; leaves $6-15 \mathrm{~mm}$. broad, usually all sheathing; panicle many-flowered; flowers whitish; perianth-segments deltoidovate, acute, abruptly narrowed to the claw; nectary not definitely margined. A plant of the sage brush region; rare in our limits.

\section{QUAMASIA. CAMAS.}

Scapose herbs, with membranous-coated edible bulbs; leaves linear, basal; inflorescence a terminal raceme; flowers large, blue or white, bracted; pedicels jointed at the base of the flower; perianth-segments 6 , separate, equal, spreading, persistent, 3-7nerved; stamens at the bases of the perianth-segments; ovary 3-celled, sessile; ovules numerous in each cavity.

Quamasia quamash (Pursh) Coville. Scape stout, 30-70 cm. tall; leaves several, mostly shorter than the stem, 5-10 mm. broad, sometimes glaucous; raceme elongated, 10-30-flowered, the pedicels short; bracts narrowly lanceo- 
late, about equalling the flowers; flowers dark blue or rarely white; perianth lobes unequally spreading, lanceolate, acute, $2 \mathrm{~cm}$. long; capsule oblong-ovate; somewhat 3-angled, 10-12 mm. long; seeds black, shining. Abundant in wet meadows, the bulbs used by the Indians as food.

\section{CLINTONIA.}

Somewhat pubescent herbs, with slender rootstocks and erect simple scapes; leaves few, broad petioled, sheathing, basal; flowers solitary-terminal or umbelled on the erect scapes, bractless; perianth-segments distinct, equal or nearly so, erect or spreading; stamens 6 , inserted at the base of the perianthsegments; ovary 2-or 3-celled; ovules 2-several in each cavity.

Clintonia uniflora (Schult.) Kunth. Rootstock creeping, slender; scapes slender, pubescent, naked or with one or two small linear bracts, 6-10 cm. tall, bearing a solitary white flower or rarely two; proper stem short; leaves $2-5$, oblong, acuminate, pubescent beneath, $10-20 \mathrm{~cm}$. long; calyx pubescent on the outside; filaments attenuate from a thicker base, pubescent below; fruit, globose or pyriform, blue. In rich woods, in the mountains.

\section{TRILLIUM. WAKE ROBIN.}

Glabrous erect unbranched herbs, with short rootstocks; leaves 3 in a whorl at the summit of the stem just under the sessile or peduncled, solitary, bractless flower; perianth of two distinct series of segments, the outer 3 (sepals) green, the inner 3 (petals) white, pink, purple or sometimes greenish; stamens 6 , hypogynous; ovary sessile, 3-6-angled or lobed; ovules several or numerous in each cavity.

Flowers white, peduncled.

T. ovatum.

Flowers purple, sessile.

T. petiolatum.

Trillium ovatum Pursh. Stems $15-40 \mathrm{~cm}$. tall, from a stout horizontal rootstock, $2-5 \mathrm{~cm}$. long; leaves broadly ovate, acuminate or acute, $5-15 \mathrm{~cm}$. long, nearly sessile; flowers odorous; peduncles erect, $3-6 \mathrm{~cm}$. long; petals lanceolate, acute, white, in age changing through various shades of pink to dark red, exceeding the green sepals; anthers yellow. In woods, in the mountains.

Trillium petiolatum Pursh. Stems short, usually almost entirely enclosed in sheath-like bracts, arising from a stout oblong upright rootstock; leaves oval or orbicular, 5-15 cm. long, petioled; flowers sessile; petals narrow, dark purple, scarcely longer than the sepals; anthers dark purple. Rich hillsides and copses.

\section{STREPTOPUS.}

Herbs with stout or slender rootstocks; leaves thin, sessile or clasping, alternate, many-nerved; flowers solitary or two together, axillary, slender-peduncled, greenish or purplish, small, nodding; peduncles bent or twisted at about the middle; perianth somewhat campanulate, its segments 6 , recurved or spreading, the outer flat, the inner keeled; stamens 6 , hypogynous; ovary 3 -celled; ovules numerous, in two rows in each cavity. 
Streptopus amplexifolius (L.) DC. Stems branched, about $1 \mathrm{~m}$. tall, from horizontal creeping rootstocks, glabrous except at the base; leaves ovate, acuminate, cordate and clasping at base, 5-12 cm. long, usually glaucous, especially beneath; flower solitary in the upper axils; pedicels bent at the base and geniculate in the middle, so that the flower is concealed by the leaf; perianth narrowly campanulate, the segments greenish, lanceolate, acuminate, strongly curved outward; anthers acuminate; berry oblong-globose, red, about $1 \mathrm{~cm}$. in diameter. Moist woods, in the mountains.

\section{XEROPHYLLUM.}

Perennials with a short thick woody rootstock and numerous radical stiff linear leaves; perianth white, of six separate spreading petal-like segments; stamens 6 , at the base of the perianthsegments; styles distinct, linear, reflexed; ovary sessile, ovate, 3-lobed.

Xerophyllum tenax (Pursh) Nutt. Pine Lily or Bear Grass. Basal leaves very numerous, harsh and stiff, linear, keeled, $5 \mathrm{~mm}$. broad, $60-90 \mathrm{~cm}$. long; cauline similar but smaller and dilated at base; stems stout, 1-2 m. tall, stiff and erect; flowers white; raceme dense, at first pyramidal, then elongating, $15-40 \mathrm{~cm}$. long in bloom, longer in fruit; pedicels spreading in flower, erect in fruit, $2-3 \mathrm{~cm}$. long. In pine woods in the mountains.

\section{DISPORUM.}

More or less pubescent herbs with slender rootstocks; stems branching, scaly below, leafy above; leaves alternate, somewhat unsymmetrical, sessile or clasping; flowers terminal, drooping, whitish or greenish-yellow, solitary or few in simple umbels; perianth-segments 6 , narrow, equal, separate; stamens 6 , hypogynous; ovary 3 -celled; ovules 2 or sometimes several in each cavity.

Fruit globose, papillose; stigma 3-cleft.

Fruit ovate, pubescent or glabrous; stigma entire.

D. majus.

D. oreganum.

Disporum majus (Hook.) Britt. Stems branched, 30-50 cm. tall, the branches pubescent; leaves oblong or oblong-ovate, long-acuminate, sessile and half-clasping, 5-7 cm. long, glabrous; flowers solitary or in pairs, yellowishwhite, on more or less curved pedicels, 5-8 mm. long; perianth campanulate, the segments narrow, oblong or oblanceolate, $10-12 \mathrm{~mm}$. long; berry pyriformglobose, $6-8 \mathrm{~mm}$. in diameter, roughened with minute shallow pits. In woods, in the mountains.

Disporum oreganum (Wats.) Benth. \& Hook. Similar to D. majus; leaves broader, ovate, distinctly cordate; perianth $12 \mathrm{~mm}$. long, the stamens exserted; stigma 3-parted; fruit globose, pubescent but becoming smooth. In mossy woods.

87. Veratrum. False Hellebore.

Tall perennial herbs, from short thick poisonous rootstocks; stem pubescent; leaves mostly broad, clasping, strongly veined and plaited; inflorescence pubescent, of terminal panicles; 
flowers greenish or yellowish-white, rather large, polygamous, on short stout pedicels; perianth-segments 6 , glandless or nearly so, adnate to the base of the ovary; stamens opposite the perianthsegments and free from them, short, mostly curved; ovary ovoid, 3 -celled, the cavities several-ovuled.

Flowers green; lower branches of the panicle drooping. Flowers white; branches of the panicle not drooping.

V. viride.

V. californicum.

Veratrum viride Ait. Green Hellebore. Stems stout, 100-150 cm. tall; leaves ovate, or the upper lanceolate, pubescent beneath, 20-30 cm. long; panicle open, $30-60 \mathrm{~cm}$. long, the lower branches more or less drooping, usually simple; perianth green, pubescent outside, the segments obovate, obtuse, about $8 \mathrm{~mm}$. long; principal bracts foliaceous, like the upper leaves. Deep woods, in wet places.

Veratrum californicum Durand. White Hellebore. Very similar to $V$. viride, but flowers white, and the branches of the panicle not drooping, usually again branched; principal bracts not foliaceous, small. Common in moist meadows.

\section{VAG Nera. False Solomon's Seal.}

Herbs with slender or short and thick rootstocks; stem simple, scaly below, leafy above; leaves alternate, short-petioled or sessile, ovate, lanceolate or oblong; inflorescence a terminal raceme or panicle; flowers white or greenish, small; perianth of 6 separate spreading equal segments; stamens 6 , on the base of the perianth-segments; ovary 3 -celled, sessile, subglobose; ovules 2 in each cavity.

Flowers small, numerous, in a dense panicle.

Flowers larger, few, in a raceme.

Leaves flat and spreading.

Leaves folded, ascending.

V. amplexicaulis.

V. sessilifolia.

V. stellata.

Vagnera amplexicaulis (Nutt.) Greene. Rootstocks stout; stems 50-100 $\mathrm{cm}$. tall, usually puberulent; leaves oblong or ovate, acuminate, puberulent, 6-12 cm. long, sessile, clasping the stem somewhat; panicle pyramidal or narrow, $3-10 \mathrm{~cm}$. long; pedicels very short; perianth spreading, the segments oblong, $2 \mathrm{~mm}$. long, as long as the ovary; filaments subulate, longer than the perianth; style about as long as the ovary. In rich woods, in the mountains.

Vagnera amplexicaulis brachystyla (Henderson) Piper. Style only half as long as the ovary. Kamiack Butte.

Vagnera sessilifolia (Baker) Greene. Rootstocks slender; stems 30-60 $\mathrm{cm}$. tall, smooth; leaves broadly lanceolate, acuminate, flat, sessile, pubescent beneath, 10-15 cm. long; raceme open, 2-5 cm. long, 5-10-flowered; pedicels 4-12 $\mathrm{mm}$. long; perianth-segments spreading, lanceolate, $4 \mathrm{~mm}$. long; stamens shorter than the styles. Common in moist copses.

Vagnera stellata (L.) Morong. Very similar to V. sessilifolia but usually smaller; leaves oblong-lanceolate, half-clasping, strongly ascending and loosely folded; raceme more crowded, the pedicels $2-4 \mathrm{~mm}$. long. Blue Mountains, Horner; rare in our limits. 


\section{Family 22. IRIDACEAE. IRIS FAMILY.}

Perennial herbs; leaves narrow, equitant, 2-ranked; flowers perfect, regular or irregular, mostly clustered, subtended by bracts; perianth of 6 segments or 6-lobed, its tube adnate to the ovary, the segments or lobes in 2 series; stamens 3 , inserted on the perianth opposite its outer series of segments or lobes; ovary inferior, mostly 3-celled; ovules mostly numerous in each cell; style 3-cleft, its branches sometimes divided.

Flowers very large; styles petal-like.

89. IRIS, 66.

Flowers moderate in size; styles filiform.

Filaments united to the top; flowers usually blue. 90. Sisyrinchium, 66.

Filaments united only at the base; flowers never blue.

91. Olsynium, 67.

89. IRIS.

Herbs with creeping or horizontal, often woody and sometimes tuber-bearing rootstocks; stems erect; leaves erect or ascending, equitant; flowers large, regular, terminal, solitary or clustered; perianth of 6 clawed segments united below into a tube, the three outer dilated, spreading or reflexed, the three inner narrower, smaller, usually erect or in some species about as large as the outer; stamens inserted on the base of the outer perianthsegments; ovary 3-celled; divisions of the style petal-like, arching over the stamens, bearing the stigmas immediately under their mostly 2-lobed tips; style-base adnate to the perianth-tube.

Iris missouriensis Nutt. Rootstocks stout, short, branched; stems 20-50 $\mathrm{cm}$. tall, naked or with one or two leaves; leaves pale or glaucous, usually shorter than the stem, $5-8 \mathrm{~mm}$. wide; flowers violet-blue, rarely white, $2-4$ in each umbel; bracts scarious, $2-6 \mathrm{~cm}$. long, acute; sepals narrowly clawed, 5-6 cm. long, the honey guides yellowish; petals erect, shorter; capsule oblongobovate, somewhat 3-angled; seeds brown. Wet places, common.

\section{SisYrinChIUM. Blue-eyed Grass.}

Perennial tufted slender herbs, with short rootstocks; stems simple or branched, 2-edged or 2-winged; leaves linear, grasslike; flowers rather small, mostly blue, terminal, umbellate, from a pair of erect green bracts; perianth-tube short or none, the 6 spreading segments oblong or obovate, equal; filaments united to the top; ovary 3-celled, each cavity several-ovuled; stylebranches filiform, undivided, alternate with the anthers.

Sisyrinchium idahoense Bicknell. Stems tufted, $20-45 \mathrm{~cm}$. tall, compressed and winged, the edges serrulate; leaves shorter than the stems, linear, acute, 1-3.5 mm. wide, all radical, or occasionally one on the stem; bracts long and narrow; flowers 3-6, pedicelled, dark blue, with a small yellow center; perianthsegments 12-18 mm. long, mucronate; filaments united to the top. Low meadows, common. 


\section{OLSYNIUM.}

Very similar to Sisyrinchium but the filaments united only at the base and the flowers never blue.

Olsynium grandiflorum (Dougl.) Raf. Stems mostly solitary, 15-30 cm. tall, compressed; roots fascicled, stout; leaf-blades 5-10 cm. long, erect, shorter than the sheaths; flowers $1-4$, the pedicels shorter than the largest bract; perianth-segments reddish-purple, broadly lanceolate, acuminate, $15-18 \mathrm{~mm}$. long; filaments broad at the base, shorter than the 3-cleft style. Very common.

\section{Family 23. ORCHIDACEAE. ORChId FAMILy.}

Perennial herbs, with corms, bulbs or tubers; leaves entire, sheathing, sometimes reduced to scales; flowers perfect, irregular, bracted, solitary, spiked or racemed; perianth superior, of 6 segments, the three outer (sepals) alike or nearly so; two of the inner ones (petals) lateral, alike; the third inner one (lip) dissimilar, often markedly so, usually larger, often spurred, sometimes inferior by the twisting of the ovary or pedicel; stamens variously united with the style into an unsymmetrical column; anther one (sometimes two); pollen more or less coherent into masses (pollinia); ovary inferior, usually long and twisted, 3-angled, 1-celled; ovules numerous on three parietal placentae; seeds numerous; endosperm none.

Perfect anthers 2; lip large, sac-like.

Perfect anther 1.

Plant saprophytic, without green herbage.

Flowers spurred, reddish or white.

Flowers spurless, white.

Plants with ordinary green herbage.

Flower and leaf solitary; plant bulbous.

Flowers several-many in racemes.

Leaves only two.

Leaves more than two.

Flowers each with a distinct spur.

Leaves several, cauline, gradually reduced upwards.

Leaves two, basal; cauline reduced to bracts.

Lateral sepals adnate to the base of the lip.

Lateral sepals free.

Flowers spurless, the lip at most saccate.

Lip with 2 callosities at base; flowers spirally arranged in a dense spike.

Lip without basal callosities. Leaves white-reticulated. Leaves green.
92. CyPRIPEDIUM, 68.

93. Corallorhiza, 68.

94. Cephalanthera, 69.

95. Cytherea, 69.

96. OPHRYS 69.

97. LimNorchis, 70.

98. Piperia, 70.

99. Lysias, 71.

100. IвIdium, 71.

101. Peramium, 71.

102. EPIPACTIS, 72. 


\section{CYPRIPEDIUM. LADY'S SLIPPER.}

Glandular-pubescent herbs with leafy stems or scapes and tufted roots of thick fibers; leaves large, broad, many-nerved; flowers solitary or several, drooping, large, showy; sepals spreading, separate or two of them united under the lip; lip a large inflated sac; column bearing a sessile or stalked anther on each side and a dilated petal-like sterile stamen above, covering the summit of the style; pollinia granular; stigma terminal, broad, obscurely 3-lobed.

Flowers yellow; lip 15-30 mm. long.

Flowers brown, with a white lip 30-50 mm. long.

C. parviflorum.

C. montanum.

Cypripedium parviflorum Salisb. Stems 20-60 cm. high; leaves 5-12 cm. long, elliptic to lanceolate; flowers 1-3, yellow, more or less marked with purple, 3-5 cm. long; petals linear, twisted; lip 15-30 mm. long; sterile anther triangular, yellow and purple spotted. In springy places about Spokane.

Cypripedium montanum Dougl. Whole plant glandular-pubescent; stems $30-50 \mathrm{~cm}$. tall, erect; leaves 4-6, oval, acuminate, 6-12 cm. long; flowers $1-3$, pedicelled; sepals brown, usually dark, narrowly lanceolate, 5-6 cm. long; upper petals like the sepals, but narrower and longer, wavy-twisted; lip white, veined with purple, oblong, $30-50 \mathrm{~mm}$. long; sterile anther somewhat triangular, yellow with purple spots, about $1 \mathrm{~cm}$. long. Woods and copses, rare.

\section{CORALLORHIZA. CORAL ROOT.}

Scapose herbs, saprophytes or root-parasites with large masses of coral-like branching roots; leaves all reduced to sheathing scales; flowers in terminal racemes; sepals nearly equal, the lateral ones united at the base with the foot of the column, forming a short spur or protuberance, the other one free, the spur adnate to the summit of the ovary; petals about as long as the sepals, 1-3-nerved; lip 3-ridged; column nearly free, slightly incurved, somewhat 2-winged; anther terminal; pollinia 4 , in two pairs, oblique, free, soft-waxy.

Lip entire, striate-veined.

C. striata.

Lip 3-lobed.

Sepals and petals 1-nerved; lip white.

Sepals and petals 3 -nerved; lip spotted.

C. corallorhiza.

C. maculata.

Corallorhiza striata Lindl. Whole plant reddish-purple, $15-40 \mathrm{~cm}$. high, the spike 15-25-flowered; sepals and petals each with 3 conspicuous nerves; lip entire, somewhat fleshy, ovate, narrowed below, concave and bearing 2 short prominent ridges near the base. Blue Mountains and Thatuna Hills, Idaho. Rare.

Corallorhiza corallorhiza (L.) Karst. Scapes 10-20 cm. tall, pale yellowish, 3-15-flowered; sepals lanceolate, somewhat acute, 1-nerved, 3-4 mm. long; spur very short; petals like the sepals but broader, obtuse; lip oblong, obtuse or notched, somewhat 3-lobed; column shorter than the petals. Very rare in deep woods, in the mountains. 
Corallorhiza maculata Raf. Whole plant reddish or sometimes green, 15-25 cm. tall; the spike many-flowered; sepals and petals 6-8 mm. long, 3nerved; spur grown to the ovary, $1-2 \mathrm{~mm}$. long; lip ovate, white, mottled with purple, 3-lobed, with prominent ridges; middle lobe obtuse or notched, the lateral ones acute; column nearly as long as the petals. Deep woods in the mountains.

\section{CEPHALANTHERA.}

Leafy plants with creeping rootstocks (saprophytic with leavts reduced to scarious bracts in ours); flowers erect, white, in a terminal raceme, very similar to Epipactis but with a longer and more slender column; stigma beakless; anther short-stalked, nearly or quite above the level of the stigma.

Cephalanthera austinae (Gray) Heller. Whole plant waxy white, 30-50 $\mathrm{cm}$. high, slender, erect; bracts linear-lanceolate, the lower with dilated sheaths; flowers 3-20, nearly sessile; sepals and petals oblong-lanceolate, subequal; lip short, saccate at base. In deep woods, rare. Blue Mountains; Rathdrum, Idaho.

\section{CYTHEREA.}

Herbs with solid bulbs and coral-like roots; leaf at the base of the stem solitary, petioled; scape low, 1-flowered, sheathed by two or three loose scales; flower large, terminal, showy, bracted; sepals and petals similar, nearly equal; lip large, saccate or swollen, 2-lobed below; column dilated, petal-like, bearing the lid-like anther just below the summit; pollinia 2, waxy, each 2-parted.

Cytherea bulbosa (L.) House. Calypso. Stems 10-15 cm. tall, enwrapped toward the blade with 3-4 scarious sheaths, the uppermost prolonged into a narrow bract; leaf solitary, radical, ovate, acute, $3-5 \mathrm{~cm}$. long, on a petiole about as long; sepals and petals ascending, lanceolate, purple, abnut $2 \mathrm{~cm}$. long; lip about as long, purple-lined, sac-like, two-lobed at the apex, with a patch of yellowish hairs within; the apex of the slipper prolonged into two tooth-like projections; column half as long as the petals. In mossy places in coniferous woods.

\section{OPHRYS.}

Small herbs, with fibrous or sometimes rather fleshy roots; leaves two, opposite, green, near the middle of the stem; flowers in terminal racemes, spurless; sepals and petals nearly alike, spreading or reflexed, free; anther without a lid, erect, jointed to the column; pollinia 2, powdery.

Lip $5 \mathrm{~mm}$. long; ovary glabrous.

Lip $9 \mathrm{~mm}$. long; ovary glandular.
O. caurina.

O. convallarioides.

Ophrys caurina (Piper) Rydb. Stems slender, 15-30 cm. high, glabrous below the leaves, the inflorescence glandular-puberulent; leaves sessile, ovate, obtuse or acutish, glabrous, 3-5 cm. long; flowers small, the slender pedicels longer than the bract or the ovary; sepals and petals lanceolate, spreading; lip $4 \mathrm{~mm}$. long, cuneate, obovate, with a slender tooth on each side near the base; capsule ovoid, 5-6 mm. long. Deep woods in the mountains. 
Ophrys convallarioides (Sw.) W. F. Wight. Similar to $O$. caurina but not so tall; leaves broad, oval or ovate, obtuse; inflorescence glandular; flowers larger, the pedicels scarcely longer than the bracts or the ovary; lip large, $9 \mathrm{~mm}$. long, cuneate, retuse, with a short triangular tooth on each side near the base. In deep moist woods.

\section{LIMNORCHIS.}

Leafy plants with thick fleshy roots, or elongated conic undivided tubers, and small greenish or whitish flowers in a long spike; sepals and petals free and spreading, several-nerved; lip entire; beak of the stigma without appendages; anther-cells nearly parallel, wholly adnate; gland naked; pollinia granular with caudicula at the base.

Flowers white.

Flowers green or purple-tinged.

L. leucostachys.

Spur clavate, much shorter than the lip; spike long and loose.

Spur not clavate, about as long as the lip; spike short and dense.

L. stricta.

L. viridiflora.

Limnorchis leucostachys (Lindl.) Rydb. Stem strictly erect, 30-90 cm. high from a fusiform tuber; leaves lanceolate, acute, the upper ones smaller; spike $6-30 \mathrm{~cm}$. long, usually rather dense; bracts acuminate, equalling or exceeding the ovary; sepals 5-6 mm. long, the upper one broader; lip lanceolate, 6-7 mm. long; spur 10-12 mm. long, slender, acute. In wet places, especially in the mountains.

Limnorchis leucostachys robusta Rydb. Spike dense; spur obtuse. More common than the species and in similar places.

Limnorchis stricta (Lindl.) Rydb. Stems stout, leafy, 50-100 cm. tall; leaves lanceolate, acuminate, $10-15 \mathrm{~cm}$. long, gradually diminishing upward into the bracts; spike slender, 20-30 cm. long, loose, the lower flowers remote; bracts narrowly lanceolate, exceeding the lower flowers, equalling the upper ones; sepals 3-nerved; lip linear, thick, as long as the spur, which is inflated and very obtuse at the tip. Springy places in the foothills.

Limnorchis viridiflora (Cham.) Rydb. Stems 20-40 cm. high from fusiform tubers; basal leaves oblanceolate, obtuse, the upper lanceolate, acute; flowers pale green, 10-12 mm. long; upper sepal ovate, broader than the spreading lanceolate lateral ones; lip lanceolate, obtuse, 4-5 $\mathrm{mm}$. long, equalling the clavate spur. Spokane County, Suksdorf.

\section{PIPERIA.}

Much like Limnorchis in the form of the flowers but the true leaves basal or nearly so, the cauline usually small or bract-like; flowers small, white or greenish; sepals ovate, 1-nerved, subequal; petals and lip of very much the same shape and slightly smaller and darker than the sepals; column very short; anther very large; cells parallel, the gland very small.

Flowers greenish; spur short.

Flowers white; spur long.

$P$. unalaschensis. $P$. elegans. 
Piperia unalaschensis (Spreng.) Rydb. Stems stout, 20-40 cm. tall, leafy at base, bracteate above; leaves $2-3$, oblanceolate, obtuse, about $15 \mathrm{~cm}$. long, usually withering before the flowers bloom; spike narrow, rather dense, 8-15 cm. long; bracts triangular, acute or acuminate, shorter than the ovary, a few along the stem below the spike; flowers small, greenish; sepals and petals lanceolate, 1-nerved, 1.5-2 mm. long; lip scarcely exceeding the petals; spur curved, about $3 \mathrm{~mm}$. long; capsule oblong, sessile. Pullman, very rare.

Piperia elegans (Lindl.) Rydb. Stouter than P. unalaschensis, somewhat taller; basal leaves $2-4$, oblong or lanceolate, $10-15 \mathrm{~cm}$. long, $3-5 \mathrm{~cm}$. wide, obtuse or acute; cauline bracts oblong, acuminate, $1-3 \mathrm{~cm}$. long; spikes usually dense, 8-20 cm. long; bracts ovate, acuminate, about equalling the white flowers or the mature ovary; sepals and petals similar, $4 \mathrm{~mm}$. long, obscurely 3 -nerved; lip like the petals, the spur slender, 7-10 mm. long; capsule oblong, nearly sessile. Pullman, very rare.

\section{LYSIAS.}

Leaves two, large, basal; sepals large and spreading; petals small and narrow; lip linear, entire; spur long; beak of stigma without appendages; anther-cells widely diverging with small beak-like processes at the base.

Lysias orbiculata (Pursh) Rydb. Leaves usually 2, elliptic to orbicular, prostrate on the ground, bright green and shining above, paler beneath, thick, usually 10-15 cm. long; scape 6-30 cm. high, bearing 1-3 lanceolate bracts; spike loose, 10-20-flowered; flowers white; lateral sepals ovate, the upper orbicular; lip linear-oblong, 15-20 mm. long; spur slender, 15-25 mm. long. In deep mossy woods, usually in colonies.

\section{IBIDIUM.}

Roots clustered; stem bracted above, leaf-bearing below or at the base; flowers small, white, yellowish- or greenish-white in a more or less spirally-twisted raceme; lateral sepals lanceolate, the upper united with the oblong petals; lip short-stalked with a callus on each side of the base, the summit somewhat dilated; column short, bearing the ovate stigma on the front and the 2-celled erect anther sessile or nearly so on the back.

Ibidium romanzoffianum (Cham.) House. Plants $8-47 \mathrm{~cm}$. tall from roots 5-8 $\mathrm{mm}$. thick, leafy below and leafy-bracted above; leaves oblong-lanceolate to linear; scape glandular-pubescent above; cauline bracts 2-3; raceme dense, cylindrical; perianth yellowish or whitish, 6-12 $\mathrm{mm}$. long; bracts of the raceme often much longer than the flowers; sepals and petals united. Blue Mountains, Horner.

\section{PERAMIUM.}

Herbs with bracted erect scapes and thick fleshy-fibrous roots; leaves basal, tufted, of ten blotched with white; flowers in bracted spikes; lateral sepals free, the upper ones united with the petals into a hood-like structure (galea); lip sessile, entire, roundish, ovate, concave or saccate, without protuberances, its apex re- 
flexed; anther without a lid, erect or incumbent, attached to the column by a short stalk; pollinia composed of angular grains, one in each sac, attached to a small disk which coheres with the top of the stigma.

Peramium decipiens (Hook.) Piper. Rattlesnake Plantain. Scape 15-30 $\mathrm{cm}$. tall, erect, glandular-puberulent, bearing several short bracts; leaves ovate, acute, with a broken white stripe down the midvein, 3-5 cm. long, shortpetioled; spike bracteate, densely many-flowered, 6-10 cm. long, one-sided; perianth glandular-hairy, white, the sepals and petals $6-8 \mathrm{~mm}$. long, about as long as the glandular ovary; lip concave, erect, the tip recurved, obtuse; column short, straight. Mossy woods, in the mountains.

\section{EPIPACTIS.}

Tall stout leafy herbs with creeping rootstocks; leaves green, clasping the stem; flowers in terminal leafy-bracted racemes; sepals and petals separate; spur none; lip free, sessile, broad, concave below, the upper portion dilated and petal-like; column erect, short; anther 1, erect; capsule oblong, beakless.

Epipactis gigantea Dougl. Stout and leafy, 30-100 cm. high, nearly smooth; leaves ovate below, reduced to narrowly lanceolate upwards, 8-20 $\mathrm{cm}$. long, acute or acuminate, somewhat scabrous on the veins beneath; raceme pubescent; flowers $3-10$, greenish, strongly veined with purple, with large foliaceous bracts on slender pedicels, 4-6 mm. long; sepals ovate-lanceolate, $12-16 \mathrm{~mm}$. long, the upper concave; petals a little smaller; the lip as long; anther $4 \mathrm{~mm}$. long.

\section{Subclass II. DICOTYLEDONES.}

Embryo with two cotyledons; stem usually differentiated into bark, wood and pith; wood cells forming annual rings; leaves mostly net-veined; parts of flowers in fours or fives, rarely in twos or sixes.

\section{Family 24. SALICACEAE. Willow Family.}

Trees or shrubs with light wood, bitter bark and brittle twigs; leaves alternate; stipules often minute; flowers solitary in the axil of each bract, dioecious, both staminate and pistillate in aments which expand with or before the leaves; staminate aments often pendulous; pistillate pendulous, erect or spreading; staminate flowers of 1-many hypogynous stamens, subtended by a gland-like or cup-shaped disk; pistillate flowers of a sessile or short-stipitate 1-celled ovary subtended by a minute disk; ovules usually numerous; fruit an ovoid or oblong or conic 2-4-valved capsule; seeds minute; endosperm none.

Ament bracts entire; stamens 1-10; stigmas short. 103. SALIX, 73.

Ament bracts fimbriate or incised; stamens numerous; stigmas elongated.

104. Populus, 75. 
103. SALIX. WILLOW.

Trees or shrubs with single-scaled buds, the scales with an adherent membrane within; leaves short-petioled, mostly narrow, with broad or minute stipules; bracts of the aments mostly entire, small or minute; flowers each with one or two small glands at its base; staminate aments dense, erect, spreading or drooping; pistillate aments usually erect or spreading; staminate flowers with $1-10$, most 2 or 5 , stamens; ovary sessile or shortstipitate.

Trees with furrowed bark; stamens 3-5 or more; aments on short leafy branchlets.

Petioles slender, glandless; leaves broadly lanceolate.

Petioles short, glandular; leaves narrowly lanceolate.

S. amygdaloides. Shrubs, rarely trees, with smooth or at least not furrowed bark; stamens 2 or 1 .

Aments on short leafy branchlets; scales pale.

Stigmas long and slender.

Stigmas short and thick.

Capsules pubescent.

S. lasiandra.

Capsules glabrous.

Leaves canescent, at least when young, entire or denticulate.

Leaves green, glabrous, pale beneath, usually somewhat serrate.

Aments sessile or nearly so, appearing with or before the

S. macrostachya.

S. argophylla.

S. exigua.

S. mclanopsis. leaves; scales dark (except in S. bebbiana).

Capsules glabrous, long-pedicelled.

Leaves glaucous beneath, shining green above, not subcordate.

Leaves not shining above nor glaucous beneath, subcordate.

Leaves pale beneath.

Leaves green on both sides.

S. piperi.

Capsules not glabrous.

Scales pale; aments appearing with the leaves.

Scales dark; aments appearing before the leaves.

Stamen 1; leaves entire, silvery-silky beneath. S. sitchensis.

Stamens 2.

Style elongate.

Style none, the stigmas sessile.

S. cordata.

S. pyrifolia.

S. bebbiana.

S. bella.

S. scoulériana.

Salix amygdaloides Anders. Almond Willow. Tree 5-10 m. tall, with cinnamon-colored fissured bark; leaves glabrous, lanceolate; serrate, attenuateacuminate, green above, glaucous beneath, $10-15 \mathrm{~cm}$. long; petioles slender, without glands; stipules ear-shaped or reniform, usually small and quickly deciduous; aments on leafy branchlets; staminate flexuous, dense, 5-6 cm. long; scale pale, hairy; stamens 5 or more; pistillate becoming loose and elongated; capsules glabrous, the slender pedicels much exceeding the pale fugacious scales; stigmas sessile or nearly so. Common on the banks of Snake River.

Salix lasiandra caudata (Nutt.) Heller. Tree $10-20 \mathrm{~m}$. tall, with rough longitudinally fissured bark; leaves lanceolate, long-acuminate, crenulate, green and glabrous on both sides, $8-16 \mathrm{~cm}$. or more long; the short petioles and the very base of the leaf glandular; stipules ear-shaped, sometimes large; 
aments on leafy branchlets; staminate dense, 3-5 cm. long; scales pale, oblong, more or less dentate; stamens 5 or more, the filaments hairy at the base; pistillate rather loose, the pale oblong scales hairy at the base, deciduous; carpel glabrous, short-pedicelled; stigma nearly sessile. Common on stream banks.

Salix macrostachya Nutt. Shrub, 2-3 m. high; leaves narrowly lanceolate, acuminate, nearly sessile, entire, 5-8 cm. long, densely sericeous on each side; stipules very small; staminate aments $2-5 \mathrm{~cm}$. long, the scales ovate, acute, woolly. On overflowed bars near Wawawai where only the staminate plants have been found.

Salix argophylla Nutt. Differs from $S$. exigua only in its more or less pubescent capsules. Intergrades are numerous. Common along streams.

Salix exigua Nutt. Shrub 3-5 m. tall, usually with a single trunk; bark rough, longitudinally cracked; twigs glabrous; leaves acute, subentire, denticulate, narrowly lanceolate or oblanceolate, 3-10 cm. long, 4-10 mm. wide, glabrate above, sparsely appressed-silky beneath, the veins obscure; petioles very short; stipules none or very small; aments on leafy branchlets, solitary or 2-4; staminate aments $2-5 \mathrm{~cm}$. long, slender, the scales lanceolate, acute; capsules glabrous, sessile; stigmas sessile. Common along streams.

Salix melanopsis Nutt. Much like $S$. exigua; twigs glabrous; leaves glabrous on both sides or glaucous beneath, remotely denticulate; stipules triangular-ovate, acute, few-toothed; capsules glabrous; stigmas sessile; scales obtuse. Low shrub on the edge of Snake River, where it is frequently covered with water until July; also on the banks of the Spokane River.

Salix piperi Bebb. Large shrub, 5-6 m. tall; leaves petioled, oblong or oblanceolate, obliquely acute or acuminate, serrulate, shining green above, densely glaucous and somewhat pubescent beneath; stipules rare, if present, triangular; aments appearing with the leaves; staminate cylindrical, $3-5 \mathrm{~cm}$. long, short-peduncled; scales black, hairy; stamens 2, the glabrous filaments united at the base for half their length; pistillate aments small, $1-3 \mathrm{~cm}$. long, on short leafy peduncles; capsules glabrous, short-pedicelled; style about equalling the stigma. Along streams, infrequent:

Salix cordata Muhl. Heart-leaved Willow. Shrub, 2-5 m. tall, with elongate branches; leaves oblong or oblong-lanceolate, acuminate, glandularserrulate, rounded or cordate at the base, nearly glabrous above, glaucous beneath, 4-8 cm. long; petioles stout; stipules conspicuous, reniform; aments appearing with the leaves, on leafy peduncles; staminate narrow, denseflowered, 4-6 cm. long, the black hairy scales persistent; pistillate looser; capsules glabrous, the long pedicels far exceeding the scales; style as long as the stigmas. Common along streams. Our form is somewhat different from the typical plant as found in the Atlantic States.

Salix pyrifolia Anders. Shrub, 1-3 m. high, with slender shiny brown twigs; leaves thin, ovate-lanceolate to obovate-oval, shortly acuminate, rounded or subcordate at base, glandular serrulate, green on both sides, 3-7 cm. long; stipules lunate to broadly ovate; peduncles short, leafy; aments appearing with the leaves, the staminate slender, 4-6 cm. long; filaments partly united; pistillate aments 3-6 cm. long; capsules glabrous, 3-4.5 mm. long. Along stream banks. This species has been much confused with $S$. cordata.

Salix bebbiana Sargent. Much branched shrub, 2-5 m. tall; leaves oblong, elliptic, acute or acuminate, crenulate or nearly entire, pale and downy beneath, green and puberulent above, strongly reticulate, $3-8 \mathrm{~cm}$. long; petioles short; stipules ear-shaped, usually falling quickly; aments on short bracteate peduncles appearing with the leaves; staminate dense, the obtuse 
scales pale, hairy; stamens 2; filaments glabrous; pistillate looser, the linear scales pale and pink-tipped; capsules pubescent, long-beaked, with sessile stigmas, the slender pedicel equalling or exceeding the persistent scales. Common along streams.

Salix sitchensis Sanson. Shrub with smooth gray bark, 2-7 m. high; branchlets slender, at first downy; leaves oblong or somewhat obovate, mostly acute, dark green above, the veins conspicuous, covered beneath with an appressed satiny white pubescence, entire or obscurely crenate, $5-10 \mathrm{~cm}$. long; petioles short; aments long, slender, ascending, densely flowered, $2-8 \mathrm{~cm}$. long; scales dark, villous; capsules ovate-conical, acute; style elongate; stigmas thick, erect. About Spokane and in the Blue Mountains.

Salix bella Piper. Pretty Willow. Shrub, 2-4 m. tall, with slender erect branches, the bark gray and smooth; branchlets shining yellow, usually glabrous, very brittle; leaves lanceolate or oblong, or oblong-obovate, acute, $3-6 \mathrm{~cm}$. or more long, green and glabrate above; densely silvery-woolly beneath, entire or nearly so; petioles short; stipules lunate, usually present; aments appearing before the leaves; staminate sessile, short and thick, 1-2 cm. long; scales acute, black, densely villous; stamens 2; pistillate short-peduncled, 2-3 cm. long; scales black, obtuse, densely villous; capsules silky hairy, nearly sessile; style $1.5 \mathrm{~mm}$. long. Along streams especially near the mountains.

Salix scouleriana Barratt. Shrub or tree, 4-10 m. tall, with dull gray bark; leaves very variable, oblong, elliptic or obovate, acute, acuminate or obtuse, entire or serrulate, green above, usually downy beneath, this becoming rusty in age, 2-12 cm. long; petioles rather short; stipules large, ear-shaped, dentate, persistent on sterile shoots; aments appearing before the leaves, very densely flowered; scales black, hairy, persistent; staminate aments sessile; stamens 2, with glabrous separate filaments; pistillate short-peduncled; carpels hairy, long-beaked, the pedicels equalling the scales; stigmas sessile. Frequent along streams and in open coniferous woods.

\section{POPULUS.}

Trees with scaly resinous buds and rounded or angled twigs; leaves long-petioled, broad or narrow; bracts of the aments fimbriate or incised; disk cup-shaped, oblique, lobed or entire; staminate aments dense, pendulous; pistillate aments sometimes raceme-like by the elongation of the pedicels, pendulous, erect or spreading; staminate flowers with 4-60 stamens; filaments distinct; ovary sessile; tuft of hair on the seed very conspicuous.

Bark smooth; petioles flattened; capsules oblong-conic, smooth.

Bark rough; petioles terete; capsule globose, hairy.

Leaves broadly ovate, truncate at base; capsules globose, pubescent.

Leaves lanceolate or oblong-lanceolate, obtuse or acute at base; capsules ovoid, smooth.

$P$. tremuloides.

$P$. trichocarpa.

Populus tremuloides Michx. Aspen. Small tree, 10-12 m. tall, with smooth light bark; leaves broadly ovate, subcordate or obtuse at base, abruptly acuminate, $3-8 \mathrm{~cm}$. long, ciliate when young, glabrate; petioles long and slender, much flattened laterally; staminate aments dense, 3-5 cm. long; stamens 7-10; bracts long-ciliate; pistillate aments $5-10 \mathrm{~cm}$. long. Common on north hillsides and along streams. 
Populus trichocarpa T. \& G. Cottonwood. Large tree, 10-30 m. tall, with rough fissured bark; leaves broadly ovate, rounded at the base, acuminate, 5-12 cm. long, puberulent when young, whitish beneath; petioles slender, terete, about equalling the blades; staminate aments dense, the bracts longhairy; stamens 50-60; pistillate aments becoming loose; capsules nearly sessile, globose, puberulent or glabrate. Banks of streams.

Populus angustifolia James. Medium sized tree, $10-20 \mathrm{~m}$. high with thick rough fissured bark; leaves oblong-lanceolate to lanceolate, acute, crenulate, 5-12 cm. long; petiole not flattened, less than one third as long as the blade; staminate aments oblong-cylindric, the bracts fringed; stamens 12-20; capsules ovoid, glabrous. A rare tree in Washington known as yet only from Spokane, Professor Bonser.

\section{Family 25. BETUlaCEAE. Birch Family.}

Trees or shrubs; leaves alternate, petioled, simple, with deciduous stipules; flowers small, monoecious, in linear-cylindric, oblong or subglobose aments; staminate aments pendulous; pistillate aments erect, spreading or drooping, spike-like or capitate; staminate flowers $1-3$ in the axil of each bract, with a membranous 2-4-parted calyx, or calyx none, and 2-10 hypogynous stamens; pistillate flowers with or without a calyx adnate to the solitary 1-2-celled ovary; ovules 1-2 in each cavity; fruit a small compressed or ovoid-globose, mostly 1-celled and 1-seeded nut or samara; endosperm none.

Stamens 2; filaments 2-cleft, each fork bearing an anther sac; fruiting bracts 3-lobed or entire.

Stamens 4; anther sacs adnate; fruiting bracts woody, erose or 5-toothed, persistent.

105. Betula, 76.

106. Alvus, 77.

\section{BETUla. Birch.}

Trees and shrubs; leaves dentate or serrate; buds scaly; flowers all in aments, expanding before and with the leaves; the pistillate aments erect or spreading; staminate flowers about 3 in the axil of each bract, with a membranous usually 4 -toothed perianth and 2 stamens, and subtended by 2 bractlets; pistillate flowers 2 or 3 (rarely 1 ) in the axil of each bract; perianth none; ovary sessile, 2-celled; nut small, a samara, shorter than the bracts.

Branchlets pubescent, not glandular warty.

Branchlets warty with resiniferous glands.

Pistillate aments stout, $2-3 \mathrm{~cm}$. long.

Pistillate aments slender, $5 \mathrm{~cm}$. long.
B. papyrifera.

B. microphylla.

B. piperi.

Betula papyrifera Marsh. Tree with a single trunk, 8-20 m. high, erect; bark grayish-bronze, the erect or spreading branchlets dull gray; leaves broadly ovate, attenuate-acute at base, somewhat lobed at the ends of the 
prominent nerves, serrate, acuminate, very sparsely hairy on both sides, scarcely glandular, 4-7 cm. long, on slender petioles $2-3 \mathrm{~cm}$. long; pistillate aments cylindrical, $3 \mathrm{~cm}$. long, $1 \mathrm{~cm}$. thick, usually drooping on slender peduncles; bracts pubescent, the central lobes longest. Blue Mountains and throughout northern Idaho, but not abundant.

Betula microphylla Bunge ( $B$. fontinalis Sargent). Small tree, 5-8 m. high, the several trunks rarely erect, the bark dark bronze; branchlets drooping, grayish, warty; leaves broadly ovate, obtuse or acute, coarsely serrate-dentate, glandular and sparsely hairy on each surface, $2-4 \mathrm{~cm}$. long, on slender petioles half their length; staminate aments about $2 \mathrm{~cm}$. long; pistillate aments solitary, cylindric, $2-3 \mathrm{~cm}$. long, drooping with the branchlets, sessile or on short peduncles; fruiting bracts pubescent and ciliolate, the central lobe largest and narrowest; wings as broad as the obovate nutlet. Common along streams.

Betula piperi Britt. Graceful tree, 8-15 m. tall, with drooping branches; bark dark bronze, even the branchlets scarcely gray, these latter very glandular; leaves ovate, obtuse or acute at the base, coarsely doubly serrate, acuminate, shining green above, glandular on both surfaces, 2-4 cm. long, on petioles half as long; pistillate aments cylindrical, $5 \mathrm{~cm}$. long, $5 \mathrm{~mm}$. thick, often flexuous, mostly in twos, dark green; staminate aments narrow, flexuous, 4-8 cm. long. Springy hillsides near Almota.

\section{ALNUS. Alder.}

Trees or shrubs; leaves dentate or serrulate; buds few-scaled; both kinds of flowers in aments, expanding before, with or after the leaves; the staminate pendulous; the pistillate erect, clustered; staminate flowers 3 , sometimes 6 , in the axil of each bract, consisting of a mostly 4 -parted perianth and 4 stamens, and subtended by 1 or 2 bractlets; filaments short, simple; anther-sacs adnate; pistillate flowers 2 or 3 in the axil of each bract, without a perianth, but subtended by 2-4 minute bractlets; ovary sessile, 2-celled; styles 2 ; bracts woody, persistent, 5-toothed or erose; nut small, compressed, wingless or winged.

Leaves simply denticulate, not at all lobed.

Leaves doubly dentate or with short lobes at the ends of the main veins.

Peduncles slender, exceeding the cones; leaves shining.

Peduncles stout, shorter than the cones; leaves dull.

A. rhombifolia.

Alnus rhombifolia Nutt. Tree 10-15 m. tall, with white bark which on older trees becomes broken into rectangular blocks; leaves ovate, elliptic or obovate, mostly cuneate at the base and obtuse at the apex, glandular-denticulate, finely puberulent on each surface, somewhat glandular beneath, 5-8 $\mathrm{cm}$. long; petioles $1 \mathrm{~cm}$. or less long; fruiting aments oblong-ovate, $1.5-3 \mathrm{~cm}$. long, on short stout peduncles; nutlets broadly obovate, the margins thickened. Along streams in warm valleys.

Alnus sinuata (Regel) Rydb. Small tree or shrub, 3-5 m. tall, erect or ascending; bark rather dark, except in old stems; twigs chestnut brown; buds smooth, gummy; leaves ovate, acuminate, obtuse or cuneate at the base, bright green, doubly dentate, glabrous above, nearly so beneath, thin, very gummy when young, 5-8 cm. long; petioles slender, $1-2 \mathrm{~cm}$. long; fruiting aments $1-1.5 \mathrm{~cm}$. long, on slender peduncles as long or longer. Along streams in the mountains. 
Alnus tenuifolia Nutt. Small tree, 5-10 m. tall; bark whitish even on the twigs; buds pubescent; leaves ovate or somewhat obovate, mostly obtuse, rounded or subcordate at the base, with a small lobe at the end of each vein, dentate-serrate, dull-green, 3-8 cm. long, sparsely pubescent on both sides, becoming glabrous above; petioles stout, pubescent, $1-1.5 \mathrm{~cm}$. long; fruiting aments ovate, $1-2.5 \mathrm{~cm}$. long, resinous, with shorter peduncles. Along streams, not rare.

\section{Family 26. ULMACEAE. ELm FAmily.}

Trees or shrubs; leaves alternate, simple, serrate or entire, petioled, pinnately veined, with usually fugacious stipules; flowers small, monoecious, dioecious, perfect or polygamous; sepals 3-9, free or united; petals none; stamens as many as the sepals and opposite them; ovary 1-celled; ovule one; fruit a samara, drupe or nut.

\section{CELTIS.}

Trees or shrubs; leaves serrate or entire, pinnately veined; flowers polygamous or monoecious, borne in the axils of the season's leaves, the staminate clustered, the fertile solitary or in 2-3-flowered clusters; calyx 4-6-parted; ovary sessile; stigmas 2 ; fruit an ovoid or globose drupe.

Celtis douglasii Planch. Hackberry. Scraggly tree or shrub, 3-5 m. tall; leaves oblique-ovate, acuminate, cuneate at the base, sharply serrate, pubescent when young, glabrous and shiny above when mature, somewhat pubescent on the veins beneath, rough, reticulated, 4-8 cm. long; petioles about $1 \mathrm{~cm}$. long; fruit reddish, globose, smooth, 5-7 mm. in diameter, on slender peduncles, about $2 \mathrm{~cm}$. long. Basaltic bluffs on Snake River; a handsome tree when grown in good soil, but under natural conditions very scraggly; leaves often distorted as a result of insect attacks.

\section{Family 27. URTICACEAE. Nettle Family.}

Herbs (in ours); leaves alternate or opposite, simple, with or without stipules; flowers small, monoecious, dioecious or polygamous; calyx of 2-5 nearly separate sepals or cup-shaped; petals none; stamens as many as the calyx-lobes and opposite them; ovary 1-celled, mostly superior; ovule solitary; fruit an akene; endosperm scanty or none.

Leaves opposite, with stinging hairs.

Leaves alternate, without stinging hairs.

108. URTICA, 78.

109. Parietaria, 79.

108. URTICA. Nettle.

Annual or perennial simple or branching herbs with stinging hairs; leaves opposite, 3-7-nerved, petioled, dentate or incised, with distinct stipules; flowers greenish, very small and numerous, 
dioecious or monoecious; staminate flowers with a deeply 4parted calyx and 4 stamens; pistillate flowers with 4 sepals, the two inner larger and in fruit enclosing the akene; the two outer smaller and spreading.

Leaves soft-pubescent on both sides.

Leaves quite glabrous above, somewhat pubescent beneath.

U. holosericea.

U. lyallii.

Urtica holosericea Nutt. Tall, 2-3 m. high, usually somewhat bristly, densely soft-pubescent throughout; leaves ovate-lanceolate, acuminate, subcordate, coarsely and evenly dentate, soft-pubescent on both sides, $8-16 \mathrm{~cm}$. long; petioles short; staminate flowers in loose narrow panicles shorter than the leaves; pistillate panicles denser, in the axils of the uppermost leaves. Variable; common in moist places especially in the warmer valleys.

Urtica lyallii Wats. Very much like $U$. holosericea, but not so tall, 1-2 m. high; stem merely bristly or glabrous; leaves broadly ovate, cordate, very coarsely dentate, green and usually glabrous above, pubescent or glabrous beneath. Infrequent, in moist places.

\section{PARIETARIA.}

Annual or perennial diffuse or erect herbs without stinging hairs; leaves alternate, entire, 3-nerved, petioled, without stipules; flowers axillary, in compact clusters, polygamous, subtended by an involucre of leafy bracts; calyx of the staminate flowers deeply 4-parted, that of the fertile flowers tubular or campanulate, 4-lobed, surrounding the ovary and the akene.

Leaves rounded or cuneate at base; bracts equalling the flowers.

P. debilis.

Leaves attenuate-acute at base; bracts exceeding the flowers. $P$. pennsylvanica .

Parietaria debilis Forst. Stems slender, pubescent, simple or branched at base, weak, $8-20 \mathrm{~cm}$. long; leaves ovate, obtuse, rounded or cuneate at base, 4-12 mm. long, rough-hairy above; petioles short; flowers few in each cluster; bracts oblong-linear, 1-2 mm. long, scarcely longer than the flowers; akenes shining gray, $1 \mathrm{~mm}$. long. Crevices of basaltic cliffs near Lewiston.

Parietaria pennsylvanica Muhl. Very similar to $P$. debilis; leaves lanceolate, attenuate-acute at base, $2-6 \mathrm{~cm}$. long; bracts much exceeding the flowers, 3-5 mm. long. Basalt crevices along the Snake and Clearwater Rivers.

\section{Family 28. LORANTHACEAE. Mistletoe Family.}

Parasitic shrubs or herbs, yellow or yellowish-green, growing on woody plants and absorbing food from their sap through specialized roots (haustoria); leaves opposite; flowers regular, terminal or axillary, clustered or solitary, dioecious (in ours); calyx-tube adnate to the ovary; stamens 2-6; ovary solitary, erect; style simple or none; stigma terminal; fruit a berry; seed solitary; endosperm usually copious and fleshy. 


\section{RAZOUMOFSKYA}

Small fleshy glabrous plants, parasitic on the branches of coniferous trees; branches 4-angled; leaves reduced to opposite connate scales; flowers dioecious, not bracted, solitary or several together in the axils of the scales; staminate flowers with 2-5parted calyx and usually equal number of stamens; pistillate flowers with an inferior ovary; berry fleshy, ovoid, more or less flattened.

Staminate flowers paniculate, nearly all terminal on distinct peduncle-like joints.

R. americana.

Staminate flowers forming simple or clustered spikes.

Plant 1-4 cm. high, scattered.

Plant larger, clustered.

Stems stout; staminate spikes stout.

Stems slender; staminate spikes slender.

R. douglasii.

R. campylopoda.

$R$. laricis.

Razoumofskya americana Nutt. Stems olivaceous, slender, much branched, the branches in pairs or whorls; staminate plants $6-10 \mathrm{~cm}$. long, the pistillate a little smaller; staminate flowers with ovate acutish lobes; fruit bluish-green, $4 \mathrm{~mm}$. long. On lodgepole pine, often abundant and causing swellings and distortions.

Razoumofskya douglasii Engelm. Stems olivaceous, scattered, usually solitary, 5-20 mm. long, simple or but little branched, the branches never in whorls; flowers in short few-flowered spikes, the staminate with broadly ovate acutish lobes; fruit $5 \mathrm{~mm}$. long. On Pseudotsuga mucronata, the parasite spreading all along the affected branch.

Razoumofskya campylopoda (Engelm.) Piper. Stems stout, 4-10 cm. long, branched, the staminate deep yellow, the pistillate olivaceous; staminate flowers in dense long spikes, the calyx-lobes 3 or 4 , oblong-ovate, acutish; fruit obovate, acute, bluish-green, $5 \mathrm{~mm}$. long. Abundant on Pinus ponderosa. Sometimes known as "Snappers" on account of the way the seeds are discharged.

Razoumofskya laricis Piper n. sp. Pistillate plants olivaceous, clustered, 5-8 cm. long, branched; joints 1.5-2 mm. thick, sharply 4-angled; staminate swollen, yellow, the flowers in short spikes; lobes ovate, acute; fruit oblong, acutish, bluish, $4 \mathrm{~mm}$. long. Common on Larix occidentalis.

\section{Family 29. SANTAlaCEaE. Sandalwood Family.}

Herbs or shrubs or trees; leaves alternate or opposite, entire, without stipules; flowers clustered or solitary, axillary or terminal, perfect, monoecious or dioecious; calyx adnate to the base of the ovary, 4-5-cleft; petals none; stamens as many as the calyx-lobes and opposite them; ovary 1-celled; ovules 2-4; fruit a drupe or nut with only one seed.

\section{COMANDRA.}

Glabrous erect perennial herbs, sometimes parasitic on the roots of other plants; leaves alternate, oblong, oval, lanceolate or 
linear, entire, pinnately veined; flowers perfect, terminal or axillary, rarely solitary, cymose, bractless; calyx campanulate, the base of its tube adnate to the ovary; limb 5-lobed; stamens 5 , rarely 4 , at the bases of the calyx-lobes and between the lobes of the disk; fruit drupaceous, globose or ovoid, crowned by the persistent calyx.

Comandra pallida A. DC. Stems erect, from woody rootstocks, $30-40 \mathrm{~cm}$. high, simple or branched above; leaves sessile, lanceolate or linear, acuminate, pale and glaucous, $2-4 \mathrm{~cm}$. long; umbels clustered; flowers $4-5 \mathrm{~mm}$. long, the whitish calyx-lobes little spreading, acute, puberulent above, scarcely equalling the green tube; fruit nut-like, globose or ovoid, 7-10 $\mathrm{mm}$. long, glaucous, reticulated, tipped by the persistent calyx. Gravelly soil, quite common. Nuts edible.

\section{Family 30. ARISTOLOCHIACEAE. Birthwort Family.}

Low herbs or twining shrubs; leaves alternate or basal, petioled, mostly cordate or reniform, without stipules; flowers axillary or terminal, solitary or clustered, perfect, mostly large; calyx-tube at least at the base adnate to the ovary, its limb 3lobed, 6-lobed or irregular; petals none; stamens 6-12, united with the style; ovary partly or wholly inferior, mostly 6-celled; ovules numerous in each cavity; fruit a 6-celled capsule or berry; seeds ovoid or oblong, angled or compressed.

\section{ASARUM. WILD GINGER.}

Stemless perennial often clustered herbs, with slender aromatic branched rootstocks; roots thick, fibrous-fleshy; leaves longpetioled, reniform or cordate, entire; flowers solitary, large, peduncled, brown-purple or mottled, borne near the ground; calyx bell-shaped or hemispheric, adnate to the ovary, at least below, regularly 3-lobed; stamens 12 , inserted on the ovary; ovary partly or wholly inferior, 6-celled, the parietal placentae intruded; ovules numerous; capsule coriaceous; seeds compressed.

Asarum caudatum Lindl. Sparsely hairy throughout; rootstocks elongate, 10-30 cm. long; leaves reniform-cordate, $5-10 \mathrm{~cm}$. broad, obtuse or acutish; petioles slender, elongate; peduncles $1-4 \mathrm{~cm}$. long; flowers brown-purple; calyx-lobes oblong-lanceolate, attenuate, $2-5 \mathrm{~cm}$. long. Deep woods, in the mountains.

\section{Family 31. POLYGONACEAE.}

Herbs or shrubs; leaves alternate or sometimes opposite or whorled, simple, mostly entire, with usually sheathing united stipules (ocreae); flowers small, regular, perfect, dioecious, monoecious or polygamous, in spikes, racemes, corymbs, umbels 
or panicles; petals none; calyx free from the ovary, 2-6-cleft or parted, the segments sometimes petal-like; stamens $4-9$, inserted near the base of the calyx or in staminate flowers crowded toward the center; pistil 1; ovary superior, 1-celled; ovule 1; fruit a lenticular or 3-angled, rarely 4-angled akène; endosperm mealy.

Flowers subtended by involucres.

113. ERIogonUm, 82.

Flowers not subtended by involucres.

Sepals 6; stigmas 3, tufted.

Sepals 4-6, usually 5; stigmas capitate.

114. Rumex, 83.

115. POLygONum, 85.

\section{ERIOGONUM.}

Annual or perennial acaulescent or leafy-stemmed herbs or shrubs; stems simple or branched, often tufted; leaves entire, alternate or whorled; flowers small, fascicled, cymose, umbellate or capitate, subtended by 5-8-toothed or cleft campanulate or cylindric involucres; calyx 6-cleft or parted, usually colored; segments equal or the outer ones larger; stamens 9; akenes pyramidal, 3 -angled, more or less swollen near the base, invested by the calyx-segments or winged.

Flowers attenuate and stipe-like at base.

Perianth very pubescent; umbel simple, dense.

Involucre with reflexed lobes; flowers cream-color. $\quad E$. douglasii.

Involucre with erect lobes; flowers yellow.

Perianth glabrous or nearly so; umbel usually compound.

Leaves large, mostly cordate.

Leaves small, never cordate.

Flowers bright yellow; leaves oval, glabrous above.

Flowers white; leaves lanceolate, tomentose on both sides.

E. piperi.

E. compositum.

E. stellatum.

E. heracleoides

Flowers not attenuate and not stipe-like at base.

Outer perianth-segments much broader than the inner.

Outer perianth-segments like the inner.

Annual; stems wiry; leaves orbicular, in a rosette.

Perennial; stems woody; leaves narrower.

E. niveum.

E. vimineum.

E. strictum.

Eriogonum douglasii Benth. Prostrate or nearly so, only the flowering stems upright; leaves in tufts on woody caudex branches, small, 1-2 cm. long, oblong or spatulate, not revolute; flowers cream-color, in simple spherical, head-like umbels, attenuate and stipe-like at base; perianth pubescent; involucre short with linear reflexed lobes. Blue Mountains, rare.

Eriogonum piperi Greene. Densely tufted on a stout woody caudex; stems erect, leafless, tomentose, $10-20 \mathrm{~cm}$. tall; leaves all basal, lanceolate or oblanceolate, acute or obtuse, white and densely hairy beneath, green and less hairy above; blade 2-4 cm. long, attenuate into a usually shorter petiole; umbels several-rayed, simple or contracted into a dense cluster; bracts 3-8, oblanceolate, $1-3 \mathrm{~cm}$. long; involucre short-toothed, villous; flowers yellow, very villous, 5-6 $\mathrm{mm}$. long. In rocky places at high altitudes.

Eriogonum compositum Dougl. Stems stout, simple, $20-30 \mathrm{~cm}$. tall, glabrous or nearly so; leaves ovate or oblong-ovate, cordate, acute, densely white-woolly beneath, green and less so above, 4-10 cm. long, on petioles as 
long or longer; umbels 6-10-rayed, mostly compound, rather dense; principal bracts linear or oblanceolate; branches very short or $2-4 \mathrm{~cm}$. long; involucres pubescent, deeply 5-lobed, the lobes acute, spreading; flowers white or yellow, sparsely pilose. Rocky places both at low altitudes and in the mountains.

Eriogonum compositum leianthum Benth. Perianth glabrous, usually yellow. In rocky places.

Eriogonum stellatum Benth. In loose tufts, woody at base, somewhat tomentose; stems erect or ascending, 20-30 cm. high; leaves oblanceolate to broadly oval, obtuse, green and glabrate above, densely white tomentose beneath; peduncle simple or branched, naked or with a single bract in the middle; bract of the involucre leaf-like; umbel compound; perianth bright yellow, glabrous. Common on stony hillsides in the Blue Mountains.

Eriogonum heracleoides Nutt. Loosely tufted, thinly tomentose throughout; flowering stems erect, $20-40 \mathrm{~cm}$. tall, with a single whorl of leaves half way up; leaves linear to oblanceolate, acute, $3-5 \mathrm{~cm}$. long, attenuate at base into a short petiole, paler and more pubescent beneath; bracts similar to the leaves, but smaller; umbels 1-10-rayed, simple or compound; involucres woolly, deeply lobed, the lobes reflexed; flowers whitish. Common on basaltic ledges.

Eriogonum niveum Dougl. Densely white-tomentose throughout; stem tufted from a loose woody caudex, $30-50 \mathrm{~cm}$. tall, loosely several-times forked, the branches in twos or threes, ascending; basal leaves ovate or oblong, obtuse, 1-3 cm. long, densely white-woolly on each side, on slender petioles; cauline narrower, nearly sessile, whorled at the forks, the upper reduced; umbels in the forks or on the sides of the branches; involucre short and broad, $4 \mathrm{~mm}$. long, 5-6-toothed, the tips somewhat recurving; flowers white or pinkish, 4-5 mm. long. In stony soil, abundant in the sagebrush region.

Eriogonum vimineum Dougl. Annual; stems wiry, erect, $15-40 \mathrm{~cm}$. tall, much branched above the base, tomentose below, the branches long and slender; leaves commonly in a single rosette at or near the base, broadly oblong or orbicular, $2-4 \mathrm{~cm}$. long, densely tomentose beneath, less so above; petiole slender, about as long as the blade; umbels small, 2-8-flowered, sessile and scattered along the sides of the long branches, or in the forks; involucres narrow, 3-4 mm. long, 5-toothed and nerved, glabrous; flowers white or pink, $2 \mathrm{~mm}$. long. In basaltic gravel or sandy soil in the warmer valleys.

Eriogonum strictum Benth. Whole plant white-tomentose; stems slender, woody, 20-30 cm. high; leaves elliptical to oblanceolate, acute, 1-2 cm. long, slender-petioled, mostly on short branches from the caudex; flowers yellowishwhite in a loose 2-3-times branched panicle; umbels solitary, in a forked cyme, with some scattered along the branches; involucres tomentose within, but merely pilose without. In the higher Blue Mountains, rare.

\section{RUMEX. Dock.}

Perennial or annual leafy-stemmed herbs, some species slightly woody; stem grooved, mostly branched; leaves entire or undulate, flat or crisped; sheaths usually cylindric, brittle, soon falling away; inflorescence of simple or compound often panicled racemes; flowers green or reddish, perfect, dioecious or polygamomonoecious, whorled, on jointed pedicels; calyx 6-parted, the three outer sepals unchanged in fruit, the three inner ones mostly developed into valves which are entire, dentate or fringed with bristle-like teeth; stamens 6; stigmas tufted; akene 3-angled, the angles more or less margined. 
Flowers dioecious; plants small.

Inner sepals not longer than the granular akene; leaves hastate.

Inner sepals longer than the smooth akene; leaves lanceolate.

R. acetosella.

R. paucifolius.

$R$. venosus.

$R$. occidentalis.

$R$. persicarioides.

R. crispus.

$R$. mexicanus.

Rumex acetosella L. Sheep Sorrel. Dioecious, widely spreading by creeping rootstocks; stems slender, $10-30 \mathrm{~cm}$. high, simple or somewhat branched; leaves $3-10 \mathrm{~cm}$. long, very acid, glabrous, mostly hastate, the basal lobes entire or toothed; sheaths scarious, becoming cut into lobes; panicle narrow, the branches ascending; bracts wanting; flowers small, on short jointed pedicels, clustered; sepals remaining small, much shorter than the 3 -angled akene. Introduced, a weed in lawns and pastures.

Rumex paucifolius Nutt. Dioecious; stems erect and slender, $30-60 \mathrm{~cm}$. high, sparingly leafy; leaves narrowly to linear-lanceolate, $5-10 \mathrm{~cm}$. long, acute or acutish, attenuate to a slender petiole, not very acid; panicle branches slender, erect; flowers reddish, small, in loose fascicles; inner sepals longer than the smooth akene. In wet meadows, infrequent.

Rumex venosus Pursh. Stems $30-60 \mathrm{~cm}$. tall, commonly woody, strongly grooved, erect or decumbent, from woody creeping rootstocks; leaves elliptic or lanceolate, entire, acute at each end, 8-12 cm. long; petioles stout, rather dense, 10-15 cm. long; valves bright red, cordate-orbicular, entire, very large, 1.5-2 cm. long, wholly without tubercles; akenes $6-8 \mathrm{~mm}$. long. In sandy soil especially on sand dunes.

Rumex occidentalis Wats. Stout, $100-150 \mathrm{~cm}$. tall; leaves oblong-ovate, mostly obtuse, $15-40 \mathrm{~cm}$. long, entire or undulate, cordate at the base; petioles of the lower leaves long and slender, of the upper stout; panicles $30-60 \mathrm{~cm}$. long, dense, usually reddish; flowers on slender pedicels, $1 \mathrm{~cm}$. long; valves broadly ovate, obtuse, more or less toothed, $6-10 \mathrm{~cm}$. long, wholly without tubercles; akene brown, $4 \mathrm{~mm}$. long. Common in swampy places.

Rumex persicarioides L. Minutely pubescent; stems erect or procumbent, branched, 15-60 cm. high; leaves linear-lanceolate, truncate or slightly cordate at base, 3-10 cm. long, wavy-margined; panicle dense, the flowers short-pedicelled in numerous close whorls; valves ovate, each bearing a tubercle on the back and 2 or 3 slender bristles on the margins. In wet places, especially where alkaline.

Rumex crispus L. Yellow Dock. Stem stout, 50-100 cm. high, grooved, from an elongated fusiform root; leaves oblong, obtuse, truncate or rounded at the base, $15-30 \mathrm{~cm}$. long, the margin wavy and crisped; petiole short; panicle rather dense, $20-40 \mathrm{~cm}$. long, greenish; flowers on pedicels $5-10 \mathrm{~mm}$. long; valves 3-4 $\mathrm{mm}$. long, broadly ovate or cordate, each bearing a tubercle; akene about $2-2.5 \mathrm{~mm}$. long, brown. A weed in grain fields and along roadsides.

Rumex mexicanus Meisn. Stems erect or decumbent, $40-90 \mathrm{~cm}$. long, slightly grooved, often branched below; leaves oblong-lanceolate or linearlanceolate, mostly acute, entire, rounded or cuneate at the base, $8-15 \mathrm{~cm}$. long; 
petioles rather short; panicle $10-12 \mathrm{~cm}$. long, the branches short, leafybracted; valves triangular-ovate, slightly toothed, 3-4 $\mathrm{mm}$. long, each bearing a large oblong tubercle; akene broad, $2 \mathrm{~mm}$. long. Wet places, common.

\section{POLYGONUM.}

Annual or perennial, terrestrial or aquatic herbs, some species woody; stems erect, prostrate, climbing or floating; leaves alternate, sessile or petioled, continuous with or jointed to the cylindric funnelform or 2-lobed often lacerate or fringed sheaths; flowers small, perfect, green, white, pink or purple, variously clustered, the clusters terminal or axillary; pedicels jointed, subtended by the sheaths; calyx 4-5-parted or cleft, the outer segments larger than the inner; stamens 3-9; stigmas capitate; akene lenticular or 3-angled (rarely 4-angled), invested by or exceeding the calyx.

\section{Stems twining; leaves cordate.}

P. convolvulus.

Stems not twining; leaves not cordate.

Leaves small, jointed on the petioles; slender annuals.

Stems not striate; flowers in rather dense spikes with imbricated bracts.

Bracts oblong, white-margined.

Bracts lanceolate, green.

Stems striate; flowers axillary or in loose or interrupted spikes.

Branches not angled; leaves scarcely reduced upwards.

Akenes exserted, smooth, shining; low alpine plant.

Akenes not exserted, dull; introduced usually prostrate plant.

Branches angled; leaves decidedly reduced upwards.

Flowers bell-shaped, 2-3 $\mathrm{mm}$. long.

Flowers funnelform, $3.5-4.5 \mathrm{~mm}$. long.

Leaves comparatively large, not jointed on the petioles.

Styles 3, long; flowers in a single dense spike-like raceme; root tuberous.

Styles 2-cleft; flowers in dense spikes; roots fibrous.

Perennial aquatic or swamp plants.

Sheaths ciliate on the spreading border. $\quad P$. hartwrightii.

Sheaths not ciliate.

Leaves elliptic, obtuse or acutish; peduncles glabrous.

Leaves lance-ovate, acuminate; peduncles

Annuals. hispid.

Sheaths ciliate.

Sheaths not ciliate.

Leaves not tomentose beneath.

Leaves tomentose beneath.

$P$. polygaloides.

$P$. confertiflorum.
P. minimum.

$P$. aviculare,

P. douglasii.

P. majus.

$P$. bistortoides.

P. amphibium.

$P$. emersum.

$P$. persicaria.

$P$. lapathifolium.

$P$. tomentosum.

Polygonum convolvulus L. Annual; stems twining or prostrate, 50-100 cm. long, glabrous or pubescent, scurfy below; leaves heart-shaped or somewhat halberd-shaped, acuminate, $2-6 \mathrm{~cm}$. long, minutely scurfy beneath; 
petioles equalling or shorter than the blades; sheaths short; flowers in clusters or slender axillary leafy racemes; calyx 5-parted, closely investing the fruit; akene 3-angled, dull black, minutely roughened. Introduced in cultivated or waste soil.

Polygonum polygaloides Meisn. Annual, glabrous; stems slender, much branched from the base, 5-20 cm. tall; leaves linear, sessile, 1-nerved, 1-3 cm. long; sheaths scarious, parted into long lobes; spikes dense, numerous, terminal, 5-10 cm. long; bracts oblong, with a broad white margin, crenulate, obtuse or acuminate, exceeding the flower; stamens 8; akene 3-angled, long, acuminate, longitudinally striate. Moist meadows, frequent.

Polygonum confertiflorum Nutt. Annual, glabrous; stems very slender, 3-10 cm. tall, with few branches; leaves linear, 1-3 cm. long; sheaths scarious, cut into lobes; spikes few, rather dense, 4-12 mm. long; bracts green, linear, acuminate, longer than the pink flowers, the margins revolute; stamens 3-5; akenes black, minutely striate. In thin soil, rare.

Polygonum minimum Wats. Annual, slightly scabrous, 5-30 cm. high, usually branched from the base; stems wiry, red; leaves oblong-lanceolate, acute or apiculate, 5-12 mm. long; flowers axillary, crowded above, usually rose-colored, erect on short pedicels; stamens 5-8; akenes smooth, shiny, longer than the sepals. In moist places at high altitudes, Blue Mountains.

Polygonum aviculare L. Knot-weed. Annual, glabrous; stems slender, prostrate, much branched, forming dense mats, the branches leafy to the top; leaves oblong or lanceolate, acute, $1-3 \mathrm{~cm}$. long, nearly sessile; sheaths scarious, cut into lobes; flowers 1 or few in the upper axils, pink, on very short pedicels which are included in the sheaths; akenes 3-angled, dull, minutely granular. Everywhere a weed; much relished by stock.

Polygonum douglasii Greene. Annual; stems slender, $15-40 \mathrm{~cm}$. tall, erect, glabrous or nearly so; branches few, erect, angled; leaves lanceolate, acute at each end, sessile at the jointed base; sheaths cylindric, scarious, becoming cut into lobes; flowering branches slender; flowers $1-3$, from the axils of the scattered bracts, soon becoming deflexed; calyx purple or whitish, with prominent green midribs; styles very short; akene 3 -angled, black, shiny. In gravelly soil, not common.

Polygonum douglasii montanum Small. Not so tall; leaves broader and shorter", flowering branches more leafy. Gravelly soil in pine woods in the mountains.

Polygonum majus (Meisn.) Piper. Annual, much branched from the base, erect or nearly so; stems wiry, terete, inconspicuously striate; leaves linearlanceolate, 2-6 cm. long, jointed at the base; sheaths scarious, about $1 \mathrm{~cm}$. long, at length cut into slender lobes; spikes elongate, 5-12 cm. long; flowers remote, short-pedicelled, horizontal or spreading; bracts consisting of the scarious sheaths and short subulate blades, about as long as the buds; calyx broadly campanulate, 4-5 $\mathrm{mm}$. long, white, with simple green midveins, reaching the apex of the short rounded lobes; styles separate for one half their length; fruit reflexed; akene black, shiny, smooth, 3-angled, acuminate, 3-3.5 $\mathrm{mm}$. long. Common in stony soil.

Polygonum bistortoides Pursh. Perennial, from a thick oblong tuber, glabrous throughout or sparsely puberulent; stem erect, simple, $30-60 \mathrm{~cm}$. tall; radical leaves oblong, acute or acuminate, $5-20 \mathrm{~cm}$. long, 3-5 cm. broad, on slender usually shorter petioles; cauline $3-4$, sessile, the uppermost much reduced, lanceolate; spikes oblong, 3-6 cm. long, dense; calyx white, deeply 5-cleft; akene chestnut-brown, 3-angled, smooth, shiny. Moist meadows near the mountains. 
Polygonum hartwrightii Gray. Perennial, on muddy banks, more or less strigose-pubescent especially on the sheaths and bracts. Spokane, Dewart. Some botanists consider this only a hairy terrestrial state of $P$. amphibium.

Polygonum amphibium L. Perennial, aquatic, glabrous or nearly so; leaves floating, elliptic or oblong, obtuse or acutish, smooth and shiny above, 5-12 cm. long, long-petioled; spikes dense, 2-3 cm. long. In ponds and lakes.

Polygonum emersum (Michx.) Britt. Perennial, sparsely scabrous throughout; stems erect or decumbent, 1-2 m. long, rooting at the nodes; leaves oblong-lanceolate, acuminate, cuneate or rounded at base, $8-16 \mathrm{~cm}$. long, short-petioled; sheaths cylindric, loose, entire; spikes dense, 3-7 cm. long, short-peduncled; calyx rose-red, 5-parted; akenes lenticular, black, shiny, slightly roughened. Common in wet meadows and on pond and river banks.

Polygonum persicaria L. Annual, erect or ascending, glabrous or puberulent; stems 15-90 cm. long; leaves lanceolate, acute or acuminate at each end, short-petioled, 5-25 cm. long, frequently with a brown-purple spot near the middle, glabrous or sparsely puberulent below and on the midrib and margins above; sheaths tubular, $10-15 \mathrm{~mm}$. long, coarsely fringed; spikes slender, 2-4 cm. long, slender peduncled, erect; calyx pink, 5-lobed; akene lenticular, black and shining. Sparingly introduced.

Polygonum lapathifolium L. Stems branched, 15-80 cri. high, erect or ascending; leaves lanceolate, acuminate, scabrous on the midrib and margins, 10-20 cm. long; peduncles minutely glandular; spikes axillary and terminal, slender, 2-10 cm. long, erect or nodding; flowers white or pink; stamens 6 ; akene ovate, lenticular. Sparingly introduced or perhaps native along Snake River.

Polygonum tomentosum incanum (Schmidt) Gurke. Annual, simple or branched, 10-30 cm. high; leaves lanceolate, acute, 2-6 cm. long, green above, white woolly beneath; peduncles decidedly glandular; spikes shorter, 1-3 cm. long. On river banks, rare.

\section{Family 32. CHENOPODIACEAE. Goosefoot Family.}

Mostly annual or perennial herbs; stems angled, striate or terete; leaves alternate or sometimes opposite, simple, entire, toothed or lobed, mostly petioled, without stipules; flowers perfect, polygamous, monoecious or dioecious, small, greenish, regular or slightly irregular, commonly in panicled spikes, with or without bracts; calyx persistent, 2-5-lobed or parted, or rarely reduced to a single sepal or in some pistillate flowers wanting; petals none; stamens as many as the calyx lobes or fewer and opposite them; disk usually none; ovary mostly free from the calyx, 1-celled; ovule 1; fruit a utricle; endosperm mealy, fleshy or wanting. 
Endosperm little or none; leaves spiny.

116. Salsola, 88.

Endosperm copious; leaves not spiny.

Fruit much exserted beyond the envelope. 117. Coriospermum, 88.

Fruit enclosed by or not longer than the calyx or bractlets.

Flowers unisexual; fruit enclosed by two bractlets.

118. Atriplex, 88.

Flowers perfect; fruit enclosed in the calyx. Sepal 1, bract-like; stamen 1. Sepals 5, united; stamens 5 .

Flowers capitate; calyx fleshy and red in fruit.

Flowers in panicles; calyx not fleshy in fruit.

119. MoNolepis, 89.

120. Blitum, 89.

121. Chenopodium, 89.

\section{SALSOLA.}

Annual bushy-branched herbs; leaves rigid, subulate, pricklepointed; flowers sessile, perfect, 2-bracteolate, solitary in the axils, or sometimes several together; calyx 5-parted; stamens 5; utricle flattened, enclosed by the calyx, the segments of which are appendaged by a broad membranous horizontal wing in fruit; endosperm none.

Salsola kali tenuifolia G. F. W. Mey. Russian Thistle. Much branched from the base, forming hemispherical plants $30-90 \mathrm{~cm}$. or more in diameter; branches striate, often reddish below; leaves linear, bluish-green, sessile, tipped with a sharp point, fleshy at first but becoming dry and stiff, $1-3 \mathrm{~cm}$. long; wings of the calyx persistent, membranous. Introduced about 1898 and now abundant in places.

\section{CORIOSPERMUM. BUGSEED.}

Annual herbs; leaves alternate, narrow, entire, 1-nerved; flowers perfect, bractless, small, green, solitary in the upper axils, forming terminal narrow leafy spikes, with the upper leaves shorter and broader than the lower; calyx of a solitary thin broad sepal, or sepals rarely 2 ; stamens $1-3$, rarely more and one of them longer; utricle ellipsoid, mostly plano-convex; endosperm fleshy.

Coriospermum hyssopifolium L. Stems spreading, much branched, 30-60 $\mathrm{cm}$. high, somewhat pubescent when young; leaves linear or linear-lanceolate, cuspidate, glabrous, 2-3 cm. long, sessile; spikes dense, $2-4 \mathrm{~cm}$. long; bracts ovate-lanceolate, acuminate, scarious-margined, 5-10 $\mathrm{mm}$. long; akenes broadly ovate or orbicular, short-mucronate, narrowly winged, $3 \mathrm{~mm}$. long. Sandy bars of rivers.

\section{ATRIPleX. Saltbush.}

Annual herbs, usually mealy or scurfy; flowers in leafy spikes, monoecious or dioecious; staminate with a 5-lobed calyx and mostly 5 stamens; pistillate of a naked pistil between 2 appressed foliaceous bracts, which are enlarged and sometimes united in fruit. 
Atriplex argentea Nutt. Whole plant silvery from the dense scurfy pubescence; leaves thickish, triangular-ovate, 1-3 cm. long, mostly petioled; staminate flowers in dense terminal spikes or axillary clusters; fruiting bracts rhombic-ovate, united, the margins dilated and sharply toothed, the sides roughened with tooth-like appendages. In alkaline soil, common in the sagebrush region.

\section{MONOLEPIS.}

Low annual branching herbs; leaves small, narrow, alternate, entire, toothed or lobed; flowers perfect or polygamous, in small axillary clusters; calyx of one persistent herbaceous sepal; stamen 1; utricle flat; endosperm mealy.

Monolepis nuttalliana (Roem. \& Schult.) Greene. Stems erect or decumbent at base, branched below, 10-40 cm. tall, glabrous or very sparsely mealy throughout; leaves lanceolate, attenuate at each end, acute or obtuse, commonly with a single large tooth or lobe on each side near the middle, $1-3 \mathrm{~cm}$. long, the upper sessile or nearly so, the lowermost slender-petioled; flowers clustered in the axils of the leaves on the elongate erect simple branches; sepal oblanceolate or spatulate, acutish. In bare soil, especially where it is somewhat saline.

\section{BLITUM. Blite.}

Annual succulent branching herbs, with alternate hastate petioled light green leaves; flowers small, green or reddish, in globose axillary sessile heads, or the upper heads forming a spike; calyx 2-5-lobed becoming pulpy in fruit; stamens 1-5; embryo a complete ring in the mealy endosperm.

Blitum capitatum L. Strawberry Blite. Glabrous throughout; stems erect or spreading, somewhat branched, $10-80 \mathrm{~cm}$. high; leaves triangular, coarsely and unevenly dentate, $2-6 \mathrm{~cm}$. long, on petioles of about the same length; flower clusters globose, dense, in the axils of the reduced upper leaves; calyx fleshy in fruit and bright red, the clusters resembling strawberries; seed black, subglobose. Apparently native but infrequent.

\section{CHENOPODIUM. Goosefoot.}

Annual or perennial, green and glabrous, white-mealy or glandular-pubescent herbs; leaves alternate, petioled, entire, sinuate-dentate or pinnately-lobed; flowers very small, green, perfect, sessile, bractless, clustered in axillary or terminal, often panicled or compound spikes; calyx 2-5-parted or lobed; stamens $1-5$; utricle embraced or enclosed by the calyx, the segments of which are herbaceous or slightly fleshy in fruit; endosperm mealy.

Calyx somewhat fleshy and red in fruit.

C. rubrum.

Calyx dry in fruit.

Pericarp loosely attached to the seed; leaves entire.

Pericarp firmly attached to the seed; leaves dentate.

Herbage glandular-pubescent.

Herbage not glandular.

Leaves mealy beneath.

Leaves glabrous.

C. leptophyllum.

C. botrys.

C. album.

C. hybridum. 
Chenopodium rubrum L. Glabrous; stems stout, angled, branching, 30$90 \mathrm{~cm}$. high; leaves triangular or lanceolate, acute, cuneate at base, sinuatelydentate; the upper ones linear-lanceolate and usually entire; spikes axillary, leafy-bracted, the flowers in dense clusters; calyx-lobes $2-4$, obtuse, somewhat fleshy; stamens 1 or 2 ; seed shining, $1 \mathrm{~mm}$. broad. In saline places, not common.

Chenopodium leptophyllum Nutt. Erect, slender, simple or branched, $30-60 \mathrm{~cm}$. high, more or less mealy throughout; leaves entire, linear, $1-3 \mathrm{~cm}$. long; inflorescence paniculate; flowers in dense clusters, these in spikes; calyx-lobes strongly keeled. A native species of infrequent occurrence.

Chenopodium botrys L. Jerusalem Oak. Stems branched from the base, the branches erect or spreading, 30-50 cm. high, glandular-pubescent throughout; leaves oblong, 2-5 cm. long, pinnately divided into 5-6 irregular toothed lobes; petioles short, or the uppermost leaves sessile; flowers very small, usually abundant, in loose axillary racemes or panicles, these forming strict narrow panicles 10-30 cm. long; sepals dry, ovate, loosely enclosing the fruit. A weed becoming abundant in the warmer valleys.

Chenopodium album L. Lamb's Quarters. Pigweed. Erect, stout, 50$100 \mathrm{~cm}$. tall, usually simple below the inflorescence, more or less white-mealy throughout; leaves rhombic-ovate, sinuate or dentate, obtuse or acute, 2-4 $\mathrm{cm}$. long, greener above; petioles slender, nearly equalling the blade; uppermost leaves lanceolate and entire; panicle commonly $30 \mathrm{~cm}$. long; spikes axillary or terminal, rather dense; fruiting calyx $1 \mathrm{~mm}$. broad, the sepals keeled and arched over the lenticular fruit; seed black, minutely pitted. A common weed in waste or cultivated ground.

Chenopodium album viride (L.) Moq. Herbage green, less mealy; inflorescence looser. Sparingly introduced.

Chenopodium hybridum L. Green and glabrous throughout or the inflorescence a little mealy, erect, $60-120 \mathrm{~cm}$. high; leaves triangular-ovate, acuminate, somewhat cordate at base, thin and rather large, $5-20 \mathrm{~cm}$. long, with a few large teeth on each side; inflorescence a loose panicle; flowers in small clusters in leafless racemes; calyx-lobes shorter than the fruit. In waste places, introduced from Europe.

\section{Family 33. AMARANTHACEAE. Amaranth Family.}

Weedy herbs; leaves thin, simple, mostly entire, alternate or opposite; flowers small, green or white, perfect, monoecious, polygamous or dioecious, bracteolate, usually in terminal spikes or axillary heads; calyx herbaceous or membranaceous, 2-5parted, the segments distinct or united at the base, equal, or the inner ones smaller; petals none; stamens $1-5$, mostly opposite the calyx-segments, hypogynous; ovary 1-celled; ovule 1 (in ours); fruit a utricle, 1-seeded (in ours); endosperm mealy, usually copious.

\section{AMARANTHUS. AMaranth.}

Annual branched erect or diffusely spreading, glabrous or pubescent herbs; leaves alternate, petioled, pinnately veined, 
entire, undulate or crisped; flowers small, green or purplish, mostly 3-bracteolate, in dense terminal spikes or axillary clusters; calyx of $2-5$ distinct sepals; stamens $2-5$; fruit an ovoid or oblong utricle, 2-3-beaked, with the persistent style. Mostly pernicious weeds.

Flowers in dense terminal spikes.

Spikes green, stout, $8-14 \mathrm{~mm}$. thick.

Spikes purple, slender, 4-6 $\mathrm{mm}$. thick.

A. retroflexus.

Flowers in axillary clusters.

Plant erect, much branched; sepals 3.

Plant prostrate; sepals 4 or 5 .

A. paniculatus.

A. graecizans.

A. blitoides.

Amaranthus retroflexus L. Pigweed. Stem stout, 50-200 cm. tall, erect, pubescent, simple or branched; leaves ovate or rhombic-ovate, acute or obtuse, obscurely crenate or entire, minutely roughened, 3-10 cm. long, slenderpetioled; spikes very dense, cylindric, erect, in large panicles; bracts subulate, 4-5 mm. long; sepals 5, oblong, acute, obtuse or emarginate. A weed in waste ground.

Amaranthus paniculatus L. Similar to A. retroflexus, but more slender; leaves oblong-ovate or lanceolate-ovate, often purplish; spikes much longer and more slender; bracts awn-pointed. Sparingly naturalized from Europe.

Amaranthus graecizans L. Tumbleweed. Erect, pale green, much branched, glabrous or nearly so, $15-60 \mathrm{~cm}$. tall; leaves oblong or narrowly obovate, obtuse or emarginate, $2-3 \mathrm{~cm}$. long, short-petioled; flowers in small axillary clusters; bracts subulate, spiny-pointed, much exceeding the sepals; sepals 3 , oblong-lanceolate, membranous; fruit roughened. A common weed in grain fields.

Amaranthus blitoides Wats. Very similar to $A$. graecizans but the branches prostrate, $30-60 \mathrm{~cm}$. long; bracts ovate-oblong, acuminate, little longer than the 3-5 sepals; fruit smooth. Apparently native, common.

\section{Family 34. AIZOACEAE. Carpet WeEd Family.}

Soft herbs, sometimes fleshy or succulent; leaves whorled or opposite; stipules wanting; flowers small, regular, perfect, solitary, cymose or glomerate; calyx 4-5-cleft or parted; petals and stamens sometimes numerous, but petals often wanting; ovary usually free from the calyx, 2-several-celled; ovules numerous in each cell (in ours); fruit a capsule; endosperm scanty or copious.

\section{3. mollugo. Carpet Weed.}

Mostly annual, much branched herbs; leaves whorled, sometimes basal or alternate; stipules scarious, membranaceous, deciduous; flowers small, whitish, cymose or axillary; sepals 5, white inside, scarious-margined, persistent; petals none; stamens hypogynous, 3 and alternate with the 3 cells of the ovary or 5 and alternate with the sepals; ovary and capsule usually 3 -celled. 
Mollugo verticillata L. Carpet Weed. Annual, glabrous throughout, prostrate; stem slender, 10-30 cm. long, branched; leaves spatulate or oblanceolate, acute or obtuse, entire, narrowed at the sessile base, 1-2 cm. long, 3-8 in a whorl; flowers small, solitary in the axils, on pedicels as long or longer; sepals oblong, shorter than the ovoid capsules; seeds shining, brown, curved. Common on the sandy banks of streams.

\section{Family 35. PORTUlacaceae. Purslane Family.}

Annual or perennial usually succulent herbs; leaves entire, alternate or opposite; flowers regular, perfect; sepals 2 or 4-8; petals 4 or 5 , hypogynous, early withering; stamens as many as or more numerous than the petals and adherent to their bases; ovary 1-celled; ovules few to many; endosperm mealy.

Ovary half inferior; sepals partly united. Ovary superior.

Capsule circumscissile; sepals 4-8.

Capsule not circumscissile; sepals 2.

Corolla zygomorphic; styles short, cleft nearly to the base.

124. Portulaca, 92.

125. Lewisia, 92.

Corolla regular; styles elongated, united nearly to the top.

126. Montia, 93.

127. Claytonia, 93.

\section{PORTULACA.}

Low fleshy herbs; leaves alternate or partly opposite; stipules scarious or none, or reduced to hairy tufts; flowers terminal and sessile, expanding in direct sunshine before mid-day, soon closing; sepals 2, coherent at the base in a tube and adnate to the ovary; stamens 7-20; ovules numerous.

Portulaca oleracea L. Purslane. Annual, prostrate, fleshy, forming mats $10-40 \mathrm{~cm}$. in diameter; leaves narrowly obovate, obtuse or truncate, narrowed at base, 1-2 cm. long, glabrous; calyx-lobes ovate, keeled; petals yellow, notched at the apex; stamens 7-12; capsule conical, acute, dehiscing below the middle. Becoming abundant as a weed along stream banks and in cultivated land.

\section{LEWISIA.}

Low acaulescent fleshy perennial herbs, with fleshy roots or a corm; flowers on short scapes, showy; sepals 4-8; petals 3-16; stamens numerous; capsule circumscissile; seeds many, black, shining.

Sepals 4-8; scape jointed and with an involucre of 5-7 bracts. L. rediviva. Sepals 2 ; scape with only 2 bracts.

With fleshy conical root; stem leaves 2 , bract-like. $\quad L$. nevadensis.

With globose corm; stem leaves 2 or 3 , linear. $\quad$ L. triphylla.

Lewisia rediviva Pursh. Rock Rose or Bitter Root. Roots thick, fusiform, often forked; leaves numerous in a basal cluster, linear or club-shaped, thick and fleshy, $2-5 \mathrm{~cm}$. long, shorter than the scape; scapes 5-8 cm. high, jointed 
in the middle, where is borne a whorl of 5-7 scarious bracts; flowers solitary, rose-colored; sepals $6-8$, the inner somewhat petal-like; petals $12-16$, oblong, $2-3 \mathrm{~cm}$. long. In rocky places where the soil is very thin. The Indians gather the thick starchy roots for food.

Lewisia nevadensis (Gray) Robinson. Root thick, conical, 2-4 cm. long; leaves all basal, linear, $2-5 \mathrm{~cm}$. long; scapes simple, $2-8 \mathrm{~cm}$. high, with a pair of scarious bracts and 1-3 small white flowers; sepals entire, $7-9 \mathrm{~mm}$. long; petals 6-8; seeds black, smooth and shining. In rock crevices in the Blue Mountains.

Lewisia triphylla (Wats.) Robinson. Stems $2-8 \mathrm{~cm}$. high, very slender, from a deep-seated small globose corm; cauline leaves linear, usually 3 in a whorl, sessile, $1-5 \mathrm{~cm}$. long; flowers few or many in a loose paniculate cluster; sepals entire; petals $3-10$. In the mountains, not common.

\section{MONTIA.}

Low branching glabrous succulent annual herbs; leaves mostly opposite; flowers small, white, nodding, axillary or racemose; sepals 2 , ovate, herbaceous, persistent; petals 5 , unlike, with two larger and three smaller; stamens 3 , alternate with the smaller petals; style very short; stigmas 3.

Montia fontana L. Stems procumbent or ascending, rooting at the nodes, 3-10 cm. high or when aquatic often longer; leaves spatulate or obovate, 4-14 mm. long; raceme terminal or axillary, few-flowered; petals white, $2 \mathrm{~mm}$. long, a little longer than the calyx. In wet places and running water.

\section{CLAYTONIA.}

Low and glabrous succulent herbs, annual or perennial, from corms or thickened rootstocks; basal leaves petioled, the cauline opposite or alternate; flowers small, white or rose-colored, in loose terminal racemes, lasting more than one day; sepals 2, ovate, herbaceous, persistent; petals 5, equal; stamens 5; style 3-notched or cleft.

Perennials with thick roots or corms.

C. lanceolata.

Perennials or annuals; roots not corm-like.

Stems with more than two opposite leaves, or leaves alternate.

Cauline leaves several pairs, opposite.

C. chamissoi.

Cauline leaves alternate.

Seeds shining, $2 \mathrm{~mm}$. broad.

Seeds dull, less than $1 \mathrm{~mm}$. broad.

C. linearis.

C. dichotoma.

Stems with only two leaves, these opposite.

Cauline leaves united, at least at the base.

Calyx $4 \mathrm{~mm}$. long; seeds $2 \mathrm{~mm}$. broad.

is

Calyx $2 \mathrm{~mm}$. long; seeds $1 \mathrm{~mm}$. broad.

C. perfoliata.

Cauline leaves not united.

Pedicels mostly bractless; perennial by rootstocks.

Pedicels mostly with bracts; roots fibrous.

Perennial, 10-50 cm. high; leaves ovate.

Annual, 5-15 cm. high; leaves narrow.

C. parviflora.

C. asarifolia.

C. sibirica.

C. arenicola. 
Claytonia lanceolata Pursh. Stems simple, 8-15 cm. tall, erect, from a globose tuber $1-4 \mathrm{~cm}$. in diameter; radical leaves few or wanting, lanceolate, acute, long-petioled; cauline a single pair, sessile, lanceolate or ovate-lanceolate, acute, 2-5 cm. long; flowers $3-10$ in a short raceme which scarcely exceeds the cauline leaves; pedicels slender; petals pink, oblong or ovate, emarginate, 8-10 mm. long; seeds black, shiny, $2 \mathrm{~mm}$. broad. Kamiack Butte.

Claytonia chamissoi Ledeb. Perennial, with slender elongate stolons, which finally bear tubers at the apex; flower stems mostly simple, $10-30 \mathrm{~cm}$. tall; leaves 3-7 pairs, broadly spatulate, 2-4 cm. long; raceme few-flowered; pedicels slender; petals pale or white, $6-8 \mathrm{~mm}$. long; stamens 5; capsule equalling the calyx; seeds kidney-shaped, minutely roughened. Moist copses, uncommon.

Claytonia linearis Dougl. Annual, branched below, 5-15 cm. tall; leaves linear, succulent, all alternate, $2-5 \mathrm{~cm}$. long, scarious-margined at base; raceme 4-10-flowered, one-sided, the pedicels curving downward; sepals $4 \mathrm{~mm}$. long; capsule shorter than the sepals; seeds shiny, $2 \mathrm{~mm}$. broad. Frequent and abundant.

Claytonia dichotoma Nutt. Very similar to $C$. linearis but smaller in every way, 2-8 cm. tall; calyx $2 \mathrm{~mm}$. long; petals scarcely exceeding the calyx; seeds $1 \mathrm{~mm}$. broad, dull. Common but inconspicuous.

Claytonia perfoliata Donn. Annual, branched from the base, 10-50 cm. high, erect; basal leaves long-petioled, the blades usually rhomboid-ovate, but varying to spatulate-linear; cauline leaves united, forming an orbicular or somewhat angled disk, 3-5 cm. broad; racemes rather loose, one-sided; calyx $4 \mathrm{~mm}$. long; petals smaller, white; seeds smooth, shiny, lenticular, $2 \mathrm{~mm}$. broad. In moist woods, Blue Mountains; common west of the Cascade Mountains.

Claytonia parviflora Dougl. Annual, branched from the base; stems usually 15-30 cm. high, erect; radical leaves long-petioled, linear, lanceolate or spatulate; cauline pair united into an orbicular somewhat angled disk, 1-4 cm. in diameter; raceme usually loose, interrupted, somewhat one-sided; calyx $2 \mathrm{~mm}$. long; petals pink or white, about twice as long; seeds shiny, usually smooth, $1 \mathrm{~mm}$. broad. In moist copses.

Claytonia parviflora depressa Gray. Small and depressed, more fleshy; whole plant commonly reddish; cauline leaves sometimes nearly separate; radical leaves broadly ovate. Very common.

Claytonia asarifolia Bong. Perennial, with short rootstocks, somewhat tufted; stems $15-30 \mathrm{~cm}$. tall, bearing a single pair of leaves below the inflorescence; leaves rather fleshy, broadly ovate, somewhat cordate, obtuse, $2-3 \mathrm{~cm}$. long, the cauline sessile, the radical slender-petioled; raceme peduncled, 3-12flowered, with few or no bracts; pedicels slender; petals white, pellucid, 10-12 $\mathrm{mm}$. long; capsule longer than the sepals; seeds bright, shiny, 1-1.5 mm. broad. In cold woods along streams in the mountains.

Claytonia sibirica L. Stems simple, erect or ascending, $15-40 \mathrm{~cm}$. high; basal leaves ovate, $2-6 \mathrm{~cm}$. long, contracted into long margined petioles; cauline pair ovate, sessile but not united; raceme bracteate, loose, the flowers on long pedicels; petals white or pink with red veins, about $6 \mathrm{~mm}$. long; seeds granulate. In wet places, especially in woods.

Claytonia arenicola Henderson. Annual; stem erect or ascending, simple, 5-12 cm. tall; leaves all linear-lanceolate or spatulate, acute, $2-6 \mathrm{~cm}$. long; raceme of 2-14 flowers, each from the axil of a small bract; pedicels slender, spreading; petals pink, notched, 6-8 $\mathrm{mm}$. long; capsule shorter than the calyx; seeds shiny, $1 \mathrm{~mm}$. broad. Along Snake River and about Spokane. 
Family 36. CARYOPHYLlaCEAE. Pink FAmily.

Annual or perennial herbs; stems often swollen at the nodes; leaves opposite, entire, with or without stipules; flowers regular and perfect; sepals 4-5, separate or united into a calyx-tube; petals equal in number to the sepals or none; stamens not more than twice as many as the sepals, hypogynous or perigynous; styles 2-5; ovary 1-celled, rarely 3-5-celled; ovules several or many, basal or attached to a central column; fruit a capsule, akene or utricle; endosperm mealy.

Sepals united; petals long-clawed.

Styles always 5; capsule with 5 or 10 teeth.

Styles 2 or 3.

Capsule 4-toothed; styles always 2.

Capsule 3- or 6-toothed; styles 3 (rarely 2, 4, or 5).

Sepals free to the base or nearly so.

Stipules present, scarious.

Styles and capsule-valves 5 .

Styles and capsule-valves 3 .

128. Agrostemma, 95.

129. VACCARIA, 95.

130. Silene, 96.

Stipules wanting.

Petals none.

Plant minute, $2-5 \mathrm{~cm}$. high, purplish. 135. Arenaria, 100.

Plant larger.

Petals present.

Petals 2-cleft or parted.

Capsule cylindric, usually curved. 133. Cerastrum, 98.

Capsule ovate or oblong, not curved. 134. ALSINE, 98.

Petals entire or notched.

Seeds without a strophiole.

Seeds each with a strophiole.

131. Spergula, 97.

132. TISSA, 97.

134. Alsine, 98.

135. Arenaria, 100.

136. Moehringia, 101.

128. AGROSTEMMA.

Annual or biennial pubescent herbs; leaves linear or linearlanceolate, acute or acuminate, sessile; flowers solitary at the ends of long axillary peduncles, large, erect, red; calyx oblong, not inflated, narrowed at the throat, 5 -lobed, 10 -nerved; petals 5, shorter than the calyx-lobes, not appendaged; stamens 10; styles 5 , alternate with the calyx-lobes; capsule 1-celled; seeds numerous, black.

Agrostemma githago L. Corn Cockle. Annual or biennial, erect, branched above, $30-90 \mathrm{~cm}$. tall, the whole plant more or less pubescent with silky somewhat appressed hairs; leaves linear, acute, $5-10 \mathrm{~cm}$. long; flowers few on long peduncles; calyx-teeth unequal, $2-3 \mathrm{~cm}$. long, about equalling the tube; petals ovate, dull red, minutely black-spotted. Sparingly introduced in grain fields.

\section{VACCARIA.}

Annual or perennial herbs; leaves ovate or ovate-lanceolate, sessile or petioled; flowers in corymbs or cymes; calyx 5-toothed, 
ovoid, oblong or cylindric in flower; petals 5 , longer or shorter than the calyx; stamens 10 ; styles 2 ; ovary 1 -celled or incompletely 2-4-celled; capsule dehiscing with 4 teeth.

Vaccaria vaccaria (L.) Britt. Cow Cockle. Annual, glabrous and glaucous, $20-60 \mathrm{~cm}$. tall, usually much branched above; leaves ovate or ovate-lanceolate, acute, somewhat connate at base, 3-6 cm. long; calyx with 5 salient angles; petals rose-pink, without appendages, $2 \mathrm{~cm}$. long. Frequently a troublesome weed in grain fields.

\section{Sillene. Catchfly.}

Annual or perennial herbs; flowers clustered or solitary, mainly pink, red, or white; calyx more or less inflated, tubular, ovoid or campanulate, 5-toothed, 10-many-nerved; petals 5, narrow, clawed, mostly crowned with a scale at the base of the blade; stamens 10 ; styles 3 , rarely 2,4 , or 5 , if 5 opposite the calyxteeth; ovary 1 -celled or incompletely $2-4$-celled; ovules many; capsule 3 or 6 -toothed.

Annuals.

Stout, viscid-pubescent throughout.

Slender, glabrous or puberulent with a portion of each internode sticky.

Perennials.

Flowers solitary in the forks of leafy branches.

Flowers in terminal panicles or occasionally solitary terminal. Ovary not stipitate; calyx usually campanulate.

Ovary stipitate; calyx cylindric, narrowed at base. Petals cleft into 4-8 linear lobes.

Petals cleft into 2 lobes.

Stems very leafy; petal-lobes small, entire.

Stems not very leafy; petal-lobes notched.

S. noctiflora.

S. antirrhina.

S. menziesii.

S. douglasii.

S. oregana.

S. spaldingii.

S. scouleri.

Silene noctiflora L. Stems stout, erect, $30-80 \mathrm{~cm}$. high; lower leaves oblanceolate or spatulate, the upper lanceolate, $5-8 \mathrm{~cm}$. long; flowers white, few and long-peduncled, in a loose cyme; fruiting calyx ovoid, white with green veins, $25 \mathrm{~mm}$. long, the teeth subulate. A weed especially' in grain fields.

Silene antirrhina L. Annual, glabrous or puberulent; stem slender, mostly simple, a portion of each internode sticky-viscid; leaves linear or lanceolate, acute, 2-6 cm. long, sessile; flowers in a forked compound cyme, long-pedicelled; calyx 10-nerved, ovate, cylindrical in fruit, 6-10 mm. long; petals white or pinkish, notched, little exceeding the calyx, Sandy or gravelly soil, infrequent.

Silene menziesii Hook. Perennial, glandular-puberulent; stems weak, erect or decumbent, usually branched, $10-30 \mathrm{~cm}$. high, leafy; leaves ellipticlanceolate, acuminate or acute at each end, $2-6 \mathrm{~cm}$. long; flowers small, solitary in the forks of leafy branches; calyx obconical, 5-6 mm. long, 5-toothed, nerves not prominent; petals white, 2-cleft, $6-8 \mathrm{~mm}$. long, usually without a crown. In woods and copses, common.

Silene douglasii multicaulis (Nutt.) Robinson. Perennial, tufted, minutely pubescent throughout; flowering stems erect, $30-50 \mathrm{~cm}$. tall, simple; leaves linear or linear-lanceolate, acute or acuminate, 5-8 cm. long; cymes fewflowered, long-peduncled; calyx 10-15 mm. long, oblong or obovoid, somewhat 
inflated, pale green, the nerves inconspicuous, the short teeth scarious-margined; petals white or pink, 2-lobed; scales oblong, obtuse; claw broad, with a short auricle on each side at the apex. Grassy hillsides, common.

Silene oregana Wats. Perennial; whole plant sticky-pubescent; stems erect, 15-30 cm. high; basal leaves oblanceolate, long-petioled; cauline lanceolate, sessile; inflorescence narrow, rather dense; pedicels slender; calyx cylindric or club-shaped; petals white, $20 \mathrm{~mm}$. long, the claws narrow and auricled, the blades cleft into 4-8 narrow segments; capsule narrowed at base into a long stipe. Common in the Blue Mountains; also near Spokane.

Silene spaldingii Wats. Perennial, viscid-tomentose; stems erect, swollen at the nodes, $30-40 \mathrm{~cm}$. high, very leafy; leaves lanceolate or oblong-lanceolate, 3-5 cm. long; flowers in a narrow panicle; calyx cylindric or obconical, 14-16 mm. long, green, net-veined; petals 2-cleft, the lobes short and entire; appendages 4, small; claw with broad auricles. A rare species. Cheney, Mrs. Tucker; Lapwai, Idaho, Spalding.

Silene scouleri Hook. Perennial, puberulent throughout, glandular-viscid above; stems erect, simple, $40-60 \mathrm{~cm}$. tall, solitary or tufted; radical leaves lanceolate or oblanceolate, 4-6 cm. long, on slender petioles of equal length; cauline several pairs, sessile at the swollen nodes, lanceolate, 5-8 cm. long; inflorescence narrow, elongated; flowers short-pedicelled, one or several in the axils; calyx cylindrical or club-shaped, $10-15 \mathrm{~mm}$. long, with 10 dark nerves and short scarious-margined teeth; petals 2-cleft, the lobes notched; auricles of the claw narrow, cleft into narrow lobes. In dry coniferous woods.

\section{SPERGULA.}

Annual branched herbs; leaves subulate, fascicled, with scarious stipules; flowers in a cymose panicle; sepals 5; petals 5, white; stamens 10 , rarely 5 ; ovary 1 -celled; capsule-valves 5 , opposite the sepals.

Spergula arvensis L. Spurry. Minutely and sparsely glandular throughout; stems several, mostly simple below the inflorescence, $30-50 \mathrm{~cm}$. long. decumbent or ascending; leaves narrowly linear, $2-3 \mathrm{~cm}$. long, in fascicles of $6-15$; flowers in a loose cyme, the pedicels becoming deflexed; petals white, 4-5 mm. long, equalling or exceeding the sepals; capsule ovoid; seeds black, acutely margined, minutely roughened. Introduced into grain fields.

132. TISSA.

Low annual biennial or perennial herbs; leaves fleshy, linear or setaceous, with scarious stipules; flowers in terminal racemose cymes; sepals 5 ; petals 5 (in ours), purplish or white; stamens $2-10$, commonly 10 ; styles 3 , very rarely 5 ; ovary 1 -celled; capsule-valves as many as the styles, when 5 , alternate with the sepals.

Stipules silvery, conspicuous, lanceolate. Stipules small, triangular.

T. rubra.

$T$. diandra.

Tissa rubra (L.) Britt. Annual, sometimes biennial or perennial, prostrate or decumbent; stems slender, $10-30 \mathrm{~cm}$. long, smooth below, glandular above; leaves linear, cuspidate, 8-12 mm. long; stipules silvery, attenuate-lanceolate, 4-5 mm. long; flowers in a small cyme; pedicels filiform, exceeding the leaf-like 
bracts; petals pink, hardly longer than the sepals. Roadsides, becoming common.

Tissa diandra bracteata (Robinson) Piper. Much like T. rubra but more glandular; leaves, excepting the reduced upper ones, not cuspidate; stipules small, short, triangular; petals pinkish, shorter than the sepals. Banks of Snake River at Almota, rare.

\section{Cerastium. Mouse-ear Chickweed.}

Annual or perennial, generally pubescent or hirsute herbs; leaves flat, rarely subulate; stipules none; flowers in terminal bracted dichotomous cymes; sepals 5 ; petals 5 , retuse or bifid, very rarely subentire, white; stamens 10 , sometimes fewer; styles 5 , sometimes 4 or 3 , opposite the sepals; capsule cylindric, 1 -celled, often curved, dehiscent by 10 , rarely 8 , apical teeth.

Petals not longer than the sepals.

Pedicels longer than the calyx.

Pedicels not longer than the calyx.

C. vulgatum.

Petals decidedly longer than the sepals.

Annual, viscid-pubescent; pods nodding.

Perennial, pubescent; pods erect.

C. viscosum.

C. nutans.

C. arvense.

Cerastium vulgatum L. Perennial, viscid-pubescent throughout, tufted, $10-30 \mathrm{~cm}$. high; leaves oblong, obtuse, or the upper ones acurish, 10-25 mm. long; inflorescence loose, the pedicels longer than the calyx; sepals obtuse, 4-5 mm. long, as long as the 2-cleft petals; capsule somewhat curved, longer than the calyx. A weed in lawns and pastures; introduced from Europe.

Cerastium viscosum L. Annual, viscid-pubescent, erect or nearly so, 10-20 cm. high; leaves oval to ovate or obovate, very obtuse, the lowest narrowed into short-margined petioles; inflorescence rather close in flower, looser in fruit; sepals acute, 3-4 mm. long; petals shorter than the sepals. A weed introduced from Europe.

Cerastium nutans Raf. Stems erect, $15-40 \mathrm{~cm}$. high, usually branched at the base; leaves oblong-lanceolate, or the lowest spatulate, acute, 1-3 cm. long; cyme open, rather many-flowered; pedicels elongated, nodding, especially in fruit; calyx 3-4 mm. long, exceeded by the petals; pods curved, three times as long as the calyx. Near Lewiston, Idaho, and about Lake Coeur d'Alene.

Cerastium arvense L. Perennial, tufted, pubescent throughout or sometimes nearly glabrous; stems weak, erect, $15-40 \mathrm{~cm}$. tall, nearly naked above; leaves linear or lanceolate, $2-3 \mathrm{~cm}$. long; flowers cymose, on slender pedicels; sepals oblong, acute, 5-6 mm. long; petals deeply notched, twice as long as the sepals. In low places, infrequent.

\section{ALSINE. ChICKWEED.}

Annual tufted generally diffuse herbs; leaves flat, rarely subulate; stipules none; flowers solitary or cymose, terminal or becoming lateral; sepals 5 or 4 ; petals 5 or 4 , rarely none, always more or less deeply bifid, often divided almost to the base, white; stamens $3-10$; styles 3 or 4 , rarely 5 ; capsules globose, ovoid or oblong, dehiscing by as many valves as there are styles. 
Lowest leaves ovate, petiolate.

Stems pubescent with a line of hairs; leaves ovate.

Stems glabrous, except at base; leaves shiny, the upper linear-lanceolate.

A. media. es all sessile.

Bracts of the inflorescence leafy.

Leaves lanceolate.

Leaves ovate.

Capsule longer than the calyx.

Capsule not longer than the calyx.

A. nitens.

A. borealis.

A. crispa.

A. viridula.

Bracts of the inflorescence small, scarious.

Pedicels erect; cyme few-flowered.

Pedicels spreading; cyme loosely many-flowered.

A. longipes.

Leaves linear, acute at each end; seeds smooth.

A. longifolia .

Leaves lanceolate, broadest near the base; seeds rough. A. graminea .

Alsine media L. Annual, weak and spreading; stems weak, 10-30 cm. long, glabrous except a line of hairs; lower leaves ovate, petioled, the upper narrower and sessile, all acute, $10-40 \mathrm{~mm}$. long; flowers solitary in the axils or somewhat cymose, on slender pedicels; calyx glandular-pubescent, nearly as long as the capsule; petals deeply 2-parted, shorter than the sepals; stamens 3,5 , or 10 . Introduced and becoming common.

Alsine nitens (Nutt.) Greene. Annual, somewhat tufted; stems erect, slender, shining, 8-15 cm. tall, branched above, pubescent only at base; lowest pair of leaves ovate, acute, petioled, $4 \mathrm{~mm}$. long, the others linearlanceolate and sessile, 5-10 mm. long; cymes loose, few-flowered, the bracts scarious; pedicels thread-like, 1-5 cm. long; sepals 3-nerved, very acute, scarious-margined, $4 \mathrm{~mm}$. long; petals deeply 2-cleft, half as long as the sepals or wanting. Stony hillsides, abundant.

Alsine borealis (Bigel.) Britt. Perennial, glabrous throughout, the weak stems ascending, branched, $15-60 \mathrm{~cm}$. long; leaves broadly lanceolate, the midnerve prominent, $15-35 \mathrm{~mm}$. long; pedicels slender, sometimes deflexed, 15-30 mm. long; sepals ovate-lanceolate, acute, scarious-margined; petals wanting or if present shorter than the sepals; styles mostly 4; capsule ovoid, about twice as long as the sepals; seeds smooth. In wet places in the mountains.

Alsine crispa (Cham. \& Schlecht.) Holzinger. Perennial, glabrous; stems weak, decumbent or prostrate, $10-30 \mathrm{~cm}$. long, simple or with but few branches; leaves thin, ovate, acuminate, 8-12 $\mathrm{mm}$. long, entire or crisped on the margin, very short-petioled; pedicels slender, $6-20 \mathrm{~mm}$. long; sepals lanceolate, 3nerved, very acute, with a narrow scarious margin; petals deeply cleft but usually wanting; capsule acutish, exceeding the sepals. In rich woods near Farmington and in the Craig Mountains.

Alsine viridula Piper. Perennial, forming dense, prostrate, circular mats, 10-20 cm. broad; herbage entirely glabrous except a few ciliate hairs at the bases of the leaves; stems $5-10 \mathrm{~cm}$. long, green, scarcely shining, branched; leaves ovate, plane, short-acuminate, dull, rather thin but the veins obscure, 5-15 mm. long, nearly as long as the internodes, each abruptly narrowed into a short petiole which bears a few long hairs; flowers solitary in the axils, the pedicels mostly shorter than the leaves; sepals oblong-ovate, acutish, green with a narrow white scarious margin, thin, 3-nerved, 2-2.5 mm. long; petals none; pods green, ovoid, not longer than the calyx; seeds dark brown, $0.5 \mathrm{~mm}$. long.

Springy places in canyons, ridges south from Wiessner's Peak, Idaho, altitude $1700 \mathrm{~m}$., Leiberg; along rivulets in woods, altitude $1400 \mathrm{~m} .$, Blue Mountains, Columbia County, Washington, Piper. 
Alsine longipes (Goldie) Coville. Somewhat tufted, with creeping rootstocks, smooth and shining throughout; stems 4-angled, erect, $15-40 \mathrm{~cm}$. high, branched above; leaves linear-lanceolate, tapering from the base to the acute apex, prominently 1-nerved, $2-3 \mathrm{~cm}$. long; flowers solitary or in very loose cymes; bracts reduced and scarious or when the flowers are few or solitary foliaceous; pedicels slender, 2-10 cm. long; petals 2 -cleft, exceeding the rather obtuse sepals; capsule longer than the calyx; seed's smooth, shining. Moist places, not rare.

Alsine longifolia (Muhl.) Britt. Erect or nearly so, the stem sharply 4-angled, glabrous, $20-40 \mathrm{~cm}$. high; leaves linear or oblong-linear, acute at each end, of ten ciliate near the base, $2-3 \mathrm{~cm}$. long; cyme open, long-peduncled, becoming lateral, many-flowered; pedicels spreading or at length deflexed; petals exceeding the sepals; capsule pale, longer than the calyx. In wet meadows, rare in our limits.

Alsine graminea (L.) Britt. Whole plant, glabrous, shining; stems 4angled, ascending, branched above, $35-60 \mathrm{~cm}$. high; leaves sessile, lanceolate, acute, $2-3 \mathrm{~cm}$. long; flowers in a loose much-forked cyme; bracts scarious, somewhat ciliate; pedicels slender, spreading or reflexed; sepals lanceolate, acute, 3-nerved, nearly equalling the capsule; petals 2-cleft, as long as the sepals; seeds minutely roughened. Very sparingly introduced.

\section{ARENARIA. SANDWORT.}

Annual or perennial mainly tufted herbs; leaves sessile, often subulate and more or less rigid; stipules none; flowers white, cymosely panicled or capitate, rarely solitary and axillary; sepals 5; petals 5, very rarely minute or wanting, entire or emarginate, white or nearly so; stamens 10 , or often fewer; styles generally 3 , rarely $2-5$; capsule globose or oblong, dehiscent at the apex by as many or twice as many valves as there are styles.

Valves of the capsule entire; petals wanting.

A. pusilla.

Valves of the capsule 2-toothed; petals present.

Sepals obtuse; flowers in loose cymes.

Sepals not obtuse.

Flowers in dense clusters.

Flowers in loose clusters.

A. capillaris.

A. congesta.

A. glabrescens.

Arenaria pusilla Wats. Wholly glabrous; stems very slender, usually branched, $2-5 \mathrm{~cm}$. high; leaves oblong or ovate, $2-3 \mathrm{~mm}$. long, distant; sepals lanceolate, acuminate, $2-2.5 \mathrm{~mm}$. long; petals wanting. Stony soil, common but very inconspicuous.

Arenaria capillaris Poir. Glabrous below, glandular-pubescent above; stems tufted, erect, 10-30 cm. tall; leaves narrowly linear, rather rigid, sharply cuspidate, chiefly grouped in fascicles at the bases of the erect stems, somewhat pungent, little spreading; cauline few, reduced; flowers in loose cymes; petals obovate, considerably exceeding the short broadly ovate obtuse sepals. Mt. Carlton, Spokane County.

Arenaria congesta Nutt. Usually glabrous throughout; stems tufted, erect, 15-40 cm. tall; joints prominent; leaves narrowly linear, rather rigid, sharply cuspidate, $2-5 \mathrm{~cm}$. long, the cauline pairs rather distant; flowers congested into $1-3$ heads on each stalk; bracts scarious; sepals ovate-lanceolate, acuminate, 3-nerved, 3-4 mm. long, shorter than the petals, scariousmargined. In rocky places especially in the mountains. 
Arenaria glabrescens (Wats.) Piper. Very similar to A. congesla of which it may be a subspecies; inflorescence loosely cymose; herbage often glandularpuberulent. On high rocky ridges in the Blue Mountains.

\section{MOEHRINGIA.}

Low perennial herbs, with lanceolate, elliptic, or oblong sessile or short-petioled soft leaves; flowers white, solitary in the axils of the leaves or in terminal cymes; sepals and petals 4 or 5 ; stamens 8 or 10 ; capsule oblong, few-seeded; seeds each with a membranous broad strophiole.

Petals longer than the obtusish sepals.

Petals shorter than the acuminate sepals.

M. lateriflora.

M. macrophylla.

Moehringia lateriflora (L.) Fenzl. Mostly puberulent throughout; stems slender, terete, erect or decumbent, simple or few-branched, 10-30 cm. high; leaves elliptic or oblong, sessile, obtuse, 1-2 cm. long; cymes few-flowered; sepals obtuse or acutish, $2 \mathrm{~mm}$. long, one half the length of the obovate petals Hillsides, not rare.

Moehringia macrophylla (Hook.) Torr. Minutely puberulent; stems erect or decumbent, angled, 5-10 cm. tall, mostly simple; leaves lanceolate, acute at each end, 2-6 cm. long; cymes few-flowered; sepals ovate-lanceolate, acuminate, $3 \mathrm{~mm}$. long, exceeding the petals. Common in dry pine woods.

\section{Family 37. NYMPHAEACEAE. WAterlily FAmily.}

Aquatic perennial herbs with horizontal rootstocks; leaves peltate or cordate, floating, submersed or rarely immersed; flowers perfect, solitary, axillary, on long peduncles; sepals $3,4,6$ or more; petals 5-many, often grading into the sepals or stamens; stamens 5-many; carpels 3-many, indehiscent, free or immersed in a fleshy receptacle or more or less coalescent into a fleshy fruit; endosperm present or none.

Leaves cordate; flowers large, yellow. Leaves peltate; flowers small, purple.

137. NymphaEa, 101. 138. BRASENia, 102.

\section{NYMPHAEA. WATERLILY.}

Acaulescent perennials from stout rootstocks, commonly slightly milky; leaves with united stipules which are sometimes adnate to the base of the petioles; calyx more showy than the corolla; sepals 5-12, concave, roundish, mostly yellow, and petallike; petals 10-20, hypogynous, small and thick, the innermost or sometimes all of them stamen-like; stamens numerous, hypogynous; stigmas radiate on the summit of the 10-25-celled ovary; ovules and seeds numerous. 
Nymphaea polysepala (Engelm.) Greene. Wokas. Leaves orbicular or broadly oval, deeply cordate, $20-30 \mathrm{~cm}$. long, 12-20 cm. broad; calyx subglobose, about $8 \mathrm{~cm}$. broad; sepals $8-12$, yellow, of ten red-tinged; petals $12-18$, ovate-cuneate, truncate, $1-1.5 \mathrm{~cm}$. long; stamens very numerous; fruit subglobose, 4-5 cm. long. In ponds and lakes.

\section{BRASENIA. WATERSHIELD.}

Aquatic herbs with creeping rootstocks; leaves alternate, longpetioled, centrally peltate, oval, floating; flowers axillary, small; sepals 3 or 4 ; petals 3 or 4 , linear, sessile; stamens $12-18$; pistils 4-18, forming club-shaped indehiscent pods, each with 1-2 seeds.

Brasenia schreberi Gmel. Watershield. Leaves alternate, long-petioled, oval, entire or obscurely crenate, centrally peltate, $2-10 \mathrm{~cm}$. long; flowers dull purple; submerged parts of the plant coated with a tough transparent jelly. In lakes, Spokane County.

\section{Family 38. RANUNCULACEAE. Buttercup FAMily.}

Annual or perennial herbs or sometimes woody plants with acrid sap; leaves usually alternate (opposite in Clematis), simple or compound; stipules none but the base of the petiole often clasping or sheathing; flowers regular or irregular; sepals 3-15, generally soon withering, often petal-like; petals $3-15$, or wanting; stamens numerous, hypogynous; carpels numerous or few or rarely solitary, separate, 1-celled, 1-many-ovuled; endosperm present.

Carpels numerous, 1-ovuled; fruit an akene.

Leaves opposite.

Leaves alternate or basal.

Flowers subtended by involucres remote from the calyx.

Flowers not subtended by involucres.

Petals none.

Leaves ternately decompound.

Leaves simple, palmately lobed.

139. Clematis, 103.

Petals present.

Sepals spurred; akenes in a long slender spike.

140. ANemone, 103.

Sepals not spurred; akenes in a head. Petals white; akenes transversely wrinkled.

Petals yellow; akenes smooth.

Carpels few, 2-many-ovuled; fruit a follicle or

141. Thalictrum, 104.

142. TrautVetteria, 104.

143. Myosurus, 104.

144. BATRACHIUM, 105.

145. Ranunculus, 105. berry.

Flowers irregular.

Upper sepal spurred; petals 4.

Upper sepal hood-like; petals 2.

Flowers regular.

Sepals spurred.

Sepals not spurred.

146. Delphinium, 108.

147. A CONItUM, 109.

148. AQuilegia, 110. 
Petals large; flowers solitary.

149. Paeonia, 110.

Petals small; flowers solitary or in racemes or umbels.

Carpels becoming berries; flowers in racemes.

Carpels becoming follicles; flowers solitary or in umbels.

150. Actaea, 110.

151. Coptis, 111.

\section{CLEMATIS.}

Perennial herbs, low and erect, or more or less woody vines, climbing by the petioles; leaves opposite; sepals 4 , rarely 3 , or more than 4, petal-like; petals none or minute; stamens numerous; pistils numerous, 1 -ovuled; styles feathery or naked in fruit.

Erect herbs; leaves compound, with narrow divisions.

C. hirsutissima. Half-woody climbers; leaf segments broader.

Flowers white, small.

Flowers large, blue.

C. ligusticifolia.

C. columbiana.

Clematis hirsutissima Pursh. Sugar Bowls. Stems tufted, 30-50 cm. tall, from a tough woody caudex; leaves 3 or 4 pairs, twice-pinnately compound, the ultimate divisions linear or lanceolate, pubescent when young, becoming glabrous; flower solitary, at first nodding, then erect, usually long-peduncled; sepals dark-blue, thick, 3-4 cm. long, closely contiguous, pubescent outside; akenes pubescent, their long tails very plumose. Common in low places.

Clematis ligusticifolia Nutt. Half-woody climber, the stem 2-10 m. long; leaves pinnately compound, of 5-7 leaflets, or the lower pair ternate; leaflets ovate or lanceolate, sometimes 3-lobed, coarsely incised-dentate or subentire, 3-6 cm. long, sparsely pubescent, becoming glabrous; flowers dioecious, in large panicles, the staminate more showy; sepals white, oblong, densely hairy, $2 \mathrm{~cm}$. long; akenes pubescent, the long tails plumose. Common in the warmer valleys.

Clematis columbiana (Nutt.) T. \& G. Half-woody climber with slender stems; leaves ternate, petioled; leaflets ovate, acuminate, sparsely pubescent, entire or nearly so; flowers solitary on naked peduncles; sepals ascending, blue, oblong-lanceolate, acute or acuminate, ciliate, 4-5 cm. long; outer stamens with the filaments more or less dilated and petal-like, the anthers wanting; akenes with long plumose tails. Moist woods in the mountains, infrequent.

\section{ANEMONE. WINDFLOWER.}

Erect perennial herbs; leaves compound or divided, all radical, except 2 or 3 cauline which form an involucre usually remote from the flower; peduncles 1-flowered, solitary or in umbels; sepals 4-20, petal-like; petals none; stamens numerous; pistils numerous; akenes pointed or tailed, flattened not ribbed.

Anemone piperi Britt. Stems erect, 1-flowered, 10-20 cm. tall, smooth or pubescent; radical leaf and three of the involucre similar, ternate or often 5 -foliolate, petiolate, the leaflets or divisions oblong-cuneate or ovate, acute or acuminate, incisely toothed or lobed, $3-5 \mathrm{~cm}$. long; sepals 4-7, oval, white; akenes puberulent, the style short. Moist woods, in the mountains. In the Blue Mountains there is a form with dark purple flowers which is perhaps distinct. 
141. THALICTRUM. MEADOW Rue.

Erect perennial herbs; leaves 2-3-ternately compound, radical and cauline, the latter alternate; flowers perfect, polygamous or dioecious, generally small, greenish-white, in corymbs, panicles or racemes; sepals 4 or 5 , petal-like or greenişh, dull-colored; petals none; stamens numerous; pistils 4-15, commonly few, 1-ovuled; akenes capitate, grooved or ribbed, inflated.

Leaflets thin; inflorescence loose.

Leaflets rather thick, veiny; inflorescence narrow, close.

T. occidentale. T. venulosum.

Thalictrum occidentale Gray. Dioecious; stems 50-100 cm. tall; leaves ternately decompound; leaflets oblong, obovate or orbicular, mostly petioled, incisely dentate at the apex, glabrous, 1-2 cm. long; panicle loose; sepals elliptic-cuneate, greenish; filaments very slender; anthers linear, slenderpointed; akenes $6-12$, in loose clusters, stipitate, lanceolate, long-acuminate, 3-nerved on each side, the mid-nerve somewhat salient, 6-8 $\mathrm{mm}$. long. Moist woods and copses.

Thalictrum venulosum Trel. Similar to $T$. occidentale; leaves glaucous, the leaflets thicker, veiny beneath, short-petioled and somewhat crowded; inflorescence narrow, rather compact; akenes sessile, thick walled, the ribs prominent. In low meadows, much rarer than $T$. occidentale.

\section{TRAUTVETTERIA.}

Tall erect perennial herbs; leaves palmately-lobed, the radical large and long-petioled; the cauline few, short-petioled or sessile; flowers white, in corymbs; sepals $3-5$, broad, concave; petals none; stamens numerous; pistils numerous, 1-ovuled; akenes capitate, sharply-angled, inflated, tipped with minute styles.

Trautvetteria grandis Nutt. Stems $30-50 \mathrm{~cm}$. tall, glabrous or nearly so; leaves broader than long, 8-30 cm. across, 5-9-cleft, the lobes oblong or obovate, acute, incisely lobed and toothed; akenes smooth, ovate, three-angled, tipped with a slender recurved beak. In moist places in the mountains.

\section{MYOSURUS. MOUSE TAIL.}

Very small annual herbs; leaves entire, linear or at first spatulate, in a basal tuft; scapes simple, 1-flowered; sepals 5, spurred at the base; petals 5, greenish-yellow, with long nectariferous claws, or none; stamens 5-20; pistils numerous, borne on a central axis, the receptacle, which becomes greatly elongated in fruit; ovule 1.

Myosurus apetalus Gay. Scapes 3-8 cm. high; leaves linear-spatulate, half the length of the scapes; fruiting spikes $2-6 \mathrm{~mm}$. long; akenes oblong, the back with a prominent keel which is prolonged into a stout beak as long as the body. The plant usually becomes reddish when mature and often covers considerable areas.

Myosurus apetalus lepturus Gray. Taller, 10-20 cm. tall; leaves linear, one fourth as long as the scapes; fruiting spikes slender, $1-5 \mathrm{~cm}$. long; akenes scarcely keeled on the back, the beak much shorter than the body. In dried-up ponds, infrequent. 


\section{BATRACHIUM. Water Buttercup.}

Perennial aquatic herbs with alternate dissected or palmately lobed leaves, the ultimate segments of the submerged leaves filiform; flowers solitary, rather small, white, borne on peduncles opposite the leaves; sepals and petals usually 5; petals oblong or oval, sometimes yellowish at base; stamens several or numerous; akenes compressed, not margined, nearly beakless, transversely wrinkled.

Batrachium aquatile (L.) Wimm. Water Crowfoot. Stems 5-40 cm. long, slender, growing in water; immersed leaves flaccid, all finely divided into filiform segments, $8-20 \mathrm{~mm}$. long; floating leaves $1-5$, reniform or orbicular, 3-5-lobed or parted; petals white, yellow at base, each bearing a naked nectariferous pit; akenes thick, transversely wrinkled, the style short; receptacle hairy. Common in ponds.

Batrachium aquatile caespitosum (DC.) Piper. Terrestrial on muddy banks, rooting at the nodes; leaves somewhat fleshy with broad divisions. Not uncommon, probably only a terrestrial state of $B$. aquatile.

Batrachium aquatile pantothrix (Brot.) Piper. All the leaves immersed and divided into capillary segments. Less common than $B$. aquatile and sometimes growing with it.

\section{RANUNCULUS. Buttercup.}

Annual or perennial herbs; cauline leaves alternate; flowers solitary or corymbed; sepals usually 5 , deciduous; petals as many or more, conspicuous or minute, with a nectariferous pit and a scale at the base of the blade; stamens numerous, occasionally few; pistils numerous, 1-ovuled; akenes capitate or spicate, generally flattened, each tipped with a minute or an elongated style.

Plants aquatic or subaquatic; leaves finely dissected when submersed, less so when aerial.

Akenes corky-margined; flowers $15-25 \mathrm{~mm}$. broad.

Akenes marginless; flowers $7-15 \mathrm{~mm}$. broad.

Plants terrestrial, but often growing in very wet places; leaves never finely dissected.

Akenes thin-walled, the faces nerved; leaves crenate; plant spreading by runners.

Akenes not thin-walled nor nerved.

Leaves entire or nearly so.

Stems creeping, rooting from the nodes.

Stems erect, not rooting from the nodes.

Plants $30-60 \mathrm{~cm}$. high; leaves lanceolate or oblong.

Plants $10-25 \mathrm{~cm}$. high; leaves cordate or subcordate.

Leaves or some of them lobed or divided.

Faces of the akenes scabrous; annuals.

Faces of the akenes smooth or merely pilose;

$R$. delphinifolius.

$R$. purshii.

R. cymbalaria.

R. flammula.

R. alismaefolius.

$R$. populago.

R. hebecarpus. mostly perennials. 
Herbage glabrous or nearly so; low species.

Basal leaves 2-4-toothed or lobed, rarely entire; cauline 3 -cleft or parted.

R. glaberrimus

Basal and cauline leaves all divided.

Annual; leaves 3-5-lobed or parted, the lobes crenately incised or cleft; akenes apiculate.

Perennial; leaves roundish, 3-5. cleft into cuneate divisions.

Herbage pubescent or hirsute; mostly tall

$R$. sceleratus.

R. eschscholtzii and coarse species.

Beaks of akenes hooked at the tip. Akenes hispid on the faces. Akenes smooth.

Beaks of akenes not hooked at the tip. Akene-beak long.

Akene-beak short.

Head of akenes oblong; petals not longer than sepals.

Head of akenes globose; petals longer than sepals.

$R$. bongardi.

$R$. bongardi douglasii.

R. platyphyllus.

R. pennsylvanicus.

R. macounii.

Ranunculus delphinifolius Torr. Aquatic or in drying ponds subaquatic or terrestrial; immersed leaves ternately dissected into very narrow lobes; emersed leaves roundish, 5-7-parted into cuneate lobes; peduncles stout; petals 5-8, bright yellow, 8-12 mm. long; akenes ovate, turgid, margined towards the base with a thick corky border, and tipped with a straight beak. Terrestrial forms have more or less pubescent leaves with the leaves parted into cuneate lobes, and smaller flowers. In ponds and slow streams, infrequent.

Ranunculus purshii Richards. Aquatic and glabrous or more commonly terrestrial on muddy banks, and then pubescent; leaves orbicular, palmately 3 -cleft, the segments 2-5-lobed; petals yellow, 4-5 mm. long, scarcely longer than the sepals; akenes without distinct border, tipped with a short straight beak. Spokane County.

Ranunculus cymbalaria Pursh. Perennial, glabrous; leaves clustered at the base and at the joints of the long slender stolons, ovate or ovate-cordate, coarsely crenate, thick; scapes 1-7-flowered, 3-15 cm. high; petals 5-8, pale yellow, 2-7 mm. long, exceeding the sepals; heads of akenes oblong, 6-12 $\mathrm{mm}$. long. Moist soil especially where saline.

Ranunculus flammula unalaschensis (Bess.) Ledeb. Stems slender, creeping, rooting at the joints, $15-30 \mathrm{~cm}$. long; leaves narrowly-lanceolate, short-petioled, acute at each end, $2-5 \mathrm{~cm}$. long, shorter than the internodes; flowers small, yellow, mostly solitary on the ascending tips of the stems; akene small, smooth, short-beaked. Gravelly borders of small streams, infrequent.

Ranunculus alismaefolius Geyer. Glabrous throughout, rather stout, 40-60 cm. tall, branched above; radical leaves long-petioled, lanceolate or ovate, obtuse, usually cuneate at the base, entire or obscurely denticulate, 5-10 cm. long; cauline leaves narrower, mostly sessile; peduncles elongated; sepals small; petals yellow, cuneate-obovate, strongly-nerved, $8 \mathrm{~mm}$. long; akenes turgid, smooth, short-beaked. Borders of ponds, common.

Ranunculus populago Greene. Flaccid and glabrous, 15-25 cm. high; stems solitary or sometimes two or three from a fascicle of fibrous roots, erect, leafy; basal leaves thin-membranaceous, round-reniform to cordate-ovate, 
obtuse, entire or obscurely crenate, long-petioled; the cauline smaller, ovate or ovate-lanceolate, sessile; peduncles many, slender, in the axils of and longer than the cauline leaves; flowers yellow, 8-15 mm. broad; petals 5-6, obovateoblong; heads of numerous thick short-pointed small nearly globose akenes. Blue Mountains, rare.

Ranunculus hebecarpus H. \& A. Annual; whole plant hairy; stems slender, mostly erect, $15-30 \mathrm{~cm}$. tall; leaves $2-3 \mathrm{~cm}$. broad, 3-parted, the lobes incisely 3-lobed; petioles of the leaves much longer than the blades; petals small, 2 $\mathrm{mm}$. long, about equalling the sepals; akenes flattened, with short hooked beaks, the sides roughened and covered with hooked hairs. In copses in dry soil in early spring.

Ranunculus glaberrimus Hook. Nearly glabrous throughout, the stems erect or ascending, $5-15 \mathrm{~cm}$. high; roots fascicled, elongate, fleshy; radical leaves ovate, entire or crenately 3 -lobed at apex, 1-3 cm. long, on petioles as long or longer; cauline cuneate-obovate, deeply 3-lobed, usually sessile; petals 5-15, broadly obovate, 5-10 mm. long, bright yellow; akenes subglobose, smooth, short-beaked, aggregated in a globose head about $1 \mathrm{~cm}$. in diameter. Common in moist places; blooming in earliest spring.

Ranunculus sceleratus L. Annual, glabrous; stems erect, hollow, 15-40 $\mathrm{cm}$. high; leaves pale green, the basal ones reniform orbicular, deeply 3-lobed, the cauline 3-5-lobed or parted and the divisions cleft or lobed; petals pale yellow, scarcely longer than the calyx; akenes short-beaked, smooth, numerous in a cylindric head. Rare in moist places but undoubtedly native.

Ranunculus eschscholtzii Schlecht. Perennial, glabrous or nearly so, 10-20 cm. high; leaves ciliate, the basal orbicular, deeply 3-5-cleft or parted, the cuneate divisions again lobed or cleft; cauline mostly 3-parted, the lobes usually entire; flowers few; petals pale yellow, 6-10 mm. long, exceeding the sepals; head of akenes oblong; akenes swollen, marginless, glabrous, tipped with a straight beak. In moist copses at high altitudes in the Blue Mountains.

Ranunculus bongardi Greene. Erect, 40-60 cm. tall, glabrous or somewhat pubescent; leaves deeply 3-5-cleft, the lower cuneate-obovate, incisely 2-5toothed; petioles longer than the blades; flowers few, in open cymes, longpedicelled; petals 5 , very small, pale yellow; akenes much flattened, hispid on the faces, each with a slender circinate beak, aggregated into globose heads. Common in shady copses.

Ranunculus bongardi douglasii (Howell) Davis. Similar to $R$. bongardi but less pubescent or sometimes glabrous; akenes smooth, the beak shorter. In moist places. All intergrades with the preceding occur.

Ranunculus platyphyllus (Gray) A. Nelson. Stout and tall, 40-80 cm. high, usually rough-pubescent with long hairs; roots fascicled, thick-fibrous; leaves pinnately 3-5-divided, the divisions stalked and again 3-5-cleft or parted; ultimate segments cuneate-oblanceolate or obovate, incisely fewtoothed; petioles of the radical leaves exceeding the blades; flowers in an open cyme, long-peduncled; sepals hairy; petals 5 , bright yellow, obovate, $1.5 \mathrm{~cm}$. long; akenes flattened, smooth, with stout straight beaks. Common in low meadows.

Ranunculus pennsylvanicus L. f. Stout and tall, hirsute with spreading hairs, erect, $30-100 \mathrm{~cm}$. high, the root usually annual; leaves ternately compound, the leaflets ovate, acute, 3-cleft; flowers small; petals pale yellow, not longer than the sepals; akenes flat, obscurely margined, each tipped with a short straight beak, crowded in a short cylindric head. In damp places, Rathdrum, Idaho, Sandberg and Leiberg. 
Ranunculus macounii Britt. Usually bristly hairy throughout; stems ascending or reclining, $30-60 \mathrm{~cm}$. long; leaves ternately divided, the segments stalked, broadly ovate, 3-cleft or parted, and incisely toothed; petals bright yellow, obovate, $6 \mathrm{~mm}$. long, exceeding the calyx; akenes in a globose head, each with a stout straight flattened beak. In low wet meadows.

\section{DELPHINIUM. LARK̀SPUR.}

Annual or perennial erect branching herbs; leaves palmately lobed or divided; flowers showy, in a raceme or panicle; sepals 5, petal-like, the upper one prolonged into a spur; petals 4 , sometimes 2; the two posterior ones spurred; the lateral, when present, small; stamens numerous; pistils $1-5$, sessile, many-ovuled, forming follicles at maturity.

Roots fascicled, elongate, not tuber-like; large plants about a meter high.

Inflorescence ashy-puberulent.

Inflorescence villous.

Roots thickened, forming an irregular tuber; smaller plants.

Pedicels mostly shorter than the spurs and the raceme spike-like; sepals erect or but little spreading.

Flowers usually 10-30; leaves rather few;

pubescence villous and somewhat viscid. D. cyanoreios.

Flowers very many; leaves rather numerous; pubescence not villous, somewhat appressed.

Leaves glabrous or mostly so, the lower with broad lobes.

Leaves puberulent, all with narrow lobes, $D$. simplex.

Pedicels longer than the spurs; sepals widespreading.

Pubescence minute, of white appressed hairs.

Pubescence villous in character, present at at least on the bracts.

Pods glabrous; inflorescence glabrous or nearly so.

Pods villous; inflorescence usually villous and viscid.

D. scopulorum stachydeum.

D. subalpinum.

D. menziesii.

D. columbianum.

D. depauperatum.

Delphinium scopulorum stachydeum Gray. Tufted, ashy-puberulent throughout; stems 1-2 m. high; leaves orbicular in outline, 5-7-cleft or parted, the lobes again cleft, those of the lower leaves cuneate and rather broad, of the upper narrower or linear; larger leaves $5-10 \mathrm{~cm}$. broad, the petioles as long or longer and scarcely dilated at the base; inflorescence paniculate, or on smaller stems racemose, the principal axis densely flowered and spike-like, often $30 \mathrm{~cm}$. long; flowers dull blue; calyx puberulent outside, the sepals erect or but little spreading, about $1 \mathrm{~cm}$. long, as is also the spur; follicles puberulent, veiny, not spreading, $1-1.5 \mathrm{~cm}$. long, longer than the pedicels. High ridges of the Blue Mountains.

Delphinium subalpinum (Gray) A. Nelson. Similar to D. scopulorum stachydeum; leaf lobes mostly cuneate; panicle looser, sparsely villous and 
somewhat viscid; flowers deep blue; calyx glabrous or nearly so, the spur longer than the sepals; follicles glabrous, $1 \mathrm{~cm}$. long, shorter than the pedicels. Moist places on the highest parts of the Blue Mountains.

Delphinium cyanoreios Piper. More or less pubescent with fine soft often dense spreading somewhat viscid hairs; stems strictly erect, simple or rarely with a few branches, $30-70 \mathrm{~cm}$. high; leaves rather few, mostly near the base, orbicular in outline, $2-5 \mathrm{~cm}$. broad, thickish, the lower cleft into broad cuneate lobes, the upper into narrower lobes or divisions; raceme moderately dense, usually 10-20-flowered; calyx pubescent like the axis, the spur about as long as the sepals; follicles densely and finely villous, not spreading. In the mountains, usually at considerable altitudes. The pubescence even when confined to the inflorescence is always characteristic.

Delphinium distichum Geyer. Pubescence of minute mostly curved and appressed hairs, never villous; stems strictly erect, $30-90 \mathrm{~cm}$. high, simple or rarely with a few erect branches; leaves rather numerous, thickish, deeply cleft or parted, the lower into cuneate rather broad segments, the upper into narrow segments, all glabrous; raceme very dense, many-flowered, almost spicate; calyx puberulent externally, the spur usually longer than the sepals; follicles puberulent, not spreading, about $1 \mathrm{~cm}$. long. In moist meadows especially in Spokane County.

Delphinium simplex Dougl. Roots short, thick; stems strict, erect, puberulent, $30-80 \mathrm{~cm}$. tall, usually simple, rarely with a few erect branches; leaves puberulent, all divided into narrow lobes, linear in the upper leaves, broader in the lower ones; petioles shorter than the blades except in the lower leaves; raceme spike-like, the pedicels shorter than the pale dull blue flowers; sepals $8-10 \mathrm{~mm}$. long, shorter than the spur; follicles puberulent, erect, about $1 \mathrm{~cm}$. long. Common in low meadows.

Delphinium menziesii DC. Stems erect, simple or branched above, 30$70 \mathrm{~cm}$. tall, appressed-puberulent at least above; leaves 3-7-parted, the divisions usually deeply cleft into $2-4$, usually 3 lobes, the segments linear or lanceolate; petioles mostly exceeding the blades; racemes loose, 5-25-flowered; pedicels spreading, mostly as long as or longer than the dark blue flowers; sepals pubescent on the outside, $2-2.5 \mathrm{~cm}$. long; spur as long, mostly acute and slender; follicles 3 , strongly diverging, pubescent, 1.4-3 cm. long. Common on rocky hillsides.

Delphinium columbianum Greene (D. nuttallii Gray). Habit and appearance of $D$. menziesii but the herbage glabrous and usually a little glaucous; follicles glabrous, spreading moderately at maturity. Mostly at low altitudes in sagebrush or scab land.

Delphinium depauperatum Nutt. Very similar to $D$. menziesii but the minute pubescence soft, rather dense, not appressed, somewhat viscid; follicles erect or but little spreading. Blue Mountains; Mt. Carlton; also along the lower Clearwater River, Idaho, where the plants are larger and stouter.

\section{ACONITUM.}

Tall erect perennial herbs; leaves palmately-lobed or divided; flowers large, showy, in terminal racemes or panicles; sepals 5, petal-like, very irregular, the upper one hooded or helmet-shaped; petals $2-5$, the upper two hooded, on long claws, concealed in the helmet; stamens numerous; pistils $3-5$, many-ovuled, forming follicles at maturity. 
Aconitum columbianum Nutt. Aconite. Stems erect, $50-100 \mathrm{~cm}$. tall, somewhat pubescent or viscid above; leaves glabrous or the upper puberulent, palmately 5-lobed; lobes cuneate-obovate, incisely serrate or cleft; petioles mostly shorter than the blades; flowers blue, in loose racemes or panicles; hood 2-3 cm. long, the helmet-shaped upper part higher than broad, strongly beaked; follicles oblong-linear, 1-1.5 cm. long, the slender beak usually recurved. Along streams especially in the mountains.

Aconitum columbianum pallidum Piper n. subsp. Herbage pale; flowers white or cream-colored. Common along the Touchet River in the Blue Mountains, Columbia County, Piper no. 2416.

\section{AQUILEGIA. COLUMBINE.}

Erect perennials with 2-3-ternately compound leaves; flowers regular, showy, on the ends of the branches; sepals 5 , regular, petal-like; petals 5 , all alike, each with a short lip and produced backward into a large hollow spur much longer than the calyx; pistils 5 , with slender styles; pods erect, many-seeded.

Aquilegia formosa Fisch. Usually sparingly pubescent; stems erect, 60-90 cm. high; leaflets broadly cuneate, paler beneath, lobed; flowers nodding, bright scarlet, yellow inside; sepals spreading; spurs nearly straight, about twice as long as their blades. Common in the mountains. A form with lighter colored flowers and more sharply incised leaves which may be distinct occurs rarely on Snake River.

\section{PAEONIA. Paeony.}

Robust perennial herbs with ternately or pinnately compound leaves and showy flowers; sepals 5 , herbaceous, persistent; petals 5-10; stamens numerous, inserted on a fleshy disk; pistils 2-5; fruit of 2-5 leathery several-seeded follicles.

Paeonia brownii Dougl. Whole plant glabrous and glaucous, $20-50 \mathrm{~cm}$. high, at first erect or ascending, in fruit decumbent; leaves thick, once or twice ternately divided or parted, the ultimate segments from narrowly oblong to obovate; sepals green, concave, unequal; petals dull brownish red, thick, scarcely longer than the sepals; follicles usually 5 , oblong, smooth, about $3 \mathrm{~cm}$. long; seeds black, shining. On open hillsides in the Blue Mountains.

\section{ACTAEA. BANEBERRY.}

Erect perennial herbs; leaves large, 2-3-ternately compound; flowers small, white, in a terminal raceme; sepals 3-5, petal-like; petals 4-10, small, spatulate or narrow-clawed; stamens numerous; ovary 1-many-ovuled, in fruit forming a large somewhat poisonous berry.

Actaea spicata arguta (Nutt.) Torr. Stems 30-60 cm. tall, erect; leaves triternately decompound; leaflets obliquely ovate or lanceolate, acuminate, coarsely incised-serrate or lobed, puberulent when young, 3-6 cm. long; racemes densely flowered, $2-3 \mathrm{~cm}$. long, becoming loose in age; berries bright red, rarely white. In woods in the mountains. 


\section{COPTIS. Goldthread.}

Low glabrous perennials with slender rootstocks; leaves all radical, ternately divided or compound; flowers on scapes, solitary, or in few-flowered umbels; sepals 5-7, petal-like; petals 5-6, small, linear, hood-shaped; stamens numerous; pistils 3-7, on slender stalks, in fruit forming a cluster of divergent follicles.

Coptis occidentalis (Nutt.) T. \& G. Scapes 2-3-flowered, $10-25 \mathrm{~cm}$. tall; leaves trifoliolate, evergreen; leaflets long-petioled, suborbicular, deeply 3-lobed, the lobes obtuse, dentate, or again lobed; sepals linear, 3-nerved, white, $1 \mathrm{~cm}$. long; petals 5-6 mm. long, short-clawed at the base, broadened at the nectary, attenuate beyond, obtuse; stamens about 12, shorter than the carpels; mature carpels $3.5 \mathrm{~cm}$. long, the fruiting portion spreading, longer than the erect stipe. In woods in the mountains along the Idaho border.

\section{Family 39. BERBERIDACEAE. BARBERRY FAMILY.}

Shrubs or herbs; leaves alternate, mostly compound or divided, with stipules or dilated bases; flowers perfect, the bracts, sepals, petals and stamens all opposite; all the parts distinct and hypogynous; sepals and petals each usually in two rows of three; anthers opening by two valves or lids hinged at the top; pistil single; style short or none; fruit a berry or pod; seeds few or several; endosperm present.

\section{BERBERIS.}

Shrubs with yellow wood; leaves alternate, simple or compound, often spiny; flowers yellow, in clustered racemes, evergreen (in ours); bractlets $2-6$; sepals 6 , petal-like; petals 6 , in two rows, each with two basal glands; stamens 6 , short; stigma peltate; fruit a berry.

Leaflets palmately nerved.

B. nervosa.

Leaflets pinnately nerved.

Leaflets 5-11, shining, strongly spinulose.

Leaflets $3-7$, dull, often glaucous, weakly spinulose.

B. aquifolium. B. repens.

Berberis nervosa Pursh. Oregon Grape. Stems erect, simple, $15-30 \mathrm{~cm}$. high; leaves $30-75 \mathrm{~cm}$. long, with 11-19 leaflets, these ovate or lanceolate, acuminate, spinulose-dentate; bud scales lanceolate, acuminate, $2-2.5 \mathrm{~cm}$. long, persistent, becoming dry and rigid; racemes terminal, one or several, 10-20 cm. long; pedicels shorter than the fruit; berries globose, purple-black with a white bloom, very acid. Lake Coeur d'Alene, rare. Abundant west of the Cascade Mountains.

Berberis aquifolium Pursh. Shrub often 1-2 m. high, erect or nearly so; leaflets' $5-11$, evergreen, shining, oblong or ovate, $4-10 \mathrm{~cm}$. long, with numerous spiny teeth; racemes usually clustered, subterminal; berries black with a bloom, usually pear-shaped. Gravelly woods about Spokane.

Berberis repens Lindl. Low depressed shrub, 20-30 cm. high, often with subterranean stolon-like branches; leaves pinnately compound, 3-7-foliolate; 
leaflets evergreen, $2-5 \mathrm{~cm}$. long, ovate, obtuse or acute, pale or glaucous, not shining, sinuately dentate with numerous spinulose teeth; racemes few, terminal; berries blackish with a bloom, sour. Common in gravelly or stony ground.

\section{Family 40. PAPAVERACEAE. Poppy Family.}

Herbs with a milky or watery juice; leaves alternate, simple or compound, without stipules; flowers perfect, regular or irregular, the parts in twos or fours; sepals 2; petals 4-12, separate or somewhat united; stamens 6 , diadelphous, or numerous and distinct; ovary 1-celled with 2 or more parietal placentae; fruit a dry one-called pod with numerous seeds.

Corolla 2-spurred at the base.

Corolla 1-spurred at the base.

153. Bikukulla, 112.

154. CAPNOIDES, 112.

\section{BIKUKULLA.}

Erect or diffuse glabrous perennial herbs; leaves ternately compound or dissected; flowers in racemes or panicles, irregular, nodding; pedicels 2-bracted; sepals 2, scale-like; petals slightly united into a 2-spurred or swollen nectariferous often witheringpersistent corolla; stamens 6 , in two sets, opposite the outer petals; placentae 2; style slender; capsule oblong or linear, 2-valved.

Bikukulla cucullaria (L.) Millspaugh. Dutchman's Breeches. Glabrous throughout; rootstock short, covered with grain-like tubers; leaves all basal, twice-ternately compound; ultimate divisions narrow, acute; scapes exceeding the leaves, bearing a one-sided raceme of 4-10 nodding flowers; corolla pinkish, yellow at the summit, the blunt spurs widely diverging, as long as the body of the corolla. Moist copses, blooming in early spring.

\section{CAPNOIDES.}

Biennial erect pale or glaucous herbs; leaves radical and cauline, decompound; flowers in racemes; sepals 2 , small; petals 4 , slightly united to a 1-spurred corolla; inner petals narrow, keeled; stamens 6 , in two sets, opposite the outer petals; placentae 2; style entire, dilated or lobed; capsule oblong or linear, 2-valved.

Capnoides aureum (Willd.) Kuntze. Squirrel Corn. Glabrous, the branched stems decumbent, $30-50 \mathrm{~cm}$. long; leaves bipinnately compound, pale and glaucous; ultimate segments cuneate-obovate, 3-5-lobed; flowers golden yellow, 2-2.5 cm. long, in short racemes; spur blunt, shorter than the body; capsule torulose, long-beaked, $2-3 \mathrm{~cm}$. long; seeds black, very shiny. Near Wawawai and Lewiston. 


\section{Family 41. CRUCIFERAE. Mustard Family.}

Herbs, rarely somewhat woody, with watery sap; leaves alternate; stipules none; flowers perfect, regular, in usually bractless racemes, spikes or corymbs; sepals 4 , usually oblong; petals 4 , rarely none, hypogynous, in the form of a cross, equal, generally clawed, alternate with the sepals; stamens 6 , rarely fewer, hypognyous, of unequal length, the two shorter opposite the sepals, the four longer opposite the petals; pistil 1, of two united carpels; pod usually 2-celled, dehiscing by the separation of two valves from the central partition, or rarely indehiscent, either much longer than broad (a silique) or short (a silicle).

Pods indehiscent.

Fruit winged; pubescence of simple hairs.

155. THYSANOCARPUS, 114.

Fruit wingless; pubescence of branched hairs. 156. ATHYSANUS, 114.

Pods dehiscent, 2-valved, either elongate (siliques) or short (silicles).

Pods elongate (siliques).

Siliques compressed parallel to the broad partition.

Valves nerveless; leaves all petioled.

Valves 1-nerved; cauline leaves sessile.

Siliques lanceolate.

Siliques linear.

Siliques terete, not at all compressed.

Pods $4 \mathrm{~cm}$. long or more.

Flowers white or red; stigmas entire; pods erect.

Flowers yellow; stigmas 2-lobed; pods spreading.

Flowers large; leaves nearly entire.

157. Cardamine, 115.

158. Phoenicaulis, 115.

159. ARABIS, 115.

161. ERYSIMUM, 117.

Flowers small; leaves pinnatifid. 164. SisymbruUM, 119.

Pods less than $4 \mathrm{~cm}$. long.

Siliques beaked; seeds globose.

Siliques beakless; seeds oblong.

Valves of the pods nerveless.

162. Brassica, 118.

Valves of the pods nerved.

Annuals; leaves pinnate or pinnatifid.

Perennials; leaves lyrate.

163. Radicula, 118.

Pods short (silicles).

Silicles compressed parallel to the partition.

Flowers solitary on scapes, white; seeds winged.

Flowers racemose; seeds wingless.

Silicles orbicular.

Silicles ovate or oblong.

160. THELYPODIUM, 117.

Silicles either not compressed or compressed

164. SisYMBriUM, 119.

165. CAMPE, 120. contrary to the partition.

166. Platyspermum, 120.

167. Alyssum, 120.

168. Draba, 121. 
Pods terete, not compressed.

Leaves pinnatifid.

163. Radicula, 118.

Leaves entire or nearly so.

Pods compressed contrary to the partition.

Valves nerveless; pod obcordate. 170. Physaria, 121.

Valves 1-nerved.

Nerves of the valves acute, forming keels or wings.

Silicles orbicular or obovate; cells 1-2-seeded.

Silicles ovate or oblong; cells 2-several-seeded.

169. Camelina, 121. es the valves obtuse, not prominent.

Silicles cuneate, notched at the apex.

Silicles not cuneate, not notched at the apex.

171. LePIDIUM, 122.

172. Thlaspi, 122.

173. Bursa, 123.

174. Hutchinsia, 123.

\section{THYSANOCARPUS.}

Erect and slender sparingly branched annual herbs, with a pubescence of simple hairs; flowers minute, white or rose-colored, in elongated racemes; pod mostly pendulous, on a slender pedicel, 1-celled, indehiscent, disk-shaped or concave, orbicular, winged, 1-seeded; seed flattened but not winged.

Thysanocarpus curvipes Hook. More or less hirsute below, glabrous above; stem erect, usually branched above, $30-50 \mathrm{~cm}$. tall; radical leaves oblong, obtuse, dentate, 3-4 cm. long, narrowed at base, with a petiole; cauline sagittate and clasping at base, acute, usually entire, commonly smaller; racemes elongated, loose; pedicels slender, recurved; pods orbicular, ovate or obovate, notched, apiculate by the persistent style, puberulent, 4-6 mm. long, the entire or crenulate wings as broad as the body. Gravelly soils, not rare.

Thysanocarpus curvipes madocarpus Piper. Pods glabrous. Quite as common as the species but nearly always growing by itself.

\section{ATHYSANUS.}

Slender annual herbs, usually branching at the base, with a pubescence of branched hairs; flowers minute, in racemes; petals small, white, or none; style short; ovules $3-4$, only one maturing; pod orbicular, indehiscent, not margined, nerveless, 1-celled, 1-seeded.

Athysanus pusillus (Hook.) Greene. Stems slender, branched from the base, 10-20 cm. tall, hirsute-pubescent throughout; leaves oblong-lanceolate, acute, usually coarsely dentate, rough-pubescent, 5-30 $\mathrm{mm}$. long; racemes loose, elongate; flowers very small, on curved pedicels; petals linear, minute, or wanting; pods orbicular, about $2 \mathrm{~mm}$. in diameter, hirsute, on recurved longer pedicels. Stony soil, rather common. 


\section{CARDAMINE. BitTer Cress.}

Mostly glabrous leafy-stemmed perennial herbs, growing in moist places; leaves entire, lobed or divided, all petioled; flowers white (in ours); pod elongated, compressed parallel to the partition; valves nerveless; seeds in one row, wingless.

Leaves all simple.

Leaves or some of them pinnate.

Basal leaves simple.

Basal leaves pinnate.

Capsules 20-30-seeded; leaflets mostly oblong.

Capsules 8-20-seeded; leaflets mostly orbicular.

\section{C. lyallii.}

C. vallicola.

C. pennsylvanica.

C. oligosperma.

Cardamine lyallii Wats. Glabrous or sparingly pubescent; stems erect from running rootstocks, $15-50 \mathrm{~cm}$. high; leaves petioled, suborbicular, reniform to cordate, sinuate, $2-6 \mathrm{~cm}$. broad; petals $6-8 \mathrm{~mm}$. long; pods erect, 20-30 mm. long, on short pedicels. Along streams in the Blue Mountains.

Cardamine vallicola Greene. Glabrous; stems erect from running rootstocks; leaves all trifoliolate or some of the radical ones rarely simple; terminal leaflets orbicular, coarsely crenate or even lobed, $5-8 \mathrm{~cm}$. long; lateral leaflets ovate, mostly entire; pods $25-30 \mathrm{~mm}$. long, erect, on widely spreading pedicels $10 \mathrm{~mm}$. long. In springy places near Spokane.

Cardamine pennsylvanica Muhl. Glabrous or nearly so, 30-60 cm. high, simple or branched; leaflets 7-13, sessile, mostly oblong, but those of the lowermost leaves suborbicular; pods suberect on spreading pedicels. In moist ground, especially in copses. Ambiguous forms seem to connect with C. oligosperma.

Cardamine oligosperma Nutt. Annual, erect, usually simple-stemmed, $15-30 \mathrm{~cm}$. high, sparsely hirsute throughout or nearly glabrous; leaflets small, orbicular, petiolulate, 3-5-lobed or toothed; raceme few-flowered; flowers $2 \mathrm{~mm}$. long; pods erect, 8-20-seeded, $12-20 \mathrm{~mm}$. long. Wet places, infrequent.

\section{PHOENICAULIS.}

Low perennial herbs with branching caudex; leaves mostly radical, the cauline, if present, reduced; flowers rose-colored or purple, in racemes on slender scapes; sepals oblong, erect; petals large, with an obovate blade and a slender claw; pod a silique, compressed parallel to the partition with 1 -nerved valves; -seeds orbicular, winged or wingless.

Phoenicaulis cheiranthoides Nutt. Perennial from a stout vertical root; caudex usually branched and covered with the bases of dead leaves; leaves mostly basal, entire, spatulate to oblanceolate, 3-10 cm. long, white with a fine dense stellate pubescence; stems nearly naked, 10-20 cm. high; flowers dark purple, in racemes; pods glabrous, spreading, $2-5 \mathrm{~cm}$. long. On stony slopes in the Blue Mountains.

159. ARABIS. Rock CRESS.

Erect annual or perennial herbs; leaves seldom divided, the cauline sessile and usually clasping and auricled at the base; 
flowers white or purple; pod long-linear, compressed parallel to the partition; valves more or less 1-nerved; seeds flattened, usually winged, in one or two rows.

\section{Seeds wingless; flowers white.}

Cauline leaves auriculate; plant glaucous, glabrous except near the base.

Cauline leaves not auriculate; plant green, glabrous above, pubescent towards the base.

Seeds winged or wing-margined.

Flowers white; seeds in a single row.

Flowers red or pink; seeds in two rows.

Cauline leaves not auriculate or cordate; leaves all entire, villous-hirsute.

Cauline leaves auriculate or cordate.

Radical leaves dentate.

Pods curved, spreading; whole plant coarsely stellate-pubescent.

Pods straight, reflexed; plant finely stellatepubescent.

A. glabra.

A. nuttallii.

A. hirsuta.

A. cusickii. pal leaves entire.

Pods reflexed; herbage covered with a fine dense white stellate pubescence.

Pods erect or nearly so; herbage green, glabrous

A. sparsiflora.

A. holboellii.

\section{Radical leav
Pods refl
white
Pods ere
above.}

Arabis glabra (L.) Bernh. Biennial, pubescent near the base, glabrous and glaucous above; stems usually simple, $60-90 \mathrm{~cm}$. high; basal leaves oblanceolate, dentate or pinnatifid, pubescent, 5-8 cm. long; cauline oblong-lanceolate, sessile, sagittate and auricled at base, all but the lower glabrous; flowers whitish, about $5 \mathrm{~mm}$. long; pods erect or ascending, linear, 4-10 cm. long, tipped with the large 2-lobed sessile stigma; pedicels 4-10 mm. long. Low ground, not common.

Arabis nuttallii Robinson. Perennial with branching rootstocks; stems erect or ascending, simple, $15-25 \mathrm{~cm}$. high, glabrous above, somewhat hirsute below; radical leaves oblanceolate, acutish, sinuate-dentate, 1-2 cm. long; cauline oblong to elliptical, sessile; flowers rather large in a short raceme; petals 5-6 mm. long; pods erect, 12-16 mm. long, beaked with a stout 'style; valves 1-nerved. In moist grassy meadows.

Arabis hirsuta Scop. Biennial, usually rough-hairy, but shade plants often nearly glabrous; stems erect, $15-50 \mathrm{~cm}$. high; basal leaves clustered, oblanceolate, entire or somewhat dentate, usually $2-5 \mathrm{~cm}$. long; cauline oblong to lanceolate, entire or dentate, cordate or auriculate at base; flowers greenish white, small; pods on slender pedicels, erect, slender, 2-5 cm. long, tipped with a very short stout style. On rocky cliffs or gravelly bars, infrequent.

Arabis cusickii Wats. Biennial, roughly hirsute throughout with simple hairs or somewhat glabrous above; stems usually several, 10-20 cm. high; radical leaves oblanceolate, about $2 \mathrm{~cm}$. long; cauline linear-oblong, sessile; pods curved, ascending or spreading, glabrous, $5-8 \mathrm{~cm}$. long; valves 1-nerved below the middle. On basalt outcroppings, rather rare.

Arabis sparsiflora Nutt. (Arabis arcuata subvillosa Wats.) Perennial roughly stellate-pubescent below, glabrous above; stems mostly simple, erect $30-60 \mathrm{~cm}$. high; radical leaves linear, oblanceolate, dentate, petioled; cauline lanceolate, subentire, sessile, with a sagittate base; flowers rose-colored; pods recurved, 5-8 cm. long, linear, acute; pedicels pubescent, 6-12 mm. long. Basalt ledges, common. 
Arabis holboellii Hornem. Much like A. sparsiflora Nutt. but the pubescence much finer; pods sharply reflexed; flowers purple or nearly white. Basalt ledges, not rare.

Arabis puberula Nutt. Biennial, the whole plant canescent with fine stellate pubescence; stems slender, erect, 10-30 cm. high; leaves all entire, the radical oblanceolate; cauline linear, sessile and slightly auriculate; pods on slender pedicels, pendulous, $2-4 \mathrm{~cm}$. long; valves 1 -nerved below the middle. Blue Mountains, Horner; rare in our limits.

Arabis lyallii Wats. Perennial from a branched base, green or somewhat glaucous, glabrous or sparingly pubescent below; stems usually several, 5-10 $\mathrm{cm}$. high; radical leaves oblanceolate, acute, with slender petioles; pods straight, erect, $2-5 \mathrm{~cm}$. long; valves 1 -nerved below the middle with some smaller veins. An alpine species occurring on the higher peaks of the Blue Mountains.

\section{THELYPODIUM.}

Stout biennial herbs, often succulent; leaves simple, entire, toothed or pinnatifid, often auricled at the base; flowers usually in rather dense racemes; sepals oblong to linear, rather short; style short; stigma entire; pods slender, terete or 4-angled; seeds oblong, in one row in each cell.

Flowers whitish; leaves fleshy.

T. lacinialum.

Flowers purple; leaves membranous.

$T$. streplanthoides.

Thelypodium laciniatum (Hook.) Endl. Biennial, glabrous and glaucous, rather succulent; stem stout, $50-100 \mathrm{~cm}$. tall, simple or somewhat branched; leaves ovate or lanceolate, irregularly pinnatifid; terminal lobe largest, coarsely dentate or entire; lateral lobes oblong or linear, entire or dentate, sometimes wanting; racemes dense, 5-40 cm. long; sepals and petals yellowish-white; pod slender, spreading, 5-12 cm. long; pedicels stout, 5-8 mm. long. Walla Walla and Snake River; a common plant in the sagebrush region.

Thelypodium streptanthoides Leiberg. Leaves green, neither glaucous nor succulent; sepals purple. Crevices of basaltic cliffs along Snake River.

\section{ERYSIMUM.}

Biennial or perennial herbs; leaves rather narrow, entire or toothed, not clasping; flowers often large, usually yellow; pod linear, 4-angled or rarely flattened, not stipitate; valves keeled, with a prominent midrib; seeds oblong, marginless, in one row in each cell.

Petals 4-5 mm. long; pods $1-2 \mathrm{~cm}$. long.

E. cheiranthoides.

Petals 16-24 mm. long; pods 5-12 cm. long.

Seeds quadrangular; leaves entire or dentate.

Seeds lenticular; leaves entire or nearly so.

E. asperum.

E. elatum.

Erysimum cheiranthoides L. Erect, branched above, minutely roughpubescent throughout; leaves lanceolate, acute at each end, entire or ninutely dentate, sessile or nearly so; racemes elongate; petals 4-5 $\mathrm{mm}$. long, yellow; pod linear, 4-angled, puberulent, very short-beaked, about $2 \mathrm{~cm}$. long, erect, on spreading pedicels about $1 \mathrm{~cm}$. long. Very sparingly introduced. 
Erysimum asperum (Nutt.) DC. Whitish throughout with appressed pubescence; stems simple, stout, $20-40 \mathrm{~cm}$. tall, erect; leaves lanceolate or oblanceolate, entire or somewhat dentate, rarely lobed, mostly petioled, 6-10 $\mathrm{cm}$. long; flowers bright yellow; petals $15-25 \mathrm{~mm}$. long; pods stout, somewhat 4-angled, about $8 \mathrm{~cm}$. long, tipped with a short stout beak and a large 2-lobed stigma; pedicels stout, $1 \mathrm{~cm}$. long. Common in, stony soil.

Erysimum elatum Nutt. Similar to $E$. asperum but taller, with sparse closely appressed pubescence; leaves all entire or nearly so, lanceolate or the lowest oblanceolate, 5-10 cm. long; seeds lenticular. On rocky banks, Blue Mountains.

\section{BRASSICA.}

Erect annual or biennial herbs; lower leaves mostly pinnate or lyrate, with a large terminal lobe; flowers yellow; pod terete or nearly so, tipped with a slender conical or somewhat flattened beak; seeds globose, in one row or rarely in two rows in each cell.

Cauline leaves auricled at base and clasping.

Cauline leaves not auricled or clasping.

B. campestris.

Beak of the pod very short, less than one-fourth the seedbearing part.

Beak of the pod long, at least half as long as the seed-bearing part.

B. nigra.

B. arvensis.

Brassica campestris L. Turnip. Smooth or nearly so, of ten glaucous, 30-90 cm. high; lower leaves petioled, somewhat lobed or toothed; upper entire or nearly so, sessile and clasping by auricled bases; flowers yellow; pedicels spreading; petals $6-10 \mathrm{~mm}$. long; pods terete, $3-5 \mathrm{~cm}$. long, narrowed into a a beak about $1 \mathrm{~cm}$. long. Grain fields and waste places; sometimes a troublesome weed.

Brassica nigra (L.) Koch. Black Mustard. Erect, $30-80 \mathrm{~cm}$. high, sparsely hirsute; leaves green, slender-petioled, the terminal lobe large and coarsely toothed, the few lateral lobes small; pods $15-18 \mathrm{~mm}$. long, erect, on very short pedicels, only the lower fourth seed-bearing; seeds dark-colored. In waste places.

Brassica arvensis (L.) B.S.P. Charlock. Stout, annual, 30-90 cm. high, hispid with scattered hairs; lower leaves pinnately parted, consisting of a large ovate-oblong terminal segment and 1 or 2 pairs of much smaller ones, all dentate; uppermost leaves sessile, none clasping; pods $2-4 \mathrm{~cm}$. long, erect or ascending, the fertile portion torulose, with a beak flat and stout and half as long. A weed in waste ground.

\section{RADICULA.}

Aquatic or marsh herbs; leaves usually lyrately or pinnately parted or toothed, auricled at base; flowers small, yellow or white; style short or slender; pods terete or nearly so; seeds turgid, minute, in two rows in each cell.

Flowers white.

R. nasturtium-aquatica.

Flowers yellow.

Plant perennial by rootstocks.

Plants annual or biennial, without rootstocks.

Pedicels 6-8 mm. long; stems erect.

Pedicels 2-4 mm. long; stems diffuse.

Pods curved; leaf-lobes acute.

Pods straight; leaf-lobes obtuse.

R. sinuata.

R. pacifica.

$R$. curvisiliqua.

$R$. obtusa. 
Radicula nasturtium-aquatica (L.) Britt. \& Rendle. Perennial, aquatic, smooth; stems procumbent, rooting at the lower nodes, $10-30 \mathrm{~cm}$. high; leaves pinnate; leaflets $3-11$, orbicular or oblong, sinuate, or the lower ones sometimes reduced to the terminal leaflet; petals white, $3-4 \mathrm{~mm}$. long; pods linear, 12-20 $\mathrm{mm}$. long, acute at each end, a little longer than the spreading pedicels. Introduced. Cultivated under the name of Water cress.

Radicula sinuata (Nutt.) Greene. Stems prostrate or decumbent, branched, glabrous or slightly scurfy-pubescent, from perennial creeping rootstocks; leaves lanceolate or oblong, $2-3 \mathrm{~cm}$. long, pinnatifid into numerous equal linear or oblong lobes, these entire or nearly so; flowers 3-4 $\mathrm{mm}$. long, yellow; pod oblong, 6-8 $\mathrm{mm}$. long, acute at each end, tipped with the long style; pedicels spreading, 5-8 mm. long. Sandy banks of Snake River at Almota.

Radicula pacifica (Howell) Greene. Annual or biennial, glabrous or nearly so, erect, $30-90 \mathrm{~cm}$. high; leaves lanceolate, pinnately cleft or parted, petioled, 5-15 $\mathrm{cm}$. long, the segments toothed; pods oblong, turgid, 8-12 mm. long, equalling the spreading pedicels. In wet places.

Radicula curvisiliqua (Hook.) Greene. Annual or biennial, glabrous or slightly pubescent, erect or decumbent, $15-40 \mathrm{~cm}$. high; leaves oblanceolate, sinuate-dentate or pinnately cleft into oblong dentate lobes; flowers small, pale yellow; petals $2 \mathrm{~mm}$. long, exceeding the sepals; pods linear-oblong, 4-16 $\mathrm{mm}$. long; styles stout or none. Wet places, common and variable.

Radicula obtusa (Nutt.) Greene. Annual or biennial, glabrous or nearly so, branching from the base, spreading; leaves pinnately parted or divided, or the upper often subentire and oblong; pedicels $2-4 \mathrm{~mm}$. long, ascending or spreading; flowers yellow; pods usually long, straight; style very short and thick. Spokane County.

\section{SISYMBRIUM.}

Mostly annual or biennial herbs; leaves neither clasping nor auriculate at the base, rarely entire, often finely dissected; flowers small, usually yellow or yellowish; style short or none; stigma 2-cleft; pod linear, short or long, flat or terete; seeds oblong.

Pubescence of simple hairs or rarely wanting.

Leaves pinnatifid into rather large irregular segments.

Leaves pinnatifid in nearly equal linear segments.

Pubescence of forked hairs or rarely wanting.

Leaves tripinnate.

Leaves pinnatifid or bipinnatifid.

Green; seeds in 1 row.

Canescent; seeds in 2 rows.

S. officinale.

S. altissimum.

S. sophia.

S. incisum.

S. canescens.

Sisymbrium officinale leiocarpum DC. Hedge Mustard. Erect, sparsely hirsute with simple hairs, or glabrous, $30-90 \mathrm{~cm}$. high, divaricately branched above; leaves pinnatifid into 5-13 lobes, the terminal longest, all more or less dentate; upper cauline leaves sessile, the others petioled; flowers yellow, $3 \mathrm{~mm}$. broad; pods glabrous, tapering from the base to the apex, $1-2 \mathrm{~cm}$. long, erect, on short pedicels. A weed in waste ground.

Sisymbrium altissimum L. Tumbling Mustard. Erect, much branched, 60-150 cm. tall, glabrous or sparsely hirsute, with simple hairs; basal leaves petioled, pinnatifid, in linear or lanceolate entire or dentate lobes; upper leaves reduced, sessile; flowers pale yellow, $5 \mathrm{~mm}$. broad; pods spreading, linear, $6-10 \mathrm{~cm}$. long, on short stout pedicels. A troublesome weed, introduce from Europe. Locally called Jim Hill Mustard. 
Sisymbrium sophia L. Erect, much branched above, 30-100 cm. tall, canescent throughout with short stellate pubescence; leaves tripinnatifid, $5-8 \mathrm{~cm}$. long, the segments linear or oblong, small; racemes elongated; pods glabrous, $1.5-2 \mathrm{~cm}$. long, curved upwards, on slender shorter pedicels; seeds in one row in each cell of the pod. Sparingly introduced.

Sisymbrium incisum Engelm. Stem slender, erect or ascending, sparingly branched, usually minutely stellate-pubescent; leaves pinnatifid or bipinnatifid; segments of the lower leaves oblong; racemes loose; flowers bright yellow; pods 7-15 mm. long, acute, usually curved, ascending, on slender pedicels of about the same length. Blue Mountains; rare in our limits.

Sisymbrium incisum filipes Gray. Similar to the species but the segments of the upper leaves elongate, often linear and entire; pods 10-15 mm. long, on slender longer pedicels. Very common in fields and on open hillsides.

Sisymbrium canescens Nutt. Similar to $S$. incisum but gray with a short soft pubescence; pods 8-12 $\mathrm{mm}$. long, shorter than the spreading pedicels. Waitsburg, Horner.

\section{CAMPE.}

Somewhat succulent perennials; stems angled; leaves entire or pinnatifid; flowers yellow, in racemes; pod linear, terete, or somewhat 4-angled, tipped with the short slender style; seeds flat, in one row.

Campe barbarea (L.) W.F. Wight. Bitter Cress. Perennial, glabrous; stems simple or branched above, $30-90 \mathrm{~cm}$. high; lower leaves pinnately cleft or divided, the terminal segment large, orbicular or ovate, entire or nearly so; lateral segments 1-5 pairs, smaller, oblong, entire or toothed; petioles short, auricled at base; upper cauline leaves obovate, clasping, the lower part pinnately-cleft; raceme dense; petals yellow, $4 \mathrm{~mm}$. long, twice as long as the sepals; pods erect or ascending, 2-3 cm. long, beaked by the slender style; petals short and stout. Wet places, not common.

\section{PLATYSPERMUM.}

Low annual herb; leaves lyrate, few-lobed or subentire; flowers minute, solitary, on naked scapes; pods compressed parallel to the partition, short, suborbicular; seeds broadly winged, in two rows.

Platyspermum scapigerum Hook. Glabrous; scapes 5-15 cm. tall, erect or ascending; leaves spatulate-oblong, nearly entire, mostly coarsely 3-7lobed, all petioled; pod orbicular-ovate, 5-10 $\mathrm{mm}$. long, beaked with the short style. In moist gravelly places in early spring, the pods ripening and dehiscing very early. The peppery pods are eaten by children.

\section{ALYSSUM.}

Low branching annual herbs; leaves mostly simple; flowers yellow; style slender; pod ovoid or orbicular, compressed; valves convex, nerveless; seeds one or two in each cell.

Alyssum alyssoides (L.) Gouan. Annual, 10-30 cm. high, stellatepubescent throughout, usually branched from the base; leaves entire, spatulate, 1-2 cm. long; flowers in racemes, 5-15 cm. long; petals pale yellow, cuneate, 
scarcely exceeding the sepals; pods orbicular, margined, notched at the apex, minutely pubescent, $3 \mathrm{~mm}$. broad, on spreading pedicels. Introduced and becoming common.

\section{DRABA.}

Low annual or perennial herbs; leaves entire or toothed; flowers white or yellow, mainly in racemes; pod oval to oblong or linear, compressed parallel to the partition; valves nearly flat, nerveless or faintly nerved; seeds few to many, in two rows in the cell, wingless.

Perennials, flowers yellow.

D. glacialis.

Annuals.

Flowers yellow.

D. nemorosa.

Flowers white.

Petals deeply 2-cleft; pods glabrous.

Petals entire; pods hispid.

D. verna.

D. caroliniana.

Draba glacialis Adams. Perennial with many short clustered leafy branches; leaves linear, entire, ciliate at base, stellate-pubescent, 5-15 mm. long, rigid in age and with a prominent midrib; scapes $5-15 \mathrm{~cm}$. long; flowers yellow; pods ovate or oblong-ovate, acute, pubescent, $2-8 \mathrm{~mm}$. long, on pedicels a little longer. On rock cliffs in the Blue Mountains.

Draba nemorosa L. Annual, the simple stems 5-40 cm. high, leafy and pubescent below; leaves sessile, oblong or ovate, usually dentate, acutish, 1-2 cm. long, stellate-pubescent; raceme loose, 3-many-flowered; flowers small, $4 \mathrm{~mm}$. broad; petals yellow, notched, a little longer than the villous sepals; pod oblong, acute, appressed-pubescent or glabrous, about $1 \mathrm{~cm}$. long, much shorter than the spreading pedicels. In warm soil in copses.

Draba verna L. Annual; stems several, leafless, 5-10 cm. high, simple, nearly glabrous; leaves in a rosette, oblong or oval, toothed or entire, obtuse, 4-8 mm. long, pubescent with branched hairs; flowers white, in a loose raceme; petals deeply 2-cleft; pods oblong, glabrous, 4-8 $\mathrm{mm}$. long, shorter than the spreading pedicels. In sandy soil.

Draba caroliniana micrantha (Nutt.) Gray. Winter annual; stems slender, usually branched, 3-10 cm. high; leaves entire, obovate to oblanceolate, sessile, stellate-hairy, 6-12 mm. long; petals small, often wanting; pods clustered in a short raceme, broadly linear, hairy, $6-15 \mathrm{~mm}$. long. In early spring in warm places.

\section{Camelina. False Flax.}

Erect annual herbs; leaves entire, toothed or pinnatifid; flowers small, yellowish; style slender; pod obovoid or pearshaped, slightly flattened parallel to the partition, many-seeded.

Camelina microcarpa Andrz. Stems erect, mostly simple, 30-90 cm. tall, hirsute below, glabrous above; leaves lanceolate, acute, sagittate at base, half-clasping, erect, entire or nearly so, stellate-pubescent; flowers pale yellow; pods obovate, $6-8 \mathrm{~mm}$. long, beaked by the persistent style, glabrous, on slender pedicels. In fields, introduced.

\section{PHYSARIA.}

Low spreading tufted perennials with stellate pubescence; sepals oblong or elliptical, short; petals longer, spatulate to 
obovate, entire; style slender; silicle obcordate, compressed at right angles to the partition, at least somewhat inflated; valves nerveless.

Physaria geyeri (Hook.) Gray. Whole plant whitish with a dense stellate pubescence; leaves mostly basal, broadly ovate, entire or more or less toothed, long-petioled; cauline leaves spatulate; stems several, spreading, $5-15 \mathrm{~cm}$. long; racemes densely flowered, $2-5 \mathrm{~cm}$. long; flowers bright yellow; pods strongly compressed, slightly inflated, broadly notched at apex, narrowed at base. Common in gravelly or sandy soil about Spokane.

\section{LEPIDIUM Peppergrass.}

Erect or diffuse annual or biennial herbs; leaves pinnatifid to toothed or entire; flowers small, white or greenish, in racemes; pod orbicular to obovate, much flattened at right angles to the partition, 2-winged at the summit, each valve with one acute nerve forming a keel; seeds flattened, solitary in each cell.

Apex of the capsules bidentate, the valves pubescent and strongly reticulated.

Apex of the capsules merely emarginate, the valves glabrous

L. dictyotum. and not reticulated.

Petals wanting or very minute.

Petals present.

L. apetalum.

L. medium.

Lepidium dictyotum Gray. Annual, branched from the base, usually spreading; stems pubescent, 3-10 cm. long; leaves linear, entire or with one or two teeth, 2-4 cm. long, pubescent or glabrous; petals wanting or when present scarcely exceeding the sepals; pods ovate, strongly net-veined, puberulent. Walla Walla County, especially in alkaline soil.

Lepidium apetalum Willd. Annual, erect, much branched above, 30-90 cm. tall, minutely puberulent, at least below; lower leaves lanceolate, incisely serrate or lobed, 3-5 cm. long and petioled; upper narrower, sometimes entire; racemes elongate, densely flowered; petals none; pod orbicular, notched, glabrous, $3 \mathrm{~mm}$. long, on longer pedicels. Plentiful in sandy soil.

Lepidium medium Greene. ( $L$. idahoense Heller.) Much like L. apetalum but petals present, about as long as the sepals; leaves serrate-dentate, seldom lobed; stamens 6; pods glabrous or puberulent. In sandy soil in the warmer valleys. A form with only two stamens occurs commonly, often growing with the normal 6 -stamened plant. This has been named $L$. idahoense Heller and a more puberulent form $L$. simile Heller.

\section{THLASPI.}

Glabrous annual or perennial herbs; basal leaves entire or toothed; cauline oblong, auricled and clasping; flowers white or purplish; pod more or less compressed at right angles to the partition, the valves often winged at the apex; seeds $2-4$ in each cell.

Pods large, winged, deeply notched; annual.

Pods small, scarcely winged or notched; perennial. 
Thlaspi arvense L. Penny Cress. Annual, erect, glabrous, simple or branched, 15-40 cm. high; radical leaves oblanceolate, petioled; cauline oblong, obtuse, sagittate and half-clasping; petals white, spatulate, exceeding the sepals; pod orbicular, 8-12 mm. long, broadly winged, deeply notched. A bad weed, sparingly introduced.

Thlaspi alpestre glaucum A. Nelson. Perennial, glabrous and glaucous; stems usually several from a branched base, $10-20 \mathrm{~cm}$. high; basal leaves obovate or elliptic, petioled, entire or toothed; cauline oblong, entire, sessile and somewhat auriculate; flowers white; pods obovate, emarginate at apex. 4-8 mm. long. In the Blue Mountains.

\section{BURSA.}

Slender and mostly smooth annual herbs; ratical leaves tufted; flowers small, white, in racemes; pod compressed at right angles to the partition, many-seeded.

Bursa bursa-pastoris (L.) Weber. Shepherd's Purse. Stellate-pubescent below, glabrous above, $30-60 \mathrm{~cm}$. tall, sparingly branched; basal leaves in a rosette, lanceolate or oblanceolate, pinnately-lobed, 2-8 cm. long, dentate or entire; flowers white, about $2 \mathrm{~mm}$. long; pods triangular, cuneate, with a broad shallow notch at the apex. A common weed.

\section{HUTCHINSIA.}

Low spreading annual with entire or pinnately-lobed leaves; flowers minute, white, in crowded racemes which elongate in fruit; stigma sessile or nearly so; silicle oval, compressed at right angles to the partition, not cuneate, not notched at the apex; each valve conspicuously 1 -nerved.

Hutchinsia procumbens (L.) DC. Branched from the base, glabrous or sparsely pubescent, $5-15 \mathrm{~cm}$. high; stems decumbent or ascending; basal leaves pinnately lobed or entire; petioles 1-2 cm. long; cauline leaves spatulate or oblanceolate, sessile, entire, or with a few lobes; petals white, about as long as the sepals, $1 \mathrm{~mm}$. long; pods smooth, elliptic, $3-4 \mathrm{~mm}$. long, on slender pedicels.

\section{Family 42. CAPPARIDACEAE. CAPER FAMILY.}

Herbs with alternate mostly palmate leaves; flowers with petals in the form of a cross; stamens 6 or more but not tetradynamous; pod 1-celled with 2 parietal placentae; seeds kidneyshaped.

\section{CLEOME.}

Annuals with flowers in bracted racemes; petals entire, with claws; stamens 6; receptacle produced between the petals and stamens; ovary stipitate; pod linear to oblong, many-seeded.

Flowers yellow.

C. lutea.

Flowers purple.

C. serrulata. 
Cleome lutea Hook. Glabrous or nearly so, 1-2 m. tall; leaves 5-foliolate; leaflets entire, lanceolate to oblong; racemes dense; flowers yellow; stipe of pod usually shorter than the pedicel. Abundant along streams in the sagebrush region. Occasional in our limits.

Cleome serrulata Pursh. Leaves 3-foliolate; leaflets entire or minutely serrulate; flowers rose-purple. Pomeroy. Spreading along the railways from the sagebrush region.

\section{Family 43. CRASSULACEAE. Stonecrop Family.}

Succulent or fleshy plants, mostly herbs; stipules none; flowers regular and symmetrical, in cymes or rarely solitary; calyx hypogynous, mostly 4-5-parted or lobed; petals of the same number as the calyx-lobes, distinct or slightly united at the base, rarely wanting; stamens of the same number or twice as many as the petals; carpels of the same number as the sepals, distinct or united below; ovules numerous; follicles 1-celled; seeds minute; endosperm fleshy.

\section{SEDUM:' STONECROP.}

Fleshy mostly glabrous herbs, erect or decumbent; leaves alternate, entire or dentate, fleshy; flowers perfect, in terminal often 1-sided cymes; calyx 4-5-lobed or parted; petals 4-5, distinct or slightly united; stamens $8-10$, perigynous, the alternate ones usually attached to the petals; carpels $4-5$, distinct or united at the base; ovules numerous; follicles few-many-seeded.

Leaves becoming scarious; carpels divergent.

S. douglasii.

Leaves not becoming scarious.

Biennial; carpels widely divergent.

Perennial; carpels erect.

S. leibergii.

S. stenopetalum.

Sedum douglasii Hook. Stems erect, branched at base, from a stout rootstock, 15-20 cm. high; leaves lanceolate, attenuate at the apex, 6-12 mm. long, becoming white-scarious when old; axils of the cauline leaves commonly bearing short deciduous leafy branches by which the plant is propagated; flowers yellow, sessile, in an open cyme; petals lanceolate, acuminate, 5-6 mm. long, longer than the stamens; follicles diverging from their united bases. Basalt rocks and gravelly soil, common.

Sedum leibergii Britt. Biennial; stems mostly single, stout, erect; radical leaves spatulate; cauline green, lanceolate, acute, 5-10 mm. long; without propagating branches in the cauline leaf axils; flowers as in S. douglasii, the cymes larger. On rock ledges, common.

Sedum stenopetalum Pursh. Perennial from branched rootstocks, glabrous or minutely puberulent, green; stems erect, $6-15 \mathrm{~cm}$. high; leaves lanceolate, broadest at base, acute, sessile, 4-8 $\mathrm{mm}$. long; flowers bright yellow, nearly sessile, in a close cyme; petals lanceolate, acuminate, twice as long as the sepals; carpels $4 \mathrm{~mm}$. long, divergent only at the tips. On cliffs along the Clearwater River, Idaho, and in the Blue Mountains. 


\section{Family 44. SAXIFRAGACEAE. SaXifrage Family.}

Herbs or shrubs; leaves alternate or opposite; stipules usually none; flowers perfect or polygamo-dioecious; calyx usually 5lobed, free or adherent to the ovary; petals usually 4 or 5 , perigynous, rarely none; stamens usually definite in number and not more than twice the number of the calyx-lobes; pistil formed by the partial or complete union of 2-5 carpels; placentae axile or parietal; seeds usually numerous; endosperm present; embryo small.

Shrubs.

Leaves alternate.

Leaves opposite.

Herbs.

Ovary 2-celled; placentae axile.

Ovary 1-celled; placentae parietal.

Petals pinnatifid or 3-cleft into thread-like divisions,

Petals not with thread-like divisions.

Petals cleft or lobed.

Petals small and entire or none.

Stamens 10.

Stamens 5.
177. Ribes, 125.

178. Philadelphus, 127.

179. Saxifraga, 127.

180. Mitella, 128.

181. Tellima, 129.

182. Tiarella, 129.

183. HeUchera, 130.

\section{RIBES. Currant, Gooseberry.}

Low sometimes prickly shrubs; leaves alternate, often fascicled, palmately-veined and lobed; flowers small, solitary or racemose, mostly terminating short and 1-2-leaved axillary shoots; calyx-tube adherent to the globose ovary and more or less extended beyond it, 5-, rarely 4-cleft, commonly colored or petal-like; petals 4-5, small, perigynous; stamens as many as the petals and alternate with them; styles 2, more or less united; ovary 1-celled; ovules few or numerous; berry globose, fleshy, usually many-seeded.

Stems armed with spines at the nodes, and of ten prickly also;

fruit not separating from the pedicel.

Calyx-lobes longer than the tube; stamens decidedly longer than the whole calyx.

R. niveum.

Calyx-lobes not longer than the tube.

Stamens scarcely longer than the whole calyx; flowers green.

Stamens decidedly shorter than the whole calyx; flowers white.

Calyx-tube cylindric, pubescent.

Calyx-tube campanulate, glabrous.

Stems not armed with spines but in some species prickly;

R. purpusi.

R. cognatum.

$R$. irriguum.

fruit easily separating from the pedicel.

Stems prickly; calyx saucer-shaped; racemes pendent. $R$. lacustre.

Stems not prickly; calyx various. 
Calyx-tube saucer-shaped; racemes erect.

Calyx-tube cylindric or campanulate.

Flowers yellow.

$R$. petiolare.

Flowers white.

R. aureum.

Berries red or orange, glabrous or slightly glandular; leaves resinous-dotted; raceme drooping.

\section{R. cereum.}

Berries black, glandular; leaves viscidpubescent; inflorescence corymbose.

$R$. viscosissimum.

Ribes niveum Lindl. Erect shrubs, 1-3 m. high, armed with stout solitary or triple dark spines but not prickly; leaves orbicular, truncate or cuneate at base, the lobes bluntly 3-5-toothed, minutely ciliate, otherwise glabrous, 1-2 $\mathrm{cm}$. long; petioles slender, longer than the leaves, the 3-5 flowers mostly nodding; calyx-tube narrow, shorter than the linear white lobes; stamens much exserted; filaments hairy; berries smooth, black, as large as a pea. Along Snake River.

Ribes purpusi Koehne. (Ribes inerme Rydb.) Low spreading shrubs, about $1 \mathrm{~m}$. high, unarmed or with feeble simple spines and a few prickles; young shoots glabrous, the leaves somewhat puberulent or glabrous; leaves orbicular, cordate, 5-lobed, coarsely-toothed, 1-3 cm. long and broad; racemes drooping, 2- or 3-flowered; calyx-tube bell-shaped, green, about $3 \mathrm{~mm}$. long, as long as the obtuse grcenish or purplish reflexed lobes; stamens exserted, as long as the lobes; filaments nearly glabrous; berries small, black. Pullman, along streams.

Ribes cognatum Greene. Erect shrubs, 1-2 m. high, armed with pale triple spines, sometimes very prickly as well; leaves and young shoots densely puberulent, sometimes glandular; leaves orbicular, trunca or cordate at base, 3-5-lobed, incisely dentate, 2-3 cm. broad; petioles hairy, long as or shorter than the blades; racemes 2 - or 3-flowered, drooping; bracts glandular; pedicels very short; calyx-tube cylindrical, whitish, pubescent, 5-6 mm. long, larger than the oblong spreading lobes. Along streams.

Ribes irriguum Dougl. Very similar to $R$. cognatum, but the calyx-tube broader, campanulate and glabrous, $3-4 \mathrm{~mm}$. long; bark often white and the spines few. Common in the Blue and Craig Mountains and about Spokane.

Ribes lacustre (Pers.) Poir. Stout, 1-2 m. high, armed with short 3-5-lobed spines and very numerous bristly prickles; leaves orbicular, cordate, deeply 5-lobed, incisely dentate, minutely glandular, 2-4 cm. long; racemes loose, drooping; flowers greenish or purplish, slender-petioled; calyx short, saucershaped, the obtuse lobes spreading; stamens very short; berries nearly black, bristly-glandular. Moist woods in the mountains.

Ribes petiolare Dougl. Unarmed, glabrous or nearly so, about $1 \mathrm{~m}$. high; leaves round-cordate, 5-lobed, serrate, resinous-dotted beneath, the slender petioles usually longer; racemes erect, $5-12 \mathrm{~cm}$. long; pedicels longer than the bracts; calyx whitish, the tube very short, the lobes erect, puberulent; ovary resinous-dotted; berry black. On the high peaks of the Blue Mountains.

Ribes aureum Pursh. Golden Currant. Unarmed, 1-2 m. high, usually glabrous throughout; leaves thick, somewhat orbicular, cuncate or rounded or truncate at base, deeply 3-lobed, the lobes coarsely 3-5-toothed or entire, 2-3 cm. broad; petioles slender, about as long as the blades; flowers bright yellow, in dense ascending or spreading racemes; calyx-tube slender, cylindrical, about $10 \mathrm{~mm}$. long, the obt use lobes spreading; petals short, oblong, frequently dark-red; stamens short; berries black, red or golden. In the warmer valleys.

Ribes cereum Dougl. About $1 \mathrm{~m}$. high, with numerous short branches, the young commonly resinous-dotted and glutinous; shoots and under sides 
of the leaves puberulent; leaves orbicular, somewhat 3-5-lobed, crenatedentate, rounded or subcordate at base, about $1 \mathrm{~cm}$. long; petioles mostly shorter than the leaves; pedicels very short; racemes short, dense, 3-5-flowered, drooping; calyx white, cylindric, 6-8 $\mathrm{mm}$. long, glandular, the short lobes obtuse; petals orbicular; berry orange-red, insipid. On warm rocky hillsides.

Ribes viscosissimum Pursh. Unarmed, about $1 \mathrm{~m}$. high, pubescent throughout and somewhat glandular; leaves cordate-orbicular, obtusely 5-lobed, somewhat doubly dentate, soft-pubescent, especially beneath, 2-5 $\mathrm{cm}$. broad; petioles about as long as the blades, hirsute-glandular; raceme ascending, shorter than the leaves; bracts oblong or obovate, obtuse, conspicuous; flowers whitish or purplish, about $10 \mathrm{~mm}$. long, on short pedicels which become slender and elongate in fruit; calyx-tube campanulate, becoming cylindric, the erect lobes acute, shorter; petals small, white; berry black, rather dry. In mountain woods.

\section{PHILADELPHUS.}

Shrubs; leaves opposite, petioled, entire or toothed, ovate or oblong, without stipules; flowers large, showy, white, solitary or cymose-clustered; calyx-tube top-shaped, 4- or 5-lobed, adherent to the ovary nearly or quite to its summit; petals 4 or 5 , large, obovate or roundish; stamens $20-40$, on the disk; styles $3-5$, more or less united; ovary 3-5-celled, inferior; ovules numerous; capsule 3-5-valved; seeds very numerous.

Philadelphus lewisii Pursh. Syringa. Shrubs 1-3 m. high, much branched above; leaves ovate, acute or acuminate, entire or sparingly dentate, glabrous or nearly so, 2-4 cm. long; petioles short; panicles narrow, few-flowered, 5-10 $\mathrm{cm}$. long; calyx-lobes acute or acuminate, twice as long as the tube, densely pubescent at the tips within; petals oblong, 1.5-2 cm. long; styles united for half their length or rarely more; stigmas narrow. A handsome shrub, the flowers odorous.

\section{SAXIFRAGA. SAXIFRAGE.}

Chiefly perennial herbs; stem short or none; radical leaves tufted; cauline mostly alternate; flowers perfect, solitary or in cymes or cymose panicles; calyx 5-lobed, free or adhering to the base of the ovary; petals 5 , entire, perigynous; stamens 10 , perigynous; carpels 2 , nearly distinct or uniting into a 2-celled ovary; placentae axile; styles distinct; capsules 2-beaked, 2celled, sometimes two almost separate follicles.

Leaves coarsely toothed, cordate, long-petioled.

Caudex bulbous; herbage somewhat glandular; leaves doubly dentate.

Caudex not bulbous; herbage glabrous; leaves simply dentate.

S. mertensiana.

$$
\text { dentate. }
$$

Leaves not coarsely toothed, not cordate, short-petioled.

Filaments broadest at top.

Filaments broadest at base.

Petals longer than the sepals.

Petals shorter than the sepals.

$$
\text { Petals oblong. }
$$

Petals obovate.

S. odontoloma.

S. saximontana.

S. fragosa.

S. columbiana.

S. planlaginea. 
Saxifraga mertensiana Bong. Leaves nearly all basal, the blades orbicular-reniform, incisely many lobed, the lobes mostly 3-toothed at apex; stems $10-30 \mathrm{~cm}$. high; panicle loose, the branches flowering at the tips and usually bearing bulblets below; sepals reflexed; petals white, oblong or obovate, short-clawed; filaments broadest at top. On moist cliffs, especially in the mountains.

Saxifraga odontoloma Piper. Glabrous or nearly so; leaves orbicularreniform, deeply cordate, coarsely and equally toothed, rather thick, longpetioled; scapes 10-30 cm. high; inflorescence corymbose, of ten loose, not bulblet-bearing; sepals reflexed; petals white, obovate; filaments broadest at top. Along streams in the Blue Mountains.

Saxifraga saximontana E. Nelson. Stems slender, erect, $20-30 \mathrm{~cm}$. high, glandular; leaves all basal, oblong-ovate, dentate or crenate, glabrous except the margins, the petioles short and broad; inflorescence a loose much branched cyme; sepals reflexed; petals white, broadly oval to ovate or obovate, shortclawed. On moist rock cliffs, along the Clearwater, Idaho.

Saxifraga fragosa Suksdorf. Erect, more or less viscid-glandular; leaves all basal, broadly ovate, entire or minutely denticulate, $3-8 \mathrm{~cm}$. long; shortpetioled; scapes $10-30 \mathrm{~cm}$. high, usually solitary; inflorescence a rather loose pyramidal cyme; calyx-lobes erect, longer than the tube; petals obovate, obtuse, white, 3-3.5 cm. long. On moist banks.

Saxifraga columbiana Piper. Erect, somewhat viscid-pubescent throughout, $30-40 \mathrm{~cm}$. high; leaves all radical, ovate or lanceolate, obtuse, petioled, entire or nearly so, the blades $2-4 \mathrm{~cm}$. long; inflorescence a narrow pyramidal branched cyme; flowers greenish, 5-6 mm. in diameter; calyx-lobes triangularovate, obtuse, longer than the short tube, becoming reflexed; petals narrowly obovate, shorter than the calyx-lobes; stamens very short; ovary disk-like, crenate on the edges, half-inferior. Springy places, common.

Saxifraga plantaginea Small. Similar to $S$. columbiana but stouter; leaves mostly oval, broad; petals obovate. Spokane, Sandberg and Leiberg.

\section{Mitella. Mitrewort.}

Low slender perennial herbs; leaves simple, mostly radical, long-petioled, ovate or orbicular; cauline rarely few, usually none; flowers small, white or greenish, in a simple raceme; calyx short, the broad tube 5-lobed, adherent to the base of the ovary and dilated beyond it; petals 5 , slender, pinnatifid or 3-cleft into thread-like lobes; stamens 10 or 5 , very short; styles 2 , short; ovary globose, 1-celled, with 2 parietal almost basal placentae, partly superior; capsule globular or depressed, hardly at all lobed: seeds several to each placenta.

Stamens opposite the pinnatifid green petals.

Stamens alternate with the petals.

Calyx green; petals pinnatifid.

Calyx white; petals 3-parted.

M. pentandra.

M. caulescens.

M. stauropetala.

Mitella pentandra Hook. Scapes $10-30 \mathrm{~cm}$. high, puberulent; leaves all basal, broadly cordate, coarsely crenate, sparsely pubescent, petioled; raceme loose; calyx saucer-shaped, the lobes short and obtuse; petals pinnately divided into 7-9 filiform lobes. In moist woods in the mountains. 
Mitella caulescens Nutt. Stems slender, 25-40 cm. high, bearing 1-3 petioled alternate leaves; basal leaves broadly ovate, cordate, 5-7-lobed, crenate-dentate, sparsely hairy; flowers greenish, in a loose raceme; petals pinnately cleft into $7-9$ filiform lobes; plants producing runners in summer. In moist woods, rare.

Mitella stauropetala Piper. Scapes $30-50 \mathrm{~cm}$. high, sparsely pubescent below, minutely glandular above; leaves all basal, orbicular, indistinctly 5-lobed, slightly crenate, reniform, with a narrow sinus, sparsely pilose and ciliate; raceme one-sided, 6-12 cm. long, 10-25-flowered; flowers white, nearly sessile; calyx-lobes oblong-ovate, crenulate, 3-nerved; petals twice as long as the sepals, 3-parted for half their length into filiform lobes, the lateral lobes divaricate. In coniferous woods in the mountains.

\section{TELLIMA.}

Perennial herbs; stem simple or branched at the base; leaves few, round-cordate, toothed or palmately-divided, chiefly alternate; petioles with stipule-like dilations at the base; flowers in a single terminal raceme; calyx 5-lobed, campanulate or turbinate, the base adhering to the base or lower half of the ovary; petals 5 , white, whitish or pink, on the throat or in the sinuses of the calyx, cleft or lobed; stamens 10 , short, included; ovary short, 1-celled, with 2 or 3 parietal placentae; styles 2 or 3 , very short; capsule conical, slightly 2- or 3-beaked; seeds very numerous. Our species bear propagating bulblets at the base and frequently in the axils of the upper leaves.

Calyx obconic; petals 3-parted.

Calyx bell-shaped; petals 3-7-parted.

T. parviflora. T. tenella.

Tellima parviflora Hook. Rough-pubescent, 15-30 cm. high; leaves palmately 3-5-parted; segments cuneate, 3-cleft, the lobes sometimes again cleft; pedicels erect, mostly as long as or longer than the calyx; calyx 4-6 mm. long, obconic or club-shaped; petals pink, deeply 3-cleft; ovary half-inferior. Stony soil, common.

Tellima tenella (Nutt.) Walp. Much like $T$. parviflora, smaller and more slender, pubescent, minutely glandular; pedicels spreading; calyx bell-shaped, $3 \mathrm{~mm}$. long; petals 3-7-cleft into linear lobes; ovary free except at base. With $T$. parviflora but blooming about two weeks earlier.

\section{TIARELLA.}

Slender perennial herbs; leaves palmately lobed, sometimes with small stipules; flowers small, white, in a terminal raceme or panicle; calyx-tube campanulate, 5-parted, nearly free from the ovary; petals 5 , entire, small, with short claws; stamens 10 ; filaments long and slender; styles 2; ovary 1-celled, 2-horned; placentae parietal, becoming almost basal in fruit; ovules numerous; capsule 1-celled, 2-valved, the valves usually unequal; seeds usually few.

Tiarella unifoliata Hook. Pubescent throughont or nearly glabrous; stems simple, $15-40 \mathrm{~cm}$. high, erect or ascending; radical leaves ovate or 
orbicular, cordate, long-petioled, 3-7-lobed, the lobes crenate-dentate; cauline 1-3, similar but smaller, short-petioled; panicle narrow, loose, 5-15 cm. long; flowers white; petals small, thread-like. In moist woods in the mountains.

\section{HEUCHERA. ALUM ROOT.}

Perennial herbs; leaves mostly basal, long-petioled, rounded, mostly cordate; cauline, if any, alternate; petioles with dilated margins or adherent stipules; flowers greenish or purple, in clusters which form a long narrow panicle; calyx tube campanulate, 5-lobed, coherent with the lower half of the ovary; lobes sometimes unequal; petals 5 , small, entire, sometimes minute or wanting, or early deciduous; stamens 5 ; styles 2 , slender; ovary 1 -celled, with 2 parietal placentae; capsule 1 -celled, more or less 2-beaked; seeds numerous.

Petioles and scape hirsute.

Petioles and scape not hirsute.

Herbage glabrous or nearly so.

Herbage glandular puberulent.

H. cylindrica.

H. glabella.

H. ovalifolia.

Heuchera cylindrica Dougl. ( $H$. columbiana Rydb.) Leaves all basal, reniform-cordate, 5-7-lobed, crenate-dentate, the teeth cuspidate, the petioles much longer than the blades and villous; stems erect, villous below, 30-60 $\mathrm{cm}$. high; inflorescence spike-like, very dense, 5-10 cm. long; calyx yellowish, 7-9 mm. long. Infrequent, Lewiston and Spokane County.

Heuchera glabella T. \& G. Tufted, glabrous or nearly so below the infiorescence; leaves all radical, cordate-orbicular, 5-9-lobed, obscurely crenate, the teeth bristle-tipped, $2-5 \mathrm{~cm}$. broad; petioles slender, mostly $2-4$ times as long as the blades; scapes stout, $30-60 \mathrm{~cm}$. high; inflorescence a spike-like panicle, glandular-puberulent; calyx yellowish, campanulate, 6-7 mm. long. Grassy hillsides, common.

Heuchera ovalifolia Nutt. Densely and minutely glandular-pubescent throughout; leaves all basal, broadly oval or ovate, slightly cordate, shallowly 5-lobed, crenate-dentate; stems erect, $10-30 \mathrm{~cm}$. high; inflorescence dense, $2-6 \mathrm{~cm}$. long; calyx greenish, 6-7 mm. long. Rocky places in the Blue Mountains.

\section{Family 45. ROSACEAE. Rose Family.}

Herbs, shrubs or trees; leaves alternate, simple or compound, usually with evident stipules which are often quickly deciduous; flowers regular, mostly perfect, rarely polygamo-dioecious; calyx of 5 , rarely $3-8$, sepals, united at the base, often surrounded by a row of bractlets; calyx-tube lined by the disk; petals as many as the sepals, rarely wanting, on the edge of the calyx-tube; stamens usually numerous, or few and coherent with the calyxtube; carpels 1-many, distinct and free, or few and coherent with the calyx-tube into a 2-several-celled inferior ovary; seeds few or solitary; endosperm none, scanty or rarely copious. 
Pistil one.

Fruit a drupe; petals present.

Fruit an akene; petals none.

Shrubs or small trees; leaves not lobed.

Herbs; leaves lobed.

Leaves palmately lobed; flowers axillary. 194. Alchemilla, 137.

Leaves pinnately lobed; flowers in a spike. 195. SANGUISORBA, 138.

Pistils more than one.

Pistils 2-5, united with each other and with the lower part of the receptacle and calyx-tube with which in fruit they form a pome.

Flowers in racemes; locules of mature pomes 10.

184. Prunus, 132.

185. Cercocarpus, 132.

Flowers in corymbs or cymes; locules 1-5.

Carpels stony in fruit; plant thorny.

186. Amelanchier, 133.

Carpels papery in fruit; plant not thorny. 188. PYRUS, 134.

Pistils few or many, free.

Fruit of few 2-several-seeded follicles.

Leaves palmately lobed.

Leaves not palmately lobed.

Stamineal disk adherent, entire; ovules

2.

Stamineal disk free at the edge, not entire; ovules 5 or more.

Fruit of numerous 1-2-seeded akenes or drupelets.

Fruit of drupelets, usually united.

Fruit of akenes.

Receptacle urn-shaped or bell-shaped, enclosing the akenes.

Receptacle fleshy; akenes numerous; petals present.

Receptacle dry; akenes 1-4; petals none.

Leaves palmately lobed; flowers axillary.

Leaves pinnately lobed; flowers in a spike.

Receptacle flat or but slightly concave.

Styles persistent, mostly plumose or geniculate.

Styles jointed, the upper part deciduous.

Styles not jointed, plumose or naked.

Styles deciduous, naked.

Styles terminal.

Stamens near the base of the receptacle-cup on a thickened ring.

Stamens well up on the receptacle-cup; no thickened ring.

Styles lateral.

Stamens 5; carpels 10-15. 200. Sibbaldia, 140.

Stamens 20; carpels numerous.

Leaves trifoliolate; re-

ceptacle fleshy in fruit. 201. FraGaria, 141.
194. Alchemilla, 137.

195. SANguisorba, 138.
196. Geum, 138.

197. Sie versia, 139.
198. Potentula, 139.

199. IVESIA, 140.
189. Opulaster, 134.

190. Holodiscus, 135.

191. SpIRAea, 135.

192. Rubus, 136. 
Leaves pinnate; receptacle not fleshy.

Flowers dark purple; receptacle spongy. 202. Comarum, 141.

Flowers yellow or whitish; receptacle dry.

Plant stolonifero u s ; flowers solitary.

Plant not stolonif203. Argentina, 142. erous; flowers cymose.

204. Drymocallis, 142.

184. PRUNUS. Plum. Cherry.

Small trees or shrubs, many with edible fruits; leaves alternate, simple, usually serrulate; flowers white or rose-colored, solitary or fascicled in the axils or in terminal racemes or corymbs; calyx 5-lobed, free from the ovary; petals 5 , on the receptacle-cup; stamens numerous; pistil 1; style 1; ovary 1 -celled, 2-ovuled; fruit a drupe; seed 1 , rarely 2 ; endosperm none.

Flowers racemose.

Flowers corymbose.
$P$. demissa.

$P$. emarginata.

Prunus demissa (Nutt.) Dietr. Chokecherry. Shrub or small tree, $2-8 \mathrm{~m}$. high; leaves ovate or oblong-ovate, cuneate, rounded or cordate at the base, sharply serrate, 5-10 cm. long, sometimes somewhat pubescent beneath; petioles $1-2 \mathrm{~cm}$. long, appearing after the leaves; calyx somewhat glandular; petals nearly orbicular; fruit globose, dark purple, 5-6 mm. in diameter, not edible; stone globose. Common along streams.

Prunus emarginata (Dougl.) Walp. Wild Cherry. Shrub or small tree 3-8 m. high; branches and bark chestnut brown, with prominent lenticels; leaves narrow, ovate, elliptical or obovate, obtuse or acute, cuneate at base, minutely serrate, glabrous or pubescent beneath, 3-8 cm. long, short-petioled; corymbs few-flowered, appearing with the leaves; flowers about $1 \mathrm{~cm}$. broad; fruit oblong, bright red, bitter; stone with a grooved ridge on one side. In dry open places in the mountains.

\section{CERCOCARPOS.}

Shrubs or small trees with alternate simple petioled leaves; flowers perfect, solitary or clustered, axillary or terminal, sessile or nearly so; calyx narrowly tubular, 5-lobed; petals none; stamens 15-25, perigynous; pistil 1, narrow, terete; fruit a coriaceous, linear, terete akene with a long exserted plumose twisted style.

Cercocarpus ledifolius Nutt. Mountain Mahogany. Scraggly shrub or tree, 3-10 m. high; leaves coriaceous, lanceolate, entire, acute, 1-nerved, tomentose beneath, usually glabrous above, short-petioled, $2-3 \mathrm{~cm}$. long, the margins more or less inrolled; flowers sessile, tomentose; tail of the akene when mature 5-7 cm. long. In sheltered places on high ridges in the Blue Mountains. 


\section{AMELANCHIER. SERvice BerRy.}

Shrubs or small trees, not thorny; leaves alternate, simple, petioled, serrate or entire; flowers white, in racemes; calyx-tube campanulate, 5-lobed, more or less adherent to the ovary; petals 5 ; stamens numerous, on the calyx-tube; styles $2-5$, united below or distinct; ovary 5 -celled, each cell 2 -ovuled; berry-like pome 10 -celled, by the growth of a false partition in each cell of the ovary; each cell 1-ovuled.

Young leaves loosely tomentose beneath, toothed only above the middle.

Young leaves glabrous, mostly sharply serrate from the base.

Young leaves bright green; petals nearly $2 \mathrm{~cm}$. long.

Young leaves pallid; petals $1 \mathrm{~cm}$. long.

A. florida.

Amelanchier florida Lindl. Shrub or small tree, 2-5 m. high; leaves broadly oblong, rounded or subcordate at base, obtuse, tomentose when young, especially beneath, glabrate, toothed above the middle or rarely entire, 2-4 cm. long; petioles pubescent, 1-2 cm. long; racemes 4-8 cm. long; calyx pubescent, the triangular acute lobes not longer than the tube; petals oblanceolate, obtuse, about $1 \mathrm{~cm}$. long. Common along streams and on moist hillsides.

Amelanchier cusickii Fernald. Shrub, 3-6 m. high, with numerous virgate branches, the young bark chestnut-brown; leaves glabrous from the first, oblong or orbicular, obtuse or acute, rounded or cordate at base, mostly sharply serrate the whole length; petioles slender, glabrous; racemes short, dense; calyx-lobes slightly hairy, acuminate, longer than the tube; petals oblongoblanceolate, obtuse, about $2 \mathrm{~cm}$. long. Common on basalt ledges along the rivers; blooming ten days earlier than $A$. florida.

Amelanchier basalticola Piper. Small shrub, with pale bark, even on the young branchlets; leaves appearing before the flowers, orbicular or oblong, mostly truncate at base and apex, serrate above the middle or less commonly from the base, glabrous and glaucous from the first, firm in texture, $1.5-2 \mathrm{~cm}$. long, on slender petioles, nearly as long; racemes very short, few-flowered; calyx-lobes attenuate-acuminate, sparsely hairy, longer than the tube; petals narrow, oblong-oblanceolate, obtuse, $10-12 \mathrm{~mm}$. long; stamens 20 , the filaments united into a disk-like structure at the base; styles separate; mature fruit not seen. Bluffs of Snake River.

\section{CRATAEgUS. ThORN. HawthorN.}

Shrubs or small trees, mostly thorny; leaves alternate, petioled, entire, serrate, lobed or pinnatifid; flowers white, rarely rosecolored, in terminal corymbs; calyx-tube cup-shaped or campanulate, adherent to the carpels, the limb 5-lobed; petals 5, roundish, on the calyx-tube; stamens many, or only 5 or 10 ; styles 1-5, separate; ovary inferior, or its summit free; ovules one to each carpel; pome small, drupe-like, with $1-5$ bony carpels, each 1 -seeded.

Calyx pubescent; fruit red; spines 3-6 cm. long.

Calyx nearly glabrous; fruit black; spines $1-3 \mathrm{~cm}$. long.

C. columbiana.

C. brevispina. 
Crataegus columbiana Howell. A much-branched shrub, 2-4 m. high; bark of older stems light gray; that of the younger twigs light brown, the lenticels conspicuous; the branches of the season and the inflorescence strigosevillous; thorns $2-5 \mathrm{~cm}$. long, dark-brown, shining, straight or nearly so, somewhat reflexed; petioles $1-2 \mathrm{~cm}$. long, bearing several glands; leaf-blades broadly oval in outline, sparingly strigose on both sides, dark and glossy above, paler and dull beneath, incised and doubly serrate at or above the middle but merely serrate on the cuneate base; tecth sharp and gland-tipped; apex short, acuminate; corymbs 4-12-flowered; calyx villous; sepals 3-5 $\mathrm{mm}$. long, prominently glandular-dentate; anthers white; fruit spherical or nearly so, about $12 \mathrm{~mm}$. in diameter, coral-red, glabrous; nutlets ridged on the back, without cavities on the ventral faces. Springy gravelly places, infrequent.

Crataegus columbiana piperi (Britt.) Eggleston. More pubescent; calyx and pedicels somewhat villous; fruit pubescent. More common than the species and intergrading with it.

Crataegus brevispina (Dougl.) Heller. Shrubs, 2-6 m. high; spines stout, $2-3 \mathrm{~cm}$. long; leaves obovate, broadly cuneate at hase, coarsely doubly dentate above the middle, acute or obtuse, sparsely pubescent on both sides when young, paler beneath, $2-5 \mathrm{~cm}$. long; petioles short, glandless; corymbs usually manyflowered; flowers about $12 \mathrm{~mm}$. broad; calyx-tube glabrous, the lanceolate lobes pubescent; anthers pink; fruit black, smooth; nutlets with cavities on the ventral faces. Common along streams.

\section{PYRUS.}

Trees or shrubs, not thorny (in ours); leaves simple or compound; flowers in corymbed cymes; calyx urn-shaped, 5-cleft; petals roundish or obovate; stamens numerous; styles 2-5; pome fleshy or berry-like, the $2-5$ carpels or cells of a papery or cartilaginous texture, 2 -seeded.

Pyrus sitchensis (Roem.) Piper. Mountain Ash. Shrub, 2-5 m. high, with smooth bark; young branches pubescent; leaves pinnate, $12-20 \mathrm{~cm}$. long; leaflets 4-6 pairs, mostly oblong, acute or acuminate, simply or doubly serrate, glabrous or nearly so, shiny above, 2-6 cm. long, 1-2 cm. broad; cymes dense, compound, $8-12 \mathrm{~cm}$. broad; flowers white, $8 \mathrm{~mm}$. broad; calyx and pedicels loosely woolly-pubescent; fruit bright-red, about $6 \mathrm{~mm}$. in diameter. In mountain woods.

\section{OPULASTER. NINEBARK.}

Branching shrubs; leaves petioled, simple, palmately-lobed; flowers in umbel-like corymbs; calyx 5-lobed; petals 5 , round, on the calyx-tube; stamens many, distinct, on the calyx-tube; pistils 1-5, more or less united; follicles 1-5, 2-valved; seeds $2-4$; endosperm copious.

Carpels pubescent, not exceeding the calyx.

O. pauciflorus. Carpels glabrous, much exceeding the calyx.

O. opulifolius.

Opulaster pauciflorus (T. \& G.) Heller. (O. malvaceus Greene.) Erect shrubs, about $1 \mathrm{~m}$. high, the branches spreading or recurved, the bark shreddy; leaves $2-8 \mathrm{~cm}$. long, broadly ovate or orbicular, bluntly $3-5$-lobed, somewhat doubly dentate, nearly glabrous above, pubescent beneath with stellate hairs: petioles 1-2 cm. long; inflorescence a corymb, 3-5 cm. broad, woolly-pubescent 
throughout; pedicels slender; calyx broadly campanulate, the blunt lobes as long as the tube; petals white, obovate, longer than the calyx-lobes; carpels 2 or 3 , pubescent, flattened, somewhat united at the base, as long as the calyx, tardily dehiscent. Mostly in pine woods, common.I

Opulaster opulifolius (L.) Kuntze. Very similar to O. pauciflorus, usually larger; carpels glabrous, a half longer than the calyx. Along streams in woods. The western form is by some authors considered distinct and has been called $O$. capitatus (Pursh) Kuntze.

st var ex

\section{HOLODISCUS.}

Thornless shrubs; leaves alternate, simply pinnately toothed or lobed, without stipules; flowers numerous, white, in terminal panicles; calyx deeply 5-lobed; petals 5 , as long as the calyx lobes, rounded; stamens 20 , on a perigynous entire ring-like adherent disk, scarcely exserted; pistils 5 , with 2 ovules, becoming 1-seeded hairy carpels almost indehiscent.

Holodiscus discolor (Pursh) Maxim. Ocean Spray. Large shrub, 2-5 m. high; young twigs pubescent; leaves triangular-ovate, mostly obtuse, truncate or cuneate at base, woolly-pubescent beneath, glabrous above, $2-5 \mathrm{~cm}$. long; panicle broadly pyramidal, much branched, $10-20 \mathrm{~cm}$. long; flowers small, white, becoming yellowish; calyx densely short-pubescent, the lobes acute, spreading. In canyons and on warm timbered slopes.

\section{SPIRAEA.}

Shrubs or perennial herbs; leaves alternate, simple, without stipules; flowers white or pink, perfect, in racemes, cymes, corymbs, or panicles; calyx 4- or 5-lobed; petals 4 or 5, exceeding the calyx and inserted on the calyx-tube; stamens numerous, distinct, on a disk which is free at the edge and crenate or glandulartoothed; filaments much exserted; pistils commonly 5 , superior, alternate with the calyx-lobes; ovules 5-11; follicles usually 5, not inflated, 1-valved; seeds few-several.

Flowers panicled.

Flowers corymbose.

S. menziesii.

S. corymbosa.

Spiraea menziesii Hook. Erect shrub, 1-1.5 m. high, not much branched, minutely pubescent on the young twigs and under side of the leaves; leaves oblong, acute or obtuse, rounded or cuneate at base, green on both sides, coarsely serrate above the middle, rarely entire, 3-6 cm. long; petioles short; panicles dense, pyramidal or oblong, 5-20 cm. long; flowers rosecolored; calyx-lobes becoming reflexed; carpels 5, glabrous. In moist places in wooded regions.

Spiraea menziesii pyramidata (Greene) Piper n. comb. (S. pyramidata Greene.) Flowers white. Often growing with the species and intermediate pink flowered forms occurring also.

Spiraea corymbosa Raf. Low shrub, 30-60 cm. high, branched below; leaves elliptic or ovate, rounded at base, $2-6 \mathrm{~cm}$. long, coarsely and unevenly serrate or incised above the middle, green and glabrous on both sides; petioles short; inflorescence a flat-topped dense corymb, 5-12 cm. across; flowers small, white; carpels 5, glabrous. Common in open woods or copses. 


\section{RUBUS.}

Perennial herbs or shrubs or vines, often prickly; leaves alternate, simple, or pinnately 3-7-foliolate, with stipules adherent to the petiole; flowers white or reddish, solitary or in racemes or corymbs; calyx 5-lobed, without bractlets; petals 5, conspicuous; stamens numerous, on the calyx-tube; styles nearly terminal; carpels numerous, on the convex receptacle, ripening into 1seeded drupelets forming an aggregate fruit.

Stems trailing; fruit not separating from the receptacle when ripe.

Stems erect or ascending; fruit separating from the receptacle

R. macropetalus. when ripe.

Leaves 3-5-lobed; stems unarmed, perennial.

Leaves 3-5-foliolate; stems prickly, biennial.

Berry red; stems not glaucous.

Berry black; stems glaucous.

Leaves glaucous beneath.

Leaves green beneath,

R. parviflorus.

$R$. strigosus.

$R$. leucodermis.

$R$. hesperius.

Rubus macropetalus Dougl. Dewberry. Stems slightly woody, biennial, prickly, trailing, 1-8 m. long, usually unbranched the first year, but bearing numerous short flowering branches the second year; leaves 3 -foliolate, rarely 5 -foliolate; leaflets ovate, mostly acute, rounded or cordate at base, doubly and somewhat incisely dentate, pubescent especially beneath, $2-5 \mathrm{~cm}$. long; calyx glandular and prickly; petals white, 1-2 times as long as the sepals which have an acute somewhat foliaceous tip; fruit black when ripe, cylindrical, $1-3 \mathrm{~cm}$. long, finely flavored. In open woods, especially old "burns."

Rubus parviflorus Nutt. Thimble Berry. Stems wholly unarmed, perennial, 1-1.5 m. high; bark brownish, becoming shreddy, usually glandularpubescent when young; leaves palmately and acutely 5-lobed, irregularly serrate, cordate at base, soft-pubescent or nearly glabrous, $10-30 \mathrm{~cm}$. broad; petioles about as long as the blades, with stipules; corymbs few-flowered; calyx glandular and woolly; petals white, about $2 \mathrm{~cm}$. long; fruit red, flatconvex, juicy, about $2 \mathrm{~cm}$. broad. Common in open woods; rare away from timber.

Rubus strigosus Michx. Red Raspberry. Stems erect, biennial, 1-2 m. high, densely armed with weak, glandular bristles or sometimes nearly unarmed; leaves mostly 3 -foliolate, rarely 5 -foliolate; leaflets ovate, acuminate, simply or doubly dentate, rounded at base, thin, usually white-tomentose beneath, glabrous above, $2-6 \mathrm{~cm}$. long; corymbs few-flowered; calyx usually pubescent and bristly; petals white, about as long as the acuminate sepals; fruit hemispherical, light red. In low woods and on talus slopes.

Rubus leucodermis Dougl. Blackcap. Erect shrubs; the biennial stems 1-2 m. high, very glaucous, armed with stout straight or curved prickles; leaves 3 -foliolate, rarely 5 -foliolate; leaflets ovate, acuminate, doubly serrulate, white-pubescent beneath, the lateral ones oblique and frequently with one or two lobes; petioles and midveins prickly; flowers small, in few-flowered corymbs; petals white, small, erect, shorter than the reflexed sepals; fruit nearly black when mature, hemispherical, glaucous or tomentose, about $1 \mathrm{~cm}$. broad. In wet places in woods.

Rubus hesperius Piper. Much like $R$. leucodermis but with more numerous stouter straight or curved prickles; leaves green and glabrous on both sides; berries black, glabrous. Snake River canyon. 
193. ROSA. ROSE.

Erect or climbing shrubs, usually with prickly stems; leaves alternate, odd-pinnate, with adherent stipules; leaflets mostly serrate; flowers solitary or in corymbs; receptacle-tube cup or urn-shaped, becoming fleshy in fruit, usually 5-lobed, without bractlets; petals 5, large, obcordate; stamens numerous, on the receptacle-tube; styles distinct or united; carpels numerous, sessile, within the receptacle-tube; akenes numerous, enclosed in the berry-like receptacle-tube.

Flowers small, about $2 \mathrm{~cm}$. in diameter; calyx-lobes deciduous from the fruit.

Flowers large, $3 \mathrm{~cm}$. or more in diameter; calyx-lobes persistent.

Flowers mostly solitary; fruit globose, $2 \mathrm{~cm}$. broad.

Flowers in corymbs; fruit ovoid or oblong, not more than

$1 \mathrm{~cm}$. broad.

R. gymnocarpa.

R. nutkana.

R. pisocarpa.

Rosa gymnocarpa Nutt. Small shrub, about $1 \mathrm{~m}$. high, armed with numerous slender straight prickles; leaflets 5-9, elliptic, cuneate at base, serrate, nearly glabrous, 5-20 mm. long; serratures and petioles glandular; flowers mostly solitary, about $2 \mathrm{~cm}$. in diameter; calyx-lobes acuminate, not foliaceous, appendaged, deciduous from the fruit; fruit oblong or pear-shaped, about $1 \mathrm{~cm}$. long. In dry woods.

Rosa nutkana Presl. Stout, 1-2 m. high, armed with few but stout prickles; leaflets 5-7, ovate or elliptic, obtuse, coarsely serrate, $1-3 \mathrm{~cm}$. long, glabrous or somewhat pubescent, usually glandular on the petioles and serratures; flowers mostly solitary, $4-5 \mathrm{~cm}$. broad; calyx-lobes glandular, foliaceous, appendaged, persistent; receptacle-tube globose, smooth; fruit globose, $2 \mathrm{~cm}$. in diameter; seeds large. Common.

Rosa nutkana macdougali (Holzinger) Piper. I Receptacle-tube and fruit densely hispid-prickly. Common.

Rosa pisocarpa Gray. Very similar to $R$. nutkana, the leaves usually finely pubescent; flowers smaller, about $3 \mathrm{~cm}$. in diameter, usually in corymbs; fruit ovoid or oblong, 5-10 $\mathrm{mm}$. in diameter. Common in low places.

\section{ALCHEMILLA.}

Low annual or perennial herbs; leaves palmately lobed or compound, with sheathing stipules; flowers perfect, small, greenish, in corymbs; calyx 4-5-lobed, with as many minute bractlets; petals none; stamens $1-4$, very small; styles basal or lateral; carpels 1-4, distinct, free from the calyx-tube; akents 1-4, enclosed in the receptacle.

Alchemilla arvensis occidentalis (Nutt.) Piper. Annual, 2-8 cm. high, simple or branched below, sparsely hairy; leaves short-petioled, fan-shaped, 3 -parted, the lobes acutely 2-3-cleft; stipules conspicuous, cleft; calyx 1-1.5 $\mathrm{mm}$. long, acutely 4-cleft, the bractlets minute; akenes ovate, pale, $1 \mathrm{~mm}$. long. Stony soil, not rare. 


\section{SANGUISORBA.}

Annual or perennial herbs; leaves alternate, odd-pinnate; stipules adherent to the petiole; flowers small, perfect (in ours), in dense terminal spikes or heads; calyx 4-lobed; petals none; stamens 4-many; styles terminal, filiform; carpels 1-3, free from the calyx-tube; akenes usually 1 , enclosed in the 4 -angled dry closed calyx-tube.

Annual; flowers greenish.

Perennial; flowers white or reddish.

S. annua.

S. latifolia.

Sanguisorba annua Nutt. Annual, erect, glabrous, $15-40 \mathrm{~cm}$. high, usually simple below; leaflets 4-6 pairs, 1-2 cm. long, ovate or oblong, deeply pinnatifid into linear obtusish lobes; flowers perfect, greenish, in short oblong spikes, 1-3 $\mathrm{cm}$. long; bracts ovate, scarious-margined, persistent; calyx-lobes broadly ovate, scarious; stamens 4, rarely 2, somewhat exserted. Dry ground, common.

Sanguisorba latifolia (Hook.) Coville. Perennial, glabrous; stems $30-90$ $\mathrm{cm}$. high, simple or branched above; leaflets 5-10 pairs, oval, about three times as long as broad, coarsely serrate, more or less cordate; stipules serrate; spikes 3-10 cm. long; flowers white. In bogs in the Blue Mountains.

\section{GEUM.}

Perennial herbs; leaves pinnate, with stipules; radical clustered; cauline smaller; flowers rather large, solitary or in corymbs; calyx 5-lobed with 5 alternate bractlets; petals 5 , obovate, usually longer than the calyx-lobes; stamens many, on the throat of the calyx; styles terminal, elongated in fruit, usually plumose or jointed, the upper part deciduous; akenes 2-6, pubescent.

Receptacle downy; terminal leaflet cuneate-obovate to oblanceolate, deeply cleft into acute lobes.

G. strictum.

Receptacle nearly naked.

Terminal leaflet broadly ovate to suborbicular, not cordate, crenately cleft into mostly obtuse lobes.

Terminal leaflet suborbicular, cordate, finely crenatedentate.

G. oregonense.

G. macrophyllum.

Geum strictum Ait. Stems 60-120 cm. high, hirsute; radical leaves pinnate; cauline 3-5-foliolate; leaflets cuneate-obovate, incisely and acutely lobed and toothed, pubescent; petioles hirsute; flowers rather large; petals golden yellow; receptacle densely pubescent; styles hairy at top. Moist meadows, rare in our limits.

Geum oregonense Scheutz. Intermediate between $G$. strictum and $G$. macrophyllum; leaflets obtuse, the terminal one broadly ovate or suborbicular, cuneate or truncate at base, more deeply lobed and toothed; receptacle glabrous; styles puberulent. In moist meadows.

Geum macrophyllum Willd. Stout, erect, $30-80 \mathrm{~cm}$. high, bristly-hairy; radical leaves pinnate, the terminal leaflet much larger than the 3-8 lateral ones, broadly ovate or suborbicular, 3-7-lobed, dentate, 5-10 cm. long; lateral leafiets ovate or elliptic, dentate, $2-3 \mathrm{~cm}$. long, usually with smaller ones interspersed; cauline leaves similar, but nearly sessile, with 1-3 leaflets or segments; 
stipules ovate, toothed, 1-2 cm. long; flowers yellow, about $1 \mathrm{~cm}$. broad, several in a loose cyme; petals obovate, longer than the reflexed acute calyxlobes; fruiting head globose, $1.5 \mathrm{~cm}$. long; akenes hispid; styles jointed and twisted near the tip, glabrous. In moist places in open woods.

\section{SIEVERSIA.}

Low perennial herbs with simple stems; radical leaves pinnate; flowers in terminal cymes; sepals 5 , erect or spreading, with 5 bractlets ; petals 5; carpels sessile; styles not jointed, persistent, erect, plumose or naked.

Sieversia ciliata (Pursh) G. Don. Erect, from stout rootstocks, 30-50 $\mathrm{cm}$. high, soft-hairy throughout; radical leaves tufted, oblanceolate in outline, 10-15 cm. long, pinnate with numerous leaflets, these cuneate, obovate, incisely cleft into acute narrow lobes; cauline leaves 1 or 2 , much reduced; flowers long-peduncled, 3-5 in a cyme; calyx purplish, the linear bractlets exceeding the triangular acute calyx-lobes; petals oblong, erect, yellowish or purplish, shorter than the calyx; akenes with straight plumose tails, $2-3 \mathrm{~cm}$. long. Common on grassy hillsides.

\section{POTENTILLA.}

Annual or perennial herbs; leaves alternate, pinnate or palmate, with stipules; flowers perfect, solitary or in cymes; sepals 5 , rarely 4 , with 5 , rarely 4 , alternate bractlets; petals 5 , seldom 4 , rounded, mostly yellow; stamens usually 20 , in two or three rows on the receptacle-tube; style small, terminal or nearly so, not elongating in fruit, neither jointed nor plumose; carpels usually numerous; ovules pendulous, anatropous; receptacles and akenes dry in fruit.

Cymes leafy; annuals or biennials with small flowers.

Lower leaves pinnate, upper ternate.

Leaves all ternate.

Petals as long as the sepals.

Petals much shorter than the sepals.

Cymes not leafy; perennials; leaves palmate with 5-9 leaflets.

Leaves densely pubescent on both sides.

Leaves glabrous at least above.

Under side of leaflets white tomentose.

Under side of leaflets green.

Calyx glandular atomiferous.

Calyx not glandular atomiferous.

$P$. rivalis.

P. monspeliensis.

$P$. biennis.

$P$. permollis.

P. blaschkeana.

P. nuttallii.

$P$. rectiformis.

Potentilla rivalis Nutt. Annual or biennial; stems erect or ascending, branched above, villous-pubescent, $30-40 \mathrm{~cm}$. high; leaves pinnate, the lower 5 -foliolate, the cauline usually 3 -foliolate; leaflets obovate, cuneate at base, incisely toothed, $2-4 \mathrm{~cm}$. long; cymes loose, leafy, many-flowered; flowers 4-6 mm. broad, on slender pedicels, bractlets about as long as the ovate acute calyx-lobes; petals yellow, shorter than the calyx-lobes; akenes smooth, gray. Banks of Snake River. 
Potentilla monspeliensis L. Annual or biennial, stout, leafy, erect, $30-80$ $\mathrm{cm}$. high, hairy; leaves 3 -foliolate, or the lowest sometimes 5 -foliolate, green; leaflets obovate to oblanceolate, serrate, 3-10 cm. long; cyme rather dense, leafy; calyx hairy; petals pale yellow, obovate; stamens usually 20; akenes glabrous, rough. In meadows, Marshall, Spokane County.

Potentilla biennis Greene. Similar to $P$. rivalis but leaves all 3-foliolate, usually somewhat glandular; leaflets broadly cuneate-obovate; inflorescence somewhat elongate; akenes white, smooth. In dry ground, common in the warmer valleys.

Potentilla permollis Rydb. Very similar to $P$. nuttallii but densely hirsutepubescent throughout with nearly white soft hairs; inflorescence rather dense; teeth of the leaflets rather long, lanceolate. In moist meadows at Endicott, Elmer.

Potentilla blaschkeana Turcz. Perennial; stems tufted, erect, $60-80 \mathrm{~cm}$. high, finely tomentose; leaflets densely white-tomentose beneath, cut half way to the midribs into linear acute flat lobes; petals broadly obovate, with a large shallow notch, twice as long as the sepals. Common on hillsides. Some of our forms have been considered distinct and have been called $P$. glomerata A. Nelson and $P$. longiloba Rydb.

Potentilla nuttallii Lehm. Perennial, with a short rootstock; stem 60-80 $\mathrm{cm}$. high, branched above, sparingly hirsute; basal leaves digitate, usually 7-foliolate, prominently veined and sparingly hirsute, not at all tomentose beneath, green; petioles pubescent with appressed hairs; cauline leaves smaller and short-petioled; cymes many-flowered; bractlets linear to lanceolate, generally shorter than the ovate-lanceolate, long-acuminate sepals which are 5-7 $\mathrm{mm}$. long; petals yellow, obovate, emarginate, $6-8 \mathrm{~mm}$. long. Around Lake Waha, Nez Perces County, Idaho.

Potentilla rectiformis Rydb. Perennial, the whole plant sparsely hirsute; stems tufted, erect, not branched below the inflorescence, 30-60 cm. high; leaves palmately 5-7-foliolate, oblanceolate, coarsely and evenly toothed, green on both sides, 5-8 cm. long; basal petioles long and slender, cauline ones short; cymes many-flowered, loose; calyx about $1 \mathrm{~cm}$. broad, the lobes longer than the tube; bractlets about as long as the acuminate calyx-lobes; petals broadly obovate, notched, equalling the calyx. Low ground, rather common.

\section{IVESIA.}

Low herbs with pinnate leaves with numerous small palmately lobed crowded leaflets; flowers yellow, in cymes; calyx bellshaped, 5-lobed, with 5 alternate bractlets; stamens 5; filaments slender, subulate or filiform; carpels few or one on a small villous receptacle; styles filiform, subterminal.

Ivesia gordoni (Hook.) T. \& G. Viscid puberulent or nearly glabrous; stems $5-20 \mathrm{~cm}$. high, from a stout caudex; leaflets $10-20$ pairs, approximate, each divided into 3-5 narrow segments; cauline leaves small, pinnatifid; cyme dense; petals scarcely exceeding the sepals, yellow. On high ridges in the Blue Mountains, rare.

\section{ISIBBALDIA.}

Depressed alpine plants somewhat woody with alternate trifoliolate leaves; flowers in cymes on nearly leafless peduncles; calyx persistent, slightly concave, 5 -lobed, with 5 bracts; petals 
5 , yellow, much smaller than the calyx-lobes; stamens 5 , on the margin of the villous disk; carpels $5-10$, on short pubescent stipes; styles lateral.

Sibbaldia procumbens L. Perennial, sparsely villous, 5-15 cm. high; leaflets 3 , rather thick, cuneate, 3-5-toothed at the truncate apex, 1-2 cm. long; peduncles usually shorter than the leaves; petals yellow, acute. Highest peaks of the Blue Mountains.

201. FRAGARIA. STRAWBERRY.

Acaulescent perennial herbs, propagating by runners; leaves alternate, basal, tufted, 3-foliolate, with obovate serrate leaflets; flowers polygamo-dioecious, white, few, in corymbs or racemes, on naked scapes; calyx deeply 5-lobed, with 5 alternate bractlets; petals 5, obovate, short-clawed; stamens numerous, in 1 row; style lateral; carpels numerous; receptacle much enlarged and fleshy in fruit, conical, scarlet, bearing the small turgid akenes on the surface.

Scapes shorter than the leaves; akenes sunk in pits in the fruit. $F$. platypetala. Scapes longer than the leaves; akenes not sunk in pits.

$F$. bracteata.

Fragaria platypetala Rydb. Rootstocks stout; scapes 10-15 cm. high, mostly shorter than the leaves; petioles silky-villous; leaflets somewhat glaucous, elliptic or obovate, broadly cuneate at base, coarsely toothed above the middle, glabrous or nearly so above, appressed silky-villous below, $2-5 \mathrm{~cm}$. long; runners long, rather stout, 12-16 mm. broad; petals nearly orbicular, longer than the sepals; fruit hemispherical, the akenes sunk in shallow pits. In meadows and open woods.

Fragaria bracteata Heller. Rootstocks stout; scapes 10-20 cm. high, usually exceeding the leaves; whole plant sparsely silky-villous; leaflets broadly obovate, cuneate at base, coarsely dentate; lateral leaflets oblique; flowers $1.5-2 \mathrm{~cm}$. broad; petals nearly orbicular, somewhat longer than the spreading sepals; fruit oblong, the akenes on the surface. In open woods, common.

\section{COMARUM.}

Stout dark green nearly glabrous perennial herbs; leaves álternate, pinnate, with large stipules; flowers large, cymose or solitary, terminal or also axillary; calyx deeply 5-lobed with 5 narrow bractlets; petals shorter than the calyx-lobes, acute, purple; stamens numerous, on the large pubescent disk; pistils numerous on the pubescent receptacle which becomes spongy in fruit; styles lateral; akenes glabrous.

Comarum palustre L. Perennial; stems decumbent, rooting below, 30-90 $\mathrm{cm}$. long; leaves pinnately 5-7-foliolate; leaflets elliptic or oblong, serrate, obtuse, more or less pubescent beneath, 5-8 cm. long; cyme few-flowered; flowers dark-purple, In swampy places, especially borders of lakes. Marshall, Piper. 


\section{ARGENTINA.}

Stoloniferous creeping herbs with pinnately compound leaves; flowers axillary solitary; calyx deeply 5 -lobed with 5 alternate bractlets; petals yellow; stamens 20 or more; carpels numerous on a small villous slightly concave receptacle; style filiform, lateral; akenes glabrous.

Argentina anserina sericea (Hayne) Piper n. comb. (Polentilla anserina sericea Hayne.) Villous herb, tufted and spreading by slender runners; leaves all basal, pinnate; principal leaflets 3-10 pairs, white silky on both sides, oblong, serrate; peduncles as long as or longer than the leaves; petals bright yellow; akenes somewhat corky and grooved on the back. In moist spots especially where alkaline.

\section{DRYMOCALLIS.}

Very similar to Potentilla; leaves pinnate; flowers yellow or whitish; stamens in groups on a thick fleshy disk; anthers flat; styles lateral, nearly basal; seeds ascending, orthotropous.

Flowers cream-colored.

D. convallaria.

Flowers bright yellow.

Petals small, slightly if at all exceeding the sepals. $\quad$ D. glandulosa.

Petals large, much exceeding the sepals.

D. valida.

Drymocallis convallaria Rydb. (D. corymbosa Rydb.) Perennial; stems erect, stout, glandular-viscid and villous, $40-60 \mathrm{~cm}$. high; basal leaves with 7-11 leaflets, these broadly obovate, cuneate at base, coarsely and somewhat doubly dentate or incised, glandular-pubescent or glabrate; cauline leaves with fewer leaflets; cyme usually dense, the branches erect; flowers 10-20 mm. broad; calyx very glandular-viscid; bractlets shorter than the calyx-lobes; petals broadly obovate, yellowish, barely exceeding the calyx-lobes; stamens about 25. Common on hillsides.

Drymocallis glandulosa (Lindl.) Rydb. Perennial; stems erect, 40-50 cm. high, sparsely villous and glandular, loosely branched above; basal leaves with 7-9 leaflets, these obovate or orbicular, simply or doubly dentate, sparsely pubescent, 1-3 cm. long; cauline leaves usually with fewer leaflets; flowers $10-$ $15 \mathrm{~mm}$. broad, in loose open cymes; calyx somewhat glandular; bractlets shorter than the ovate acute or acuminate calyx-lobes; petals oval or obovate, about as long as the sepals. Dry open woods.

Drymocallis valida (Greene) Piper. Similar in habit to D. convallaria; glandular-pubescent throughout; leaflets 7-11, mostly obovate to orbicular, incisely serrate, $3-6 \mathrm{~cm}$. long; cyme rather loose and flat-topped; petals elliptic to suborbicular, one third longer than the sepals. In open pine woods, rare in our limits.

\section{Family 36. LEGUMINOSAE.}

Herbs, shrubs or trees; leaves alternate, mostly compound, with stipules; flowers irregular (papilionaceous) (in ours), perfect or sometimes polygamous, in spikes, heads, racemes or panicles; calyx 4-5-toothed or cleft; lobes equal or unequal, sometimes 2-lipped; petals more or less united or separate, perigynous or 
hypogynous, usually papilionaceous, that is, with the upper or odd petal (standard) larger than the others and usually turned backward or spreading; the two lateral ones (wings) oblique and exterior to the two lower; the last pair connivent and commonly more or less coherent by their anterior edges, forming the keel, which usually encloses the stamens and pistil; stamens 10, rarely 5 or many, monadelphous, diadelphous or occasionally distinct; pistil 1,1-celled or several-celled by the intrusion of partitions, free; ovules 1-many; fruit a legume; endosperm mostly none.

Stamens distinct.

Stamens monadelphous or diadelphous.

Anthers of two forms, round and oblong.

Anthers all alike.

Leaves palmate or trifoliolate.

Foliage glandular-dotted.

Foliage not glandular-dotted.

Flowers in heads.

Flowers in racemes.

Racemes close, spike-like; pods curved or twisted.

Racemes loose, long; pods straight. 210. MeLILOTUS, 149.

Leaves pinnate.

Foliage dotted with conspicuous glands. 211. GLYCYRRHIZA, 149.

Foliage not dotted with conspicuous glands.

Leaves abruptly pinnate, usually with tendrils.

Style filiform, hairy near the tip only.

Style flattened, hairy on the inner side.

Leaves odd pinnate; with no tendrils.

Flowers in umbels or solitary; pods linear.

Flowers in spikes or racemes, rarely solitary, then the pods not linear.

212. ViCIA, 149.

213. Lathyrus, 150.

214. HOSACKIA, 151.

215. Astragalus, 151.

\section{THERMOPSIS.}

Perennial herbs; leaves alternate, palmately 3 -foliolate, with large foliaceous stipules; flowers large, yellow, in terminal or axillary racemes; calyx campanulate, the lobes equal and separate or the two upper united; standard nearly orbicular, equalling the oblong wings and about equalling the keel; stamens 10 , distinct; ovary sessile or short-stipitate; ovules numerous; pod sessile or short-stipitate in the calyx, flat, linear, straight or curved.

Thermopsis montana Nutt. Stout, $60-100 \mathrm{~cm}$. high, the glabrous somewhat glaucous stems slightly branched above; leaflets oblong or oval, mostly 
obtuse, cuneate at base, 3-6 cm. long, glabrous above, pubescent beneath; stipules ovate or lanceolate, large; petioles longer than the leaflets; raceme terminal, short-peduncled, 8-16 cm. long; flowers yellow, somewhat whorled, stout-pedicelled; calyx pubescent, with short broad teeth; corolla nearly $2 \mathrm{~cm}$. long; pods pubescent, dark-colored, linear, slender-beaked, $5-10 \mathrm{~cm}$. long, erect, 8-12-seeded. In moist places in pine woods.

Thermopsis montana ovata Robinson. Leaflets broader, ovate. In moist places in pine woods; more common than the species.

\section{LUPINUS. LUPINE.}

Annuals or herbaceous or shrubby perennials; leaves alternate or basal, palmately 5-13-foliolate; flowers showy, often whorled, in terminal spikes or racemes; calyx 2-lipped, the upper lip often bifid, the lower sometimes 3-toothed; standard orbicular with reflexed sides; wings obovate, united at the summit and enclosing the falcate keel; stamens united into a closed tube; ovary sessile; pod more or less flattish, leathery and hairy.

Corolla yellow.

Flowers large; petals about $16 \mathrm{~mm}$. long, deep yellow; leaflets $10-15 \mathrm{~mm}$. broad.

L. sabinii.

Flowers smaller; petals about $10 \mathrm{~mm}$. long, light yellow; leaflets less than $10 \mathrm{~mm}$. broad.

L. sulphureus. Corolla violet.

Calyx saccate or spurred at the base.

Calyx symmetrical or nearly so. Leaves glabrous above.

Stems glabrous.

Stems villous.

Leaves pubescent on both sides.

Flowers nearly sessile, in long spike-like racemes; pubescence coarse and rather loose.

Flowers on well developed pedicels.

Pubescence not silky; stems loosely retrorsevillous.

Pubescence silky.

Stems scape-like, simple, the leaves chiefly basal.

Leaflets $3 \mathrm{~cm}$. long; pedicels loosely pubescent.

Leaflets 4-5 $\mathrm{cm}$. long; pedicels appressedpubescent.

L. laxiflorus.

L. burkei.

L. wyethii.

L. leucophyllus.

L. retrorsus. leafy, usually branched above.

Pubescence of stem loose and spreading. L. sericeus.

Pubescence of stem appressed.

Bracts not exceeding the full grown buds.

L. ornatus. Bracts exceeding the full grown buds. L. flexuosus.

Lupinus sabinii Dougl. Stems tall, erect, sparsely pubescent, 60-120 cm. high; leaflets 8-11, oblanceolate, acuminate, appressed-pubescent on both sides with white hairs; petioles about as long as the leaflets; stipules subulate, villous; raceme $15-30 \mathrm{~cm}$. long; pedicels spreading, puberulent, $1 \mathrm{~cm}$. long, scarcely equalling the flowers; bracts setaceous, equalling the calyx, quickly 
deciduous; calyx finely tomentose; upper lip short, slightly emarginate; standard emarginate, glabrous; keel ciliate. Common near the lower timber line at the head of the Touchet River in the Blue Mountains. A purpleflowered form occurs rarely.

Lupinus sulphureus Dougl. Stems erect, sparsely appressed-puberulent, 60-100 cm. high; leaflets $9-15$, narrowly oblanceolate, usually folded, densely puberulent on both sides but green; petiole much longer than the leaflets; stipules subulate, villous, about $1 \mathrm{~cm}$. long; raceme erect, rather dense, 10-20 $\mathrm{cm}$. long; pedicels spreading, densely puberulent, shorter than the flowers; calyx very silky, ebracteolate, somewhat saccate or very short-spurred at base; corolla pale yellow, about $10 \mathrm{~cm}$. long; standard glabrous; keel sparsely ciliate; pods silky-villous. In the Blue and Craig Mountains.

Lupinus laxiflorus Dougl. Rather slender, about $60 \mathrm{~cm}$. high; pubescence finely-silky, but the plant green; leaflets $6-11$, oblanceolate, obtuse or acute, silky on both sides, 3-4 cm. long; petioles slender, usually twice as long as the leaflets, or none; racemes loose, 10-15 cm. long; pedicels slender, 5-6 mm. long; calyx short, spurred at base; corolla about $1 \mathrm{~cm}$. long; standard glabrous or pubescent. Open pine woods.

Lupinus burkei Wats. Green and glabrous or nearly so; stems erect, 60-100 cm. high; leaflets 6-11, oblanceolate, acute, glabrous above, sparsely appressed-pubescent beneath; petioles of the lower leaves very long; stipules lanceolate; racemes dense, $10-40 \mathrm{~cm}$. long, the pedicels short, $2-4 \mathrm{~mm}$. long; bracts lanceolate, villous, somewhat persistent; calyx pubescent; corolla blue-violet; standard glabrous; pods dark, 10-20 mm. long, 4-6-seeded, loosely villous. In moist places, especially in meadows.

Lupinus wyethii Wats. Villous, not silky, erect, 30-50 cm. high; leaflets $7-11$, oblanceolate, acute or acuminate, $2-4 \mathrm{~cm}$. long, glabrous above; petioles $2-4$ times as long as the leaflets; racemes strict, 15-30 cm. long; pedicels slender; flowers dark-blue, $10-15 \mathrm{~mm}$. long; standard glabrous. A very showy species, locally abundant.

Lupinus leucophyllus Dougl. Densely silky-villous and somewhat tomentose, erect, $60-90 \mathrm{~cm}$. high; leaflets 7-10, oblanceolate, acute or acuminate, pubescent on both sides, 3-6 cm. long; petioles about as long or longer; flowers sessile or nearly so, in elongated short-peduncled dense racemes, often 30-40 $\mathrm{cm}$. long; standard somewhat hairy on the back. Common in low ground.

Lupinus retrorsus Henderson. Stems erect, $60-90 \mathrm{~cm}$. high, villous with soft spreading or retrorse white hairs; leaves narrowly oblanceolate, acute or acuminate, villous but green above, densely white villous beneath, 4-7 cm. long; petioles villous; raceme densely flowered, $6-20 \mathrm{~cm}$. long; bracts subulate, hairy, quite persistent, longer than the buds; pedicels $1-4 \mathrm{~mm}$. long; calyx villous; corolla $8-12 \mathrm{~mm}$. long; banner hairy; keel ciliate; pods densely villous. Lake Coeur d'Alene, opposite Harrison, Idaho.

Lupinus piperi Robinson. Silky and canescent, leafy at the base; root single, perpendicular; stems 1 to 6 , scapose, rather stout, simple, erect, curvedascending, or decumbent, covered with a loosely appressed pubescence; leaflets $5-8$, oblanceolate, acute or acutish, about $3 \mathrm{~cm}$. long; petioles 5 to $10 \mathrm{~cm}$. Iong; peduncles $7-13 \mathrm{~cm}$. in length, equalling the showy rather loose racemes; pedicels 3-4 $\mathrm{mm}$. long, tomentose with widely spreading hairs; corolla deep blue; the standard broad, entirely glabrous, paler toward the center; keel ciliated; pods $20-24 \mathrm{~mm}$. long, 4 or 5-seeded. Common in gravelly soil about Spokane and Spangle.

Lupinus hellerae Heller. Silvery canescent; stems several, clustered, erect, $30-35 \mathrm{~cm}$. high; leaves numerous, mostly basal; leaflets $7-9$, oblong- 
lanceolate, tapering at base, 4-5 $\mathrm{cm}$. long, acutish and mucronate; petioles 10-15 cm. long; stipules linear-lanceolate; racemes about $15 \mathrm{~cm}$. long, rather loose with the flowers somewhat in whorls; pedicels with appressed pubescence; calyx silky; corolla blue; standard glabrous; keel bearded. Gravelly or sandy soil, banks of the Clearwater River near Lewiston, Idaho.

Lupinus - sericeus Pursh. Stems stout, villous, 40-70 cm. tall; leaves canescent and somewhat villous, not silvery; leaflets $6-8$, oblanceolate, acute, 3-5 cm. long, about equalling the petioles; bracts not exceeding the buds; flowers 10-12 mm. long, bluish-purple, in rather loose racemes; standard pubescent. In the canyons of Snake River and its tributaries.

Lupinus ornatus Dougl. Pubescence silky or silky-villous, the whole plant silvery-green, $30-40 \mathrm{~cm}$. high; leaflets $6-8$, oblanceolate, acute, pubescent on both sides, $2-4 \mathrm{~cm}$. long; petioles as long or longer; racemes rather loose, short-peduncled; flowers almost $10 \mathrm{~mm}$. long, stout-pedicelled; standard hairy. Abundant on the high prairies.

Lupinus flexuosus Agardh. ( $L$. ornatus bracteatus Robinson; L. subulatus Rydb.) Very similar to $L$. ornatus, but usually taller, $40-70 \mathrm{~cm}$. high; stems usually leafless on the lower part and radical leaves few or absent; bracts subulate, often recurved, conspicuously exceeding the buds, somewhat persistent. In gravelly soil near Spokane, Piper.

\section{PSORALEA.}

Perennial herbs, usually glandular-dotted; leaves mostly 3-5foliolate, with stipules; flowers in spikes or racemes; calyx-lobes 5 , the lower longest; corolla papilionaceous; stamens 10, diadelphous or sometimes monadelphous; anthers of two kinds; ovary sessile or short-stalked, 1-ovuled; pod seldom longer than the calyx, thick, often wrinkled, indehiscent, 1-seeded.

Leaflets broadly ovate.

Leaflets lanceolate.

$P$. physodes.

$P$. lanceolata.

Psoralea physodes Dougl. Erect or ascending, bushy, $30-50 \mathrm{~cm}$. high, sparsely hairy; leaflets ovate, acute, 3-4 cm. long, somewhat glandular; peduncles as long as or longer than the leaves; flowers in dense short racemes; bracts small; calyx black-hairy, $8-10 \mathrm{~mm}$. long, in age becoming larger and inflated; corolla dirty-white, the keel tipped with purple; pod membranaceous, pubescent, suborbicular, enclosed in the calyx. Near Troy, Idaho, one of two stations where this plant occurs east of the Cascade Mountains; west of these mountains it is common.

Psoralea lanceolata scabra (Nutt.) Piper. Erect or ascending, 30-60 cm. high, sparsely puberulent, dotted throughout with coarse black glands; leaflets 3 , entire, narrowly or broadly oblanceolate, acute, obtuse or emarginate at apex, cuspidate, 1-3 cm. long; petioles at least as long as the leaflets; peduncles barely exceeding the leaves; racemes short, dense; flowers bluishwhite, $5 \mathrm{~mm}$. long, short-pedicelled; calyx-teeth shorter than the tube; pod subglobose, 5-6 mm. long, glandular and white-hairy. Sandy banks of Snake River.

208. TRIFOLIUM. Clover.

Tufted or diffuse herbs; leaves mostly palmately, sometimes pinnately, 3-foliolate; stipules united with the petiole; flowers in 
heads or in umbel-like heads; calyx-teeth 5 , nearly equal; petals more or less persistent, the claws of all but the standard united more or less below the stamen-tube; stamens 10 , diadelphous or the tenth only partly separate; pod small and membranous, 1-6-seeded, included in the calyx.

Heads not subtended by an involucre.

Flowers pedicelled, in rather loose heads.

Stoloniferous; flowers white.

Not stoloniferous; flowers pink.

Flowers sessile, in dense heads.

Annual; calyx-teeth plumose, longer than the corolla.

T. repens.

T. hybridum.

Perennial; calyx-teeth not plumose, shorter than the corolla.

Calyx and leaves glabrous; heads usually oblongcylindric.

Calyx and leaves pubescent; heads ovoidorbicular.

Flowers red; stipules aristate.

Flowers whitish; stipules acuminate.

Heads subtended by an involucre.

Involucre deeply cleft, the lobes fringe-toothed; flowers dark-purple.

Perennial with creeping rootstocks; heads 10-20 $\mathrm{mm}$. broad.

Annual; heads 5-10 mm. broad.

Involucre not deeply cleft, its lobes serrate or entire; flowers white or pink; annual.

Glabrous; calyx-teeth slender and branched.

Pubescent; calyx-teeth subulate, scarious-margined. T. microcephalum.

Trifolium repens L. White Clover. Perennial, glabrous or sparsely pubescent, with creeping stems, 10-30 cm. long, which root at the nodes; leaflets obovate, obtuse or notched at apex, cuneate at base, denticulate, 1-2 $\mathrm{cm}$. long; petioles elongated; stipules narrow, acute; peduncles longer than the leaves; head globose; flowers white, 6-10 mm. long, pedicelled, at length reflexed; calyx-teeth acuminate, shorter than the tube. Everywhere introduced.

Trifolium hybridum L. Alsike Clover. Perennial, erect or decumbent, not creeping, glabrous or nearly so, the stem $30-60 \mathrm{~cm}$. long; leaflets obovate, obtuse or notched, cuneate at base, sharply serrulate, $1-2.5 \mathrm{~cm}$. long; petioles about as long as the leaflets; stipules membranous, ovate-lanceolate, acuminate; peduncles elongated; heads globose; flowers pink or pinkish, 6-8 mm. long, on slender pedicels, at length reflexed; calyx-teeth subulate, about as long as the tube, much shorter than the corolla. Sparingly introduced.

Trifolium arvense L. IRabbit's Ear Clorer. Annual, erect, somewhat silky-pubescent throughout, 10-30 cm. high; leaflets linear or oblanceolate, obtuse or notched, denticulate near the apex, 1-2 cm. long; petioles mostly shorter than the leaflets; stipules narrow, with long subulate tips; peduncles 2-4 cm. long; head oblong, dense, 10-25 $\mathrm{mm}$. long, without an involucre; calyx plumose, the subulate lobes longer than the tube and the pink or whitish corolla. Sparingly introduced.

Trifolium douglasii House. ( $T$. altissimum Dougl.) Perennial from a thick root, erect, stout, glabrous; leaflets linear or oblong, narrowed at both 
ends, acute or obtuse, cuspidate, $2-4 \mathrm{~cm}$. long, strongly veined, the veinlets usually protruding as slender teeth; stipules nearly as long as the leaflets, acute, entire, or nearly so; peduncles $5-10 \mathrm{~cm}$. long; heads globose or oblongcylindric, 2-3 cm. long; flowers red, sessile, at length reflexed, 12-15 mm. long; calyx-tube strongly nerved, the subulate teeth twice as long, the lowest straight, the others twisted. Low meadows, common.

Trifolium pratense L. Red Clover. Perennial, erect or decumbent, rarely branched, $20-40 \mathrm{~cm}$. high, somewhat pubescent throughout; leaflets elliptic or obovate, obtuse or rarely emarginate, denticulate, $1-4 \mathrm{~cm}$. long, frequently dark-spotted near the middle; petioles short; heads globose or ovoid, sessile or nearly so, $2 \mathrm{~cm}$. long; flowers red, 10-12 mm. long; calyx-teeth subulate, shorter than the corolla. Introduced and common.

Trifolium latifolium (Hook.) Greene. Sparsely puberulent, especially above; perennial from a stout root but with long slender root-like underground branches; stems slender, $10-15 \mathrm{~cm}$. high; stipules broadly ovate, acuminate, obscurely toothed or lobed; petioles slender; leaflets mostly ovate, denticulate, obtuse, mucronate, 5-20 mm. long; peduncles exceeding the leaves; heads globose, $1.5-2 \mathrm{~cm}$. broad, loosely $15-30$-flowered; pedicels as long as the calyx-tube; calyx teeth subulate, longer than the tube; flowers whitish, 10-12 mm. long, all reflexed in age. In open woods, simulating closely in appearance common white clover.

Trifolium spinulosum Dougl. ( $T$. fimbriatum Lindl. ?.) Perennial by creeping rootstocks, glabrous throughout; branches prostrate or ascending, 20-40 cm. long; leaflets oblong-obovate to oblanceolate, spinulose-denticulate, the lower obtuse or even retuse, the upper acute or acuminate, mostly 1-3 cm. long; stipules triangular, acuminate, with a few teeth; heads subglobose, 1-2 cm. broad; involucre short, laciniately parted; calyx lobes unequal, subulate, somewhat spiny, 2-3 times as long as the tube; petals purple with paler or white tips. In wet meadows.

Trifolium variegatum Nutt. Annual, glabrous throughout; stems decumbent, $10-30 \mathrm{~cm}$. long, branching, leafy; leaflets obovate to obcordate, minutely and sharply serrulate, veiny, 6-12 $\mathrm{mm}$. long; stipules broad, fringed-toothed; peduncles very slender, longer than the leaves; heads small, 4-12-flowered; involucre shorter than the flowers, campanulate, fringe-toothed; calyx glabrous, its teeth subequal, subulate, longer than the tube; petals purple with white tips, pods 2 -seeded. In moist ground, common.

Trifolium cyathiferum Lindl. Annual, glabrous; stems weak, ascending, 10-30 cm. high; leaflets oblanceolate or obovate, serrulate, acute, obtuse or truncate, cuneate at base, 1-2 cm. long; petioles slender; stipules ovate or lanceolate, laciniate; peduncles longer than the leaves; heads commonly $\mathbf{1 . 5}$ $\mathrm{cm}$. broad; involucre large and conspicuous, whitish with green margin, many-nerved, with short sharply-toothed lobes; flowers whitish; calyx membranous, prominently 5-nerved, the nerves prolonged and branched, equalling the corolla; pod 2-seeded. Springy gravelly places, rare.

Trifolium microcephalum Pursh. Annual, erect or spreading, soft villous; stems 5-30 cm. long; leaflets obovate, usually retuse, serrulate, $8-12 \mathrm{~mm}$. long; petioles slender; stipules entire, acuminate; heads small, many-flowered; involucre membranaceous, about 9-lobed, the lobes 3-nerved, entire; calyx hairy, the teeth subulate; corollas pale pink; pods glabrous, 1-seeded. In gravelly or sandy soil.

\section{MEDICAGO.}

Annual or perennial herbs with small trifoliolate leaves; leaflets toothed; flowers small, yellow or violet, in axillary spikes; pods 1-several-seeded, curved or coiled. 
Medicago lupulina L. Black Medic. Yellow Trefoil. Low pubescent decumbent branched annual; leaflets cuneate-obovate, toothed at the apex; flowers yellow, in short spikes; pods curved, black, slightly hirsute, 1-seeded. Becoming a weed in the Palouse hills.

Medicago sativa L. Alfalfa. Erect smooth much branched perennial; leaflets obovate-oblong, toothed, especially near the apex; flowers violet or blue, in spike-like racemes; pods coiled. Roadsides; escaped from cultivation.

\section{MELILOTUS.}

Annual or biennial herbs; leaves pinnately 3 -foliolate; leaflets denticulate; flowers in racemes; calyx campanulate, with short equal teeth; corolla deciduous, free from the stamen-tube; stamens diadelphous; anthers all alike; ovary sessile or stipitate, few-ovuled; pod coriaceous, 1-2-seeded.

Melilotus alba Desr. Sweet Clover. Biennial, stout, erect, branching, 1-2 m. high, finely puberulent or nearly glabrous; leaves slender-petioled; leaflets oblong or obovate, denticulate, mostly truncate at apex, 1-2 cm. long; stipules subulate; racemes slender, 10-20 cm. long; flowers white, sweetscented, 4-5 $\mathrm{mm}$. long, reflexed on short pedicels; calyx-teeth subulate, as long as the tube; pod ovoid, $2-3 \mathrm{~mm}$. long. Sparingly introduced.

\section{GLYCYRRHIZA.}

Perennial glandular-dotted herbs with long thick sweet roots; leaves odd-pinnate, with minute deciduous stipules; flowers in axillary spikes; calyx with the two upper lobes shorter or partly united; stamens usually diadelphous; anther-sacs confluent at the a pex, the alternate ones smaller; pod prickly, ovate or oblonglinear, compressed, often curved, few seeded.

Glycyrrhiza lepidota Nutt. Wild Licorice. Erect, stout, $50-100 \mathrm{~cm}$. high, glandular-puberulent throughout; leaves $10-20 \mathrm{~cm}$. long; leaflets $6-8$ pairs, oblong-lanceolate, acuminate, mucronate, $3-5 \mathrm{~cm}$. long, glandulardotted; peduncles shorter than the leaves; spikes dense, 3-6 cm. long; flowers greenish-yellow, about $1 \mathrm{~cm}$. long; calyx campanulate, $6-8 \mathrm{~mm}$. long, the acute teeth about as long as the tube; pods $1.5 \mathrm{~cm}$. long, thickly armed with long hooked prickles. In sandy or gravelly soil in the warmer valleys.

\section{VICIA. Vetch.}

Climbing or trailing herbaceous vines; leaves pinnate, tendrilbearing, with half-sagittate or entire stipules; flowers solitary or in loose peduncled axillary racemes; calyx 5-cleft or toothed, unequal, the two upper teeth often shorter or the lowest longer; wings adherent to the short keel; stamens diadelphous or nearly so; style filiform, hairy near the tip only; ovary 2-many-ovuled; pod flat, 2-valved, 2-several-seeded.

Vicia americana Muhi. Perennial, stout or slender, 30-100 cm. high, nearly glabrous; leaflets 4-8 pairs, usually elliptic or ovate, obtuse or truncate, mucronulate, entire or toothed above, glabrous above, minutely puberulent 
beneath, about $2 \mathrm{~cm}$. long; tendrils well developed; stipules deeply toothed; peduncles usually shorter than the leaves, 4-8-flowered; flowers purple-violet, 15-20 mm. long, short-pedicelled; calyx-tube campanulate with short broad unequal teeth, somewhat pubescent; pods glabrous, $2-4 \mathrm{~cm}$. long, $6-8 \mathrm{~mm}$. broad. Common in copses.

Vicia americana linearis (Nutt.) Wats. Leaflets linear, acute. In dry ground, infrequent.

\section{LATHYRUS.}

Mostly smooth perennial herbaceous vines or erectherbs; leaves pinnate, mostly with tendrils or tendrils much reduced or wanting; flowers in racemes or sometimes solitary; peduncles usually equalling or exceeding the leaves and several-flowered; calyxteeth nearly equal or the upper ones somewhat shorter than the lower; corolla rather larger than in Vicia; stamens diadelphous or monadelphous below; style dorsally flattened near the top, hairy on the inner side; ovules generally numerous; pod flat or terete, 2-valved.

Plants climbing by simple or 3-forked tendrils.

Plants erect; tendrils wanting or much reduced.

Corolla white; leaflets oblong or ovate.

Corolla purple; leaflets linear to obovate.

L. pauciflorus.

L. obovatus.

L. bijugatus.

Lathyrus pauciflorus Fernald. Glabrous throughout, $60-90 \mathrm{~cm}$. high; stems angled; leaflets 3-6 pairs, oblong-elliptic, thickish, prominently veined, paler beneath, acute and cuspidate, rounded at base, $2-4 \mathrm{~cm}$. long; stipules about half as long as the adjacent leaflets; tendrils simple or branched; peduncles exceeding the leaves, 3-5-flowered; flowers violet, about $2 \mathrm{~cm}$. long; calyx-teeth slightly pubescent, about as long as the tube; pods smooth, 4-6 $\mathrm{cm}$. long. Warm slopes, infrequent.

Lathyrus pauciflorus tenuior Piper. Leaflets linear or linear-lanceolate, 3-6 cm. long, otherwise as in the species. Less common than the species.

Lathyrus obovatus (Torr.) White. Erect or decumbent, 12-25 cm. high; leaflets 1-2 pairs, elliptic or ovate, obtuse, cuspidate, thinly pubescent and paler beneath, $2-4 \mathrm{~cm}$. long; stipules narrow, acuminate; tendrils none; peduncles exceeding the leaves, 2-4-flowered; flowers stout-pedicelled, white or ochroleucous, nearly $2 \mathrm{~cm}$. long; calyx-teeth triangular-acute, shorter than the tube. Waitsburg, Horner, and near Troy, Idaho.

Lathyrus obovatus stipulaceus White. Stipule broadly ovate, obtuse, one-third to one-half as large as the leaflets; flowers more numerous. Near Spokane.

Lathyrus bijugatus White. Erect, $10-15 \mathrm{~cm}$. high, glabrous or sparsely pubescent; stems not winged; leaflets 1-2 pairs, oblong or elliptic, acute, cuspidate, about $2 \mathrm{~cm}$. long; stipules sagittate, narrow, 5-10 $\mathrm{mm}$. long; tendrils none, but the rachis prolonged into a slender tip; peduncles shorter than the leaves, 1-4-flowered; calyx-teeth triangular, acute, about as long as the tube; corolla purple, 8-10 $\mathrm{mm}$. long. On stony hillsides.

Lathyrus bijugatus sandbergii White. Leaflets linear or linear-lanceolate, $4-6 \mathrm{~cm}$. long. With the species on stony hillsides. 


\section{HOSACKIA.}

Herbs or shrubs; leaves pinnate, 1-many-foliolate; stipules minute and gland or spine-like; flowers yellow or reddish, solitary or in umbels; calyx-teeth nearly equal; petals free from the diadelphous stamens; standard ovate or roundish; pod linear, compressed or somewhat terete, sessile, several-seeded.

Annuals; flowers solitary.

H. americana.

Perennials; flowers in umbels.

Foliage glabrous or nearly so; pods linear, glabrous, manyseeded.

H. bicolor.

Foliage pubescent; pods curved, pubescent, 1 or 2 -seeded. H. decumbens.

Hosackia americana (Nutt.) Piper. Annual, erect, usually branched, 30$60 \mathrm{~cm}$. high; leaves 3-foliolate, or the upper 1 -foliolate, nearly sessile; leaflets ovate or lanceolate, silky-pubescent, acuminate, stalked, 6-20 mm. long; stipules gland-like, dark; peduncles as long as or longer than the leaves; fowers pink, 4-6 mm. long; caly $x$ villous, the slender lobes twice as long as the tube, nearly equaling the corolla; pod linear, narrow, often reflexed, glabrous and shining, $2-3 \mathrm{~cm}$. long. Sandy soil, common.

Hosackia americana pilosa (Nutt.) Piper. Similar to the species but the pubescence hirsute and spreading. Gravelly stream banks, rare.

Hosackia bicolor Dougl. Perennial, glabrous or nearly so throughout, erect or decumbent, $30-50 \mathrm{~cm}$. high, stout; leaflets 5-9, obovate, mostly obtuse, cuneate at base, 1.5-2 cm. long; stipules broad, scarious; peduncles exceeding the leaves; flowers nearly sessile, spreading, 3-7 in an umbel; calyx about $6 \mathrm{~mm}$. long, the teeth shorter than the campanulate tube; corolla yellow, the wings white, 2-2.5 cm. long; pod linear, narrow, glabrous, 4-6 cm. long. Wet places, rare.

Hosackia decumbens Benth. Perennial, many-stemmed from a thick woody root, villous and more or less tomentose; stems decumbent, branched, $30-60 \mathrm{~cm}$. long; leaflets 5-7, oblong to obovate, cuneate at base, mostly acute, 6-10 mm. long; stipules minute, spine-like, deciduous; peduncles scarcely longer than the leaves; flowers yellow, in 5-10-flowered umbels, each umbel with a 1-3-foliolate bract; calyx silky, the teeth as long as the tube; pods falcate, pubescent, mostly 2 -seeded. Common on the gravelly plains about Spokane.

\section{ASTRAGALUS.}

Chiefly perennial herbs; leaves odd-pinnate, with stipules; flowers in spikes or racemes; calyx with 5 nearly equal teeth; corolla and its slender-clawed petals usually narrow, spreading, equalling or exceeding the wings and blunt-keeled; stamens diadelphous; anthers all alike; ovary sessile or stipitate; ovules numerous; pod sometimes inflated, 1-celled or 2-celled by a false partition; seeds few or many.

Pods membranaceous, thin, much inflated.

Herbage slightly pubescent; pods 2-celled.

Herbage silky or villous; pods 1-celled.

Pod coriaceous or chartaceous, not inflated.

A. lentiginosus.

Herbage white-woolly or hairy.

A. hookerianus. 
Pods 2-celled, small, ovate, short-villous.

Pods 1-celled, large, curved, soft-woolly.

Flowers ochroleucous; leaflets 13-17.

Flowers violet; leaflets 21-25.

A. spaldingii.

A. purshii.

A. inflexus.

Herbage and pods either glabrous or short-canescent.

Pods stipitate, the stipe equalling or exceeding the calyx.

Pods with both sutures prominent.

A. collinus.

Pods with the dorsal suture impressed or intruded.

Leaflets broadly oval, glabrous; pods oblong, thick.

Leaflets oblong to linear, pubescent at least

A. beckwilhii. beneath; pods linear.

Pods slender, curved, the stipe much exceeding the calyx; leaflets puberulent on both sides.

Pods stout, straight, the stipe not exceeding the calyx; leaflets glabrous above.

Pods sessile or nearly so.

Pods 2-celled by the intrusion of the sutures.

Flowers greenish or yellowish; pods oblong.

Flowers purple or purplish.

Pods oblong; flowers spicate.

Pods ovate; flowers capitate.

A. arthuri.

A. arrectus.

A. mortoni.

A. adsurgens.

A. hypoglottis.

Pods 1-celled.

Flowers in racemes; leaflets not rigid nor pricklypointed.

Flowers subsessile in the leaf axils; leaflets rigid, prickly-pointed.

A. reventus.

A. viridis.

Astragalus lentiginosus Dougl. Slightly appressed puberulent but green; stems spreading, $10-30 \mathrm{~cm}$. long; stipules ovate, acuminate; leaflets 11-21, obovate to oblong, obtuse or retuse, 6-12 mm. long; flowers purple; pods ovate, curved, acuminatc, not stipitate, perfectly 2-celled, puberulent. In moist somewhat alkaline situations. Rare in our limits.

Astragalus hookerianus (T. \& G.) Gray. Herbage pale, silky or villous, with a fine whitish pubescence; stems ascending, $10-30 . \mathrm{cm}$. long, usually much branched at base; leaflets 7-9 pairs, oblong, petiolulate, 4-6 mm. long; stipules lanceolate, the lower ones sheathing; peduncles shorter than the leaves, the racemes few-flowered; bracts setaceous, about as long as the pedicels; calyx pubescent with black and white hairs, the teeth subulate, shorter than the tube; corolla whitish, the tip of the keel purple tinged; pods shortly stipitate, much inflated, thin, ovoid, 1-3 cm. long, pale, mottled with purple splotches. High rocky ridges of the Blue Mountains, first collected by Douglas.

Astragalus spaldingii Gray. Densely white-villous throughout; stem erect or decumbent, $30-50 \mathrm{~cm}$. high; leaves $6-10 \mathrm{~cm}$. long, short-petioled; leaflets 10-15 pairs, lanceolate, acute at each end, sessile, about $1 \mathrm{~cm}$. long; peduncles longer than the leaves; flowers in dense spikes, $2-6 \mathrm{~cm}$. long; calyx densely villous, the linear lobes as long as the campanulate tube; corolla white, the keel purple-blotched, 7-8 mm. long; pod villous, ovoid, beaked, 1- or 2-seeded, as long as the calyx, the dorsal suture slightly impressed. Not rare, on hillsides.

Astragalus purshii Dougl. Herbage densely white-villous; stems ascending or spreading, 10-20 cm. long; leaflets 6-8 pairs, oblong, sessile, about $1 \mathrm{~cm}$. long; stipules lanceolate, acuminate; peduncles shorter than the leaves; flowers 
in short racemes; bracts narrow, exceeding the pedicels; calyx-lobes subulate, subequal, half the length of the tube; corolla $3-3.5 \mathrm{~cm}$. long, pale yellowish, the tip of the keel purple; pods ovoid, densely villous, stout beaked, curved, about $2 \mathrm{~cm}$. long. Gravelly soil about Spokane.

Astragalus inflexus Dougl. Densely white-villous and tomentose throughout; stems prostrate or decumbent, $10-30 \mathrm{~cm}$. long; leaves short-petioled; leaflets 21-25, ovate, acuminate, short-stalked, about $1 \mathrm{~cm}$. long; peduncles shorter than the leaves; racemes rather densely few-flowered, the flowers short-pedicelled; calyx-teeth awl-shaped, much shorter than the cylindric tube; corolla violet, rarely yellowish, about $20 \mathrm{~mm}$. long; pod villous, stoutbeaked, curved, 2-2.5 cm. long. Sandy bars of Snake River.

Astragalus collinus Dougl. Erect, $30-50 \mathrm{~cm}$. high, greenish, but with an appressed pubescence throughout; leaves $5-10 \mathrm{~cm}$. long; leaflets $5-10$ pairs, oblong-truncate or retuse, cuneate at base, short-stalked, about $1 \mathrm{~cm}$. long, smoother above; peduncles mostly terminal, longer than the leaves; flowers yellow, reflexed, in racemes, 5-12 cm. long; calyx-tube oblong, campanulate, gibbous at base, $1 \mathrm{~cm}$. long, the teeth short, triangular, acute; corolla 12-15 $\mathrm{mm}$. long; pods linear, acuminate, puberulent, $2-3 \mathrm{~cm}$. long, $3 \mathrm{~mm}$. wide, the stipitate base as long as the calyx. On warm hillsides.

Astragalus beckwithii T. \& G. Glabrous or nearly so; stems ascending or spreading, 20-40 cm. long; leaflets 7-11 pairs, oval to nearly orbicular, obtuse or retuse, $5-10 \mathrm{~mm}$. long, pale, thickish; peduncles about as long as the leaves; flowers $5-8$, in a short raceme, yellowish, 10-15 mm. long; calyx glabrous or with a few black hairs, the subulate teeth about equalling the campanulate tube; pods straight, $2.5-3 \mathrm{~cm}$. long, glabrous, turgid, coriaceous, the dorsal suture slightly intruded, the ventral prominent. Bluffs of Snake River, near Lewiston, Idaho, Henderson, and along the Tukanon, Brandegee.

Astragalus arthuri Jones. Erect or nearly so, $40-60 \mathrm{~cm}$. high, pale green, with a fine appressed pubescence, leafy only toward the base; leaves oblong, 6-10 cm. long; leaflets 10-13 pairs, oblong, obtuse, 5-12 $\mathrm{mm}$. long, glabrous above, short-petioled; peduncles $10-20 \mathrm{~cm}$. long, each bearing about ten reflexed or spreading pods; pods slender, falcate, stipitate, $5-5.5 \mathrm{~cm}$. long when mature, $2 \mathrm{~mm}$. broad, acuminate, puberulent, triangular in cross section, the dorsal suture deeply intruded; flowers not seen. Craig Mountains near Lake Waha, Idaho, and Blue Mountains near the mouth of the Grande Ronde River.

Astragalus arrectus Gray ( $A$. palousensis Piper). Erect, 30-60 cm.' high, sparsely appressed-pubescent throughout; leaves erect of ascending, 10-20 $\mathrm{cm}$. long; leaflets about 15 pairs, oblong, somewhat truncate, cuneate at base, puberulent on both sides, 1-2 cm. long; peduncles stout, much longer than the leaves; flowers whitish, in rather dense erect racemes; calyx $5 \mathrm{~mm}$. long, blackpubescent, the tube campanulate, twice as long as the short acute teeth; corolla 10-12 mm. long; pods linear, short-beaked, 12-16 mm. long, $5 \mathrm{~mm}$. wide, thinly puberulent, slightly roughened, the dorsal suture pressed inwards, the stipitate base as long as the calyx. Grassy hillsides, not rare.

Astragalus mortoni Nutt. Erect, $30-80 \mathrm{~cm}$. high, minutely appressedpubescent, but green; leaves $10-15 \mathrm{~cm}$. long; leaflets $7-10$ pairs, ovate, oblong or obovate, truncate or notched at the apex, rounded or cuneate at the base, $1.5-2.5 \mathrm{~cm}$. long; peduncles as long as or longer than the leaves, stout; spikes dense, 5-10 cm. long; flowers reflexed, but the fruit erect; calyx campanulate, gibbous, $7-8 \mathrm{~mm}$. long, the triangular acuminate teeth shorter than the tube; corolla greenish, 12-15 mm. long; pods sessile, densely crowded, linear, 10-15 $\mathrm{mm}$. long, 3-4 mm. thick, with a slender hooked beak. Open woods and meadows. 
Astragalus adsurgens Pall. Herbage puberulent with fine white appressed hairs or becoming glabrous; stems ascending, 20-50 cm. high; leaflets 7-12 pairs, oblong, obtuse, $2-2.5 \mathrm{~cm}$. long; peduncles exceeding the leaves; flowers purplish, nearly sessile, in dense oblong spikes; bracts lanceolate, shorter than the calyx; calyx-teeth subulate, half as long as the tube; pods erect, oblong, straight, 8-10 $\mathrm{mm}$. long, finely pubescent, triangular-compressed, with a deep dorsal furrow. Silver Lake, Spokane County. "This is originally from Siberia but our plant is the same species.

Astragalus hypoglottis L. Herbage somewhat hairy; stems slender, procumbent or ascending, 8-15 $\mathrm{cm}$. long; leaflets 7-10 pairs, oblong to obovate, obtuse to retuse; peduncles longer than the leaves; flowers violet, in a short dense head; bracts longer than the hairy calyx; calyx-teeth subulate as long as the tube; pods ovate, straight, triangular-compressed, silky-villous. In damp meadows; our plant varies from the European type and is also known as .4stragalus agrestis Dougl.

Astragalus reventus Gray. Erect, $30-60 \mathrm{~cm}$. high, with harsh appressed puberulence; leaves erect or ascending; leaflets 10-15 pairs, linear, usually obtuse or truncate, cuneate at base, subsessile; peduncles stout, much longer than the leaves; flowers whitish, in rather dense erect racemes; calyx $5 \mathrm{~mm}$. long, black-pubescent, the tube campanulate, twice as long as the acute teeth; corolla $10 \mathrm{nim}$. long; pods transversely roughened, wrinkled, turgid, the dorsal suture not impressed, from narrowly ovoid to globose, stout-beaked, 1.5-2 $\mathrm{cm}$. long. Bluffs of Snake River.

Astragalus viridis (Nutt.) Sheldon. Herbage silky-canescent; stems much branched, spreading, forming circular mats; leaflets 2 or 3 pairs, linear-subulate, rigid, spine-tipped, 1-2 cm. long; flowers yellowish or purplish, solitary or two or three and nearly sessile in the axils; calyx hairy, the teeth subequal; pods ovate, compressed, pubescent, usually containing one seed. High ridges of the Blue Mountains.

\section{Family 47. Geraniaceae. Geranium Family.}

Annual or perennial herbs; leaves basal, alternate or opposite, often with stipules; flowers solitary or clustered, perfect, regular, commonly symmetrical, the parts in fives; sepals persistent; stamens usually twice as many as the petals, mostly in two sets, those alternate with the petals sometimes sterile; ovary 1 , deeply 3-5-lobed and 3-5-celled; ovules 2 in each cavity; fruit a capsule; carpels 1 -seeded, separating when mature from the axis.

Leaves palmate, variously cleft or divided. Leaves pinnately compound (in ours).

Geranium, 154. ERODIUM, 155.

\section{GERANIUM. WILd Geranium.}

Annual or perennial herbs; leaves palmately-lobed, cleft or divided, with stipules; flowers regular, on axillary 1-2-flowered peduncles; sepals 5 ; petals 5 , hypogynous; stamens 10 , rarely 5 , generally 5 longer and 5 shorter; ovary 5 -lobed, 5 -celled, beaked with a compound style; capsule 5-celled, each 1-seeded, and longtailed, at maturity separating from the long beak of the receptacle, splitting from below upward. 
Perennials; flowers large.

G. viscosissimum.

Annuals; flowers small.

Peduncle short; inflorescence compact.

Peduncles long; inflorescence loose.

Seeds reticulately ridged; fruits $2 \mathrm{~cm}$. long.

Seerls smooth or nearly so; fruits $1 \mathrm{~cm}$. long.

G. carolinianum.

G. bicknellii.

G. pusillum.

Geranium viscosissimum Fisch. \& Mey. Stout, perennial, $30-60 \mathrm{~cm}$. high, villous and glandular throughout, somewhat branched above; leaves orbicular, 5-10 cm. broad, 5-7-cleft or parted; lobes cuneate, oblong, inciselylobed or toothed; petioles of the radical leaves elongate, of the cauline short; flowers purple-red, $2-3 \mathrm{~cm}$. broad; carpels glandular, 2-3 cm. long. Common on hillsides.

Geranium carolinianum L. Annual, erect, branched, $15-30 \mathrm{~cm}$. high, pubescent throughout and somewhat glandular; leaves orbicular, $3-6 \mathrm{~cm}$. broad, deeply 5-9-cleft; lobes cuneate-oblong, acutely and incisely toothed or lobed; petioles slender; peduncles short, 2-flowered, the inflorescence rather compact; flowers pink, 8-10 mm. broad; sepals ovate, acuminate, short-awned, ciliate; carpels hispid, the beaks $2 \mathrm{~cm}$. long; tipped with a short slender style; seeds reticulated. Sandy soil in copses.

Geranium bicknelii Britt. Similar to $G$. carolinianum; peduncles scattered, elongate; flowers in pairs the pedicels much longer than the calyx; petals rose-colored; beak of the fruit tipped with a long slender style 4-6 mm. long. In open woods.

Geranium pusillum Burm. f. Annual spreading finely-pubescent, the weak stems 15-30 cm. long; leaves 1-3 cm. broad, 7-9-cleft into equal cuneateoblong lobes, these 3-toothed at apex; peduncles scattered, 2-flowered; flowers pink or violet, 4-5 mm. broad; sepals acute, not awned; petals notched; anther-bearing stamens only 5; carpels canescent, small, including the tails about $1 \mathrm{~cm}$. long; seeds smooth. A weed in lawns and waste places.

\section{ERODIUM.}

Herbs, generally with jointed nodes; leaves opposite or alternate, with stipules; flowers regular, in axillary umbels; sepals 5; petals 5 , hypogynous; anthers 5 , the 5 shorter stamens sterile or wanting; ovary 5 -lobed, 5 -celled, beaked by the united styles; tails of the carpels bearded on the inner side, becoming twisted.

Erodium cicutarium (L.) L'Her. Alfilaria. Filaree. Branched and spreading from the base, hairy-pubescent, the weak stems $10-60 \mathrm{~cm}$. long; leaves pinnate, $3-15 \mathrm{~cm}$. long, the leaflets pinnatifid into narrow acute lobes; peduncles generally longer than the leaves, bearing 2-10 pink flowers; sepals acute, nearly as long as the entire petals, these $4 \mathrm{~mm}$. long; carpels puberulent, the tails 5-7 cm. long, spirally-twisted when ripe. Introduced and becoming common.

\section{Family 48. LINACEAE. Flax Family.}

Herbs or rarely shrubs; leaves all simple and entire, mostly alternate; stipules none; flowers perfect, regular, symmetrical, in axillary or terminal cymes, or panicles; sepals 5 or 4 ; petals as many as and alternate with the sepals; stamens of the same 
number and alternate with the petals; pistil 1 ; styles $2-5$; ovary 2-5-celled; fruit usually a capsule, often 4-10-celled by false partitions; endosperm fleshy or none.

218. LINUM. FLAX.

Annual or perennial herbs; bark tough and fibrous; leaves alternate or opposite, sessile, entire, without stipules; flowers perfect; sepals, petals, stamens and styles 5 , regularly alternate with each other; pistil of 5 united carpels, 5 -celled, with 2 seeds in each cell; each cell divided in fruit by a false partition making a 10-celled pod.

Flowers small, yellow.

L. digynum.

Flowers large, blue.

Annual; stigmas as long as the styles.

Perennial; stigmas short.

L. usitatissimum.

L. lewisii.

Linum digynum Gray. Annual, glabrous and glaucous, much branched, 10-15 cm. high; stems slender, striate; leaves opposite, elliptic, 5-10 mm. long, the lower entire and obtuse, the upper acute and serrate; stipules none; flowers in loose leafy racemes or corymbs, short-pedicelled; sepals ovate, unequal, glandular, serrate or lacerate; petals yellow, $3 \mathrm{~mm}$. long, without appendages; capsule a little shorter than the calyx. Rare, in springy gravelly places.

Linum usitatissimum L. Common Flax. Frect annual; stem 30-50 cm. high; leaves alternate, linear-lanceolate, 2-5 cm. long; stipules none; flowers in loose cymes; sepals acute, ciliate, the inner margin scarious; petals blue, $10 \mathrm{~mm}$. long; capsule nearly indehiscent, as long as the calyx; its septa not ciliate. Escaped from cultivation.

Linum lewisii Pursh. Perennial, with a woody base, the erect branches $30-40 \mathrm{~cm}$. high, glabrous throughout; leaves alternate, numerous, linear or narrow, mostly very acute, $1-3 \mathrm{~cm}$. long; stipules none; flowers few, in a corymbose cyme; sepals ovate, acuminate, the inner margin scarious, usually entire, 4-6 $\mathrm{mm}$. long; petals blue, $15-20 \mathrm{~mm}$. long, obovate, without appendages; filaments with slender appendages; capsule ovoid, longer than the calyx, incompletely 10 -celled and 10-valved. Common in low ground.

\section{Family 49. EUPHORBIACEAE.}

Herbs (in ours), with milky juice; leaves opposite, alternate or whorled, entire or toothed, sessile or petioled; stipules present or wanting; flowers monoecious or dioecious, often much reduced and subtended by an involucre which resembles a calyx; parts of flowers various, often different in staminate and pistillate flowers; calyx none or minute; petals often wanting; stamens 1-many, free or united; ovary usually 3-celled; fruit a 3-lobed capsule; endosperm copious. 


\section{EUPHORBIA. SPURGE.}

Perennial or annual herbs (in ours); flowers monoecious, included in a cup-shaped 4-5-lobed involucre resembling a calyx or corolla and usually bearing large thick glands at its sinuses; glands rounded or of ten petal-like or crescent-shaped; staminate flowers numerous, of a single naked stamen, jointed upon a short pedicel which usually has a minute bract at its base; pistillate flowers solitary in the center of the involucre, pedicelled, and soon exserted; calyx none, or rarely present and minute; styles 3, 2-cleft; stigmas 6; ovary 3-celled, 3-ovuled.

Stems prostrate or nearly so; glands of the involucre with petal-like appendages.

Seeds with sharp transverse ridges.

Seeds pitted and wrinkled.

Stems erect; glands of the involucre without petal-like appendages.

Leaves filiform, very numerous; seeds smooth. E. cyparissias.

E. glyptosperma. E. serpyllifolia.

Leaves not filiform nor very numerous; seeds not smooth. E. dictyosperma.

Euphorbia glyptosperma Engelm. Annual, glabrous, prostrate or decumbent; stems much branched from the base, 5-30 cm. long; leaves opposite, oblong, obtuse, very oblique at the obtuse or subcordate base, serrulate or sometimes entire, short-petioled, 4-12 cm. long; stipules whitish, fringed; involucres solitary-axillary, somewhat clustered near the tips of the branches, campanulate, $1 \mathrm{~mm}$. long; glands somewhat saucer-shaped, with narrow crenate or lobed appendages; seeds whitish, with sharp transverse ridges, but not pitted. Common in sandy soil, in the warmer valleys.

Euphorbia serpyllifolia Pers. Very similar to $E$. glyptosperma, always prostrate; leaves narrowly obovate, usually cuneate at base; seeds slightly ridged and pitted. In dried-up ponds and stream margins.

Euphorbia cyparissias L. Perennial, erect, branched above, 30-60 cm. high; leaves numerous, linear, alternate, those at the base of the umbels whorled, sessile, entire, 1-2 cm. long; lower leaves reduced to scales; inflorescence terminal, a many-rayed umbel; bracts opposite, broadly ovate, sessile, 5-8 mm. long, yellowish; involucres campanulate, $2 \mathrm{~mm}$. long; glands crescentshaped, without appendages; seeds smooth. Sparingly escaped from gardens.

Euphorbia dictyosperma Fisch. \& Mey. Annual, erect, glabrous throughout, 15-30 $\mathrm{cm}$. high, branched above; cauline leaves alternate, obovate or oblanceolate, obtuse, serrate or nearly entire, narrowed into a sessile base, 1-3 cm. long; floral leaves opposite, longer than broad, mucronate; involucre about $1 \mathrm{~mm}$. long, the rounded lobes sometimes ciliate; glands transversely elliptical, yellow, about $1 \mathrm{~mm}$. wide; stamens 5-15; styles split only above the middle; capsules subglobose, warty; seeds ovoid, purplish, with low reticulated ridges. Banks of Snake River and at Walla Walla.

Family 50. Callitrichaceae. Water Starwort Family.

Aquatic or rarely terrestrial usually tufted herbs; leaves opposite, entire, spatulate or linear, without stipules; flowers minute, perfect or monoecious, axillary; perianth none; bracts 
two, sac-like, or none; stamen 1; pistil 1; styles 2, filiform; ovary 4-celled; ovule 1 in each cell; fruit nutlike, compressed, 4-lobed, 4-celled, more or less winged or keeled; endosperm oily.

\section{Callitriche. Water Starwort.}

Low slender usually tufted herbs; leaves spatulate or linear or both, entire; flowers monoecious, solitary or 2 or 3 in the axil of a leaf, with or without a pair of membranaceous bracts; staminate flower a single stamen; pistillate flower a single 4-celled ovary, sessile or pedicelled, with 2 distinct sessile stigmas.

Callitriche verna L. Aquatic or growing in the mud; floating leaves obovate, obtuse or emarginate, the others linear or spatulate, 1-nerved, $1-2 \mathrm{~cm}$. long; when terrestrial, leaves all linear; bracts 2 , as long as or longer than the fruit or wanting; fruit oval, emarginate, $1 \mathrm{~mm}$. long, the edges grooved and narrowly winged; styles erect, shorter than the fruit. Not rare, in ponds and pools.

\section{Family 51. ANACARDIACEAE. Cashew Family.}

Trees or shrubs with resinous or milky acrid juice; leaves alternate, usually compound, without stipules, not punctate; flowers regular, small, polygamo-dioecious or perfect; calyx 5lobed; petals 5; stamens as many or twice as many as the petals, rarely fewer or more; styles 3; ovary 1-celled, 1-ovuled; fruit generally a small drupe; endosperm scant or none.

\section{RHUS.}

Trees or shrubs, some poisonous to the skin; flowers polygamous or dioecious, seldom truly perfect, small, greenish or rarely yellow or rose-color; calyx small, 5-parted; petals 5; stamens 5; ovule basal.

Leaflets 9-31; fruit red, pubescent.

Leaflets 3; fruit white, glabrous.
R. glabra.

$R$. toxicodendron.

Rhus glabra occidentalis Torr. Sumac. Shrub or small tree, 2-5 m. high, with ridged bark, glabrous and somewhat glaucous except the inflorescence; leaflets $9-31$, broadly lanceolate, acuminate, serrate, paler beneath, 5-8 cm. long; inflorescence a dense panicle, usually puberulent, $10-12 \mathrm{~cm}$. long; flowers green or yellowish, polygamous; drupes red, 4-5 mm. in diameter, densely clustered, covered with short hairs. Common in the warmer valleys.

Rhus toxicodendron L. Poison Ivy. Low shrubs, weak or decumbent, 50-100 cm. high; leaflets 3 , broadly ovate, acuminate, entire, or with a few tooth-like lobes, glabrous or pubescent beneath, 5-10 cm. long, the lateral ones with shorter stalks; petioles longer than the leaflets; panicles shorter than the petioles; flowers green; drupes globose, 4-6 mm. in diameter, shiny, whitish, longitudinally ribbed; stone striate. In the warmer valleys; very poisonous. Our form seldom or never climbs and has been considered a distinct species, $R$. rydbergii Small. 


\section{Family 52. CELASTRACEAE. Stafftree Family.}

Shrubs, often climbing; leaves simple and undivided, alternate or opposite; stipules none or small and early withering; flowers regular, usually perfect, small; pedicels commonly jointed; calyx 4-5-lobed, the lobes imbricated; petals 4-5, spreading; stamens 4-5, perigynous on a disk, alternate with the petals; ovary sessile, free from or confluent with the disk; fruit a somewhat fleshy dehiscent pod; endosperm fleshy.

Evergreen smooth shrub; stamens 4; petals 4. Deciduous spiny shrub; stamens 10 ; petals 5 .
222. Pachistima, 159.

223. Forsellesia, 159.

\section{PACHISTIMA.}

Low evergreen shrubs; leaves opposite, smooth, serrulate, coriaceous; flowers perfect, very small, green, solitary or fascicled in the axils; calyx-lobes 4 , broad; petals 4 ; stamens 4 , on the edge of the disk; style very short; ovary free; pod small, oblong, 2-celled; seeds 1 or 2 , enclosed in a white membranous manycleft aril.

Pachistima myrsinites (Pursh) Raf. Evergreen glabrous shrub, much branched, $30-60 \mathrm{~cm}$. high; leaves oblong, lanceolate or obovate, acute or obtuse, cuneate at base, serrulate, nearly sessile, $1-3 \mathrm{~cm}$. long, the margin somewhat revolute; flowers yellowish or purplish, $3 \mathrm{~mm}$. broad; peduncles and pedicels short, 2-3 mm. long; capsule oblong, acute, 5-6 mm. long. In woods, Thatuna Hills.

\section{FORSELLESIA.}

Low and rigid shrubs, with slender spinescent branches; leaves small, alternate, sessile, entire; stipules minute, setaceous-subulate; flowers small, perfect, solitary, terminating short axillary branches or in spur-like fascicles; calyx deeply 5-cleft; petals 5; stamens 10; style short or none; ovary 1-celled, of a single ovoid carpel; ovules 2; fruit a coriaceous follicle, 1-2-seeded.

Forsellesia spinescens (Gray) Greene. Low much branched shrubs, somewhat spiny, $1 \mathrm{~m}$. or less high; leaves numerous, oblanceolate, acute, short-petioled, glabrous or puberulent, pale-green and glaucous, $6-16 \mathrm{~mm}$. long; stipules minute, usually reddish; flowers on pedicels as long as the leaves; petals yellow, narrow, $6 \mathrm{~mm}$. long; capsules ovoid, acutely beaked, striate, often curved. In basalt crevices, along Snake River.

\section{Family 53. ACERACEAE. Maple Family.}

Trees or shrubs; leaves simple or pinnately or palmately compound, opposite, without stipules (in ours); flowers small, regular (in ours), polygamous or dioecious; sepals 4-5; petals of ten none (in ours); stamens $3-12$, inserted on the fleshy disk; ovary 2- 
celled and lobed (in ours), with 2 ovules in each cell (in ours); endosperm none.

\section{ACER. MAPLE.}

Trees or shrubs; leaves opposite, palmately-lobed, without stipules; flowers small, polygamo-dioècious, in clusters; calyx colored, usually 5-lobed; petals 5 and equal or none; stamens 3-12; styles 2; ovary 2-lobed, 2-celled; ovules 2 in each cell; fruit a double samara, 2-winged above, separable at maturity, each 1 -seeded.

Acer glabrum douglasii (Hook.) Piper. Small tree, 3-10 m. high, with smooth light-gray bark; leaves simple, rarely 3-foliolate, orbicular, acutish, 5-lobed, coarsely serrate, truncate or subcordate at base, glabrous, dark-green above, paler beneath, 5-10 cm. long; petiole slender; flowers polygamous, in small corymbs; petals narrow, spatulate-oblong, veiny, about as long as the similar sepals; fruit glabrous, roughened, the wings diverging at less than a right angle, $2.5-3 \mathrm{~cm}$. long. In the mountains, along streams.

\section{Family 54. Balsaminaceae. Balsam Family.}

Usually glaucous succulent herbs with watery juice; leaves alternate, simple, without stipules; flowers irregular with a petal-like imbricated usually spurred calyx; petals 4 , united in two pairs; stamens 5, with short filaments and more or less united anthers; ovary 5-celled; seeds without endosperm.

\section{IMPATIENS. JEWELWEED.}

Delicate herbs with translucent stems; leaves coarsely toothed, petioled; flowers axillary or panicled, often of two kinds; large sterile ones and smaller cleistogamous ones which ripen good seed; sepals apparently four, the posterior ones usually spurred; petals 4 , united in two pairs; filaments 5 , each with a scale-like appendage; appendages united and covering the stigma; pod with evanescent partitions, opening suddenly when touched and projecting the seeds.

Impatiens biflora Walt. Stems erect, often branched above, $60-90 \mathrm{~cm}$. high; leaves elliptical, acute, coarsely crenate-serrate, paler beneath, 5-8 cm. long, the petioles nearly as long; flowers orange-colored, spotted with brown; saccate sepal longer than broad, tapering into a spur half as long. Swamps and springy places, Spokane, Rock Lake and Mud Lake, Idaho.

\section{Family 55. RHAMNACEAE.}

Erect shrubs or small trees; leaves simple; stipules small and early deciduous or none; flowers small and regular, sometimes polygamo-dioecious; disk fleshy; calyx 4- or 5-toothed; petals 
4 or 5 , on the disk, or sometimes none; stamens 4 or 5 , perigynous, alternate with the sepals and opposite the petals; ovary sessile; fruit a drupe or pod, with 1 seed in each cell; endosperm sparingly fleshy.

Fruit a drupe; flowers solitary or in umbels. Fruit a dry capsule; flowers in panicles.
226. Rhamnus, 161.

227. Ceanothus, 161.

\section{RHAMNUS.}

Shrubs or small trees; leaves alternate, petioled, pinnatelyveined, with small deciduous stipules; flowers greenish, polygamous or dioecious, in axillary clusters; calyx 4- or 5-cleft; calyx-tube bell-shaped, lined with the disk, both free from the ovary; petals 5 , small, oblong, sessile, acute or none; stamens 4 or 5 ; ovary $2-4$ celled; fruit a berry-like drupe, with $2-4$ separate seed-like nutlets.

Shrub; petals wanting; leaves nearly glabrous beneath. Tree; petals present; leaves downy beneath.

R. alnifolia.

R. purshiana.

Rhamnus alnifolia L'Her. Shrub, 1-2 m. high; leaves oval, acute at each end, serrate, 5-8 cm. long, straight veined; petioles slender, puberulent; fruit black, 3-seeded. In swamps near Spokane and about Lake Coeur d'Alene, Idaho.

Rhamnus purshiana DC. Small tree, 3-12 m. high, with nearly smooth dark-gray bark; young twigs pubescent; leaves elliptic, obtuse or acuminate, rounded at base, somewhat undulate, denticulate, pubescent, especially beneath, 5-15 cm. long; petioles 1-2 cm. long, downy; umbels stout-peduncled, 8-15-flowered; flowers 3-5 mm. long; sepals 5; petals minute, hood-shaped; fruit black, obovoid, as large as a pea, 3-seeded, insipid. Along streams, uncommon. Bark used medicinally under the name Cascara sagrada.

\section{CEANOTHUS.}

Shrubs, sometimes evergreen; leaves alternate, petioled; flowers perfect, in small umbel-like clusters, forming dense panicles at the summits of naked branches; calyx 5-lobed; calyx and disk adherent to the ovary; petals hooded, spreading; stamens 5; ovary 3-lobed; fruit 3-lobed, dry and very oily, splitting into its three carpels when ripe.

Evergreen; leaves varnished.

Deciduous; leaves not varnished.

C. velutinus.

C. sanguineus.

Ceanothus velutinus Dougl. Sticky Laurel. Stout shrub, 1-2 m. high, much branched; branchlets puberulent; leaves oval, obtuse, subcordate at base, prominently 3 -nerved, finely denticulate, thick and firm, glabrous and gummy above, puberulent beneath, $5-8 \mathrm{~cm}$. long; petioles stout; flowers white, in terminal panicles 5-10 cm. long; peduncles stout, puberulent; pedicels slender; carpels subglobose, 3-lobed above, nearly smooth. Thatuna Hills, common. 
Ceanothus sanguineus Pursh. Buckbrush. Shrub, 1-3 m. high, with slender smooth usually reddish branchlets; leaves thin, elliptical or ovate, obtuse, rounded at base, finely serrate; glabrate above, paler and puberulent beneath, 5-8 cm. long; petioles slender; panicles lateral, $6-10 \mathrm{~cm}$. long, their peduncles villous; flowers white; capsules smooth, 3-lobed. Thatuna Hills, common. This plant forms a very important, and fattening food for sheep on the summer range because of its oily seeds.

\section{Family 56. MALVACEAE. MaLlow Family.}

Herbs, or shrubs; leaves alternate, palmately-veined, with stipules; flowers regular, showy; peduncles axillary, jointed; calyx valvate; sepals 5 , united at base, often subtended by an involucre of numerous bractlets; corolla convolute; petals 5 , their bases united with each other and with the stamen-column; stamens numerous, monadelphous, in a column; pistils several, the ovaries united in a ring or forming a several-celled pod; endosperm scant.

Bractlets none; stamens in two series.

Bractlets three; stamens monadelphous.

Stigmas terminal, capitate.

Stigmas on the inner face of the styles.

228. Sidalcea, 162.

229. Sphaeralcea, 162. 230. MaLVA, 163.

\section{SIDALCEA.}

Herbs; leaves rounded, mostly lobed or parted; flowers pink or red, in a narrow terminal raceme or spike; involucre none; stamen-column double, the filaments of the outer series united usually into 5 sets opposite the petals; styles filiform, stigmatic on the inner surface; carpels 5-9, 1-ovuled, separating at maturity from the short axis, indehiscent.

Sidalcea oregana Gray. Perennial, puberulent throughout; stems erect, about $1 \mathrm{~m}$. high, branched above; lower leaves orbicular, about 9-cleft, the segments incised; upper leaves more deeply cleft or parted, the segments narrower; petioles mostly longer than the blades; stipules linear; racemes strict, 10-30 cm. long; calyx densely puberulent, 5-6 mm. long, the lobes deltoid, acuminate; petals pink, about $2 \mathrm{~cm}$. long; carpels roughened on the back. Low ground, common.

\section{SPHAERALCEA.}

Herbs or shrubs; flowers in narrow panicle-like racemes; involucre of 3 bractlets which are distinct or united at the base; petals notched or entire; stamen-column anther-bearing at the summit; styles stigmatic at the apex; carpels 2-valved; seeds usually 2 or 3 in each cell.

Leaves $2-4 \mathrm{~cm}$. long; flowers scarlet.

Leaves 5-15 cm. long; flowers rose-colored.

S. munroana. S. rivularis. 
Sphaeralcea munroana (Dougl.) Spach. Perennial, hoary-pubescent throughout; stems prostrate or decumbent, rarely erect, $20-40 \mathrm{~cm}$. long; leaves broadly ovate, crenulately toothed or lobed, 2-4 cm. long; petioles mostly as long as the blades; panicle narrow, $10-30 \mathrm{~cm}$. long; flowers bright scarlet; petals about $1 \mathrm{~cm}$. long; carpels reniform, oval, 3-4 mm. long. Sandy ground in the warmer valleys.

Sphaeralcea rivularis (Dougl.) Torr. Stout, perennial, 1-1.5 m. tall, green, sparsely pubescent; leaves large, palmately 5-7-lobed, the lobes acute, coarsely dentate; petioles stout, mostly as long as the blades; panicle narrow, erect, 15-60 cm. long; petals rose-colored, 2-3 cm. long; carpels very bristly, $2 \mathrm{~cm}$. long. Along streams especially in the warmer valleys.

\section{MALVA.}

Pubescent or glabrous herbs; leaves dentate, lobed or dissected; flowers perfect, axillary or terminal, solitary or clustered; involucre 3-leaved; calyx 5-cleft; petals 5, obcordate; styles numerous, stigmatic down the inner side; fruit depressed, separating at maturity into as many 1 -seeded indehiscent carpels as there are styles.

Malva rotundifolia L. Mallow. Cheeses. Annual or biennial, pubescent or glabrous; stems prostrate, branched near the base, $20-60 \mathrm{~cm}$. long; leaves round-reniform, 5-7-lobed, crenate-dentate, $2-5 \mathrm{~cm}$. broad; petioles long and slender; flowers pale blue, about $1 \mathrm{~cm}$. broad, clustered in the axils; pedicels slender, $1-2 \mathrm{~cm}$. long; carpels $12-15$, puberulent, not reticulated. A weed sparingly introduced.

\section{Family 57. HYPERICACEAE. St. Johnswort FAMILy.}

Herbs or shrubs; leaves opposite, entire, mostly sessile, with translucent or dark-colored glandular dots; stipules wanting; flowers perfect, regular; sepals $4-5$; petals $4-5$, hypogynous; stamens commonly in three or more clusters; styles $2-5$, usually distinct or nearly so; capsule 1-celled, with 2-5 parietal placentae, or 3-5-celled; endosperm none.

\section{HYPERICUM. ST. JOHNSWORT.}

Perennial herbs; leaves sessile, entire, punctate; flowers yellow, in cymes; sepals 5 ; petals 5 ; stamens numerous; ovary 1-celled, with 3-5 parietal placentae, rarely 3-5-celled.

Erect, $30-60 \mathrm{~cm}$. tall; stamens 60 or more.

Spreading, 5-15 cm. tall; stamens 15-20.
H. scouleri.

$H$. anagalloides.

Hypericum scouleri Hook. Stems erect, simple or branched above, $15-60 \mathrm{~cm}$. high; leaves oblong-ovate, obtuse, half-clasping at base, $2-3 \mathrm{~cm}$. long, black-dotted on the margin; inflorescence a corymb, loose or rather dense; sepals ovate-lanceolate, obtuse or acute; petals bright yellow, black dotted on the margin, $1 \mathrm{~cm}$. or less long; stamens numerous, in three fascicles. Moist places, common. 
Hypericum anagalloides nevadense Greene. Stems weak, erect or ascending, 8-15 $\mathrm{cm}$. high; leaves pale and glaucous, ovate, obtuse, somewhat clasping, $1 \mathrm{~cm}$. or less long; cymes peduncled, loose, the branches elongated; flowers small, not dotted, 6-8 mm. broad, dark yellow; sepals unequal, lanceolate, acuminate, in fruit much longer than the capsule. Forming loose mats in springy places; not common.

\section{Family 58. ELATINACEAE. WATERWORT FAMILY.}

Low annual marsh herbs; leaves opposite, not punctate, with membranous stipules; flowers minute, axillary, regular, symmetrical; sepals $2-5$, free; petals $2-5$, hypogynous; stamens as many or twice as many as the petals; ovary $2-5$-celled, with a many-ovuled axile placenta; fruit a capsule.

Plants glabrous; flower parts $2-4$.

Plants pubescent; flower parts 5.

232. Elatine, 164. 233. BERGIA, 164.

232. ELATINE.

Dwarf glabrous plants growing in or near the water, often rooting at the nodes; sepals $2-4$, obtuse; petals $2-4$, hypogynous; stamens as many or twice as many as the petals; styles or sessile stigmas 2-4; pod membranaceous, 2-4-celled, several-manyseeded.

Elatine californica Gray. Plants small, 2-5 cm. high; leaves obovate or spatulate, attenuate at base or the lowermost petioled; flowers white, on short peduucles; petals 3 or 4 and stamens 6-8; seeds cylindrical, curved, marked by 10-12 longitudinal lines and many transverse markings. In low wet meadows near Spokane.

\section{BERGIA.}

Diffuse or ascending herbs, branching, often pubescent; leaves entire or serrate; flowers axillary, solitary or clustered; parts of the flower in fives; sepals acute, with a prominent midrib; capsule crustaceous, ovoid, 5-valved; seeds numerous.

Bergia texana (Hook.) Seubert. Annual, branched from the base, 4-20 cm. high; stems erect or ascending, glandular-pubescent; leaves lanceolate, obovate or spatulate, serrate, 1-2 cm. long, petioled; flowers in small axillary fascicles; sepals acuminate, $3 \mathrm{~mm}$. long, equalling the white or pinkish petals; stamens 5 or 10 . Sandy banks of Snake River at Almota, very rare.

Family 59. ViolaceaE. Violet Family.

Herbs with alternate or basal leaves, with stipules; flowers perfect, axillary, nodding; sepals 5, hypogynous; corolla somewhat irregular, 1-spurred, of 5 petals; stamens 5, hypogynous; anthers adnate, united over the pistil; ovary 1-celled, with 3 
parietal several-ovuled placentae; capsule 3-valved; endosperm copious.

\section{VIOLA. VIOLET.}

Mostly perennial herbs; leaves alternate, with foliaceous stipules; peduncles 1-flowered, axillary; flowers usually of two kinds, the earlier ones perfect and conspicuous, but often sterile, the later (near the ground in stemless species) with small and rudimentary petals, cleistogamous and producing numerous seeds; sepals unequal, more or less auricled; petals unequal, the lower spurred; the two lower stamens spurred.

Stemless; leaves and flowers all from a subterranean rootstock; flowers violet.

Stems leafy, though sometimes very short.

Flowers violet or violet-tinged.

Style capitate; stipules entire.

Style slender, not capitate; stipules toothed.

Flowers yellow.

Stigma beardless; leaves reniform-orbicular.

V. nephrophylla.

Stigma bearded.

Glabrous; leaves cordate-reniform, crenulate.

Puberulent; leaves ovate to oblong-lanceolate.

Leaves coarsely toothed or lobed.

Leaves entire or nearly so.

V. canadensis.

V. adunca.

V. orbiculata.

V. glabella.

V. venosa.

V. nuttallii.

Viola nephrophylla Greene. Glabrous or nearly so; leaves thickish, reniform to cordate, faintly crenate, obtuse, $2-6 \mathrm{~cm}$. long, rather pale; flowers violet, on peduncles $10-20 \mathrm{~cm}$. long, exceeding the leaves; lateral petals bearded, the spurred one villous; sepals ovate-lanceolate, obtuse; capsules oblong, glabrous. In springy places.

Viola canadensis L. Herbage minutely pubescent, but at length glabrate, 20-30 cm. high; leaves cordate, serrate, acute, rather large; stipules scarious, lanceolate; flowers whitish, the back of the petals tinged with violet; lateral petals bearded; spurred petal yellow at base within and dark-veined; sepals narrow, acuminate; capsule oval, glabrous. In woods, Craig Mountains.

Viola adunca Smith. Stems leafy, short or at length elongated, from creeping rootstocks, nearly glabrous throughout; leaves ovate, obtuse, slightly cordate at base, crenate, usually brown dotted, 1-3 cm. long, on slender petioles, 5-8 cm. long; stipules foliaceous, lanceolate, fringe-toothed; flowers violetpurple, rarely white; petals $6-12 \mathrm{~mm}$. long, the lateral ones bearded; spurs nearly straight, as long as the petals. Stony hillsides and copses. Common and variable.

Typical Viola adunca has puberulent leaves. The glabrous or nearly'glabrous form is Viola adunca glabra Brainerd.

Viola orbiculata Geyer. Rootstocks short, scaly; leaves orbicular, cordate, glabrous or nearly so, the deep sinus often closed, obscurely crenate, $1-4 \mathrm{~cm}$. broad; petioles slender, $5-10 \mathrm{~cm}$. long; flowering scapes about as long as the leaves; petals yellow, $7-10 \mathrm{~mm}$. long, the blunt spurs short. Early plants appear as if acaulescent, the leafy branches being produced later and bearing only cleistogamous flowers. Coniferous woods, in the mountains. 
Viola glabella Nutt. Whole plant glabrous or nearly so; rootstock rather stout, creeping; stem leafy above, $10-20 \mathrm{~cm}$. tall; radical leaves reniform, acuminate, crenate-serrate, $1-5 \mathrm{~cm}$. broad, long-petioled; cauline similar, short-petioled; stipules thin, membranous, ovate or lanceolate, entire; peduncles 2-6 cm. long; petals yellow, purple-veined, 10-12 mm. long; spur short and broad. Moist rich woods, in the mountains.

Viola venosa (Wats.) Rydb. ( $V$. atriplicifolia Greene.) Minutely puberulent or glabrous, $5-15 \mathrm{~cm}$. high; leaves mostly ovate, cuneate or truncate at base, coarsely dentate or angularly lobed, purple veined, the blades 5-20 $\mathrm{mm}$. long; peduncles little exceeding the leaves; petals 8-12 $\mathrm{mm}$. long, yellow, the upper ones dark purple or brownish on the back, the lateral ones bearded at the base; capsules globose, pubescent. High ridges of the Blue Mountains in stony soil.

Viola nuttallii linguaefolia (Nutt.) Piper n. comb. ( $V$. linguaefolia Nutt.) Stems mostly very short from rather thick fleshy roots; leaves numerous, more or less pubescent; blades oblong or narrowly ovate, obtuse, cuneate or truncate at the base, crenate or entire, $2-4 \mathrm{~cm}$. long; petioles margined, longer than the blades; stipules narrow, entire; flowers yellow, the peduncles usually shorter than the leaves; petals about 5-10 mm. long; spur short and blunt. Rather rare, in meadows.

Viola nuttallii major Hook. ( $V$. flavovirens Pollard.) Flowers larger, the petals $10-14 \mathrm{~mm}$. long; leaves sometimes more hairy. In the Blue and Craig Mountains.

\section{Family 60. LOASACEAE.}

Herbs, with rough-barbed or stinging hairs; leaves alternate or opposite, without stipules; flowers perfect; calyx 4- or 5-lobed, adherent to the ovary; stamens usually very numerous, rarely few, some of the outer occasionally petal-like; ovary 1-celled, with 2 or 3 parietal placentae; endosperm mostly scant or none.

\section{MENTZELIA.}

Annual or biennial erect herbs, more or less rough with rigid barbed hairs, the stems becoming white and shining; leaves alternate, mostly coarsely toothed or pinnatifid; flowers terminal, solitary or in cymose clusters; calyx cylindrical, 5-parted; petals 5 or 10 , regular, spreading, perigynous; stamens perigynous; styles 3 , more or less united into one; capsule few-manyseeded.

Biennial; flowers large; outer filaments dilated. Annual; flowers small; filaments all filiform.

M. laevicaulis. M. inlegrifolia.

Mentzelia laevicaulis (Dougl.) T. \& G. Biennial; stem stout, erect, 30-100 $\mathrm{cm}$. high, hoary-pubescent throughout or glabrate, branched above; radical leaves lanceolate, acute, petioled, 10-15 cm. long, coarsely dentate or lobed, hoary-pubescent; cauline similar, sessile, gradually reduced upwards; flowers nearly sessile, terminal, mostly solitary; calyx-lobes lanceolate-attenuate, 2-3 cm. long; inner petals, when present, narrow; stamens numerous, as long as the style, shorter than the petals; capsule oblong, about $2 \mathrm{~cm}$. long. Gravelly places, locally abundant. 
Mentzelia integrifolia (Wats.) Rydb. Annual, puberulent throughout; stem white, erect, rarely decumbent, more or less branched, $10-40 \mathrm{~cm}$. high; leaves oblong or lanceolate or the upper ovate, entire or sinuately pinnatifid, 2-6 cm. long, sessile; flowers yellow, sessile or nearly so, in leafy cymes, 6-10 mm. broad; calyx-lobes deltoid-lanceolate, shorter than the petals; capsule linear, 2-3 mm. long; seeds nearly cubical, smooth, grooved on the angles. Dry soil, Wawawai and Cedar Mountains, Idaho.

\section{Family 61. CACTACEAE. Cactus Family.}

Fleshy and thickened plants; stems flattened, terete, ridged or tubercled, continuous or jointed, leafless or with small leaves, generally spiny; spines from cushions of minute bristles; flowers solitary, sessile, perfect, regular, showy; sepals and petals numerous, in several rows, the bases adherent to the ovary; stamens numerous, on the calyx-tube; style 1 ; ovary 1 -celled, with several parietal placentae; ovules numerous; fruit a 1-celled berry; endosperm scanty or copious.

\section{OPUNTIA PrickLy Pear.}

Jointed, much-branched plants; leaves small, terete, subulate, early deciduous, on young branches; flowers usually lateral, large; calyx-tube not prolonged beyond the ovary; lobes numerous, spreading; petals numerous, slightly united; stamens very numerous, in several rows; fruit a berry, often prickly.

Opuntia polyacantha Haw. Prostrate, frequently in large tufts; joints of the stem flattened, orbicular or oblong, $5-12 \mathrm{~cm}$. long, pale-green; leaves minute, 3-4 mm. long; cushions pale bristly; spines 4-8, whitish, usually red-tipped, 5-20 mm. long, mostly deflexed; flowers yellow, 4-5 cm. broad; fruit ovate, dry, $2.5 \mathrm{~cm}$. long, with a shallow saucer-like apex. Rocky and sandy places, banks of Snake River.

\section{Family 62. LYTHRACEAE.}

Herbs; leaves mostly opposite and entire, with no stipules; flowers axillary or whorled, perfect; calyx enclosing but free from the ovary; petals $4-7$, as many as the calyx-teeth, perigynous, or none; stamens $4-14$, on the calyx; style 1 ; ovary $2-4$-celled; ovules numerous, rarely few; fruit a membranous capsule; endosperm none.

Flowers mostly more than one in the axils; capsule bursting irregularly.

237. Ammannia, 168.

Flowers mostly solitary in the axils; capsule septicidally dehiscent.

238. Rotala, 168. 


\section{AMMANNIA.}

Low and inconspicuous smooth herbs; leaves opposite, narrow; flowers small, 1-several in the axils; calyx bell-shaped, usually 4-angled, 4-toothed and with 4 intermediate short tooth-like appendages in the sinuses; petals 4 , small, early deciduous, or wanting; stamens 4-8; capsule globular, enclosed in the calyx, mostly 4-celled, bursting irregularly.

Ammannia coccinea Rottb. Erect or ascending, glabrous, 5-30 cm. high, branched below; leaves oblong-linear, acute or obtuse, auriculate-clasping at the sessile base, entire, $2-4 \mathrm{~cm}$. long; flowers $1-5$ in the axils, sessile or nearly so; petals broadly spatulate, truncate; style slender, about one-half as long as the capsule. Sandy banks of Snake River at Almota, rare.

\section{ROTALA.}

Low annual mostly glabrous herbs; stems 4-angled; leaves opposite, sessile or sometimes petioled; flowers small, axillary, mostly solitary; calyx 4-lobed; petals 4; stamens 4, short; ovary free from the calyx, globose, 4-celled; capsule globose, enclosed by the membranous calyx, 4-celled, septicidally dehiscent.

Rotala ramosior (L.) Koehne. Annual, glabrous, simple or branched below, 5-15 cm. high, erect or ascending; leaves entire, oblong or spatulate, obtuse or acute, $1-2 \mathrm{~cm}$. long, narrowed into a short petiole at base, not auricled; flowers mostly solitary in the axils; calyx 2-3 mm. long; petals minute; style very short. Moist places, especially lake shores and stream banks, rare.

\section{Family 63. ONAGRACEAE. Evening Primrose Family.}

Herbs with simple alternate or opposite leaves; stipules none; flowers perfect, symmetrical, the parts in twos or fours; calyxtube adherent to the ovary; petals on the throat of the calyx or rarely wanting; stamens as many as or twice as many as the petals or calyx-lobes, on the calyx-tube; style single, slender; stigma-lobes as many as the cells of the ovary; fruit a capsule or small nut; endosperm none.

Parts of the flower in twos.

239. Circaea, 169.

Parts of the flower in fours.

Fruit indehiscent, nut-like, few-seeded. 240. Gaura, 169.

Fruit dehiscent, many-seeded.

Calyx-limb persistent; petals minute or wanting.

241. IsNARDiA, 169.

Calyx-limb deciduous; petals conspicuous.

Seeds silky-hairy; lower leaves mostly opposite.

242. EpIlobium, 170.

Seeds not hairy; leaves all alternate.

Anthers attached at or near the base, erect. 
Petals with claws.

Petals without claws.

243. Clarkia, 171.

Anthers attached near the middle, versatile.

Stamens unequal, the outer ones longer.

Annuals; small flowered, caulescent.

Biennials; large flowered, acaulescent or nearly so.

245. Gayophytum, 172. Stamens equal.

Stigmas deeply 4-cleft, the lobes linear.

Stigmas entire or nearly so.

Calyx-tube longer than the ovary; flowers large.

Calyx-tube shorter than

the ovary; flowers small. 249. Sphaerostigma, 174.

246. Pachylophus, 173.

247. OENotherA, 173.

248. TARAXIA, 174.

239. CIRCAEA.

Delicate perennial herbs with opposite leaves on slender petioles; flowers white, in terminal or axillary racemes; parts of the flower in twos; calyx-tube prolonged, deciduous; lobes reflexed; fruit indehiscent, small, bur-like, 1-2-celled, with hooked hairs; cells 1 -seeded.

Circaea pacifica Asch. \& Magn. Nearly glabrous but pilose with white hairs on the upper part of the stem, 12-50 cm. high; stem usually simple, from a small tuber; leaves ovate-orbicular, nearly entire or slightly denticulate, $3.5-6 \mathrm{~cm}$. long, base truncate or rarely cordate, apex acute or sometimes obtuse; petioles one third as long to as long as the blade; bracts of the inflorescence foliaceous, or setaceous or none; flowers $2.5-3 \mathrm{~mm}$. long, rarely pinkish in the buds; fruit mostly white-hairy. In moist shady woods.

\section{GAURA.}

Annual, biennial or perennial herbs, somewhat woody at base; leaves alternate, sessile; flowers white or rose-colored, in spikes or racemes; calyx-tube much prolonged beyond the ovary, 4-lobed, rarely 3 -lobed; petals 4 , with claws, unequal; stamens mostly 8 , turned down; fruit hard and nut-like, 3- or 4-ribbed or angled, indehiscent or nearly so, usually 1-celled and 1-4-seeded.

Gaura parviflora Dougl. Annual, erect, 1-2 m. high, whitish-pubescent throughout, the stems villous; leaves numerous, ovate or lanceolate, acute, entire or denticulate, rounded at base, nearly sessile, silky-pubescent, somewhat villous-ciliate, $6-10 \mathrm{~cm}$. long; flowers small, pink, 3-4 mm. broad, in erect spikes, 8-30 cm. long; bracts lanceolate, quickly deciduous; fruit sessile, fusiform, glabrous, $6-8 \mathrm{~mm}$. long. In sandy soil in the warmer valleys.

\section{ISNARDIA.}

Annual, or perennial succulent herbs with prostrate creeping or floating stems; leaves opposite, fleshy, narrowed into petioles 
shorter than the blades; flowers perfect, axillary, sessile; calyx turbinate, with 4 segments, persistent; petals 4 and small, or none; stamens 4; filaments short; stigma 4-lobed, often nearly sessile; ovary 4-celled, very short; ovules numerous; capsule 4angled, septicidal; seeds numerous.

Isnardia palustris L. Glabrous; stems creeping or sometimes floating, $15-30 \mathrm{~cm}$. long; leaves all opposite, ovate or oval, $1-2 \mathrm{~cm}$. long, acute, petioled; flowers sessile, axillary; petals very small and reddish, or none; capsules shortoblong, 4-sided, sessile, not attenuate at base. In ditches and shallow lake borders. Waitsburg, Horner.

\section{EPILOBIUM. Willow Herb.}

Mostly perennial herbs; leaves nearly sessile, denticulate or entire, alternate or opposite; flowers axillary or terminal, solitary or clustered; calyx-tube scarcely prolonged beyond the ovary, 4-cleft; petals 4 , spreading or somewhat erect; stamens 8 , the 4 alternate ones shorter; fruit a dehiscent capsule; seeds numerous, with a tuft of silky hairs at the end.

Calyx-tube not prolonged beyond the ovary; flowers large. E. angustifolium. Calyx-tube prolonged beyond the ovary; flowers mostly small.

Annuals; stigmas mostly 4-cleft.

Stems $8-20 \mathrm{~cm}$. tall, but little branched; herbage puberulent.

E. minutum.

Stems $30-90 \mathrm{~cm}$. tall, usually much branched; herbage glabrous or glandular.

Perennials; stigmas subentire.

E. paniculatum.

Stems tall, $30-90 \mathrm{~cm}$. high.

Petals 6-10 mm. long; herbage canescent-puberulent.

Petals 3-5 mm. long; herbage not canescentpuberulent.

Stems low; species mostly alpine or subalpine.

Seeds smooth or nearly so. Foliage not glaucous. Foliage glaucous.

Seeds papillate.

Plants producing stolons.

Plants not producing stolons.

E. franciscanum.

E. adenocaulon.

E. hornemanni.

E. fastigiatum.

E. hornemanni.

E. ursinum.

Epilobium angustifolium L. Fireweed. Perennial, erect, about $1 \mathrm{~m}$. high, glabrous or puberulent; leaves numerous, lanceolate, acute, entire or denticulate, nearly sessile, $8-16 \mathrm{~cm}$. long; lateral veins confluent at the margin; raceme erect, many-flowered, $20-40 \mathrm{~cm}$. long; flowers rose-colored, $2-3 \mathrm{~cm}$. broad; pedicels slender, exceeding the narrow bracts; petals obovate, entire, clawed; stigma 4-lobed; capsules spreading, linear, canescent, 5-10 cm. long. Not uncommon, sometimes a troublesome weed.

Epilobium minutum Lindl. Annual, simple or branched, puberulent, $10-30 \mathrm{~cm}$. high; leaves lanceolate, acute, undulate or denticulate, mostly alternate, $1-2 \mathrm{~cm}$. long, narrowed at base; calyx-tube funnelform; petals pinkish, obcordate, 3-4 $\mathrm{mm}$. long; stigma deeply 4-lobed; capsules shortstalked, curved, ascending or erect, $2-2.5 \mathrm{~cm}$. long. In dry open woods. 
Epilobium paniculatum Nutt. Annual, glabrous or minutely pubescent, much-branched above, $30-60 \mathrm{~cm}$. high; bark becoming loose and papery at base; leaves linear or linear-lanceolate, often curved and folded, acute, denticulate, 2-5 cm. long, attenuate to a short petiole; flowers pink or whitish, variable in size, usually $4-10 \mathrm{~mm}$. broad, in loose racemes terminating the almost naked branches; petals notched; capsules lanceolate-linear, $1-1.5 \mathrm{~cm}$. long, on pedicels about as long. Common and variable.

Epilobium franciscanum Barbey. Very similar to E. adenocaulon, but canescent-puberulent throughout or somewhat pilose above; leaves mostly sessile. In moist places near Spokane, Piper.

Epilobium adenocaulon Haussk. Perennial by short stolons which produce fleshy rosettes in the fall; stems erect, $30-60 \mathrm{~cm}$. high, usually simple, leafy, glabrous or puberulent, sometimes glandular above; leaves mostly opposite, lanceolate, acutish, closely denticulate, glabrous or puberulent, $5-7 \mathrm{~cm}$. long, mostly short petioled; inflorescence terminal, becoming loose; petals notched, about $4 \mathrm{~mm}$. long, pink; capsules linear, nearly sessile, $6-8 \mathrm{~cm}$. long, usually puberulent; seeds minutely papillate. Low ground, common. Very variable.

Epilobium adenocaulon occidentale Trel. Remotely leafy; leaves more triangular-lanceolate, erect, prominently denticulate, very short-petioled. Pullman and Spokane.

Epilobium hornemanni Reichenb. Perennial, often tufted, 10-30 cm. high, erect, usually puberulent or glandular in the inflorescence; leaves ovate, entire or denticulate, $2-4 \mathrm{~cm}$. long, narrowed at base to a short petiole; petals pink or purple, $5-8 \mathrm{~mm}$. long; capsule pedicellate; seeds smooth or minutely roughened. Along rills in the Blue Mountains.

Epilobium fastigiatum (Nutt.) Piper. Perennial, glabrous and glaucous, usually tufted, the stems mostly simple, 10-20 cm. high; leaves sessile, all opposite, ovate or ovate-lanceolate, serrulate, or nearly entire, $1-2 \mathrm{~cm}$. long; petals usually pink, 4-8 mm. long; stigma clavate; capsules $6-7 \mathrm{~cm}$. long; seeds minutely roughened. Moist places, Blue Mountains.

Epilobium ursinum Parish. Stems slender, erect, $15-30 \mathrm{~cm}$. high; herbage sparsely pubescent or somewhat pilose, the inflorescence minutely glandularpubescent; leaves lanceolate, sessile, denticulate-serrate, acutish, 2-3 cm. long, a little longer than the internodes; flowers few; petals white or lavender, about $5 \mathrm{~mm}$. long; capsules ascending, glabrous, $3 \mathrm{~cm}$. long, on pedicels half as long; seeds rough. Little Potlatch River, Idaho, Sandberg, Heller and MacDougal.

\section{CLARKIA.}

Annual, with erect brittle stems; leaves alternate or opposite, on short slender petioles, the uppermost sessile; flowers in terminal racemes; calyx-tube obconical above the ovary, 4-cleft; petals 4 , with claws, lobed or entire, purple or violet; stamens 8 , those opposite the petals often sterile; anthers attached at their bases, erect; ovary 4-celled; capsule linear, attenuate above, coriaceous, erect, somewhat 4 -angled, 4-celled and 4-valved to the middle; seeds numerous.

Petals 3-lobed.

C. pulchella.

Petals entire.

C. rhomboidea.

Clarkia pulchella Pursh. Stems erect, much branched above, $15-60 \mathrm{~cm}$. high, puberulent; leaves linear or linear-lanceolate, entire; rather obtuse, 
short-petioled, glabrous or puberulent, $2-6 \mathrm{~cm}$. long; flowers red, in cory mblike racemes; petals about $20 \mathrm{~mm}$. long, the broad blades 3 -lobed, the long claw with a slender tooth on each side; inner four anthers rudimentary; stigma-lobes much dilated; capsule oblong, truncate at apex, 2-3 cm. long, puberulent, stout-pedicelled. Common on the prairies.

Clarkia rhomboidea Dougl. Slender, erect, usually simple, $15-60 \mathrm{~cm}$. high, puberulent; leaves broadly lanceolate, acute at each end, entire, 1-4 $\mathrm{cm}$. long, slender-petioled; flowers few, scattered; petals rhomboidal, entire, about $1 \mathrm{~cm}$. long, the claw of ten toothed; stamens all perfect; filaments with hairy scales at base; capsules stout, 4-angled, acuminate, nearly sessile, 2-3 $\mathrm{cm}$. long. In dry open woods.

\section{BOISDUVALIA.}

Erect leafy annual herbs; leaves alternate, sessile, simple; flowers small, in leafy simple or compound spikes; calyx-tube funnelform above the ovary, 4-lobed; petals 4, 2-lobed, purple or white; stamens 8 , those opposite the petals shorter; anthers attached near their bases, erect; ovary 4-celled, several-ovuled; capsule membranaceous, ovate-oblong to linear, nearly terete, acute, sessile, dehiscent to the base; seeds $3-8$, in one row in each cell.

Upper leaves much shorter than the lower ones; capsule septifragal.

Upper leaves about as long as the lower ones; capsule loculicidal. Leaves narrowly lanceolate, pubescent.

Leaves ovate-lanceolate, of ten glabrous.

B. densiflora.

Boisduvalia densiflora (Lindl.) Wats. Erect, simple or with a few branches below, hoary-puberulent throughout or nearly glabrous, $30-90 \mathrm{~cm}$. high; lower leaves lanceolate, acuminate, denticulate, 2-6 cm. long; upper leaves gradually shorter and sometimes broader, ovate, acuminate, nearly entire, crowded; spikes dense; corolla 6-8 mm. broad, purplish; capsules oblong, 5-8 $\mathrm{mm}$. long, the partitions not adherent to the valves in dehiscence; seeds 3-6 in each cell. Common in low ground, variable.

Boisduvalia stricta (Gray) Greene. Erect, simple or rarely branched below, villous throughout, $30-40 \mathrm{~cm}$. high; leaves all alike, lanceolate, acute, entire or denticulate, $2-3 \mathrm{~cm}$. long; flowers in the axils of the upper leaves and occasionally of the lower also; corolla 2-3 mm. long, purplish; capsules slender, acuminate, $8-10 \mathrm{~mm}$. long; partitions adherent to the valves; seeds 6-8 in each cell. Growing with B. glabella and in similar places.

Boisduvalia glabella (Nutt.) Walp. Erect and simple or more commonly branched at base and decumbent, $10-30 \mathrm{~cm}$. high, leafy, densely villous to glabrous; leaves all alike, ovate-lanceolate, acute or acuminate, serrate or dentate, 1-2 cm. long; flowers sessile in the upper axils, occasionally also in the lower ones, shorter than the leaves; corolla purplish, $2 \mathrm{~mm}$. long, capsules fusiform, tapering from a broader base, $6-7 \mathrm{~mm}$. long, the partitions adherent to the valves; seeds 4-6 in each cell, somewhat fusiform. Common in the bottoms of dried ponds. Puzzling intermediate forms occur between this and B. stricla.

\section{GAYOPHYTUM.}

Very slendẹr caulescent branching annuals; leaves alternate, linear, entire; flowers axillary; calyx-tube not prolonged beyond 
the ovary, 4-parted; petals 4 , white or rose-colored, very small, obovate or oval, with a very short claw; stamens 8 ; anthers broad or rounded, attached by the middle, those opposite the petals on shorter filaments and usually sterile; ovary 2-celled; fruit a dehiscent capsule, seeds few-many, naked, in one row.

Capsules nearly sessile; stems simple or branched from the base.

Capsules on slender pedicels; stems branched above.

Seeds glabrous.

Seeds canescent.

G. pumilum.

G. ramosissimum.

G. lasiospermum.

Gayophytum pumilum Wats. Erect, simple or branched at base, 5-15 $\mathrm{cm}$. high, glabrous or minutely puberulent; leaves numerous, lanceolate, acute, attenuate to the sessile base, 1-2 cm. long; flowers minute; capsules stout, sessile, 10-22 mm. long, usually appressed to the stem; seeds smooth. Moist bare places in the mountains.

Gayophytum ramosissimum T. \& G. Erect, with usually many slender branches, glabrous below, puberulent above, 15-40 cm. high; leaves linear or linear-lanceolate, 1-4 cm. long, acute, attenuate at the sessile base; flowers pink, small, 2-4 mm. broad, pedicelled; capsules oblong or somewhat clubshaped, often torulose, 6-12 mm. long, spreading, on slender pedicels, sometimes deflexed; seeds not hairy. Dry soil, especially in open woods.

Gayophytum lasiospermum Greene. Very similar to G. ramosissimum and to be distinguished certainly only by the seeds, which are canescent with an appressed silky-pubescence. In sandy or gravelly soil.

\section{PACHYLOPHUS.}

Perennial acaulescent or nearly acaulescent herbs; leaves basal, pinnatifid or pinnately-toothed, petioled; flowers basal, more or less tufted; calyx-tube linear-funnelform; segments narrow, onethird to one-half the length of the tube; petals white or pink; stamens 8 , equal; anthers attached near the middle, versatile; capsule 4-celled, pyramidal, its angles retuse or obtuse, transversely wrinkled; seeds sessile, in one or two rows.

Pachylophus marginatus (Nutt.) Rydb. Stemless or nearly so, with a thick tap-root; leaves all radical, lanceolate or oblanceolate, obtuse or acute, sinuately irregular-dentate or pinnatifid, 5-10 cm. long, narrowed into a petiole about as long, villous or nearly glabrous except the villous margin; flowers barely exceeding the leaves, rose-colored, $4-6 \mathrm{~cm}$. broad; calyx-tube narrow, 5-10 cm. long, much longer than the ovary, the lobes lanceolate, somewhat reflexed; capsule oblong-ovate, sessile or nearly so, 3-4 cm. long. Bluffs of Snake River.

247. OENOtherA. Evening Primrose.

Annual, biennial or perennial herbs with prostrate or erect stems; leaves alternate, entire, toothed or pinnatifid; buds erect or drooping; flowers white, pink or yellow, blooming by night or by day; flowers axillary or in terminal spikes; calyx-tube elongated, terete, filiform or enlarged upward; segments narrow, 
tips free or united in bud, finally reflexed; stamens 8 , equal, with filiform filaments and linear anthers; ovary 4-celled, the united styles filiform; stigma 4-cleft; ovules numerous, in one, two or more rows, horizontal or ascending; capsule 4-celled, 4angled, loculicidal; seeds numerous, angled or terete, with or without a tubercle.

Oenothera strigosa Rydb. Annual or biennial, erect, 50-200 cm. high, usually simple, appressed-canescent throughout; leaves numerous, lanceolate or oblanceolate, acute, denticulate, 3-12 $\mathrm{cm}$. long, the lower narrowed at base and petioled, the upper sessile; spikes terminal, elongate in fruit; flowers yellow, $2-4 \mathrm{~cm}$. broad, opening in the evening; calyx-tube slender, $2-3 \mathrm{~cm}$. long, much longer than the ovary or the spreading lobes; capsules oblong, narrowed above, sessile, $2-2.5 \mathrm{~cm}$. long. Common in the warmer valleys.

\section{TARAXIA.}

Acaulescent plants with pinnatifid or entire leaves and yellow or white axillary flowers; calyx 4-parted, the tube longer than the ovary, the segments reflexed; stamens 8 , erect; anthers versatile; stigma capitate, entire or nearly so; capsule sessile; seeds in 2 rows, ascending.

White-pubescent; leaves deeply pinnatifid. Glabrous or nearly so; leaves entire or pinnatifid.

T. tanacelifolia. T. heteraniha.

Taraxia tanacetifolia (T. \& G.) Piper. Densely white pubescent; leaves lanceolate or oblanceolate, petioled, deeply pinnatifid, acuminate, $5-15 \mathrm{~cm}$. long; calyx-tube 3-8 cm. long, the lobes linear-lanceolate; petals $1-2 \mathrm{~cm}$. long; capsules terete, attenuate toward the apex. In moist places, local.

Taraxia heterantha (Nutt.) Small. Glabrous or nearly so; leaves oblonglanceolate, acute or acuminate, entire or somewhat denticulate, $5-15 \mathrm{~cm}$. long; calyx-tube 4-6 cm. long, the lobes narrowly lanceolate; petals broadly obovate, retuse, 8-12 mm. long; capsule oblong, narrowed at each end. Moist ground.

Taraxia heterantha taraxicifolia (Wats.) Small. Leaves deeply pinnatifid. In moist ground. The subspecies sometimes occurs with the species.

\section{SPHAEROSTIGMA.}

Annual or biennial caulescent herbs; flowers axillary or in spikes; calyx-tube obconical or shortly funnelform; stamens 8 , equal in length; anthers attached near the middle, versatile; stigma entire; capsule 4-celled, terete or angled; seeds in one row in each cell.

Capsule linear, more or less curved.

Capsule broadest at base, attenuate upward.

Seeds pale, linear; flowers very small.

S. conlorlum.

Seeds dark, clavate; flowers larger.

S. andinum.

S. hilgardi.

Sphaerostigma contortum (Dougl.) Walp. Slender annual, usually branched from the base, $10-15 \mathrm{~cm}$. high, sparsely puberulent or glabrous; leaves narrowly linear, entire or denticulate, $2-3 \mathrm{~cm}$. long, sessile; flowers sessile, in the axils, somewhat shorter than the leaves; petals reddish-yellow, $2 \mathrm{~mm}$. long, 
as long as the reflexed calyx-lobes; capsules sessile, linear, somewhat 4-sided, usually twisted or bent at the base, $2-3 \mathrm{~cm}$. long. Sandy soil, along Snake River.

Sphaerostigma andinum (Nutt.) Walp. Canescently puberulent; stems simple or more usually branched from the base, 3-10 cm. high; leaves linearspatulate, entire, $10-20 \mathrm{~mm}$. long, petioled; flowers sessile, in short dense spikes, the bracts leaf-like; petals yellow, 1-2 mm. long; capsules 6-8 mm. long, canescent; seeds pale, linear. In dried-up ponds especially where alkaline.

Sphaerostigma hilgardi (Greene) Small. Similar to $S$. andinum and often growing with it; petals larger, 3-4 $\mathrm{mm}$. long; seeds dark-colored, thicker at one end. Sprague, Sandberg and Leiberg, probably within our limits.

\section{Family 64. ARALIACEAE. Ginseng FAmily.}

Perennial herbs, shrubs or trees; leaves simple or compound with dilated petioles; flowers umbellate, paniculate or racemose; calyx adherent to the ovary, the limb entire or toothed; petals 5, epigynous; stamens 5, epigynous, alternate with the petals; styles 2 or more; ovary 2 or more celled, crowned with a disk; fruit a few-celled drupe.

Herb; leaves compound.

Shrub; leaves simple.
250. Aralia, 175.

251. Echinopanax, 175.

\section{ARALIA.}

Aromatic perennial herbs or shrubs with compound leaves; flowers polygamous, in umbels, white or green; ovary 5-celled; ovules solitary.

Aralia nudicaulis L. Wild Sarsaparilla. Stem very short, mostly subterranean; leaf solitary, long-stalked, ternate, each division pinnately 5foliolate; leaflets oval or ovate, serrate, acuminate; scape shorter than the leaf, naked, bearing 2-7 umbels; flowers greenish-white. In deep woods, Mt. Carlton, Spokane County, and adjacent Idaho.

\section{ECHINOPANAX.}

Stout shrubs, ours very prickly; leaves simple, long-petioled, suborbicular, palmately-lobed; flowers perfect or polygamous, in numerous umbels which are in racemes or panicles; calyx-margin narrow or obsolete, obscurely crenate-lobed; carpels (in ours) 2.

Echinopanax horridum (Smith) Dcne. \& Planch. Devil's Club. Shrub; stems $1-4 \mathrm{~m}$. long, mostly decumbent below, armed with pale prickles; leaves all at the summit of the stem, 10-30 cm. broad, palmately 5-13-lobed; lobes acute and serrate; petioles and principal veins prickly beneath; flowers greenishyellow; fruit scarlet. Swamps in the Blue Mountains. 
Family 65. UMBELliferae. Parsley Family.

Herbs; stems usually hollow; leaves compound or simple; petioles often dilated at the base; flowers small, in umbels or rarely heads, the umbels often subtended by primary bracts (the involucre); in compound umbels, the secondary rays often subtended by secondary bracts (the involucels); calyx entirely adherent to the ovary; petals and stamens on the calyx-tube; base of the style (stylopodium) often expanded; ovary 2-celled, 2ovuled; fruit of 2 seed-like dry carpels with contiguous inner surfaces (the commissure), each carpel marked lengthwise with 5 primary ribs and often with 4 intermediate secondary ones, in the intervals between which oil-tubes are commonly found; carpels often separating from each other, supported on the summit of a slender axis (the carpophore). Mature fruits are absolutely necessary for accurate determinations in this family.

Flowers in dense heads; fruit scaly.

252. ERyngium, 177.

Flowers not in heads, evidently in umbels; fruit not scaly.

Fruit bristly.

Bristles covering the whole fruit surface.

Bristles only on the ribs of the fruit.

Fruit elongated, linear; bristles appressed.

Fruit short, ovate; bristles spreading.

Fruit not bristly.

Fruit strongly flattened dorsally.

Plants caulescent and branching and flowers white; stylopodium conical.

Wings of the two carpels contiguous; leaves ternately compound.

Wings of the two carpels distinct: leaves ternate-pinnately or pinnately compound.

Plants acaulescent or if caulescent flowers

253. Sanicula, 177.

254. OSMORHIZA, 177.

255. Caucalis, 178. yellow; stylopodium flat or none.

Lateral wings thin; plant usually low. 258. Cogswellia, 179.

Lateral wings thick; plant tall and stout.

Fruit not dorsally flattened.

Oil tubes obsolete or obscure.

Oil tubes distinct.

Oil tube one in each interval.

Flowers yellow.

Flowers white.

256. Heracletu, 178.

257. ANgelica, 179.

259. Leptotaenia, 181.

254. OSMORHIZA, 177.

261. ZiZIA, 182.

Leaflets lanceolate or broader. 262. CicurA, 182.

Leaflets linear.

Stylopodium conical; calyx teeth prominent.

Stylopodium none; calyx teeth obsolete.

263. Carum, 182.

264. Leibergia, 183. 
Oil tubes more than one in each interval.

Stylopodium conical.

Fruit globose.

Fruit oblong.

265. Berula, 183.

Stylopodium flat or none.

Ribs of the fruit winged. 267. Pteryxia, 184.

Ribs of the fruit not winged. 268. SIUM, 184.

\section{ERYNGIUM.}

Glabrous perennials; leaves often rigid, coriaceous, entire, spinosely toothed, or divided; flowers white or blue, sessile, in dense bracteate heads; sepals very prominent, rigid and persistent; stylopodium wanting; styles short or long, often rigid; fruit ovoid, flattened laterally, covered with hyaline scales or tubercles; carpel with ribs obsolete; oil-tubes mostly 5,3 dorsal and 2 commissural; seed face plane.

Eryngium articulatum Hook. Erect, 30-70 cm. tall; branches dichotomous, usually with a peduncled head in the forks; lower leaves mostly reduced to long nodose petioles sometimes bearing a lanceolate entire or spinuloseserrate blade; upper leaves opposite, sessile, usually jagged near the base; heads globose, blue; bracts lanceolate, spiny-toothed, exceeding the head; calyx-lobes lanceolate, cuspidate, 4-5 mm. long; style shorter than the calyxlobes. Wet places, not common.

\section{SANICUla. Sanicle.}

Perennial tall rather glabrous herbs, with ternate or palmate leaves; flowers perfect and staminate mixed in heads in few-rayed umbels, yellow or green; involucral bracts few; calyx-teeth evident, persistent; fruit globular, the carpels not separating, ribless, the whole surface covered with hooked bristles.

Sanicula septentrionalis Greene. Erect, slender, 10-35 cm. high; basal leaves few, small, ternate, or biternate, the obovate segments cleft or toothed; cauline leaves few, more sharply toothed; peduncles arising singly along the stem; umbels with 3-5 rays; involucre of pinnatifid leaf-like bracts; fruiting rays $1.5-3.5 \mathrm{~cm}$. long; flowers yellow; fruit $4 \mathrm{~mm}$. long. Blue Mountains.

\section{OSMORHIZA. SWeEt CiCEly.}

Glabrous to hirsute perennials, $30-90 \mathrm{~cm}$. high; roots thick, aromatic; leaves ternately decompound; leaflets broad, ovate to lanceolate, variously toothed; involucre and involucels fewleaved or wanting; flowers white or purple, in few-rayed and few-fruited umbels; calyx-teeth obsolete; stylopodium conical, sometimes depressed; styles mostly short; fruit linear to linearoblong, more or less attenuate at base, obtuse, acuie or beaked at apex, glabrous or bristly on the ribs; carpels slightly flatiened dorsally or not at all, nearly pentagonal in section, with equal ribs and thin pericarps, often tapering into a long tail-like 
attenuation at the base; oil-tubes obsolete in the mature fruit (often numerous in young fruit); seed face from slightly concave to deeply sulcate.

Fruit glabrous.

Fruit with bristly ribs.

O. occidentalis.

Foliage glabrous or nearly so.

Foliage strigose-pubescent.

O. divaricata.

O. brevipes.

Osmorhiza occidentalis Torr. Stout, more or less puberulent, $40-80 \mathrm{~cm}$. tall; leaves 2-3-ternate; leaflets ovate-oblong, acute, serrate, 4-10 cm. long; umbel 5-12-rayed; involucels few or none; fruit 12-16 mm. long, obtuse at base, glabrous, shining, beaked, the ribs prominent and sharp. On moist slopes in the mountains.

Osmorhiza divaricata (Britt.) Nutt. Glabrous or nearly so, 30-60 cm. tall; leaves biternate; leaflets ovate or lanceolate, acute or acuminate, thin, coarsely serrate and more or less incised; umbels 2-9-rayed; pedicels mostly 1-2 cm. long; involucels none; fruit 16-20 mm. long, bristly-hairy on the ribs, the carpels distinctly beaked, much narrowed at the base. In woods.

Osmorhiza brevipes (Coult. \& Rose) Suksdorf. (Washinglonia brevipes Coult. \& Rose.) Similar to $O$. divaricata but pubescent with white hairs; pedicels shorter, 4-12 $\mathrm{mm}$. long, decidedly shorter than the fruit, which is 14-16 mm. long. In open woods, Blue Mountains.

\section{CAUCALIS.}

Mostly hispid annuals; leaves pinnately dissected, with very small segments; flowers white; calyx-teeth prominent; fruit short, ovate or oblong, flattened laterally; carpel with 5 filiform primary ribs with spreading bristles and 4 prominently winged secondary ones with barbed or hooked prickles; stylopodium thick, conical; oil-tubes solitary in the intervals.

Caucalis microcarpa H. \& A. Annual, erect, branched, 8-20 cm. tall, more or less hairy; leaves pinnately much dissected, the ultimate segments linear-oblong, $2.5 \mathrm{~mm}$. long; umbels unequally 3-6-rayed; involucral bracts resembling the leaves; involucels usually entire; fruit oblong, armed with rows of hooked prickles. Sandy soil, in the warmer valleys.

\section{HERACLEUM.}

Tall stout perennials; leaves large, ternately compound; involucres deciduous; involucels of numerous bractlets; flowers white, in large many-rayed umbels; calyx-teeth small or obsolete; petals obcordate, the outer ones often dilated and 2-cleft; stylopodium thick, conical; fruit broadly ovate, very much flattened dorsally, somewhat pubescent; carpel with dorsal and intermediate ribs filiform; the broad lateral wings contiguous to those of the other carpel, strongly nerved toward the outer margin; oil-tubes solitary in the intervals, conspicuous, about half as long as the carpel, 2-4 on the commissural side; seed very much flattened dorsally. 
Heracleum lanatum Michx. Cow Parsnip. Very stout, 1-2 m. tall, pubescent throughout; leaves ternate or biternate; petioles much dilated; leaflets round-cordate, $10-25 \mathrm{~cm}$. broad, irregularly lobed and dentate; rays 5-15 cm. long; fruit obcordate, 8-12 mm. broad, the oil-tubes conspicuous. Abundant along streams.

\section{ANGELICA.}

Stout perennial herbs; leaves ternate, then pinnate, rarely simply pinnately compound; involucre scanty or none; involucels of small bractlets or none; flowers in large terminal umbels; calyx-teeth mostly obsolete; stylopodium conical; fruit flattened dorsally, ovate or oblong, glabrous or pubescent; calyx-tube prominent, crenulate; carpel with strong ribs, the lateral ribs usually broadly winged, distinct from those of the other carpel, forming a double-winged margin to the fruit; oil-tubes 1-several, in the intervals, or indefinite, $2-10$ on the commissural side; seed face plane or somewhat concave.

Ovaries glabrous; oil tubes solitary in the lateral intervals.

Ovaries puberulent; oil tubes in pairs in the lateral intervals.

A. lyallii.

A. canbyi.

Angelica lyallii Wats. Stout, $60-150 \mathrm{~cm}$. tall, glabrous or the inflorescence sometimes puberulent; leaves ternate, then once or twice pinnate; leaflets ovate or lanceolate, acute, serrate or dentate, 2-10 cm. long; umbel manyrayed; involucre and involucels wanting; fruit oblong, 4-6 $\mathrm{mm}$. long, the lateral wings about as broad as the body; oil tubes solitary in all the intervals. In wet places in the mountains.

Angelica canbyi Coult. \& Rose. Rather slender, 60-90 cm. high, glabrous except the inflorescence; leaves bipinnate; leaflets linear to ovate, acute, laciniately toothed, $2.5-5 \mathrm{~cm}$. long; umbel 10-20-rayed; involucre and involucels wanting; fruit oblong, $6 \mathrm{~mm}$. long, the lateral wings half as broad as the body; oil tubes solitary in the dorsal intervals, in pairs in the lateral. High ridges of the Blue Mountains at the lower timber line.

\section{COGSWELLIA.}

Acaulescent or short caulescent dry ground perennials; roots fusiform or tuberous; leaves ternate to dissected, sometimes pinnate; involucre none; involucels mostly present; flowers yellow, white or purple; calyx-teeth obsolete, very rarely evident; stylopodium wanting; fruit strongly flattened dorsally, oblong to orbicular; carpel with filiform and approximate dorsal and intermediate ribs and winged laterals coherent till maturity with those of the other carpel; pericarp thin; oil-tubes 1-several in the intervals (rarely obsolete), $2-10$ on the commissural silde; seed dorsally flattened, with plane face (rarely slightly concave).

Low plants arising from thick tubers.

Flowers yellow; tubers elongate.

Flowers white; tubers globose.

Fruit puberulent.

C. cous.

Fruit glabrous.

C. gormani. 
Oil tubes none; tubers of ten moniliform.

Oil tubes present; tuber solitary.

Tuber large; oil tubes solitary in the intervals.

Tuber small; oil tubes several in each interval.

Taller plants, the roots elongate, scarcely tuberous (sometimes so in C. ambigua).

Involucels conspicuous; flowers white.

Herbage sparsely tomentose.

Herbage densely puberulent.

Involucels small or wanting; flowers yellow.

Fruit linear; leaves 1 or 2 times pinnate with ultimate segments $1-5 \mathrm{~cm}$. long.

Fruit oblong; leaves decompound or 2 or 3 times pinnate with ultimate segments $5-15 \mathrm{~cm}$. long.

Leaves much dissected with short segments; wings of fruit broad; plant ill-scented.

Leaves 1-3 times ternate, the segments elongate; plants not ill scented.
C. geyeri.

C. canbyi.

C. farinosa.
C. macrocarpa.

C. artemisiarum.

\section{C. ambigua.}

C. grayi.

C. triternata.

Cogswellia cous (Wats.) Jones. Proper stem none; peduncles $8-12 \mathrm{~cm}$. tall; tuber subglobose or elongate; leaves glabrous, bipinnately compound, the ultimate segments oblong, acute, mostly entire; umbel 3-12-rayed, the rays unequal, 1-4 cm. long; flowers yellow; fruit oblong, sparsely puberulent, shortpedicelled, 6-8 mm. long, with narrow wings; oil-tubes large, solitary between the ribs, 4- 6 on the inner side. Bluffs of the Snake and Clearwater Rivers and in the Blue Mountains, in stony soil. The principal species used as food by the Indians under the name couse.

Cogswellia gormani (Howell) Jones. Glabrous or nearly so, the proper stems short or none; peduncles $5-7 \mathrm{~cm}$. tall, ascending or spreading; tubers globose, about $2 \mathrm{~cm}$. in diameter, bearing numerous roots on the under side; leaves bipinnate, the ultimate segments oblong or linear; umbel unequally 1-10-rayed; flowers white; anthers purple; fruit ovate, sessile, puberulent, $6 \mathrm{~mm}$. long. Abundant in rocky places.

Cogswellia geyeri (Wats.) Jones. Acaulescent or nearly so; tubers round, deep seated, of ten several in a series; herbage glabrous; leaves once or twice ternate and then more or less pinnate, the ultimate segments linear and callus-tipped; umbel unequally 8-18-rayed, the numerous lanceolate bractlets of the involucels united; flowers white; fruit oblong, glabrous, $8-10 \mathrm{~mm}$. long, $5 \mathrm{~mm}$. broad, the thin wings half as broad as the body; oil tubes none. Common in sandy or gravelly soil about Spokane.

Cogswellia canbyi (Coult. \& Rose) Jones. Proper stem short, mostly underground, arising from a large globose tuber with thick black rind; leaves ternate, then pinnatifid, the ultimate segments small with $3-5$ linear lobes; scape 8-20 cm. high, usually reddish; umbel with 5-10 subequal rays; fruits pedicelled, oblong-ovate, glabrous, $8 \mathrm{~mm}$. long; oil tubes solitary in the intervals, $2-4$ on the inner side. In rocky ground on the lower Clearwater River, Idaho.

Cogswellia farinosa (Hook.) Jones. Proper stems usually short; peduncles $10-30 \mathrm{~cm}$. high; tubers globose, rarely 2 or 3 in a row; leaves once or twice palmate; leaflets linear, 1-8 cm. long, 3-5 together; umbel unequally 5-15rayed, the rays $2-5 \mathrm{~cm}$. long; flowers white; fruit pedicelled, linear-oblong, glabrous, 6-8 mm. long. Rock ledges on the bluffs of Snake River.

Cogswellia macrocarpa (Nutt.) Jones. Proper stems short, the peduncles $10-40 \mathrm{~cm}$. high, white-pubescent throughout; roots elongate, fusiform; leaves decompound, the ultimate segments ovate or linear, short; umbels 3-20-rayed, the involucels conspicuous, lanceolate; flowers white; fruit oblong, glabrous, 6-20 m m. long. On basalt outcroppings, common. 
Cogswellia artemisiarum (Piper) Coult. \& Rose. Very similar to C. macrocarpa in all respects but the herbage finely and densely puberulent and the plant usually smaller. Common in sandy soil amongst sagebrush. Hunt's Junction, Leckenby.

Cogswellia ambigua (Nutt.) Coult. \& Rose. Glabrous, 10-60 cm. tall, the stems usually leafy; roots globose or more commonly elongate; leaves once or twice pinnately compound, the ultimate segments linear, 1-5 cm. long; umbels unequally 8-18-rayed; flowers yellow; fruit linear, narrow, 6-8 mm. long, on pedicels about as long. Stony soil, common.

Cogswellia grayi Coult. \& Rose. Glabrous and somewhat glaucous, the peduncles $8-40 \mathrm{~cm}$. high; leaves decompound, the ultimate segments very numerous, short, filiform; umbel 6-16-rayed; flowers yellow; fruit oblong, 8-16 mm. long, glabrous. Common in springy gravelly places. The whole plant is very ill-smelling.

Cogswellia triternata (Pursh) Jones. Peduncles 30-70 cm. tall; leaves bipinnate or triternate, puberulent; leaflets linear-lanceolate, $5-15 \mathrm{~cm}$. long; umbel unequally 5-18-rayed, the rays $1-5 \mathrm{~cm}$. long; fruit oblong, glabrous, 6-12 mm. long; oil-tubes large, solitary between the ribs; two on the inner side. Low meadows, common.

\section{LEPTOTAENIA.}

Usually tall or stout, glabrous, nearly acaulescent; roots thick, fusiform, often very large; leaves usually large, pinnately decompound; involucre of few bracts or none; involucels of numerous small bractlets; flowers yellow or purple; calyx-teeth obsolete or sometimes evident; stylopodium wanting; fruit flattened dorsally, oblong-elliptical, glabrous; carpel with dorsal and intermediate ribs filiform or obscure; lateral wings very thick and corky; commissural face with a prominent central longitudinal ridge left after separation from the carpophore; oil-tubes 3-6 in the intervals, 4-6 on the commissural side, mostly small, sometimes obsolete; seeds very flat, with plane or slightly concave face.

Fruit narrowly oblong; foliage glabrous.

L. salmoniflora.

Fruit elliptical or oval; foliage puberulent.

Pedicels about as long as the fruit.

Pedicels much shorter than the fruit.

L. multifida.

L. foliosa.

Leptotaenia salmoniflora Coult. \& Rose. Stems 20-40, cm. high; leaves decompound, glabrous, very finely dissected, the ultimate segments filiform; umbel 4-10-rayed, the rays $2.5-4 \mathrm{~cm}$. long; flowers yellow; fruit oblong, 10 $\mathrm{mm}$. long, the dorsal ribs prominent; oil-tubes large. Common on basalt cliffs along Snake River.

Leptotaenia multifida Nutt. Stout, $30-90 \mathrm{~cm}$. tall; leaves ternately decompound, puberulent, the ultimate segments oblong-linear; umbel manyrayed; rays equal; flowers yellow; fruit elliptical, smooth, 8-12 mm. long; dorsal ribs very obscure; oil-tubes nearly obsolete. Common on hillsides.

Leptotaenia foliosa (Hook.) Coult. \& Rose. Stout, 40-60 cm. high; leaves 2-or 3-times ternate, then pinnate; ultimate segments linear and entire or cut into linear lobes, puberulent on the midrib and margins; umbel 8-22-rayed, flowers yellow; fruit on very short pedicels; sterile flowers on slender pedicels. Lake Waha, Idaho. A poorly known species. 


\section{ZIZIA.}

Smooth perennials with simple to ternately compound leaves; involucre none; involucels of small bractlets; flowers yellow; calyx-teeth prominent; stylopodium wanting; styles long; fruit flattened laterally, ovate to oblong, glabrous; central fruit of each umbellet sessile; carpel with filiform ribs; oil-tubes large and solitary in the broad intervals, 2 on the commissural side and a small one in each rib; seed terete, longitudinally grooved beneath the oil-tubes.

Zizia cordata (Walt.) Koch. Glabrous, $30-80 \mathrm{~cm}$. tall; lower leaves simple, cordate, crenately toothed, $2-8 \mathrm{~cm}$. long, sometimes lobed or even ternate, mostly long-petioled; upper leaves short-petioled, palmately compound, of 3-5 leaflets, ovate or lanceolate, incised and serrate; fruit ovate, 3 $\mathrm{mm}$. long. Common in copses.

\section{CICUTA.}

Smooth poisonous marsh perennials; leaves pinnately compound; leaflets serrate; involucre of few bracts or none; involucels of several slender bractlets; flowers white; calyx-teeth rather prominent; stylopodium low, sometimes low-conical; fruit flattened laterally, oblong to orbicular, glabrous; carpels with strong flattish corky ribs, the lateral largest, at least in section; oil-tubes solitary in the intervals, two on the commissural side; seed nearly terete or somewhat dorsally flattened with face from plane to slightly concave.

Fruit oblong.

C. occidentalis.

Fruit orbicular.

C. vagans.

Cicuta occidentalis Greene. Poison Parsnip. Stout, 60-90 cm. high, glabrous or nearly so; rootstock short and thick; leaves twice-pinnate; the leaflets lanceolate, sharply serrate, acute, short-petioled, thickish, conspicuously veined; fruit oblong, 3-4 mm. long. Moist places, not rare.

Cicuta vagans Greene. Very similar to $C$. occidentalis in all respects but the fruits orbicular, 2-3 mm. long. In wet places but much less common than $C$. occidentalis.

\section{CARUM. CARAWAY.}

Smooth erect slender herbs; roots fascicled, tuberous or fusiform; leaves pinnate, with few linear leaflets; involucels of few to many bracts; flowers white; calyx-teeth prominent for the size of the fruit; stylopodium conical; fruit compressed laterally, orbicular to oblong, glabrous; carpels with filiform or inconspicuous ribs; oil-tubes large and solitary in the intervals, 2-6 on the commissural side; seeds dorsally flattened, more or less longitudinally grooved beneath the oil-tubes, the face plane or slightly concave.

Carum gairdneri (H. \& A.) Gray. Stems erect, slender, 30-100 cm. tall, simple or branched above; roots fusiform, clustered; leaves few, mostly 
pinnate, with 3-7 linear leaflets, 5-15 cm. long, the lowermost rarely bipinnate, the upper simple; umbels $6-15$-rayed, the rays $2-4 \mathrm{~cm}$. long; involucels linear, acuminate; fruit subglobose, flattened, 1-2 mm. long, with small calyx-teeth. Common in low meadows. Roots edible, a favorite food of the Indians.

\section{LEIBERGIA.}

Slender glabrous acaulescent plants from tubers; leaves ternately or pinnately divided into long filiform leaflets; flowers white, in irregular umbels; calyx teeth obsolete; fruit flattened laterally, linear, beaked; carpels with 5 filiform ribs; stylopodium none; oil tubes small, one in each interval, two on the commissural side.

Leibergia orogenioides Coult. \& Rose. Scapes slender, 10-50 cm. high from a small globose tuber; leaves pinnate with 3-7 leaflets; leaflets linear, 1-7 cm. long, acute, entire; rays of the umbel 3-10; unequal, slender, $2-12 \mathrm{~cm}$. long; involucre none; involucels of 3-4 small bractlets; fruit lanceolate, $8 \mathrm{~mm}$. long, terete or somewhat compressed above. Spokane County and adjacent Idaho. An early vernal plant along streams.

\section{BERULA.}

Smooth aquatic perennials, with simply pinnate leaves; involucre and involucels of conspicuous narrow bracts; flowers white; calyx-teeth minute; fruit flattened laterally, nearly round, glabrous; carpels nearly globose with slender inconspicuous ribs; stylopodium conical; oil tubes numerous and contiguous, closely surrounding the seed cavity.

Berula erecta (Huds.) Coville. Stems erect, 20-90 cm. high; leaflets 5-9 pairs, linear to oblong or ovate, serrate or incised or somewhat laciniately lobed, $2-8 \mathrm{~cm}$. long; peduncles $2-5 \mathrm{~cm}$. long; fruit barely $2 \mathrm{~mm}$. long. Springy places near Spokane.

\section{LIGUSTICUM. Lovage.}

Smooth perennials from large aromatic roots; leaves usually large, ternately or ternately pinnately compound; flowers white or pinkish in large many rayed umbels; involucre usually none; involucels narrow; calyx teeth small or obsolete; fruit oblong or ovate, flattened laterally, if at all, glabrous; carpel with prominent and equal ribs; stylopodium conical; oil tubes $2-6$ in the intervals, $6-10$ on the commissural side.

Leaflets large and broad, serrate.

Leaflets small, pinnatifid.

L. verticiltalum.

L. leibergi.

Ligusticum verticillatum (Geyer) Coult. \& Rose. Glabrous; stems stout, 60-70 cm. high; leaves once or twice ternate, then pinnate; leaflets ovate or oblong, serrate to dentate, paler beneath; umbel unequally many-rayed, the rays in fruit $2.5-7 \mathrm{~cm}$. long; fruit oblong, $6 \mathrm{~mm}$. long, the ribs winged; stylopodium short-conical. In open woods, Craig Mountains, Idaho. 
Ligusticum leibergi Coult. \& Rose. Glabrous; stem stout, branched above, $60-90 \mathrm{~cm}$. tall; leaves large, twice ternate, then pinnate; leaflets ovate or oblong, deeply cleft into narrow sharp-pointed and sometimes serrate lobes; umbel many-rayed; rays $2.5-5 \mathrm{~cm}$. long; involucels wanting; fruit oblong, 4-5 mm. long, the ribs winged. In wet ground especially in the mountains.

\section{PTERYXIA.}

Acaulescent or nearly so, clothed at the base by the persistent leaf-sheaths; leaves bright green or somewhat pale, clustered at the base, with main divisions ternate, then pinnately finelydissected into short linear segments; involucre mostly none; involucels of narrow bractlets; flowers yellow or white; calyxteeth evident; fruit oblong to orbicular, glabrous; carpel usually strongly flattened dorsally, with wings; stylopodium wanting; oil-tubes several in the intervals; seed-face plane or with a shallow and broad cavity.

Leaves with pale rigid segments.

Leaves greener with segments not rigid.

$P$. terebinthina.

$P$. foeniculacea.

Pteryxia terebinthina (Hook.) Coult. \& Rose. Rootstock simple or but little branched; stems $20-40 \mathrm{~cm}$. high; leaves tripinnate, pale, the ultimate segments rigid, entire or toothed, mucronate, 1-2 mm. long; fruit oval or suborbicular, 7-8 mm. long, the thin wings $2 \mathrm{~mm}$. broad, wavy. Rock Creek, Cotion. A common species in the sagebrush region.

Pteryxia foeniculacea Nutt. Rootstock much branched, bearing numerous stems $30-50 \mathrm{~cm}$. tall; leaves pinnately decompound, very finely dissected, green and glabrous, the ultimate segments linear, $2-4 \mathrm{~mm}$. long; fruit oblong, 6-8 $\mathrm{mm}$. long, the wings not as broad as the body, not wavy. In rock crevices on the banks of Snake River and in the Blue Mountains.

268. SIUM.

Perennial, growing in water or in wet places; leaflets serrate or pinnatifid; involucres and involucels of numerous narrow bracts; flowers white; calyx-teeth minute; stylopodium depressed; styles short; fruit flattened laterally, ovate to oblong, glabrous; carpel with prominent corky nearly equal ribs; oil-tubes 1-3, in the intervals, never solitary in all the intervals, 2-7 on the commissural side; seed subangular, with plane face.

Sium cicutaefolium Schrank. Stout, $60-80 \mathrm{~cm}$. tall; leaves pinnate, with 7-17 linear or lanceolate serrate acuminate leaflets, these 5-12 cm. long; umbel many-rayed, the rays $2.5-4 \mathrm{~cm}$. long; fruit $3 \mathrm{~mm}$. long, with prominent ribs. Margins of ponds, infrequent.

\section{Family 66. CORNACEAE. Dogwood FAMILy.}

Trees or shrubs, rarely herbs; leaves simple, alternate or opposite; flowers regular, perfect, polygamous or dioecious, in cymes or heads; calyx-tube adherent to the ovary; petals and stamens 4 , on the margin of an epigynous disk in the perfect 
flowers; style 1; ovary 1-2-celled, with one ovule in each cell; fruit a 1-2-seeded drupe.

\section{CORNUS. DOGWOOD.}

Herbs or shrubs (in ours); leaves opposite, sometimes apparently whorled, entire; flowers perfect, in a cyme or head-like cluster; calyx minutely 4-toothed; petals 4, oblong or ovate; stamens 4, with slender filaments; style 1; drupe ovoid or oblong, with a 2 -celled 2 -seeded stone.

Flowers in head-like cymes with a conspicuous involucre; fruit red.

Flowers in loose cymes, not involucrate; fruit white or blue.

Cyme branches and leaves appressed-pubescent beneath.

Cyme branches and leaves loosely pubescent beneath.

C. canadensis.

C. slolonifera.

C. occidentalis.

Cornus canadensis L. Perennial herb, 10-20 cm. high, the rootstocks woody; stems scaly below, bearing 2 or 3 pairs of leaves above, forming a false whorl and sometimes a pair near the middle; leaves ovate or oblong, acute or acuminate, narrowed at base, sessile, entire, sparsely puberulent, $2-4 \mathrm{~cm}$. long; peduncle solitary, 4-5 cm. long; involucral bracts 4-6, white, ovate, 8-16 $\mathrm{mm}$. long; flowers greenish, small, in dense heads; fruit bright red, globular, $4 \mathrm{~mm}$. in diameter. In rich woods, in the mountains.

Cornus stolonifera Michx. Shrub, 1-3 m. high, with bright red twigs, these usually puberulent when young; leaves opposite, entire, ovate or oval, acuminate or acute, cuneate at base, appressed-puberulent or glabrous, paler beneath, 4-8 cm. long; petiole 1-2 cm. long; cymes short-peduncled, 2-6 cm. broad, usually appressed-puberulent; flowers white, $6-8 \mathrm{~mm}$. broad; fruit globose, blue; stone somewhat flattened, usually broader than long. Common along streams.

Cornus occidentalis (T. \& G.) Coville. Very similar to $C$. stolonifera but more or less pubescent with loose not appressed hairs, especially the under side of the leaves, the twigs and the inflorescence; fruit whitish. Along streams about Spokane.

\section{Family 67. PYROLACEAE. Pyrola Family.}

Perennial green herbs or chlorophyll-less and leafless rootparasites or saprophytes; flowers solitary, racemose or corymbose, often on a scape, perfect, nearly regular; calyx 2-6-lobed or parted, free from the ovary; corolla gamopetalous and 5toothed or of 5 separate petals; stamens 10 , with one- or twohorned anthers; ovary superior, 4 - or 5-celled; style short or slender, often declined; capsule globose, 4- or 5-lobed, loculicidally 4- or 5-valved.

Petals united almost to the tips.

Petals free almost or quite to the base.

Flowers solitary.

Flowers not solitary.

Infloresence a corymb; style short.

Inflorescence a raceme; style mostly long.

270. Pterospora, 186.

271. Moneses, 186.

272. Chimaphila, 186.

273. Pyrola, 187. 


\section{PTEROSPORA.}

Stout simple purplish-brown clammy-pubescent root-parasitic herbs without chlorophyll; stem wand-like, with scattered lanceolate scales toward the base, in place of leaves; flowers many, nodding, white, in a long bracted raceme; corolla gamopetalous, ovate, urn-shaped, 5-toothed; stamens 10; anthers 2-celled, awned on the back; stigma 5-lobed; capsule globose, flattened, 5-lobed, 5-celled; seeds very numerous.

Pterospora andromedea Nutt. A reddish purple glandular-hairy herb, with straight simple flowering stems, $30-90 \mathrm{~cm}$. high; roots coral-like, much branched; scale-like leaves brownish, scarious, attenuate-lanceolate, largest and most numerous below, $1-3 \mathrm{~cm}$. long; raceme elongated, the flowers nodding, on pedicels $1-2 \mathrm{~cm}$. long, bracts small, narrow; flowers white or pinkish, 4-5 $\mathrm{mm}$. broad; capsules flattened, globose, $1 \mathrm{~cm}$. wide. Coniferous woods in the mountains. The plants die after blooming.

\section{MONESES.}

Low perennial glabrous herbs; flowers solitary on a slender scape, drooping, white or pink; petals 5 , distinct, widely spreading, orbicular; stamens 10; filaments not enlarged in the middle, naked; anthers conspicuously 2-horned; style exserted; stigma large, peltate, with 5 short radiating lobes; ovary globose, 4-5celled; ovules numerous; capsule subglobose, 4-5-celled, 4-5valved; seeds numerous, minute.

Moneses uniflora (L.) Gray. Rootstock very slender: stems erect, bearing 2-4 pairs or whorls of leaves; leaves obovate or orbicular, obtuse, finely crenate or dentate, 8-20 $\mathrm{mm}$. long, narrowed at the base, with a shorter petiole; scapes 5-12 cm. high, 1-flowered, usually bearing a solitary bract; flowers white, nodding, $12-20 \mathrm{~mm}$. broad; capsules erect, $6-8 \mathrm{~mm}$. broad. Coniferous woods, in the mountains, rare.

\section{CHIMAPHILA. Pipsissewa.}

Low nearly herbaceous perennials; leaves irregularly opposite, whorled or scattered, coriaceous, short-petioled, serrate; flowers in corymbs on a leafy stem; petals 5 , widely spreading, orbicular; anthers 2-horned; stigma large, peltate, with 5 narrow and conspicuous radiating lobes; valves of the capsule naked.

Flowers many; leaves cuneate-oblanceolate, numerous. Flowers few; leaves ovate or oblong-lanceolate, few.

C. umbellata. C. menziesii.

Chimaphila umbellata (L.) Nutt. Stems $15-30 \mathrm{~cm}$. high, erect from horizontal rootstocks; leaves evergreen, leathery, cuneate-oblanceolate, acute, serrate, $2-4 \mathrm{~cm}$. long, short-petioled, glabrous or minutely puberulent; flowers 4-8, pink, about $1 \mathrm{~cm}$. broad, in terminal corymbs; filaments bearded on the margins; capsule 6-8 mm. broad. Deep coniferous woods, in the mountains.

Chimaphila menziesii (R. Br.) Spreng. Stems 10-15 cm. high; leaves few, ovate or oblong-lanceolate, acute at each end, serrulate, 1-2.5 cm. long, the principal veins bordered with white; peduncle 1-3-flowered; petals white or pinkish; bracts ovate or orbicular; filaments expanded and hairy in the middle. In deep coniferous woods. 


\section{PYROLA.}

Low and smooth perennial herbs; leaves roundish, petioled, evergreen, basal or nearly so; flowers nodding, in a simple raceme, on a more or less scaly-bracted scape; corolla of 5 concave more or less converging petals; stamens 10; ovary 4- or 5-celled; ovules very numerous; fruit a flattened globose 5-lobed 5-celled capsule.

Style straight.

Leaves orbicular; style very short.

Leaves ovate; style long.

P. minor.

Style curved downward.

Green leaves none or very rudimentary. $\quad P$. aphylla.

Green leaves present.

Calyx-lobes obtuse, very short; flowers greenish.

P. chlorantha.

Calyx-lobes acute.

Flowers white or whitish.

Flowers red or pink.

Leaves coriaceous, shiny, acute.

Leaves thin, dull, obtuse.

P. picta.

$P$. bracteala.

P. elata.

Pyrola minor L. Leaves all basal, orbicular, obscurely crenulate, $2-4 \mathrm{~cm}$. long, the margined petioles nearly as long; scapes erect, $5-20 \mathrm{~cm}$. high; pedicels recurved; flowers white or pinkish, rather crowded; petals orbicular, naked at the base; anthers obtuse; stigma large, obscurely 5-lobed. Base of Mt. Carlton, Kreager.

Pyrola secunda L. Rootstocks slender, usually much branched; stems erect or ascending; leaves somewhat clustered at the base, ovate, obtuse or acute, crenate, 1-3 cm. long, on slender petioles $1 \mathrm{~cm}$. long; scapes 10-25 cm. high, with few scale-like bracts, which also occur between the leaves; raceme one-sided, 3-8 cm. long; flowers white, on short pedicels, soon nodding; corolla regular; petals oblong, $4 \mathrm{~mm}$. long, each with a pair of tubercles at base; anthers obtuse; stigmas large, 5-lobed. Deep woods, in the mountains.

Pyrola aphylla Smith. Very similar to $P$. bracteata, but the green leaves reduced to scales. In coniferous woods.

Pyrola chlorantha Sw. Leaves orbicular, often retuse, thick, not shiny, small, mostly $2-3 \mathrm{~cm}$. long, shorter than the petiole; scapes $10-20 \mathrm{~cm}$. high, bractless or with solitary bracts; raceme 3-10-flowered; petals greenish-white, rounded; calyx-lobes very short and obtuse; anthers beaked. In deep coniferous woods.

Pyrola picta Smith. Rootstocks creeping; leaves tufted at base, oblong, ovate or orbicular, obtuse or acute, mucronate, obscurely denticulate or entire, green, variegated with white along the veins, often purple beneath, $2-6 \mathrm{~cm}$. long; petioles margined, 1-3 cm. long; scapes erect, 15-30 cm. high, with few bracts, 10-20-flowered; calyx-lobes short, ovate, about one-fourth as long as the petals; corolla irregular; petals white, $6-7 \mathrm{~mm}$. long; anthers constricted at the apex; style deflexed, with a projecting collar at the base of the stigma. Coniferous woods, in the mountains.

Pyrola bracteata Hook. Leaves all basal, green, coriaceous, ovate, acute, rounded at base, crenulate, 3-6 cm. long; petioles margined, as long as the blades; scapes $20-40 \mathrm{~cm}$. high, with several brownish scarious lanceolate bracts; racemes many-flowered; calyx-lobes triangular-lanceolate, acute, about half as long as the petals; corolla irregular, dull-red, about $1 \mathrm{~cm}$. broad; anthers slightly constricted at apex; style declined, with a collar-like ring at the base of the stigma. Deep woods, in the mountains. 
Pyrola elata Nutt. Very similar to $P$. bracteata; but leaves broadly obovate or orbicular, obtuse, thinner, not shiny; flowers paler. In wet places in woods.

\section{Family 68. ERICACEAE. Heather FAMILy.}

Perennial herbs or shrubs; leaves simple, commonly alternate, articulated to the stem, without stipules; flowers regular, or nearly so; corolla generally gamopetalous, 4- or 5-lobed; stamens as many or twice as many as the corolla lobes, hypogynous; style single; ovary with as many cells as the corolla-lobes, or rarely less; seeds small; endosperm fleshy.

Calyx adherent to the ovary.

Calyx free from the ovary.

Fruit a berry-like drupe.

Fruit a dry capsule.

Leaves linear, small.

Leaves elliptical, large.
274. Vaccinium, 188.

275. Arctostaphylos, 189.

276. Phyllodoce, 189.

277. Menziesia, 189.

\section{VACCINIUM. HUCKLEBERRY.}

Branching shrubs with alternate leaves sometimes coriaceous; flowers small, solitary or in racemes or clusters; corolla various in shape, epigynous, 4 - or 5-cleft; stamens 8 or 10 ; anthers sometimes 2 -awned on the back; fruit a 4 - or 5-celled or sometimes 8-10-celled berry; seeds numerous.

Tall shrubs, 1-2 m. high.

Low shrubs, less than $50 \mathrm{~cm}$. high.

Branches sharply angled; berries red or wine-color.

Branches terete; berries blue, with a bloom.
V. macrophyllum.

V. scoparium.

V. caespitosum.

Vaccinium macrophyllum (Hook.) Piper. Huckleberry. Shrub, 1-2 m. high, glabrous throughout or nearly so; leaves oval or ovate, acute, rarely obtuse, cuneate at base, finely serrate, paler beneath, 1-4 cm. long, shortpetioled; pedicels slender; calyx-limb entire; corolla nearly globose, yellowish, 4-5 $\mathrm{mm}$. long; fruiting pedicels erect; fruit without a bloom, dark-wine-color or nearly black. Open pine woods, common.

Vaccinium scoparium Leiberg. Low bushy glabrous shrub, $15-40 \mathrm{~cm}$. high, with numerous erect branches, green and all sharply angled; leaves very small, oval to ovate, serrate, bright green; corolla ovoid, $2 \mathrm{~mm}$. long; berries light red, 2-4 mm. in diameter. In lodgepole pine forests, Blue Mountains.

Vaccinium caespitosum Michx. Low bushy shrub, 10-30 cm. high, glabrous or minutely puberulent; leaves obovate, obtuse or acute, crenulateserrulate, cuneate at base, very short-petioled, 1-2 cm. long; flowers solitary in the axils, longer than the drooping pedicels; calyx-lobes very short; corolla pink, ovoid, 5-6 mm. long; berry blue, with a bloom, sweet, 3-5 mm. in diameter. North hillsides, common. 


\section{ARCTOSTAPHYLOS.}

Low shrubs; leaves alternate, coriaceous, persistent, entire or with a few irregular teeth; flowers small, nodding, pink or white, in terminal racemes or clusters; calyx free from the ovary; corolla ovate and urn-shaped, with 5 short teeth; stamens 10; anthers with two reflexed awns on the back; drupe berry-like with 5-10 seed-like nutlets.

Arctostaphylos uva-ursi (L.) Spreng. Kinnikinnick. Prostrate or trailing shrub with red bark, the much branched stems $20-80 \mathrm{~cm}$. long, forming dense mats, glabrous throughout or minutely puberulent; leaves evergreen, leathery, spatulate-obovate, obtuse or notched, cuneate at base, 1-3 cm. long, shortpetioled; flowers in short racemes; corolla pink, ovate, 4-5 mm. long; filaments hairy; fruit bright-red, glabrous, $5-8 \mathrm{~mm}$. in diameter. Dry pine woods, common.

\section{PHYLLODOCE.}

Low alpine heath-like evergreen undershrubs; leaves numerous, linear, obtuse, serrulate; flowers solitary or in umbels at the ends of the branches; calyx free from the ovary; corolla 5toothed; stamens 10; anthers pointless, shorter than the fila- ments; fruit a 5-celled, 5-valved, many-seeded dry capsule.

Phyllodoce empetriformis (Smith) D. Don. Much branched,15-50 cm. high; flowers in umbels; corolla rose-colored, campanulate, 4-5 $\mathrm{mm}$. long, the lobes shorter than the tube. In wet meadows, Blue Mountains, $2000 \mathrm{~m}$. altitude.

\section{MENZIESIA.}

Shrubs with alternate hairy deciduous leaves; flowers small, nodding, greenish-purple, in terminal corymbs or umbels, developed with the leaves; calyx small or minute, flattish, 4 -toothed or lobed; corolla cylindrical to urn-shaped, 4-lobed; stamens 8; capsule ovoid, woody, 4-celled, 4-valved, many-seeded.

Menziesia ferruginea Smith. Erect shrub, 1-2 m. high, the branches inclined to be falsely whorled, the young branchlets puberulent; leaves thin, oblong or obovate, obtuse, short-mucronate, cuneate at base, serrulate and ciliate, minutely puberulent, paler beneath, $2-5 \mathrm{~cm}$. long; petioles 'short; pedicels slender, $2-4 \mathrm{~cm}$. long, glandular-puberulent; corolla oblong or ovoidcampanulate, reddish-yellow, $7-9 \mathrm{~mm}$. long; filaments glabrous or pubescent below; capsules oblong or obovoid, mostly glabrous; seeds tailed at each end. Deep woods, in the mountains.

\section{Family 69. PRIMULACEAE. Primrose Family.}

Herbs; leaves simple, mostly entire, alternate, opposite or in a basal cluster, without stipules; flowers regular, perfect; corolla gamopetalous, $4-8$, usually 5 -lobed or cleft; stamens as many as and opposite the corolla-lobes, epipetalous; ovary superior, 1- 
celled,"with a free central placenta rising from the base; fruit a capsule; seeds several or many; endosperm fleshy.

Stems short; leaves in a basal rosette.

Stems tlongated, leaf-bearing.

Leaves clustered near the summit of the stem.'

Leaves alternate or opposite, not clustered.

Flowers in axillary spikes; leaves punctate.

Flowers solitary, axillary; leaves not punctate.

Flowers sessile, small.

Flowers pedicelled, large.
278. Dodecatheon, 190.

279. Trientalis, 191.

280. Naumburgia, 191.

281. Centunculus, 191. 282. Steironema, 191.

\section{DodecatheoN. Shooting Star.}

Perennial smooth or viscid-puberulent stemless herbs; leaves all in a basal cluster, oblong or spatulate; flowers showy, nodding, solitary or in an umbel on a scape, with an involucre; calyx deeply 5-cleft; corolla with a very short tube, 5-parted, purple or white; filaments distinct and short or united into a tube; capsule ovoid or oblong, many-seeded.

Filaments united into a tube half as long as the anthers.

Plant glabrous.

Plant viscid-puberulent.

Filaments free or filament-tube very short.

Plant glabrous.

Plant viscid-puberulent.
D. vulgare.

D. puberulum.

D. conjugens.

D. viscidum.

Dodecatheon vulgare (Hook.) Piper. Glabrous throughout, $15-45 \mathrm{~cm}$. high; leaves spatulate-oblanceolate, obtuse, entire or rarely denticulate, 5-10 cm. long, narrowed into a winged petiole as long; umbels 5-20-flowered; bracts of the involucre triangular-lanceolate, acute, $6-20 \mathrm{~mm}$. long; pedicels 1-6 cm. long; calyx-lobes broadly lanceolate, acute or acuminate, not much longer than the tube; petals purple, $1 \mathrm{~cm}$. long; stamineal tube yellow, half as long as the purple anthers; capsules ovoid, $6-9 \mathrm{~mm}$. long, splitting into 5 teeth at the apex when mature. Wet meadows rare.

Dodecatheon puberulum (Nutt.) Piper. (D. cusickii Greene.) Resembling $D$. vulgare very closely, but viscid-puberulent throughout; leaves usually smaller; scapes 10-30 cm. high. Stony hillsides, common. A whiteflowered form is occasionally found.

Dodecatheon conjugens Greene. Glabrous throughout, 10-30 cm. high; leaves 2 or 3 , rarely more, oblanceolate, obtuse, entire, $5-10 \mathrm{~cm}$. long, narrowed at base into a short petiole; flowers usually solitary, less commonly 2,3 or more; calyx-lobes oblong-lanceolate, acute, twice as long as the tube; petals 15-20 mm. long, dark-purple; capsules oblong, 10-12 $\mathrm{mm}$. long, cirumscissile near the top, then deeply splitting into truncate teeth. Low copses, rare.

Dodecatheon viscidum Piper. Similar to $D$. conjugens but larger and glandular-puberulent throughout; leaves lanceolate to oblong; calyx-lobes four times as long as the tube. In moist meadows near Spangle. 


\section{TRIENTALIS. STAR-FLOWER.}

Low smooth perennials, with simple erect stems; leaves few, alternate, minute and scale-like, except a whorl of thin veiny leaves at the summit of the stem; corolla spreading, flat, without a tube; filaments slender, united at the base; anthers oblong, revolute after dehiscing; capsule few-seeded.

Trientalis latifolia Hook. Stems $10-30 \mathrm{~cm}$. high, from small rather deepseated tubers; leaves 4-7, whorled near the top, lanceolate to oblong-oval, acute, 3-8 cm. long, short-petioled; pedicels very slender, shorter than the leaves; petals pink, lanceolate, acuminate. In woods, Blue Mountains.

\section{NAUMBURGIA.}

Erect perennial leafy herbs with slender rootstocks; leaves opposite, sessile, punctate; flowers in axillary spikes; calyx 5-7divided, the segments linear; corolla deeply 5-7-parted, the tube very short and the segments narrow; stamens $5-7$, exserted; filaments slender, slightly united at the base; capsule 5-7-valved, few-seeded.

Naumburgia thyrsiflora (L.) Duby. Glabrous or nearly so; stems simple' $20-60 \mathrm{~cm}$. high, erect, from creeping rootstocks; leaves lanceolate, sessile' $3-5 \mathrm{~cm}$. long, the lower ones reduced and scale-like; peduncles axillary from the 1-4 middle pairs of leaves; flowers small, in a dense oblong spike, pale yellow; calyx-lobes linear-lanceolate, acute; capsule glandular-dotted. In wet places, Rock Lake; banks of Spokane River at Spokane; Mud Lake, Kootenai County, Idaho.

\section{CENTUNCULUS.}

Small annuals with leafy stems; leaves entire; flowers small, inconspicuous, sessile or nearly so, solitary axillary; corolla rotate, with a short tube, usually withering on the summit of the pod; stamens 4 or 5 ; filaments beardless.

Centunculus minimus L. Glabrous; stems slender, $5-20 \mathrm{~cm}$. high; leaves ovate to obovate, narrowed at base, 4-6 mm. long; flowers axillary, sessile or nearly so, the parts mostly in fours, sometimes in fives; calyx-lobes lanceolate-subulate. In low wet places, Spokane County, and adjacent Idaho.

\section{STEIRONEMA.}

Leafy-stemmed perennials; leaves all opposite but seemingly in whorls on the flowering branches; flowers yellow, on slender axillary peduncles; calyx 5-parted; corolla rotate, deeply 5parted; capsules 10-20-seeded.

Steironema ciliatum (L.) Raf. Stems erect, usually simple, $30-90 \mathrm{~cm}$. high, puberulent above or wholly glabrous; leaves opposite, or the upper whorled, ovate, acuminate, rounded or cordate at base, the margin ciliate, $2-4 \mathrm{~cm}$. long; petioles broad, coarsely ciliate, $1-2 \mathrm{~cm}$. long; pedicels exceeding the leaves; flowers yellow, $1.5-2 \mathrm{~cm}$. broad; calyx-lobes lanceolate, acuminate, shorter than the petals. Along streams and ponds, common. 
Family 70. Gentianaceae. Gentian Family.

Mostly herbs; leaves entire, opposite, sessile, without stipules; flowers perfect, regular, solitary or clustered; corolla gamopetalous, 4-12-parted; stamens as many as the corolla-lobes and alternate with them, epipetalous; ovary 1-celled, with 2 parietal placentae; fruit a capsule, usually 2-valved; seeds numerous; endosperm copious.

Style filiform, usually deciduous; anthers oblong to

linear, mostly twisting or curving with age.

283. Centaurion, 192.

Style stout and persistent or none; anthers remaining straight.

Corolla funnelform or bell-shaped, without glands. 284. Gentiana, 192.

Corolla rotate, with a fringed glandular spot on each lobe.

285. Frasera, 193.

\section{CENTAURION.}

Low branching annual herbs; leaves sessile or clasping; flowers white or reddish; calyx 4- or 5-parted; corolla funnel or salverform, 4- or 5-parted, the tube slender; anthers exserted, erect, oblong to linear, twisting spirally with age; style filiform, usually deciduous; stigmas capitate or 2-lipped.

Centaurion muehlenbergii (Griseb.) W. F. Wight. Annual, erect, simple or with many erect branches, $10-20 \mathrm{~cm}$. high, glabrous, flowering almost from the base; leaves oblong or ovate, obtuse; flowers white, rarely pink, about 1 $\mathrm{cm}$. long, mostly sessile, in leafy cymes; corolla-tube longer than the calyx, its spreading lobes short, obtuse. Springy places, rare.

\section{Gentiana. Gentian.}

Herbs; leaves opposite; flowens solitary or in cymes, showy, in late summer or autumn; calyx 4- or 5-cleft; corolla funnelform or bell-shaped, 4- or 5-lobed, regular, without glands, often with intermediate plaited folds which bear appendages at the sinuses; anthers remaining straight with age; style stout, persistent or none; stigmas 2 .

Annual; corolla without appendages in the sinuses.

G. acuta.

Perennial; corolla with appendages in the sinuses.

Calyx-lobes oblong to ovate-lanceolate.

Calyx-lobes linear to narrowly lanceolate.

G. oregana.

G. affinis.

Gentiana acuta Michx. Annual, erect, simple, or with few erect branches, glabrous, 5-40 cm. high; leaves rather few, the basal spatulate-oblanceolate, obtuse, petioled; cauline oblong-lanceolate, acute or obtuse, sessile, 5-30 mm. long; peduncles from the axils of most of the leaves, 1-4 cm. long; calyx cleft below the middle, the lobes acute, usually very unequal; corolla $5-15 \mathrm{~mm}$. long, without folds in the sinuses, the acutish lobes with a fringe of bristles on their bases within. Open woods, in the mountains. 
Gentiana oregana Engelm. Perennial, pale green, the stems erect, 15-50 $\mathrm{cm}$. high; leaves in numerous pairs, ovate, sessile, acuminate or obtuse, 2-4 $\mathrm{cm}$. long; the margins minutely scabrous; flowers few in a terminal cluster or often many in racemose clusters; bracts oblong-lanceolate, short-petioled; calyx-lobes lanceolate, a little longer than the tube; corolla deep blue, 25-35 $\mathrm{mm}$. long, the plaits extended into somewhat cleft appendages shorter than the acute or acuminate lobes. Low or moist places, rather common.

Gentiana affinis Griseb. Perennial, tufted, green; stems erect or ascending, 20-30 cm. high; leaves rather narrow, oblong, lanceolate or linear, $2-4 \mathrm{~cm}$. long; bracts lanceolate to linear; flowers 5-20, in racemes; calyx-lobes unequal, linear or subulate, mostly shorter than the tube; corolla blue, $3 \mathrm{~cm}$. long, the appendages cleft and shorter than the lobes. Spokane County.

\section{FRASERA.}

Tall, erect herbs, with mostly simple stems; leaves opposite or whorled; flowers rather large, numerous, in open cymes arranged in an elongated panicle; calyx deeply 4-parted; corolla 4-parted, rotate, each lobe with a glandular and fringed pit on its face; anthers oblong, remaining straight with age; stigma 2lobed.

Leaves narrow, opposite.

F. albicaulis. Leaves broad, whorled.

F. fastigiata.

Frasera albicaulis Dougl. Minutely puberulent throughout, pale-green; stems erect, 15-45 cm. high; leaves opposite, mostly clustered at base, oblonglanceolate, obtuse, 3-nerved, with a white hard margin, 5-10 cm. long, the basal ones narrowed into margined petioles; panicle narrow, its branches erect, 5-15 $\mathrm{cm}$. long; calyx-lobes lanceolate, 6-10 mm. long; corolla blue, somewhat exceeding the calyx; glands oblong, coarsely fringed, sac-like at base; scales between the filaments cleft into thread-like lobes; pods flat, twice as long as the calyx, tipped by the persistent style; seeds dark, flat, rough. Hillsides, not common.

Frasera fastigiata (Pursh) Heller. Glabrous throughout; stems stout, $100-150 \mathrm{~cm}$. high; leaves marginless, the basal ones spatulate-oblanceolate, abruptly acuminate or obtuse, $15-40 \mathrm{~cm}$. long, narrowed at base into a margined petiole; cauline in whorls of 3 , sessile, $8-20 \mathrm{~cm}$. long; panicle terminal, 10-30 $\mathrm{cm}$. long, rather dense; bracts lanceolate or subulate; sepals attenuate-lanceolate, about $8-10 \mathrm{~mm}$. long; corolla blue-purple, longer than the calyx; glands round, a single one near the base of each lobe; styles very short; capsules ovate, much flattened; seeds flat, thin-margined, minutely pitted. Common in open pine woods, Whitman and Spokane Counties and adjacent Idaho.

\section{Family 71. MENYANTHACEAE.}

Perennial aquatic or marsh herbs, with basal or alternate entire crenate or trifoliolate leaves; flowers clustered, regular, perfect; calyx deeply 5-parted, persistent; corolla funnelform to rotate, 5-lobed or 5-cleft; stamens 5, epipetalous, alternate with the corolla-lobes; style long, short, or none; ovary 1-celled with two parietal placentae; fruit dehiscent or indehiscent. 


\section{MENYANTHES. BUCKBEAN.}

Perennial herbs, with thick creeping rootstocks sheathed by the membranous bases of the petioles; leaves trifoliolate; calyx 5-parted; corolla funnelform, 5-cleft; style slender, persistent; stigma 2-lobed; capsule bursting irregularly, many-seeded.

Menyanthes trifoliata L. Perennial from scaly rootstocks; leaves trifoliolate, the petioles sheathing at base; leaflets oblong to obovate, entire, obtuse; peduncles stout; racemes 10-20-flowered; corolla white or rose-tinged, its lobes bearded above; capsule ovoid. In bogs near Troy and Spokane and about Rock Lake and Lake Pend Oreille.

\section{Family 72. APOCYNACEAE.}

Herbs (in ours) with acrid milky juice; leaves entire, opposite, without stipules; flowers regular; calyx free from the ovaries; corolla gamopetalous, 5-lobed; stamens 5, alternate with the corolla-lobes, epipetalous; pistils of two carpels, the ovaries separate (in ours), the styles or stigmas united; fruit a pair of follicles; seeds many, often downy-tufted at the apices; endosperm not copious.

\section{APOCYNUM. DOGBANE.}

Perennial herbs; leaves opposite, mucronate-pointed; flowers small, in cymes, on short pedicels; calyx 5-parted, the lobes acute; corolla bell-shaped, 5 -cleft, bearing 5 triangular appendages below the throat, opposite the lobes; stamens 5 , on the very base of the corolla; fruit of two long and slender follicles; seed with a tuft of long silky down at the apex.

Corolla lobes revolute; leaves ovate.

Corolla lobes erect; leaves lanceolate to oblong.

Calyx and bracts ciliolate.

Calyx and bracts entire.

\section{A. pumilum.}

A. ciliolatum.

A. cannabinum.

Apocynum pumilum (Gray) Greene. Much branched from the base, 30-40 $\mathrm{cm}$. high; branches erect or ascending, glabrous throughout or rarely puberulent, usually very floriferous; leaves ovate, cuspidate, 1-4 cm. long, dark-green above, pale beneath, short-petioled; flowers rose-colored; calyx-lobes about equalling the tube; corolla 5-6 mm. long, the lobes reflexed; pod 6-8 cm. long, spreading or reflexed. Common on hills, difficult to eradicate and sometimes a troublesome weed. A puberulent prostrate form which may be distinct occurs in open pine woods in the Thatuna Hills, Idaho.

Apocynum ciliolatum Piper. Stems erect, very leafy, branched above, 60-70 cm. high, glabrous; leaves elliptic or elliptic-lanceolate, puberulent on both sides, 4-7 cm. long, 2-3 cm. wide, nearly sessile; panicle ample, rather loose, its branches erect, glabrous; bracts lanceolate, ciliate; pedicels pubescent; calyx lobes deltoid, acute, erect, ciliolate, shorter than the corolla tube; corolla pink, $5 \mathrm{~mm}$. long, the erect lanceolate acutish ciliolate lobes as long as the tube, which is nearly glabrous within. Wawawai. 
Apocynum cannabinum L. Glabrous throughout or sometimes puberulent, pale green; stems erect, branched above, $60-100 \mathrm{~cm}$. high; leaves oblongelliptic or somewhat lanceolate, cuspidate-acuminate, rounded or cuneate at base, the margin slightly revolute, $2-6 \mathrm{~cm}$. long; petioles $5-8 \mathrm{~mm}$. long; calyxlobes lanceolate-acuminate, $2-3$ times as long as the tube; corolla white, 3-5 $\mathrm{mm}$. long, the lobes erect; pods reflexed, linear, tapering at each end, $6-8 \mathrm{~cm}$. long. Two forms of this occur in our limits, the commoner one with flowers $3 \mathrm{~mm}$. long, in a small terminal cyme, surrounded by leafy branches ( $A$. suksdorfi Greene) along streams and in rich fields in the warmer valleys; the other with flowers $5 \mathrm{~mm}$. long in large loose cymes, occurring at Albion, Whitman County.

\section{Family 73. ASCLEPIADACEAE.}

Herbs with milky juice; leaves entire, opposite, whorled or rarely alternate, without stipules; flowers regular, 5-merous, usually in simple umbels; corolla gamopetalous, 5-lobed; stamens attached to the stigma, all the pollen of each anther-cell in one waxy mass; pistils of 2 carpels with two distinct ovaries, bui with a common stigma; fruit a pair of follicles; seed with a coma of silky down; endosperm scant.

\section{ASCLEPIAS. MILKWEED.}

Perennial herbs, with copious milky juice; leaves opposite; flowers numerous, in umbels, subtended by a whorl of small bracts, the involucre; calyx and corolla deeply 5-parted; stamens on the very base of the corolla, monadelphous, short, crowned behind each anther with a hood-like appendage from the cavity of which rises a horn; anthers adherent to the solid stigma; ovaries with short styles; follicles ovate or lanceolate; seeds numerous, each with a long tuft of down, the coma.

Leaves ovate or oblong, white-tomentose; follicles warty.

Leaves linear or lanceolate, glabrous; follicles smooth.

A. speciosa.

A. mexicana.

Asclepias speciosa Torr. Stems stout, erect, simple, $80-90 \mathrm{~cm}$. high, thinly white-tomentose throughout; leaves opposite, oblong-ovate, cuspidately acute, rounded at base, $10-15 \mathrm{~cm}$. long, short-petioled; peduncles stout, longer than the very woolly pedicels; corolla dark-purple, $1 \mathrm{~cm}$. long, the lobes oblongobtuse; hoods yellowish, spreading, much longer than the stamens and stigma, abruptly narrowed above the dilated base, 12-15 $\mathrm{mm}$. long; horn projecting from near the base; capsules narrowly ovoid, tapering above, white-woolly and with numerous soft spines, $8 \mathrm{~mm}$. long. In moist soil.

Asclepias mexicana Cav. Glabrous below the inflorescence; stems simple, erect, $40-60 \mathrm{~cm}$. high; leaves mostly in whorls of 3-6, the lowermost opposite, linear or lanceolate, rarely oblong, acute or obtuse, 3-8 cm. long, short-petioled; inflorescence puberulent; peduncles longer than the pedicels; flowers small, 5-6 mm. broad, whitish or purplish; hoods ovate, entire, shorter than the stamens, each exceeded by the incurved subulate horn. Valley of the Snake River; Spokane. 


\section{Family 74. CONVOLVULACEAE.}

Mostly twining or trailing herbs, often with milky juice; leaves alternate; flowers regular, perfect, mostly showy; calyx 5 -lobed; corolla gamopetalous, 5-plaited or lobed, convolute or twisted in the bud; ovary 2-celled; ovules 2 in each cell, the cells sometimes becoming 4 in the fruit by false partitions; fruit a globular, 2-6-seeded capsule; endosperm mucilaginous.

\section{Convolvulus. Morning Glory.}

Herbs or somewhat woody plants, twining, erect or prostrate; flowers 1 or 2 in the axils of the leaves; corolla funnelform to campanulate; stamens included; style undivided, or 2-cleft only at the apex; capsules globose, 2-celled, or imperfectly 4-celled by false partitions between the two seeds or by abortion 1-celled.

Calyx enclosed by two large bracts.

Calyx not bracted.

Convolvulus sepium L. Usually glabrous, climbing over shrubs to a height of 2-3 m.; leaves sagittate or somewhat hastate, acuminate, 2-5 cm. long; basal lobes entire or angularly 2-lobed; peduncles nearly as long as the leaves; calyx enclosed by two large ovate bracts; corolla white, sometimes pink, 4-6 cm. long; stigmas capitate, oval or oblong. Banks of Snake River.

Convolvulus arvensis L. Stems prostrate, trailing 30-120 cm. long; whole plant pubescent; leaves oblong or ovate, obtuse or acute, $1-4 \mathrm{~cm}$. long, sagittate or hastate or auricled at base; petioles 1-2 cm. long; peduncles longer than the leaves, mostly 1- or 2-flowered; pedicels each with two small bracts; corolla pinkish, 1-2 cm. long; stigmas thread-like. A troublesome weed, as yet sparingly introduced.

\section{Family 75. CUSCUTACEAE. Dodder Family.}

Whitish or yellowish parasitic twining vines, with leaves reduced to minute alternate scales; sepals 5 , separate or united into a 5-lobed or parted calyx; corolla gamopetalous, urn-shaped or bell-shaped, 5-lobed, usually with fimbriate or crenulate scales on the tube alternating with the lobes; stamens 5 , alternate with the corolla-lobes; ovary globose to oblong, 2-celled; ovules 2 in each cell; capsule circumscissile or indehiscent, 1-4-seeded.

\section{CUSCUTA. DODDER.}

Leafless annual herbs with yellow or red stems, twining and parasitic on the plants to which they cling; flowers small, clustered; calyx 4- or 5-cleft or of 5 sepals; corolla urn- or bell-shaped, 4- or 5-cleft; stamens with a scale-like appendage at the base; ovary 2-celled, 4-ovuled; capsule usually 4-seeded. 
Ovary and capsule pointed.

C. indecora.

Ovary and capsule globose.

C. arvensis.

Flowers in dense clusters; style shorter than the ovary.

Flowers in loose clusters; styles longer than the ovary. Stems coarse; calyx-lobes obtuse.

Stems fine; calyx-lobes acute.

C. cephalanthi.

C. californica.

Cuscuta indecora Chois. Stems coarse; flowers 3-5 mm. long, pedicelled, in loose clusters; calyx rather fleshy, the lobes acute; corolla lobes ovatelanceolate, acute, as long as the tube, spreading, minutely crenulate and papillose; scales large, broadly oval, deeply fringed; seeds about 4. Mostly on leguminous and composite plants. Waitsburg, Horner.

Cuscuta arvensis Beyrich. Stems fine, pale yellow; flowers 1.5-2 mm. long, in dense clusters; calyx-lobes obtuse, broad; corolla-lobes ovate-lanceolate, acuminate, slightly longer than the tube; scales large, oval, fringed; seeds 4 . On alfalfa, Waitsburg, Horner.

Cuscuta cephalanthi Engelm. Stems coarse, dark yellow; flowers $2 \mathrm{~mm}$. long, on thick pedicels, in loose clusters; calyx-lobes oblong, obtuse, about as long as the tube; corolla lobes oblong, obtuse, shorter than the tube; scales fringed. Climbing high on shrubs along streams.

Cuscuta californica Chois. Stems fine, pale yellow; flowers 2.5-3 mm. long, on slender pedicels, in loose clusters; corolla lobes acute, lanceolate, about as long as the tube; scales wanting. On low shrubs, in dry places.

\section{Family 76. POLEMONIACEAE.}

Herbs; leaves alternate or opposite, simple or divided, without stipules; flowers regular, perfect, 5-merous, except the pistils; corolla gamopetalous, convolute in the bud; lobes not plaited; stamens epipetalous, alternate with the corolla-lobes, distinct; style 3-lobed; ovary 3-celled; capsule 3-celled, 3-valved, the valves usually breaking away from the triangular central column; seeds few-many; seed-coats when wetted commonly becoming mucilaginous and developing spiricles.

Calyx distended and at length burst by the capsule.

Corolla large, salverform; leaves all opposite, entire.

Corolla usually small, tubular, funnelform or sal-

291. PhLox, 197.

verform; leaves mostly alternate, usually not entire.

292. Gilia, 198.

Calyx not distended nor burst by the capsule.

Corolla rotate or campanulate; leaves pinnate, the leaflets entire.

Corolla tubular.

Calyx-lobes spine-tipped; leaves pinnatifid. Calyx-lobes not spine-tipped; leaves entire.

293. Polemonium, 200.

294. Navarretia, 201. 295. Collomia, 201.

\section{PHLOX.}

Perennial herbs or half shrubby plants; leaves opposite, sessile, entire; flowers in cymes, terminal or in the upper axils, mostly 
bracted; calyx narrow, 5-cleft; corolla salverform with a long tube, a narrow opening and broad or rounded lobes; stamens included, very unequally inserted on the upper part of the corollatube; ovules 1 or sometimes 2 ; capsules ovoid, with but one seed in each cell.

Densely tufted with crowded leaves; flowers solitary on the shoots.

Loosely tufted and taller; flowers in cymes.

Style short, not longer than the ovary.

Style long, usually equalling the corolla tube.

Inflorescence not glandular; leaves $1 \mathrm{~mm}$. wide.

Inflorescence glandular; leaves $2-4 \mathrm{~mm}$. wide.

P. rigida.

P. speciosa.

P. longifolia.

$P$. viscida.

Phlox rigida Benth. (P. piperi E. Nelson.) Perennial from a woody much branched base; leafy stems erect or ascending, 10-20 cm. high, sparsely glandular-pubescent throughout; leaves spreading, acerose, sharp-pointed, 10-15 $\mathrm{mm}$. long; flowers solitary on short peduncles; calyx hirsute, the teeth rigid, subulate, sharp-pointed; corolla pale bluish, the tube hairy at base within, nearly twice as long as the calyx, the lobes cuneate-obovate, 6-9 mm. long. Common in pine woods about Spokane, and in the Blue Mountains.

Phlox speciosa Pursh. Perennial, woody at base, the erect branches 10-40 $\mathrm{cm}$. high, glandular-pubescent above becoming glabrous or nearly so toward the base; leaves linear, attenuate from the base, $2-5 \mathrm{~cm}$. long, the margins white, thickened; cymes loose, the pedicels $1-3 \mathrm{~cm}$. long; calyx-lobes subulate, not as long as the tube; corolla pink, its tube exceeding the calyx; lobes obcordate, 8-14 mm. long; style very short, not longer than the ovary or stigmas. Common in moist ground.

Phlox speciosa elatior Hook. Corolla-lobes entire. In moist ground, rather rare. Apparently a mere form.

Phlox longifolia Nutt. Perennial, woody and loosely branched at base, the branches erect or nearly so, $10-30 \mathrm{~cm}$. high, glabrous or puberulent; leaves narrowly-linear, sharp-pointed, $2-3 \mathrm{~cm}$. long; flowers in loose cymes, erect; pedicels 1-3 cm. long; calyx-tube somewhat angled, exceeded by the subulate teeth; corolla pink-purple, the tube longer than the calyx; lobes obovate, entire, 8-12 mm. long; style slender, as long as the corolla-tube. In the warmer valleys, variable.

Phlox viscida E. Nelson. Perennial; stems erect, 10-15 cm. high; herbage green, viscid-pubescent throughout, more dense on the pedicels and calyx; leaves linear or lance-linear, rather rigid, sharp-pointed, 2-4 cm. long; calyx $13 \mathrm{~mm}$. long, the lobes subulate, as long as the tube; corolla pinkish, the tube slightly longer than the calyx, the lobes obovate, finely erose; ovules solitary in each cell. Blue Mountains.

\section{GIIIA.}

Herbs or half-shrubby plants; leaves alternate or opposite; calyx narrow, the lobes acute, the tube scarious below the sinuses; corolla tubular-funnelform, the limb little spreading (in ours); stamens equally or unequally inserted; capsules with 1-many seeds. 
Shrubs; leaves acerose.

Herbs; leaves not acerose.

G. pungens.

Perennials or biennials.

Flowers large, usually scarlet, in an elongated panicle. G. aggregata.

Flowers rather small, white or whitish, in a corymb. G. nuttallii. Annuals.

Leaves all alternate.

Leaves or some of them opposite.

G. capitata.

Leaves all opposite, dissected into filiform segments.

Corolla almost rotate, $8-10 \mathrm{~mm}$. broad.

Corolla tubular-funnelform.

Leaves all entire; the lower opposite, the upper alternate.

Stems simple below; flowers 8-10 mm. long.

Stems branched from the base; flowers 5-7 $\mathrm{mm}$. long.

G. pharnaceoides.

G. harknesii.

G. gracilis.

G. humilis.

Gilia pungens hookeri (Dougl.) Gray. Shrubs with tufted branches; very leafy stems $10-30 \mathrm{~cm}$. high, more or less glandular above; leaves strict, alternate except the lowest, 3-7-palmately parted with acerose segments; flowers sessile, solitary in the upper leaf-axils; bracts shorter than the calyx which is tubular, glandular-ciliate, with subulate teeth; corolla rose-colored, white or yellowish, tubular; stamens unequally attached to the corolla, scarcely exserted; capsule oblong, shorter than the calyx. Spokane. Common in the sagebrush region.

Gilia aggregata (Pursh) Spreng. Biennial, loosely pubescent throughout or rarely puberulent-viscid above, $30-80 \mathrm{~cm}$. high, simple or sparingly branched; leaves 4-6 cm. long, pinnately parted into many linear mucronate lobes, 1-2 $\mathrm{cm}$. long; panicle narrow, loose or interrupted; calyx glandular, the subulate lobes twice as long as the tube; corolla showy, scarlet, tubular-funnelform, much exceeding the calyx, $3 \mathrm{~cm}$. long, the lobes spreading or recurved, ovatelanceolate, acute or acuminate, about $1 \mathrm{~cm}$. long; stamens unequally inserted; seeds numerous in each cell, the coats developing spiricles when wetted. Common on stony hillsides.

Gilia nuttallii Gray. Perennial, tufted from a woody base, somewhat puberulent; stems erect, $10-30 \mathrm{~cm}$. high, mostly simple; leaves sessile, opposite, palmately parted into 3-7 segments, these linear, somewhat rigid, mucronate, scabrous, 1-2 cm. long; flowers in a terminal dense cluster; calyx-lobes subulatelanceolate, rigid; corolla white, with yellow throat, the tube puberulent at the outside, not exceeding the calyx, the lobes obovate, 6-7 mm. long; ovules 2 in each cell. In sterile soil, Blue Mountains.

Gilia capitata Hook. Annual, glabrous or nearly so; stems slender, erect, loosely branched, $20-60 \mathrm{~cm}$. high; leaves alternate, once or twice pinnately divided into very narrow segments; flowers pale blue, in dense globose clusters terminating long naked peduncles; calyx-lobes lanceolate-acuminate, about as long as the tube; corolla $8-10 \mathrm{~mm}$. long, the oblong or linear lobes as long as the tube, which is but little dilated in the throat; seeds developing mucilage and spiracles when wetted. Sandy soil, banks of Snake River and on the north fork of Latah Creek.

Gilia pharnaceoides Benth. Annual; stems very slender, usually loosely branched above, $10-20 \mathrm{~cm}$. high, somewhat puberulent; leaves all opposite, all palmately parted into $2-5$ filiform segments, 5-12 $\mathrm{mm}$. long; pedicels filiform; calyx campanulate, $4 \mathrm{~mm}$. long, the triangular acute lobes shorter than the tube; corolla white or bluish, rotate, about $6 \mathrm{~mm}$. broad, pubescent in the throat, the lobes broadly obovate; ovules 6-8 in each cell; seed coats becoming mucilaginous when wetted. In gravelly or sandy soil, abundant in Spokane County. 
Gilia harknessii Curran. Annual; very slender, simple or branched above, 5-15 cm. high, glabrous; leaves sessile, all palmately parted into $3-9$ threadlike lobes, 5-10 mm. long, all opposite; flowers on slender spreading pedicels, 1-4 cm. long; calyx-lobes unequal, shorter than the tube; corolla whitish, 3 $\mathrm{mm}$. long, barely exceeding the calyx; stamens unequally inserted; ovules and seeds solitary in each cell; seed-coats becoming mucilaginous when wetted. Stony soil, in the mountains.

Gilia gracilis (Dougl.) Hook. Annual; erect, usually simple, 10-30 cm. high, branched above, glabrous below, pubescent and glandular above; leaves sessile, entire, the lower opposite, oblong or obovate, 1-2 cm. long, the upper alternate, lanceolate, acute, 2-4 cm. long; flowers solitary in the forks or axils, short-pedicelled, somewhat cymose through the reduction of the leaves; calyxlobes subulate, mucronate, twice as long as the campanulate tube, this at length splitting to the base; corolla tubular-salverform, 8-10 $\mathrm{mm}$. long, the tube yellow, not longer than the calyx-lobes, the limb purple-pink; stamens unequally inserted; ovules and seeds solitary in each cell; seed-coats without spiricles. Very common everywhere.

Gilia humilis (Greene) Piper. Annual, usually branched from the base, the branches ascending, minutely pubescent throughout, 5-15 $\mathrm{cm}$. high; lower leaves opposite, oblong or oblanceolate, obtuse; upper alternate, linear, 1-2 cm. long; calyx-lobes subulate, twice as long as the tube, at length splitting to the base and spreading; pedicels unequal; corolla-tube yellow, 4-10 mm. long, scarcely longer than the calyx, the limb purple, $3 \mathrm{~mm}$. broad; ovules and seeds solitary in each cell, not developing spiricles. Common on hillsides.

\section{3. .POLEMONIUM. JACOB'S LADDER.}

Annual or perennial herbs; leaves alternate, pinnate, with entire leaflets; flowers in corymbs, nearly bractless; calyx rotate or campanulate, the tube very short; stamens equally inserted at the summit of the corolla-tube; capsule few-several-seeded.

Annuals; corolla white, nearly rotate.

Perennials; corolla blue, campanulate.

Stems low, 15-30 cm. high.

Stems erect, 60-90 cm. tall.

Leaflets oblong-ovate.

Leaflets linear.
P. micranthum.

P. humile.

$P$. coeruleum.

$P$. pectinatum.

Polemonium micranthum Benth. Annual, branched from the base, spreading, 6-20 cm. high, somewhat viscidly pubescent throughout; leaves mostly petioled, $1-4 \mathrm{~cm}$. long; leaflets $5-13$, obovate or lanceolate, acute or obtuse, 3-8 mm. long; peduncles solitary, opposite the leaves; calyx-lobes triangular, as long as the broadly campanulate tube; corolla white, rotate, not equalling the calyx; ovules 2 or 3 in each cell. Sandy soil, infrequent.

Polemonium humile R. \& S. Perennial, loosely tufted, viscid-puberulent; stems $15-30 \mathrm{~cm}$. high, bearing 1-3 leaves; leaflets 15-21, oblong-lanceolate to oval, 10-15 mm. long; flowers blue, in open cymes; calyx-lobes triangular, about as long as the tube; corolla campanulate-funnelform, the broad rounded lobes longer than the tube; filaments hairy at base; capsule 2-4-seeded. At the edge of the timber, highest peaks of the Blue Mountains. The plants have a bad odor.

Polemonium coeruleum L. Perennial from horizontal rootstocks, glandular-pubescent throughout; stems $60-90 \mathrm{~cm}$. high, erect, 5-10-leaved; leaflets 
15-23, oblong-ovate, 1-3 cm. long; flowers blue, the close clusters panicled; calyx-lobes lanceolate, about equalling the tube; corolla about $2 \mathrm{~cm}$. broad, the obovate lobes longer than the tube; filaments hairy at base; capsules 6-10seeded. In wet places at Marshall, Spokane County, and along the St. Maries river in Idaho.

Polemonium pectinatum Greene. Perennial, the base somewhat woody, smooth and glabrous except the viscid-glandular inflorescence; stems erect, $50-100 \mathrm{~cm}$. high; leaflets narrowly linear, 11-15, obtuse or acutish, $2-3 \mathrm{~cm}$. long; inflorescence a rather compact compound cyme; corolla bluish or bluishpurple. A rare species known definitely only from the vicinity of Rock Lake, Sandberg and Leiberg.

\section{NAVARRETIA.}

Glabrous or viscid-pubescent annual herbs; leaves all alternate, pinnatifid, setaceous or spiny; flowers crowded in bracteate clusters on the ends of the branches; calyx-tube scarious, the ribs prolonged into unequal bristle-tipped lobes; corolla tubular; capsule 1-3-celled, 1-many-seeded.

Herbage glandular-viscid with a bad odor.

N. squarrosa. Herbage neither glandular nor with a bad odor.

N. intertexta.

Navarretia squarrosa (Esch.) H. \& A. Skunk Weed. Annual, glandular, erect or spreading, simple or much branched, $10-30 \mathrm{~cm}$. high, very leafy; leaves mostly alternate, pinnately parted and the segments cleft or parted, the lobes sharp pointed, the upper ones and the bracts becoming spine-like; calyx-lobes subulate, spiny-tipped, usually entire, longer than the tube; corolla pale blue, $8-10 \mathrm{~mm}$. long, the tube shorter than the calyx, the limb small; stamens included; ovules 8-12 in each cell. Along roadsides, rare in our limits, very ill-smelling.

Navarretia intertexta (Benth.) Hook. Annual; stems erect and simple below or more commonly much branched and spreading, 5-15 cm. high, pubescent; leaves all alternate, once or twice pinnately cleft into linear spinescent lobes, glabrous or nearly so; flowers crowded in head-like clusters, the bracts and calyx-tube villous with white hairs; calyx-lobes more or less cleft into spinose divisions; corolla tubular, funnelform, pale blue, equalling the calyx-lobes, 5-6 mm. long; stamens exserted; ovules and seeds 3 or 4 in each cell; seed-coats developing spiricles. Common in low ground.

vine

\section{COLLOMIA.}

Herbs with alternate entire leaves; calyx not distended by the capsule, obconical, the lobes not spine-tipped; corolla tubular funnelform, with open throat and a spreading limb of short obtuse lobes; stamens unequally inserted on the corolla tube; capsule narrowed at the base; seeds usually 1 in each cell, mucilaginous and forming spiricles when wetted.

Corolla salmon-color, $2-3 \mathrm{~cm}$. long.

Corolla pink, $1 \mathrm{~cm}$. long.

C. grandiflora.

C. linearis.

Collomia grandiflora Dougl. Annual, erect, usually simple, $30-40 \mathrm{~cm}$. high, viscid-glandular below; leaves sessile, all alternate, lanceolate or linear, 
the upper broader, all entire, 2-6 cm. long; flowers crowded in a terminal headlike cluster; calyx obconical, the lobes broad, obtuse, shorter than the tube, corolla salmon-color, narrowly funnelform, 15-25 mm. long; stamens unequally inserted; ovules and seeds solitary in the cells, the seed-coats developing spiricles when wetted. In stony soil; rare in our limits.

Collomia grandiflora diffusa (Mulford) Piper, Usually taller, 40-60 cm. high, the flowers in several to many racemosely arranged smaller heads. Very common in stony soil.

Collomia linearis Nutt. Annual, erect, simple or branched above, 10-30 $\mathrm{cm}$. high, pubescent throughout or glabrous below, glandular above; leaves sessile, alternate, linear or lanceolate, acute, entire, 2-6 cm. long; flowers crowded in head-like clusters; calyx-lobes triangular, acute, as long as the obconic tube; corolla pink, 8-10 mm. long, slender-tubular, the lobes small; stamens unequally inserted; ovules and seeds solitary in each cell; seed-coats with spiricles. Low ground, quite common.

poril - ray- iene

\section{Family 77. HYDROPHYLLACEAE. WATERLEAF FAMily.}

Herbs, commonly hairy; leaves mostly alternate; flowers perfect, regular, on naked 1-flowered scapes or in dense one-sided cymes or false racemes; calyx 5 -parted or of 5 sepals; corolla gamopetalous, deeply 5-lobed; stamens on the corolla-tube, alternate with its lobes; style 2-cleft, or styles 2 and separate; ovary entire, 1-celled, with 2 pariental placentae or 2-celled by the union of the placentae; fruit a 2-valved, 4-many-seeded capsule; endosperm copious.

Leaves all basal.

Leaves not all basal.

Placentae narrow.

Placentae broad and fleshy.

Perennials; stamens exserted.

Annuals; stamens included.
296. CAPNOREA, 202.

297. Phacelia, 203.

298. HYDROPHYLLUM, 204.

299. NEMOPHILA, 204.

\section{CAPNOREA.}

Stemless perennials; leaves spatulate or oblong, entire, with margined petioles; flowers purplish or white, on naked 1-flowered scapes; calyx 5-parted, rarely 6- or 7-parted, the lanceolate or linear lobes sometimes unequal; corolla campanulate or rotate, 5-cleft, rarely 6- or 7-cleft; stamens on the base of the corolla-tube, unequal, included; ovary partly 1-celled, tapering into a short style, barely 2-cleft at the tip; ovules numerous on dilated placentae.

Corolla campanulate.

C. lasiantha.

Corolla saucer-shaped.

Leaves pubescent beneath.

Leaves glabrous except on the margins.

C. villosula.

C. pumila. 
Capnorea lasiantha Greene. Rootstocks stout; scapes $6-8 \mathrm{~cm}$. long; leaves spatulate to oblong, obtuse, sparsely strigose-pubescent, $2-4 \mathrm{~cm}$. long, the petioles mostly as long; corolla campanulate, the lobes shorter than the tube. In moist soil, not rare.

Morots - Ranil

Capnorea villosula Greene. Rootstocks slender; scapes 5-6 cm. high, shorter than the leaves; leaves few, spatulate, obtuse, pubescent beneath, 1-3 cm. long, the petiole as long or shorter; corolla rotate, about $1 \mathrm{~cm}$. broad, the lobes longer than the tube. Moist hillsides, near Pullman. Mnoss-ap-ri'

Capnorea pumila (Dougl.) Greene. Very similar to C. villosula but the leaves glabrous except on the margins. Moist places, infrequent. Ranth-pari/

\section{PHACELIA.}

Perennial or mostly annual herbs; leaves simple, lobed or divided, alternate, or the lowest opposite; flowers in one-sided raceme-like cymes; calyx deeply 5-parted, the lobes usually narrow and similar; corolla from almost rotate to narrow-funnelform, commonly with appendages inside of the tube, consisting of 10 vertical plaits in pairs between the bases of the filaments; stamens equally inserted low down or at the base of the corolla; ovary with narrow parietal placentae; ovules and seeds 4numerous.

Leaves pinnately cleft into narrow subequal lobes; flowers blue.

Leaves entire or with a few much smaller lateral divisions.

Corolla bright blue, rather large; ovules 12-16.

Corolla white or bluish, small; ovules 4.

P. idahoensis.

$P$. linearis.

$P$. heterophylla.

Phacelia idahoensis Henderson. Perennial, erect, 50-70 cm. high, nearly glabrous below, villous-hirsute in the inflorescence, leafy to the top; leaves pinnately-parted, the divisions again cleft; inflorescence a dense narrow thyrsus, with many short densely-flowered lateral branches; flowers pale blue; corolla open campanulate, the lobes equalling the tube, which bears ten vertical appendages within. In wet meadows, Craig Mountains and near Collins, Idaho.

Phacelia linearis (Pursh) Holzinger. Annual, 10-50 cm. high, simple below the inflorescence; whole plant rough-hairy, usually with some shorter white pubescence; leaves sessile, linear or lanceolate, entire or cleft into 2-5 narrow lobes; inflorescence usually branched, consisting of spike-like racemes; pedicels short; calyx-lobes linear, hispid-ciliate; corolla violet-blue, nearly rotate, $12-15 \mathrm{~mm}$. broad, appendages 10 , narrow, free from the filaments; stamens equalling the corolla; filaments sparsely hairy; style 2-cleft; capsule shorter than the calyx; ovules 12-16; seeds pitted-reticulate. Stony soil, common in the warmer valleys.

rey is

Phacelia heterophylla Pursh. Biennial, erect, 50-150 cm. high, roughhairy and canescent throughout; leaves lanceolate, acute, simple or with 1 or 2 pairs of small lateral leaflets, the lower petioled, the upper nearly sessile; inflorescence compound, of racemosely arranged spikes, much coiled when in bud; calyx-lobes linear or lanceolate, very hispid; corolla white or whitish, 5-lobed, exceeding the calyx; appendages 10, broad, united at base to the filaments; stamens much exserted, the filaments sparsely hairy; capsule ovate, acute; ovules 4 ; seed-coats pitted and honey-comb-like. Common and variable. 


\section{HYDROPHYLLUM. WATERLEAF.}

Perennial herbs; leaves long-petioled, mostly pinnately-parted; flowers white or violet, in cymose dense clusters; calyx 5-parted into narrow divisions; corolla bell-shaped, a nectariferous grooved appendage opposite each lobe; stamens and style exserted beyond the corolla-lobes; ovary lined with dilated and fleshy placentae; ovules 4 ; capsule 2-valved, 1-4-seeded.

Flowers blue, in dense clusters.

Flowers whitish, in looser clusters.

H. capitatum. H. albifrons.

Hydrophyllum capitatum Dougl. Rootstocks short, with long fascicled fleshy roots; stems exceeded by the leaves, 10-30 cm. high; leaves ovate, $5-10 \mathrm{~cm}$. long, soft-hairy, pinnately parted or divided into 5-7 lobes or divisions, these cuneate, obovate, entire or coarsely toothed or cleft; petioles 6-12 $\mathrm{cm}$. long, generally longer than the blades; peduncles shorter than the petioles; inflorescence a dense round cyme, $2-4 \mathrm{~cm}$. broad; calyx hispid, the divisions lanceolate, without appendages in the sinuses; corolla blue. Moist stony places, common.

Paril- $\mathrm{Ta}_{4}$

Hydrophyllum albifrons Heller. Roots densely fascicled; stems $30-40 \mathrm{~cm}$. high, exceeded by the leaves, sparingly hairy; leaves $10-20 \mathrm{~cm}$. long, pinnately 5-7-divided; divisions ovate, incisely and coarsely cleft and toothed, 3-6 cm. long; lower petioles elongated; inflorescence a rather dense cyme; exceeding the leaves; calyx soft-hispid, deeply 5-parted into lanceolate divisions without appendages in the sinuses; corolla whitish. In low copses common.

rey

\section{NEMOPHILA.}

Diffuse and tender annual herbs; leaves opposite or partly alternate, pinnatifid or lobed; peduncles terminal or lateral, 1-flowered, slender; calyx enlarging more or less in fruit, 5-parted, with a reflexed appendage at each sinus; corolla rotate or nearly campanulate, deeply 5-lobed, the throat appendaged more or less with 10 internal scales or plates; stamens and style shorter than the corolla; ovules 4 or many; capsule similar to the preceding, ripening $1-16$ seeds.

Nemophila breviflora Gray. Whole plant sparsely hirsute, erect when young, later prostrate; stems 5-40 cm. long; leaves alternate, 1-2 cm. long, pinnately 3-5-parted, the divisions oblong-lanceolate, acute, entire; peduncles about equalling the petioles; calyx appendages much smaller than the proper lobes, both ciliate; corolla campanulate, white, shorter than the calyx lobes; internal appendages cuneate, fringed at the summit; ovules four; seed solitary, nearly filling the capsule. On the highest mountains.

\section{Family 78. BORAGinaceaE. Borage Family.}

Mostly rough-hairy herbs; leaves alternate, entire, without stipules; flowers regular, perfect; calyx 5-parted; corolla 5-lobed, sometimes with projecting appendages (fornices) in the throat; stamens 5 , inserted on the corolla-tube; style 1 ; ovary usually 
deeply 4-lobed, forming in fruit 4 seed-like nutlets, or separating into two 2-seeded nutlets; nutlets attached by the base or inner angle or face to the receptacle, which is sometimes elongated (the gynobase); endosperm none. Mature fruits are necessary for accurate determinations in this family.

Ovary undivided, sometimes 2-4-grooved, style terminal.

Ovary 4-parted; the style arising from between the parts.

Nutlets armed with barbed prickles.

Nutlets not armed with barbed prickles.

Corolla tubular or tubular-funnelform.

Corolla funnelform or rotate.

Nutlets erect, attached by the very base.

Racemes bractless; corolla rotate; roots slender.

Racemes bracteate; corolla funnelform; roots thick.

Nutlets erect or oblique, attached above

300. Heliotropium, 205. the base, on a more or less prominent fruiting receptacle (the gynobase).

Corolla yellow or orange, with naked open throat.

301. Lappula, 206.

302. Mertensia, 206.

Corolla white or blue with prominent swellings in the throat.

Perennials.

Annuals.

Gynobase elongated, the nutlets attached for at least one third their length.

Gynobase short, the nutlets with a small scar.

Nutlets erect, attached just inside the base; lower leaves opposite.

Nutlets oblique or incurved, attached about the middle by a long process.

303. Myosotis, 208.

304. LithosPeRMUM, 208.

305. Amsinckia, 208.

306. Oreocarya, 209.

307. CRyptanthe, 209.

308. Allocarya, 210.

309. Plagiobothrys, 210.

300. HELIOTROPIUM. HELIOTROPE.

Annual or perennial herbs; leaves alternate, entire; calyx deeply 5 -parted, persistent; corolla salverform or funnelform, the sinuses more or less plaited in the bud; anthers nearly sessile; ovary 2-4-lobed but not divided; style terminal; fruit separating into two 2-celled carpels or four 1 -seeded nutlets.

Heliotropium curassavicum L. Perennial, glabrous and slightly glaucous; stems ascending, $15-30 \mathrm{~cm}$. long; leaves succulent, lanceolate to spatulate, almost veinless, $2-5 \mathrm{~cm}$. long; spikes in pairs, these rarely again forked, densely flowered, bractless; corolla white or bluish; style very short; fruit 4-lobed, separating into 4 one-seeded nutlets. Mostly in saline soil. Waitsburg, Horner. 


\section{LAPPULA.}

Annual, biennial or perennial rough-hairy herbs; flowers small, in racemes or spikes; calyx 5-parted, reflexed or open in fruit; corolla short-salverform or somewhat funnelform, white or blue, the throat closed with prominent appendages (fornices); nutlets attached by some part of the inner angle or face to the gynobase, armed either along a distinct margin or more or less over the whole back with backwardly-barbed prickles.

Annuals; scar of the nutlets linear.

Lateral prickles of the fruit united.

Lateral prickles of the fruit free.

L. cupulata.

L. occidentalis.

Perennials; scar of the nutlets triangular or ovate.

Lateral prickles of the fruit free to the base or nearly so.

Lateral prickles of the fruit united for half their length.

Corolla blue, the lobes narrowest at base.

Corolla greenish, the lobes broadest at base.

L. diffusa.

L. ciliata.

L. hispida.

Lappula cupulata (Gray) Rydb. Annual, erect, loosely branched, 15-50 $\mathrm{cm}$. high, hispid-pubescent throughout; leaves all sessile, linear, obtuse, 1-3 $\mathrm{cm}$. long; racemes becoming very loose and elongated, leafy-bracteate; pedicels stout, shorter than the calyx; corolla very small, white or blue, its tube barely as long as the calyx; nutlets convex on the back, granular-roughened, the margins with a border of united prickles, thus forming a shallow cup; ventral face convex, covered with whitish tubercles; scar long and narrow, nearly as long as the nutlet. Along Snake River.

Lappula occidentalis (Wats.) Rydb. Very similar to L. cupulata; the flowers white or pale blue; marginal prickles of the nutlets separate or barely united at base. Frequent in gravelly or sandy soil.

Lappula diffusa (Lehm.) Greene. Perennial, 40-90 cm. high, erect or nearly so, branched, the pubescence rather sparse and not harsh; leaves 8-15 $\mathrm{cm}$. long, spatulate to oblong-lanceolate, the lowest petioled, the upper sessile and broader; racemes panicled, spreading, becoming loose; pedicels $6-10 \mathrm{~mm}$. long, becoming reflexed; corolla blue, rotate, the tube shorter than the limb; nutlets triangular-ovate, 4-6 mm. long, obscurely keeled, scabrous on the back, the marginal flat prickles separate. In the Blue Mountains.

Lappula ciliata (Dougl.) Greene. Perennial, the whole plant appressedcanescent and bristly hirsute; stems $20-30 \mathrm{~cm}$. high; leaves mostly basal, linear-lanceolate, 5-12 cm. long; inflorescence a panicle of loosely flowered racemes; corolla bright blue, rotate, $5-10 \mathrm{~mm}$. broad; nutlets $5 \mathrm{~mm}$. long, rough on the back, the marginal prickles united for about half their length. Common about Spokane in gravelly soil.

ray

Lappula hispida (Gray) Greene. Stems erect, 30-50 cm. high, the herbage green but rough hispid with stout spreading often papillose-based hairs; flowers greenish white in loose racemes; nutlets $5 \mathrm{~mm}$. broad, the marginal prickles narrow, 3-4 mm. long, the back bearing glochidiate bristles; inner face smooth. In the Blue Mountains, rare.

302. MERTENSIA. Bluebells.

Glabrous or pubescent perennial herbs; flowers blue or rarely white, mostly bracțless, in panicled racemes or in corymbs; calyx 
deeply 5-cleft or parted; corolla tubular-funnelform or trumpetshaped to almost campanulate, the open throat bearing obvious or obsolete transverse folds or crests; filaments flattened or nearly filiform; style filiform; stigma entire; nutlets from somewhat fleshy to membranaceous, not armed with barbed prickles.

Plants tall and leafy, 50-100 cm. high, the leaves thin and broad.

Upper leaf surface smooth or merely papillose.

Upper leaf surface strigose.

Calyx lobes canescent.

Calyx lobes not canescent.

Plants low, 15-40 cm. high, the leaves narrow or thickish.

Leaves glabrous or merely papillose above.

Leaves strigose above.

Corolla tube 3 or 4 times as long as the limb.

Corolla tube once or twice as long as the limb.

M. subcordata.

M. membranacea. M. paniculata.

M. pulchella.

M. oblongifolia.

M. horneri.

Mertensia subcordata Greene. Very similar to $M$. membranacea and M. paniculata. Leaves glabrous or merely papillose above; calyx-lobes pubescent on the back. In the Blue Mountains.

Mertensia membranacea Rydb. Tall, erect, 60-120 cm. high, branched above; leaves ovate to ovate-lanceolate, acuminate, rounded or cuneate at base, appressed strigose above, sparsely pilose beneath, $3-10 \mathrm{~cm}$. long, the lower with petioles as long as the blades; racemes few-flowered, loosely panicled; calyx canescent, the lobes lanceolate, acute; corolla blue, 8-14 $\mathrm{mm}$. long, its tube twice as long as the calyx, and little longer than the limb. In mountain woods, Mount Carlton; and the Thatuna Hills, Idaho.

Mertensia paniculata (Ait.) G. Don. Very similar to $M$. membranacea but the calyx green, the lobes glabrous except on the margins. Mount Carlton, Kreager: and Cedar Mountain, Idaho.

Mertensia pulchella Piper. Stems erect, solitary, or rarely two, glabrous, 15-20 cm. high; tubers shallow-seated, simple or fasciculate-branched, black; leaves green, elliptic or ovate, mostly obtuse, thickish, glabrous beneath, more or less papillose above, scabrous-ciliate, the lower narrowed at base and short-petioled, the middle and upper ones ovate, sessile, often half-clasping, 2-10 cm. long; lowest leaves much reduced, scarious; flowers in a close cluster, usually 10-15; calyx parted nearly to the base, the lobes oblong-lanceolate, very acute denticulate; corolla blue, its tube three to four times as long as the calyx and nearly as broad as the ampliate limb; filaments dilated, as long as the anthers; nutlets small, dark gray, finely muriculate, attached by a pale and prominent scar, inclosed in the tube of the much enlarged fruiting calyx. Along the Clearwater River and in the Craig Mountains, Idaho.

Mertensia oblongifolia (Nutt.) G. Don. Very similar to $M$. pulchella but the leaves appressed strigose above; corolla tube three or four times as long as the limb. On moist hillsides, not rare. Marab-Mpot-Kay.

Mertensia horneri Piper. Stems 8-15 cm. high, glabrous, solitary or rarely 2 or 3 , erect from a shallow-seated oblong black tuber; basal leaves none; cauline $2-5$, oblong, obtuse, pale and somewhat glaucous, appressedpuberulent above, glabrous beneath, sessile or the lower ones short-petioled, $2-3 \mathrm{~cm}$. long; lowest leaves reduced and scarious; inflorescence close; calyx glaucous, parted nearly to the base, its lobes oblong-lanceolate, very acute, denticulate-ciliate on the margin; corolla blue, $10-12 \mathrm{~mm}$. long, its tube about twice as long as the calyx; filaments dilated, as long as the anthers. Waitsburg, Horner. 
303. MYOSOTIS. FORGET-ME-NOT.

Low spreading herbs, usually soft-hairy; cauline leaves sessile; flowers blue or white, in at length elongated racemes, without bracts; corolla short-salverform or almost rotate, its throat contracted by transverse crests, the rounded lobes convolute in the bud; anthers ovate or oblong; nutlets small, ovoid, smooth and shining, thin-crustaceous; scar small.

Perennial; calyx hairs straight; corolla blue. Annual; calyx hairs hooked; corolla white.

M. laxa.

M. macrosperma.

Myosotis laxa Lehm. Perennial from slender rootstocks, appressedpubescent throughout; stems weak and slender, 10-30 cm. long; leaves oblonglanceolate to spatulate, $2-3 \mathrm{~cm}$. long; racemes very loose; pedicels much longer than the calyx; calyx-lobes as long as or longer than the tube; corolla pale blue; nutlets oval, biconvex, with a narrow margin, very smooth and shiny, black, 1-1.5 mm. long; scar minute. In wet places, Walla Walla, Savage.

Myosotis macrosperma Engelm. Annual, erect, rough-hairy throughout, $10-40 \mathrm{~cm}$. tall, branched above or simple; leaves oblong-linear or oblanceolate, obtuse, sessile, 1-2 cm. long; racemes elongated and loose in fruit, leafy at the base; pedicels shorter than the calyx; fruiting calyx 4-5 $\mathrm{mm}$. long, deeply 5-cleft, the lobes lanceolate, unequal, hispid with hooked hairs; corolla small, white; nutlets oval, biconvex with a narrow margin, very smooth and shiny, silvery-grey, 1-1.5 mm. long; scars minute. Moist ground, not rare.

\section{LITHOSPERMUM.}

Mostly herbs with reddish roots; leaves sessile; flowers leafybracted, axillary or subaxillary; calyx 5-parted; corolla salverform, funnelform or sometimes approaching campanulate; filaments mostly very short; anthers short, included; style slender; stigma mostly truncate, capitate or 2-lobed; nutlets ovoid, bony, either polished and white or dull and rough.

Lithospermum ruderale Dougl. Perennial, tufted, the stems simple, 15-30 cm. high, pubescent with long and short hairs; leaves numerous, lanceolate, rarely linear, attenuate-acute, sessile, $5-10 \mathrm{~cm}$. long, minutely soft-hispid; flowers in a dense leafy cluster; corolla greenish-yellow, campanulate-funnelform, pubescent inside, nearly naked in the throat, 10-12 $\mathrm{mm}$. long; style slender; nutlets light-colored, ovate, acute, hard and smooth, 3-4 mm. long. Common on hillsides.

\section{AMSINCKIA.}

Rough-hispid annuals; leaves oblong or linear; corolla salverform or tubular-funnelform with a slender tube and open throat, the limb sometimes plaited at the sinuses, yellow; style filiform; stigma capitate or 2-parted; nutlets crustaceous or coriaceous, unappendaged, ovate-triangular, attached below the middle to an oblong-pyramidal gynobase.

Erect; calyx-lobes linear.

Spreading; calyx-lobes lanceolate or ovate, 2 or 3 of them often united.

A. intermedia.

A. lycopsoides. 
Amsinckia intermedia Fisch. \& Mey. Tar weed. Erect, usually simple, $30-60 \mathrm{~cm}$. high, the bristly hairs mostly white; leaves lanceolate or linear, 5-12 cm. long, the upper somewhat broader at base; raceme becoming much elongated in fruit; calyx-lobes linear, acute, very bristly in fruit, 6-8 mm. long; corolla yellow, 5-6 mm. long; nutlets dark-colored, the back convex and somewhat keeled, obliquely ridged and roughened with tubercles. A troublesome weed, in wheat fields.

Forit lay

Amsinckia lycopsoides Lehm. At first erect but soon producing weak ascending or decumbent branches from near the base, 30-60 cm. long; whole plant sparsely covered with white bristles, those on the leaves becoming pustulate at base; leaves green, lanceolate, acutish, sessile, entire or undulate, the largest 3-5 cm. long; inflorescence $15-30 \mathrm{~cm}$. long, most of the flowers subtended by a bract; calyx lobes lanceolate, often unequal, sparsely hispid, in fruit becoming 4-5 $\mathrm{mm}$. long; corolla orange-yellow, 5-6 $\mathrm{mm}$. long. This species is most abundant near the seashore but readily becomes a weed. Specimens collected at Spokane were probably introduced from the coast region.

\section{OREOCARYA.}

Stout coarse canescent or pilose hispid biennials and perennials; leaves radical and cauline; flowers white (in ours), in crowded paniculate or thyrsoid clusters; pedicels filiform, persistent; calyx 5-parted, spreading in fruit; corolla salverform, 5-lobed, with swellings in the throat; nutlets attached laterally to the pyramidal receptacle.

Oreocarya sericea (Gray) Greene. Perennial, canescent throughout with a dense fine pubescence interspersed with bristly hairs; stems stout, 10-20 $\mathrm{cm}$. high; leaves spatulate or oblanceolate, obtuse, the cauline sessile, the basal narrowed into a broad petiole; inflorescence a narrow thyrsus; calyx bristly hirsute; corolla white, the tube not longer than the calyx and as long as its lobes; nutlets oblong-ovate, somewhat roughened on the back. Common about Spokane in gravelly soil.

\section{CRYPTANTHE.}

Very similar to Allocarya, but the nutlets attached for onethird or more of their length by the ventral face or angle to a slender mostly subulate gynobase.

Surface of the nutlet rough.

Calyx teeth twice as long as the acuminate nutlets.

Calyx teeth little longer than the acute nutlets.

Surface of the nutlets smooth and shining.

Nutlets solitary, rarely 2 , narrow, attenuate-acuminate. C. flaccida.

Nutlets 4, ovate, acute or short-acuminate.

Ventral groove simple to the base.

Ventral groove forked at the base.

C. ambigua.

C. muriculata.

C. affinis.

C. calycosa.

Cryptanthe ambigua (Gray) Greene. Slender, 15-30 cm. high, short-hispid; leaves oblong-linear, 1-2 cm. long; spike nearly bractless, rather few-flowered; fruiting calyx 6-8 mm. long, with rather small bristles, the lobes linear, twice as long as the fruit; nutlets all four maturing, ovate, acute, rough, with papillae of two sizes; ventral groove forked at the very base. Pine woods, Thatuna Hills, Idaho. 
Cryptanthe muriculata (A.DC.) Greene. Erect, branched from the base, 10-20 cm. high, hispid throughout; leaves oblong or linear, 1-3 cm. long; spikes of ten in pairs of $3-5$ in a cluster, bractless; fruiting calyx $5 \mathrm{~mm}$. long, short-bristly, with linear lobes which are a little longer than the fruit; corolla 5-6 mm. broad, with prominent appendages in the throat; nutlets $2 \mathrm{~mm}$. long, usually all four present, ovate-triangular, obtuse, roughened with minute papillae and some larger ones on the back and usually on the ventral face; ventral groove extending from the apex to near the base where it widens out into a triangular depression. Infrequent, in loose soil.

Cryptanthe flaccida (Lehm.) Greene. Erect, 20-40 cm. high, branched, minutely strigose and canescent throughout; leaves linear, narrow, $1-3 \mathrm{~cm}$. long; flowers in slender bractless spikes, loose and elongated in fruit; fruiting calyx 4-5 mm. long, appressed to the stem, the sepals linear, very bristly, especially at the base; corolla white, 2-3 mm. long; nutlets solitary, smooth and shining, pear-shaped, attenuate-acuminate, shorter than the sepals, with a groove on the ventral side, extending the whole length and somewhat widened at the base.

Cryptanthe affinis (Gray) Greene. Slender, branched from the base, erect or ascending, 10-30 cm. high, rather soft-hairy; leaves oblong-linear, obtuse, $1-2 \mathrm{~cm}$. long; spikes loose, nearly bractless, $2-6 \mathrm{~cm}$. long; fruiting calyx $3 \mathrm{~mm}$. long, hispid; nutlets all four maturing, dark, smooth, ovate-oblong, acute, 1.5 $\mathrm{mm}$. long, ventral groove simple, continuing the whole length of the nutlet. Open pine-woods, in the mountains.

Cryptanthe calycosa (Gray) Rydb. Erect or ascending, commonly branched from the base, $15-30 \mathrm{~cm}$. high, long-hairy and hispid throughout; leaves oblong-linear, obtuse, 2-5 cm. long; spikes bractless, solitary or in pairs, 1-8 cm. long; fruiting calyx $5 \mathrm{~mm}$. long, very bristly, the lobes linear; corolla white; nutlets 4 , narrowly pear-shaped, acute, smooth and shiny, $2 \mathrm{~mm}$. long; ventral groove forked near the base, but no depression between the forks. Common and abundant.

\section{ALLOCARYA.}

Annuals or perennials; flowers small, white; calyx 5-parted, erect or little spreading in fruit; corolla white, usually with appendages at the throat; nutlets not armed with barbed prickles, attached only at the inside of the base to a slightly elevated gynobase.

Allocarya hispidula Greene. Annual, much branched from the base, spreading or ascending, 10-30 cm. high, sparingly hairy; leaves few, linear, obtuse, 1-3 cm. long; spikes slender, elongate, leafy-bracteate near the base; corolla white, small; fruiting calyx $2 \mathrm{~mm}$. long, hispid; nutlets ovate-oblong, with obliquely rough-ridges on the three faces, keeled the whole length on the ventral face; scar nearly basal. In dried up ponds and similar places, common.

\section{PLAGIOBOTHRYS.}

Very similar to Allocarya and Cryptanthe but the radical leaves in a rosette and the nutlets attached by the middle of the somewhat concave inner face to a hemispherical or globular gynobase. 
Plagiobothrys tenellus (Nutt.) Gray. Annual, with usually many stems from the base, 5-20 cm. high, rather soft-hairy throughout; radical leaves in a rosette, oblong-linear or lanceolate, 5-20 mm. long; cauline few, lanceolate, 5-10 mm. long; spike loose, leafy at base; fruiting calyx $3 \mathrm{~mm}$. long, hispid with yellow hairs, the lobes lanceolate; nutlets silvery grey, shining, prominently keeled and papillate, somewhat cross-shaped because of the constrictions at the base and apex, incurved, hollowed on the ventral face, with a projecting process which attaches it to the gynobase. Sandy soil in the warmer valleys.

Fek- March

\section{Family 79. VERBEnACEAE. Verbena Family.}

Herbs or shrubs, not aromatic; leaves opposite; flowers perfect; corolla either 2-lipped or irregular; stamens 4, didynamous; style single, terminal; stigma entire or 2-lobed; ovary not lobed; fruit 2-4-celled, dry or drupaceous, usually splitting when ripe into as many 1 -seeded indehiscent nutlets; endosperm scant or none.

\section{VERBENA.}

Herbs; flowers sessile, in single or panicled bracteolate spikes; calyx tubular, 5-toothed, one tooth often shorter; corolla salverform, more or less unequally 5-cleft; stamens included, the upper pair occasionally without anthers; style slender; stigma mostly 2-lobed; fruit splitting into 4 seed-like nutlets.

Spikes narrow, dense; bracts short.

V. hastata.

Spikes loose; bracts exceeding the flowers.

V. bracteosa.

Verbena hastata L. Perennial, erect, $30-90 \mathrm{~cm}$. high, simple below the inflorescence, rough-puberulent throughout; stems 4-sided; leaves oblong or broadly lanceolate, acute or acuminate, coarsely serrate, $6-12 \mathrm{~cm}$. long, shortpetioled; spikes numerous, clustered at the summit of the stem, slender, 5-15 $\mathrm{cm}$. long; bracts shorter than the calyx; corolla blue, $3 \mathrm{~mm}$. broad. In moist places.

Verbena bracteosa Michx. Branches prostrate or spreading, $15-30 \mathrm{~cm}$. long, rough-hairy throughout, the root of ten becoming woody; leaves oblong or obovate, cuneate at base, pinnately 3 -cleft, coarsely dentate, 1-3 cm. long; petiole short, margined; spikes terminal, 1-10 cm. long; upper bracts entire, lanceolate, acuminate, becoming rigid; the lower somewhat cleft, all exceeding the flowers; corolla blue, $4 \mathrm{~mm}$. long; anthers without appendages. Common in dry ground and inclined to become a weed.

\section{Family 80. LABIATAE. Mint Family.}

Mostly aromatic herbs with 4-sided stems; leaves simple, opposite; corolla more or less 2-lipped, the upper lip 2-lobed or sometimes entire, the lower 3-lobed; stamens on the corolla-tube, didynamous or diandrous; style usually 2-lobed at the apex; ovary deeply 4-lobed or parted; fruit of 4 seed-like nutlets or - akenes, each with one erect seed; endosperm mostly none. 
Corolla nearly regular.

Anther-bearing stamens 2.

Anther-bearing stamens 4.

Corolla-lobes 5.

Corolla-lobes 4.

Corolla irregular, distinctly 2-lipped.

Anther-bearing stamens 2.

Anther-bearing stamens 4.

Calyx with a protuberance on the upper side.

Calyx without a protuberance.

Calyx-teeth 10, spiny.

Calyx-teeth 5 , not spiny.

Calyx-teeth unequal, the upper one very large.

Calyx-teeth almost equal.

Calyx distinctly 2 -lipped.

Calyx not 2-lipped.

Upper corolla-lip flat.

Plant creeping; flowers axillary.

Plant erect; flowers in whorled heads.

311. Lycopus, 212.

312. Trichostema, 213.

313. Mentha, 213.

314. Ramona, 214.

315. Scutellaria, 214.

316. Marrubium, 215.

317. Dracocephalum, 215.

318. Prunella, 215.

er corolla-lip concave.

Upper pair of stamens longer than the lower.

Anther-cells parallel. 321. Agastache, 216.

Anther-cells divergent.

Upper pair of stamens

322. Nepeta, 216. shorter than the lower.

Throat of corolla dilated.

Throat of corolla not dilated.

319. Micromeria, 215.

320. Madronella, 216.

323. Lamium, 217.

324. Stachys, 217.

\section{LYCOPUS.}

Low perennial herbs, glabrous or puberulent, not aromatic; leaves sharply-toothed or pinnatifid; flowers small, mostly white, in dense axillary whorls; calyx bell-shaped, nearly equally 4- or 5lobed; anther-bearing stamens 2, distant; the upper pair either sterile or wanting.

Plants stoloniferous at base; calyx teeth subulate.

Plants not stoloniferous; calyx teeth triangular-cuspidate.

L. americanus.

L. lucidus.

Lycopus americanus Muhl. Glabrous or puberulent; stems erect, simple or little branched, $30-60 \mathrm{~cm}$. high, from creeping rootstocks; leaves lanceolate or ovate-lanceolate, acuminate or acute, cuneate at base, coarsely serrate or sinuately incised, $2-5 \mathrm{~cm}$. long; petioles short; flowers sessile, in dense axillary whorl-like clusters; bracts subulate; calyx-teeth triangular-cuspidate, stiff, nearly as long as the small white corolla, exceeding the nutlets; sterile stamens slender, with thickened tips. Low ground. 
Lycopus lucidus Turcz. Stems stout, erect, 60-100 cm. high, sharply angled, simple or branched above; leaves oblong-lanceolate to lanceolate, acute or acuminate, sharply and coarsely serrate, rounded at base, 5-10 cm. long, sessile or very short petioled; bracts lanceolate or ovate, the outer ones conspicuou, acuminate; calyx-teeth subulate-lanceolate, nearly as long as the tube; corolla white, scarcely longer than the calyx; sterile stamens slender, clavate at the tips. Rock Lake and Spokane County.

\section{TRICHOSTEMA.}

Low annual branched herbs, or somewhat woody plants; leaves entire; calyx bell-shaped, oblique, deeply 5-cleft, the 3 upper teeth elongated and partly united, the 2 lower very short; corolla small, almost equally 5 -parted, the 3 lower lobes more or less united; stamens 4, much exserted; anther-cells divergent and at length confluent.

Trichostema oblongum Benth. Annual, erect, branched, 10-30 cm. high, the stem soft-hairy; leaves oblong or oval, acute, entire, 1-3 cm. long, canescently pubescent, narrowed at base, with a short petiole; flowers in nearly sessile axillary dense cymes; pedicels short; calyx campanulate, hairy, equally 5-cleft, the narrow lobes much longer than the teeth, equalling the corollatube; corolla violet. Springy places, rare and local. Rather unpleasantly scented.

\section{MENTHA. Mint.}

Aromatic fragrant perennial herbs; flowers very small, in dense clusters, forming false whorls in the axils or in terminal spikes; calyx bell-shaped or tubular, 5-toothed, equal or nearly so; corolla with a short included tube, almost equally 4 -cleft, the upper lobe broadest, entire or notched; anther-bearing stamens: 4 , equal, erect, distant.

Whorls of flowers all axillary.

M. canadensts, Whorls of flowers in terminal spikes or some in the upper axils. $M$. spicata.

Mentha canadensis borealis (Michx.) Piper. Erect, simple or branched, $20-40 \mathrm{~cm}$. high; stems usually simple, glabrous except in the angles; leaves ovate or broadly lanceolate, mostly acute, rounded or cuneate at the base, sharply serrate, short-petioled, glabrous; flowers in dense sessile axillary clusters; calyx $2-3 \mathrm{~mm}$. long, the triangular acute teeth short; corolla paleviolet, rarely white, $5 \mathrm{~mm}$. long, its lobes rounded, its tube exceeding the calyx. Low ground, common.

Mentha canadensis lanata Piper. Similar to $M$. canadensis borealis but the stems and leaves downy or woolly with white hairs. Spokane County and adjacent Idaho.

Mentha spicata L. Green and glabrous throughout, the stems $30-60 \mathrm{~cm}$. high, simple below the inflorescence; leaves oblong-lanceolate, acute or acuminate, serrate, narrowed to a sessile or short-petioled base, $2-5 \mathrm{~cm}$. long; spikes terminal, narrow, the flowers in interrupted whorls; bracts lanceolate, usually ciliate; calyx hairy, the tube campanulate, little longer than the subulate teeth; corolla purple, its tube exceeding the calyx. Sparingly introduced. 


\section{RAMONA.}

Half shrubs or woody herbs; flowers numerous, in terminal or axillary heads or spikes; calyx 2-lipped, the upper lip 3-toothed or entire, the lower deeply 2-cleft; corolla 2-lipped, the upper lip spreading, 2-lobed or emarginate, the lower spreading, 3-lobed; stamens 2, exserted; nutlets smooth.

Ramona incana (Benth.) Dougl. Stems woody, usually tufted, 20-60 cm. high, whitish and somewhat woolly pubescent throughout; leaves numerous, entire, spatulate to obovate, obtuse or notched, $2 \mathrm{~cm}$. long; flowers capitateglomerate in the upper axils; bracts scarious, obovate to oval, pubescent and ciliate, usually purplish; calyx scarious, bilabiate, the broad retuse upper lip longer than the teeth of the lower lip; corolla $15 \mathrm{~mm}$. long, purple. Gravelly soil near Spokane and common in the sagebrush region.

\section{SCUTELLARIA. SkULlCaP.}

Annual or perennial herbs, sometimes woody, not aromatic; flowers in axillary or terminal racemes or solitary in the axils of leaves or bracts; calyx bell-shaped in flower, 2-lipped, with a gibbous protuberance on the upper side, splitting to the base at maturity, the upper lip at length usually falling away; corolla with an elongated curved ascending tube, dilated at the throat, 2-lipped, the upper erect, arched or galeate; stamens 4 , ascending under the upper corolla-lip, the lower pair longer.

Flowers small, in axillary or terminal racemes.

S. lateriflora.

Flowers larger, solitary in the leaf axils.

Lower lip of corolla not villous; leaves serrate. S. galericulata.

Lower lip of corolla villous within; leaves entire or nearly so.

S. angustifolia.

Scutellaria lateriflora L. Perennial, glabrous; stems erect, branched, 20-60 cm. high; leaves thin, lanceolate-ovate to oblong-ovate, acuminate, coarsely serrate, rounded at base, $3-8 \mathrm{~cm}$. long, petioled; flowers blue, in axillary or sometimes terminal, one-sided racemes; corolla 5-8 $\mathrm{mm}$. long, the lips short, subequal; nutlets smooth. In moist copses, rare in our limits.

Scutellaria galericulata L. Perennial, glabrous or slightly pubescent; stems erect, $20-80 \mathrm{~cm}$. high, simple or loosely branched; leaves oblong to ovate-lanceolate, acute, serrate, subcordate at base, $2-6 \mathrm{~cm}$. long, shortpetioled; flowers solitary in the axils; pedicels shorter than the calyx; corolla blue, puberulent, the lower lip longer than the upper; nutlets muriculate. In wet meadows.

Scutellaria angustifolia Pursh. Perennial, with rather stout somewhat moniliform rootstocks, $15-20 \mathrm{~cm}$. high, puberulent or glabrous; stems simple or little branched; cauline leaves broadly linear or oblong, obtuse, entire, narrowed at base, sessile or nearly so, 1-2 cm. long; radical ovate, on longer petioles, sometimes toothed; flowers solitary in the axils; pedicels as long as the calyx; corolla violet-blue, $25 \mathrm{~mm}$. long, puberulent outside; lower lip villous within; nutlets minutely granulate. Moist soil, especially in stony places, common. 


\section{MARRUBIUM.}

Bitter-aromatic whitish-woolly perennials, branched at the base; leaves wrinkled; flowers small, much crowded in axillary whorls; calyx tubular, 5-10-nerved, nearly equally 10-toothed, the teeth spiny-pointed; corolla 2-lipped, the upper lip erect, notched; the lower spreading, 3-cleft; the middle lobe broadest; stamens 4 , short, included in the corolla-tube, the upper pair longer.

Marrubium vulgare L. Horehound. Stems tufted, erect, simple, about $30 \mathrm{~cm}$. high, densely white woolly, especially below; leaves broadly ovate, obtuse, coarsely crenate, thickish, rounded or cuneate at base, rough, woolly beneath, 1-3 cm. long, on petioles nearly as long; flower clusters dense, axillary; calyx-teeth 10 , subulate, hooked at the apex, hardened in fruit; corolla white. Abundantly introduced.

\section{DRACOCEPHALUM.}

Coarse herbs with blue flowers in dense bracteate terminal clusters; calyx tubular, 15-nerved, 5-toothed; corolla 2-lipped, the upper lip erect, emarginate, the lower 3-lobed; stamens 4, anther-cells divergent; nutlets ovoid, smooth.

Dracocephalum parviflorum Nutt. Stems stout, erect, 20-60 cm. high; leaves ovate-lanceolate, incisely dentate, $3-8 \mathrm{~cm}$. long, slender-petioled; inflorescence spike-like, the flowers densely crowded in whorls in the upper axils; bracts oblong to ovate, cut-toothed, the teeth bristle-tipped; calyx cylindric, puberulent, the upper tooth broadest, all acuminate; corolla pale blue, slightly exceeding the calyx. Medical Lake, Henderson.

318. PRUnella. Heal All.

Low perennials; flowers in terminal or axillary heads or spikes; calyx tubular-bell-shaped, about 10-nerved, 2-lipped, not gibbous on the upper side, closed in fruit; upper lip broad and flat, truncate, with 3 short teeth, the lower 2-cleft; corolla 2-lipped, slightly contracted at the throat and dilated at the lower side just beneath it; upper lip arched, erect, entire; the lower reflexedspreading, 3-cleft; stamens 4, ascending under the upper lip, the lower pair longer.

Prunella vulgaris lanceolata (Barton) Fernald. Glabrous or nearly so, erect or ascending, 15-40 cm. high; leaves ovate-oblong or oblong-lanceolate, acute or obtuse, rounded or cuneate at base, entire or crenate, $2-6 \mathrm{~cm}$. long; petioles slender, about half as long as the blades; spikes terminal, very dense, $2-5 \mathrm{~cm}$. long; bracts very broad, ovate or orbicular, cuspidate-acuminate, ciliate; calyxteeth somewhat ciliate; corolla violet, $8-12 \mathrm{~mm}$. long, hardly twice as long as the purplish calyx. Moist ground, not common.

\section{MICROMERIA.}

Low sweet-odorous plants; flowers small, in the axils of the leaves; calyx oblong or tubular, about 10-nerved, terete, not 
gibbous, about equally 5-toothed; corolla short, distinctly 2lipped; upper lip flattish, neither concave nor hooded, entire or notched; the lower spreading, 3-parted; stamens 4, the lower pair longer.

Micromeria chamissonis (Benth.) Greene. ' Perennial, somewhat pubescent, with slender trailing stems, $30-60 \mathrm{~cm}$. long; leaves orbicular or ovate, obtuse, rounded or subcordate at base, coarsely dentate or subentire, 6-25 $\mathrm{mm}$. long; petioles short; flowers solitary, axillary; pedicels slender, 2-bracted near the base; calyx 3-4 mm. long, the teeth triangular; corolla white or purplish, $8 \mathrm{~mm}$. long, its tube exceeding the calyx. Open woods, Thatuna Hills, Idaho. Odor balsamic.

\section{MADRONELLA.}

Erect woody perennials, with entire leaves and small purple or white flowers in terminal heads which are subtended by broad thin bracts; calyx tubular, 5-toothed, not 2-lipped; corolla 2lipped, the upper lip 2-cleft, the lower 3-cleft; stamens 4, the lower pair the longer; anther-cells at length divergent.

Madronella odoratissima (Benth.) Greene. Stems woody, tufted, 20-40 $\mathrm{cm}$. high, puberulent throughout; leaves firm, green, entire, narrowly oblong, 2-3 cm. long, very short-petioled; inflorescence a dense head; bracts broadly ovate, obtuse, thin, usually purple-tinged; calyx puberulent, the lanceolate teeth hirsute; corolla pale violet, $6-8 \mathrm{~mm}$. long. In sterile soil, Spokane County, and in the Blue Mountains. Very fragrant.

\section{AGASTACHE.}

Tall perennial herbs; leaves ovate, serrate, petioled; flowers small, in terminal spikes; calyx tubular-bell-shaped, 15-nerved, oblique, 5-toothed, the upper teeth rather longer; corolla 2lipped, the tube about as long as the calyx, the upper lip nearly erect, concave, 2-lobed, the lower somewhat spreading, 3-cleft; stamens 4, exserted from the corolla; anther-cells parallel.

Agastache urticifolia (Benth.) Rydb. Glabrous or nearly so, the erect usually simple stems $50-150 \mathrm{~cm}$. tall, tufted; leaves ovate, cordate, obtuse or acute, coarsely dentate, green on both sides, 3-6 cm. long, short-petioled; spikes terminal, stout, densely puberulent, $6-10 \mathrm{~cm}$. long or sometimes with smaller ones from the upper axils; calyx tubular-campanulate, the teeth lanceolate, acuminate, purple-tinged; corolla violet-purple. Whole plant pleasantly scented. Low ground, not rare.

\section{NEPETA.}

Perennial herbs; calyx tubular, often incurved, obliquely 5toothed; corolla 2-lipped, dilated in the throat; the upper lip erect, rather concave, notched or 2-cleft; the lower spreading, 3-cleft, the middle lobe largest, notched or entire; stamens 4, ascending under the upper corolla-lip, the upper pair longer; anther-cells divergent. 
Nepeta cataria L. Calnip. Perennial, erect, $30-90 \mathrm{~cm}$. high, finely canescent throughout; leaves ovate or oblong, acute, dentate, somewhat cordate at base, $2-6 \mathrm{~cm}$. long, petioled, densely canescent; spike stout, dense, 2-10 cm. long; calyx-teeth subulate, the longest one-half as long as the tube; corolla white or purplish, with dark dots, $10-12 \mathrm{~mm}$. long, its tube exceeding the calyx. Sparingly introduced.

\section{LAMIUM.}

Decumbent herbs; calyx tubular-bell-shaped, about 5-nerved, with 5 nearly equal awl-pointed teeth; corolla 2-lipped, dilated at the throat, the tube longer than the calyx; the upper lip arched, narrowed at the base; the middle lobe of the spreading lower lip broad, notched at the apex, contracted at the base; the lateral lobes small, at the margin of the throat; stamens 4 , ascending under the upper lip; the lower pair longer.

Lamium amplexicaule L. Biennial, branched from the base, sparingly pubescent; stems simple, erect, $15-20 \mathrm{~cm}$. high; lower leaves orbicular, coarsely crenate, truncate or cordate at base, 1-2 cm. long, on petioles as long or longer; upper sessile, half-clasping, rather distant; flowers sessile, in axillary and terminal clusters; calyx pubescent, the sharp teeth nearly as long as the tube; corolla purple, the lower lip spotted, 12-15 $\mathrm{mm}$. long. Sparingly introduced in cultivated ground.

\section{STACHYS.}

Herbs, rarely woody, not aromatic; calyx tubular-bell-shaped, 5-10-nerved, equally 5-toothed or the upper teeth united to form an upper lip; corolla not dilated at the throat, 2-lipped, the tube about equalling the calyx; the upper lip concave, often arched, erect or rather spreading, entire or nearly so; the lower usually longer and spreading, 3-lobed, the middle lobe largest and nearly entire; stamens 4 , ascending under the upper lip, the lower pair longer.

Stachys palustris L. Perennial, erect, $30-60 \mathrm{~cm}$. high, soft-pubescent throughout or the stem short-hairy; leaves oblong or ovate-lanceolate, mostly obtuse, crenate-serrate, rounded or cordate at the nearly sessile base, 5-10 $\mathrm{cm}$. long; spikes short-peduncled, the clusters rather close together, the lower with leafy bracts; upper bracts lanceolate; calyx hairy, the tube campanulate, little longer than the subulate teeth; corolla pink-purple, $1 \mathrm{~cm}$. long; the upper lip pubescent; the tube equalling the calyx. Wet places.

\section{Family 81. SOLANACEAE.}

Herbs or shrubs, commonly rank-scented, with colorless juice; leaves alternate, without stipules; flowers regular, 5-merous, solitary or in cymes, on bractless pedicels; calyx mostly 5-lobed; corolla gamopetalous, mostly 5-lobed, usually plaited in the bud; stamens as many as the corolla-lobes and alternate with them; 
style 1; ovary entire, superior, 2-celled, becoming a many-seeded capsule or berry; endosperm fleshy.

Corolla rotate; fruit a berry.

Corolla funnelform to salverform; fruit a capsule.

Flowers solitary.

Flowers in racemes or panicles.

325. Solanum, 218.

326. DATURA, 218.

327. Nicotiana, 219.

\section{SOLANUM. NighTSHAdE.}

Herbs or shrubs; calyx and rotate corolla 5-parted or cleft, the latter plaited in the bud; stamens epipetalous, exserted; filaments very short; anthers converging; styles elongated; ovary 2-celled, rarely more; fruit a berry.

Climbing shrub; flowers violet.

S. dulcamara.

Annual herb.

Flowers yellow; plant prickly.

Flowers white; plant not prickly.

S. rostratum.

S. nigrum.

Solanum dulcamara L. Bittersweet. Perennial, half-shrubby, with climbing or spreading branches, sometimes $1 \mathrm{~m}$. or more long, pubescent or glabrate; leaves ovate, acuminate, cordate, simple, 2-6 cm. long, or many of them with 3 lobes or 3 -divided at base, the lateral segments smaller; petiole slender, shorter than the blades; cymes loose; flowers usually purple, $10-12 \mathrm{~mm}$. broad; corolla-lobes spreading, triangular, acuminate; berries subglobose, red. Sparingly introduced.

Tay

Solanum rostratum Dunal. Buffalo Bur. Very prickly yellowish herb with an abundant stellate pubescence; leaves once or twice pinnatifid; calyx densely prickly; corolla yellow; stamens and style much declined. Becoming introduced in recent years.

Solanum nigrum L. Annual, glabrous or somewhat pubescent, usually branched, $15-30 \mathrm{~cm}$. high; leaves ovate or triangular, acute or obtuse, cuneate at base, sinuately toothed or rarely entire, $1-4 \mathrm{~cm}$. long; petioles shorter than the blades; flowers in lateral peduncled small cymes; calyx-lobes obtuse; corolla white, deeply 5 -cleft, the lobes spreading; berries globose, black. In cultivated soil, along Snake River.

\section{DATURA.}

Rank narcotic-poisonous annual or perennial weeds, erect, tall, branching; leaves alternate, petioled, ovate; flowers large, showy, solitary, on short peduncles, in the forks of the stems; calyx prismatic, 5-toothed, deciduous; corolla funnelform, with a 5-10-toothed plaited border; fruit a globular prickly 4 -valved 2-celled capsule; seeds rather large, flat.

Flowers white; prickles of the fruit unequal, the lower shorter. D. stramonium. Flowers pale-violet; prickles of the fruit equal.

D. tatula.

Datura stramonium L. Jamestown or Jimson Weed. Annual, glabrous or nearly so, green, 30-90 cm. high; leaves ovate, acuminate or acute, coarsely toothed or lobed, usually narrowed at base, petioled, $6-20 \mathrm{~cm}$. long; calyx-tube 
5-angled, not half as long as the white corolla, this 6-10 cm. long; capsule ovoid, densely prickly, the lower prickles usually shorter. Sparingly introduced.

Datura tatula L. Much like $D$. stramonium, but the stem purplish, the corolla pale-violet and the prickles of the fruit nearly equal in length. Introduced in a few places.

\section{NICOTIANA. Tobacco.}

Rank acrid-narcotic herbs; leaves mostly entire; flowers in racemes or panicles, sometimes showy; calyx bell-shaped or oblong, 5-toothed or lobed, persistent; corolla commonly funnelform or salverform, the plaited border 5-lobed; stigma capitate, somewhat 2-lobed; fruit a smooth 2-4-valved 2-celled capsule; seeds numerous, small.

Nicotiana attenuata Torr. Annual, erect and slender, 30-60 cm. high, glandular-pubescent, especially above; leaves entire, petioled, the upper lanceolate or linear, attenuate-acuminate, the lower oblong or ovate, $3-10 \mathrm{~cm}$. long; panicle loose, bracteate only below; calyx $6-8 \mathrm{~mm}$. long, the teeth lanceolate or subulate, subequal, much shorter than the tube; corolla white, tubular-salverform, $2.5-3 \mathrm{~cm}$. long, the limb ascending, 5-lobed, 8-12 $\mathrm{mm}$. broad; capsule as long as the calyx-tube. Sandy soil in the lower valleys.

\section{Family 82. SCROPHULARIACEAE. Figwort FAMily.}

Herbs, sometimes shrubs; leaves alternate or opposite, without stipules; flowers perfect, mostly complete and irregular; corolla irregular, more or less 2-lipped, the upper lip 2-lobed, the lower 3-lobed; stamens on the corolla-tube, the fertile 4 and didynamous or only 2, rarely 5 present and all fertile; style single; stigma entire or 2-lobed, fruit a 2-celled usually many-seeded capsule, with axile placenta; seeds mostly small; endosperm copious.

Anther-bearing stamens 5; leaves alternate.

328. Verbascum, 220.

Anther-bearing stamens 2 or 4 ; leaves alternate, opposite or whorled.

Fifth sterile stamen present.

Corolla spurred at the base.

Corolla not spurred.

Sterile stamen elongated, about equalling the others.

Sterile stamen a gland or scale adherent to the upper side of the corolla.

Peduncles several-flowered.

Peduncles 1-flowered.

Corolla conspicuously 2-lipped.

Corolla obscurely if at all 2-lipped. 333. TONELLA, 224.

Fifth sterile stamen not present.

329. LINARIA, 220.

330. Pentstemon, 221.

331. Scrophularia, 223.

332. Collinsia, 223.

Stamens 2; anther-bearing.

Calyx 5-parted.

Calyx 4-parted.

334. Gratiola, 224.

Leaves alternate, mostly basal.

335. SYNTHYRIS, 224.

Leaves at least the lower opposite.

Stamens 4, either perfect or sterile. 
Anther-bearing stamens 2; sterile stamens 2.

Sterile filaments 2-forked, exserted. 337. IlySANTHES, 226.

Sterile filaments simple, included. 334. Gratiola, 224.

Anther-bearing stamens 4.

Corolla nearly regular.

Corolla 2-lipped.

Stamens not enclosed in the upper lip.

339. Limosella, 226.

Stamens enclosed in the upper lip.

Anther-cells equal.

Calyx inflated in fruit; leaves opposite.

Calyx not inflated; leaves alternate or whorled.

Anther-cells unequal.

Corolla-lips unequal, the upper larger.

340. Mimulus, 226.

Corolla-lips almost equal.

341. Rhinanthus, 228.

342. Pedicularis, 229.

343. Castilleja, 229.

344. ORTHOCARPUS, 230 .

328. VERBASCUM. Mullein.

Tall and usually woolly biennial herbs; leaves alternate, the cauline sessile or decurrent; flowers in large terminal spikes or racemes; calyx 5-parted; corolla 5-lobed, rotate, the lobes slightly unequal; stamens 5, all anther-bearing; style flattened at the apex; capsule globular, many-seeded.

Plant densely woolly.

Plant glabrous or sparsely glandular.

V. thapsus.

V. blattaria.

Verbascum thapsus L. Densely woolly throughout, the stout erect stems 1-2 m. high, somewhat wing-angled by the decurrent bases of the leaves; leaves thick, oblong, acute, entire or obscurely dentate, narrowed toward the base, 10-30 cm. long, gradually reduced upwards; flowers yellow, 16-20 mm. broad, in a dense long spike; stamens unequal, the two lower and longer glabrous, the others with hairy filaments. Introduced as a weed.

Verbascum blattaria L. Stems slender, erect, 30-60 cm. high, not angled, glabrous below, glandular-pubescent above; leaves oblong, obtuse or the upper acute, crenate-dentate or cut-lobed, all but the lower sessile and partly clasping, $6-8 \mathrm{~cm}$. long; raceme loose; pedicels spreading; calyx glandular; corolla yellow or white, $2-2.5 \mathrm{~cm}$. broad; stamens all with hairy filaments; capsules subglobose, 6-7 mm. long. Sparingly introduced.

\section{LINARIA.}

Herbs with alternate leaves or the lower opposite; flowers in terminal spikes or racemes; calyx 5-parted; corolla bilabiate, spurred on the lower side, the throat nearly closed; stamens didynamous; capsule thin, opening by pores beneath the summit.

Linaria linaria (L.) Karst. Butter and Eggs. Glabrous; stems erect, $30-100 \mathrm{~cm}$. high; leaves linear, sessile, pale or glaucous, very numerous, 1-3 $\mathrm{cm}$. long; inflorescence a dense raceme; calyx lobes oblong, acute; corolla 2-3 $\mathrm{cm}$. long, yellow with an orange throat; seeds rough, winged. Introduced along roadsides and in fields. 


\section{PENTSTEMON. Beard-tongue.}

Perennial herbs; leaves opposite, the upper sessile or partly clasping, the floral reduced to bracts; flowers showy, in a racemose panicle; calyx 5-parted; corolla tubular, more or less inflated or bell-shaped, either decidedly or slightly 2-lipped; the upper lip 2-lobed, the lower 3-cleft; anther-bearing stamens 4; the sterile fifth filament about equalling the others; style long; stigma entire; capsule many-seeded.

Anthers woolly.

Calyx-lobes lanceolate, $5-10 \mathrm{~mm}$. long.

Calyx-lobes subulate-lanceolate, $10-15 \mathrm{~mm}$. long.

$P$. fruticosus.

Anthers not woolly.

Anther-cells splitting their whole length or nearly so.

Plants glabrous and more or less glaucous.

Plants pubescent or glabrous but not glaucous.

Leaves or at least some of them dentate.

Leaves broad, mostly ovate.

Leaves narrow, oblong, lanceolate or oblanceolate.

Corolla blue-purple, $15-25 \mathrm{~mm}$. long.

Leaves entire.

Corolla white, $10-15 \mathrm{~mm}$. long.

P. scouleri.

Flowers 10-20 mm. long.

Flowers $6-10 \mathrm{~mm}$. long.

Corolla blue.

Corolla pale yellow.

Anther-cells splitting only at the apex, the bases sac-like.

Leaves glandular-pubescent.

Leaves glabrous or puberulent beneath, not glandular.

Inflorescence glandular; corolla $3 \mathrm{~cm}$. long.

Inflorescence not glandular; corolla smaller.

Leaves linear or lanceolate; corolla purple, 10-15 $\mathrm{mm}$. long.

Leaves lanceolate to ovate; corolla red, 20-25 $\mathrm{mm}$. long.

P. glaber.

P. pinetorum.

P. erianthera.

$P$. deustus.

P. altenualus.

$P$. procerus.

$P$. confertus.

$P$. glandulosus.

P. venustus.

P. triphyllus.

P. richardsonii.

Pentstemon fruticosus (Pursh) Greene. Stems simple, ascending from a branched woody base, $15-40 \mathrm{~cm}$. high; leaves coriaceous, glabrous, lanceolate, oblanceolate or ovate, mostly acute, entire or with a few teeth, narrow at base, the lower short-petioled, $1-4 \mathrm{~cm}$. long; inflorescence a raceme, rarely a panicle, 2-11-flowered, viscid-pubescent; bracts much reduced; sepals ovate-lanceolate, attenuate-acuminate, $8-12 \mathrm{~mm}$. long; corolla tubular-funnelform, dullpurple, somewhat 2 -lipped, 3-4 cm. long; anthers very woolly, dehiscing their whole length; sterile filament bearded. In rock crevices in the mountains.

Pentstemon scouleri Lindl. Differs from $P$. fruticosus only in its narrower leaves and longer calyx-lobes. Kettle Falls, Douglas; Mount Carlton, Kreager; near Spokane, Miss Reed.

Pentstemon glaber Pursh. Glabrous throughout and glaucous; stems wholly herbaceous, stout, erect, $30-100 \mathrm{~cm}$. high; leaves entire, the lowest spatulate to oblong-lanceolate, the cauline ovate-lanceolate and sessile, 5-10 $\mathrm{cm}$. long; panicle narrow, densely flowered; peduncles and pedicels very short; sepals broad, acute or acuminate, somewhat erose; corolla bright blue, 3-4 $\mathrm{cm}$. long, rather abruptly dilated above the short tube; anthers glabrous or with a few hairs; sterile filament naked or slightly bearded. Gravelly soil, Spokane County and in the Blue Mountains. 
Pentstemon pinetorum Piper. Tall, $60-100 \mathrm{~cm}$. high, with several stems from horizontal rootstocks; stems usually glabrous or nearly so; radical leaves ovate or elliptic, mostly entire, acute, glabrous, thickish and evergreen; the blades $1-7 \mathrm{~cm}$. long, attenuate into a petiole as long or longer; cauline leaves 3-5 pairs, the lower pairs oblong or broadly spatulate, the upper decidedly ovate, all sessile, obtuse or acute, more or less dentate; inflorescence a more or less glandular-viscid panicle of 4-8 whorled clusters; calyx-lobes ovate, acuminate, usually decidedly glandular; corolla bright blue, varying to pink and pale yellow. Kamiack Butte, Cedar Mountain and Craig Mountains, Idaho.

Pentstemon erianthera Pursh ( $P$. cristatus Nutt.) Pubescent or puberulent below, the inflorescence glandular; stems several from a woody base, $20-30 \mathrm{~cm}$. high; radical leaves spatulate-oblanceolate, acute, mostly dentate, 5-10 cm. long; cauline ovate-lanceolate, clasping at base; panicle narrow, interrupted; peduncles and pedicels short; sepals broadly lanceolate, acute; corolla bright blue, somewhat funnelform, 15-20 mm. long, glandular-pubescent outside, the throat sparsely bearded; sterile filament bearded with long yellow hairs. Gravelly soil about Spokane.

Pentstemon deustus Dougl. Wholly glabrous below the inflorescence but not glaucous; stems leafy, erect, tufted, $20-40 \mathrm{~cm}$. high, from a woody base; lowest leaves oblanceolate, petioled, the cauline lanceolate, acute, irregularly dentate, sessile by broad bases, 2-5 cm. long; panicle narrow, leafy below, 8-20 $\mathrm{cm}$. long; peduncles mostly short, several-many-flowered; sepals lanceolateovate, acuminate, slightly margined, sparsely glandular; corolla white or yellowish, minutely viscid-glandular, $10-15 \mathrm{~mm}$. long, narrowly funnelform, 2-lipped; anthers dehiscing their whole length; sterile filament naked. Rocky places in the lower valleys.

Pentstemon attenuatus Dougl. Differs from $P$. confertus only in its larger corolla, 10-20 mm. long, usually yellow, sometimes blue. Kamiack Butte; Blue Mountains; Craig Mountains, Idahi.

Pentstemon procerus Dougl. Very similar to $P$. confertus but the flowers blue and usually a little smaller. Common, usually in moist ground.

Pentstemon confertus Dougl. Glabrous throughout but not glaucous; stems erect, commonly $30-40 \mathrm{~cm}$. high; leaves all entire; the radical oblong, lanceolate or oblanceolate, acute or obtuse, 3-6 cm. long, attenuate at the base into a petiole; the cauline similar, sessile, the upper of ten ovate, acuminate; panicle strict, narrow, leafy below, 14-40 cm. long, of 2-8 whorl-like clusters; flowers $6-10 \mathrm{~mm}$. long; sepals glabrous, the scarious margin irregularly dentate or erose, about as long as the capsule; corolla yellow or nearly white, 2-lipped; lower lip bearded; anthers dehiscing their whole length; sterile filament bearded. Common.

Pentstemon glandulosus Lindl. Pubescent and glandular throughout; stems 50-100 cm. high; radical leaves ovate-lanceolate, acute, dentate, narrowed at base into a petiole, $10-15 \mathrm{~cm}$. long; cauline similar but sessile, the upper cordate-clasping; panicle interrupted, leafy below; lower peduncles 2-4 cm. long, the upper ones short; sepals ovate, acuminate, $6-8 \mathrm{~mm}$. long; corolla dull-purple, funnelform, dilated in the throat, shortly 2-lipped, 25-30 mm. long, pubescent outside; anthers dehiscent at apex, the base sac-like; sterile filament glabrous. Snake River Bluffs near Lewiston and Craig Mountains, Idaho.

Pentstemon venustus Dougl. Glabrous; stems tufted, erect, $40-60 \mathrm{~cm}$. high; leaves oblong-lanceolate to ovate-lanceolate, closely serrate, 4-5 cm. long; panicle narrow; peduncles 1-3-flowered; calyx very small, the sepals ovate, acute or acuminate; corolla funnelform, bluish-purple, $2.5-3 \mathrm{~cm}$. long, the lobes ciliate; stamens sparsely pilose above. Common in the Blue Mountains; also in the Craig Mountains and along the Potlatch River, Idaho. 
Pentstemon triphyllus Dougl. Puberulent; stems slender, from a branched woody base, $30-50 \mathrm{~cm}$. high; leaves in whorls of 3 , or the uppermost alternate, linear or lanceolate, entire or few-toothed, sessile, 1-2 cm. long; panicle loose, narrow; peduncles 2-5-flowered; pedicels short; calyx glandular, 3-4 mm. long; corolla 2-lipped, purple, $15 \mathrm{~mm}$. long, minutely viscid-glandular; anthers dehiscing only at the apex, the base sac-like; sterile filament densely bearded. Rock crevices near Albion and along Snake River; also reported from the Blue Mountains by Douglas.

Pentstemon richardsonii Dougl. Glabrous; stems from a branched woody base, erect or ascending, $60-90 \mathrm{~cm}$. high, often branched; leaves lanceolate to ovate, mostly deeply toothed or pinnatifid, 3-8 cm. long, those on the branches alternate; panicle loose, somewhat glandular; sepals ovate, acute; corolla red, somewhat funnelform, $20-25 \mathrm{~mm}$. long; sterile filament with a few hairs near the tip. On basalt ledges, Spokane County.

\section{SCROPHULARIA. FIGWORT.}

Perennial herbs; leaves opposite; flowers small, in loose cymes in a narrow terminal panicle; calyx deeply 5-cleft; corolla 5lobed, the 4 upper lobes erect, the lower spreading; stamens 4 ; the fifth sterile one a scale-like rudiment at the summit of the corolla-tube; capsule many-seeded.

Scrophularia californica Cham. Puberulent; stems stout, simple, about $1 \mathrm{~m}$. high, somewhat 4-sided; leaves triangular-ovate, acute, coarsely and unevenly toothed or cleft, 5-12 cm. long, on petioles about half as long; panicle narrow, $20-40 \mathrm{~cm}$. long, somewhat glandular; bracts lanceolate-attenuate; flowers dull-purple or green; calyx-lobes rounded, as long as the tube; corolla $6-8 \mathrm{~mm}$. long; rudimentary stamen broad, spatulate; capsules conical, glandular. Low ground, not common. Our form is not typical.

\section{COLLINSIA.}

Annuals or biennials; leaves simple, opposite, sessile or the lowest petioled and the upper whorled; flowers solitary or clustered in the upper axils; calyx deeply 5-cleft; corolla with the tube saccate at the base on the upper side, deeply 2-lipped; the upper lip 2-cleft, the lower 3-cleft, the middle lobe keeled and sac-like; anther-bearing stamens 4 ; sterile stamen a gland-like structure; capsule 4-many-seeded.

Corolla 5-7 mm. long; tube longer than the limb.

Corolla $12-16 \mathrm{~mm}$. long; tube shorter than the limb.

C. ténella.

C. grandiflora.

Collinsia tenella (Pursh) Piper. (C. parviflora Dougl.) Glabrous or minutely puberulent, branched from the base, erect or spreading, $10-20 \mathrm{~cm}$. high; lower leaves oblong or orbicular, petioled, often toothed; the upper nearly sessile, oblong or linear, acutish, 1-2 cm. long, often in whorls of 3-5; flowers slender-pedicelled, solitary or nearly so in the axils, even of the lower leaves; calyx-lobes lanceolate, acute, longer than the tube, not equalling the corolla; corolla violet or blue, $6-7 \mathrm{~mm}$. long, 2-lipped for half its length. Common everywhere.

Manat - Bavit - ley

Collinsia grandiflora Dougl. Very similar to C. tenella but larger, 15-30 $\mathrm{cm}$. high; leaves larger, the cauline in whorls of 3-7; calyx-lobes triangularsubulate, very acute, longer than the tube; corolla blue-violet, $8-16 \mathrm{~mm}$. long. In open woods near Troy, Idaho, and along the Clearwater River. 


\section{TONELLA.}

Very similar to Collinsia but the cauline leaves mainly ternately divided or 3-parted; corolla obscurely 2 -lipped, the 5 more or less unequal lobes somewhat rotately spreading, the tube somewhat gibbous above; ovules and seeds $1-4$ in each cell.

Tonella floribunda Gray. Stems slender, usually branched, $10-50 \mathrm{~cm}$. high; basal leaves simple, ovate, entire or few-toothed, 5-10 $\mathrm{mm}$. long, slenderpetioled; cauline all 3-parted or divided, short-petioled or sessile; divisions oblong, linear or lanceolate, obtuse, short-stalked, 1-3 cm. long, bearing a few short stiff hairs on the back and margin; inflorescence sparsely pubescent with stalked glands; flowers slender-pedicelled, in whorls, from the axils of the reduced upper leaves; calyx-lobes linear; corolla blue, with darker lines within, nearly rotate, $1 \mathrm{~cm}$. broad, the lobes of the lower lip smaller than those of the 2-cleft upper lip. A charming little plant, common along streams in Snake River canyon.

\section{GRATIOLA. Hedge Hyssop.}

Low mostly perennial branching herbs; leaves opposite, sessile; peduncles axillary, 1-flowered; calyx 5-parted, the narrow divisions usually equal; upper lip of corolla entire or 2-cleft, the lower 3 -cleft; anther-bearing stamens 2 ; sterile filaments 2 , simple and included, or none; style dilated or 2-lipped at the apex; capsule 4-valved, many-seeded.

Viscid puberulent; calyx subtended by a pair of bractlets at base.

Glabrous; calyx without bractlets.

G. virginiana. G. ebracteata.

Gratiola virginiana L. Annual; stems erect, branched below, viscidpuberulent or pubescent above, nearly glabrous at base, $10-30 \mathrm{~cm}$. high; leaves sessile, oblong-lanceolate, acute, entire or toothed, usually narrowed at base, 1-2 cm. long, glabrous or nearly so; pedicels slender, equalling the leaves; calyx enclosed at base by 2 foliaceous bracts which equal the lobes; corolla $8-10 \mathrm{~mm}$. long, its yellow tube nearly twice as long as the calyx; lobes whitish, the two upper notched; capsule ovoid. Wet places, common.

Gratiola ebracteata Benth. Very similar to G. virginiana but glabrous and the calyx bracts wanting; stems usually simple; leaves somewhat longer, lanceolate, mostly entire, tapering from near the base into a long slender apex; capsule subglobose, obscurely 4 -angled. In wet places or even in shallow water, base of Cedar Mountain, Idaho; rare in our limits.

\section{SYNTHYRIS.}

Perennial herbs; leaves alternate, crenate, the radical roundish or cordate; flowers small, blue, purplish or green, in a spike or raceme; calyx 4-parted; corolla campanulate, with 4 more or less unequal lobes, or none; stamens 2 , from just below the upper sinuses, or in one apetalous species on the hypogynous disk, exserted; stigmas simple; capsule many-seeded.

Petals blue; flowers in a raceme; leaves orbicular.

Petals none; flowers in a reddish spike; leaves ovate.

S. reniformis. S. rubra. 
Synthyris reniformis (Dougl.) Benth. Glabrous below the inflorescence; stems $10-30 \mathrm{~cm}$. high; leaves all basal, orbicular, $2-5 \mathrm{~cm}$. broad, reniform at base, with many short lobes, these coarsely crenate; petioles much longer than the blades; scapes erect, the raceme spike-like; a few bracts below the inflorescence; calyx-lobes oblong, obtuse; corolla blue; capsule flattened, notched at apex, 5-7 mm. long. In the mountains at high altitudes, Blue Mountains; Kamiack Butte; Craig Mountains, Idaho.

Synthyris rubra (Dougl.) Benth. Erect, $30-50 \mathrm{~cm}$. high, whitish-pubescent throughout; basal leaves ovate, obtuse, somewhat cordate and cuneate at base, crenate, 2-6 cm. long, long-petioled; cauline smaller, sessile; spike densely flowered; calyx greenish or reddish, the sepals oblong, viscid-pubescent, $4 \mathrm{~mm}$. long; corolla none; stamens much exserted, inserted on the hypogynous disk; capsule globose, somewhat flattened, rounded at apex, longer than the sepals. Common on grassy hillsides.

\section{VERONICA. SPEEDWELl.}

Chiefly herbs; leaves opposite or whorled, or the upper alternate; flowers small, in racemes or spikes or sometimes solitary in the axils; calyx 4-parted; corolla rotate, 4-parted, the lower lobes and sometimes the lateral ones narrower; stamens 2 , exserted; style entire; stigma single; capsule flattened, fewmany-seeded.

Annuals; flowers solitary.

Glabrous or merely puberulent; petals white; leaves mostly entire.

Pubescent; petals blue; leaves crenate.

Pedicels short; upper leaves reduced.

Pedicels long; upper leaves not reduced.

. peregrina.

Perennials; flowers in racemes.

Peduncles terminal.

Peduncles axillary.

Leaves linear or linear-lanceolate; capsule deeply notched.

$V$. arvensis.

V. tournefortii.

V. humifusa.

Leaves oblong-lanceolate to ovate; capsule with a shallow notch.

V. scutellata.

V. americana.

Veronica peregrina L. Annual, erect, branched from the base, glabrous or puberulent and glandular, $8-40 \mathrm{~cm}$. high; lower leaves opposite, petioled, oblong, obtuse, dentate; upper alternate, linear, obtuse or acute, entire or nearly so, 1-2 cm. long; flowers white, solitary in the axils; pedicels very short, not as long as the flowers; corolla 1-2 mm. broad; capsules orbicular, notched, about as long as the calyx. Common in moist places, variable.

Veronica arvensis L. Annual, pubescent; stems simple or branched at base, $5-20 \mathrm{~cm}$. high, erect or nearly so; leaves ovate, crenate, the lower shortpetioled, the upper sessile; bracts lanceolate, entire; flowers smahl, shortpedicelled; corolla pale blue, shorter than the calyx; capsule obcordate. Introduced in fields.

Veronica tournefortii C. C. Gmel. Leaves about $1 \mathrm{~cm}$. long, orbicular or broadly ovate, often subcordate, crenately toothed, the blades shorter than the pedicel; corolla $1 \mathrm{~cm}$. broad; calyx-lobes ovate-lanceolate, spreading; capsule triangular, deeply notched. Sparingly introduced from Europe. 
Veronica humifusa Dickson. Perennial, glabrous or puberulent; stems erect or decumbent, $10-15 \mathrm{~cm}$. high; leaves opposite, oval, ovate or orbicular, crenate-dentate or subentire, short-petioled, about $1 \mathrm{~cm}$. long; racemes terminal; bracts oblong, alternate; pedicels erect, equalling or exceeding the calyx; corolla blue, dark-striped, $4 \mathrm{~mm}$. broad; capsule orbicular, notched at apex, as long as the calyx. Moist places, rather common.

Veronica scutellata L. Perennial, glabrous or nearly so, rooting at the lower joints; stems $15-30 \mathrm{~cm}$. high; leaves all sessile, lanceolate or nearly linear, mostly denticulate or entire, attenuate-acute, $3-5 \mathrm{~cm}$. long; racemes axillary from alternate axils, slender, few-flowered, as long as or exceeding the leaves; pedicels slender, spreading; corolla blue, 4-5 $\mathrm{mm}$. broad; capsule notched both at apex and base. Wet places, not common.

Veronica americana Schwein. Perennial, glabrous throughout, rooting at the lower nodes; stems decumbent, usually branched, 30-60 cm. long; leaves all opposite, oblong, ovate or lanceolate, obtuse, serrate, rounded at the base, short-petioled; racemes opposite, in the upper axils, exceeding the leaves; pedicels spreading, longer than the bracts and flowers; flowers blue with darker stripes, $4 \mathrm{~mm}$. broad; capsule with a shallow notch at the apex, 4-5 mm. broad. Wet places, infrequent.

\section{ILySanthes. False Pimpernel.}

Small and smooth annual herbs; leaves opposite, sessile; peduncles axillary, 1-flowered, the upper becoming racemose; calyx becoming 5-parted, the divisions becoming narrow and nearly equal; upper lip of corolla short, erect, 2-lobed, the lower larger, spreading, 3-cleft; anther-bearing stamens 2 ; sterile filaments unequally 2-forked, exserted; stigma 2-lobed; capsule many-seeded.

Ilysanthes dubia (L.) Barnhart. Glabrous, simple or branched from the base, $5-12 \mathrm{~cm}$. high; leaves sessile, ovate, acute or with a few teeth, $1-2 \mathrm{~cm}$. long, the upper ones reduced; pedicels slender, twice as long as the leaves, spreading in fruit; flowers 6-8 $\mathrm{mm}$. long; calyx-lobes linear, as long as the purple corolla; capsule ovoid-oblong, 4-6 mm. long. Sandy banks of streams, rare.

\section{LIMOSELLA. MUDWORT.}

Very small glabrous annual herbs, stoloniferous, rooting and creeping in the mud; leaves narrow, entire, fleshy, in dense clusters around the simple 1 -flowered naked peduncles; flowers small; calyx campanulate, 5-toothed; corolla rotate-campanulate, 5-cleft, nearly regular; stamens 4 , all anther-bearing; style short; stigma thickish; capsule many-seeded.

Limosella aquatica $L$. Tufted; leaves spatulate, obtuse, $2-5 \mathrm{~cm}$. long, the blade usually much shorter than the petiole; peduncles shorter than the leaves; corolla white or pinkish, $2 \mathrm{~mm}$. broad, hardly longer than the calyx; capsules globose, obtuse, 2-2.5 mm. long. Muddy places, near Moscow, Idaho, Henderson.

340. MimUlUS. MONKEY Flower.

Herbs with mostly simple opposite leaves; flowers axillary, on simple peduncles; calyx prismatic, or rarely campanulate, usually 
5-angled, 5-toothed, the upper tooth usually the largest; corolla irregular, 2-lipped; upper lip erect or reflexed, 2-lobed, the lower spreading, 3-lobed; stamens 4, all anther-bearing; stigma 2-lobed; seeds numerous.

Flowers reddish or purple.

Corolla small, 5-10 mm. long.

Corolla larger, $15 \mathrm{~mm}$. or more long.

Flowers $30-40 \mathrm{~mm}$. long.

Flowers $15-20 \mathrm{~mm}$. long.

Pedicels $2-3 \mathrm{~mm}$. long.

Flowers yellow.

Pedicels 5-15 mm. long.

M. breweri.

M. lewisii.

M. nanus.

M. clivicola.

Calyx not angled, deeply 5-cleft.

Calyx 5-angled, 5-toothed.

Leaves pinnately veined; plant musk-scented.

M. pilosus.

Leaves palmately veined; plant inodorous.

Flowers large; plants nearly or quite glabrous.

Perennial; lip of corolla spotted.

Annual; lip of corolla with a large blotch.

Flowers small; plants pubescent.

Fruiting calyx distended.

Fruiting calyx cylindric.

Plant erect, not villous.

Plant spreading or prostrate, villous and shiny-viscid.

M. moschatus.

M. langsdorfii.

M. nasutus.

M. breviflorus.

M. peduncularis.

M. floribundus.

Mimulus breweri (Greene) Rydb. Annual, viscid-pubescent, 3-12 cm. high, simple or branched; leaves linear-lanceolate, sessile or nearly so, entire, $1-2 \mathrm{~cm}$. long; peduncles as long as the calyx; calyx cylindric, the short teeth triangular-obtuse; corolla pale rose-color, 5-10 mm. long. Moist banks in the Blue Mountains.

Mimulus lewisii Pursh. Perennial, viscid-pubescent; stemś simple, erect, 30-50 cm. high; leaves oblong-ovate, denticulate, acute, $3-4 \mathrm{~cm}$. long, the nerves conspicuous; peduncles exceeding the leaves; calyx angular-campanulate, the teeth triangular, sharp-pointed; corolla rose-red, $4 \mathrm{~cm}$. long, 2-lipped, the tube longer than the calyx, the lobes rounded and spreading. Along. streams in the highest parts of the Blue Mountains.

Mimulus nanus H. \& A. Annual, simple or branched from the base, 2-15 $\mathrm{cm}$. high, finely glandular-pubescent throughout; leaves oblong to obovate or oblanceolate, narrowed at the base, entire or denticulate, 5-20 mm. long; pedicels 2-3 mm. long; calyx tubular, the teeth subequal, triangular, acutish, one-fourth as long as the tube; corolla dark purple, with a darker throat, funnelform and flaring, $18-20 \mathrm{~mm}$. long, bilabiate, the limb $10 \mathrm{~mm}$. broad; seeds oblong, less than $1 \mathrm{~mm}$. long, brown, twice as long as broad. On moist banks, Craig Mountains, Idaho.

Mimulus clivicola Greenman. Closely similar to M. nanus; corolla reddish, spotted in the throat, more funnelform and less flaring; pedicels 5-15 mm. long; calyx distinctly narrowed at the base; seeds smaller, thicker, not twice as long as broad. On hillsides in open pine woods, Thatuna Hills and Craig Mountains, Idaho.

Mimulus pilosus (Benth.) Wats. Annual, erect, usually much branched, villous throughout with soft somewhat viscid hairs, $10-30 \mathrm{~cm}$. high; leaves oblong or lanceolate, acute, entire, sessile, $1-3 \mathrm{~cm}$. long; pedicels about equalling 
the leaves; calyx campanulate, not at all angled, deeply 5-cleft, oblique at the orifice; corolla yellow, shortly 2 -lipped, 6-8 $\mathrm{mm}$. long, the lobes nearly equal. Moist sandy places in the warmer valleys.

Mimulus moschatus Dougl. Perennial, villous and shiny viscid, muskscented; stems weak, spreading, ascending or erect, 10-40 cm. high; leaves oblong-ovate, denticulate, $2-5 \mathrm{~cm}$. long, all petioled; peduncles shorter than the leaves; calyx tubular-prismatic, $8-12 \mathrm{~mm}$. long, the unequal teeth acute; corolla pale yellow, spotted in the throat, about $2 \mathrm{~cm}$. long. Springy places in the Blue Mountains; also Thatuna Hills, Idaho.

Mimulus langsdorfii Donn. Perennial by short stolons, erect or decumbent, glabrous or puberulent, $15-60 \mathrm{~cm}$. high, or depauperate plants much smaller and dying after blooming; leaves several-nerved from the base, ovate, obtuse or acute, rounded or subcordate at base, the lower long-petioled and often with ragged lobes at base, the upper short-petioled or sessile; floral leaves of ten cuneate; flowers in a raceme, the pedicels as long as or shorter than the flowers; calyx in fruit 5-angled and inflated, the upper lobe longest, the others turned toward it, all much shorter than the tube; corolla yellow, hairy and of ten spotted in the throat, usually $2-3 \mathrm{~cm}$. long, the tube exceeding the calyx. Springy places.

Mimulus nasutus Greene. Much like $M$. langsdorfi but strictly annual, the leaves usually orbicular; corolla $1-1.5 \mathrm{~cm}$. long, pale-yellow, the tube barely as long as the calyx, the lower lip usually with a large purple blotch. Moist cliffs, especially along Snake River.

Mimulus breviflorus Piper. Annual, the slender stem simple, or more commonly branched from the base, erect, 4-20 cm. high, minutely puberulent throughout or nearly glabrous above; leaves lanceolate, rarely oblanceolate or ovate, acute or inconspicuously few-toothed, narrowed at base into a short petiole or subsessile, usually shorter than the internodes, gradually reduced above, mostly about $1 \mathrm{~cm}$. long; flowers solitary in the axils, on slender pedicels which about equal the leaves; calyx narrowly campanulate, somewhat constricted above, $2-3 \mathrm{~mm}$. long in flower, $6-8 \mathrm{~mm}$. in fruit, the short acute triangular teeth nearly equal; corolla pale-yellow, tubular, 4-5 mm. long, the lobes short and rounded; stigma scarcely protruding beyond the calyx. Moist ground, local and not common.

Mimulus peduncularis Dougl. Much like $M$ : floribundus but more slender, erect, puberulent, not villous; leaves $5-25 \mathrm{~mm}$. long, slender-petioled; pedicels slender, as long as or longer than the leaves; calyx-teeth very short. Banks of Snake River, Rock Lake and Lake Waha, Idaho; rare.

Mimulus floribundus Dougl. Annual, erect when young, soon spreading or prostrate, villous-pubescent throughout with slimy-viscid hairs; stems of ten 30-50 cm. long; leaves ovate, somewhat cordate, acute, dentate, 4-40 mm. long; petioles shorter than the blades; flowers opposite, in the axils; pedicels barely exceeding the leaves; fruiting-calyx $7 \mathrm{~mm}$. long, campanulate, the 5 triangular teeth equal, one-fourth as long as the tube; corolla pale yellow, $1 \mathrm{~cm}$. long, the limb little spreading. Moist banks, in the warmer valleys.

\section{RHINANTHUS.}

Annual erect herbs, with opposite leaves; flowers yellowish, in a one-sided spike; calyx membranaceous, 4-toothed, inflated in fruit; corolla 2-lipped, the upper lip arched, ovate, obtuse, with two lateral teeth; the lower lip 3-lobed; stamens 4, all antherbeàring, enclosed in the upper lip; anther-cells equal; capsule orbicular, flattened. 
Rhinanthus kyrollae Chabert. Stems erect, 30-60 cm. high, simple or more commonly with ascending branches; leaves lanceolate, sessile, $2-5 \mathrm{~cm}$. long, serrate, minutely scabrous; bracts pale green, ovate-lanceolate, with slender acuminate teeth; calyx $1.5 \mathrm{~cm}$. long; corolla pale yellow. In gravelly soil, Spokane County, Suksdorf; Palouse City, Henderson; Troy, Idaho, Piper.

342. PEDICULARIS. LOUSEWORT.

Perennial herbs; leaves toothed or pinnatifid, the floral bractlike; flowers rather large, in a spike; calyx 2-5-toothed, irregular; corolla strongly 2 -lipped, the upper lip (galea) arched, laterally compressed, sometimes beaked; the lower 3-lobed; stamens 4, enclosed by the upper lip; anthers equally 2-celled; capsule several-seeded.

Leaves lanceolate, doubly crenulate.

P. racemosa.

Leaves pinnately lobed or parted.

Corolla yellow, with a slender inrolled beak.

Corolla whitish, with a broad hood-like beak.

$P$. contorta.

P. bracteosa.

Pedicularis racemosa Dougl. Ascending or spreading, glabrous throughout or puberulent above, the stems simple or somewhat branched, $30-40 \mathrm{~cm}$. long; leaves alternate, lanceolate, acute or obtuse, doubly crenulate. 5-10 $\mathrm{cm}$. long; petioles short; flowers short-pedicelled, in racemes, with gradually reduced leaves or bracts; calyx 2-cleft in front, 2-toothed behind; corolla white or reddish, the galea much incurved, nearly reaching the apex of the broad lip. In open woods in the mountains.

Pedicularis contorta Dougl. Glabrous; stems simple, erect, $20-30 \mathrm{~cm}$. high; basal leaves petioled, 5-8 $\mathrm{cm}$. long, pinnately parted into linear toothed segments; cauline leaves similar, sessile; spikes densely many-flowered, 5-10 $\mathrm{cm}$. long; calyx cleft before and behind, the lobes 2-toothed; corolla pale yellow, the galea slender, elongate and somewhat circinate, about as long as the lower lip. In alpine meadows, Blue Mountains.

Pedicularis bracteosa Benth. Glabrous below, sparsely pubescent above; stem stout, erect, $30-100 \mathrm{~cm}$. high, with tuber-like roots; leaves ovate or oblong in outline, 5-12 cm. long, the basal petioled, the cauline nearly sessile, pinnately parted or divided into narrow lanceolate or linear, serrate or incised divisions, 1-5 cm. long; inflorescence an erect dense spike, 10-50 cm. long; bracts ovate, acuminate, entire or nearly so, exceeded by the flowers; calyx 5-cleft, with narrow triangular lobes; corolla whitish, $2 \mathrm{~cm}$. long, galea longer than the lip, curved, hooded at the apex, the orifice entire. In moist woods in the mountains.

343. Castilleja. Painted Cup, Indian Pink, or Indian Paint Brush.

Perennial herbs, sometimes woody at the base; leaves alternate, entire or cleft into linear lobes; the floral ones usually dilated, colored and more showy than the yellow, red or whitish spiked flowers; calyx tubular, flattened, 2- or 4-lobed; corollatube included; upper lip (galea) much longer than the lower, narrow, arched and keeled, enclosing the 4 unequal stamens; lower lip short, 3-lobed; anthers unequally 2-celled; capsule many-seeded. 
Bracts whitish or yellowish; galea shorter than the corollatube.

Galea short and broad.

C. pallescens.

Galea slender.

Pubescence harsh.

Pubescence soft, pilose.

Bracts scarlet or crimson, occasionally yellow; galea as long as or longer than the corolla-tube.

Leaves and bracts cleft into linear lobes.

Leaves and bracts entire.

C. lutescens.

C. camporum.

Castilleja pallescens (Gray) Greenman. Whole plant ashy puberulent; stems several, erect from a woody base, $10-30 \mathrm{~cm}$. high; leaves rather rigid, mostly 3-5-parted with linear lobes, $2-3 \mathrm{~cm}$. long; bracts similar, broader, the upper with their tips whitish or yellowish; calyx deeply 2-cleft, the lobes notched at the summit; corolla yellowish, the galea short and broad, the lip somewhat saccate. Dry soil, especially in the sagebrush region.

Castilleja lutescens (Greenman) Piper. Erect from a woody base, 30-50 $\mathrm{cm}$. high, harshly short-pubescent throughout; stems simple or branched above; leaves lanceolate-linear, attenuate, all but the upper entire, $3-5 \mathrm{~cm}$. long; upper leaves and bracts broader, 3-5-lobed, the bracts yellowish; calyx equally cleft before and behind, the divisions 2-cleft; corolla yellowish, exceeding the calyx; upper lip twice as long as the prominently 3-lobed lower lip. Dry hillsides, common.

Castilleja camporum (Greenman) Howell. Stems erect, $15-50 \mathrm{~cm}$. high with soft-pilose somewhat viscid pubescence; leaves lanceolate, a few of the lower entire, the upper cleft into 3-7 narrow lobes; inflorescence pale, greenishyellow, elongated in fruit; calyx $2-2.5 \mathrm{~cm}$. long, equally cleft before and behind, the lateral divisions 2-lobed or rarely entire, obtuse at apex; corolla longer than the calyx; upper lip nearly twice as long as the prominently 3-lobed lower lip. Low meadows, rare.

Castilleja angustifolia (Nutt.) G. Don. Stems usually clustered from a woody base, erect, $20-50 \mathrm{~cm}$. high, more or less pubescent throughout, somewhat pilose; leaves pubescent, the lower linear or linear-lanceolate, mostly entire, the upper broader, cleft to about the middle into 3-5 narrow lobes; inflorescence short and dense, becoming elongate in fruit; bracts like the leaves but broader and more deeply cleft, pilose below, the tips scarlet, rarely yellow; calyx 2-3 cm. long, with lanceolate lobes; corolla $2 \mathrm{~cm}$. long, the upper lip hardly as long as the tube, much longer than the short 3-lobed lower lip. Thatuna Hills, Kamiack Butte and Snake River Bluffs; very variable.

Castilleja miniata Dougl. Glabrous below the inflorescence; stems erect, simple or nearly so, $30-100 \mathrm{~cm}$. high; leaves lanceolate or linear-lanceolate; acute or acuminate, entire, sessile, $3-5 \mathrm{~cm}$. long; spikes dense, pubescent; bracts broad, mostly 3-5-toothed or cleft, scarlet-tipped, shorter than the flowers; calyx about equally cleft before and behind, the divisions 2-cleft; corolla yellowish, $3 \mathrm{~cm}$. long, the upper lip straight and slender, longer than the tube; lower lip very short; pod ovoid, 10-12 $\mathrm{mm}$. long, enclosed in the calyx. Low ground, common.

\section{ORTHOCARPUS.}

Low annuals, very similar to Castilleja; calyx 4-cleft; corolla tubular; the upper lip (galea) scarcely longer and usually much narrower than the inflated 1-3-saccate lower ones; anthers unequally 2 -celled, or the smaller anther-cell rarely wanting. 
Lower corolla-lip with 3 conspicuous swellings, much larger than the galea.

Lower corolla-lip simply saccate, scarcely larger than the galea.

Bracts very different from the leaves, the upper ones entire.

Bracts less different from the leaves, all 3-5-lobed.

O. hispidus.

Orthocarpus hispidus Benth. Annual, slender, erect, simple or with few erect branches, rough-hairy throughout, $10-40 \mathrm{~cm}$. high; leaves linear or lanceolate, attenuate, entire or pinnately cleft into 3-5 linear lobes, 2-6 cm. long; spikes dense, narrow; bracts like the leaves, but shorter and broader; calyx-teeth subulate, shorter than the corolla-tube; corolla white, slender, 12-14 mm. long; lip with 3 sac-like swellings; galea straight, pointed. Low ground, not common.

Orthocarpus tenuifolius (Pursh) Benth. Annual, erect, branched above, $10-20 \mathrm{~cm}$. high, sparsely hairy; leaves narrow, $2-4 \mathrm{~cm}$. long, entire or pinnately cleft into 3-5 linear lobes; spikes dense, 1-6 cm. long, $2 \mathrm{~cm}$. broad; bracts broad, obtuse, purple-tipped, the upper entire, the lower with 1-2 small lobes on each side, coarsely ciliate; calyx half as long as the corolla, 2-lipped, each lip bearing 2 subulate teeth; corolla yellow, narrow, exceeding the bracts, $15 \mathrm{~mm}$. long, the small hooked galea surpassing the sac-like lip. Low ground, common.

Orthocarpus luteus Nutt. Annual, somewhat viscidly pubescent; stems erect, slender, $15-40 \mathrm{~cm}$. high; leaves mostly entire, linear to lanceolate, long-acuminate, 2-4 cm. long; spike dense, the bracts green, broader and shorter than the leaves, mostly 3-cleft; calyx-teeth acute; corolla bright yellow, 10-12 mm. long, much longer than the calyx. Spokane County, rare.

\section{Family 83. OROBANCHACEAE. BROOMRAPE FAMILY.}

Root-parasitic herbs, destitute of foliage and green color, yellowish or brownish throughout; leaves reduced to alternate scales; flowers solitary, in loose clusters or in spikes; calyx 4- or 5toothed or parted; corolla gamopetalous, tubular, more or less 2-lipped, hypogynous; stamens 4, didynamous, epipetalous; style long; stigma large; ovary 1 -celled, with 2 or 4 parietal placentae; capsule 1-celled, 2-valved; seeds very numerous, minute.

Flowers in spikes, sessile or nearly so, bracteate.

Flowers solitary or in loose clusters, long-pedicelled, bractless.

345. Orobanche, 231.

346. Thalesia, 232.

\section{OROBANCHE.}

Parasitic herbs on the roots of various plants, usually yellowish or reddish; flowers in spikes, sessile or nearly so, with bracts; calyx deeply 2 -lobed, the lobes of ten 2-cleft; corolla irregular, the tube slightly curved, the upper lip erect or incurved, the lower spreading; capsule 2-valved.

Orobanche ludoviciana Nutt. Whole plant reddish-yellow, viscid-pubescent; stem stout, erect, simple or with erect branches, scaly, 15-25 cm. long; flowers 2-bracted at the base of the calyx, in dense spikes, looser below; calyx unequally 5-cleft, the lobes linear-lanceolate; corolla yellowish, 12-15 mm. 
long, the lobes acute, hardly spreading. In the sand on the banks of Snake River on the roots of Artemisia dracunculoides and Chrysopsis villosa.

346. THALESIA.

Yellowish, violet or nearly white herbs; parasitic on the roots of various plants; scale-leaves scattering; flowers solitary or in loose clusters; calyx 4- or 5-cleft; corolla 2-lipped, the upper lip erect, mostly 2-lobed or emarginate, the lower spreading; stamens included.

Calyx-lobes subulate, longer than the tube.

Calyx-lobes triangular, shorter than the tube.

T. uniflora.

T. fasciculata.

Thalesia uniflora (L.) Britt. Stem stout, 1-4 cm. long, mostly subterranean, with a few ovate obtuse scales and bearing 1-5 or more 1-flowered glandular-puberulent peduncles 5-12 $\mathrm{cm}$. high; calyx glandular, the obconic or campanulate tube exceeded by the narrow subulate lobes; corolla violet or yellowish, 1-2.5 cm. long, glandular-puberulent without. Parasitic mainly on Tellima and Eriogonum. Not rare.

Thalesia fasciculata (Nutt.) Britt. Stems elongated, 2-12 cm. long, bearing a cluster of 2-30 very glandular 1-flowered peduncles, 5-10 cm. high; calyx-tube campanulate, about as long as the broad triangular lobes; corolla yellowish, 1-2 cm. long. In sandy or gravelly soil. On the roots of various plants.

\section{Family 84. Plantaginaceae. Plantain Family.}

Mostly stemless herbs; flowers regular, 4-merous, in spikes; corolla gamopetalous, dry and membranaceous, veinless; stamens 4 or rarely 2 on the corolla-tube, alternate with its lobes; ovary 2 or falsely 3-4 celled; ovules 1 -several in each cavity.

\section{Plantago. Plantain.}

Leaves nerved or ribbed, radical; flowers small, in bracted spikes, on naked scapes; calyx of 4 persistent sepals; corolla salverform or rotate, 4-parted; stamens 4 , or rarely 2 , in all or some flowers with long exserted filaments; ovary 2-celled; ovules 1-several in each cell; capsule 2-celled, 2-several-seeded.

Leaves broad, oval or ovate.

Leaves narrow, lanceolate or linear.

P. major.

Leaves pubescent, green.

Leaves white-villous.

$P$. lanceolata.

P. purshii.

Plantago major L. Common Plantain. Perennial, pubescent or glabrous, the erect scapes mostly $10-30 \mathrm{~cm}$. high; leaves broadly ovate, 3-5-ribbed, obtuse or acute, rounded at base, entire or coarsely dentate, 3-20 cm. long; on stout channeled petioles; spikes $5-20 \mathrm{~cm}$. long; flowers all alike, perfect; sepals ovate or oblong, obtuse, shorter than the acutish capsule; seeds 6-15. Introduced and spreading, or one form perhaps native. 
Plantago lanceolata L. English Plantain. Perennial, with a stout taproot, erect, $30-45 \mathrm{~cm}$. high, more or less pubescent; leaves $5-20 \mathrm{~cm}$. long, sparsely pubescent, woolly at the base of the broad petiole; spikes dense, 1-3 cm. long, a little thicker at the base; bracts and sepals scarious; flowers all alike, perfect; capsule oblong, obtuse, 2-seeded; seeds concave on the inner face. Introduced in lawns and meadows as a weed.

Plantago purshii R. \& S. Annual, 5-30 cm. high, white-hairy or woolly throughout; leaves 5-10 cm. long, 1-3-nerved, linear or lanceolate, acute, narrowed at the base into a petiole; spikes dense, 1-10 cm. long; bracts subulate, exceeding the flowers, becoming rigid; flowers perfect but of two kinds on separate plants, in one the four stamens being long and exserted, in the other short and included; sepals oblong, obtuse, with broad scarious margins; corolla white, the spreading lobes ovate. Dry soils.

\section{Family 85. RUBIACEAE. MADDER FAMILy.}

Herbs (in ours); leaves opposite, entire, with intervening stipules or whorled without stipules; flowers generally perfect; calyx 4- or 5-lobed or toothed, coherent with the ovary; corolla gamopetalous, regular, 4- or 5-lobed or toothed; stamens on the corolla and alternate with its lobes; ovary inferior, 2-5-celled; endosperm hard, copious.

Leaves whorled, without stipules. Leaves opposite, with stipules.

348. Galium, 233.

349. Kelloggia, 234.

\section{Galium. Bedstraw OR Cleavers.}

Annual or perennial herbs with 4-angled stems; leaves whorled, without apparent stipules; flowers small, usually cymose; calyxteeth obsolete; corolla rotate, 4-parted, rarely 3 -parted; stamens as many as the corolla-lobes, short; styles 2, short; stigmas capitate; ovary 2-lobed, 2-celled; ovules solitary; fruit dry or fleshy, globular, separating when ripe into 2 closed 1 -seeded carpels.

Annuals.

Leaves mostly in fours; stems smooth.

Leaves 6-8 in a whorl; stems rough on the angles.

Stems reclining; fruit 4-6 mm. broad. Perennials.

Stems erect or ascending; fruit $2-3 \mathrm{~mm}$. broad.

Stems woody at the base.

Stems herbaceous.

Leaves 3-nerved.

Leaves 1-nerved.

Fruit smooth; whorls of 4,5 , or 6 leaves.

Fruit not smooth; whorls of 6 leaves.

Fruit granulate-scabrous.

Fruit hispid with hooked hairs.

G. bifolium.

G. áparine.

G. vaillantii.

G. multiflorum.

G. boreale.

G. trifidum.

G. asperrimum. G. triflorum.

Galium bifolium Wats. Glabrous; stems erect, $10-20 \mathrm{~cm}$. high, simple or but little branched; leaves linear to oblanceolate, $8-15 \mathrm{~mm}$. long, the upper often in twos; peduncles 1-flowered, about as long as the leaves; flowers white. In moist open places in the Blue Mountains at high altitudes. 
Galium aparine L. Stems weak and reclining, retrosely prickly on the angles, $30-120 \mathrm{~cm}$. long; leaves linear or linear-spatulate, mostly cuspidate more or less retrorsely-hispid, especially on the margins and midribs, $5-8 \mathrm{~cm}$. long; pedicels from the upper axils or terminal, bearing solitary flowers, fruit on erect pedicels, densely hispid with somewhat hooked bristles, 3-4 $\mathrm{mm}$. broad. In woods and copses.

Galium vaillantii DC. Similar to $G$. aparine but smaller in every way, the stems $10-30 \mathrm{~cm}$. high, mostly erect; leaves $1-2 \mathrm{~cm}$. long; flowers more numerous; fruit about $2 \mathrm{~mm}$. broad. In dry woods.

Galium multiflorum Kellogg. Stems erect, tufted, $10-30 \mathrm{~cm}$. high; leaves in fours or the upper in twos, broadly ovate, sessile, mucronate, 5-15 mm. long; flowers yellowish, dioecious or polygamous, short pedicelled, in rather dense clusters or the fertile scattered; fruit densely bristly. In rocky ground, high ridges of the Blue Mountains.

Galium multiflorum watsoni Gray. Like the species but the leaves oblong and thinner. Blue Mountains, Horner.

Galium boreale L. Glabrous or nearly so; stems rather slender, but erect, $30-60 \mathrm{~cm}$. high, leafy; leaves 3-nerved, oblong-linear, lanceolate or linear, obtuse to acuminate, mostly 1-3 cm. long; flowers white, in small cymes which form a large terminal panicle; bract-like leaves much reduced and in pairs; fruit globose, small, hispid, but becoming glabrous. Common in moist meadows and on north hillsides.

Galium trifidum subbiflorum Wiegand. Stems ascending, very weak and slender, 15-20 cm. high, retrorsely scabrous on the angles; leaves linear, scabrous on the margins and midribs; peduncles axillary or terminal, recurved, mostly 1-flowered; flowers very small, white, the parts often in threes; fruit glabrous. In wet places.

Galium asperrimum Gray. Stems weak, reclining, $30-120 \mathrm{~cm}$. long, retrorsely-hispid on the angles; leaves in sixes or on the smaller branches in fives or fours, 1-nerved, narrowly oblong or lanceolate, cuspidate, shining above, retrorsely hispid on the midribs and margins, 1-3 cm. long; cymes loosely few-flowered, forming very large leafy panicles; peduncles and pedicels very slender; corolla white; fruit about $2 \mathrm{~mm}$. broad, roughened with short tubercles or minutely hispidulous. Plentiful in moist copses.

Galium triflorum Michx. Stems weak, prostrate to ascending, 30-100 cm. long, retrorsely hispid on the angles; leaves lanceolate, bristle-tipped, $2-8 \mathrm{~cm}$. long; peduncles 3-flowered, rarely 6-flowered; flowers greenish-white, all pedicelled; fruits covered with hooked bristles. In moist copses and open woods.

\section{KELLOGGIA.}

Small perennial herbs with opposite leaves with stipules; flowers small, in loose cymes or panicles, usually 4-merous; calyxteeth minute; corolla funnelform to salverform; stamens and style more or less exserted; ovary 2-celled; fruit small, dry, coriaceous, with hooked bristles, separating at maturity into 2 closed carpels.

Kelloggia galioides Torr. Glabrous or nearly so; stems clustered, erect or ascending, 10-30 cm. high; leaves lanceolate, sessile, $2-5 \mathrm{~cm}$. long, the stipules small and scarious, entire or 2-toothed; flowers on long pedicels, in a loose cyme; corolla 4-5 mm. long, white or pinkish, the lobes about as long as the tube; fruit oblong, covered with hooked bristles. In open woods in the Blue Mountains. 


\section{Family 86. CAPRIFOLIACEAE.}

Shrubs or rarely herbs; leaves opposite, without genuine stipules; flowers perfect, generally in cymes; calyx-tube adherent to the ovary; corolla gamopetalous, tubular or rotate, 4- or 5-cleft, sometimes irregular; stamens distinct, as many as the corollalobes, rarely fewer; ovary 2-5-celled, or not rarely 1-celled; ovules solitary or several; endosperm fleshy.

Corolla rotate or urn-shaped; flowers in compound cymes.

Leaves pinnate.

Leaves simple.

Corolla tubular or bell-shaped; flowers not in compound cymes.

Creeping herbaceous vines.

Shrubs, erect or climbing.

Corolla regular, bell-shaped.

Corolla more or less irregular, tubular, commonly 2 -lipped.

350. Sambucus, 235.

351. VIBURNUM, 235.

352. LinNAEA, 236

353. SYMPHORICARPOS, 236.

354. LONICERA, 237.

350. SAMBUCUS. Elder.

Shrubs or trees; leaves opposite, pinnate; leaflets serrate or laciniate; flowers small, white, numerous, in compound cymes; calyx-lobes minute or obsolete; corolla gamopetalous, open urnshaped, 5-cleft; lobes broadly spreading; stamens 5, distinct; stigmas 3; fruits of berry-like drupes with 3-5 nutlets, each with one seed.

Cymes flat-topped; berries glaucous.

Cymes pyramidal; berries not glaucous.

S. glauca.

S. melanocarpa.

Sambucus glauca Nutt. Shrub, 2-5 m. high, glabrous throughout, somewhat glaucous; young pith white; leaves pinnate; leaflets $5-9$, thickish, oblong or ovate-lanceolate, acuminate, sharply serrate, short-stalked, paler beneath, 8-12 cm. long; lower leaflets sometimes more or less divided; subulate stipels occasionally present; cymes usually 5-rayed, large, flat-topped; flowers white, $4-5 \mathrm{~mm}$. broad; fruit black, very glaucous; nutlets rugose. Common along streams.

Sambucus melanocarpa Gray. Shrub, 2-3 m. high; young pith brown; leaflets $5-9$, oblong or narrowly ovate, long-acuminate, sharply and evenly serrate, cuneate at base, puberulent but becoming glabrous, 4-6 cm. long; inflorescence broadly pyramidal; flowers white, $3 \mathrm{~mm}$. broad, turning brown when dried; fruit black without a bloom; nutlets rugose. In woods in the mountains.

\section{VIBURNUM.}

Shrubs or small trees; leaves simple, commonly toothed, sometimes deeply lobed; flowers white, in flat compound cymes; calyx stigmas 1-3; fruit a 1-celled 1-seeded drupe with soft pulp and a thin crustaceous stone. 
Viburnum pauciflorum Pylaie. High-bush Cranberry. Shrub, 1-2 m. high, the branchlets glabrous; leaves orbicular or ovate, mostly 3-lobed, truncate or subcordate at base, pubescent beneath; cymes peduncled, on short 2-leaved branches, small, 1-2 cm. broad; flowers white, all perfect; drupes globose, red. Along streams in the mountains; infrequent.

\section{LINNAEA. TWIN-FLOWER.}

Creeping and trailing small evergreen herbs; leaves ovate or orbicular, opposite, petioled; flowers in pairs, on the summit of elongated terminal peduncles; calyx-teeth 5, awl-shaped, deciduous; corolla funnelform, almost equally 5 -lobed, purple and whitish, hairy inside; stamens 4, two shorter, all included and inserted near the base of the corolla; ovary and the small dry pod 3-celled, but one seed ripening, the other ovules abortive.

Linnaea borealis longiflora Torr. Twinflower. Stem perennial, trailing, slender, pubescent, $30-100 \mathrm{~cm}$. long; leaves obovate or orbicular, obtuse, crenate above the middle, mostly cuneate at base, sparingly pubescent, 10-25 $\mathrm{mm}$. long, short-petioled; flowering branches erect, $8-10 \mathrm{~cm}$. high, leafy below, forked above into two, very rarely more, glandular pedicels, each bearing a single nodding flower; calyx-lobes lanceolate, about twice as long as the very glandular tube; corolla pink, hairy inside, $1-1.5 \mathrm{~cm}$. long. In woods, in the mountains.

\section{SYMPHORICARPOS. SNOWBERRY.}

Low and branching shrubs; leaves oval or oblong, shortpetioled, entire or wavy-margined; flowers 2-bracteolate, in axillary and terminal spikes or clusters, rarely solitary; calyx-teeth 5 or 4 , short, persistent; corolla regular or nearly so, bell-shaped to salverform, white or pink, 5- or 4-lobed; stamens as many as the corolla-lobes, epipetalous; ovary 4-celled, two of these being 1-ovuled and fertile, the two alternate several-ovuled and sterile; fruit globular and berry-like, containing 2 bony seed-like nutlets.

Corolla cylindric-campanulate, 6-7 $\mathrm{mm}$. long.

S. acutus.

Corolla campanulate, $2-5 \mathrm{~mm}$. long.

Erect shrub; leaves glabrous.

Trailing shrub; leaves pubescent.

S. racemosus.

S. mollis.

Symphoricarpos acutus (Gray) Howell. A much branched shrub, 30-100 $\mathrm{cm}$. high; leaves thickish, oblong to orbicular, entire or coarsely lobed, obtuse or rarely acute, densely and finely puberulent, 1-2 cm. long; corolla cylindriccampanulate, pink, 6-7 mm. long, pubescent within, the tube 2-3 times as long as the lobes; stamens and style included, glabrous; berries white. In rocky places, especially abundant in the Blue Mountains.

Symphoricarpos racemosus Michx. Erect much branched shrub, 30-90 $\mathrm{cm}$. high; leaves ovate or oval, acute or obtuse, rounded or cuneate at base, entire or on vigorous shoots sinuately-toothed or lobed, pubescent beneath, short-petioled, 1-4 cm. long; flowers in terminal and axillary racemes; corolla pink, campanulate, 4-5 mm. long, villous on the lobes within, these obtuse, shorter than the tube; stamens and style included; berries white. Common in open woods.

ray - Jane - Tak

Symphoricarpos racemosus laevigatus Fernald. Leaves glabrous beneath, usually thicker. Common in open prairies. 
Symphoricarpos mollis Nutt. Whole plant covered with a short dense pubescence; stems weak, reclining, $30-120 \mathrm{~cm}$. long; leaves oblong to oval, 1-2 cm. long, entire or on vigorous shoots deeply and sinuately lobed, acute or obtuse; flowers in clusters of 1-6; corolla pink, campanulate, $4 \mathrm{~mm}$. long, slightly villous within, the lobes obtuse, as long as the tube; stamens and style included; berries white. In dry open woods in the mountains, infrequent.

\section{LONICERA. HONEYSUCKLE.}

Erect or climbing shrubs; leaves opposite, mostly entire; flowers in spikes or pairs; calyx .minutely 5-toothed; corolla tubular or funnelform, often gibbous at the base, more or less irregularly 5-lobed, commonly 2 -lipped; stamens 5 , epipetalous; ovary 2- or 3-celled, with numerous ovules in each cell; berry several-seeded.

Vine; flowers orange, in terminal clusters; upper leaves connate.

Shrubs; flowers on axillary peduncles in pairs; upper leaves not connate.

Bracts large, foliaceous; flowers yellow; berries black.

Bracts small; flowers whitish; berries red.

L. ciliosa.

Lonicera ciliosa (Pursh) Poir. Stems slender, twining to a height of 3-7 m.; young parts glaucous; leaves oval, obtuse, glaucous beneath, ciliate, $2-6 \mathrm{~cm}$. long, short-petioled; uppermost pairs on the flowering branches connate into oval or orbicular disks; peduncles terminal, rarely in the axils of the penultimate pair of leaves; flowers sessile, in whorls; corolla yellow or orange, sparsely hairy; tube narrow, gibbous near the base, $2-2.5 \mathrm{~cm}$. long; limb spreading, slightly 2 -lipped; berries orange-red. In mountain woods.

Lonicera involucrata Banks. Shrub, 1-3 m. tall, not twining; leaves oblong, ovate or obovate, mostly acuminate, rounded or cuneate at base, sparsely pubescent beneath or glabrate, $5-15 \mathrm{~cm}$. long, short-petioled; peduncles axillary, shorter than the leaves; flowers yellow, a single pair, surrounded at base by an involucre of 4-6 bracts, the inner ones of which are united at base and become purple in fruit; corolla tubular with short lobes, glandular-puberulent, $10-15 \mathrm{~mm}$. long; berries black, not united. Along streams, in the mountains.

Lonicera utahensis Wats. Much branched shrubs, 1-2 m. high, not twining; leaves oblong, oval or ovate, obtuse, pubescent beneath, and somewhat ciliate, $1-5 \mathrm{~cm}$. long, short-petioled; flowers white or nearly so, in a pair at the apex of the peduncles, 1-2 cm. long, with 2 small bracts at the base of ovary; corolla oblong-funnelform, $2 \mathrm{~cm}$. long, the 5 lobes nearly equal, the tube with a sac-like projection at base; berries red, not united. In woods in the mountains. Fprif - May

\section{Family 87. VALERIANACEAE. VALERIAN FAMILy.}

Herbs; leaves opposite, without stipules; flowers perfect or dioecious, in panicled or clustered cymes; calyx-tube coherent with the ovary; corolla gamopetalous, tubular or funnelform, often irregular, 3-5-cleft; stamens distinct, 1-3, fewer than the corolla-lobes, epipetalous; ovary inferior, with one fertile 1-ovuled cell and two abortive or empty ones; fruit indehiscent; endosperm none. 
Tall perennial herbs. Low annual herbs.
355. Valeriana, 238.

356. VALERIANELLA, 238.

355. VALERIANA. VALERIAN.

Tall perennial herbs, with strong-scented thickened roots; leaves simple or pinnate; calyx-lobes of several plumose bristles (pappus) which are rolled inward in flower but which unroll as the fruit matures; corolla commonly gibbous near the base, 5 -lobed, nearly regular; stamens 3 ; abortive cell of the ovary small or obscure, obliterated in the akene-like fruit which is therefore 1-celled.

Leaves thick; root large, fusiform; fruits pubescent.

Leaves thin; roots fibrous; fruits glabrous.

Leaflets entire.

Leaflets dentate.

V. edulis.

V. occidentalis. $V$. sitchensis.

Valeriana edulis Nutt. Tobacco Root. Perennial from a stout tap-root; stems erect, smooth, $40-90 \mathrm{~cm}$. high; basal leaves tufted, petioled, spatulate or oblanceolate, entire or pinnately parted into 3-5 narrow lobes, puberulent or glabrous, usually finely ciliate, $10-40 \mathrm{~cm}$. long; cauline 1-3 pairs, sessile or nearly so, pinnately parted into linear or lanceolate segments, the upper much reduced; flowers greenish-yellow, polygamo-dioecious, sessile, in small cymes which are arranged in large loose panicles; fruit ovate, puberulent or glabrous, 2-3 mm. long. Low ground, common; rank-smelling. Tas-Jine

Valeriana occidentalis Heller. Perennial from branched rootstocks; stems $60-80 \mathrm{~cm}$. high, puberulent below; basal leaves simple, elliptic-lanceolate, obtuse, the blade as long as the petiole; cauline leaves short-petioled, bearing about 9 lanceolate acute leaflets, the terminal one much the largest; flowers creamy-white; calyx glabrous, the lobes linear-lanceolate; corolla funnelform, 3-4 mm. long; stigma entire; fruit glabrous. Known only from the Craig Mountains, Idaho.

Valeriana sitchensis Bong. Perennial from stout rootstocks, glabrous or nearly so; stems erect, $60-90 \mathrm{~cm}$. high; basal leaves simple or trifoliolate, the blades broadly ovate to orbicular; cauline 3-5-foliolate, the leaflets sessile, ovate to oblong, coarsely sinuate to sinuate-dentate; flowers whitish or pinkish, in dense umbels; calyx sparsely pilose; corolla funnelform, 6-7 $\mathrm{mm}$. long; stigma entire; fruit glabrous. High altitudes, Blue Mountains, Horner.

\section{VALERIANELLA.}

Low annual dichotomously branched herbs; leaves tender, rather succulent; flowers small, bracted, whitish, cymosely clustered; calyx merely toothed or teeth obsolete; corolla funnelform, manifestly or obscurely 2-lipped; stamèns 3 , rarely 2 ; fruit 1-celled, 1-seeded.

Valerianella macrocera (T. \& G.) Gray. Annual, erect, simple or loosely branched, $10-30 \mathrm{~cm}$. high, wholly glabrous; leaves only a few pairs, sessile, oblong or oblong-obovate, entire, 1-3 cm. long; flowers pink, in a terminal globose or oblong head or in several whorled clusters; corolla $4 \mathrm{~mm}$. long, the spur one-half as long as the tube or longer, frequently adnate to it; lobes nearly equal, rounded; fruit glabrous or puberulent, deep-saucer-shaped, $2 \mathrm{~mm}$. long. Stony hillsides, common. 
Family 88. DIPSACACEAE. Teasel Family.

Herbs; leaves opposite or whorled, without stipules; flowers in dense heads, surrounded by an involucre as in the Compositae; calyx-tube adherent to the ovary; corolla epigynous, 2-5-lobed; stamens $2-4$, distinct, on the corolla-tube and alternate with its lobes; ovary inferior, 1-celled; ovule 1; fruit an akene with persistent calyx-lobes; endosperm fleshy.

\section{DIPSACUS. Teasel.}

Rough-hairy or prickly tall biennial or perennial herbs; leaves large, opposite, the bases sometimes united into a cup; flowers in dense terminal peduncled oblong heads; bracts of the involucre and scales of the receptacle rigid or spiny-pointed; calyx 4toothed or lobed; corolla oblique, 2-lipped, 3-lobed; stamens 4; stigma oblique or lateral; akene free from or adherent to the involucel.

Dipsacus sylvestris Huds. Biennial, 1-2 m. high, the stems and midribs armed with stout prickles; lower leaves lanceolate, obtuse, crenate, rarely cleft at base, 15-30 cm. long; upper leaves sessile, often cuneate, acuminate, entire; heads ovoid, becoming cylindric, 5-10 cm. long; involucre of linear cuspidate prickly bracts, some of which are longer than the head; bracts of the receptacle ovate, armed with long straight awns; flowers lilac. Sparingly introduced.

\section{Family 89. CAMPANULACEAE. Bellflower FAMily.}

Herbs, with milky juice; leaves alternate, without stipules; flowers regular, generally blue, showy, scattered; calyx adherent to the ovary; corolla 5-lobed, bell-shaped; stamens 5, usually free from the corolla; anthers distinct or united; style 1, the upper portion provided with pollen-collecting hairs; stigmas 2 or more; ovary 2-5-celled, with axile placenta; capsule 2-severalcelled, many-seeded; endosperm fleshy.

Corolla irregular; anthers united.

Corolla regular; anthers separate.

358. Bolelia, 240.

Ovary and capsule long and narrow.

Capsule opening at the top by a hole left by the falling away of the base of the style; flowers all alike.

Capsule opening on the sides by 2 or 3 little valves which leave small round perforaations; flowers of two kinds.

Ovary and capsule short and broad or globular.

Calyx-lobes broad; flowers of two kinds.

Calyx-lobes narrow; flowers all alike.

359. Githopsis, 240.

360. Specularia, 240.

361. Heterocodon, 241.

362. Campanula, 241. 


\section{BOLELIA.}

Low and spreading glabrous annuals, rather succulent and tender; leaves sessile, narrow, entire, the upper reduced to bracts; flowers axillary, sessile; calyx-tube adherent to the ovary, very long and slender, 3-sided, usually twisted; corolla 2-lipped, with a very short tube; filaments and anthers both united into a tube; capsule long and slender, early becoming 1-celled.

Bolelia elegans (Dougl.) Greene. Stems erect, simple or branched near the base, $10-30 \mathrm{~cm}$. high, glabrous throughout or very minutely puberulent; leaves sessile, ovate or lanceolate, acute, $8-20 \mathrm{~mm}$. long; flowers blue, in a rather loose spike; bracts like the leaves but broader; calyx-tube very narrow, becoming 3-4 cm. long and appearing like a pedicel; calyx-lobes narrow, unequal; lower lip of the corolla sharply 3-lobed, 8-10 $\mathrm{mm}$. long and broad, blue with a large white and yellow center; divisions of the upper lip lanceolate. Common on the margins of ponds, sometimes over extensive areas.

\section{GITHOPSIS.}

Low annual herbs; flowers all alike; calyx with a 10-ribbed tube and 5 long and narrow foliaceous lobes; corolla tubularcampanulate, 5-lobed; filaments short, dilated at the base; stigmas 3; ovary 3-celled; capsule strongly ribbed, crowned with the rigid calyx-lobes about as long or longer, opening by a round orifice left by the falling away of the base of the style; seeds very numerous.

Githopsis specularioides Nutt. Annual, erect, simple or branched from the base, hirsute-pubescent throughout, 5-20 cm. high; leaves sessile, linear or oblong, coarsely dentate, 3-12 mm. long; flowers terminal on the stem or on axillary stout peduncles, erect; calyx-lobes linear, acuminate, glabrous above, 1 -nerved, rigid, erect, as long as the narrowly-obconic tube; corolla blue, barely exceeding the calyx-lobes. Very rare, bluffs of Snake River, near Almota, Sheldon; Waitsburg, Horner.

\section{SPECULARIA.}

Annuals; cauline leaves sessile or clasping; flowers blue or purple, terminal or axillary, of two kinds, the earlier smaller, close-fertilized, with a rudimentary corolla which never opens, with mostly 3 or 4 calyx-lobes; the later with 5 calyx-lobes; corolla rotate, 5-lobed; ovary 3 or sometimes 2-celled; capsule more or less elongated, opening by 2 or 3 small lateral valves which leave round or oval perforations, usually over partitions.

Specularia perfoliata (L.) A. DC. Venus's Looking Glass. Stems slender, erect, leafy, $20-40 \mathrm{~cm}$. high, rough-hairy on the angles; leaves orbicular, cordate, crenate, clasping at base, 1-2 cm. long, scabrous on the margins and veins; flowers of 2 sorts, the earlier close-fertilized and with only rudimentary corollas, the later with showy violet corollas $4-10 \mathrm{~mm}$. broad, solitary or 2 or 3 in the axils; calyx of the close-fertilized flowers with 3 or 4 short lobes; of the corolla-bearing flowers with subulate lobes slightly longer than the tube; capsule top-shaped, opening near the middle. Banks and copses. 
361. HETEROCODON.

A very delicate little annual; flowers of two sorts, the lower and earlier ones with merely rudimentary corollas and selffertilized in the bud; calyx with an obovate or inversely pyramidal tube much shorter than the foliaceous lobes, these broadly ovate, sharply toothed, veiny, 3 or 4 in the earlier; 5 in the later flowers; corolla short-campanulate, 5-lobed; stamens and style as in Campanula; capsule 3-celled, 3-angled, bursting on the side; seeds numerous.

Heterocodon rariflorum Nutt. Annual, the slender stems simple or branched below, $8-20 \mathrm{~cm}$. high, sparsely hairy; leaves ovate or orbicular, sessile and partly clasping, coarsely dentate, somewhat scabrous-ciliate, 3-10 $\mathrm{mm}$. long; earlier flowers without corolla, the later ones with blue corollas, barely exceeding the calyx; calyx 5-8 $\mathrm{mm}$. long, more or less hispid, the ovate acuminate usually toothed lobes a little longer than the tube. Rare in moist places.

\section{CAMPA NULA. Bellflower.}

Chiefly perennial herbs; flowers all alike, showy; calyx-lobes narrow; corolla campanulate or nearly so, 5-lobed or cleft; stamens 5; filaments dilated at base; capsule short, 3-5-celled, opening on the side or near the base by 3-5 small uplifted valves leaving round perforations, many-seeded.

Campanula rotundifolia L. Perennial, glabrous, erect, branched at the very base, 10-40 cm. high; basal and lower leaves broadly ovate or orbicular, cordate, dentate or entire, petioled; cauline linear, the lower somewhat spatulate, acute, sessile, 2-7 cm. long; flowers solitary or racemose, erect; pedicels slender, nodding in the fruit; calyx-lobes subulate, longer than the tube, onehalf or one-third as long as the corolla; corolla campanulate, blue, $12-20 \mathrm{~mm}$. long; capsule openings near the base. Dry woods, Thatuna Hills.

\section{Family 90. COMPOSITAE.}

Annual, biennial or perennial herbs or undershrubs (in ours); leaves without stipules; flowers in a close head on a common receptacle, surrounded by one or more rows of bracts (the involucre); heads 1-many, discoid when all the flowers bear tubular corollas, ligulate when the corollas are all strap-shaped, radiate when the outer corollas are strap-shaped and the inner tubular, in which case the outer are ray-flowers and the inner diskflowers; receptacle often covered with bracts or scales (chaff), each subtending a flower; calyx gamosepalous, its tube wholly adherent to the ovary, its limb (pappus) none or cup-shaped or developed into teeth, scales, awns or capillary bristles; corollas alike in all the flowers of the head or dissimilar, either tubular or 
strap-shaped (ligulate), gamopetalous, epigynous; stamens 5, epipetalous, their anthers united into a tube (syngenesious); style 2-cleft at the apex or in sterile flowers usually entire; ovary bicarpellary, inferior, 1-celled, 1-ovuled, with basal placenta; fruit an akene sometimes surmounted by the pappus, of ten compressed at right angles to the subtending chaff (laterally compressed) or compressed parallel to the chaff (obcompressed).

Corollas strap-shaped in all the flowers of the head; plants with milky juice.

Pappus of scale-like or plumose bristles.

Flowers not yellow.

Akenes beaked; flowers violet.

Akenes beakless; flowers pink or

white.
Flowers yellow.

363. Tragopogon, 246.

Heads nodding when young; pappus scales $15-20$, each with a very plumose awn.

Heads erect, even when young; pappus scales less than 15 , or if more than 15 awnless.

Scales 20-24, not awned.

Scales 5-10, with an awn from the notched apex.

Pappus of capillary bristles, never plumose.

364. Ptiloria, 246.

365. Ptilocalais, 246.

366. Nothocalais, 247.

367. UROPAPPUS, 247.

Heads solitary; leaves all basal.

Akenes muricate or spinulose at the apex.

Akenes smooth at the apex.

368. TARAXACUM, 247.

369. Agoseris, 248.

Heads several; leaves not all basal.

Akenes flattened.

Akenes beaked, or if short-beaked flowers not yellow.

370. LACTUCA, 249.

Akenes beakless; flowers yellow. 371. SoNCHUS, 249.

Akenes terete, cylindric or prismatic.

Pappus copious, white and soft.

Pappus a single row of rough tawny bristles.

Corollas tubular in all the flowers of the head or

372. CREPIS, 250.

373. Hieracium, 250. strap-shaped in only the marginal ones; plants without milky juice.

Ray flowers none; corollas all tubular.

Flowers of the heads not all alike, some heads having imperfect flowers.

Perfect and imperfect flowers in the same head.

Marginal flowers neutral and sterile, often larger than the central ones, resembling ray flowers.

Marginal flowers perfect or pis374. Centaurea, 251. tillate and fertile, not resembling ray flowers. 
Pappus of capillary bristles.

Involucral bracts in one row.

Involucral bracts in several rows.

375. Petasites, 252.

376. Gnaphalium, 252.

Pappus a short crown or none.

Heads large, $1.5-2 \mathrm{~cm}$. in diameter.

Heads small, $5 \mathrm{~mm}$. or less in diameter.

Lower leaves opposite. 377. IvA, 253.

Lower leaves alternate.

Leaves entire or nearly so, ovate.

Leaves incised, or if entire, lanceolate or linear.

Staminate and pistillate flowers in

378. Adenocaulon, 253.

374. Centaurea, 251.

different heads.

Pappus capillary; fertile invo-

lucre not bur-like.

Leaves prickly; heads large.

Leaves not prickly; heads small.

Pappus of staminate flowers either clubshaped or barbed at the apex.

379. ARtemisia, 253.

Pappus of all the flowers alike and neither clubshaped nor barbed.

387. Cirsium, 259.

none; fertile involucre

380. Antennaria, 254.

381. Anaphalis, 256.

Pappus none;
bur-like.

Bracts of staminate heads separate; bur large, with many scales.

Bracts of staminate heads

382. Xanthium, 256. united; bur small, with 1-4 scales.

Spines in 1 row; pistillate flowers 1 in a head.

383. Ambrosia, 257.

Spines in several rows; pistillate flowers $1-4$ in each head.

Flowers of the heads all perfect and alike.

384. GaertNeriá, 258.

Pappus of separate capillary bristles.

Flowers whitish.

385. Coleosanthus, 258.

Flowers yellow or brownish.

Involucral bracts in 3-4 rows.

Heads $2-3 \mathrm{~mm}$. in diameter.

Heads $20-30 \mathrm{~mm}$. in diameter.

386. Chrysothamnus, 259.

407. HOOREBEKIA, 273.

Involucral bracts in 1 row or nearly so.

Involucre campanulate. 408. SENECIO, 274.

Involucre hemispheric to rotate. 
Pappus not of separate capillary bristles.

Pappus of numerous bristles united into a ring at the base. 387. Cirsium, 259.

Pappus not of bristles united into a ring.

Pappus of rigid backwardlybarbed awns.

Pappus not of backwardly-

411. BIDENS, 276. barbed awns.

Pappus of hyaline or chaffy scales.

Pappus none or a minute crown.

Involucre scarious. $\quad 389$. MATRICARIA, 261. Involucre not scarious.

Heads solitary. 390. RUDBEckIA, 261. Heads in clusters.

Disk flowers 1-5. 395. MADIA, 263.

Disk flowers numerous.

Ray flowers present, at least some of the 391. Psilocarphus, 262.

marginal flowers having strap-shaped corollas.

Pappusinone.

Involucre scarious.

Receptacle naked.

Receptacle chaffy.

388. Chaenactis, 261.

Involucre narrow; rays short. 393. ACHILLEA, 262.

Involucre broad; rays conspicuous.

Involucre not scarious.

394. ANthemis, 263.

Akenes all laterally compressed. 395. MADIA, 263.

Akenes or at least part of them turgid or obcompressed.

Involucral bracts not at all enclosing the ray akenes.

Involucral bracts at least partly enclosing the ray akenes.

Ray akenes turgid, each partly enclosed by the involucral bract.

Ray akenes usually obcompressed, each wholly enclosed by the base of the involucral bract.

Pappus present, at least in the disk 396. Balsamorhiza, 264.

397. Hemizonia, 264.

398. LAGophYLLA, 265.

flowers.

Pappus of capillary bristles.

Ray flowers not yellow.

Low shrub.

Herbs, woody only at the base.

Bracts of the involucre in many series, their tips spreading.

Bracts of the involucre in 1-5 series, their tips

399. ERICAMERIA, 265. erect.

400. Machaeranthera, 265. 
Bracts in 1-2 series; rays usually narrow and numerous.

Bracts in 2-5 series; rays broader, less numerous.

401. ERIGERon, 266.

Ray flowers yellow.

Pappus double, the outer row very short.

Pappus in one row.

Heads in panicles.

Panicle thyrsoid; receptacle alveolate.

Panicle flat-topped; receptacle fimbrillate.

402. ASTER, 268.

403. Chrysopsis, 271.

404. Solidago, 272.

405. Euthamia, 272.

Heads solitary or in corymbs.

Leaves all or mostly opposite.

406. ARNICA, 272.

Leaves alternate.

Heads large, 1.5

cm. or more broad.

Heads $1 \mathrm{~cm}$. or less broad.

Involucre campanulate.

Involucre hemi-

408. Senecio, 274.

407. HOOREBEKIA, 273. spheric or broader.

Bracts of involucre 810, broad. 409. Crocidium, 275.

Bracts of involucre numerous, narrow.

401. Erigeron, 266.

Pappus not of capillary bristles.

Receptacle chaffy.

Pappus of scales or awns.

Scales of the pappus 12-20, thin, fringed.

Scales of the pappus awn-

\author{
410. Ptilonella, 276.
}

like, not chaffy.

Awns 2 or 4 , retrorsely barbed.

Awns 2, subulate.

Pappus crown-like or of short

411. BIDENS, 276.

412. COREOPSIS, 276.

chaffy teeth or awns.

Rays pistillate and fertile. 413. Wyethia, 277.

Rays neutral.

Akenes flat and thin. 414. Helianthella, 277.

Akenes prismatic. 415. Helianthus, 277.

Receptacle not chaffy,

Involucral bracts in several rows.

416. Grindelia, 278.

Involucral bracts in 1 row. 
Akenes linear, more or less 4-angled.

Involucral bracts united.

Involucral bracts separate.

Akenes obpyramidal.

Receptacle bristly.

Receptacle naked.

417. ERIOPHYLLUM, 278.

418. Rigiopappus, 279.

419. Gaillardia, 279.

420. Helenium, 279.

\section{TRAGOPOGON.}

Stout leafy-stemmed and usually branching biennials or perennials, with milky juice; leaves entire, grass-like, clasping; flowers yellow or purple, in large solitary heads; involucre simple, of several equal bracts; pappus of numerous long-plumose bristles; corollas all ligulate; akenes narrowly fusiform, 5-10ribbed, long-beaked.

Tragopogon porrifolius L. Salsify. Oyster Plant. Biennial, glabrous throughout, the stout stems about $1 \mathrm{~m}$. high; leaves lanceolate, attenuate from the broader somewhat clasping base, $10-15 \mathrm{~cm}$. long; peduncles long and stout, swollen under the head; involucral bracts lanceolate, acuminate, 4-5 cm. long, exceeding the violet rays; outer akenes roughened, the inner smooth, $1 \mathrm{~cm}$. long, attenuate into a beak of equal length; pappus brownish, as long as the beak, plumose nearly to the tip. Escaped from gardens and spreading. say.

\section{PTILORIA.}

Leafy-stemmed and branching herbs, with milky juice and small heads; flowers pink or white; receptacle without chaff or bristles; pappus of plumose or partly plumose bristles or rarely chaffy awns or narrow scales; corollas all ligulate; akenes short, truncate at both ends, about 5-ribbed or angled.

Pappus bristles fuscous, short-plumose; annual.

Pappus bristles white, long-plumose; perennial.

$P$. paniculata.

$P$. tenuifolia.

Ptiloria paniculata (Nutt.) Greene. Annual, erect, divaricately branched, 40-80 cm. high; leaves linear, sessile, entire or the lower ones pinnatifid, 2-6 $\mathrm{cm}$. long, or much reduced on the flowering branches; heads 3-8-flowered, numerous, in loose panicles, short-pedicelled; involucre 8-9 $\mathrm{mm}$. long, the outer scales very short; receptacle naked; akenes roughened, $4-5 \mathrm{~mm}$. long; pappus grayish-brown, of 15-25 bristles, plumose nearly to the broadened base, a little longer than the akene. Bluffs of Snake River.

Ptiloria tenuifolia (Torr.) Raf. Stems herbaceous, slender, ascending, much branched, $20-40 \mathrm{~cm}$. high, from a stout woody root; leaves narrowly linear, mostly entire; heads mostly terminating the slender branches; involucre 8-10 mm. high; pappus bright white, very plumose; akenes much as in $P$. paniculata. In dry ground, infrequent.

\section{PTILOCALAIS.}

Puberulent or glabrous perennials, leafy at the base with usually laciniate leaves and long-peduncled heads, nodding in the 
bud; involucre campanulate; bracts herbaceous, in several series; receptacle flat or convex; akenes linear, 8-10-ribbed or striate; pappus of white soft bristles.

Ptilocalais nutans (Geyer) Greene. Perennial, from one or more fusiform tubers, simple or branched, puberulent or glabrous, $10-40 \mathrm{~cm}$. high; leaves $10-20 \mathrm{~cm}$. long, lanceolate or linear-lanceolate, rarely oval, sometimes entire, usually laciniate-pinnatifid into numerous linear lobes; peduncles stout and elongated; heads 8-20-flowered; involucre oblong or turbinate-campanulate, $2 \mathrm{~cm}$. long, the larger 8-10 bracts lanceolate, attenuate-acuminate; pappus of 15-20 soft white plumose bristles, broadened at base, as long as the columnar akenes. Common on hillsides.

366. NOTHOCALAIS.

Perennials with linear-attenuate wavy radical leaves with white-tomentulose margins; heads solitary on scape-like peduncles; involucre campanulate; bracts in 2 rows, narrowly lanceolate, nearly equal; receptacle flat; akenes fusiform, contracted or beaked at the summit, 10-ribbed; pappus white and soft, of scabrous-margined unequal scales.

Nothocalais troximoides (Gray) Greene. Nearly acaulescent from a stout vertical root; leaves tufted, linear-lanceolate, long-attenuate, thickish, pale or somewhat glaucous, glabrous or nearly so, 10-15 cm. long; scapes 15-30 $\mathrm{cm}$. high; involucre $2 \mathrm{~cm}$. high, the bracts lanceolate, subequal, glabrous; akenes fusiform, not beaked, 8-10 $\mathrm{mm}$. long; pappus bright white, longer than the akene. Locally abundant, especially in adobe soils.

\section{UROPAPPUS.}

Stemless or short-stemmed herbs, with milky juice; leaves mostly radical, often pinnatifid; flowers yellow, the heads terminal, on scapes or long peduncles, mostly nodding before flowering; receptacles without chaff or bristles; pappus chaffy or plumose; corollas in all the flowers of the head ligulate; akenes 8-12 ribbed.

Uropappus linearifolia (DC.) Nutt. Annual, branched at the base, 15-40 $\mathrm{cm}$. high; leaves lanceolate, $10-15 \mathrm{~cm}$. long, mostly pinnatifid into linear lobes, loosely pubescent when young, becoming glabrous; peduncles stout, glabrous, striate-grooved; involucre cylindric, $2.5-3 \mathrm{~cm}$. high, glabrous, the bracts of two lengths, lanceolate, acuminate; akenes fusiform, attenuate upwards, $10-12 \mathrm{~mm}$. long; pappus silvery, as long as the akenes, consisting of five linear scales, abruptly terminating in shorter awns. In loose rocks, banks of Snake River.

\section{TARAXACUM.}

Acaulescent biennials or perennials, with milky juice; leaves radical, pinnatifid; heads large, on scapes; flowers yellow; receptacle flat, naked; involucre of 2 rows of bracts; pappus of copious and white-capillary bristles which are not plumose; corollas all ligulate; akenes oblong or fusiform, angled, about 10 -ribbed, attenuate at base, with a long filiform beak at the apex. 
Taraxacum taraxacum (L.) Karst. Dandelion. Glabrous or loosely pubescent when young; leaves oblong or oblanceolate, variously pinnatifid, the lobes usually toothed and turned backward, 10-20 cm. long; peduncles 10-30 cm. high; involucre cylindric, the inner bracts either linear or linearlanceolate, the outer similar but shorter and reflexed; heads many-flowered; rays yellow; akenes brownish, spinulose above, the pyramidal apex abruptly narrowed into a slender beak, twice as long as the body; pappus white, copious. Abundantly introduced.

369. AGOSERIS.

Acaulescent annuals or perennials, with milky juice; leaves radical, clustered; heads solitary, on scapes; flowers yellow, rarely orange or purplish; bracts of the involucre in a few rows; receptacle flat, not chaffy; pappus of copious white capillary bristles, which are not plumose; corollas all ligulate; akenes oblong or linear, terete, 10-ribbed, the apex contracted into a neck or prolonged into a beak.

Leaves glaucous; beak of the akene short.

Leaves not glaucous; beak much longer than the body of the

A. glauca. akene.

Annuals; heads small.

Perennials; heads large.

A. heterophylla.

A. grandiflora.

Agoseris glauca (Nutt.) Greene. Perennial, leaves lanceolate or linear, entire or dentate or variously pinnatifid, acuminate or attenuate at apex, pale or glaucous, glabrous or loosely pubescent, $10-25 \mathrm{~cm}$. long; peduncles stout, erect, usually glabrous or glabrate, except at the base of the involucre, 30-60 $\mathrm{cm}$. high; involucre hemispherical, $20-35 \mathrm{~mm}$. high, glabrous or nearly so; acuminate, the outer shorter; corollas pale yellow; akene pubescent, 10-ribbed, 10-14 mm. long, attenuate into a stout nerved beak shorter than the body; pappus white, copious, the slender bristles scabrous, longer than the akene. Low ground, common and variable. Pyril - M-4

Agoseris glauca scorzoneraefolia (Schrad.) Piper. Involucre pubescent; otherwise as in the species. In dry ground, not rare.

Agoseris heterophylla (Nutt.) Greene. Annual; leaves linear, lanceolate or oblanceolate, entire or variously toothed or pinnatifid, 5-12 cm. long, loosely pubescent; peduncles erect, pubescent or glabrate, $10-30 \mathrm{~cm}$. high; involucre campanulate, 1-2 cm. high, the bracts in two series, the outer shorter and usually pubescent; akenes numerous, oblong or fusiform, the outer ones or sometimes all of them thicker, the ribs developed into wings which are sinuately folded, all attenuate into a narrow beak, twice or thrice as long as the body; pappus bright white, soft and copious.

Agoseris heterophylla normalis Piper. Akenes with straight ribs, those of the outermost often wing-like. Both the species and the subspecies are very common.

Agoseris grandiflora (Nutt.) Greene. Perennial, loosely pubescent or glabrate; leaves lanceolate or oblanceolate, attenuate-acuminate to obtuse, mostly pinnatifid into numerous lobes, $10-20 \mathrm{~cm}$. long; peduncles stout, $30-60$ $\mathrm{cm}$. high; involucre campanulate, tomentose at base, $3-4 \mathrm{~cm}$. high, the bracts in about 3 series; akenes fusiform, acutely 10-ribbed, $6 \mathrm{~mm}$. long, attenuate into a slender beak, $20 \mathrm{~mm}$. long; pappus bright white, soft and capillary, much shorter than the beak. Dry ground, common. 


\section{LACTUCA. Wild LetTuCE.}

Leafy-stemmed herbs, with milky juice; flowers yellow or blue or whitish, in paniculate few to many-flowered heads; bracts of the involucre in 2-few rows, the outer shorter; receptacle flat, naked; pappus of copious very short and fine capillary bristles which are not plumose; corollas all ligulate; akenes flat or flattish, narrowed at the summit or beaked.

Pappus brown; flowers whitish.

L. spicata.

Pappus white; flowers not whitish.

Flowers yellow; leaves spiny.

Flowers blue; leaves not spiny.

L. scariola.

L. pulchella.

Lactuca spicata (Lam.) Hitchc. Biennial, erect, 1-3 m. high, glabrous or nearly so, pale green, very leafy; leaves coarsely pinnatifid, the lobes irregularly toothed, the uppermost sessile and sometimes clasping; heads in a long narrow panicle; involucre $10 \mathrm{~mm}$. high; flowers bluish to whitish; akenes short-beaked. In moist ground, in open woods.

Lactuca scariola integrata Gren. \& Godr. Prickly Lettuce. Annual or biennial, erect, 1-2 m. high, glabrous and somewhat glaucous; leaves oblong or lanceolate, spiny on the margin and midrib, entire or irregularly toothed or cleft, sessile and usually auriculate-clasping at base, 5-20 cm. long, the uppermost, much reduced; heads in large loose panicles; involucre narrowly cylindric, glabrous, $10-12 \mathrm{~mm}$. long, the outer bracts much shorter than the inner ones; flowers yellow; akenes flattened, narrowed into a beak longer than the body, as long as the bright white pappus. A troublesome weed, introduced from Europe.

Lactuca pulchella (Pursh) DC. Blue-flowered Lettuce. Perennial, erect, leafy, $30-90 \mathrm{~cm}$. high, puberulent or glabrate; leaves lanceolate, tapering at each end, acute or cuspidate, entire or sinuately toothed or lobed, 5-15 cm. long; lower leaves petioled; heads loosely panicled; involucre cylindric, glabrous, 12-14 $\mathrm{mm}$. long, the outer bracts successively shorter, all lanceolate, acute; flowers blue or violet; akenes flat, not margined, $4 \mathrm{~mm}$. long, very short beaked; pappus copious, white. Locally abundant. A very troublesome weed in some sections.

\section{SONCHUS. SOW THISTLE.}

Leafy-stemmed mostly glabrous generally coarse herbs, with milky juice; flowers yellow, in corymbose or paniculate heads; bracts of the involucre imbricated, the outer shorter; receptacle flat, naked; pappus of copious very fine and short capillary bristles, which are not plumose; corollas all ligulate; akenes flat or flattish, truncate, not beaked.

Sonchus asper (L.) Hill. Annual, erect, 30-90 cm. high, somewhat glaucous, glabrous below, glandular, above; lower leaves ovate or broadly spatulate, obtuse or acute, rarely lobed, spinulose-dentate, the petioles margined; upper leaves oblong or oval, sessile and clasping at base, acuminate; heads cymosely arranged; involucre cylindric-campanulate, about $1 \mathrm{~cm}$. broad, glabrous; flowers yellow; akenes flat, margined, 3 -nerved on each side. Sparingly introduced. 


\section{CREPIS.}

Annual, biennial or perennial plants with milky juice; heads several-many-flowered; flowers yellow; involucre usually double; receptacle flat, naked, sometimes alveolate; pappus simple, of copious and white capillary bristles which are not plumose; corollas all ligulate; akenes oblong, linear or fusiform, nearly terete or obtusely angled, 10-20-ribbed, generally contracted at base and more tapering at the apex, sometimes even beaked.

Involucral bracts bearing soft bristles.

Involucral bracts not bearing soft bristles.

Heads 5-10-flowered; stems tall, slender.

Heads 25-30-flowered; stems stout, low.

C. barbigera.

C. gracilis.

C. occidentalis.

Crepis barbigera Leiberg. Perennial, erect, 40-50 cm. high, minutely viscid-pubescent; basal leaves oblong-lanceolate, $15-30 \mathrm{~cm}$. long, attenuateacute, pinnately toothed, lobed or parted; cauline similar, smaller; heads in a loose cyme; involucre 10-15 mm. long; bracts linear-oblong, acutish, strongly carinate and armed with one or two rows of stout soft usually pale bristles; akenes $8-10 \mathrm{~mm}$. long, olive green, 10 or 12 ribbed; pappus copious, shorter than the akene. In rocky or gravelly soil. C. atrabarba Heller is a form of this species or perhaps distinct, from Lake Waha. It has smaller heads with fewer flowers and short black bristles on the involucre. Its true relationship may be with $C$. gracilis but only immature plants are known.

Crepis gracilis (D. C. Eaton) Rydb. Perennial, erect, thinly canescent or glabrate, $30-60 \mathrm{~cm}$. high; leaves lanceolate, attenuate-acuminate, with few or numerous slender teeth or lobes, or divided into narrow segments, rarely entire, 10-20 cm. long, the basal ones petioled; heads 5-10-flowered, loosely or somewhat compactly corymbose; involucre oblong-cylindric, ashy-puberulent, the principal bracts 5-9 in number, $10-12 \mathrm{~mm}$. long, with a few small ones at base; akenes acutely 10-ribbed when mature, oblong-fusiform, attenuate toward the apex, a little longer than the bright white soft pappus. Rather common, very variable.

Crepis occidentalis Nutt. Perennial, erect, thinly white-tomentose throughout, 8-30 cm. high; stems usually with few erect branches; leaves broadly lanceolate, acute or acuminate, $5-10 \mathrm{~cm}$. long, pinnately toothed or cleft into narrow lobes, short-petioled or sessile; heads on stout peduncles; involucre oblong-cylindric, 12-18 mm. long, tomentose and with a few large black glandular hairs, the principal bracts lanceolate, acuminate, the smaller basal bracts relatively broader; flowers 25-30; akenes brownish, fusiform, 8-10 mm. long, 10-18-ribbed, longer than the bright white pappus. In loose rocks, not common.

\section{HIERACIUM. HAWKWEED.}

Hispid and hirsute often glandular perennials with milky juice; leaves merely toothed or entire; heads small to medium, paniculate or rarely solitary; flowers yellow or sometimes white; bracts of involucre in two rows; receptacle flat, naked; pappus of a single row of rough tawny bristles which are not plumose; corollas all ligulate; akenes oblong or columnar, terete or 4- or 5angled, mostly 10 -ribbed or striate, the apex truncate. 
Stems many-leaved; involucre imbricated.

H. canadense.

Stems few-leaved; involucre a series of equal bracts and a few short outer ones.

Flowers white; involucre nearly glabrous.

Flowers yellow; involucre hairy or glandular.

Heads small, black-hairy.

Heads larger; hairs not black.

H. albiflorum.

H. gracile.

H. scouleri.

Hieracium canadense Michx. Somewhat scabrous throughout; stems stout, $30-120 \mathrm{~cm}$. high; leaves numerous, lanceolate, entire or incisely serrate, sessile and somewhat clasping at base, gradually smaller upwards, 1-10 cm. long, none clustered at base; heads corymbed, rarely solitary, on stout peduncles; involucre hemispheric, puberulent or glabrous, sometimes glandular, 1-2 cm. broad, the bracts in 2-3 series, the uppermost loose; akenes columnar; pappus brownish. Low giound, rare.

Hieracium canadense columbianum (Rydb.) Piper. (H. columbianum Rydb.) Lower part of stem pilose, otherwise as in the species. Spokane County.

Hieracium albiflorum Hook. Stems slender, erect, $50-80 \mathrm{~cm}$. high, villous below; leaves oblong or oblong-spatulate, thin, entire or faintly toothed, the lower tapering into broad petioles, the upper mostly sessile, all beset with sparse villous white hairs, especially the lowest; heads 15-30-flowered; involucre narrow, glabrous or with a few hairs, the bracts linear-lanceolate, pale; akenes strongly striate. In dry open woods.

Hieracium gracile Hook. Tufted; stems usually several, 15-30 cm. high; leaves mostly basal, oblong-spatulate, entire or nearly so, broadly petiolate, 3-8 cm. long, glabrous or merely puberulent; heads several, racemose or corymbose; involucre $8 \mathrm{~mm}$. high, blackish with both hirsute and glandular hairs; akenes cylindric; pappus sordid or fuscous. An alpine species occurring on the higher peaks of the Blue Mountains.

Hieracium scouleri Hook. Erect, $30-60 \mathrm{~cm}$. high, densely beset throughout with long soft white hairs with swollen bases; basal leaves lanceolate or oblanceolate, entire, acute or obtuse, $10-20 \mathrm{~cm}$. long, tapering into margined petioles; cauline similar, sessile, 5-12 cm. long; inflorescence corymbose or paniculate, glandular; involucre $1 \mathrm{~cm}$. high, very glandular and long-villous; flowers yellow; akenes columnar; pappus fuscous. Common on hillsides. Very variable in the amount and length of the pubescence.

\section{CENTAUREA.}

Herbs; heads many-flowered; flowers all with tubular and deeply 5-cleft corollas, some of the marginal ones commonly sterile, often much larger and conspicuous, the others perfect and fertile; involucre globular, the scales tipped or margined with spines or scarious appendages; receptacle very bristly; pappus of numerous rigid or sometimes chaffy naked bristles; akenes mostly compressed, attached by one margin just above the base.

Annual, white woolly; leaves linear or lanceolate, entire. Biennial, green; leaves oblong to lanceolate, some dentate.

C. cyanus.

C. consimilis.

Centaurea cyanus L. Bachelor's Button. Stems erect, slender, usually branched, 30-90 cm. high; heads solitary on slender branches; involucre 
ovoid; bracts in about four series, pale, the middle ones margined with a silvery scarious-toothed border; ray flowers large, white, blue, pink or violet. A common weed in fields and waysides. \%ay

Centaurea consimilis Boreau. Perennial, 30-60 cm. high, rough-pubescent; lower leaves oblong or spatulate, some dentate, petioled; uppper lanceolate, sessile, mostly entire, acute; heads $2 \mathrm{~cm}$. broad; bracts dark-brown, pectinately fringed, the uppermost scarious-margined, erose; flowers red, all perfect, the marginal ones not enlarged; akenes 4-sided; pappus none. Sparingly introduced.

\section{PETASites. Sweet Coltsfoot.}

Perennial herbs with creeping rootstocks; leaves large, radical, the cauline reduced to bracts; heads numerous in a raceme or corymb on the end of a scape-like stem, with some imperfect flowers; flowers whitish or purplish; involucral bracts in one row; akenes narrow, 5-10-ribbed, with soft white pappus.

Petasites sagittata Pursh ( $P$. dentata Blankinship). Leaves triangularovate to hastate-reniform, coarsely sinuate-dentate, green above, densely white-tomentose beneath, 10-30 cm. long; flowering stems covered with large scale-like leaves; heads in a dense convex cyme; flowers purplish, violet-scented. In swamps, Spokane County and adjacent Idaho.

\section{GNAPHALIUM. CUDWEED.}

Woolly herbs; leaves alternate, entire; heads small, discoid; pistillate flowers very numerous, in more than one row; perfect flowers fewer in the center; staminate flowers none; all flowers white or yellow; pappus-bristles slender, not thickened above; akenes oblong or ovate.

Plants low; flowers in dense leafy clusters; involucres very woolly.

Plants tall; flowers in looser leafless clusters; involucres woolly only at base.

Glandular; leaves green above.

Not glandular; leaves white-woolly.

Involucre white; cymes loose.

Involucre yellowish; cymes dense.

G. palustre.

G. decurrens.

G. microcephalum.

G. chilense.

Gnaphalium palustre Nutt. Annual, much branched at base, 5-12 $\mathrm{cm}$. high, very woolly throughout; leaves lanceolate, oblong or spatulate, $1-2 \mathrm{~cm}$. long; heads $2-3 \mathrm{~mm}$. high, sessile, in small terminal or axillary clusters, which are very woolly and subtended by leaves; involucre of few scales, these linear, acute or obtuse, brownish with white tips; akenes glabrous, the bristles falling separately. Common in dried-up pond bottoms.

Gnaphalium decurrens californicum (DC.) Gray. Perennial, erect, 30-60 $\mathrm{cm}$. high, glandular beneath a thin early-deciduous tomentum; basal leaves spatulate; cauline spatulate-lanceolate or linear-lanceolate, acute, all conspicuously decurrent at the base, $2-5 \mathrm{~cm}$. long; heads in dense clusters, these usually corymbed; involucre turbinate-campanulate, yellowish-white; bracts thin, scarious, ovate-lanceolate, mostly acute; akenes smooth. Open woods, Thatuna Hills. 
Gnaphalium microcephalum Nutt. Pubescence woolly, dense, white, close; stems several, slender, erect, $30-60 \mathrm{~cm}$. high; leaves linear or the lower lanceolate, decurrent at base; heads in clusters of several, these paniculate; involucres turbinate to campanulate, woolly only at base, $3-4 \mathrm{~mm}$. high; bracts bright white, scarious, obtuse. In gravelly or sandy soil.

Gnaphalium chilense Spreng. Erect, very leafy, 30-60 cm. high, simple or branched below; persistently tomentose, not glandular; leaves linearlanceolate or somewhat spatulate, acute, $5-8 \mathrm{~cm}$. long, scarcely decurrent at base; heads $4-5 \mathrm{~mm}$. high, in one or few dense clusters; involucre hemispheric, the bracts greenish-white, oblong, obtuse; akenes glandular. Prairies and open woods.

\section{IVA.}

Herbs; leaves simple, at least some of the lower opposite; heads small, nodding, in the axils of the leaves or in terminal spikes or panicles; flowers monoecious, in the same head; a few marginal ones pistillate, the others staminate and more numerous; bracts of the involucre few, rounded, commonly united into a cup; receptacle chaffy, with scales subtending the sterile flowers; akenes obovate, thick.

Iva zanthiifolia Nutt. Annual, tall and stout, 1-2 m. high, pubescent or puberulent; leaves opposite or the uppermost alternate, broadly ovate, acuminate, incisely serrate, scabrous above, 3-ribbed, 6-12 cm. long; petiole stout, with a few scattered stout hairs; panicles terminal and in the axils of the upper leaves, bractless, large and dense; heads sessile or nearly so, about $2 \mathrm{~mm}$. broad, hemispherical; involucral bracts in two series of $5 \mathrm{each}$, the outer broadly ovate, the inner obovate or oblong and truncate; akenes usually 5 . Introduced along railways, and becoming weedy.

Iva axillaris Pursh. See page 280.

\section{ADENOCAULON.}

Slender perennial herbs, with alternate petioled leaves, green above, white-woolly beneath; heads few, small, 5-10-flowered, glandular, in a loose panicle; involucral bracts in one row; receptacle flat, naked; flowers all tubular, the marginal pistillate, fertile, the central perfect but sterile; akenes elongated at maturity, club-shaped; pappus none.

Adenocaulon bicolor Hook. Stem $30-90 \mathrm{~cm}$. high; leaves triangular, somewhat cordate, with angular toothed margins; petioles margined. In dense woods in the mountains.

\section{ARTEMISIA. SAgebrush. WORMWOod.}

Herbs or undershrubs, bitter and odorous; leaves alternate, usually dissected; heads numerous, small, in racemes or panicles, several to many-flowered, discoid; flowers yellow or yellowish, all tubular, the outermost series pistillate or all alike, the more numerous perfect flowers either fertile or sterile; involucral-scales dry, imbricated in a few rows, appressed; receptacle flattish to hemispherical, naked, sometimes hairy; pappus none; corollas of 
pistillate flowers slender and small, 2- or 3-toothed, those of the perfect flowers enlarged above, 5-toothed; akenes obovoid or oblong, almost always glabrous.

Green and glabrous.

Perennial; leaves linear, mostly entire.

Biennial; leaves 1-2-pinnately parted.

Canescent or tomentose.

Leaves narrowly 3-5-parted into linear segments.

Leaves and segments broader.

Receptacle pilose; involucre canescent.

Receptacle not pilose; involucre not canescent.

Involucre white-tomentose; herbage not glandular.

Involucre glabrous or nearly so; herbage atomiferous glandular.

A. dracunculoides.

A. biennis.

A. rigida.

A. absinthium.

A. gnaphalodes.

A. atomifera.

Artemisia dracunculoides Pursh. Perennial, herbaceous, very odorous, usually tufted, the slender stems $100-150 \mathrm{~cm}$. high, glabrous throughout; leaves linear, entire or 3-cleft, $2-10 \mathrm{~cm}$. long, numerous; heads nodding, numerous, in large and leafy panicles; involucre campanulate, glabrous, $2 \mathrm{~mm}$. high; disk-flowers sterile; receptacle naked; akenes glabrous. Common in the valleys.

Artemisia biennis Willd. Biennial, glabrous, the stems simple, $30-50$ $\mathrm{cm}$. high, leafy to the top; leaves numerous, 5-8 cm. long, all 1-2-pinnately parted into linear acute entire or toothed segments; heads small, in short spikes in the axils of the uppermost leaves crowded in a slender leafy panicle; involucre campanulate, $3 \mathrm{~mm}$. broad, the bracts green scarious-margined; akenes oblong; pappus none, receptacle naked. Colton, Piper: Waitsburg, Horner.

Artemisia rigida (Nutt.) Gray. Scabland Sagebrush. Perennial, woody at base, the branches erect, strict, $15-30 \mathrm{~cm}$. high, leafy to the top; leaves rigid, silvery-canescent, mostly cleft or parted into 3-5 linear segments, rarely simple, 1-3 cm. long; inflorescence a leafy spike, the heads solitary in the axils; involucre oblong-campanulate, $3 \mathrm{~mm}$. long, 5-12-flowered; flowers all alike, perfect. In thin rocky soil.

Artemisia absinthium L. Wormwood. Half shrubby, much branched, 50-100 cm. high, silvery-canescent throughout; leaves 2-3 times pinnately parted, the segments lanceolate, acute; heads hemispheric, $3-5 \mathrm{~cm}$. broad, in rather dense panicles; bracts mostly oblong, obtuse, scarious-margined. Introduced and spreading.

Artemisia gnaphalodes Nutt. Perennial, herbaceous, $30-90 \mathrm{~cm}$. high, densely white-tomentose throughout; leaves $2-6 \mathrm{~cm}$. long, lanceolate and entire or 3-5-toothed or cleft into linear or lanceolate lobes, persistently tomentose beneath, of ten glabrate above; heads in large usually dense panicles; involucre oblong-campanulate, 3-4 mm. long, persistently white-woolly; receptacle naked; disk-flowers fertile. Common and variable.

Artemisia atomifera Piper. Much like A. gnaphalodes, the leaves usually more deeply lobed, early becoming glabrous above; involucre becoming glabrous or nearly so, at least when mature; herbage minutely atomiferous glandular throughout. Common on the banks of Snake River.

380. ANTENNARIA. EverLasting.

Low white-woolly cespitose perennials; leaves alternate, entire; heads small, solitary or corymbose, completely dioecious; re- 
ceptacle naked; staminate flowers with the pappus-bristles thickened or barbellate at the apex; pistillate with the slender pappusbristles united at base into a ring.

Pappus bristles of staminate flowers not dilated at the tips.

Heads several, brown.

Heads solitary, whitish.

Pappus bristles of staminate flowers dilated at tips.

Plants not stoloniferous.

Pistillate heads oblong, the bracts pinkish.

Pistillate heads not oblong, the bracts white.

Pubescence floccose-woolly.

Pubescence close, silky.

Plants stoloniferous.

Heads loosely racemose; inflorescence glandular.

Heads corymbose; inflorescence not glandular.

Leaves oblanceolate, $3-5 \mathrm{~cm}$. long, green above.

Leaves smaller, narrower, grayish above.

Heads 6-8 mm. high; bracts white or pinkish.

Heads 4-7 mm. high; bracts rosy, rarely white.

A. stenophylla.

A. dimorpha.

A. geyeri.

A. pulcherrima.

A. luzuloides.

A. racemosa.

A. howellii.

A. parvifolia.

A. rosea.

Antennaria stenophylla Gray. Stems slender, erect, leafy, 10-15 cm. high, without stoloniferous branches; leaves narrowly linear, 3-6 cm. long, attenuate at each end, covered with a fine appressed silvery wool; heads few, in a dense cluster; involucre turbinate, 3-5 $\mathrm{mm}$. high; bracts obtuse, dark brown or in the staminate plant the inner ones white-tipped; akenes scabrous. In thin rocky or "scab" lands, locally abundant.

Antennaria dimorpha (Nutt.) T. \& G. Densely tufted from stout rootstocks, 2-5 cm. high, silvery canescent throughout; leaves spatulate or oblanceolate, mostly acute, $1-2 \mathrm{~cm}$. long; heads solitary, on very short few leaved stems; staminate heads subglobose, $8 \mathrm{~mm}$. high, the involucral scales ovatelanceolate, obtuse; pappus not thickened at the tip, minutely toothed; pistillate head subcylindric, $8-12 \mathrm{~mm}$. high, with broadly lanceolate, mostly acute involucral scales, glabrous except at base; pappus of long fine smooth bristles; akene oblong-linear, pubescent with short hairs, which are 2-hooked at the summit. Stony soil, of ten occupying considerable aieas. March - Fpril

Antennaria geyeri Gray. Persistently white-tomentose throughout; stems stout, from a branched woody base, $8-20 \mathrm{~cm}$. high; leaves spatulate to oblanceolate, acute, 1-2 cm. long; heads densely clustered; involucres very woolly at base, cylindric in the pistillate heads, $8 \mathrm{~mm}$. long, in the staminate shorter; bracts pink, rarely white, acute in the pistillate, obtuse in the staminate heads; akenes glandular. Spokane County.

Antennaria pulcherrima (Hook.) Greene. Loosely white-woolly throughout; stems erect, $30-50 \mathrm{~cm}$. high, without stolons; lower leaves oblanceolate, acute, 10-15 cm. long; cauline linear-lanceolate, smaller; heads 6-8 mm. high, cymose, in a rather dense cluster; involucres very woolly at base; bracts brownish with white scarious tips, obtuse or in the pistillate heads-often acutish; pappus-bristles of the staminate flowers abruptly dilated at the tips. In moist ground.

Antennaria luzuloides T. \& G. Tufted, 10-40 cm. high, silvery throughout and closely woolly; leaves numerous, lincar or linear-lanceolate, acute, the lowest petioled, the upper sessile, 2-10 cm. long; heads numerous, in corymbs, yellowish-white; staminate subglobose, $4 \mathrm{~mm}$. high, the inner involucral bracts obtuse, with ivory-white papery tips; pappus with much dilated 
obtuse tips; pistillate heads oblong, 4-5 mm. long, the pale involucral bracts thin, scarious at the tips; akenes glandular. Stony hillsides, common.

Antennaria racemosa Hook. Perennial by stout leafy stolons; stems slender, erect, $15-40 \mathrm{~cm}$. high, glabrous or nearly so; basal leaves oval or ovate, obtuse, green and glabrous or glabrate above, white-woolly beneath, 1-3 cm. long, cuneate at base, petioled; cauline sessile, lanceolate, mostly acute, 1-3 $\mathrm{cm}$. long; inflorescence glandular, racemose or somewhat paniculate; staminate heads always racemose, subglobose, 4-6 $\mathrm{mm}$. high, slender-peduncled, the involucral scales brownish, obtuse; pappus with thickened tips; pistillate heads usually corymbose, oblong, $6-8 \mathrm{~mm}$. long, the involucral scales greenish, narrow-tipped; pappus simple. Open woods, in the mountains.

Antennaria howellii Greene. Stems slender, 15-30 cm. high, grayish woolly; stolons prostrate, leafy, 5-10 cm. long; basal leaves cuneate-oblanceolate, petioled, 1-nerved, acutish, $3-5 \mathrm{~cm}$. long, becoming green above, persistently white-tomentose beneath; heads in a close cyme; involucre campan ulate, $8 \mathrm{~mm}$. high; bracts linear-lanceolate, the tips white and scarious; akenes glandular. In dry open pine woods.

Antennaria parvifolia Nutt. (A. aprica Greene). Persistently grayishtomentose throughout; stems $10-15 \mathrm{~cm}$. high; stolons short, leafy; leaves oblanceolate to obovate, acute to obtuse, about $2 \mathrm{~cm}$. long; heads rather large, in compact clusters, the pistillate $6-8 \mathrm{~mm}$. high; involucral bracts numerous, well imbricated, white or pinkish, often brownish at base, acute to obtuse on the pistillate heads, more broadly obtuse and white on the staminate. Gravelly prairies about Spokane.

Antennaria rosea (D. C. Eaton) Greene. Densely white-tomentose throughout; stems slender, $20-30 \mathrm{~cm}$. high; stolons ascending; leaves narrowly oblanceolate, acute, $15-20 \mathrm{~mm}$. long; heads in rather close clusters; involucres 5-6 mm. high; pistillate bracts rose-colored, rarely white, obtuse; the staminate plant unknown. In dry sandy or gravelly soil.

\section{ANAPHALIS. Everlasting.}

White-woolly perennial herbs with erect leafy stems and entire leaves; heads numerous, small, discoid, dioecious but usually with a few perfect flowers in the center of the pistillate heads; pappus bristles of staminate flowers little if at all thickened at the apex, that of the fertile flowers not at all united at the base.

Anaphalis margaritacea occidentalis Greene. Stems erect, 20-60 cm. high; leaves broadly lanceolate, sessile; heads numerous, in a terminal corymb 4-15 cm. broad. In open coniferous woods.

\section{XANTHIUM. CocklebUR.}

Annual herbs; leaves alternate, petioled; heads monoecious, in axillary or terminal clusters or short interrupted spikes; the pistillate heads 2 -flowered and below the several-flowered staminate ones; involucre of the staminate heads of several distinct narrow scales; involucre of the pistillate heads bur-like, ovoid or oblong, closed, indurated, 2-celled, 2-flowered, armed all over with strongly hook-tipped bristles; pappus none; corolla none; akenes obovoid, thick. 
Leaves lanceolate, bright green above, white-tomentose beneath, the axils bearing spines.

Leaves ovate to orbicular; axils without spines.

Body of the burs $2.5-3 \mathrm{~cm}$. long; prickles about 100 ,

hispid, strongly hooked.

X. spinosum.

$X$. speciosum.

Body of the burs $1.5-2 \mathrm{~cm}$. long.

Prickles about 20 , about as long as the diameter of the body of the narrowly oblong bur.

Prickles 50-70.

Burs oblong or slightly ovate; prickles about 50 , each two thirds as long as the diameter of the bur.

Burs ovate; prickles about 70 , each one half as long as the diameter of the bur.

$X$. oligacanthum.

$X$. affine.

$X$. varians.

Xanthium spinosum L. Chinese Thistle. Much branched, the stems decumbent or ascending, pubescent, 30-60 cm. high; leaves ovate-lanceolate, acute or acuminate, entire or 3-lobed, cuneate at base, sessile or nearly so, white-tomentose beneath, green and shiny above, 5-12 cm. long; axils bearing stout 2- or 3-parted yellow spines; burs oblong-cylindric, solitary or 2 or 3 in the upper axils, $1-1.5 \mathrm{~cm}$. long, armed with slender rather weak prickles and beaked with 1 or 2 stouter ones. Sparingly introduced.

Xanthium speciosum Kearney. Cocklebur. Coarse and stout, 15-90 cm. high, scabrous throughout; leaves broadly ovate, coarsely toothed or somewhat angularly lobed, cuneate at base, $5-10 \mathrm{~cm}$. long, on stout, usually longer petioles; burs about $4 \mathrm{~cm}$. long, armed with numerous hooked spines, the two terminal ones stoutest, all of them glandular-hispid, except at their apexes, and about $1 \mathrm{~cm}$. long. Common along Snake River.

Xanthium oligacanthum Piper. Stem erect or spreading, 30-60 cm. high, sparsely hispid; leaves reniform-orbicular, obscurely lobed and crenate, harshly scabrous, hispid on both faces, the petioles as long as or longer than the blades; burs oblong, the body $1.5 \mathrm{~cm}$. long, 5-7 mm. thick, the stout beaks somewhat incurved; prickles 15-25, uncinate-tipped, about as long as the diameter of the bur; surface of the bur and base of prickles pubescent. Bolles, Piper; Waitsburg, Horner.

Xanthium affine Greene. Similar to $X$. oligacanthum in foliage and habit; beaks of the burs slender with long incurving tips; prickles numerous, all hooked at the tip, two thirds as long as the diameter of the bur, their bases as well as the spaces between covered with stout hairs. Common about Spokane.

Xanthium varians Greene. Very similar to $X$. affine; beaks of the burs shorter and stouter; prickles less numerous, half as long as the diameter of the bur, hirsute at base as is also the body of the bur. Waitsburg, Horner.

\section{AMBROSIA. RAGWEED.}

Annual or perennial herbs; leaves pinnately-lobed, at least the lower opposite; heads small, greenish, monoecious; pistillate heads 1-flowered, in terminal bractless racemes or spikes; involucralbracts of staminate heads united; pistillate flowers enclosed in an akene-like 1-celled involucre, usually armed with a single series of tubercles or prickles; pappus none; corollas of staminate flowers broad, 5-toothed; of the pistillate none; akenes ovoid or obovoid, thick. 
Leaves all opposite; receptacle not chaffy.

Leaves opposite and alternate; receptacle chaffy.

Fruiting involucre spiny; leaves thin.

Fruiting involucre tubercled; leaves thick.

A. trifida.

A. artemisiaefolia. A. psilostachya.

Ambrosia trifida L. Stems stout, 1-6 m. high, rough-hairy; leaves roughhairy, deeply 3-lobed, the lobes oval-lanceolate and serrate; petioles margined; fruit obovoid, tubercled. Sparingly introduced from the eastern states.

Ambrosia artemisiaefolia diversifolia Piper. Annual, with many slender branches, pubescent, 30-90 cm. high; upper leaves alternate, the lower opposite, ovate or lanceolate, the uppermost sessile, often entire and acute, the others variously pinnately lobed, mostly petioled; blades $1-3 \mathrm{~cm}$. long; staminate heads numerous, pedicelled, drooping, bractless, the involucre crenate; pistillate heads solitary or clustered, sessile in the leaf axils below the staminate racemes; fruit $3 \mathrm{~mm}$. long, short-beaked, armed with 4-6 teeth or spines. Native on the gravelly banks of Snake River at Almota.

Ambrosia psilostachya DC. Perennial, with numerous rootstocks, hirsutely and strigosely pubescent; stems stout, erect, $60-120 \mathrm{~cm}$. high; leaves thick, the lower petioled, the upper sessile, once or twice pinnately cleft; lobes lanceolate, acute, entire or toothed; staminate heads short-peduncled, in strict racemes; pistillate heads solitary in the axils; fruit obovoid or oblong, $3 \mathrm{~mm}$. long, short-pointed, rough-reticulated, unarmed or with a few short teeth. Introduced sparingly from the eastern states.

\section{GAERTNERIA.}

Herbs (in ours) with mostly alternate leaves; sterile and fertile heads separate or sometimes mixed in the inflorescence; fertile involucre 1-4-celled, with a single pistil in each cell, armed with spines in more than one row, bur-like.

Gaertneria acanthicarpa (Hook.) Britt. Annual, erect or spreading, $30-60 \mathrm{~cm}$. high, loosely branched, hispid-pubescent; leaves bipinnatifid, or the upper pinnatifid; racemes panicled; fertile involucre 1-flowered, armed with flat subulate spreading straw-colored spines. Rare on the gravelly banks of Snake River.

\section{COLEOSANTHUS.}

Herbs or undershrubs with opposite or alternate leaves; heads whitish; involucre campanulate, the scales imbricated, lanceolate or linear, the outer shorter, none herbaceous; receptacle flat, naked; pappus one row of separate capillary barbed or scabrous bristles.

Leaves cordate-triangular, coarsely toothed.

Leaves oblong or lanceolate, entire.

C. grandiflorus.

C. linifolius.

Coleosanthus grandiflorus (Nutt.) Kuntze. Stems herbaceous, branched, erect or ascending, $60-90 \mathrm{~cm}$. high; leaves ovate or triangular-cordate, coarsely toothed, acuminate, $5-10 \mathrm{~cm}$. long, puberulent, on slender petioles; heads paniculate, drooping, each about 40 -flowered; involucral bracts thin, the outer short and ovate, the inner oblong-linear; akenes minutely hispid, not glandular, Banks of Spokane River.

Coleosanthus linifolius (D. C. Eaton) Kuntze. Stems numerous, usually simple, erect, from a branched woody base, $15-30 \mathrm{~cm}$. high; leaves oblong or 
oblong-lanceolate, entire, sessile, firm, puberulent and viscidulous, $2-4 \mathrm{~cm}$. long; heads peduncled, erect, many-flowered; involucral bracts all acute, the outer oblong-lanceolate, short, the inner linear; akenes glandular. In gravelly or sandy soil, along streams.

\section{CHRYSOTHAMNUS. RABBIT BRUSH.}

Herbs or undershrubs; leaves narrow, alternate; heads mostly small, with 5-30 yellow flowers, in corymbs, cymes or panicles; flowers all perfect, with tubular corollas; rays none; involucre imbricated; receptacle flat; pappus simple, of copious unequal tawny capillary bristles; style-branches with appendages; akenes narrow, terete or angular, slightly if at all compressed.

Chrysothamnus nauseosus (Pall.) Britt. Shrub, $30-90 \mathrm{~cm}$. high, with numerous, erect, somewhat fascicled branches, these densely and permanently white-woolly; leaves numerous, narrowly-linear, entire, white-woolly, somewhat pungently pointed, 2-6 cm. long; heads numerous, in terminal dense corymbs; involucre about $8 \mathrm{~mm}$. high; the bracts acutish, sparsely tomentose or glabrate; corolla-tube villous, the lobes lanceolate; akenes linear; pappus soft. Very abundant in the sagebrush region, extending up the valleys and coulees and rarely on to the high prairies.

Chrysothamnus nauseosus graveolens (Nutt.) Piper. Woolly pubescence early deciduous or scanty from the first, the branches and leaves becoming green and glabrous or nearly so. Very abundant with the species.

\section{CIRSIUM. THISTLE.}

Biennial or perennial herbs; leaves alternate, sessile, mostly pinnatifid and prickly; heads usually large, terminal, manyflowered; flowers all tubular, perfect and all alike, rarely imperfectly dioecious; involucre ovoid or spherical; bracts imbricated, in many rows, the tips scarious or prickly; receptacle thickly clothed with soft bristles or hairs; pappus of numerous bristles united into a ring at the base, plumose, deciduous; akenes oblong, flattish, not ribbed.

Dioecious; heads $1-1.5 \mathrm{~cm}$. in diameter; perennial by spreading roots.

Hermaphrodite; heads larger; biennials.

Outer and inner bracts all with spiny tips.

Outer bracts spine-tipped; inner ones unarmed.

Involucre loose, the outer bracts nearly or quite as long as the inner.

Involucre close, the outer bracts much shorter than the inner.

Heads clustered, subsessile, leafy; bracts herbaceous, not glandular on the back.

Heads not clustered, peduncled; bracts coriaceous, glandular on the back.

Outer bracts with spines nearly as long.

Outer bracts with much shorter spines.

Leaves canescent on both sides; flowers usually pink.

Leaves green above; flowers whitish.

C. arvense.

C. lanceolatum.

C. edule.

C. foliosum.

C. ochrocentrum.

C. undulatum.

C. palousense. 
Cirsium arvense (L.) Scop. Canada Thistle. Perennial, with slender creeping rootstocks; whole plant green, thinly tomentose when young, becoming glabrous, much branched, 1-2 m. high; leaves numerous, oblonglanceolate, pinnately-lobed, sessile and somewhat clasping at base, $10-20 \mathrm{~cm}$. long; prickles numerous, rather weak; heads small, corymbed, dioecious; staminate heads globose, the flowers much exserted; pistillate heads oblongcampanulate, the flowers scarcely projecting; bracts of the involucre well imbricated, somewhat ciliate, the short ovate outer ones spine-tipped, the inner ones lanceolate, soft-tipped; flowers pink-purple. Becoming quite commonly introduced.

Cirsium lanceolatum (L.) Scop. Bull Thistle. Stems stout, somewhat woolly, usually branched, leafy to the top, $100-150 \mathrm{~cm}$. high; leaves lanceolate, deeply pinnatifid, hispid-pubescent but green above, white-tomentose beneath, decurrent at base, $6-15 \mathrm{~cm}$. long, armed with numerous stout prickles; heads large, on stout leafy peduncles; involucre well imbricated, sparsely woolly; bracts lanceolate, acuminate, all tipped with stout erect spiny points; flowers purple. Abundantly introduced.

Cirsium edule Nutt. Stems usually tall and nearly simple, 1-2 m. high, thinly pubescent; leaves numerous, lanceolate, pinnately-lobed, pubescent above, woolly beneath, but soon green and glabrate on both sides, $5-20 \mathrm{~cm}$. long; prickles rather weak; heads large, usually clustered, short-peduncled, often surrounded by the upper leaves; involucre persistently white-woolly; bracts loose, all tapering to slender rather weak prickly points, the outer broader and shorter, not glandular; corolla purple, the lobes thickened at the tips, shorter than the throat; pappus-bristles a little thickened at the tips. Moist places in the mountains.

Cirsium foliosum (Hook.) DC. Stems stout, erect, simple, about $1 \mathrm{~m}$. high, very leafy, villous and somewhat woolly; leaves lanceolate or linearlanceolate, pinnately-lobed, green and villous above, permanently whitewoolly beneath, $10-50 \mathrm{~cm}$. long, only the lowest petioled; prickles numerous, weak and slender; heads large, few, in a dense terminal cluster, surrounded at base by the upper leaves which are usually reddish; involucral-bracts loosely imbricated, thin, flat, the outer acuminate, sometimes with a weak prickly point, the inner with scarious dilated somewhat fringed tips; flowers pink, the corolla-lobes as long as or longer than the throat. North hillsides, common. A peculiar plant, apparently a hybrid between this species and C. palousense, sometimes occurs in its company.

Cirsium ochrocentrum Gray. Stout and tall, 1-2 m. high; leaves mostly deeply pinnatifid, white woolly on both surfaces, less so above, strongly armed with stout yellow prickles; heads $2-5 \mathrm{~cm}$. high, solitary on stout peduncles; bracts coriaceous, the outer ones with a glandular line on the back, each armed with a stout prickle as long as the bract; flowers purple or cream-colored. Blue Mountains, inf requent.

Cirsium undulatum (Nutt.) Spreng. Stout, erect, 50-200 cm. high, the whole plant except the heads persistently white-tomentose, or the leaves sometimes glabrate above; leaves lanceolate, pinnately-lobed or parted, 5-15 cm. long; prickles few or numerous, rather stout; heads large, on stout peduncles; involucre well imbricated, the bracts thick, with a glandular spot near the tip, all tipped with spreading prickly points; corollas rose-red or whitish, the lobes about as long as the throat; pappus bristles a little thickened at the apex. Along Snake River, common, and about Spokane.

Cirsium palousense Piper n. comb. (Carduus palousensis Piper). Stem erect, loosely branched above, $30-90 \mathrm{~cm}$. high, tomentose when young, becoming glabrous; leaves lanceolate, pinnatifid into rather few lobes, early becoming green and glabrous above, persistently white-woolly 
beneath, 5-15 cm. long; prickles few; heads large, on nearly naked long peduncles; involucre hemispheric; the bracts firm, closely imbricated in several successively shorter ranks; all prickly pointed and bearing an oblong or linear glandular spot near the tip; flowers yellowish-white; corolla-lobes shorter than the throat. Common on the prairies.

\section{CHAENACTIS.}

Annual, biennial or perennial herbs; leaves alternate, 1-3pinnately dissected; heads medium or large, peduncled, terminating the branches; ray-flowers none; flowers yellow, white or flesh colored, all perfect and tubular but an outer series more or less enlarged simulating rays; involucre campanulate or hemispherical; bracts equal, in 1-2 rows; pappus of 4-12 awnless and nearly or quite nerveless hyaline or chaffy scales; akenes slender, linear, tapering to the base, more or less 4 -angled.

Chaenactis douglasii (Hook.) H. \& A. Perennial, loosely white-tomentose throughout, erect, $30-50 \mathrm{~cm}$. high, branched above; leaves oblong-lanceolate in outline, 5-10 $\mathrm{cm}$. long, bipinnately parted into numerous rather crowded obtuse segments; heads corymbed; involucre viscid-pubescent, 10-12 mm. high; bracts linear, obtuse; flowers all alike, cream-colored or pinkish; akenes pubescent, those of the outer flowers often glandular; pappus of 8-12 large obtuse silvery scales, two-thirds as long as the akenes or in the outer flowers only one-third as long. Gravelly soil.

\section{MATRICARIA.}

Herbs; very similar to Chrysanthemum but ray-flowers none (in ours); involucre hemispherical or flatter, of numerous more or less scarious appressed scales, in few rows; receptacle highconical or ovate; pappus none or a minute crown.

Matricaria matricarioides (Less.) Porter. Annual, 5-20 cm. high, simple or branched, sparsely pubescent or glabrous; leaves oblong, 1-3 cm. long, once or twice pinnately dissected into small linear ącute segments; heads 5-9 $\mathrm{mm}$. high, terminating short stout peduncles; involucre saucer-shaped, the scales oblong, obtuse, green, with scarious margins; ray-flowers none; diskflowers yellowish-green; receptacle conical; akenes oblong; pappus represented by a low sometimes 1-2-toothed crown. Dry ground, very common.

\section{RUDBECKIA.}

Mostly perennial herbs; leaves alternate; heads many-flowered, mostly with sterile ray-flowers but rayless in ours; disk-flowers perfect; receptacle elongated, becoming columnar; pappus a chaff-like cup or 4 chaffy teeth more or less united into a cup; akenes quadrangular and mostly laterally compressed.

Rudbeckia occidentalis Nutt. Stems erect, 50-100 cm. tall, smooth; leaves ovate, acuminate, coarsely dentate or nearly entire, short-petioled or the upper sessile, usually pubescent beneath, smooth above, 6-12 $\mathrm{cm}$. long; heads rayless; disk at length ovate-conical or columnar, $3-5 \mathrm{~cm}$. long, darkbrown; involucre loose, foliaceous; akenes $3 \mathrm{~mm}$. long; pappus merely a low scarious rim on the apex of the akene. Moist open places, in the mountains. 


\section{PSILOCARPHUS.}

Low woolly annuals; leaves entire, mostly opposite; heads small, discoid, many-flowered, in terminal capitate clusters and in the forks of the branches, surrounded by the upper leaves; fertile flowers numerous, in several series on the globular chaffy receptacle; pappus none; akene loose in the bladder-like bract, oblong or narrower, slightly compressed.

Heads sparsely covered with long loose woolly hairs.

Heads covered with short close wool.

P. elatior.

$P$. oreganus.

Psilocarphus elatior Gray. Erect and simple or more commonly branched from the base and spreading, 5-10 cm. high, loosely white-woolly throughout; leaves lanceolate or linear-spatulate, $1-2 \mathrm{~cm}$. long; heads $6-8 \mathrm{~mm}$. broad, subtended by leaves; fruiting bracts appressed, tomentose; akenes cylindrical. Common in low ground, especially dried-up ponds.

Psilocarphus oreganus Nutt. Stems ascending, 2-5 cm. high; leaves narrowly oblanceolate, $8-10 \mathrm{~mm}$. long; heads covered with close wool; bracts $2 \mathrm{~mm}$. long; akenes cylindric. In dried-up ponds, Spokane County.

\section{CHRYSANTHEMUM.}

Herbs; heads many-flowered; ray-flowers usually elongated, numerous, pistillate; disk-flowers usually all fertile; involucre hemispherical or flatter, the scales more or less scarious, shortappressed, imbricated in several rows; receptacle flat or convex, naked; pappus none; disk-corollas often flattened or 2-winged below, 4-or 5-toothed; akenes short, nearly terete, several ribbed or angled, truncate at apex.

Chrysanthemum leucanthemum pinnatifidum Lecoq. \& Lemotte. Oxeye Daisy. Perennial, erect, $30-60 \mathrm{~cm}$. high, glabrous or nearly so, usually simple; basal leaves oblong or spatulate, incisely pinnatifid or toothed; cauline smaller, sessile and partly clasping, linear; heads $3-5 \mathrm{~cm}$. broad, on long naked peduncles; involucral-bracts oblong-lanceolate, obtuse, rusty at tip; rays 20-30, white; akenes many-ribbed, pappus none. Sparingly introduced.

\section{ACHILLEA.}

Perennial herbs, rather strong-scented; leaves alternate, serrate or pinnately dissected; heads small, in corymbs, manyflowered; flowers yellow, white or sometimes rose-colored, all fertile; ray-flowers few or several, mostly short or broad, pistillate; involucre narrow, the scales imbricated in a few rows, appressed; receptacle flattish to conical, with thin chaff; pappus none; akenes oblong or ovate, obcompressed, surrounded by a narrow and cartilaginous margin.

Achillea millefolium lanulosa (Nutt.) Piper. Yarrow or Milfoil. Perennial, erect, usually tufted, $30-60 \mathrm{~cm}$. high, loosely pubescent throughout with white somewhat woolly hairs; basal-leaves short-petioled, oblong or oblonglanceolate, 8-20 cm. long, pinnately divided into very numerous segments; 
segments once or twice pinnately-cleft or parted into linear acute lobes; heads small, numerous, in convex or flat-topped terminal corymbs; involucre ovoid or subglobose, $3-5 \mathrm{~mm}$. high; rays 4 or 5, white, $2-4 \mathrm{~mm}$. long. Abundant everywhere.

\section{ANTHEMIS.}

Herbs; leaves alternate, mostly tripinnately divided; heads many-flowered; ray-flowers numerous, commonly conspicuous, pistillate or sometimes sterile; disk-flowers fertile; involucre broad, the scales very numerous, imbricated and appressed; receptacle convex to oblong-conical, chaffy, with slender or thin scales or awns, subtending at least the central flowers; pappus none, or a short chaffy crown; akenes obovoid or oblong, 4- or 5angled, 8-10-ribbed or many-striate, truncate at the apex.

Leaves glabrous, ill-scented; rays neutral.

A. cotula.

Leaves pubescent, not ill-scented; rays fertile.

A. arvensis.

Anthemis cotula L. Dog Fennel. May-weed. Annual, much branched, puberulent or glabrate, $30-60 \mathrm{~cm}$. high; leaves 1-3 times pinnately-dissected into thread-like lobes; heads $2 \mathrm{~cm}$. broad; receptacle conical, with bristly bracts near the apex, none at the margin; involucral bracts oblong, obtuse, pubescent; rays white, 10-18, becoming reflexed in age; akenes 10-ribbed, roughened; pappus none. A weed, becoming common; the herbage strong scented.

Anthemis arvensis L. Corn Chamomile. Pubescent annual herb resembling $A$. cotula but not ill-scented; leaves less finely 1-2-pinnately parted; chaff lanceolate, pointed, subtending and exceeding all the disk-flowers; akenes smooth; pappus a minute border. Sparingly introduced.

\section{MADIA. TARWEED.}

Annuals; leaves linear or lanceolate, entire or slightly toothed, at least the upper alternate; heads peduncled, clustered; flowers yellow; ray-flowers 1-20 and pistillate, or rarely wanting; diskflowers 1-5, perfect; receptacle chaffy only at the margin; pappus none or of several small scales in the sterile flowers; rayakenes laterally compressed, enclosed in the infolded involucralscales; disk-akenes laterally compressed.

Heads small, long-peduncled; disk flower solitary.

Heads larger, sessile or short-peduncled; disk flowers several.

Involucres laterally compressed; heads densely glomerate.

Involucres campanulate; heads loose or scattered.

Akenes of the rays broad; herbage lemon-scented.

Akenes of the rays compressed; herbage heavy-scented.

M. exigua.

M. glomerata.

M. citriodora. $M$, racemosa.

Madia exigua (Smith) Greene. Stems slender, erect, usually branched above, hirsute-pubescent below, glandular above, $10-30 \mathrm{~cm}$. high; leaves linear, 1-3 cm. long; heads 2-3 mm. high, long-peduncled, loosely corymbed; bracts of the involucre 4-8, enclosing as many ray-flowers which scarcely exceed the bracts; disk-flowers solitary; akenes black, obovate, but lop-sided, that of the disk-flower straight, those of the ray-flowers curved. Dry ground, rather common. 
Madia glomerata Hook. Stems erect, simple or with erect branches, very leafy to the top, $30-100 \mathrm{~cm}$. high, hirsute, the inflorescence glandular; leaves linear or linear-lanceolate, ascending, 2-6 cm. long, scabrous and hirsute; heads densely crowded, at length somewhat racemose; rays few or none, short; disk-flowers 2-5; corollas pubescent; akenes black, club-shaped, those of the ray-flowers flattened and 1-nerved on each face, those of the disk-flowers somewhat 4-angled; pappus wanting. Very common. M. ramosa Piper is probably only a slender loosely branched form.

Madia citriodora Greene. Stems erect, 30-60 cm. high, simple or branched above; herbage villous, slightly glandular in the inflorescence, lemon-scented; leaves linear, narrow, entire or nearly so; heads peduncled, corymbose; rays 8 or 9, yellow, 3-lobed; marginal bracts of the receptacle somewhat united; rayakenes rounded on the back, obovate-triangular, smooth. Waitsburg, Horner.

Madia racemosa (Nutt.) T. \& G. Stems erect, $30-90 \mathrm{~cm}$. high, simple or branched above, hirsute below, glandular above; leaves linear or lanceolate, acute, $2-8 \mathrm{~cm}$. long; heads $6-10 \mathrm{~mm}$. high, hemispherical or broadly ovoid, racemosely or corymbosely arranged, commonly peduncled; corolla pubescent; rays $5-8$, rarely 10 ; disk-flowers few; akenes flattened and nerved on the broader faces or the nerve lacking; pappus none. Very variable and as here described including $M$. dissitiflora T. \& G., whose supposed distinctions break down completely.

\section{BALSAMORRHIZA.}

Low perennials; leaves mostly radical; heads large, usually solitary; flowers yellow; receptacle flat or barely convex with linear-lanceolate chaff; pappus none; ray-akenes obcompressed; disk-akenes prismatic-quadrangular or laterally compressed.

Leaves sagittate, entire, canescent.

Leaves deltoid, laciniate, green.

B. sagittata.

B. terebinthacea.

Balsamorhiza sagittata (Pursh) Nutt. Root stout and woody, resinous, the bark coarsely ridged; basal leaves erect or nearly so, sagittate-hastate or oblong-cordate, entire, silvery-canescent, $10-25 \mathrm{~cm}$. long, on slender petioles about as long or longer; cauline leaves few, small, spatulate or oblanceolate; peduncles hardly exceeding the leaves, $30-50 \mathrm{~cm}$. high; involucre white-woolly, $3-4 \mathrm{~cm}$. broad; rays $10-25$, yellow, entire and acute or rarely few-toothed at the apex. Very plentiful, on open prairies. Yoril-May

Balsamorhiza terebinthacea (Hook.) Nutt. Herbage green or very slightly canescent; leaves oblong-lanceolate, usually incisely toothed or cleft, but sometimes merely dentate, scabrous, $10-20 \mathrm{~cm}$. long, becoming rigid when mature; stems several, $20-30 \mathrm{~cm}$. high, bearing 2 linear-lanceolate small leaves near the middle; involucre woolly, its bracts subequal; akenes glabrous. On bare or rocky soil, Blue Mountains, and Craig Mountains, Idaho.

\section{HEMIZONIA.}

Mostly annual herbs, usually more or less glandular and viscid and heavy-scented; leaves alternate or sometimes opposite; heads not large, many- or sometimes few-flowered; involucral bracts rounded on the back, partly enclosing the turgid more or less oblique ray-akenes; disk-akenes abortive or infertile. 
Hemizonia pungens (H. \& A.) T. \& G. Hairy, but only slightly glandular; stems 30-60 cm. high; basal leaves bipinnatifid, cauline simply pinnatifid, the lobes lanceolate or linear-lanceolate, entire, very sharp-pointed; the leaves on the branchlets entire, small and crowded, rigid, spine-tipped; involucral bracts lanceolate, spine-tipped; receptacle convex; rays short, narrow, toothed at the apex; pappus none. Introduced about Walla Walla from California.

\section{LAGOPHYLLA.}

Annuals; stem slender, much-branched; leaves alternate or opposite, mostly entire; heads small, few-flowered; ray-flowers about 5, pistillate, fertile; disk-flowers as many, perfect but sterile; involucre of as many scales as the ray-flowers; receptacle small and flat; pappus none; ray-akenes obovate, much obcompressed, smooth, enclosed by the base of the involucral bract; disk-akenes slender and abortive.

Lagophylla ramosissima Nutt. Erect, loosely branched, 15-70 cm. high; stems light colored, puberulent; leaves all but the lowest attenuate, entire, linear-lanceolate or the lowest somewhat spatulate, $1-3 \mathrm{~cm}$. long, all white villous; heads 5-6 mm. long, in small clusters on the leafy branches; involucralbracts ciliate with long hairs, and usually with a few stalked glands on the back; rays yellow, small; akenes $3 \mathrm{~mm}$. long, club-shaped, with a ridge down the inner face. Dry ground, common.

\section{ERICAMERIA.}

Low tufted half shrubs with linear leaves, which are punctate and resinous; heads in corymbose panicles; involucral bracts chartaceous, imbricated in several rows; flowers few, white or cream-colored; pappus bristles unequal, slender, dull white or yellowish.

Ericameria nana Nutt. Forming much-branched depressed tufts 10-12 $\mathrm{cm}$. high, $30 \mathrm{~cm}$. or more broad; herbage glabrous but gummy.; leaves small, linear to narrowly spatulate, rigid, acute, 6-12 $\mathrm{mm}$. long; heads corymbed or rarely solitary; involucre turbinate, the bracts lanceolate, very acute, chartaceous, a few outer ones passing into the leaves; flowers white or creamcolored; ray-flowers 4-6, small; disk-flowers 8-12, their corollas deeply cleft; styles setaceous, hispid. On rocks, Snake River canyon at the mouth of the Tukanon and in the Blue Mountains.

\section{MACHAERANTHERA.}

Annual, biennial or perennial leafy-stemmed branched herbs; leaves alternate, entire, serrate or pinnatifid; heads showy, terminating the branches; involucre of imbricated canescent bracts in numerous rows and with herbaceous or foliaceous usually spreading or reflexed tips; ray-flowers numerous, violet to red or purple, pistillate; disk-flowers perfect, yellow, changing to red or brown; pappus of numerous stiff rough unequal bristles; akenes narrowed below, pubescent. 
Machaeranthera canescens viscosa (Nutt.) Piper. Biennial, erect, much branched above, and simple or branching at the base, $30-60 \mathrm{~cm}$. high, whitishpuberulent throughout; leaves rigid, linear-lanceolate or the lower spatulate, cuspidately-toothed or entire, 2-6 cm. long, those of the flowering branches much reduced; heads usually numerous, paniculate or corymbosely arranged; involucre turbinate-campanulate, $10-15 \mathrm{~mm}$. broad, the bracts in numerous imbricated ranks, the tips green, very glandular on the upper side, at length spreading or recurved; rays purple or violet, $8-10 \mathrm{~mm}$. long; akenes canescent; pappus sordid. Dry soil, often abundant and becoming a weed.

401. ERIGERON. Fleabane.

Herbs; very similar to Aster, but differing in the usually nakedpeduncled heads; involucre simpler, of narrow and erect equal bracts, not coriaceous and without herbaceous tips; rays narrower and usually very numerous, often in more than one row; pappus more scanty or fragile, sometimes with a conspicuous short outer row; style appendages very short and roundish or obtuse; akenes mostly 2-nerved.

Rays very short or wanting.

Plant low; head solitary.

Plants tall; heads several to many.

Rays wanting; leaves firm; root perennial.

Rays present, very short; root annual or biennial.

Annual; heads panicled; involucre glabrous.

Biennial; heads corymbose; involucre hairy.

Rays conspicuous, much surpassing the disk.

Roots annual or biennial, fibrous.

Stems diffusely branched; rays white or violet.

Stems erect, branched above; rays white.

Roots stout; plants perennial.

Tall species with flat, rather broad and large leaves.

Involucre viscid; rays $30-50$, broad.

Involucre smooth or hirsute; rays 100-150, narrow.

Leaves entire; ray flowers violet.

Leaves dentate; ray flowers pink.

Low species; leaves narrow.

Rays yellow; leaves linear, entire.

Rays not yellow.

Leaves parted into linear lobes.

Leaves entire, narrow.

E. bloomeri.

E. inornatus.

E. canadensis.

E. acris.

E. divergens.

E. ramosus.

E. membranaceus.

Stems simple, scapiform; head always solitary.

Stems branched, leafy, usually bearing several heads.

Pubescence long and dense.

Pubescence short.

Radical leaves linear-lanceolate, 3-nerved.

Radical leaves filiform or linear, 1-nerved.

E. speciosus.

E. philadelphicus.

E. filifolius.

E. compositus.

E. poliospermus.

E. hispidissimus.

E. corymbosus.

E. linearis.

Erigeron bloomeri Gray. Perennial, densely tufted, from a woody base; pubescence fine and appressed; basal leaves spatulate-linear, 2-6 cm. long, 
the cauline linear; stems 5-15 cm. high, each bearing a single head, this 10-12 $\mathrm{cm}$. high; involucre villous, the bracts equal; rays none; pappus simple; akenes glabrous. Stony ridges, Blue Mountains.

Erigeron inornatus Gray. (E.eradiatus (Gray) Piper.) Perennial from a woody base, glabrous or sparsely hirsute, green, leafy; stems few, erect, rather rigid, $30-40 \mathrm{~cm}$. high; leaves linear, $2-5 \mathrm{~cm}$. long, only $2-4 \mathrm{~mm}$. wide; heads cymose, whitish, rayless; involucres campanulate, the bracts glabrous and unequal; pappus simple; akenes pubescent. In dry pine woods, Blue Mountains.

Erigeron canadensis L. Annual, strictly erect, simple or with erect branches, usually $30-100 \mathrm{~cm}$. high, loosely hirsute throughout; leaves numerous, linear, entire or the lower spatulate and incisely lobed or dentate; heads panicled, very numerous, small, $3-5 \mathrm{~mm}$. high; involucres cylindric; rays whitish, very small. Native but weedy in habit and abundant in cultivated land.

Erigeron acris L. Biennial, erect, glabrous or sparsely pubescent, 30-60 $\mathrm{cm}$. high; basal leaves spatulate-lanceolate; cauline lanceolate, sessile, all entire, acute or obtuse, 5-10 cm. long; heads paniculate or corymbose, 6-8 $\mathrm{mm}$. broad; involucre puberulent and somewhat hirsute; rays very narrow, pinkish, equalling the disk, within them a series of tubular filiform pistillate flowers; akenes smooth; pappus copious, brownish. Open woods, in the mountains.

Erigeron divergens T. \& G. Annual, usually tufted and branched, softhirsute throughout, leafy to the top; lower leaves spatulate, obtuse, $2-8 \mathrm{~cm}$. long; upper cauline lanceolate, sessile, smaller, all entire or sometimes toothed or lobed; heads numerous, short-peduncled; involucre 4-5 $\mathrm{mm}$. high, hirsute; rays white or violet, very numerous, 5-6 $\mathrm{mm}$. long; pappus double, the inner of a few deciduous bristles, the outer persistent, very short, about as long as the breadth of the akenes; receptacle becoming convex. Sandy soil, infrequent.

Erigeron ramosus septentrionalis Fernald \& Wiegand. Annual or biennial, erect, branched above, sparsely hirsute, leafy to the top; lower leaves spatulatelanceolate, acute, entire or dentate, the blades 5-8 cm. long; upper cauline lanceolate, entire, sessile, smaller; heads loosely corymbed; involucre $3-4 \mathrm{~mm}$. high, glabrous or with a few bristly hairs; rays white, numerous, short, 4-6 $\mathrm{mm}$. long; pappus of the disk-flowers double, the inner of few deciduous bristles, the outer of short persistent scales; ray-flowers with few or no bristles to the pappus. Meadows, uncommon.

Erigeron membranaceus Greene. Perennial; stems erect, 30-60 cm. high or dwarfed in high alpine forms; leaves thin and glabrous except the ciliate margin, the lower oblong-spatulate, $10-15 \mathrm{~cm}$. long, the upper lanceolate to ovate-lanceolate; heads solitary or several, all on long peduncles, each 2-2.5 $\mathrm{cm}$. broad; involucral bracts lanceolate, acuminate, viscid, often purpletinged; rays about 30 , violet, $10 \mathrm{~mm}$. long; akenes sparsely pubescent. Abundant in the Blue Mountains at and above the limits of trees. Some high alpine forms have all the leaves narrow.

Erigeron speciosus DC. Perennial, tufted, sparingly hirsute or nearly glabrous; stems $30-50 \mathrm{~cm}$. high, leafy to the top, erect; leaves lanceolate, entire, acute or acuminate, usually ciliate at least at the base; the upper cauline sessile by a broad base; the lower and radical petioled, 5-15 cm. long; heads few, in a loose corymb; involucre hirsute or nearly glabrous, 5-6 mm. high; rays about 100 , narrow, violet, about $1 \mathrm{~cm}$. long; akenes pubescent; pappus double, the outer bristles very short. Gravelly soil, infrequent. Ely 
Erigeron philadelphicus L. Perennial, sparsely hairy; stems erect, branched above, $30-90 \mathrm{~cm}$. high; basal leaves oblong or oblong-obovate, obtuse, dentate, 3-6 cm. long, narrowed into a short petiole; cauline mostly entire, sessile and half-clasping; heads numerous in a cyme; involucre hemispheric; rays pink, numerous, very narrow; akenes puberulent. Moist banks and meadows.

Erigeron filifolius (Hook.) Nutt. (E. peucephyllus Gray.) Perennial, green or slightly canescent, the pubescence minute and appressed; stems 10-30 $\mathrm{cm}$. high, erect, little branched; leaves linear or slightly dilated at tip, 2-5 $\mathrm{cm}$. long; involucre 6-8 mm. high, hirsute, bracts unequal; rays 20-40, golden yellow, about $1 \mathrm{~cm}$. long; pappus double. In thin rocky soil.

Erigeron compositus Pursh. Pernnial, tufted from a woody crown; leaves hirsute or glabrous; basal leaves long-petioled, the blade 1-3-times ternately divided into linear obtuse lobes, 4-10 mm. long; cauline sessile, mostly linear and entire; flowering stems $6-15 \mathrm{~cm}$. high, bearing solitary heads; rays $30-50$, pink or white, $6-10 \mathrm{~mm}$. long; a kenes short-pubescent; pappus simple. In sandy soil. Manch - Aproit

Erigeron poliospermus Gray. Perennial, in dense tufts, sparsely hispid throughout; stems numerous, simple, $2-10 \mathrm{~cm}$. high, each bearing a single head; leaves spatulate, obtuse, the petioles slender; involucre densely hairy, the bracts narrow; rays 20-30, violet or white, rather broad; akenes white hairy; pappus double. In dry soil, most common in the sagebrush region.

Erigeron hispidissimus (Hook.). Piper (E. concinnus T. \& G.). Perennial, erect, commonly tufted from a stout crown, $10-30 \mathrm{~cm}$. high, very pubescent, with long and soft hairs; leaves spatulate-linear, entire, $2-8 \mathrm{~cm}$. long, nearly erect; heads loosely corymbed; involucre hirsute, $5 \mathrm{~mm}$. high; rays white, pink or violet, numerous, 5-6 mm. long; pappus double, the outer short but conspicuous. Dry ground, common about Spokane.

Erigeron corymbosus Nutt. Perennial, tufted, erect or decumbent, 15-50 $\mathrm{cm}$. high, harshly pubescent throughout; radical leaves linear-lanceolate, spatulate, 3-nerved, 6-15 cm. long; cauline linear, 1-nerved, acuminate, sessile, gradually smaller to the top; heads slender-peduncled, sometimes solitary, mostly in loose corymbs; involucre $7-8 \mathrm{~mm}$. high, whitish, hirsute; rays $30-50$, violet, rarely white, $6-12 \mathrm{~mm}$. long; pappus double, the outer bristles very short, sometimes wanting. Common on grassy prairies.

Erigeron linearis (Hook.) Piper. Perennial, the caudex woody, branched; pubescence whitish, fine and appressed; stems $15-50 \mathrm{~cm}$. high, loosely branched above and bearing few to many heads; leaves linear or slightly dilated at tip, firm, 2-5 cm. long; involucre 4-5 $\mathrm{mm}$. high, the bracts subequal, appressedpubescent; rays pink to violet, $6-8 \mathrm{~mm}$. long; pappus simple. In gravelly soil, usually abundant where sagebrush occurs.

\section{ASTER.}

Mostly perennial herbs; leaves alternate; heads solitary, corymbed or panicled, many-flowered, radiate; ray-flowers several or numerous, in one row, fertile or rarely sterile, white, purple or blue, never yellow; disk-flowers yellow, often turning purple; involucre imbricated; bracts commonly with herbaceous tips; receptacle flat or convex, naked; pappus tawny, simple, of copious slender scabrous capillary bristles; anthers tipped with an appendage; styles appendaged; akenes more or less compressed, rarely slender, 4-5-nerved. 
Leaves coriaceous, serrate; involucre well imbricated.

A. conspicuus.

Leaves membranaceous, rarely somewhat serrate.

Involucre viscid or pruinose glandular.

Leaves oblong-linear; heads few, subracemose.

Leaves oblong to spatulate or lanceolate; heads numerous, in a panicle.

Involucre not viscid or glandular.

Heads small, less than $1 \mathrm{~cm}$. broad.

Rays white; involucre campanulate. Rays violet; involucre turbinate.
Heads larger, $1 \mathrm{~cm}$. broad or more.

A. campestris.

A. integrifolius.

Involucral bracts closely appressed, mainly coriaceous; leaves entire or nearly so.

Leaves glaucous; akenes glabrous.

Leaves puberulent; akenes pubescent.

Involucral bracts looser, largely herbaceous.

Leaves few, large, scarcely reduced upward, the cauline with auriculate or clasping bases.

Heads solitary or few, long-peduncled; leaves dark-green, usually glabrous.

Heads several; stems leafy to the top; leaves

thin, pale, usually pubescent.
Leaves numerous, either small or much reduced

\section{A. foliaceus.}

A. laevis.

A. jessicae.

A. multiflorus.

A. columbianus. upward; cauline sessile, not at all auriculate.

Involucral bracts, at least the outer ones, foliaceous and passing into the leaves. Leaves firm, entire, numerous.

Leaves thinner, less numerous, usually serrate near the middle.

A. cusickii.

Involucral bracts not at all foliaceous.

Heads solitary, naked, pedunculate.

Heads corymbose.

Leaves serrulate, those of the inflorescence much reduced.

Leaves entire, those of the inflorescence not much reduced.

A. eatoni.

A. douglasii.

A. stenomeres.

A. occidentalis.

A. fremonti.

Aster conspicuus Lindl. Stout smooth-stemmed herbs, $30-60 \mathrm{~cm}$. high; leaves oblong or obovate, thick and firm, acute or obtuse, serrate, 5-12 cm. long, harshly-scabrous on both sides, all sessile; inflorescence glandular; heads usually many, in large corymbs; involucre campanulate, 10-15 mm. broad; bracts well imbricated, scarious, mostly acute, ciliate and glandular, many of them green-tipped; rays violet, $1-1.5 \mathrm{~cm}$. long; akenes minutely pubescent; pappus sordid. Open pine woods. Common.

Aster campestris Nutt. Puberulent above and usually viscid-glandular; stems simple or but little branched, $30-40 \mathrm{~cm}$. high; leaves oblong-linear, ascending, entire, ciliate, 3-nerved, acute, 3-5 cm. long; heads few, subracemose, on leafy branchlets; involucre hemispherical, 6-7 $\mathrm{mm}$. high; bracts linear-lanceolate, acute, subequal, glandular-puberulent, in about 3 rows; rays 20-30, violet; pappus sordid; akenes pubescent. Infrequent; at Spokane, Waitsburg and Walla Walla.

Aster integrifolius Nutt. Stems stout, usually simple, $30-60 \mathrm{~cm}$. high, sparsely villous below, viscid-glandular above; basal leaves large, firm, oblong to spatulate, acute, apiculate, entire or obscurely serrulate, 10-20 cm. long; cauline much smaller, lanceolate, half-clasping at the narrowed base; heads in 
a loose leafy panicle, the branchlets and involucre glandular; involucre broadly turbinate, the linear bracts in 2 or 3 ranks, the outermost often large and foliaceous; rays violet, $15-25,10-12 \mathrm{~mm}$. long; akenes pubescent; pappus rigid, somewhat tawny. In open woods, Blue Mountains.

Aster multiflorus Ait. Erect, $30-90 \mathrm{~cm}$. high, rough pubescent; leaves linear or oblong-linear, entire, acute, sessile or somewhat clasping, rigid, 1-3 cm. long or those on the flowering branches much smaller; heads in large panicles, densely crowded, often secund on the spreading branches, nearly sessile; involucres turbinate-campanulate, $3-5 \mathrm{~mm}$. broad, the numerous bracts well imbricated, rough-pubescent and ciliate, their green tips outwardly recurved; rays white, $3-4 \mathrm{~mm}$. long; akenes puberulent; pappus sordid. Dry soil.

Aster columbianus Piper. Erect, $30-60 \mathrm{~cm}$. high, sparsely rough-pubescent; leaves not rigid, linear, entire, acute, sessile, $2-6 \mathrm{~cm}$. long, those of the flowering branches much reduced; heads small, usually numerous, in rather loose elongated panicles; involucre turbinate, well-imbricated, 5-7 mm. broad, the bracts linear, cuspidate-acute, green and spreading at tip, ciliate except at the apex; rays violet, 6-7 mm. long; akenes canescent; pappus sordid. Rocky banks of streams, rare.

Aster laevis geyeri Gray. Erect, about $1 \mathrm{~m}$. high, glabrous and somewhat glaucous throughout; leaves ovate, oblong or oblong-lanceolate, acute or obtuse, entire or rarely serrate, $5-15 \mathrm{~cm}$. long, the basal petioled, the cauline sessile or half-clasping by a broad base; inflorescence loosely paniculate or corymbose; involucre turbinate, about $1 \mathrm{~cm}$. broad, the rigid bracts wellimbricated, acute, appressed, green-tipped; rays violet, 8-12 $\mathrm{mm}$. long; akenes glabrous or nearly so; pappus sordid. In gravelly soil especially along streams.

Aster jessicae Piper. Perennial, tufted, 100-150 cm. high, soft-pilose throughout; basal leaves ovate or oval, acute or acuminate, entire or fewtoothed, long-petioled, 6-10 cm. long; cauline broadly lanceolate, acute, entire, narrowed at base into a short broadly-margined petiole or sessile, 2-10 cm. long; heads in loose panicles, the peduncles stout, leafy; involucre campanulate, $10-17 \mathrm{~mm}$. broad, the bracts green, lanceolate, acute, softlypubescent, the lower little shorter, some of them intergrading into the leaves; rays violet, broad, $1 \mathrm{~cm}$. or more long; akenes pubescent; pappus sordid. Low ground. Whitman and Latah Counties, rare.

Aster foliaceus frondeus Gray. Glabrous or sparsely pubescent; stems stout, erect or ascending, simple or usually with a few branches, $20-60 \mathrm{~cm}$. high; leaves few, the lower large, $8-10 \mathrm{~cm}$. long, oblanceolate, tapering into winged petioles; cauline sessile, broadly half-clasping at the base; heads few, large, $1.5-2.5 \mathrm{~cm}$. broad, usually on naked peduncles; involucre $10-14 \mathrm{~mm}$. high, the bracts herbaceous, linear-lanceolate, loose, all about equalling the the disk, the outer largest; rays dark-violet, about $1 \mathrm{~cm}$. long; akenes not glabrous. Blue Mountains. In moist meadows.

Aster cusickii Gray. Pale green, glabrous or sparsely pubescent especially in the inflorescence; stems $60-80 \mathrm{~cm}$. high, leafy, branched above; leaves few, thinnish, oblong to oblong-lanceolate, entire, the basal contracted into broad petioles, the cauline half-clasping; inflorescence leafy; heads few, large, $12 \mathrm{~mm}$. high, involucral bracts loose and foliaceous, the outer as long as the inner and passing into the leaves; rays pale violet, $10-15 \mathrm{~mm}$. long akenes glabrous. Common in the Blue Mountains, near the limit of trees.

Aster eatoni (Gray) Howell. Very similar to $A$. douglasii; leaves numerous, firm, entire, $2-4 \mathrm{~cm}$. long; heads smaller, $6-8 \mathrm{~cm}$. high, usually very numerous and subracemose on the branches; bracts green and foliaceous, very unequal, the outer ones passing into the leaves. Edges of fields and along streams in open places. 
Aster douglasii Lindl. Glabrous or nearly so; stems erect, branched above, $30-120 \mathrm{~cm}$. high; leaves thinnish, lanceolate, sessile, broadest near the middle, acute, serrate near the middle or entire, 5-15 cm. long, those on the branches much smaller; heads usually numerous, panicled; involucre $10-12 \mathrm{~mm}$. high, the bracts green at the tips, narrow, acute, the outer ones sometimes foliaceous and passing into the reduced leaves of the branchlets; rays pale violet, 10-12 $\mathrm{mm}$. long. Moist places along the Spokane River. A very variable species as at present understood, the typical plant occurring near the seacoast.

Aster stenomeres Gray. Stems tufted, rigid, pubescent, from a branched woody base, $10-30 \mathrm{~cm}$. high; leaves numerous, linear, 1 -nerved, $1-2 \mathrm{~cm}$. long, acute, mucronate, rather rigid, very scabrous; involucre hemispheric, 12-15 $\mathrm{mm}$. broad; bracts linear, attenuate-acute, rather thin, in two series, usually purple-tinged, pubescent; rays violet, $15-20 \mathrm{~mm}$. long; akenes flat, villous; pappus sordid, double, the outer bristles very short. Summit of Mount Carlton, Kreager, and near Rathdrum, Sandberg, Heller \& MacDougal.

Aster occidentalis intermedius Gray. Perennial, erect, glabrous or nearly so; leaves rather thick, the basal lanceolate, acute, somewhat serrate or entire, petioled, the cauline sessile, lanceolate, mostly serrate, the uppermost much reduced; inflorescence loosely corymbose-paniculate; involucre campanulate, $10-12 \mathrm{~cm}$. broad, the bracts loosely imbricated, subequal, linear, acute, green but not at all foliaceous; rays violet or white, $1 \mathrm{~cm}$. long; akenes sparsely pilose; pappus sordid. In dry or gravelly soil.

Aster fremonti (T. \& G.) Gray. Perennial, somewhat pubescent or nearly glabrous, $50-100 \mathrm{~cm}$. high, usually branched above; larger leaves thin, oblonglanceolate, entire, acute or obtuse, scabrous on the margin, $2-5 \mathrm{~cm}$. long, only the lowermost petioled, the others sessile and partly clasping, those on the flowering branches small, linear; heads loosely corymbose, the peduncles nearly naked; involucre $7-9 \mathrm{~mm}$. high, broadly campanulate, the bracts all alike, linear, acute, loosely imbricated, nearly equal; rays violet, $6-8 \mathrm{~mm}$. long. In moist copses, common and variable.

\section{CHRYSOPSIS.}

Low herbs; leaves numerous, alternate, sessile; heads solitary or in corymbs with yellow flowers; rays fertile or sometimes wanting; involucral-scales narrow, acute, with scarious margins; receptacle flat; style-branches with appendages; pappus double, of two kinds, the interior of long copious capillary bristles, the exterior of short bristles or chaffy scales; akenes oblong-linear or ovate-oblong, compressed, hairy.

Leaves canescent, strigose, or hirsute. Leaves green, hirsute and hispid.

C. villosa.

C. hispida.

Chrysopsis villosa (Pursh) Nutt. Perennial, the stems decumbent or suberect, $15-30 \mathrm{~cm}$. long, canescent throughout and more or less villous; leaves numerous, oblong or oblanceolate, mostly acute, sessile or nearly so, 2-3 cm. long; heads solitary or corymbed terminating short leafy branches; involucre hemispherical, $10-15 \mathrm{~mm}$. broad; bracts canescent or nearly glabrous; rays golden-yellow; akenes obovate, pubescent; outer pappus very short. In gravelly or rocky soil.

Chrysopsis hispida (Hook.) Nutt. Very similar to C. villosa but herbage green; pubescence hirsute and hispid, not canescent; heads somewhat smaller. In gravelly soil, Spokane County. 
404. SOLIDAGO. GOLdENROD.

Perennial herbs; leaves alternate; heads small, mostly in panicles or panicled racemose clusters, radiate, the ray-flowers fertile, yellow; involucre imbricated, the bracts usually without herbaceous tips; pappus simple, of a single series of mostly equal and slender scabrous capillary bristles; style-appendages lanceolate or triangular-subulate; akenes terete or angular, 5-12-ribbed.

Leaves thick, the radical spatulate, much longer than the cauline.

S. missouriensis. Leaves thinner, all alike.

Heads 5-7 mm. high; panicle moderately dense.

Heads 4-5 $\mathrm{mm}$. high; panicle very dense.

S. serotina.

S. elongata.

Solidago missouriensis Gray. Tufted, glabrous throughout, 20-60 cm. high; radical and lower leaves thickish, spatulate-lanceolate, acute, entire or obscurely serrate, $10-15 \mathrm{~cm}$. long, sometimes $2 \mathrm{~cm}$. broad; cauline linear or lanceolate, often somewhat folded, $2-8 \mathrm{~cm}$. long, with much smaller ones fascicled in the upper axils; panicle pyramidal, $8-15 \mathrm{~cm}$. long; heads $4-6 \mathrm{~mm}$. high, usually secund on the erect or recurved branches; rays 6-12, small; bracts lanceolate, obtuse, the outermost much shorter. Hillsides, common.

Solidago serotina Ait. Stems stout and tall, 100-150 cm. high, very smooth below the inflorescence, the stem often glaucous; leaves lanceolate or oblong-lanceolate, acuminate, prominently 3-nerved, and usually saliently sharply-serrate, 6-15 cm. long, smooth on both sides; heads 5-7 mm. high, crowded on the spreading often curved branches of the large pyramidal panicle; bracts thin, linear, obtuse; rays 7-14, yellow; akenes pubescent. In open copses along streams.

Solidago serotina salebrosa Piper. Leaves harshly scabrous on both surfaces, 'usually less serrate, otherwise like the species. Much commoner than the species and in similar places.

Solidago elongata Nutt. Very similar to $S$. serotina but stem green not glaucous; panicle smaller, more compact; heads smaller; rays 12-20. Moist places in open woods, Spokane County and adjacent Idaho.

405. EUTHAMIA.

Erect scabrous perennials with narrow alternate leaves; flowers in numerous small heads in terminal flat-topped corymbose panicles; heads many-flowered, the ray-flowers yellow, equalling and more numerous than the disk-flowers; receptacle fimbrillate; akenes villous.

Euthamia occidentalis Nutt. Glabrous; stems $90-120 \mathrm{~cm}$. high, erect, branched above; leaves linear, entire, 3-nerved, the principal ones $5-10 \mathrm{~cm}$. long; heads peduncled, in small corymbs; involucral bracts narrow, acute; rays $16-20$. Frequent in wet places.

\section{ARNICA.}

Perennial herbs; stems mostly simple, from creeping rootstocks or a corm-like base; leaves all or some of them opposite, simple, 
entire, or merely toothed; heads rather large, solitary or few, usually long-peduncled, many-flowered; flowers yellow, all fertile; ray-flowers elongated, pistillate, or sometimes none; involucre broadly campanulate, the bracts in 1-2 rows; receptacle naked, flat; pappus a single series of rather rigid strongly scabrous or barbellate capillary bristles; akenes linear, 5-angled or 5-10ribbed, somewhat hirsute or nearly glabrous.

Basal leaves cordate.

Basal leaves lanceolate.

A. cordifolia.

A. fulgens.

Arnica cordifolia Hook. Erect from horizontal rootstocks, $20-40 \mathrm{~cm}$. high, sparsely pubescent; basal leaves ovate or orbicular, deeply cordate, dentate, acute or obtuse, $5-10 \mathrm{~cm}$. long, on petioles about as long; cauline usually 2 pairs, less broad, the short petioles margined; heads long-peduncled; involucres turbinate-campanulate, $15-20 \mathrm{~mm}$. high, viscid-pubescent, the linear-lanceolate bracts acute; rays $8-12$, yellow, $2-3 \mathrm{~cm}$. long; akenes pubescent. Open woods, Thatuna Hills. F. Ciprit - May

Arnica fulgens Pursh. Erect, $30-60 \mathrm{~cm}$. high, the crown thickened and rusty-woolly sometimes with creeping rootstocks; whole plant viscid-pubescent; basal leaves spatulate-lanceolate, 3-nerved, entire or nearly so, obtuse, 5-12 cm. long; cauline 2 or 3 pairs, sessile, the upper sometimes very small; heads 1-3, long-peduncled; involucres $10-12 \mathrm{~mm}$. high, densely glandular-pubescent; rays yellow, $12-16 \mathrm{~mm}$. long; tubes of disk-corollas hairy; akenes pubescent. Moist hillsides, common. The subterranean characters may vary according to soil; the form without rootstocks has been named as a species, $A$. pedunculata Rydb.

\section{HOOREBEKIA.}

Herbs or low undershrubs; leaves alternate, soft or rigid; heads solitary, terminal, or clustered, many-flowered; ray-flowers fertile or rarely none; involucre imbricated; bracts with or without foliaceous tips; receptacle flat or flattish; pappus tawny or reddish, of copious and unequal capillary bristles, somewhat rigid; style-branches with appendages; akenes turbinate and linear, terete, angled or more or less compressed.

Involucre woolly, its bracts not rigid; leaves soft.

H. lanuginosa.

Involucre glabrous, its bracts rigid; leaves coriaceous.

Heads large, solitary or few, rayless.

Heads middle-sized, racemose; rays small.

H. carthamoides.

H. racemosa.

Hoorebekia lanuginosa (Gray) Piper. Whole plant covered with a nearly white tomentose pubescence; leaves not rigid, mostly basal and spatulate, the upper narrowly linear, 2-5 cm. long; stems $15-30 \mathrm{~cm}$. high, terminated by a solitary head; involucre hemispheric, woolly, the bracts lanceolate-acute, thin; rays 15-20; akenes white-silky. On gravelly slopes in the Blue Mountains.

Hoorebekia carthamoides (Hook.) Piper. Erect, stout, $30-40 \mathrm{~cm}$. high, rough-pubescent or scabrous, becoming glabrous; basal leaves spatulatelanceolate, coriaceous, cuspidate, entire or nearly so, 10-40 cm. long; upper cauline smaller, sessile, by rather broad bases; heads solitary, terminal, or 
1-2 in the upper axils, $1.5-2.5 \mathrm{~cm}$. broad; involucre hemispherical, $1-2 \mathrm{~cm}$. high; bracts green, coriaceous, oblong-lanceolate or ovate, cuspidate, the lowermost leaf-like, entire or nearly so, pubescent; rays usually present, small, scarcely or not exceeding the pappus, sterile; akenes smooth, glabrous, flat, 4-nerved; pappus coarse, brownish, nearly as long as the corolla. Kamiack Butte, in open pine woods; very variable.

Hoorebekia racemosa (Nutt.) Piper. Perennial; stems erect, 60-90 cm. high, sparsely soft-hairy; leaves lanceolate, coriaceous, acute, entire, 5-15 cm. long, the cauline sessile, the basal petioled, all somewhat scabrous on both surfaces and with sparse pubescence; heads racemosely or somewhat paniculately arranged, mostly long-peduncled; involucre turbinate or campanulate, $1-1.5 \mathrm{~cm}$. broad, the well-imbricated bracts linear, acute, pubescent, rigid and coriaceous, green-tipped; rays $6-8 \mathrm{~mm}$. long; akenes pubescent; style-branches filiform; pappus brownish Dry soil, rather common.

\section{SENECIO.}

Herbs or shrubby plants; leaves all alternate; heads usually solitary or in corymbs, many-flowered; flowers yellow, all fertile; ray-flowers pistillate or occasionally none; involucral bracts herbaceous, mostly narrow, equal, in one row, or with a few short outer bracts; receptacle flat or merely convex, naked; pappus of very numerous and mostly white, fine and soft capillary and merely scabrous bristles; akenes terete or somewhat angled, usually 5-10-ribbed.

Annual; calyculate bracts of the involucre closely appressed, black-tipped.

S. vulgaris.

Perennial; calyculate bracts of the involucre not closely appressed, not black-tipped (except in S. atriapiculatus).

Leaves or some of them pinnate or pinnatifid, densely white-woolly.

Leaves not pinnate or pinnatifid, not densely whitewoolly.

Stems clustered, leafy to the inflorescence.

Leaves triangular-lanceolate, petioled, coarsely dentate.

Leaves lanceolate, sessile, serrate to subentire.

Stems usually solitary; leaves mostly basal, the cauline greatly reduced.

Herbage wholly glabrous, glaucous.

Herbage usually pubescent, not glaucous.

Heads $8-10 \mathrm{~mm}$. high; bracts about 13 .

Heads 10-12 mm. high; bracts about 21 . Inflorescence open.

Inflorescence dense.

\section{S. howellii.}

S. triangularis. S. serra.

\section{S. hydrophilus.}

S. exaltatus.

S. atriapiculatus. S. condensatus.

Senecio vulgaris L. Annual, sparsely pubescent or glabrous, usually branched, 15-30 cm. high; leaves spatulate or oblong in outline, $1-3 \mathrm{~cm}$. long, half-clasping at base, pinnately-lobed, the lobes short and usually toothed; heads few to many, in corymbs; involucre 5-7 mm. high, the inner bracts linear, acute, often black-tipped, the outer few and short; rays wanting; akenes puberulent; pappus copious, white. Introduced and becoming common.

Senecio howellii Greene. Perennial, the whole herbage covered with a close white tomentum; stems erect, tufted, $20-40 \mathrm{~cm}$. high; basal and lower 
leaves entire or more or less lobed, oblong, obtuse, the blades 2-4 cm. long, shorter than the petioles; upper leaves sessile or nearly so, pinnately lobed or parted; heads cymose, slender peduncled; involucre cylindric to campanulate, 5-7 mm. high; bracts linear-lanceolate, acute, the outer short ones wanting; rays 8-12. Common on gravelly soil about Spokane. Usually confused with S. canus Hook. which has much looser pubescence. May.

Senecio triangularis Hook. Perennial, glabrous throughout, $30-90 \mathrm{~cm}$. high; stem simple, leafy to the top; leaves narrowly or broadly triangular, acute or acuminate, evenly dentate, truncate at base or the lower of ten cordate and the upper cuneate, $5-15 \mathrm{~cm}$. long, on short petioles; heads corymbed; involucre 6-8 mm. high; bracts linear-lanceolate, acute, pubescent at tip; rays 6-12, yellow. In moist places in the mountains.

Senecio serra Hook. Perennial, glabrous, about $1 \mathrm{~m}$. high, very leafy, simple or branched above; leaves lanceolate, acute and usually cuspidate, serrate-dentate or the small upper ones entire, $5-15 \mathrm{~cm}$. long, all sessile by a narrowed base; heads corymbed, very numerous; involucre 5-6 mm. high, the bracts linear, acute; rays 5-10, yellow, 6-10 mm. long. Low ground, common.

Senecio serra lanceolatus (T. \& G.) Piper. Leaves all entire or nearly so. Waitsburg, Horner.

Senecio hydrophilus Nutt. Perennial, wholly glabrous and slightly glaucous; stems erect, $60-100 \mathrm{~cm}$. high, stout; leaves fleshy with obscure veins, entire or nearly so, the basal oblanceolate, short-petioled, 10-30 cm. long; cauline sessile or half-clasping, lanceolate; heads numerous, in a dense cyme, short-peduncled; involucre cylindric, $6 \mathrm{~mm}$. high; bracts $8-12$; rays small, few or sometimes wanting. In wet places especially on river banks.

Senecio exaltatus Nutt. Very similar to $S$. atriapiculatus but taller, 60$90 \mathrm{~cm}$. high, and less pubescent or even wholly glabrous; leaves larger, thinner, the basal oblong to spatulate, the blades $10-15 \mathrm{~cm}$. long, on petioles nearly as long; heads loosely corymbose; involucral bracts about 13, 5-7 mm. long. In moist meadows and copses. S. hydrophiloides Rydb. seems to be only a large wholly glabrous form.

Senecio atriapiculatus Rydb. Perennial, erect, 30-60 cm. high, sparsely floccose-woolly; basal leaves spatulate, oblanceolate or obovate, mostly acute; dentate, 5-10 cm. long, including the margined petiole; cauline sessile and half-clasping, much smaller, often dentate or laciniate; heads numerous, in rather dense corymbs; involucral bracts $6.5-8.5 \mathrm{~mm}$. high, linear, acute, blacktipped. Common on hills.

Senecio condensatus Greene. Much like S. atriapiculatus but stouter and rather succulent; upper leaves not much reduced; heads densely clustered. On rocky ridges in the Blue Mountains.

\section{CROCIDIUM.}

Small annual herbs with alternate leaves; heads solitary, terminal, small, radiate, the flowers all fertile; involucre hemispherical, of 8-12 thin herbaceous bracts in one row; ray-flowers about 12, yellow; disk-flowers more numerous, yellow; style branches short and broad, with large appendages; pappus of one row of deciduous equal white barbed bristles but none in the ray-flowers. 
Crocidium multicaule Hook. Woolly when young but soon glabrate; stems numerous, tufted, $5-25 \mathrm{~cm}$. high; radical leaves in a basal tuft, obovate or spatulate, few-toothed, sessile or short-petioled; cauline leaves small, linear; heads slender-peduncled, small but showy; involucral bracts oblongovate. Foothills of the Blue Mountains, Horner.

\section{PTILONELLA.'}

Annuals; heads rather few-flowered; ray-flowers 3-6, short and broad, pistillate; disk-flowers 7-12, perfect, some of the central sterile; involucral-bracts $6-10$, nearly in one row; receptacle convex, chaffy; pappus of 10 or 12 linear hyaline scales, each with a stout awn-like midrib, rarely wanting; ray-akenes neither obcompressed nor laterally compressed.

Ptilonella scabra (Hook.) Nutt. Erect, branched above, 10-20 cm. high, scabrous-puberulent below, sometimes glabrous above; leaves numerous, attenuate, linear, somewhat involute, 1-2 cm. long; heads few, somewhat corymbed, terminating leafy branches; involucre 5-6 $\mathrm{mm}$. high; ray and disk flowers white; anthers purple. In thin soil, locally abundant.

\section{BIDENS. Beggar Ticks.}

Annual or perennial herbs; leaves opposite; heads small or medium, yellow or sometimes white; ray-flowers 3-10, sterile or none, in which case the flowers are all perfect and tubular; receptacle chaffy; pappus of $2-4$ rigid backwardly-barbed awns; ray and disk-akenes obcompressed.

Rays none; leaves pinnately 3-5-divided.

B. vulgata.

Rays conspicuous; leaves lanceolate, serrate.

B. cernua.

Bidens vulgata Greene. Annual, the stems erect, usually branched above, glabrous, $30-90 \mathrm{~cm}$. high; leaves pinnately 3-5-foliolate, petioled; leaflets lanceolate, acute, serrate, abruptly narrowed at the base; heads $15-25 \mathrm{~cm}$. broad, stout-peduncled; involucre broadly campanulate, the outer 10-16 bracts foliaceous, linear, unequal, much exceeding the brownish scariousmargined inner ones; ray flowers none; akenes flat, obovate, 7-9 $\mathrm{mm}$. long, somewhat pubescent, ciliate on the margins; awns 2, half as long as the akene, retrorsely barbed. Common along Snake River.

Bidens cernua L. Annual, glabrous or minutely hispid; stems erect, simple or with few short branches, $30-60 \mathrm{~cm}$. high; leaves linear-lanceolate to lanceolate, coarsely and unequally serrate, acuminate, sessile and somewhat cuneate at base, $6-12 \mathrm{~cm}$. long; heads short-peduncled, $12-15 \mathrm{~mm}$. broad; outer involucral bracts foliaceous, much longer than the membranous inner ones; rays $6-12$, bright yellow, or sometimes absent; akenes elongate, wedge-shaped, 4 -angled and bearing 4 backwardly barbed awns half as long as the body. A very variable species growing in wet places, blooming in autumn.

\section{COREOPSIS.}

Annual or perennial herbs usually with opposite leaves; heads many-flowered, radiate; involucre of 2 rows of about 8 bracts each, the outer spreading and foliaceous, the inner appressed and 
nearly membranaceous; ray-flowers mostly 8 , neutral, yellow or purple, rarely wanting; receptacle flat with deciduous membranaceous chaff; akenes obcompressed, often winged, with 2 barbless subulate awns.

Coreopsis atkinsoniana Dougl. Glabrous; stems $30-100 \mathrm{~cm}$. high, erect, usually branched; leaves all opposite, the lowest bipinnately parted into linear lobes, reduced upward to simple linear bracts; heads cymosely paniculate; involucral bracts in two series, the outer short, the inner ovate, scariousmargined, 6-8 $\mathrm{mm}$. long; rays yellow, with brown bases; akenes oblong, narrowly winged, bearing two short subulate teeth. In wet places on river banks.

\section{WYETHIA.}

Perennial herbs; stems simple, rarely branching; leaves alternate, mostly entire and ample; heads many-flowered, solitary or few, medium or large; flowers yellow; ray-flowers elongated, pistillate or fertile; pappus a chaffy crown or cup; ray-akenes neither obcompressed nor laterally compressed.

Wyethia amplexicaulis Nutt. Whole plant dark-green and glabrous, more or less resinous; radical leaves oblong-lanceolate or oblanceolate, entire or somewhat dentate, acute or acuminate, erect or nearly so, $15-40 \mathrm{~cm}$. long, narrowed at base into a short petiole; cauline shorter and relatively broader, sessile and partly clasping at base; stems $30-60 \mathrm{~cm}$. high, bearing a terminal head and usually 1-5 smaller lateral ones, all peduncled; involucre $2-3 \mathrm{~cm}$. high; bracts lanceolate, acute, the outer ones longest, loose, somewhat spreading; rays bright-yellow, about $3 \mathrm{~cm}$. long; akenes clavate, $8-10 \mathrm{~mm}$. long, with a well developed crown, cut into small teeth and rarely bearing 1-2 awns. Abundant in wet meadows. This plant is one of the so-called "compassplants." F\%. May

\section{HELIANTHELLA.}

Perennial herbs; leaves entire, opposite or the upper alternate; heads large, terminal, chiefly solitary and long-peduncled; flowers yellow; ray-flowers neutral; disk-flowers perfect; receptacle flat or convex, chaffy; pappus a pair of persistent awns or chaffy teeth, and a crown of intermediate thin chaffy scales; ray-akenes laterally compressed; disk-akenes 4-angled or laterally compressed, all very flat, winged when young.

Helianthella douglasii T. \& G. Rough-hairy throughout, simple or branched above, erect, $60-120 \mathrm{~cm}$. high; leaves opposite, or the upper alternate; lower ones spatulate-lanceolate, obtuse or acute, 6-15 $\mathrm{cm}$. long, the upper cauline lanceolate, sessile, smaller; heads solitary and terminal or several, terminating the branches; involucres $2-3 \mathrm{~cm}$. broad, the bracts lanceolate, hirsute-ciliate, little imbricated; rays $2-3 \mathrm{~cm}$. long; akenes obovaté, more or less ciliate; pappus a pair of long chaffy awns, with broadened bases. Rocky hillsides, common.

415. HELIANTHUS. SUNFLOWER.

Coarse annuals or perennials; leaves entire or toothed, all or at least the lower ones opposite; heads solitary or corymbose, 
medium or large; ray-flowers yellow, sterile; disk-flowers yellow, brownish or dark-purple; receptacle flat or convex; pappus a pair of early-falling chaffy scales or awns; akenes neither very flat nor winged; ray-akenes laterally compressed; disk-akenes 4-angled, compressed.

Helianthus annuus L. Annual, the stems rough-hairy, erect, 1-2 m. high or depauperate forms much smaller; leaves alternate, except the lowest, all petioled, 3-ribbed at base, ovate, acute, dentate or entire, very rough on both sides, the lower somewhat cordate, very variable in size; heads $5-15 \mathrm{~cm}$. broad; receptacle flat or depressed; chaff shorter than the flowers, usually 3-cleft; disk dark-colored; a kenes pubescent, 5-8 mm. long; pappus of 2 scales. Common in dry meadows in the lower valleys.

\section{GRINDELIA. Gum Plant.}

Biennial or perennial herbs; leaves sessile or partly clasping; heads yellow, medium or rather large, solitary, terminating leafy branches, or occasionally more or less corymbose, many-flowered, gummy; rays fertile, numerous, narrow, or rarely none; involucral-scales numerous, narrow; receptacle flat or convex; pappus of 2-8 rigid and early-deciduous awns; style-branches tipped with an appendage; akenes compressed or turgid or the outermost somewhat 3-angled.

Grindelia nana Nutt. Stems erect, $15-60 \mathrm{~cm}$. high, simple or branched above; basal leaves spatulate, petioled, the upper sessile and partly clasping, entire or serrate, glabrous; heads hemispherical, $10-14 \mathrm{~mm}$. broad; bracts with slender revolute tips, sticky-viscid; rays 16-30, 5-8 cm. long; akenes narrow, somewhat 2-toothed at summit; pappus awns 2 or 3 . In thin soils, usually abundant where found.

\section{ERIOPHYLLUM.}

Perennial herbs, sometimes shrubby at base; leaves usually alternate and entire or pinnately or ternately parted or lobed; ray-flowers present, fertile; involucre campanulate or obovoid; bracts erect, commonly united at base, oval or oblong; pappus of nerveless and mostly pointless scales; throat or limb of diskcorollas rather narrow; style-branches truncate or rarely minutely tipped; akenes narrow, mostly 4-angled.

Akenes glandular.

Akenes glabrous or nearly so.

Leaves all entire or subentire.

Leaves mostly cleft or parted.

E. multiflorum.

E. pedunculatum. E. lanatum.

Eriophyllum multiflorum (Nutt.) Rydb. Much like E. pedunculatum and equally variable; leaves of the flowering stems varying from linear to oblanceolate, entire or 3-lobed at the apex, those of the sterile shoots 5-7-lobed or cleft; akenes glandular, $4 \mathrm{~mm}$. long. Common especially in the sagebrush region. 
Eriophyllum pedunculatum Heller. Stems several, erect, simple, 30-50 $\mathrm{cm}$. high; leaves all entire or obscurely denticulate, oblong-lanceolate, $3-5 \mathrm{~cm}$. long, acute, densely white-tomentose beneath, green and sparsely tomentose above; heads long-peduncled; involucre lanate, the bracts acuminate with recurved tips; corollas glandular; akenes glabrous. Near Lake Waha, Heller.

Eriophyllum lanatum (Pursh) Forbes. Perennial, erect or decumbent at base, loosely white-woolly throughout; leaves spatulate or cuneate-obovate, the lowermost and upper ones often entire, the others 3-7-lobed or parted; heads long-peduncled; involucre lanate, campanulate, $10-12 \mathrm{~mm}$. high; bracts $8-12$, oblong, obtuse; rays $6-15$, golden-yellow; disk-corollas glandular; akenes glabrous; pappus short. In gravelly soil, common and variable. F. Mpril- Yacy

\section{RIGIOPAPPUS.}

Annuals; leaves alternate, linear, entire; heads rather manyflowered; ray-flowers 5-12, pistillate; all the flowers fertile; involucre of one or two rows of rather rigid herbaceous erect subulate-linear bracts; receptacle flat, naked; pappus of 3-5 rigid opaque subulate awn-shaped scales; akenes linear, slender, compressed, those of the disk more or less 4-angled.

Rigiopappus leptocladus Gray. Erect, slender, minutely pubescent, 10-30 $\mathrm{cm}$. high, simple or usually with slender branches that are leafless below; leaves alternate, linear, acute, erect, $1-3 \mathrm{~cm}$. long, or those near the tips of the slender branches much smaller; heads $8-10 \mathrm{~mm}$. high; flowers yellow or purplish; akene linear, transversely rugose, hirsute, $5 \mathrm{~mm}$. long; pappus of 3-5 rigid lanceolate scales nearly as long as the akenes. In sandy soil in the lower valleys.

\section{GAILLARDIA.}

Pubescent herbs; leaves alternate, entire or incised or even pinnatifid; heads solitary and long-peduncled, large; ray-flowers yellow or partly dark-purple, sterile; disk-flowers usually purplish or brownish; involucral-bracts in 2-3 series, the outer larger and foliaceous; receptacle convex or hemispherical, with one or more awns among the flowers resembling chaff; pappus of 6-10 hyaline chaffy scales with a prominent midrib which is prolonged into a naked awn, or in the sterile rays, scales awnless; akenes oblong, top-shaped, each surrounded by a tuft of hairs.

Gaillardia aristata Pursh. Perennial, erect, 30-60 cm. high, roughpubescent; lower leaves spatulate, long-petioled, the upper sessile, all entire or more or less pinnately lobed, $5-12 \mathrm{~cm}$. long; heads long-peduncled; involucre hairy, the lanceolate acuminate bracts unequal, the longest about 1 cm.; disk-flowers dark-purple; rays 10-18, yellow, purplish at base, 15-20 mm. long; bristles of the receptacle as long as the akenes or longer." Prairies, common. F\% Mag- Tume.

\section{HELENIUM.}

Erect, simple or branching herbs; leaves all alternate and all but the lower sessile; heads small or large, many-flowered, on naked terminal peduncles; ray-flowers yellow, several or numer- 
ous, pistillate; disk-flowers yellow or turning brownish or purplish, small and very numerous, all fertile; involucral bracts spreading or reflexed at maturity; pappus of 5-12 thin or hyaline chaffy scales with or without midribs; akenes top-shaped, striate-ribbed, hairy on the ribs.

Helenium autumnale grandiflorum (Nutt.)' Gray. Perennial, erect, 30-90 $\mathrm{cm}$. high, glabrous or puberulent; leaves oblong or ovate-lanceolate, acute, dentate or nearly entire, 5-12 cm. long, decurrent on the stem forming wings, heads few or many, long-peduncled, $10-15 \mathrm{~mm}$. broad; involucre nearly flat, the bracts linear or linear-spatulate, pubescent; rays 10-16, yellow, somewhat drooping, 1-2 cm. long, all fertile; akenes pubescent; pappus scarious, the scales acuminate, awn-pointed. Banks of Snake River.

\section{ADDENDA.}

(Insert on page 253.)

\section{IVA.}

Heads in dense panicles; leaves ovate to orbicular, coarsely serrate.

Heads solitary, axillary; leaves oblong to obovate, most entire.

I. xanthiifolia.

I. axillaris.

Iva xanthiifolia Nutt. See page 253.

Iva axillaris Pursh. Stems erect or nearly so, 30-60 cm. tall, simple or but little branched, arising from creeping rootstocks; leaves numerous, firm in texture, narrowly oblong to obovate, sessile, entire or nearly so, obtuse; 2-3 cm. long; heads axillary, mostly solitary, the peduncle much shorter than the leaf; involucre hemispheric, the bracts united into a 4- to 5-lobed or cleft cup. Washtucna, Elmer. Abundant in the sagebrush region. 


\section{GLOSSARY.}

Acaulescent. Stemless or apparently so, or with the stem underground.

Acerose. Needle-shaped; with a sharp rigid point.

Acrid. Sharp and harsh to the taste. Adnate. United, especially where different organs are fused.

A kene. A dry, one-celled, one-seeded, indehiscent fruit.

Alveolate. Resembling a honeycomb.

Ament. A catkin; a scaly spike.

Amphitropous (ovule or seed). Halfinverted and straight but with a lateral hilum.

Ampliate. Abruptly expanded.

Anatropous (ovule or seed). Inverted and straight with the micropyle next to the hilum.

Androgynous. Having both staminate and pistillate flowers.

Annulus. A ring, especially the ring of thick-walled cells on a fern sporangium.

Apiculate. Ending in a short pointed tip.

Appressed. Lying close and flat against.

Aristate. Tipped with a stiff short bristle.

Atomiferous. Bearing minute scattered granules.

Auricle. An ear-shaped appendage.

Awn. A bristle-like terminal or dorsal appendage.

Barbellate. Minutely barbed.

Bifid. Two-cleft.

Bilabiate. Two-lipped.

Biternate. Twice-ternate.

Bract. A modified reduced leaf occurring in the inflorescence.

Bracteate. Having bracts.

Bracteolate. Having small bracts.

Callosity. A hardened thickening.

Callus. A hard protuberance; in the grasses, the tough often hairy swelling at the base of the lemma or palet.
Calyculate. Having bracts around the flower which imitate a calyx.

Campanulate. Bell-shaped, that is cup-shaped with a broad base.

Canescent. Hoary with a grayish pubescence.

Capillary. Hair-like.

Capitate. Shaped like a head; collected into a head.

Carpel. A simple pistil or one of the units of a compound pistil.

Carpophore. The slender prolongation of the axis which bears the ripe carpels (Umbelliferae).

Cartilaginous. Firm and tough, cartilage-like.

Caryopsis. A grain, that is a seedlike fruit with a thin wall adherent to the single enclosed seed (Poaceae).

Caudex. The persistent base of an otherwise annual herbaceous stem.

Caudicula. The thread-like or strapshaped stalk of a pollinium.

Caulicle. The stem-like part of an embryo; the hypocotyl.

Cauline. Pertaining to the stem; on the stem.

Cernuous. Nodding; slightly drooping.

Cespitose. Growing in tufts; forming mats.

Chaff. A small thin bract becoming dry and membranous.

Chartaceous. Papery.

Chlorophyll. The green coloringmatter found in plants.

Ciliate. Fringed with hairs on the margin.

Ciliolate. Minutely ciliate.

Circumscissile. Opening by the formation of a circular line of cleavage and the falling off of the top like a cap.

Clavate. Club-shaped, gradually thickened upwards.

Cleft. Margin indented half way to the midrib or more, especially if the incisions are sharp. 
Cleistogamous. Pollinated in the bud, without the flowers opening.

Commissure. The surface by which one carpel joins another (Umbelliferae).

Compressed. Flattened, especially laterally.

Coriaceous. Leathery.

Corm. The enlarged fleshy base of a stem; like a bulb but solid.

Cotyledon. The first leaves of the embryo plant already formed in the seed.

Crenulate. Finely crenate.

Crested. With an upraised crest-like appendage.

Crustaceous. Hard and brittle.

Culm. A hollow stem (Poaceae).

Cuneate. Wedge-shaped.

Cuspidate. Tipped with a cusp, that is a sharp rigid point.

Cymose. Bearing cymes, or cymelike.

Declined. Bent downward.

Decompound. More than once compound.

Decumbent. Reclining but with the apex ascending.

Decurrent. Extending down the stem below the point of insertion.

Dehiscence. The method of opening.

Deltoid. Triangular with the apex upward.

Denticulate. Minutely dentate.

Diadelphous. Stamens in two separate groups.

Diandrous. With two stamens.

Didynamous. Stamens in two pairs of unequal length.

Diffuse. Widely or loosely spreading.

Dioecious. Stamens and pistils on different plants.

Discoid. Disk-like; in the Compositae, a discoid head is one without ray-flowers.

Disk-flowers. The flowers with tubular corollas which are in the center of the head in certain Compositae.

Dissected. Divided into numerous small segments.

Divaricate. Widely divergent.

Divergent. Spreading away from each other.
Divided. Margin indented to the midrib but the segments not quite distinct.

Dorsal. Relating to or attached to the back of an organ.

Drupaceous. Drupe-like.

Drupe:' A fleshy fruit with the inner portion hard and stony, one-celled and containing but one seed.

\section{Ebracteate. Without bracts.}

Elaters. Thread-like appendages to spores which curl and uncurl with changes in the moisture conditions of the air.

Emarginate. Having a very shallow notch at the apex.

Embryo. The tiny plant as it rests partly grown in the seed.

Endosperm. The food cells in the seed surrounding the embryo.

Epicotyl. The growing point and young bud in the embryo in the seed.

Epigynous. Apparently growing on top of the ovary.

Equitant. Astride; as when leaves are alternately folded over each other in two ranks (Iris).

Erose. Irregularly toothed as if the margin were gnawed out.

Evanescent. Soon fading away.

Exserted. Projected beyond an envelope, as the stamens from the corolla.

Falcate. Scythe-shaped.

Farinaceous. Containing starch; starch-like.

Fascicle. A close bundle or cluster.

Fasciculate. In close bundles (fascicles).

Fertile. Capable of producing pollen or fruic.

Fibrous. Composed of or resembling fibers.

Fimbriate. Fringed.

Fimbrillate. With a minute fringe.

Flexuous. Zigzag; bending alternately in opposite directions.

Floccose. With fleshy tufts of soft woolly hairs.

Foliaceous. Leaf-like.

Fornix, (plural-fornices). A swelling in the throat of the corolla.

Fugacious. Fading or falling very early. 
Fuscous. Grayish-brown.

Fusiform. Spindle-shaped.

Galea. A helmet-shaped or beak-like upper lip of a corolla.

Galeate. Helmet-shaped; having a galea.

Geniculate. Bent abruptly, like a knee.

Gibbous. With a protuberance or swelling on one side.

Glabrate. Nearly glabrous or becoming glabrous.

Gland. A secreting organ or a protuberance resembling one.

Glaucescent. Somewhat glaucous.

Glaucous. Covered with a whitish bloom.

Glochidiate. Barbed at the tip.

Glomerate. In small compact clusters.

Glumaceous. Glume-like.

Glume. A chaff-like bract, especially the two empty bracts at the base of a grass spikelet.

Glutinous. Sticky, glue-like.

Grain. A one-celled, one-seeded indehiscent seed-like fruit in which the wall of the fruit adheres to the seed, a caryopsis.

Granulate. Appearing as if covered with minute granules.

Gynobase. An enlargement or prolongation of the receptacle bearing the ovary or in the fruit the nutlets (Boraginaceae).

Hastate. Halberd-shaped.

Haustoria. Root-like organs which parasitic plants send into the cells of their hosts to absorb food.

Hermaphrodite. Having both sexes; in flowering plants, with both stamens and pistils.

Hilum. The attachment scar on the seed.

Hirsute. Pubescent with rather coarse stiff hairs.

Hispid. Covered with rigid hairs or bristles.

Hyaline. Transparent or translucent.

Hypocotyl. The stem-like part of the embryo (caulicle).

Hypogynous. Attached to the receptacle below and entirely free from the ovary.
Imbricated. Overlapping and breaking joints like shingles.

Incised. Cut sharply and irregularly more or less deeply.

Indehiscent. Not opening when ripe.

Indurated. Hardened.

Indusium. The protective membranous covering formed over the fruitdot in many ferns.

Involucel. A secondary involucre enveloping an umbellet (Umbelliferae).

Involucrate. Having an involucre.

Involucre. A circle or cluster of bracts surrounding a flower or group of flowers.

Involute. Rolled inward.

Keel. A projecting midrib on the dorsal side of a leaf or scale; the two anterior united petals in a papilionaceous flower (Leguminosae).

Lacerate. Irregularly cleft as if torn.

Laciniate. Cut into narrow pointed lobes.

Lemma. A bract in a grass spikelet which bears a flower in its axil.

Lenticular. Lentil-shaped, that is, with the shape of a double-convex lense.

Ligulate. Strap-shaped; or with strapshaped corollas.

Ligule. A thin often scarious projection from the summit of the leaf-sheath in grasses and similar plants.

Limb. The expanded part of a petal or sepal.

Lobed. Margin indented less than half way to the midrib.

Locule. One of the cavities or cells in an ovary.

Loculicidal. Dehiscing so that the clefts open into the cavities of the ovary.

Lodicule. One of the tiny scales sometimes found in a grass flower.

Lunate. Crescent-shaped or halfmoon-shaped.

Lyrate. Pinnatifid with a large and rounded terminal lobe and the lower lobes small.

Megasporangium. The case in which the megaspores are produced. 
Megaspore. One of the large spores in certain fern allies and the seed plants, which is stored with food and which produces a female gametophyte.

Membranaceous. Membrane-like; thin, soft and more or less translucent.

Microsporangium. The case in which microspores are produced; a cell of an anther.

Microspore. One of the small spores in certain fern-allies and the seedplants, which produce the male gametophyte; a pollen grain.

Monadelphous. Stamens united all in one cluster.

Moniliform. Appearing like a string of beads.

Monoecious. With stamens and pistils in separate flowers on the same plant.

Mucronate. Tipped with a short small abrupt tip.

Mucronulate. Slightly mucronate.

Muricate. Rough with short hard points.

Muriculate. Very finely muricate.

Narcotic. Numbing or sleep-producing.

Nectariferous. Producing nectar.

Nectáry. An organ or a spot where nectar is secreted.

Nerve. A small slender usually unbranched rib.

Neutral. Without stamens or pistils.

Node. The place in a stem where the woody bundles fuse and where the leaves and buds are normally produced.

Nut. A hard indehiscent one-celled and one-seeded fruit, though usually developing from a compound ovary.

Nutlet. A tiny nut.

$O b$ - Inverted.

Obcompressed. Compressed dorsoventrally instead of laterally.

Obsolete. Not evident.

Ochroleucous. Yellowish-white.

Ocrea. A tubular stipule (Polygonceae).

Olivaceous. Olive-green.

Operculum. A lid; the cap of a circumscissile capsule.
Orthotropous (ovule or seed). Erect, with the micropyle at the apex opposite the hilum.

Palea. A delicate bract which encloses the grass flower and stands spposite the lemma.

Panicle. A loose irregularly compound inflorescence with pedicelled flowers.

Paniculate. Borne in panicles; resembling a panicle.

Papilionaceous. Butterfly-like, that is having the upper petal enlarged and spreading, the two lateral ones small and oblique, and the two anterior ones connivent into a keel.

Papillose. Having minute nipple-like projections.

Pappus. The modified calyx-limb in the Compositae, composed of a ring or a crown of hairs, chaff or scales.

Parasitic. Depending on another living organism for its food-supply.

Parted. Margin indented nearly but not quite to the midrib.

Pectinate. Pinnatifid, with narrow close segments; comb-like.

Pellucid. Clear, transparent.

Peltate. Shield-shaped, with its stalk attached near the center of the dorsal surface.

Pentamerous (5-merous). Five in number.

Penultimate. The next to the last.

Pericarp. The matured ovary wall forming a protective coat in the fruit.

Perigynium. The inflated sac which encloses the ovary in Carex.

Perigynous. Around the ovary; that is, adnate to the perianth or to a receptacle-cup.

Petiolulate. Having a petiolule.

Petiolule. The stalk of a leaflet.

Pilose. With soft hairs.

Pinnule. One of the smaller subdivisions of the primary divisions of a pinnately compound leaf.

Pistil. The organ in the flower which produces the ovules and provides for their pollination.

Plumose. Having fine hairs like a plume.

Plumule. The growing-point or bud of an embryo (epicotyl). 
Pollinium. A mass of waxy pollen composed of coherent pollen-grains (Orchidaceae).

Polygamo-dioecious. With perfect and staminate flowers on some plants and perfect and pistillate flowers on others.

Polygamous. Having both perfect and unisexual flowers on the same plant.

Prismatic. Angular with flat sides, like a prism in shape.

Pruinose. Covered with a whitish powder.

Puberulent. Minutely pubescent.

Pubescence. Hairiness.

Pubescent. Covered with hairs, especially short soft ones.

Pulvinus. A cushion-like swelling.

Punctale. Dotted.

Pungent. Terminated in a rigid sharp point; penetrating.

Pyramidal. Pyramid-like.

Pyriform. Pear-shaped.

Quadrifoliolate. With four leaflets.

Raceme. A simple inflorescence of pedicelled flowers on a common more or less elongated axis.

Rachilla. The axis of a grass spikelet.

Rachis. The main axis of an inflorescence.

Radiate. Arranged radially from a center; having ray-flowers.

Radical. Pertaining to the root; occurring at the base of the stem.

Raphe. The ridge on a more or less inverted seed caused by the fusion of the stalk with the seed.

Ray. A branch of an umbel; a rayflower.

Ray-flower. One of the marginal ligulate flowers of a radiate head in the Compositue.

Receplacle. The modified axis on which the flower parts are borne.

Reniform. Kidney-shaped.

Resiniferous. Producing resin.

Reticulated. In the form of a network; net-veined.

Retrorse. Directed backward.

Rotate. Wheel-shaped; flat and circular in outline.

Rudiment. A partially developed functionless organ.

Rugose. Wrinkled.
Rugulose. Slightly wrinkled.

Saccate. Sac-shaped.

Sagittate. Arrow-shaped.

Salverform. Having a slender tube abruptly expanded into a flat limb.

Salient. Prominent.

Samara. An indehiscent winged fruit (Aceraceae).

Saprophylic. Depending on dead organic matter for its food.

Scabrid. Minutely scabrous.

Scabrous. Covered with short hairs or points.

Sca pose. Bearing or resembling a scape.

Scarious. Thin dry membranaceous, not green.

Secund. One-sided.

Septicidal. Dehiscing through the partitions and between the cells.

Septifragal. Dehiscing into parts which break away from the partitions.

Serratures. Serrations.

Serrulate. Finely serrate.

Setaceous. Bristle-like.

Sheath. A tubular envelope like the lower part of the leaf in the grasses.

Silicle. A short silique (Cruciferae).

Silique. A long 2-celled slender pod (Cruciferae).

Sinuate. Outline strongly wavy.

Sinus. The recess or indentation between two lobes.

Sordid. Dirty-white.

Sorus. A cluster of spore-cases; a fruit-dot (Polypodiaceae).

Spathaceous. Spathe-like.

Spathe. A large petal-like bract enclosing an inflorescence.

Spatulate. Gradually narrowed downward from a rounded summit.

Spike. A simple inflorescence with the flowers sessile on a more or less elongated common axis.

Spikelet. A small spike, especially the peculiarly specialized one in the grasses.

Spinescent. Becoming spiny.

Spinulose. With very small spines.

Sporangia. Spore-cases.

Sporocarp. A pod-like structure enclosing the spore-cases (Marsileaceae).

Spur. A hollow sac-like or tubular extension of the calyx or corolla or both, usually nectariferous. 
Stellate-pubescent. With star-shaped hairs.

Sterile. Incapable of producing; as a flower without a pistil or a stamen without an anther.

Stipel. A stipule-like organ at the base of a leaflet.

Stipitate. With a stalk.

Stolon. A runner or a basal branch that tends to strike root.

Stoloniferous. Having stolons.

Striate. Marked with longitudinal lines or ridges.

Strigose. Covered with short stiff straight appressed hairs.

Strophiole. An appendage near the hilum on certain seeds.

Stylopodium. A disk-like expansion at the base of the style (Umbelliferae).

Suffrutescent. Slightly or obscurely shrubby.

Sub- Somewhat or slightly.

Subulate. Awl-shaped.

Succulent. Juicy; fleshy.

Supra-axillary. Produced not in but above the leaf-axils.

Suture. The line of dehiscence.

Syngenesious. Stamens with united anthers but separate filaments.

Tawny. Dull yellowish brown.

Terete. Cylindrical or nearly so; not compressed.

Ternate. In threes.

Tetradynamous. With four long and two short stamens.

Thallus. A plant body not differentiated into root stem and leaf.

Thyrsoid. Resembling a thyrsus.

Thyrsus. A contracted cylindrical ovoid and usually compact panicle.
Torulose. Cylindrical with contractions at intervals.

Tridentate. Having three teeth.

Truncate. Endling abruptly as if cut off squarely.

Tuberiferous. Bearing tubers.

Turbinate. Top-shaped; inversely conical.

Turgid. Swollen; distended by pressure from within.

Umbellate. In umbels or like an umbel.

Unisexual. Having but one sex; in flowering plants with either but not both stamens or pistils.

Utricle. A small bladder-like oneseeded fruit.

Vascular. Having woody bundles.

Velum. The membrane partly covering the sporangium in the leaf of Isoetes.

Ventral. Belonging to the anterior or inner face of an organ; the opposite of dorsal.

Villous. With numerous long and soft hairs.

Virgate. Wand-shaped; slender, straight, erect.

Viscid. Glutinous, sticky.

Whorl. Leaves or other parts arranged in a circle of three or more at the same node.

Zygomorphic. Bilaterally symmetrical; that is, capable of being divided symmetrically in but one plane. 


\section{INDEX.}

Abies.................... 11

Acer.................. 160

Aceraceae. . . . . . . . . . 159

Achillea................. 262

Aconite.................. 110

Aconitum................ 109

Actaea ................. 110

Adenocaulon.............. 253

Adder's tongue............. 61

Agastache.............. 216

Agoseris................. 248

Agropyron.............. 39

Agrostemma.............. 95

Agrostideae............... 19

Agrostis............... 26

Aizoaceae.............. 91

Alchemilla . . . . . . . . . . . . 137

Alder.................... 77

Alfalfa................ 149

Alfilaria............... 155

Alisma................ 17

Allium ................ 59

Allocarya............... 210

Almond willow................ 73

Alnus................... 77

Alopecurus.............. 24

Alsike clover............... 147

Alsine.................... 98

Alum root............... 130

Alyssum................ 120

Amaranth................ 90

A maranth family............. 90

Amaranthaceae . . . . . . . . . 90

Amaranthus............. 90

Ambrosia................... 257

Amelanchier. . . . . . . . . . . 133

Ammannia ................ 168

Amsinckia............... 208

ANACARDIACEAE. . . . . . . . 158

Anaphalis................ 256

Anemone............... 103

Angelica................ 179

AngiospermaE ............ 12

Antennaria................ 254

Anthemis................ 263

APOCYNACEAE . . . . . . . . . . . 194

Apocynum . . . . . . . . . . . . . 194

Aquilegia . . . . . . . . . . . 110

Arabis................ 115
Araceae............... 52

Aralia................. 175

Araliaceae............. 175

Arbor vitae............... 10

Arctostaphylos............... 189

Arenaria................. 100

Argentina............... 124

Aristida............... 22

Aristolochiaceae......... 81

Arnica ................. 272

Arrhenatherum.......... 27

Arrow grass................. 16

Arrow grass family. .......... 16

Arrowhead.................. 17

Artemisia.............. 253

A rum family............ 52

Asarum................ 81

Asclepias. . . . . . . . . . . . . 195

Asclepiadaceae. . . . . . . . . 195

Ash, Mountain............ 134

Aspen................. 75

Aster.................... 268

Astragalus............... 151

Atriplex.............. 88

Athyrium............... 3

Athysanus.............. 114

Avena................. 28

Aveneae.............. 19

Bachelor's button. . . . . . . . 251

Balsam family. ............... 160

Balsaminaceae. . . . . . . . . 160

Balsamorhiza............... 264

Baneberry................ 110

Barberry family............. 111

Barnyard grass............... 20

Barley, Wild.............. 41

Wall............... 41

Batrachium................. 105

Bear grass................ 64

Beard-tongue. . . . . . . . . . 221

Beckmannia............ 38

Bedstraw................. 233

Beech fern................ 2

Beggar ticks............... 276

Bellflower. . .............. 241

Bellflower family. . . . . . . . . 239

Berberidaceae............. 111

Berberis............... 111 
Bergia................. 164

Berula............... 183

Betula............... 77

Betulaceae............ 76

Bidens.................. 276

Bikukulla............... 112

Birch.................. 76

Birch family............. 76

Birthwort family. . . . . . . . . 81

Bitter cress..............115, 130 root............... 92

Bittersweet................ 218

Black medic. . . . . . . . . . . . . 149

mustard.............. 118

Blackcap.................. 136

Bladder fern............. 4

Blite.................. 89

Strawberry........... 89

Blitum.................. 89

Bluebells............... 206

Blue-eyed grass............. 66

Blue-flowered lettuce. . . . . . . . 249

Bluegrass................. 33

Annual............. 34

Canada.............. 34

Kentucky............ 34

Fowl.............. 35

Bluestem............... 39

Boisduvalia ............ 172

Bolelia................. 240

Borage family. . . . . . . . . 204

BoraginaCEAE . . . . . . . . . 204

Botrychium............ 4

Brasenia................. 102

Brassica................ 118

Bromegrass............... 32

Bromus............... 32

Broomrape family. . . . . . . . 231

Buckbean................. 194

Buckbrush.............. 162

Buffalo bur............... 218

Bugseed................. 88

Bull thistle................... 260

Bulrush, Western............ 51

Bunchgrass, Blue........... 37

Wheat................. 39

Bur reed................... 13

Bur-reed family............ 13

Bursa.................... 123

Butter and eggs............... 220

Buttercup................. 105

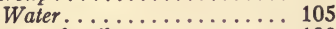

Buttercup family............. 102

Button, Bachelor's............ 251

Cabbage, Yellow skunk....... 52

Cactaceae............... 167
Cactus family............ 167

Calamagrostis............ 25

Callitrichaceae........... 157

Callitriche.............. 158

Calochortus............... 60

Calypso.................. 69

Camas................... 62

Death............... 62

Camelina................ 121

Campanula............. 241

Campanulaceae .......... 239

Campe.................. 120

Canada thistle............. 260

Canary grass............. 22

Reed............... 22

Caper family............... 123

Capnoides............... 112

Capnorea................ 202

Capparidaceae .......... 123

Caprifoliaceae........... 235

Caraway................ 182

Cardamine............... 115

Carduus................. 260

Carex................ 43

Carpet weed............. 91

Carpetweed family........... 19

Carum................. 182

Caryophyllaceae . . . . . . . 95

Cascara sagrada........... 161

Cashew family. . . . . . . . . . 158

Castilleja............... 229

Catchfly................ 96

Cat-tail................ 13

Cat-tail family............. 13

Caucalis................ 178

Ceanothus............... 161

Cedar, Giant.............. 10

Celastraceae.............. 159

Celtis................ 78

Centaurea............... 251

Centaurion.............. 192

Centunculus.............. 191

Cephalanthera............ 69

Cerastium.............. 98

Cercocarpus............. 132

Chaenactis .............. 261

Chaetochloa.............. 20

Chamomile, corn ............ 263

Charlock................. 118

Cheeses.................... 163

Cheilanthes.............. 2

Chenopodiaceae........... 87

Chenopodium ............ 89

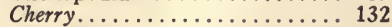

Wild .................. 132

Chickweed............... 98

Mouse-ear........... 98 
Chimaphila

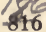

Chinese thistle............... 257

Chlorideae............... 20

Chokecherry.............. 132

Chrysanthemum........... 262

Chrysopsis................. 271

Chrysothamnus........... 259

Cicuta................ 182

Cinna.................. 24

Circaea................... 169

Cirsium. ................ 259

Clarkia.................. 171

Claytonia................ 93

Cleavers................ 233

Clematis................. 103

Cleome................. 123

Clintonia............... 63

Clover................... 146

Alsike............... 147

Rabbit's ear............ 147

Red ............147, 148

Sweet.............. 149

White................ 147

Cockle, Corn.............. 95

Cow.............. 96

Cocklebur............256, 257

Cogswellia................ 179

Coleosanthus.............. 258

Collinsia ................. 223

Collomia................. 201

Coltsfoot, Sweet. . . . . . . . . . 252

Comandra............... 80

Comarum................ 141

Common flax. . . . . . . . . . . . 156 plantain............. 232

Compositae .............. 241

Convolvulaceae.......... 196

Convolvulus.............. 196

Coptis................. 111

Coral root............... 68

Corallorhiza.............. 68

Coreopsis................ 276

Coriospermum ............ 88

Corn chamomile............ 263 cockle.............. 95

Cornaceae. . . ......... 184

Cornus................. 185

Cottonwood ........................ 76

Couch grass................. 40

Couse.................. 180

Cow cockle............... 96 parsnip............... 179

Cranberry, High-bush......... 236

Crassulaceae............ 124

Crataegus................ 133

Crepis..................... 250

Cress, Bitter. ...........115, 120
Cress Penny............... 123

Rock................. 115

Crocidium.............. 275

Crowfoot, Water............ 105

Cruciferae. . . . . . . . . . 113

Cryptanthe................ 209

Cudweed................ 252

Currant................ 125

Golden............... 126

Cuscuta................. 196

Cuscutaceae.............. 196

Cyperaceae............ 42

Cyperus................. 49

Cypripedium............. 68

Cytherea................. 69

Dactylis................ 33

Daisy, Oxeye............. 262

Dandelion................ 248

Datura................. 218

Death camas.............. 62

Delphinium.............. 108

Deschampsia............. 28

Devil's club................ 175

Dewberry................ 136

Dicotyledones.......... 72

Dipsacaceae. . . . . . . . . 239

Dipsacus............... 239

Disporum.............. 64

Dock.................... 83

Yellow................ 84

Dodder.................... 196

Dodder family................. 196

Dodecatheon............. 190

Dogbane................. 194

Dog fennel. . . . . . . . . . . . 263

Dogwood.................. 185

Dogwood family............ 184

Draba................. 121

Dracocephalum........... 215

Drymocallis............... 142

Duckweed family............ 53

Dutchman's breeches.......... 112

Echinochloa............. 20

Echinopanax............. 175

Elatinaceae. . . . . . . . . . 164

Elatine........................ 164

Elder.................... 235

Eleocharis.............. 50

Elm family............. 78

Elymus................... 40

English plantain........... 233

Epilobium............. 170

Epipactis.............. 72

EQuisetaceae............ 5

EquisetineaE............ 5 
Equisetum............. 6

Eragrostis.............. 30

Ericaceae.............. 188

Ericameria.............. 265

Erigeron............... 266

Eriogonum............. 82

Eriophyllum ............ 278

Erodium............... 155

Eryngium.............. 177

Erysimum.............. 117

Erythronium............. 61

Euphorbia............. 157

EUPHORBIACEAE ............ 156

Euthamia............... 272

Evening primrose........... 173

Evening primrose family. . . . . 168

Everlasting............... 254

False flax.............. 121

pimpernel................ 226

Fennel, Dog. . . . . . . . . . 263

Fern plants.............. 1

Fescue................ 36

Festuca............... 36

Festuceae............... 20

Figwort................. 223

Figwort family. . . . . . . . . . . 219

Filaree ............... 155, 219

FILICINEAE . . . . . . . . . 1

Filix.............. 4

Fir, Red.............. 12

Subalpine............... 12

White................. 12

Fireweed............... 170

Flax .................. 156

Common............. 156

False................. 121

Flax family................ 155

Fleabane.............. 226

Forget-me-not............. 208

Forsellesia................. 159

Foxtail, Green . . . . . . . . . 21

Fragaria.............. 141

Frasera................ 193

Fritillaria............. 61

Gaertneria.............. 258

Gaillardia................. 279

Galium.................. 233

Gaura.................... 169

Gayophytum............ 172

Gentian.................... 192

Gentian family. . . . . . . . . . . 192

Gentiana................. 192

Gentianaceae............ 192

GeraniacEAE. . . . . . . . . 154

Geranium.............. 154
Geranium family. ........... 154

Geum. . . ............... 138

Ginger, Wild............. 81

Ginseng Family. ........... 175

Githopsis................. 240

Glycyrrhiza. . . . . . . . . . 149

Gnaphalîum............ 252

Golden Currant............ 126

Goldenrod............... 272

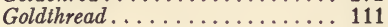

Gooseberry............... 125

Goosefoot................ 89

Goosefoot family. . . . . . . . 87

Grape, Oregon . . . . ......... 111

Grape fern............... 4

Grass, Annual blue.......... 33

Barnyard............ 20

Bear................. 64

Blue............... 33

Blue bunch............ 37

Blue-eyed............. 66

Brome............... 32

Canada Blue............. 34

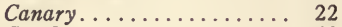

Couch................ 40

Fowl blue.............. 35

Kentucky blue.......... 34

Orchard.............. 33

Nut............... 49

Orchard.............. 33

Ouack.............. 40

Reed canary........... 22

Reed meadow. . . . . . . .... 38

Rye.............. 40

Squirrel tail............ 41

Tall meadow oat. . ....... 27

Velvet............... 27

Wheat............... 39

Wheat Bunch........... 39

Wool................ 46

Grass family............... 18

Gratiola................. 224

Grindelia............... 278

Gum plant................. 278

GYMNOSPERMAE......... 8

Hackberry............. 78

Hawkweed . . . . . . . . . . 250

Hawthorn. . . . . . . . . . . . 133

Heal All. . . . . . . . . . . . . . 215

Heart-leaved willow......... 74

Heather family................ 188

Hedge hyssop............. 224

Hedge mustard. . . . . . . . . . . . 119

Helenium ............... 279

Helianthella............... 277

Helianthus.............. 277 
Heliotrope.............. 205

Heliotropium............. 205

Hellebore, False............ 64

Green............... 65

White.............. 65

Hemicarpha............ 52

Hemizonia. . . . . . . . . . . . 264

Heracleum............. 178

Heteranthera............ 53

Heterocodon.............. 241

Heuchera................ 130

Hieracium ............. 250

High-bush cranberry......... 236

Holcus................ 27

Holodiscus.............. 134

Honeysuckle............... 237

Hookera............... 58

Hoorebekia............. 273

Hordeae................. 20

Hordeum.............. 41

Horehound. . . ........... 215

Hosackia............... 151

Horsetail................. 6

Huckleberry. . . . . . . . . . . 188

Hutchinsia .............. 123

Hyacinth, Wild.............. 59

HYDROPHYLLACEAE . . . . . . 202

Hydrophyllum . . . . . . . . . 204

HYPERICACEAE . . . . . . . . 163

Hypericum ............. 163

Hyssop, Hedge............ 224

Ibidium............. 71

Ilysanthes.................. 226

Impatiens . . . . . . . . . . . . . 160

Indian paint brush.......... 229 pink................. 229

IRIDACEAE ............. 66

Iris.................. 66

Iris family. ............. 66

Isnardia............... 169

IsOETACEAE . . . . . . . . . 7

Isoetes................ 7

Iva................. 253

Ivesia ............... 140

Ivy, Poison. . . . . . . . . 158

Jacob's ladder . . . . . . . . . . . 200

Jamestown weed. . . . . . . . . 218

Jerusalem oak............. 90

Jim Hill mustard. . . . . . . . . . 119

Jimson weed . . . . . . . . . . 218

JuNCACEAE . . . . . . . . . . 54

Juncoides............... 57

Juncus............... 54

Juniper............... 9

Juniperus.............. 9
Kelloggia............... 234

Knot-weed.............. 86

Koeleria.............. 30

LabiataE.............. 211

Lace fern................ 3

Lactuca................. 249

Lady's slipper............. 68

Lagophylla............... 265

Lamb's quarters. ............. 90

Lamium................. 217

Lappula................ 206

Larch, Western. .......... 11

Larix................... 11

Larkspur................... 108

Lathyrus. . . . .......... 150

Laurel, sticky. . . . . . . . . . 161

LEGUMINOSAE. . . . . . . . . . 142

Leibergia . . . . . . . . . . . . 183

Lemna................ 53

Lemnaceae . . . . . . . . . 53

Lepidium.............. 122

Leptotaenia.............. 181

Lettuce................... 249

Blue-flowered. . . . . . . 249

Prickly............. 249

Wild................ 249

Lewisia................. 92

Licorice, Wild. . . . . . . . . 149

Ligusticum............. 183

LILIACEAE . . . . . . . . . . . . 58

Lily, Mariposa............ 60

Pine................ 64

Lily family............. 58

Limosella.................. 226

Limnorchis.............. 70

LINACEAE. . . . . . . . . . 155

Linaria................... 220

Linnaea................ 236

Linum................. 156

Lithospermum............ 208

LOASACEAE.............. 166

Lonicera................ 237

Looking glass, Venus's........ 240

LORANTHACEAE............ 79

Lousewort. . . . . . . . . . . . . 229

Lovage. . . . . . . . . . . . . 183

Lupine. . . . . . . . . . . . . . . 144

Lupinus.................. 144

LYCOPODINEAE . . . . . . . . . 6

Lycopus................... 212

Lysichiton............. 52

LythraceaE ................ 167

Machaeranthera............ 265

Madder family............. 233

Madia.................... 263 
Madronella.............. 216

Mahogany, Mountain........ 132

Mallow.................. 163

Mallow family................ 162

Malva................. 163

MALVACEAE.............. 162

Maple.................... 160

Maple family............. 159

Mariposa lily................. 60

Marrubium............. 215

Marsilea................ 5

Marsileaceae........... 5

Matricaria............... 261

May-weed................ 263

Meadow grass, Reed.......... 38

Meadow rue. . ............... 104

Medic, Black.............. 149

Medicago................. 148

Melica.................. 31

Melilotus................ 149

Mentha............... 213

Mentzelia............... 166

Menyanthaceae........... 193

Menyanthes.............. 194

Menziesia................ 189

Merathrepta............. 28

Mertensia............... 206

Mesquite.............. 27

Micromeria............. 215

Milkweed................ 195

Milfoil.................. 262

Mimulus................. 226

Mint.................... 213

Mint family.............. 211

Mistletoe family............. 79

Mitella................. 128

Mitrewort.............. 128

Moehringia................ 101

Mollugo................. 91

Moneses.................. 186

Monkey flower............... 226

MONOCOTYLEDONES.......... 13

Monolepis................ 89

Montia................... 93

Morning glory.............. 196

Mountain ash............... 134 Mahogany............... 132

Mouse tail.................... 104

Mouse-ear chickweed.......... 98

Mudwort................... 226

Muhlenbergia............. 22

Mullein................. 220

Mustard, Black............. 118

Hedge................ 119

Jim Hill. . . . . . . . . . . . 119

Tumbling................. 119

Mustard family............. 113
Myosotis............... 208

Myosurus............... 104

Najadaceae. ............. 16

Najas................. 16

Naumburgia............. 191

Navarretia............... 201

Nemophila................. 204

Nepeta................ 216

Nettle................ 78

Nettle family............ 78

Nicotiana............... 219

Nightshade.............. 218

Ninebark................ 134

Nothocalais............ 247

Nut grass................ 49

Nymphaea.............. 101

Nymphaeaceae........... 101

Oak, Jerusalem . . .......... 90

Oat, Smooth wild............ 28

Oatgrass, Tall meadow........ 27

Oats...................... 28

Ocean spray.............. 134

Oenothera.............. 173

Olysnium............... 67

ONAGRACEAE . .............. 168

Onion................ 59

OpHIOglossaceae......... 4

Ophrys.................. 69

Opulaster................ 134

Opuntia................ 167

Orchard grass............. 33

OrchidaceaE............ 67

Orchid family................. 67

Oregon grape.............. 111

Oreocarya.............. 209

ORobanchaceae.......... 231

Orobanche............... 231

Orthocarpus............. 230

Osmorhiza............... 177

Oxeye daisy. . . . . . . . . . . 262

Oyster plant. ............. 246

Pachistima............... 159

Pachylophus.............. 173

Paeonia................. 110

Paint brush, Indian.......... 229

Painted Cup.............. 229

Paniceae................. 19

Panicularia............. 37

Panicum............... 21

Papaveraceae........... 112

Parietaria.................. 79

Parsley family.............. 176

Parsnip, Cow............... 179

Poison................ 182 
Pear, Prickly............. 167

Pedicularis............... 229

Pellaea................ 2

Penny cress.............. 123

Pentstemon.............. 221

Peony................... 110

Peppergrass.............. 122

Peramium............. 71

Petasites.............. 252

Phacelia............... 203

Phalarideae............... 19

Phalaris................ 21

Phegopteris............. 2

Phleum............... 23

Phlox................. 197

Phoenicaulis.............. 115

Phyllodoce.............. 189

Physaria............... 121

Picea.................. 11

Pigweed.............90, 91

Pimpernel, False............ 226

Pink, Indian............. 229

Pink family............. 95

Pinaceae................ 9

Pine.................... 10

Bull................ 11

Lodgepole............ 10

Western white.......... 10

Yellow................... 11

Pine family.............. 9

Pine lily................ 64

Pinus................... 10

Piperia............... 70

Pipsissewa............... 186

Plagiobothrys............ 210

Plantaginaceae . . . . . . . . 232

Plantago................ 232

Plantain................ 232

Common............ 232

English.............. 233

Rattlesnake............ 72

Plantain family............ 232

Platyspermum............ 120

Plum...................... 132

Poa.................. 33

Poaceae............... 18

Poison ivy.............. 158 parsnip.............. 182

Polemoniaceae............. 197

Polemonium.............. 200

Polygonaceae............ 81

Polygonum................ 85

Polypodiaceae ............ 1

Polypogon............... 24

Polystichum............. 3

Pondweed................... 15

Pondweed family........... 53
Pontederiaceae.......... 53

Poppy family.............. 112

Populus................. 75

Portulaca.............. 92

Portulacaceae . . . . . . . . 92

Potamogeton............. 15

Potamogetonaceae. . . . . . . 14

Potentilla................ 139

Pretty willow............. 75

Prickly lettuce............. 249 pear................... 167

Primulaceae. . . . . . . . . . . 189

Primrose family............ 189

Prunella............... 215

Prunus................ 132

Pseudotsuga............. 12

Psilocarphus. . . . . . . . . . . 262

Psoralea................ 146

Pteridium.............. 2

Pteridophyta............ 1

Pterospora............... 186

Pteryxia................ 184

Ptilocalais.............. 246

Ptilonella................. 276

Ptiloria................... 246

Purslane................ 92

Purslane family............ 92

Pyrola................. 187

Pyrola family. . . . . . . . . . 185

Pyrolaceae.............. 185

Pyrus................ 134

Quack grass................ 40

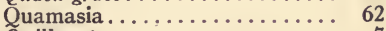

Quillwort................. 7

Rabbit brush.............. 259

Rabbit's ear clover. . . ......... 147

Radicula............... 118

Ragweed.................. 257

Ramona................. 214

RANUNCUlaCEAE . . . . . . . . . 102

Ranunculus............. 107

Raspberry, Red............ 136

Rattlesnake plantain......... 72

Razoumofskya............ 80

Red clover............... 148

raspberry.............. 136

Redtop............... 27

Rhamnaceae. . . . . . . . . . 160

Rhamnus.............. 161

Rhinanthus.............. 228

Rhus................ 158

Ribes.................. 125

Rigiopappus............ 279

Rock cress................ 115

Rose.............. 92 
Rosa................... 137

ROSACEAE............... 130

Rose................. 137

Rock.............. 92

Rose family. .............. 130

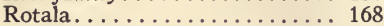

Rubiaceae............... 233

Rubus................. 136

Rudbeckia............... 261

Rumex.................. 83

Rush.................. 54

Spike............. 50

Wood .................. 57

Rush family................ 54

Russian thistle............. 88

Ryegrass................. 40

Sagebrush................ 253

Scabland............... 254

Sagittaria............... 17

St. Johnswort. . . . . . . . . . 163

St. Johnswort family. . . . . . . 163

SALICACEAE............... 72

Salix................... 73

Salsify. . . . . . . . . . . . 246

Salsola................ 88

Saltbush................ 88

Sambucus............... 235

Sandalwood fam $! l y . . . \ldots \ldots \ldots . . . .80$

Sandwort................... 100

Sanicle.................. 177

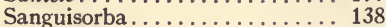

Sanicula............... 177

SantalaceaE............ 80

Sarsaparilla, Wild.......... 175

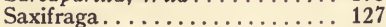

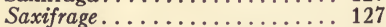

Saxifrage family. ........... 124

SAXifragaceae............ 125

Scabland sagebrush........... 254

Scheuchzeria .............. 16

Scheuchzeriaceae.......... 16

Scirpus................ 51

Scrophularia............... 223

SCROPHULARIACEAE . . . . . . . 219

Scutellaria................ 214

Sedge.................. 43

Sedge family. . . . . . . . . . . 42

Sedum.................. 124

Selaginella............... 7

SElAGINELLACEAE.......... 6

Senecio.................... 274

Service berry............... 133

Sheep sorrel. ................. 84

Shepherd's purse............ 123

Shooting star. . . . . . . . . . . . . 190

Sibbaldia................. 140
Sidalcea............... 162

Sieversia................ 139

Silene................ 96

Sisymbrium................ 119

Sisyrinchium............ 66

Sitanion............... 42

Sium................... 184

Skullcap................ 214

Skunk cabbage, Yellow........ 52

Snappers............... 80

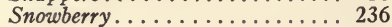

SolanaCEAE. . . . . . . . 217

Solanum.................. 218

Solidago.................. 272

Solomon's seal, False......... 65

Sonchus................... 249

Sorrel, Sheep............. 84

Sow thistle................ 249

SPARganiaceae........... 13

Sparganium............. 13

Spartina............... 38

Specularia............... 240

Speedwell................. 225

Spergula................ 97

SPERMATOPHYTA.......... 8

Sphaeralcea............... 162

Sphaerostigma............. 174

Sphenopholis............. 30

Spike rush............... 50

Spiraea..................... 135

Spirodela............... 53

Sporobolus................. 25

Spruce, Douglas............... 12

Engelmann........... 11

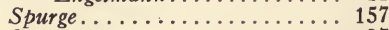

Spurry..................... 97

Squirrel corn ................ 112

tail................ 41

Stachys.............. 217

Stafftree family. . . . . . . . . 159

Star-flower. ............... 191

Steironema................. 191

Sticky laurel.................. 161

Stipa................... 22

Stonecrop................. 124

Stonecrop family. . . . . . . . . . 124

Strawberry................ 141

Strawberry blite............. 89

Streptopus.............. 63

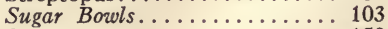

Sumac.................... 158

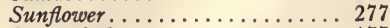

Sweet cicely............... 177

clover.................... 149

coltsfoot............... 252

Symphoricarpos.............. 236

Synthyris................ 224 
Tamarack.............. 11

Taraxacum............. 247

Taraxia................ 174

Tarveed..............209, 263

Taxaceae............ 8

Taxus................ 9

Teasel.................. 239

Teasel family.............. 239

Tellima................. 129

Thalesia.............. 232

Thalictrum............. 104

Thelypodium............ 117

Thermopsis............... 143

Thimble berry ............. 136

Thistle............... 259

Bull................ 260

Canada............... 260

Chinese............. 257

Russian............ 88

Sow................ 249

Thlaspi.................. 122

Thorn................. 133

Thuja.............. 10

Thysanocarpus........... 114

Tiarella................. 129

Timothy.................. 23

Mountain............ 23

Tissa................ 97

Tobacco..................... 219

Tobacco root............... 238

Tonella................. 224

Tragopogon.............. 246

Trautvetteria.............. 104

Trefoil, Yellow............. 149

Trichostema.............. 213

Trientalis................ 191

Trifolium .................... 146

Triglochin.............. 16

Trillium.............. 63

Trisetum ................ 29

Tule.................. 51

Tumbleweed................ 91

Tumbling mustard............ 119

Turnip................ 118

Twin-flower............... 236

Typha................ 13

TyPhaceaE . . . . . . . . . 13

Ulmaceae . . . . . . . . . . 78

UMBELLIFERAE . . . . . . . . 176

Uropappus. . . . . . . . . . . . 247

Urtica................... 78

URTICACEAE............ 78

Vaccaria............... 95

Vaccinium
Vagnera............... 65

Valerian............... 238

Valerian family............ 237

Valeriana............... 238

VALERIANACEAE.......... 237

Valerianella............... 238

Venus's looking glass. . . . . . . . 240

Veratrum............... 63

Verbascum............... 220

Verbena................. 211

Verbena family. ........... 211

Verbenaceae............ 211

Veronica.................. 225

Vetch................. 149

Viburnum.............. 235

Vicia.................. 149

Viola.................... 165

ViolaceaE.............. 164

Violet. .................. 165

Violet family............. 164

Wake robin.............. 63

Washingtonia............. 178

Water cress............... 119 plantain............. 17 starwort.............. 158

Water starwort family........ 157

Waterleaf................. 204

Waterleaf family. . . . . . . . . 202

Waterlily................. 101

Waterlily family. . . . . . . . . . 101

Watershield............... 102

Waterwort family. . . . . . . . . 164

Wheatgrass................ 39

White clover. . . . . . . . . . . 147

Wild cherry............... 132 geranium............. 154

lettuce............... 249

licorice. ............. 149

sarsaparilla............... 175

Willow................ 73

Almond............ 73

Heart-leaved............ 74

Pretty.............. 75

Willow family............ 72

Willow herb............... 170

Windflower. ................. 103

Wood rush . . . . . . . . . . . 57

Woodsia............... 3

Wokas....................... 102

Woolgrass............... 47

Wormwood............253, 254

Wyethia............... 277

Xanthium.............. 256

Xerophyllum ............. 64 
Yarrow.

262 Zannichellia

Yellow trefoil.

149 Zigadenus.

Yew, Western.

9 Zizia.

Yew Family. 

- dIVERSITY OF CALIFORNIA, LOS ANGELES

VARSITY LIBRARY

ramped below

SOUTHER University of Calliformla

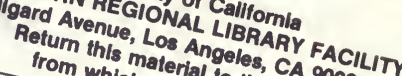

from which it wal to the CA 11 bra $024-1388$

y 


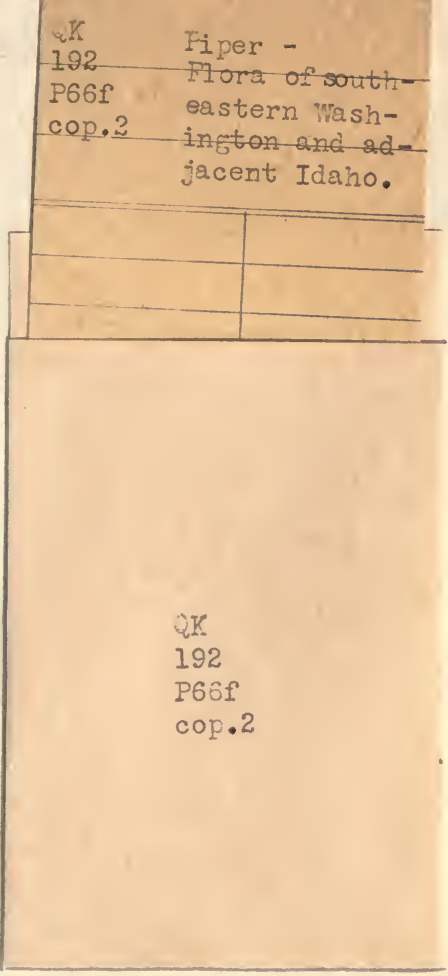


